INTERVENÇÃO EM PATRIMÔNIO ARQUITETÔNICO MODERNO - UM ESTUDO DE TRÊS CASAS PAULISTAS 


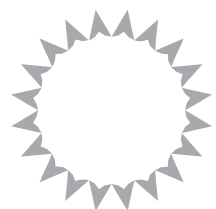


APOENA AMARAL E ALMEIDA

\section{INTERVENÇÃO EM PATRIMÔNIO ARQUITETÔNICO MODERNO - UM ESTUDO DE TRÊS CASAS PAULISTAS}

DISSERTAÇÃO APRESENTADA À FACULDADE DE ARQUITETURA E URBANISMO

DA UNIVERSIDADE DE SÃO PAULO PARA OBTENÇÃO DO TÍTULO

DE MESTRE EM ARQUITETURA E URBANISMO

ÁREA DE CONCENTRAÇÃO PROJETO DE ARQUITETURA

ORIENTADORA PROFA. DRA. HELENA APARECIDA AYOUB SILVA 
Autorizo a reprodução e divulgação total ou parcial deste trabalho, por qualquer meio convencional ou eletrônico, para fins de estudo e pesquisa, desde que citada a fonte.

apoamaral@terra.com.br

lena.ayoub@usp.br

Almeida, Apoena Amaral e

A447i Intervenção em patrimônio arquitetônico moderno: um estudo de três casas paulistas / Apoena Amaral

e Almeida. São Paulo, 2013

246 p. : il.

Dissertação (Mestrado - Área de Concentração:

Projeto de Arquitetura) - FAUUSP

Orientadora: Helena Aparecida Ayoub Silva

1. Patrimônio arquitetônico (Preservação, Restauro) São Paulo (SP) 2. Arquitetura moderna (Preservação, Restauro) - São Paulo (SP) 3. Casas - São Paulo (SP)

4. Artigas, João Batista Vilanova, 1915-1985 5. Rocha,

Paulo Archias Mendes da, 1928 6. Warchavchik, Gregori,

1896-1972 7. Lemos, Carlos A.C., 1925 I.Título

CDU 72.025.3(816.11) 


\section{INTERVENÇÃO EM PATRIMÔNIO ARQUITETÔNICO MODERNO -}

\section{UM ESTUDO DE TRÊS CASAS PAULISTAS}

RESUMO Com o objetivo de evidenciar o entendimento da preservação da arquitetura moderna como patrimônio cultural, o trabalho centrou-se no estudo de um grupo de obras residenciais de arquitetura moderna, realizadas no município de São Paulo entre os anos 1950 até meados dos anos 1970, que sofreram intervenções a partir da década de 1990. Essas intervenções originaram-se de projetos arquitetônicos

contemporâneos que consideraram as edificações existentes como patrimônios arquitetônicos, mesmo que não sejam edificações tombadas pelos órgãos oficiais de patrimônio cultural (municipal, estadual e federal). A pesquisa, ao examinar alguns exemplos concretos (projetos específicos) refletiu sobre um campo disciplinar de atuação do arquiteto que vem crescendo ao longo das últimas duas décadas: a intervenção em edificações existentes visando sua recuperação, consolidação ou restauro. Para viabilizar o embasamento necessário à contextualização das obras e das análises realizadas, foi possível verificar o processo de consolidação da arquitetura moderna paulista, seja através de sua historiografia, seja através dos estudos que a caracterizam como patrimônio cultural, evidenciando as especificidades para sua salvaguarda, conservação e intervenção, além de examinarem suas relações com os critérios teórico-metodológicos vigentes.

Através desses pressupostos, analisamos - com o apoio de diagramas, desenhos executivos e fotos - três casas ícones da arquitetura moderna paulista: residência Olga Baeta, residência Mário Masetti e residência Fernando Millan - a primeira de autoria de Vilanova Artigas projetada em 1957 e as duas subsequentes de Paulo Mendes da Rocha, projetadas em 1969 e 1970, respectivamente - a fim de ressaltar não só importância desses projetos como Bens Culturais, mas procurando identificar instrumentos técnico-operacionais diretamente ligados ao campo da preservação e avaliar seus resultados.

PALAVRAS-CHAVE casas (Arquitetura); preservação; arquitetura moderna; patrimônio cultural - São Paulo; casas (Vilanova Artigas); casas (Paulo Mendes da Rocha); casas (Gregori Warchavchik); casas (Carlos Lemos).

\section{INTERVENTION IN MODERN ARCHITECTURAL HERITAGE -} A STUDY OF THREE HOUSES IN SÃO PAULO

ABSTRACT Aiming to demonstrate an understanding of the preservation of modern architecture as cultural heritage, the work focused on the study of a group of modern architecture residential works, built in São Paulo from the 1950's until the mid-1970's, which were intervened starting from the 1990's.

Such interventions are the results of contemporary architectural projects that considered the existing buildings as architectural cultural heritage even if the buildings were not considered so by official agencies (municipal, state, and federal).

The research, when examining some concrete examples (specific projects), reflected a disciplinary field of expertise of the architect, which has grown over the past two decades: the intervention in existing buildings, aiming at their renovation, consolidation, or restoration. In order to enable the necessary foundation to contextualize the work and the performed analyses was possible to verify the consolidation process of modern paulista architecture. This was done either through its historiography or through studies that characterize it a cultural heritage, highlighting the specifics for protection, conservation, and intervention, besides examining their relationships with existing theoretical and methodological criteria.

Through these assumptions, we analyzed - with the help of diagrams, technical drawings, and photos - three iconic houses of modern paulista architecture: Olga Baeta Residence, Mario Masetti Residence and Fernando Millan Residence. The first residence was designed by Vilanova Artigas in 1957 and the other two by Paul Mendes da Rocha in 1969 and 1970, respectively. We aimed to emphasize not only their importance as Cultural Property, but to identify technical and operational tools directly related to the preservation field and evaluate their results.

KEYWORDS houses (Architecture); preservation; modern architecture cultural heritage - São Paulo; houses (Vilanova Artigas); houses (Paulo Mendes da Rocha); houses (Gregori Warchavchik); houses (Carlos Lemos). 

para Célia, Oswaldo, Gabi e Horácio (in memorian) 


\section{AGRADECIMENTOS}

À Helena Ayoub pela generosa orientação e confiança na realização deste trabalho. Por compartilhar tempo, conhecimento e experiência desde os tempos da FAU-USP.

Ao Rafael Perrone e à Helena Ayoub por me acolherem na disciplina Fundamentos de Projeto - AUP 608, no programa de estágio PAE e pelas conversas instigantes no café juntamente com Roberto Toffoli, grande parceiro nesta disciplina.

À Beatriz Mugayar Kühl e ao Luís Antônio Jorge, pela leitura atenta e ricas observações na Banca de Qualificação.

Aos professores da pós-graudação: Artur Simões Rozestraten, Beatriz Mugayar Kühl, Francisco Spadoni, Julio Roberto Katinsky, Livia de Araujo Donnini Rodrigues, Luiz Américo de Souza Munari, Maria Lucia Bressan Pinheiro, Maria Luiza Corrêa e Paulo Bruna, obrigado pela contribuição direta ou indireta neste trabalho.

Aos funcionários da biblioteca da FAU-USP, pela ajuda em todas as etapas de pesquisa: Ana Paula Lingner, Iracema Silva Mayara Faria Aliano, Neusa Kazue Habe e Valéria Valente e também da biblioteca da FAU Maranhão: Beatriz Barros, Bruno Horioka, Cleide Gigli, Maria José Polletti, Paolo Santos e Lucas de Oliveira.

Aos funcionários da secretaria da FAU Maranhão, por todo apoio desde as primeiras orientações: Cida, Cilda, Cristina, Diná, Ivani, Lucia e em especial a Isa, que está sempre na "linha de frente".
Durante a elaboração deste trabalho, agradeço em especial à Célia de Lourdes Amaral pelas transcrições e infindáveis revisões, ao Oswaldo Francisco de Almeida Júnior pela leitura e correções nas referências bibliográficas e citações, ao José Maria de Macedo Filho pela leitura minuciosa e inúmeras sugestões, ao Dhiego Torrano pela modelagem tridimensional, ao Pedro Ribeiro pela ajuda nos desenhos complementares e à Taynah Spinola pelo auxílio nos diagramas e na fortuna crítica, fundamentais para a conclusão dessa pesquisa.

Ao Geraldo Borba, que mesmo indiretamente, me acompanhou e auxiliou com sua dedicação e paciência.

À Marisa Nagumo pela atenção e tempo dedicado à produção gráfica e à Letícia Mendes e Alessandro Kassai pelas informações preciosas e inúmeras dicas.

Aos arquitetos: Angelo Bucci, Carlos Leite, Carlos Warchavchik, Eduardo Colonelli, Paulo Mauro Mayer e Paulo Mendes da Rocha, agradeço a disponibilidade para os depoimentos e ao empréstimo de material. Um agradecimento especial à Dulcineia e à Elaine por toda a ajuda na pesquisa do Acervo Paulo Mendes da Rocha Arquitetos Associados.

Ao Acervo Escritório Paulistano de Arquitetura, à Ana Mello, à Coleção Gregori Warchavchik, à Kelly Naguissa, ao Leonardo Finotti, ao Nelson Kon e à Marisa Nagumo, pela disponibilização das fotos que ilustram este trabalho. 
Aos amigos do grupo de orientandos - Eduardo Gurian, Cesar Shundi, Gabriel Manzi e Fábio Onuki, obrigado pelas discussões e pelo compartilhamento do processo de pesquisa; em especial à Maira Rios, pela parceria inestimável em diversas disciplinas na pós-graduação e nos primeiros passos dessa jornada.

Aos colegas da pós-graduação, que juntos compartilharam informações e dúvidas em diversas disciplinas, em especial ao João Yamamoto (Joca), à Juliana Fiorini e à Clara Reynaldo.

Ao Silvio Oksman, obrigado pelas conversas iniciais, troca de ideias e pela inspiradora dissertação, as quais foram de extrema importância para o desenvolvimento deste trabalho.

À todos os sócios, parceiros e colaboradores que me auxiliaram ao longo dos anos nos inúmeros escritórios que trabalhei, destaque para Carlos Ferrata (KK), Eduardo Ferroni (Dudu), Moracy Amaral e Pablo Hereñu, companheiros no Bela Vista Arquitetos.

À equipe do 2A+V Arquitetos: João Miguel, Júlia Risi, Julia Rettmann, Luise Elbern, Marcelo Arend, Mariana Victor, Mona Feldman, Paola Ornaghi, Pedro Hasse, Pedro Ribeiro, Taynah Spinola, Tomás do Amaral e em especial à Ana Paula de Castro e Vito Macchione pela total ajuda e compreensão pela minha ausência e ainda pela tradução cuidadosa do resumo juntamente com Daniele Liu.
À Christiane Costa, ao Marcos Piffer e ao Paulo von Poser, o "núcleo duro" de Plástica da FAUs, pelas aulas compartilhadas dentro e fora do ambiente acadêmico.

Ao casal de ouro, José Maria de Macedo Filho e Christiane Costa, pelas discussões enriquecedoras, pelos trabalhos e concursos que realizamos ao longo dos três últimos anos, apoio incondicional em todos os momentos e pela generosa hospitalidade santista.

Aos eternos professores: Alexandre Delijaicov, Angelo Bucci, Alvaro Puntoni, Edgar Dente, Luciano Margotto, Marcos Acayaba, Paulo Mendes da Rocha, pelas aulas inesquecíveis.

À Cristiane Muniz, Fábio Valentim, Fernanda Barbara e Fernando Viégas, por compartilharem com generosidade projetos e conhecimento, irremediável influência na minha formação.

Ao Sensei (Jorge Kishikawa) pelo exemplo no Caminho da Espada que me inspirou e me fez acreditar que travar mais essa batalha era possível.

Aos meus pais, Célia e Oswaldo e aos meus avós, Maroca e Oswaldo por todo amparo e incentivo na minha formação, que me permitiu chegar até aqui. Aos meus irmãos, que me acompanham desde sempre, Moracy, parceiro na descoberta e vivência da arquitetura, e Iberê, entusiasta das novas tecnologias.

À Gabrielly Silva (Gabi), por todo o seu amor e carinho nesses 16 anos juntos e pelo total apoio "desde a graduação"!!! 


\title{
SUMÁRIO
}

\author{
INTRODUÇÃO 15
}

\section{A ARQUITETURA MODERNA EM SÃO PAULO: RECONHECIMENTO E PRESERVAÇÃO 21}

1.1 A CONSOLIDAÇÃO DO PATRIMÔNIO MODERNO PAULISTA 21

1.1.1 A importância do imóvel enquanto bem cultural e sua consolidação como patrimônio através da historiografia 22

1.1.2 Arquitetura moderna brasileira e as especificidades paulistas 23

1.1.3 A inclusão da arquitetura moderna em São Paulo no rótulo brutalista 25

1.1.4 0 uso do concreto aparente na arquitetura moderna paulista e a configuração espacial como elementos de identificação 26

1.1.5 Arquitetura moderna e os órgãos de patrimônio: o caso paulista 27

1.2 AS ESPECIFICIDADES DA PRESERVAÇÃO DA ARQUITETURA MODERNA 32

1.2.1 A presença dos arquitetos autores, vínculos e fatores externos 33

1.2.2 A pátina no moderno 35

1.2.3 As especificidades técnicas da arquitetura moderna devido às suas características de vanguarda 35

1.2.4 A preservação do moderno: patologias e outras questões puramente técnicas 38

1.2.5 Mudar a função para sobreviver 41

1.3 PRESERVAÇÃO E INTERVENÇÃO: OS CRITÉRIOS TEÓRICO-METODOLÓGICOS 42

1.3.1 Restauro e outras definições 42

1.3.2 Carta de Veneza e suas bases teóricas 44

1.3.3 Desdobramentos teóricos na atualidade 48

\section{TRÊS CASAS PAULISTAS: COMPREENSÃO E DECOMPOSIÇÃO 55}

2.1 DIAGRAMAS COMPARATIVOS: ACESSOS/SETORIZAÇÃO DE USOS/CIRCULAÇÃO/ESTRUTURA/FECHAMENTOS/SOMBRA 55

2.2 RESIDÊNCIA OLGA BAETA 60

2.3 RESIDÊNCIA MÁRIO MASETTI 65

2.4 RESIDÊNCIA FERNANDO MILLAN 68 
3 TRÊS CASAS PAULISTAS: RECOMPOSIÇÃO E INTERVENÇÃO 71

3.1 DIAGRAMAS COMPARATIVOS: DEMOLIÇÃO/INTERVENÇÃO 73

3.2 PROJETO, OBRA E CIRCUNSTÂNCIA: RESIDÊNCIA OLGA BAETA 76

3.3 PROJETO, OBRA E CIRCUNSTÂNCIA: RESIDÊNCIA MÁRIO MASETTI 79

3.4 PROJETO, OBRA E CIRCUNSTÂNCIA: RESIDÊNCIA FERNANDO MILLAN 82

3.5 AS INTERVENÇÕES E SEUS DETALHES: RESIDÊNCIA OLGA BAETA 85

3.6 AS INTERVENÇÕES E SEUS DETALHES: RESIDÊNCIA MÁRIO MASETTI 95

3.7 AS INTERVENÇÕES E SEUS DETALHES: RESIDÊNCIA FERNANDO MILLAN 104

CONSIDERAÇÕES FINAIS 113

REFERÊNCIAS BIBLIOGRÁFICAS 121

SITES CONSULTADOS 127

SIGLAS E ABREVIAÇÕES 129

CRÉDITO DAS IMAGENS 131

ANEXOS 135

Anexo A: residência rua Itápolis "Casa Modernista" 137

Anexo B: residência Olga Baeta 171

Anexo C: residência Luis Eduardo Magalhães Gouveia 191

Anexo D: residência Mário Masetti 209

Anexo E: residência Fernando Millan 233

Anexo F: Tabela comparativa bens tombados na cidade de São Paulo,

entre 1930 e 1979, nos órgãos patrimoniais (CONPRESP, CONDEPHAAT e IPHAN) 243 

"Un monumento es un documento del pasado que tuvo un origen y un destino cresciente o menguante. Su arquitectura encarno unos valores, unas leyes, una inteligencia, una belleza, un carácter, un espíritu penetrado en su sustância y amasado en el tiempo, que la hicieron ser unas veces admirada, otras ignorada, y en muchos casos despreciada (...) cada intervención sobre su ser la aparta o la aproxima a su mejor condición: aquella que pone de manifiesto sus cualidades más auténticas. A todos aquella que descubre y aumenta sus potenciales. Aquella que es capaz de imbricarse en su 'inteligencia', como si de un nuevo impulso vital se tratara, para hacerla renascer de sus próprias entrañas en un cruce de autenticidades que verifica simultáneamente todos los presentes que dignificaron su condición (...) de nosotros depende saber ver, entender y sentir ló que cada situación demanda y el lugar que nos corresponde en esse processo abierto que nos da la oportunidad de poder demostrar que sabemos distinguir entre ló que se debe afirmar y en qué nos debemos someter. Cómo aundar fuerza, delicadeza, claridad y respeto. Cuándo grandeza significa renuncia o reclama atrevimiento. Dónde adequación es mesura y discreción o requiere presencia. Por qué nuestra actuación es necesaria y cuánto aporta de verdad."

VICTOR LÓPEZ COTELO, 2005, p. 2*

* Esse texto foi utilizado como prólogo da revista TECTÓNICA - MONOGRAFIAS DE ARQUiteCTURA, TECNOLOGIA Y CONSTRUCCIÓn, Madri, ATC Ediciones, n. 18, março 2005. Esse número tem como tema a restauração e o respectivo texto retrata poeticamente os objetivos dessa pesquisa. 

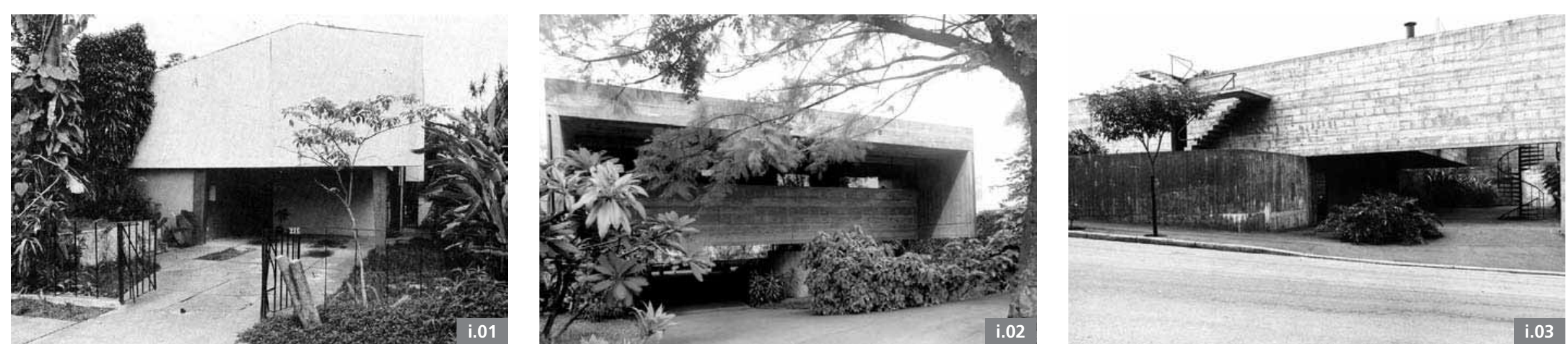


\section{INTRODUÇÃO}

O presente trabalho centrou-se no estudo três casas ícones da arquitetura moderna paulista: residência Olga Baeta [FIG. i.01], residência Mário Masetti [FIG. i.02] e residência Fernando Millan [FIG. i.03] - a primeira de autoria de Vilanova Artigas projetada em 1957 e as duas subsequentes de Paulo Mendes da Rocha, projetadas em 1969 e 1970, respectivamente -, que sofreram intervenções a partir da década de 1990.

Esses projetos de intervenção consideraram as edificações existentes como bens culturais, mesmo não sendo tombados por órgãos oficiais de patrimônio cultural (municipal, estadual e federal).

Através de análises dessas obras, procuramos identificar instrumentos técnico-operacionais e seus critérios teóricometodológicos diretamente ligados à preservação e ao restauro, no intuito de contribuir na discussão desse campo disciplinar específico.

A principal justificativa para elaboração deste trabalho é a escassez de material publicado ou acadêmico que relacione a prática profissional da arquitetura (projeto e obra) com as bases teóricas da área de Patrimônio Histórico (Cartas Patrimoniais), sobretudo relacionadas ao Patrimônio Arquitetônico Moderno.

Vale ressaltar que, em se tratando de um campo de atuação relativamente recente no Brasil, os instrumentos comumente utilizados são aqueles relacionados ao patrimônio histórico anterior à arquitetura moderna (clássico, neoclássico e colonial), já amplamente difundidos por meio de publicações e traduções importantes (Camilo Boito, Cesare Brandi, Françoise Choay, Viollet Le-Duc, John Ruskin, etc.), cujas referências projetuais estão diretamente ligadas às práticas europeias de intervenção.

Embora a proximidade temporal dos objetos de estudo nos forneça uma grande quantidade de fontes primárias ${ }^{1}-$ documentação completa de peças gráficas (desenhos técnicos, croquis, perspectivas, etc.), fotografias, memoriais justificativos e de especificação (entre outros), além da presença dos autores e/ou colaboradores -, essa mesma proximidade levou à exclusão momentânea do patrimônio moderno do [as notas referentes à

Introdução encontram-se

a partir da p. 18]

i.01 Residência Olga Baeta, São Paulo, Vilanova Artigas, 1956-1957 i.02 Residência Mário Masetti,

São Paulo, Paulo Mendes da Rocha, 1968-1970

i.03 Residência Fernando Millan São Paulo, Paulo Mendes da Rocha e João de Gennaro, 1970-1975 
campo disciplinar da preservação e do restauro. Essa exclusão deve-se, também, à utilização, nos exemplares da arquitetura moderna, de materiais industriais em contraponto às técnicas tradicionais, cujos detalhes de manufatura e execução perderam-se no tempo.

Ao nos aprofundarmos na bibliografia relacionada diretamente à arquitetura moderna no Brasil, fica clara a presença de dois grupos de programas, um de âmbito público e outro de âmbito privado. São, respectivamente, as instituições de ensino e as residências unifamiliares. Acayaba indica essa questão em seu livro Residências em São Paulo - 1947-1975:

"Na década de 30, diante de uma cidade provinciana e de um poder público indiferente quanto ao caráter de seus edifícios, a arquitetura moderna em São Paulo restringia-se ainda a exemplares isolados quase que exclusivamente às habitações de uma pequena clientela composta de burgueses progressistas e intelectuais que procuravam os novos bairros residenciais. Foi, então, principalmente através desses projetos que a arquitetura moderna começou a se desenvolver na cidade." (ACAYABA, 1986, p. 15)

Bruand complementa essa informação ao discorrer sobre as condições políticas em seu livro A Arquitetura Contemporânea no Brasil:

"Que os edifícios públicos tenham tido tamanha importância na arquitetura brasileira contemporânea não é obra do acaso; o fenômeno pode ser explicado pela organização política do país, pela ampliação das necessidades dela resultantes e pelo prestígio que essa arquitetura assumiu junto aos governantes (...) com a ascensão de Getúlio Vargas ao poder, como presidente de 1930 a 1945, o estado de espírito das classes dominantes não foi sensivelmente modificado, mas ocorreu uma profunda transformação na estrutura administrativa, um mês após a Revolução, quando foi criado o Ministério da Educação (...) as escolas assumiram nova importância, ao mesmo tempo em que universidades começaram a ser criadas (...) a arquitetura 'moderna', portanto, que começava a tomar impulso, encontrou ali um campo de ação que lhe foi generosamente aberto." (BRUAND, 2008, p. 26-27)

E, ainda, em uma publicação recente sobre a obra de Vilanova Artigas, Wisnik esclarece essa situação ao descrever:

"En 1958, el gobierno del estado de São Paulo creó un 'plan de acción' para suplir en poco tiempo la enorme carencia de equipamientos escolares, llegándose a construir efectivamente más de seiscientas nuevas unidades entre 1959 y 1962. Esa fue la ocasión extraordinária que hizo que los arquitectos residentes em São Paulo recibieran, por primera vez, encargos públicos relevantes (...) "2 (WISNIK, 2010, p. 19)

Em face dessas informações, pareceu-nos importante elaborar um recorte mais preciso ${ }^{3}$, associado ao programa arquitetônico: como se partíssemos de uma base comum para análises de diferentes considerações relacionadas a um programa específico. Escolhemos, então, as residências como programa base, cuja importância na arquitetura moderna em São Paulo é destacada por Kamita, que afirma: “Na 
maioria dos casos, os programas residenciais se tornariam espécies de laboratórios para inovações formais, construtivas e tecnológicas." (2004, p. 143)

Também, ao discutir as "Residências em São Paulo", Acayaba reitera a importância do projeto das casas como possibilidade de ensaio, concluindo: “Na prática, a casa é muitas vezes a única ocasião para o profissional experimentar." (2011, p. 15)

Ainda em relação a essa escolha, consideramos apropriada essa aproximação com o programa ${ }^{4}$ residencial, onde o entendimento funcional não requer nenhum conhecimento específico prévio, possibilitando o acesso direto às questões específicas do restauro e de sua metodologia projetual.

Assim, ao apresentar um estudo sobre Intervenções em Patrimônio Arquitetônico Moderno, o trabalho tem o intuito de refletir sobre um campo disciplinar ${ }^{5}$ de atuação do arquiteto que vem crescendo ao longo das últimas décadas no Brasil, acrescentando mais dados e informações para o estudo da história da arquitetura brasileira, em especial a arquitetura moderna, contribuindo para sua melhor compreensão ${ }^{6}$ e valorização, como aponta Guerra: “A história da arquitetura moderna brasileira está, em grande parte, por se fazer." (2002)

Após a aproximação desse universo tão particular, que é o patrimônio arquitetônico moderno em São Paulo, em especial o âmbito dos projetos residenciais, elaboramos a pesquisa focada em cinco casas que sofreram intervenções a partir da década de 1990: residência na rua Itápolis, também conhecida como "Casa Modernista”, de autoria de Gregori
Warchavchik, projetada em 1928; residência Olga Baeta de autoria de João Batista Vilanova Artigas e Carlos Cascaldi, projetada em 1957; residência Luis Eduardo Magalhães Gouveia de autoria de Carlos Lemos e Eduardo Corona, projetada em 1961; residência Mário Masetti e residência Fernando Millan - de autoria de Paulo Archias Mendes da Rocha, projetadas em 1969 e 1970, respectivamente.

Vale ressaltar que essas intervenções foram, todas, objeto de projetos arquitetônicos; alguns mais, outros menos detalhados; mas, todos, sem exceção, consideraram as edificações preexistentes como patrimônios arquitetônicos mesmo que algumas delas não estivessem tombadas ${ }^{7}$ pelos órgãos oficiais de patrimônio cultural (municipal, estadual e federal).

Sobre essa questão - se o imóvel é tombado ou apenas é de interesse histórico - Araujo explica que:

“(...) la consciencia del valor de esta herencia en términos arquitectónicos, como valor coletivo que no se limita a los edifícios emblemáticos, sino a un extenso patrimônio, de modo a que poco a poco la arquitectura moderna va conseguiendo um cierto reconocimento (...) la fundación del Docomomo ya en 1990 es una clara muestra de este renovado interes. ${ }^{\prime 8}$ (ARAUJO, 2010, p. 4)

Após o término das pesquisas iniciais, da coleta do material base e da elaboração do Memorial de Qualificação, verificou-se que dentre as cinco casas pré-selecionadas, as projetadas por Warchavchik ${ }^{9}$ e por Lemos e Corona não tinham material suficientemente completo em comparação com as 
demais. Com isso, optou-se por eliminá-las do presente trabalho, no que tange às análises e discussões específicas sobre suas intervenções. Contudo, o material coletado e produzido sobre essas duas residências até o momento da Banca de Qualificação estará apresentado nos Anexos desta dissertação, com o objetivo de auxiliar trabalhos de outros pesquisadores no futuro ${ }^{10}$.

Elaborou-se, então, a comparação e a análise dos projetos e intervenções nas três casas remanescentes, com o objetivo de verificar de que forma as ações específicas para cada projeto poderão auxiliar no avanço do estudo de intervenções em patrimônio arquitetônico moderno.

Na conclusão, buscou-se apontar possíveis caminhos que possibilitem futuras intervenções de conservação, restauro, atualização e, até mesmo, ampliação, sob a ótica das diretrizes estabelecidas pelas cartas de preservação do patrimônio e pelos órgãos de preservação - sendo as edificações protegidas ou não -, mas cujos valores sejam reconhecidos como bens culturais. Procurou-se, também, indicar possibilidades de inserção, de maneira mais efetiva, da arquitetura moderna no conjunto de bens a serem preservados.
NOTAS

1 "Aliás o número de arquivos de arquitetura moderna vem crescendo exponencialmente em número e extensão: verdadeiros bancos genéticos, alguns conservam projetos desenhados com tal riqueza de detalhamento (...)." COMAS, Carlos Eduardo Dias; SANTOS,

Cecilia Rodrigues dos; ZEIN, Ruth Verde. Autoridades, emendas, paradoxos e peculiaridades da preservação do patrimônio arquitetônico moderno. Salvador: Faculdade de Arquitetura da Universidade Federal da Bahia, 2008. (Seminário DOCOMOMO Brasil N-Ne, 2, 04 a 07 junho 2008 Salvador), p. 01. Disponível em $<$ http://www. docomomobahia.org/ Comas_Santos_Zein.pdf $>$. Acesso em: 26/02/2009.

2 Tradução nossa. "Em 1958, o governo do estado de São Paulo criou o Plano de Ação para suprir em pouco tempo a enorme carência de equipamentos escolares, chegando a construir efetivamente mais de seiscentas novas unidades entre 1659 e 1962. Essa foi uma ocasião extraordinária que fez com que os arquitetos residentes em São Paulo recebessem, pela primeira vez, encargos públicos relevantes (...)." 3 Inicialmente imaginamos que o cerne da dissertação que se pretendia elaborar seria a partir de uma classificação quanto às tipologias de intervenção (interna, externa, horizontal, vertical, volume aposto, acréscimos, recuperação, subtração, obras de consolidação, modificação de fachada, etc.) em patrimônio moderno, listando aproximadamente 40 projetos, executados ou não, e apontando, de maneira geral, suas relações com possíveis bases teóricas. Apesar de optamos por estudar obras executadas como objeto principal, tínhamos a clareza de que, no desenvolvimento do trabalho, poderiam figurar projetos não construídos, ajudando, sobremaneira, a

ilustrar determinados exemplos operativos relacionados à prática metodológica projetual, assim como indica Frampton: "A história da arquitetura moderna refere-se tanto à consciência e a intentos polêmicos quanto às próprias construções."

FRAMPTON, Kenneth. História crítica da arquitetura moderna. Tradução: Jefferon L. Camargo / Marcelo Brandão Cipolla. São Paulo: Martins Fontes, 2008.

4 Sobre esse termo, Lemos define: "[Programa de necessidades] seria uma lista de funções programadas cuja abrangência viria incluir as condições de habitabilidade ligadas à segurança, ao conforto, ao clima, às intempéries, etc." Ver: LEMOS,

Carlos Alberto Cerqueira. Casa

paulista - história das moradias anteriores ao ecletismo trazido pelo café. São Paulo: Edusp - Editora da Universidade de São Paulo, 1999 5 "Pensar na restauração como campo disciplinar que atua para preservar bens de interesse

cultural significa refletir sobre seus referenciais, definições, objetivos, instrumentos teórico-metodológicos técnico-operacionais. Esse processo auxilia o esclarecimento de muitos equívocos que ocorrem no trato de bens culturais, por não serem claras, atualmente, as razões por que se preserva." KÜHL, Beatriz Mugayar. A restauração como campo disciplinar autônomo. Anais do Museu Histórico Nacional. Rio de Janeiro, v. 40, 2008a, p. 353.

6 "Para bem restaurar é necessário amar e entender o monumento, seja estátua, quadro ou edifício (...)" BOITO, Camilo. Os restauradores. Tradução: Beatriz Kühl. São Paulo: Ateliê Editorial, 2003, p. 31.

7 Das cinco casas objeto inicial de estudo, apenas a residência na rua Itápolis é tombada nas três instâncias - IPHAN, CONDEPHAAT e CONPRESP - Federal, Estadual e Municipal, respectivamente. Na dissertação de Silvio Oksman, ele informa que o CONDEPHAAT (Processo n. 39844/2000) está elaborando um dossiê específico sobre a obra do arquiteto Vilanova Artigas, mas na listagem dos edifícios que se pede o tombamento 
apenas a residência Rio Branco

Paranhos (1943) e a primeira e a

segunda casa do arquiteto (1942

e 1949 respectivamente) são

programas residenciais. Atentar ao

fato que só o Artigas tem 76 casas

construídas na cidade de São

Paulo. Informação resultante da

dissertação de Maurício Miguel

Petrosino. Para mais informações

ver: PETROSINO, Maurício Miguel.

João Batista Vilanova Artigas:

residências unifamiliares: a

produção arquitetônica de 1937

a 1981. São Paulo: FAU-USP, 2009.

Dissertação (Mestrado) - Faculdade

de Arquitetura e Urbanismo/USP

São Paulo.

8 Tradução nossa. “(...) a consciência

do valor da herança em termos

arquitetônicos, como valor coletivo

que não se limita aos edifícios

emblemáticos, se não, a um extenso

patrimônio, de modo que pouco a

pouco a arquitetura moderna vai

conseguindo certo reconhecimento

(...) a fundação do Docomomo já

em 1990 é uma clara amostra deste

renovado interesse."

9 A obra de Gregori Warchavchik

foi recentemente estudada do

ponto de vista da preservação.

Esse estudo indica a interpretação

da historiografia da arquitetura

moderna como orientadora nas

práticas de salvaguarda e de como

fundamentar critérios de seleção

e intervenção, ver: INVANOMOTO,
Denise. Futuro do Pretérito:

historiografia e preservação na

obra de Gregori Warchavchik. São

Paulo: FAU-USP, 2012. Dissertação

(Mestrado) - Faculdade de

Arquitetura de Urbanismo/USP,

São Paulo.

10 Faz parte desses Anexos, os

seguintes itens: entrevistas com os

arquitetos autores das intervenções,

imagens reduzidas das pranchas

originais, imagens reduzidas das

pranchas do projeto de intervenção,

fortuna crítica de periódicos e

livros e tabela comparativa de

bens modernos tombados ou

considerados de interesse na cidade

de São Paulo. 



\section{A ARQUITETURA MODERNA EM SÃO PAULO: RECONHECIMENTO E PRESERVAÇÃO}

Este capítulo apresenta questões relativas à preservação do patrimônio arquitetônico do século $\mathrm{xx}$, em especial da arquitetura moderna e está estruturado em três partes com o objetivo de introduzir e instrumentalizar as análises dos capítulos subsequentes.

A primeira parte tem como objetivo discutir a consolidação do patrimônio moderno, tendo como base a historiografia e ainda explicitar as características da produção dessa arquitetura em São Paulo.

A parte seguinte busca compreender as especificidades relacionadas à preservação da arquitetura moderna, elencando temas levantados por diversos autores no enfrentamento dessa discussão.

Por fim, a terceira parte, se propõe a examinar os critérios metodológicos e suas aplicações no patrimônio recente, baseados na Carta de Veneza e discutir, entre outras coisas, como as ações de restauro podem auxiliar na ampliação do conjunto de bens patrimoniais, além de garantir a sua salvaguarda.
1.1 A CONSOLIDAÇÃO DO PATRIMÔNIO MODERNO PAULISTA

O processo de reconhecimento da arquitetura moderna como patrimônio cultural, teve início já na última década do século XX, contribuindo para que a produção dessa arquitetura recente começasse a ser considerada como documento histórico. Sobre o conceito de documento/monumento e como se desenvolvem essas escolhas, Le Goff afirma:

"De fato, o que sobrevive não é o conjunto daquilo que existiu no passado, mas uma escolha efetuada quer pelas forças que operam no desenvolvimento temporal do mundo e da humanidade, quer pelos que se dedicam à ciência do passado e do tempo que passa, os historiadores." (LE GOFF, 1990, p. 535)

A partir dessa premissa, concluímos que o objeto arquitetônico deve ser entendido como documento histórico que carrega consigo uma série de informações, tanto de [as notas referentes ao Capítulo 1 encontram-se a partir da p. 51] 
sua própria produção e conceitos, quanto de parte da sociedade que a concebeu. Como evidencia Antinucci, ao mencionar Brandi: "uma obra de arte não se compreende se reconhece, pois o que se reconhece é o inteiro processo que a produziu." (ANTINUCCI, 1966, p. 7-33 apud KÜHL, 2008a, p. 362)

Nesse sentido, Argan comenta em seu livro Projeto e Destino que essa é uma característica do ser humano, que "não se adapta ao ambiente, mas adapta o ambiente a si" deixando marcas não casuais, "signos que têm o valor de mensagens e com os quais podemos começar a reconstruir a sua história". E que podemos considerar documentos desde "narrativas escritas e memórias transmitidas" até "os vestígios de estabelecimentos, os restos de construções, as armas, os utensílios, tudo". E conclui: "Não há documento que não seja o produto de um projeto de uma operação técnica." (2004, p. 16)

Por sua vez, apesar de suas características específicas, o tombamento dessa arquitetura recente segue o mesmo padrão do patrimônio em geral, ou seja, pela sua excepcionalidade, por suas características técnico-construtivas, por sua importância no quadro da historiografia da arquitetura e ainda em casos emergenciais, como aponta Wolff: “O outro aspecto a determinar os tombamentos é o risco iminente de sua destruição." (WOLFF, 1998. apud OKSMAN, 2011)

Podemos concluir, então, que o papel da memória e da história é fundamental para embasar as razões por que devemos preservar e como devemos atuar em relação à preexistência, baseados nas vertentes teóricas, que nos dispo- nibilizam os instrumentos conceituais que devem guiar a nossa atuação prática. (KÜHL, 2006, p. 20-21)

Como um alerta aos próximos anos, do que iremos enfrentar ao nos depararmos com a discussão sobre o reconhecimento e as corretas razões para se restaurar o patrimônio moderno, Salvo evidencia:

"O propulsor que ativa o processo não é, pois, o preventivo reconhecimento do valor histórico-arquitetônico que deveria ser um prelúdio ao ato metodológico da restauração, mas a descoberta do estado de devastação de um patrimônio que, de modo evidente, perdeu forma e completude, não obstante o breve tempo transcorrido (...)" (SALVO, 2008, p. 201)

\subsubsection{A IMPORTÂNCIA DO IMÓVEL ENQUANTO BEM CULTURAL E SUA CONSOLIDAÇÃO COMO PATRIMÔNIO ATRAVÉS DA} HISTORIOGRAFIA

Ainda sobre a questão da memória, podemos afirmar, no caso da arquitetura produzida no século $\mathrm{xx}$, que a historiografia tem um papel de suma importância para a sua consolidação e seu efetivo reconhecimento, como relata Dedecca:

"As revistas configuram-se como uma das principais fontes para o entendimento político e ideológico de seu tempo e nos ajudam a compreender redes de sociabilidade, lugares de aprendizado e trocas intelectuais, indicando a dinâmica do movimento de fermentação e circulação de ideias, permitindo traçar um campo arquitetônico configurado sobretudo de práticas difusas e interativas." (DEDECCA, 2009)

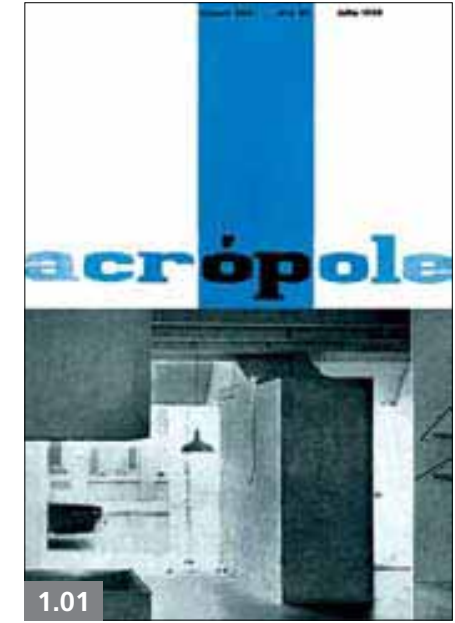

1.01 Revista Acrópole, capa com arte de Alexandre Wollner e edição especial sobre Zanettini, Campos Filho e Korciuszko Corrêa 
A importância das revistas, mesmo que escassas, no processo de reconhecimento e de forjamento de uma arquitetura particularmente paulista, é também destacada por Acayaba:

"Havia poucas publicações sobre as casas modernas brasileiras (...) os projetos brasileiros conhecíamos através da revista Acrópole (...) a dedicação com que estas casas foram estudadas, reunidas e reproduzidas, começou a definir, de certo modo, a existência da escola paulista." (ACAYABA, 2011, p. 28-33) [FIG. 1.01]

Essa ideia é compartilhada por Segawa que argumenta: "A disseminação mais ampla de alguns dos valores da arquitetura paulista, no entanto, se deu por meio da revista 'Acrópole', editada em São Paulo." (1997, p. 152)

\subsubsection{ARQUITETURA MODERNA BRASILEIRA E AS ESPECIFICIDADES PAULISTAS}

Levando essa discussão para os primórdios do surgimento da arquitetura moderna no Brasil, o próprio Segawa ${ }^{2}$ as sinala que, apesar do projeto para o Ministério da Educação e Saúde Pública [FIG. 1.02] figurar como "ponto inicial de uma arquitetura moderna de feitio brasileiro" (1997, p. 92), foi somente com o pavilhão brasileiro da Feira Mundial de Nova York em 1938 [FIG. 1.03] - "considerado um dos pontos altos de toda a exposição" (1997, p. 93) e com uma "positiva repercussão no Brasil" (1997, p. 93) - que se materializou, primeiramente, os cinco pontos ${ }^{3}$ de Le Corbusier, pois a sede do MESP encontrava-se ainda em obra ${ }^{4}$.
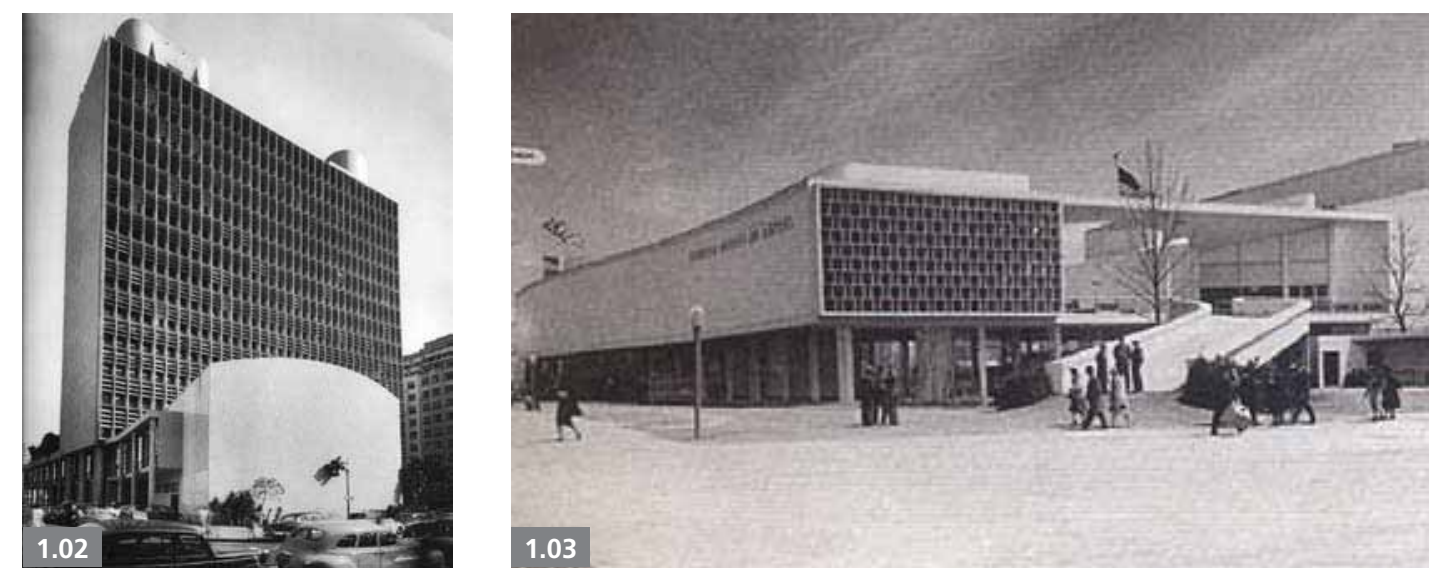

De qualquer maneira, não podemos deixa de reconhecer a importância da obra do arquiteto Gregori Warchavchik como fundamental na arquitetura moderna no Brasil, bem como a importância da "Casa Modernista" [FIG. 1.04] como precursora de um novo jeito de morar, como assinala Kamita:

"A 'casa modernista' foi exposta ao grande público da cidade de São Paulo em 1929, como exemplar do novo modo de construir e morar. Além da pureza do volume prismático e da planta funcional, o arquiteto desenhou os interiores (armários, peças de mobiliário, acessórios) seguindo os padrões do desenho moderno bauhausiano." (KAMITA, 2004, p. 142)

Sobre as diferenças comumente colocadas em relação à arquitetura moderna produzida em São Paulo em relação à do Rio

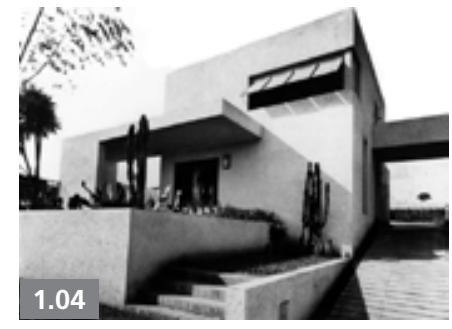

1.02 Ministério da Educação e Saúde Pública (MESP), atual Palácio Gustavo Capanema e também conhecido como MEC, Rio de Janeiro. Equipe: Affonso Eduardo Reidy, Carlos Leão, Ernani Vasconcellos, Jorge Moreira, Lucio Costa e Oscar Niemeyer, 1937-1945 1.03 Pavilhão de Nova York,

Lucio Costa e Oscar Niemeyer, 1938 1.04 Casa na rua Itápolis "Casa Modernista", São Paulo, Gregori Warchavchik, 1930 
de Janeiro, podemos afirmar que tal se deve, muito provavelmente, às nossas características urbanas e morfológicas.

Na história da cidade, inúmeras edificações e obras públicas contribuíram para modificar e mascarar as condições geográficas naturais do sítio original de São Paulo. (AB'SABER, 1963) [FIG. 1.05]

Como descreve Prado Jr.

"Deriva dessa topografia irregular o sentido geral do desenvolvimento da cidade e a estrutura do seu plano fundamental. A cidade nasceu justamente do promontório que forma a várzea do Tamanduateí de um lado, e o Vale do Anhangabaú do outro, dominando aí a pla nície extensa formada por aquela várzea e a do Tietê, no ponto em que confluem. (...) pode-se dizer que a estrutura da cidade de São Paulo foi grandemente influenciada pelos fatores geográficos, sobretudo o relevo e os cursos d'água que lhe marcaram profundamente a fisionomia." (PRADO JR., 1933, p. 125)

A ideia da relação direta dessas nossas peculiaridades de território com a arquitetura moderna produzida em São Paulo é compartilhada por diversos autores que destacam a espacialidade mais introspectiva como resultado, em especial ligada ao programa residencial. Dentre esses autores, podemos nos apoiar em Acayaba, que comenta:

"A solução de espaço interno está ligada à trama urbana paulista. A falta de paisagem em São Paulo conduziu a essa tendência para a interiorização. Daí, então, essas casas com pátios, jardins no centro ou voltadas para os fundos." (ACAYABA, 1986, p. 68-70)
Wisnik, também reforça essa particularidade da arquitetura paulista: "Produzida em uma cidade que cresceu vertiginosamente e quase sem planejamento, sob a lógica selvagem da especulação imobiliária, essa arquitetura vai se introverter." (2004, p. 42)

Tratando dessa e de outras particularidades da arquitetura moderna em São Paulo, Zein, em sua dissertação Arquitetura brasileira, escola paulista e as casas de Paulo Mendes da Rocha, aborda a dificuldade de reconhecimento da "escola paulista":

"Sem que seja totalmente reconhecida como tal, nem mesmo por seus pares, e menos ainda a nivel nacional e internacional, a escola paulista pode e deve ser considerada uma outra vanguarda brasi-

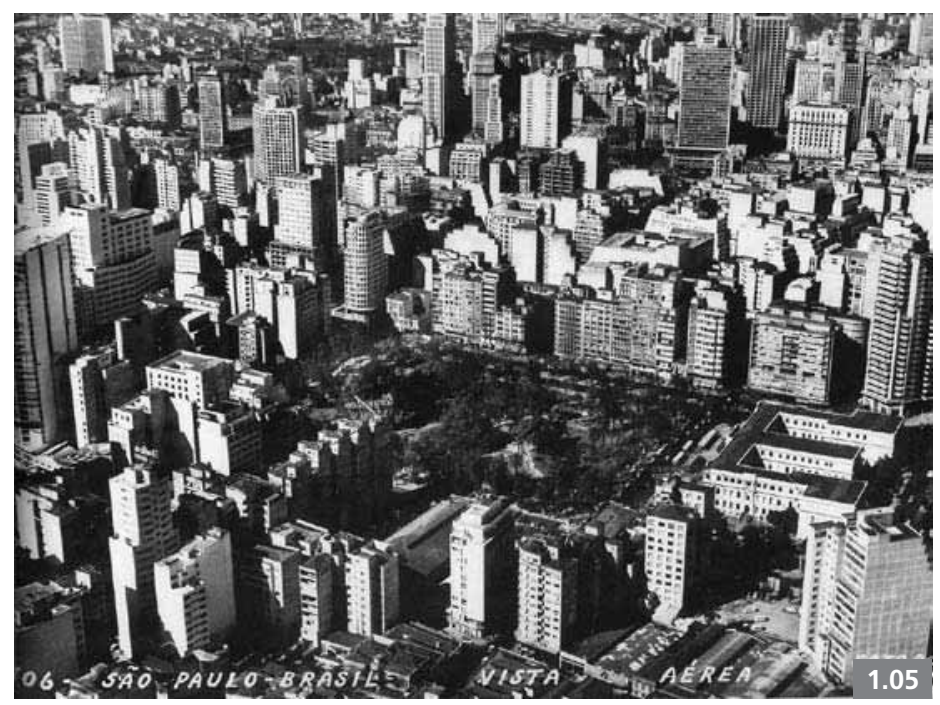

1.05 Praça da República centro de São Paulo - vista aérea. Cartão-postal edifício Colombo 
leira, cuja afirmação principia a fermentar entre os arquitetos nos anos'50, consolidando-se localmente nos anos 1960 e expandindo nacionalmente sua influência formal nos anos' 70 . Conhecida também como arquitetura paulista brutalista, destaca entre seus epígonos nome como João Batista Vilanova Artigas, Paulo Mendes da Rocha, Ruy Ohtake, Decio Tozzi, Eduardo de Almeida, entre outros, incluindo de maneira mais oblíqua, arquitetos como Carlos Millan e Joaquim Guedes, e igualmente, embora de maneira menos reconhecida, a figura impar de Lina Bo Bardi." (ZEIN, 2000, p. 10)

Já em um artigo para o Seminário росомомо Brasil, realizado em Niterói no ano de 2005, Zein descreve de maneira sistemática as características dessa arquitetura tão peculiar produzida entre os anos 1950 e meados dos anos 1970 em São Paulo, indicando-as em tópicos: quanto ao partido, quanto à composição, quanto às elevações, quanto ao sistema construtivo, quanto às texturas e ambiência lumínica e quanto às características simbólico-conceituais. Com isso, busca compreender essa específica produção arquitetônica e reiterar a existência de uma "escola". (ZEIN, 2005, p. 16-18)

\subsubsection{A INCLUSÃO DA ARQUITETURA MODERNA EM SÃO PAULO NO RÓTULO BRUTALISTA}

No capítulo $O$ aparecimento do Brutalismo e seu sucesso em São Paulo, Bruand cita a importância da obra de Vilanova Artigas para a afirmação desse estilo e ressalta o exemplo da utilização do concreto armado, mesmo em alguns programas de menor escala, como, por exemplo, os projetos residenciais:
"Da casa de Olga Baeta (1956-19857) até a segunda casa de Bittencourt (1960), passando pela casa de Rubens Mendonça (1957-1958), assiste-se a várias modalidades de emprego do concreto bruto em tipo de programas onde ele parecia ser menos indicado." (BRUAND, 2008, p. 298) [FIGS. 1.06 E 1.07]

Por sua vez, Sergio Ferro, em entrevista à Marlene Acayaba, defende que, apesar da negação ${ }^{5}$ da palavra "brutalismo" 6 por Artigas, este já havia iniciado, por experiência própria, ensaios espaciais, plásticos e técnicos que iam ao encontro desse caminho um pouco antes do surgimento do referido "movimento". Ao comparar a postura de Artigas com a de Le Corbusier ${ }^{7}$ no Convento de La Tourette [FIG. 1.08], Ferro assinala que, apesar desse último ter sido um modelo plástico de conduta, não possuía - diferentemente de Artigas - a característica de "verdade estrutural":
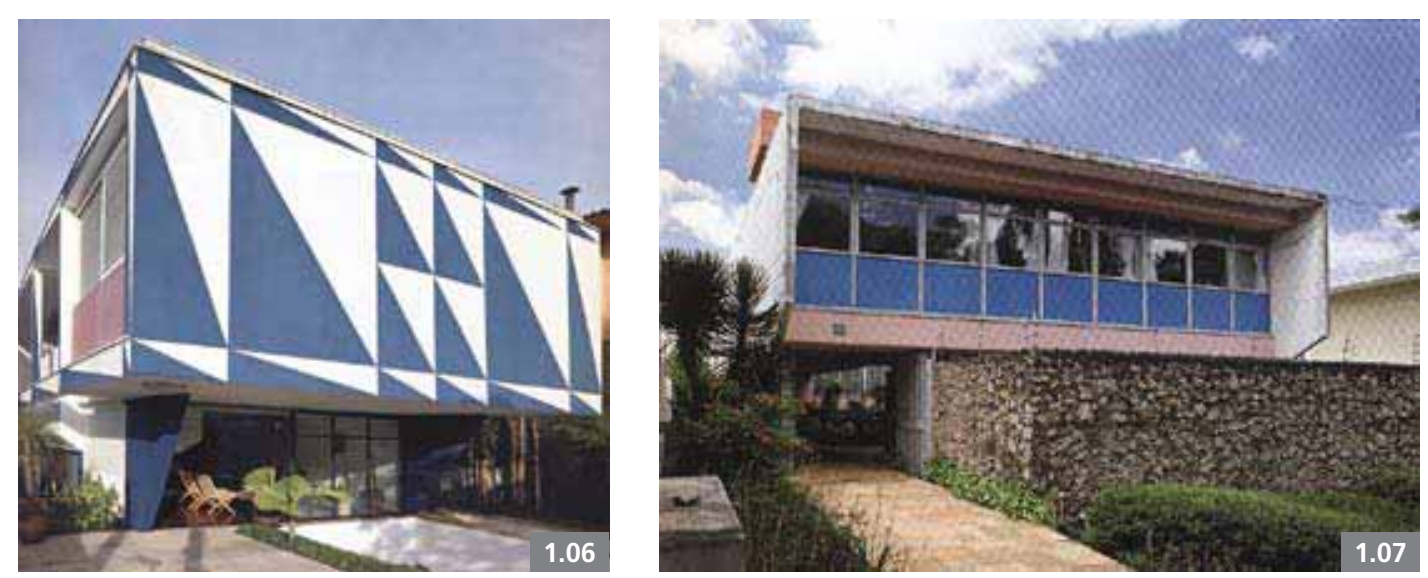

1.06 Casa Rubens de Mendonça, São Paulo, Vilanova Artigas e Carlos Cascaldi, 1958-1959 1.07 Segunda casa Taques Bittencourt, São Paulo, Vilanova Artigas e Carlos Cascaldi, 1959-1960 
"Enquanto na obra de Artigas a estrutura é clara, bem pensada e aparente, no convento o que se vê não é a estrutura real. Desse modo, aquela espécie de sinceridade construtiva da obra de Artigas toma um sentido inverso no convento, onde há muito 'décor', muito reboco e argamassa. No Brasil, nesse período, principalmente através de Artigas, a tese de base era aproveitar cada componente da técnica construtiva com máxima clareza e honestidade." (ACAYABA, 1986, p. 68)

\subsubsection{O USO DO CONCRETO APARENTE NA ARQUITETURA MODERNA PAULISTA E A CONFIGURAÇÃO ESPACIAL COMO ELEMENTOS DE IDENTIFICAÇÃO}

Assim como Bruand, a ideia da importância do concreto como característica identitária da arquitetura moderna paulista, também é defendida por Acayaba: “(...) o emprego extensivo do concreto armado aparente em volumes compactos resultou em uma estética própria." (1986, p. 68)

Zein complementa esse argumento, sustentando, mais uma vez, que, ao se falar de "escola paulista", devemos ter em mente a estrutura e a técnica construtiva:

"(...) talvez o que defina a sua especificidade não seja apenas seus elementos de composição ou materiais de eleição, mas igualmente a ênfase colocada nos aspectos como a racionalidade construtiva e clareza estrutural." (ZEIN, 2000, p. 14)

Apoiados neste raciocínio, podemos então afirmar que, mais do que os materiais simplesmente, é essa nova configuração

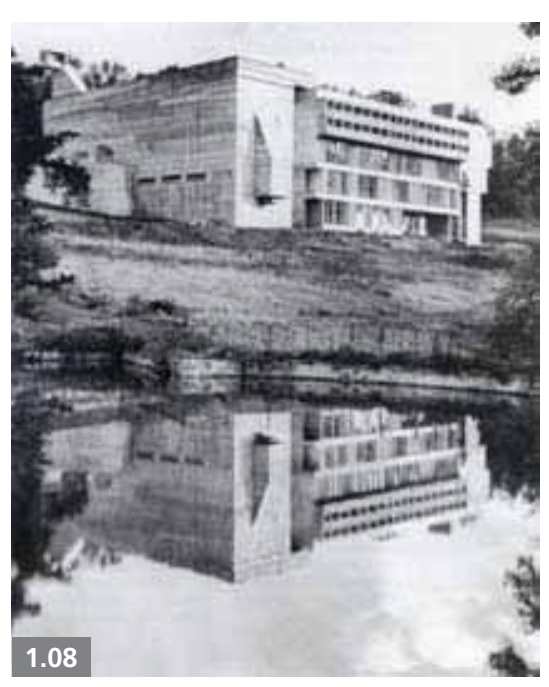

espacial que dá à arquitetura moderna paulista a sua identidade. Lemos reforça essa ideia e postula que o desenho desse espaço será indutor também de mudanças de hábitos de seus ocupantes, e afirma:

“(..) a continuidade espacial é a tônica e, nisso, há uma espécie de 'proletarização' dos programas através das superposições então consequentes e inevitáveis (...) com essa pretendida continuidade espacial, as paredes divisórias deixam de ser efetivamente isoladoras de atividades para tornarem-se simplesmente selecionadoras de ambientes, havendo uma intencional promiscuidade (...) realmente, a tendência de muitos é 'aproveitar' as vantagens das modernas estruturas, com suas possibilidades de grandes vôos ou largos espaços, para sugerir um 'novo' modo de vida." (LEMos, 1989, p. 74)
1.08 Convento La Tourette, Eveux-sur-Arbresle, Le Corbusier, 1953-1960 
Kamita, também percebe essa importante transformação que a arquitetura moderna em São Paulo iria indicar, sendo o programa residencial o disseminador das mudanças que a sociedade iria sofrer: “(...) a casa moderna cumpriria a tarefa de informar e convencer uma sociedade ainda não integralmente preparada, da adequação, da necessidade, da inevitabilidade do Novo." (KAmita, 2004, p. 142)

\subsubsection{ARQUITETURA MODERNA E OS ÓRGÃOS DE PATRIMÔNIO:} O CASO PAULISTA

Ao se tratar da relação entre Patrimônio Cultural e a arquitetura moderna no Brasil, uma informação que deve ser levada em conta é que "a arquitetura moderna foi precocemente reconhecida como patrimônio cultural", sendo esta uma especificidade brasileira, fruto da formação do corpo técnico ${ }^{8}$ do SPHAN 9 .

Oksman ainda aponta que, apesar do tombamento da Igreja da Pampulha [FIG. 1.09] e do MEC [FIG. 1.02] em 1947, essa ação não teve continuidade e "a grande produção moderna brasileira, da segunda metade do século xx, demorou a ser protegida" e "diversos edifícios modernos emblemáticos foram desfigurados ou demolidos". (2011, p. 20)

Simona Salvo em sua conferência $A$ intervenção na arquitetura contemporânea como tema emergente do restauro, deixa claro as razões do "atraso na reflexão" sobre o ingresso da arquitetura moderna no "terreno da tutela", ao afirmar que:

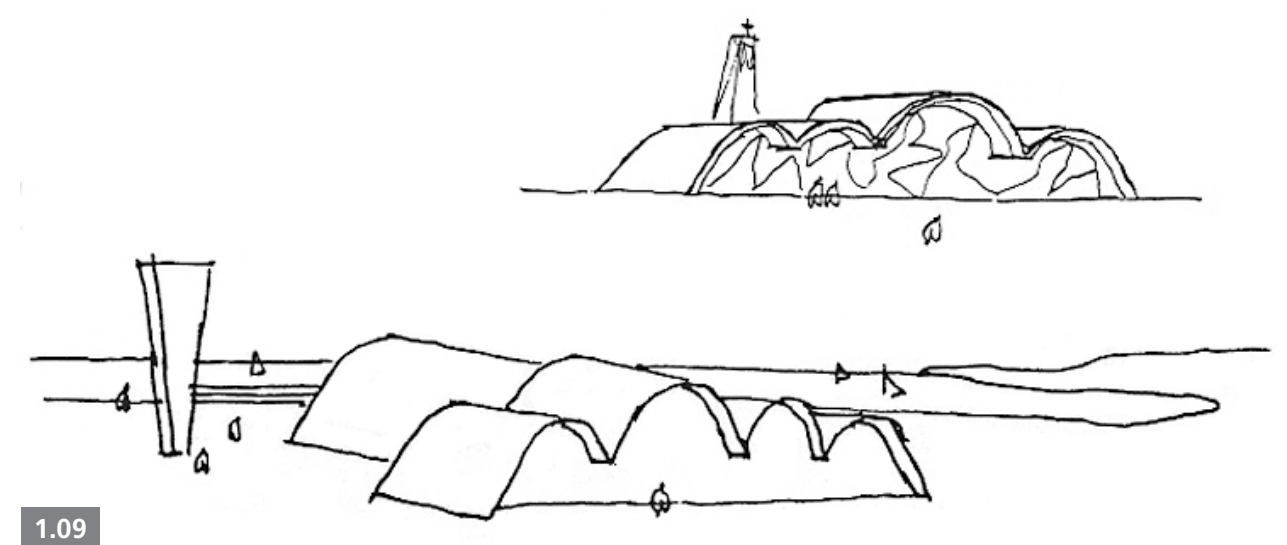

"O cerne do problema está (...) no desconforto histórico-crítico que, inevitavelmente, cerca o reconhecimento de um valor de obras recentíssimas, dificultado pela ausência de um congruente distanciamento 'histórico' e da falta de uma historiografia consolidada." (SALVO, 2008, p. 198)

Ainda sobre esse tema - e apoiado nos gráficos apresentados a seguir - fica claro o pouco, ou talvez ainda incipiente, interesse dos órgãos de preservação tanto pela arquitetura moderna, quanto, especificamente, por seus exemplares residenciais, tendo em vista o reduzido número de imóveis com essas características que se encontram tombados em São Paulo. Por sua vez, a permanência em razoável estado de conservação de diversos exemplares, sobrevivendo até mesmo à especulação imobiliária, é fruto de um reconhecimento por parte dos próprios proprietários, que aceitam a legitimidade de sua condição de bem cultural, como exemplifica Camargo:
1.09 Igreja de São Francisco de Assis, Pampulha, Belo Horizonte, Oscar Niemeyer, 1940 - croqui 
GRÁFICOS COMPARATIVOS - PATRIMÔNIO ARQUITETÔNICO DO

MUNICÍPIO DE SÃO PAULO ENTRE OS ÓRGÃOS DE PRESERVAÇÃO ${ }^{10}$

IPHAN (criado em 1937)

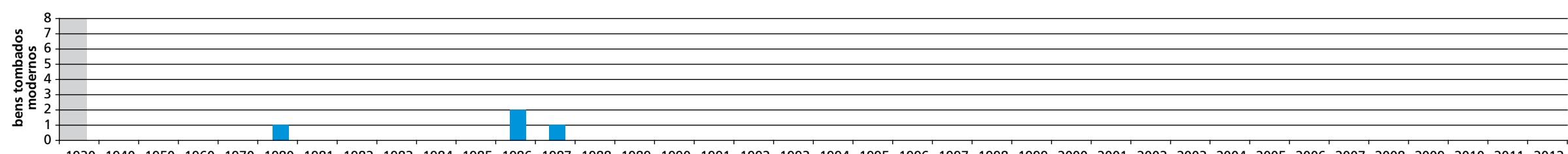

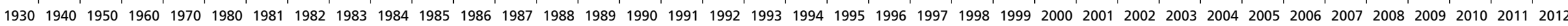

\section{CONDEPHAAT (criado em 1968)}

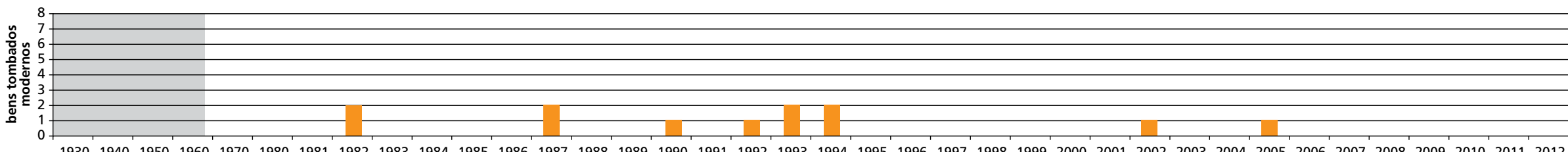

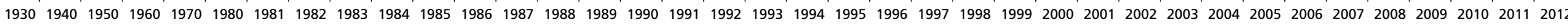

CONPRESP (criado em 1985)

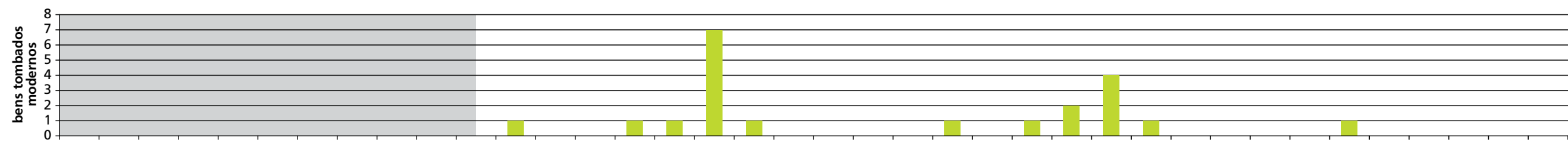

19301940195019601970198019811982198319841985198619871988198919901991199219931994199519961997199819992000200120022003200420052006200720082009201020112012 
IPHAN -

21 bens tombados

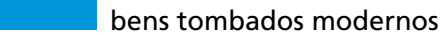

bens tombados não modernos

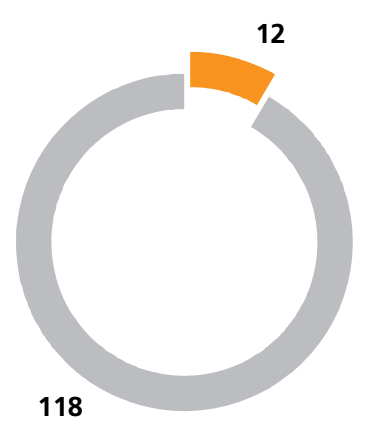

CONDEPHAAT -

130 bens tombados

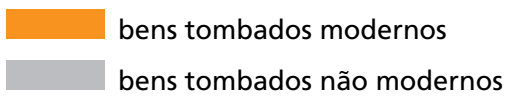

bens tombados não modernos

CONPRESP -

aprox. 300.000* bens tombados

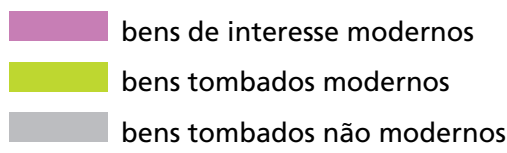

* Não foi possivel localizar a quantidade exata
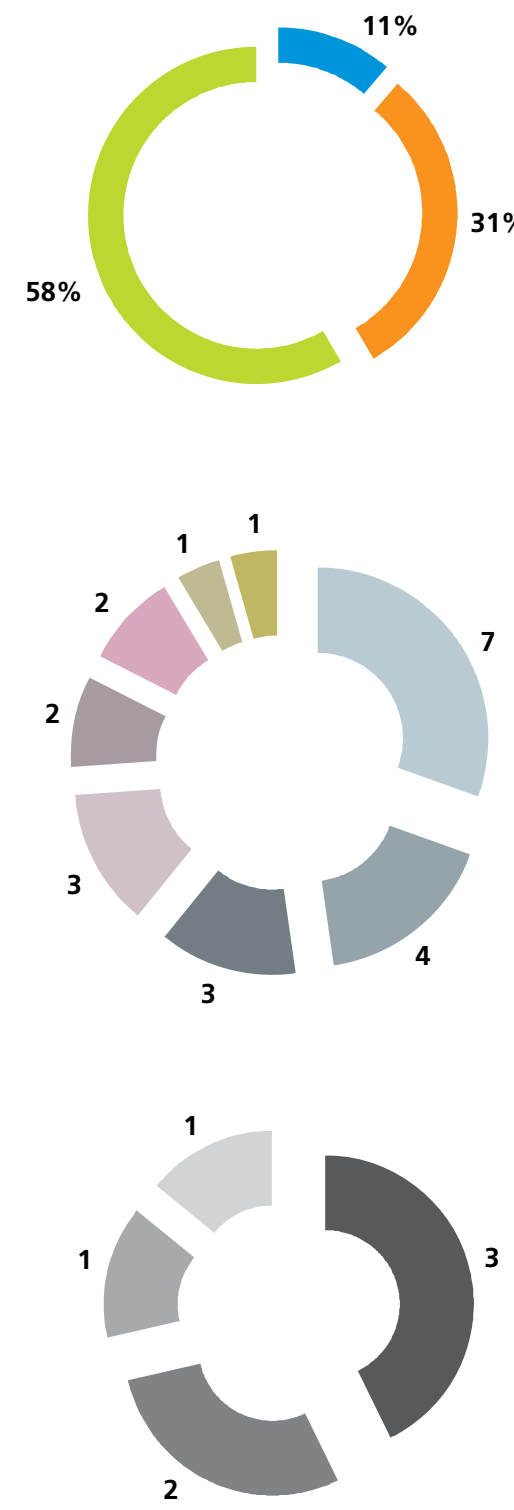

PATRIMÔNIO MODERNO -

bens tombados modernos** -

divisão por órgãos de preservação (em porcentagem)

\section{IPHAN \\ CONDEPHAAT \\ CONPRESP}

** Dos 37 tombamentos de bens modernos nos

três órgãos, 14 são repetições, totalizando apenas

23 bens tombados modernos

PATRIMÔNIO MODERNO -

23 bens tombados modernos -

divisão por programa arquitetônico

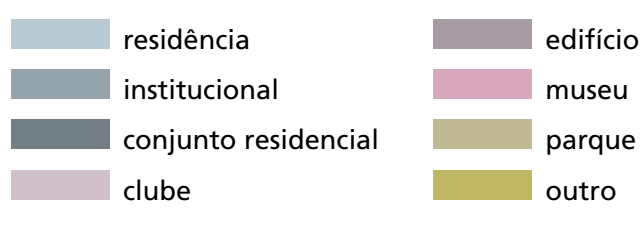

PATRIMÔNIO MODERNO -

7 residências -

divisão por autoria

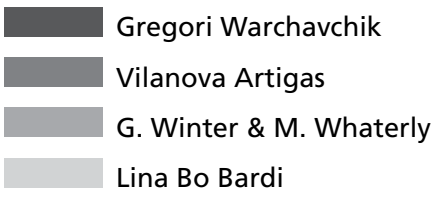




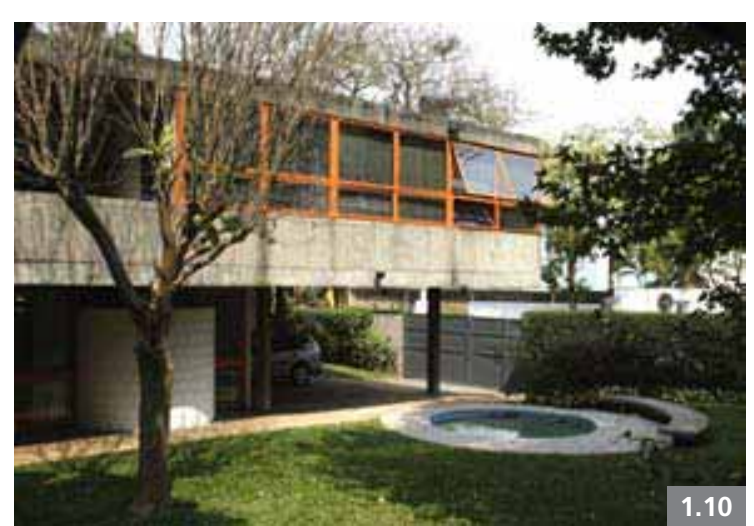

"As casas mais paradigmáticas do arquiteto Carlos Millan ainda estão com seus proprietários originais e inalteradas, fornecendo muitos elementos para a discussão do patrimônio residencial moderno." (CAMARGO, 2007, p. 2) [FIG. 1.10]

Assinala, ainda, que, apesar das residências paulistas serem reconhecidas tanto como tema de pesquisa, como de análise historiográfica, esse reconhecimento não está totalmente difundido nos órgãos oficiais, "dada à complexidade dos problemas relativos à sua preservação".

Esse reconhecimento por parte dos proprietários também não é unânime, devido a pouca informação e quase nenhum apoio dos órgãos competentes, como descreve Camargo novamente:

"O tombamento dos imóveis, das residências particulares, é entendido pelos seus proprietários como uma punição e não uma valorização, e sem o apoio da sociedade, esse instrumento legal perde a força." (CAMARGO, 2007, p. 2)
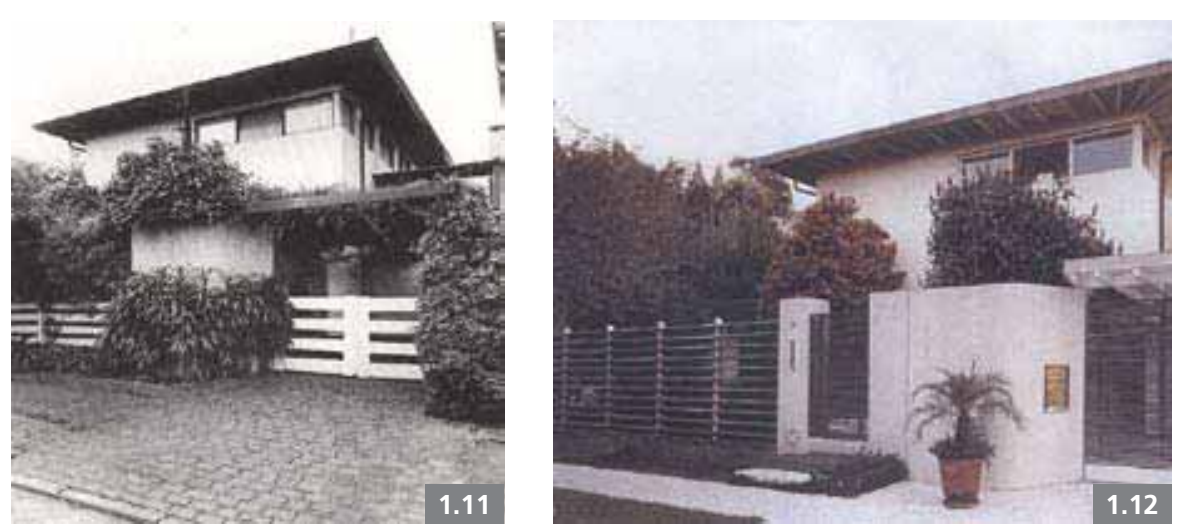

Essa opinião é compartilhada também por Oksman, que entende que "os casos de tombamento de residências são bastante polêmicos por envolver questões de propriedade" e que o processo de aprovação junto ao Estado envolvendo um bem tombado, exige um empenho "financeiro" e "burocrático" oneroso ao proprietário, ressaltando, ainda: "Além disso, há a incompreensão de que o tombamento não é um congelamento do imóvel, mas uma diretriz que orienta as intervenções no sentido de preservação deste bem." (OKSMAN, 2011, p. 72)

Um exemplo feliz de que o reconhecimento de um imóvel como bem cultural pode indicar novos caminhos a serem seguidos, é a intervenção do arquiteto Mauro Munhoz ${ }^{11}$ em uma residência projetada por Oswaldo Bratke em 1945 [FIGS. 1.11 E 1.12], cuja identificação ${ }^{12}$ por parte do arquiteto, permitiu adotar "uma intervenção que valorizasse o bem original, atualizando-o segundo suas necessidades". (CAMARGO, 2007, p. 7)

Por sua vez, a casa na rua Gaivotas (residência Krutman) ${ }^{13}$ [FIGS. 1.13 A 1.16], projetada por Vilanova Artigas em 1968, não teve a mesma sorte. Neste caso, a Fundação Vilanova Artigas
1.10 Residência Roberto Millan, São Paulo, Carlos Barjas Millan, 1960 1.11 Residência na rua Sofia, São Paulo, Oswaldo Bratke, 1945 1.12 Residência na rua Sofia reforma Mauro Munhoz, 2000-2002 1.13 Residência Krutman, São Paulo, Vilanova Artigas, 1968 - plantas 1.14 Residência Krutman - corte longitudinal

1.15 Residência Krutman - elevação 1.16 Residência Krutman - estudo elaborado pelos arquitetos Alexandre Delijaicov e Vera Domschke, que integrava a residência ao projeto do edifício, 1986 

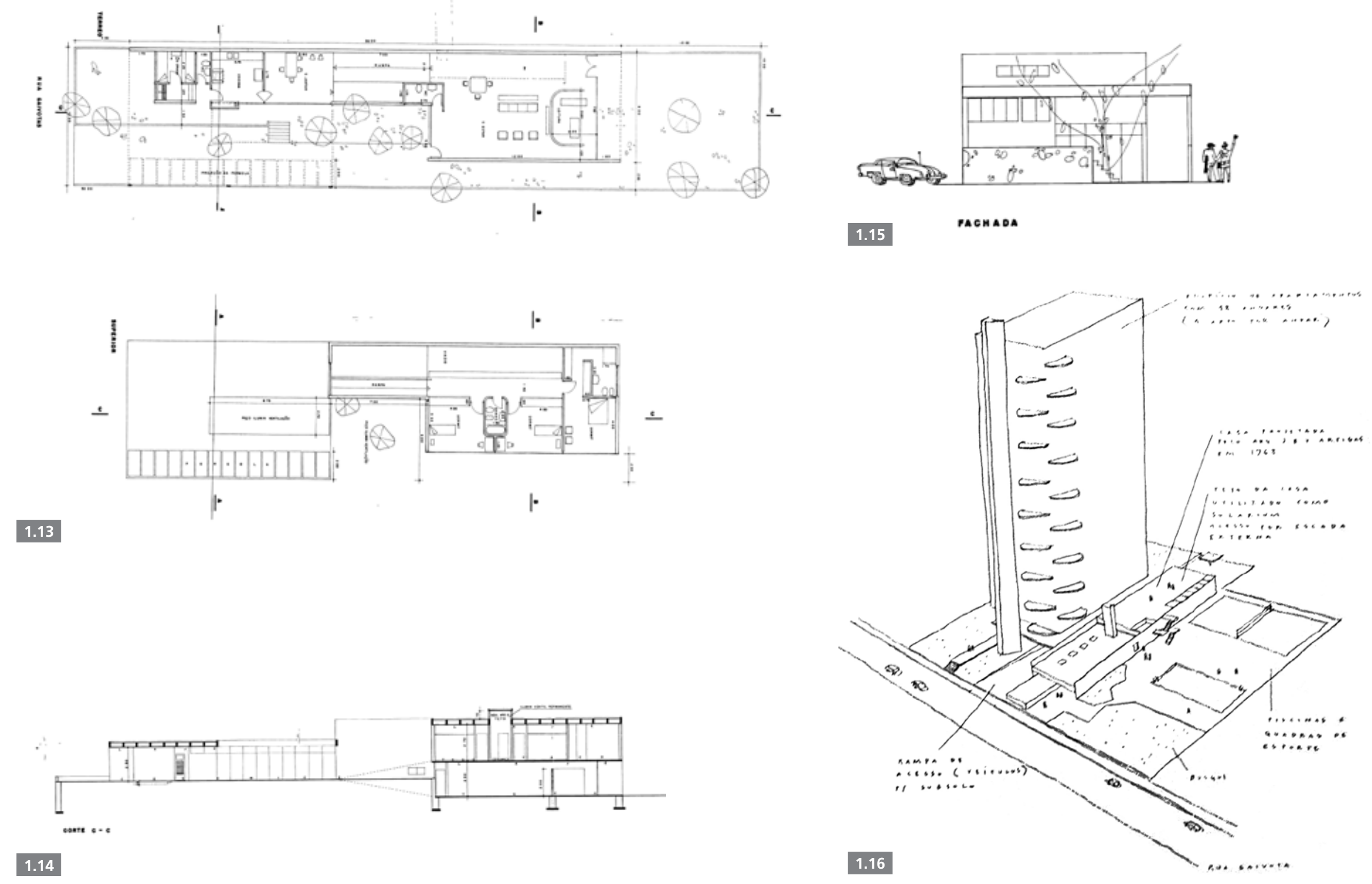
tentou negociar com a Construtora Paulo G. Boghosian para evitar a sua demolição. Colaborando nesse processo, os arquitetos Alexandre Delijaicov e Vera Domschke elaboraram um estudo preliminar, modificando apenas a implantação do edifício no terreno que iria ser construído, propondo a integração da nova edificação com a casa remanescente - esta iria abrigar alguns programas de lazer -, conforme podemos constatar em desenho publicado na revista Projeto ${ }^{14}$. Apesar das tratativas, a residência foi demolida, dando lugar a um edifício de apartamentos com 18 andares, projetado pelo arquiteto Israel Rewin.

É preciso ponderar, porém, que a solução em se preservar a qualquer custo, pode acarretar resultados nefastos, como descreve Oksman:

"A especificidade dos programas de alguns dos edifícios modernos e, portanto, a eventual dificuldade em atualizá-los é um dos argumen tos utilizados para justificar demolições e reformas que muitas vezes corrompem os seus valores. A demanda por mudança de uso e ade quação de espaços é uma questão que não pode ser negligenciada. Corre-se o risco de esvaziar um edifício e condená-lo a uma condição de falta de uso que acaba por destruí-lo simbólica e fisicamente." (OKSMAN, 2011, p. 40)

Por fim, Moreira ajuda a sintetizar:

"Uma estratégia mais ampla precisa ser elaborada para lidar com a complexidade e a escala da arquitetura do século $X X$, que inclui edifícios em altura, campi universitários, fábricas e casas estandardizadas." (MOREIRA, 2010, p. 199).

\subsection{AS ESPECIFICIDADES DA PRESERVAÇÃO DA ARQUITETURA MODERNA}

Neste item, se pretende examinar posturas e discussões acerca das intervenções em arquitetura moderna, a fim de compreender como as intervenções podem auxiliar na preservação de um bem cultural, no reconhecimento de seus valores intrínsecos e na sua atualização - tanto de instalações, como de usos - sem denegrir e modificar de maneira irreversível a edificação respeitando as normas e recomendações de preservação e de restauro, em especial as da Carta de Veneza, de $1964 .^{15}$

Sobre essa discussão específica, que relaciona restauro e patrimônio moderno, Salvo esclarece - em seu artigo Restauro e "restauros" das obras arquitetônicas do século 20: intervenções em arranha-céus em confronto - não ser esse um assunto recente, pois a questão "já se coloca há vinte anos", embora "ainda não se atingiu uma maturidade suficiente". Apesar de inúmeras experiências e oportunidades. Esclarece, ainda, ser possível identificar duas posturas distintas em relação a esse enfrentamento. A primeira, para "obras de valor reconhecido" produzidas na primeira metade do século $\mathrm{xx}$, onde as ações seguem o caminho da repristinação ${ }^{16}$, buscando reconduzir a obra ao estado "original"; a segunda, para as obras do segundo pósguerra - que se encontram "numa espécie de limbo" entre o reconhecimento de seu valor patrimonial e o "repertório formal" -, tem-se adotado a opção por "intervenções de contínua e desenvolta substituição". (2007, p. 139-143) Nestes dois casos, a tendência é a de "refazer antes de se conservar" (2007, p. 140) e suas consequências negativas são óbvias, de-
1.17 Edifício Pirelli, Milão, Gio Ponti, 1956-1961. Intervenção coordenada por Pietro Petraroia, Maria Antonietta Crippa, Carla Di Francesco e Giovann Carbonara, 2004

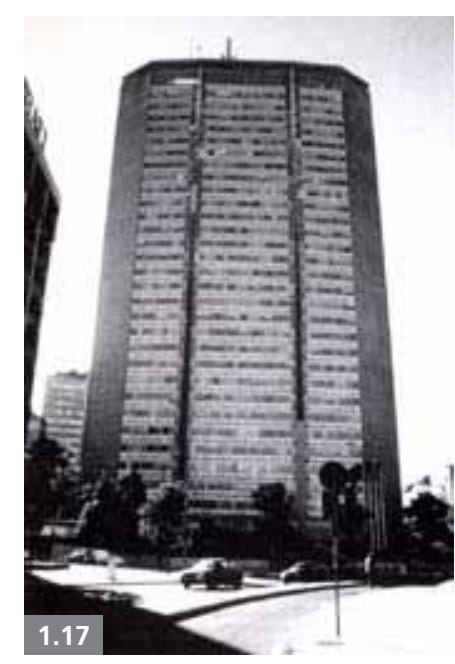


terminando "através do cancelamento de partes e de materiais autênticos, uma indubitável e progressiva perda de memórias arquitetônicas recentes" (2007, p. 141), como declara Salvo.

E conclui:

"Parece, com efeito, difusa e compartilhada - mas não, certamente, provada - a conviç̧ão de que as obras modernas não sejam restauráveis por acusa de sua natureza material, muito diversa daquela das obras antigas, para as quais se desenvolveu toda a prática da conservação." (SALVO, 2007, p. 141)

Não obstante, na contramão da tendência repristinatória, temos a obra realizada nas fachadas do arranha-céu da Pirelli ${ }^{17}$ [FIG. 1.17], que foi minuciosamente analisada por Salvo em seu artigo: Arranha-céu Pirelli: crônica de uma restauração, exemplo de sua "excepcionalidade e do caráter refinado da operação realizada na fachada", demonstrando, na prática, que é possível incorporar às intervenções de edifícios da arquitetura moderna as práticas de conservação e do restauro, enfrentando "a sua complexidade com o mesmo rigor teórico, metodológico e científico" das restaurações das obras anteriores ao século XX. (SALVO, 2007, p. 143-144)

\subsubsection{A PRESENÇA DOS ARQUITETOS AUTORES, VÍNCULOS E FATORES EXTERNOS}

Um caso bastante específico é a presença dos arquitetos autores como agentes da intervenção. Também, mas não tão raro, são os "discípulos que restauram os mestres", pois, pre-

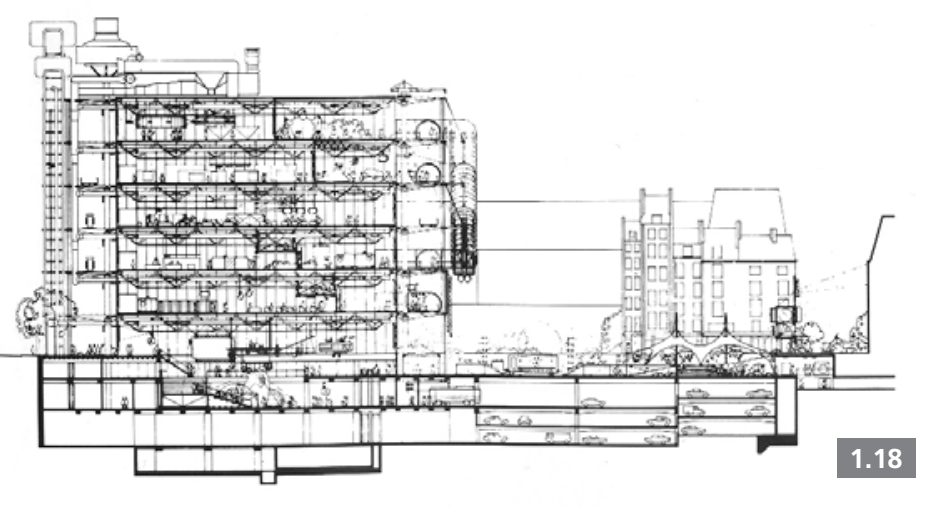

1.18 Centro Georges Pompidou (Beaubourg), Paris, Renzo Piano e Richard Rogers, 1971-1978 tensamente, imaginam saber dar continuidade digna à obra; ou, ainda, os próprios "filhos arquitetos" que, a partir de relações privilegiadas com o autor, determinam intervenções corretivas sem nenhuma preocupação com os critérios teórico-metodológicos do restauro. (SALVo, 2008, p. 206)

Ainda em Salvo, pode-se avaliar dois infelizes exemplos. No primeiro caso, a intervenção de Renzo Piano para o "Beaubourg" (Centro Georges Pompidou) [FIG. 1.18], cujo projeto ele mesmo realizou juntamente com Richard Rogers na década de 1970. Nessa intervenção executou-se "uma série de modificações", visando uma reestruturação dos espaços expositivos, das circulações e a resolução de "problemas funcionais e de gestão", que acarretaram na própria "traição da carga inovadora" contida no projeto na época de sua inauguração. (SALVO, 2008, p. 206) Neste sentido, Salvo expressa o seu desapontamento: 

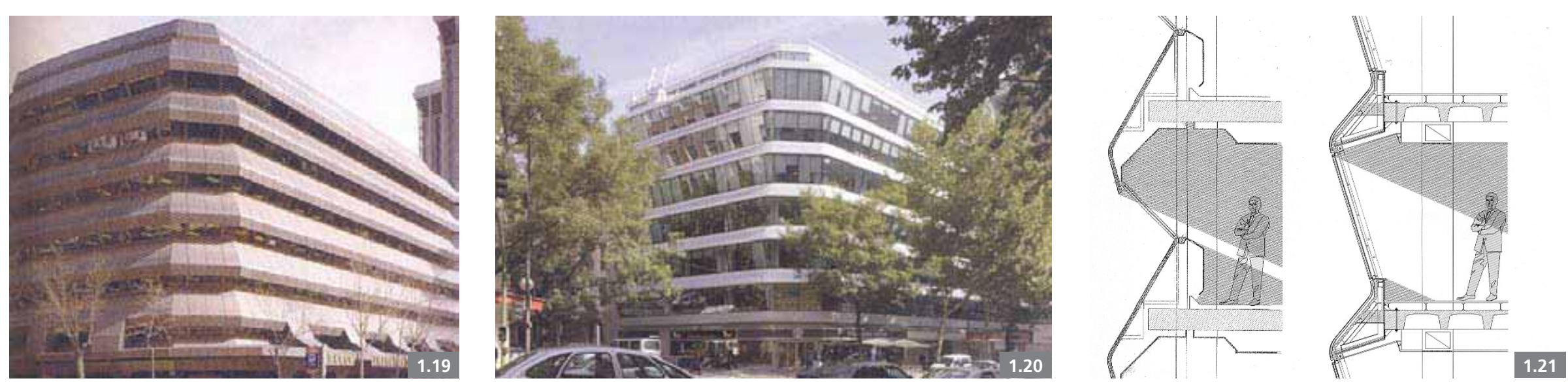

"Como, inevitavelmente, tende a fazer qualquer artista chamado a retrabalhar a sua própria obra, Piano 'reviu e corrigiu' a estruturação do velho Beauborg (...) realiza[ndo] uma espécie de repensamento pós-modernista da própria obra." (SALVO, 2008, p. 206)

O segundo exemplo ${ }^{18}$, também de resultado questionável em relação à postura frente a um bem de reconhecida importância, foi a intervenção nas fachadas do edifício de escritórios na rua Génova [FIG. 1.19], em Madri. O edifício foi, originalmente, projetado por Antônio Lamela em 1973 e teve seu projeto de "restauração" elaborado pelo Estudio Lamela ${ }^{19}$ [FIG. 1.20], em 2004. Neste caso, optou-se pelo refazimento de toda a fachada da edificação. Buscando atender à solicitação de aumento de luminosidade no interior da edificação. A nova fachada, não só elaborada com novos materiais, também modificou significativamente a relação de proporções das aberturas dos caixilhos e dos panos opacos. Mesmo a tentativa de se fazer no desenho dessa nova pele um perfil que faz menção às suas linhas originais [FIG. 1.21] não foi sufi- ciente sequer para resgatar a sua "imagem original"; mesmo porque - caso fosse essa a intenção -, isso apenas reiteraria a postura de seus autores de não entendimento dos conceitos de bem cultural, como expressa Kühl:

"Infelizmente, uma postura anistórica, a falta de entendimento em relação às raízes culturais da preservação e a ausência de critérios claros para a atuação em bens culturais, se verifica também em relação a edifícios do modernismo e a outras construções recentes." (KÜHL, 2008b, p. 200)

Essa proposta, também, contém uma questão, presente no âmago da discussão sobre restauro de patrimônio moderno: a presença e participação dos autores originais, ou de seus colaboradores, nos projetos de intervenção em obras de sua autoria, e que, não raro, revela a dificuldade em se atuar "segundo um distanciamento crítico e de modo fundamentado em relação à importância documental e formal dos bens". (KÜHL, 2008b, p. 201)
1.19 Edifício de escritórios na rua Génova, Madri, Antonio Lamela, 1973 - vista geral

1.20 Edifício de escritórios na rua Génova - resultado final da fachada executada, proposta pelo Estudio Lamela em 2004

1.21 Edifício de escritórios na rua Génova - cortes comparativos com as soluções da fachada original e da proposta executada pelo Estudio Lamela 


\subsubsection{A PÁTINA NO MODERNO}

Uma questão que não podemos deixar de comentar refere-se à pátina associada às edificações de patrimônio arquitetônico moderno.

A pátina está intimamente ligada às teorias de restauro, pois ilustra de maneira inequívoca a passagem do tempo e, em consequência, o envelhecimento do próprio bem. Por outro lado, quando lidamos com edificações do século Xx, essa imagem está associada à degradação ou abandono.

Nas edificações da arquitetura moderna, essa imagem da pátina parece conflitar com o próprio conceito com que a modernidade está relacionada, ou seja, o novo como imagem, o novo como construção, o novo como conceito, como expressa Salvo:

"Um equivocado potencial figurativo (como 'ícone') e a aparente inconsistência histórica do 'novo' invertem nossa espontânea propensão a conservar, agindo, ao contrário, na direção oposta, desencorajando esta última e encorajando, ademais, a repristinação da 'fácies' originária." (SALVO, 2008, p. 210)

Ainda sobre essa questão, Moreira conclui:

"A não aceitação da pátina levou muitas vezes à troca de materiais de revestimento em vez de sua recuperação e manutenção, afetando assim a autenticidade do edifício." (MOREIRA, 2010, p. 196)

Um exemplo positivo dessa aceitação, foi a intervenção na Ex-Casa del Fascio ${ }^{20}$ [FIG. 1.22] em Como: "correta e bem exe- cutada, alinhada com a melhor práxis de algumas das superintendências italianas" limitou-se a operações conservativas (limpeza, consolidação e proteção) nas placas de mármore botticino da fachada, que se encontrava em péssimo estado de conservação devido a problemas de manutenção nos anos de 1960. Sua substituição limitou-se a "poucas placas não recuperáveis", representando, assim, "um pioneiro caso de intervenção em obra moderna". (SALVO, 2008, p. 208)

\subsubsection{AS ESPECIFICIDADES TÉCNICAS DA ARQUITETURA MODERNA DEVIDO ÀS SUAS CARACTERÍSTICAS DE VANGUARDA}

Quanto às especificidades técnicas da arquitetura moderna, devido às suas características de vanguarda, sabemos que buscou processos mais rápidos de construção, a redução das espessuras, o aumento dos vãos estruturais, novos materiais experimentais, a ampliação do vazio e novas soluções de coberturas, entre outras coisas, resultando não só em seu envelhecimento precoce, como também no surgimento de patologias que ameaçam muitas vezes a própria permanência do bem.

Araujo descreve essa situação com bastante objetividade:

"La construcción moderna es, en general, más precaria que la tradicional, debido en gran parte a su progresivo aligeramiento: La masividad es una defensa contra el tiempo, y la construcción ligera tiene un peor envejecimiento que la de mayor peso propio. Pero además, la arquitectura moderna nació ligada al empleo de tecnologías

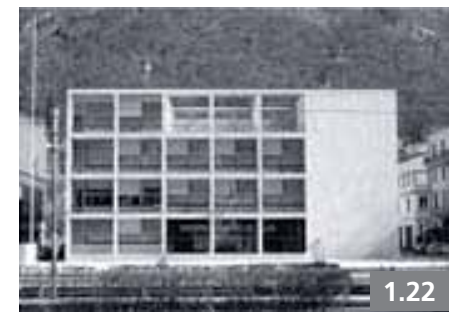

1.22 Ex-casa del Fascio, Como, Giuseppe Terragni, 1932-1936 
y materiales completamente nuevos en su tiempo, que acabaron con el ciclo del sistema mural. El siglo XX fue una continua experimentación con soluciones no siempre afortunadas, pero sobre todo nuevas, con un comportamiento a largo plazo difícil de prever. La suma de aligeramiento y experimentación produjo una arquitectura problemática ante el paso del tiempo."21 (ARAUJO, 2010, p. 4)

Em relação a essa característica de inovação tecnológica, Ferraz $^{22}$ cita um relatório do CIAM, elaborado por Gregori Warchavchik, onde este comenta a não existência de "material isolante" ${ }^{\prime 23}$, o que de certa forma exemplifica a dificuldade que esses arquitetos enfrentaram, no Brasil, para atender, dentro dessa nova plasticidade, as soluções primordiais da arquitetura moderna. Ainda como exemplo, Segawa relata progressos na oficina do próprio Warchavchik, deixando clara a iniciativa de criação de mão de obra especificada para atender às novas demandas dessa nova arquitetura. (SEGAWA, 1997, p. 46)

Araujo argumenta que a busca da preservação do patrimônio moderno requer uma posição que se deve assumir - a conservação do princípio construtivo original -, a qual aceita que "o edifício terá carências de diferentes tipos, mas estes muitas vezes são os seus valores e não se pode resolvê-las sem atentar contra eles"24 (ARAUJO, 2010, p. 5), concluindo que "parece melhor valorizar aquilo que se tem de positivo, o que não é difícil, porque a arquitetura daqueles anos é portadora de muitos elementos e soluções hoje perdidas; e, portanto, recuperar materiais e técnicas até há pouco convencionais, alcança a cada dia um novo sentido, sobretudo por conservar ainda certos valores 'artesanais'". ${ }^{25}$ (ARAUJO, 2010, p. 5)

E Oksman, complementa:

"O caráter experimental de determinadas soluções acarretou, em alguns casos, perda de desempenho, envelhecimento do material è às vezes problemas estruturais. Paradoxalmente, há situações em que é exatamente nestes pontos que estão os valores dos edifícios a serem preservados." (OKSMAN, 2011, p. 30)

Moreira, em seu artigo Os desafios postos pela conservação da arquitetura moderna, apresenta alguns tópicos que, segundo o próprio autor, "merecem uma reflexão mais cuidadosa" quando se enfrenta essa questão. Dentre eles podemos destacar: a "dificuldades para se encontrar e introduzir novos usos", o "uso de materiais novos sem tradição construtiva", o "problema do detalhamento", o "uso de materiais usados em série", os "problemas de adequação" nos sistemas infraestruturais, a "ausência de uma cultura da manutenção", a "dificuldade de aceitação da pátina" e os "problemas existentes no reconhecimento e tombamento". (MOREIRA, 2010, p. 189)

Montaner, em seu artigo Intervenciones em Arquitectura Moderna, também exprime preocupação em relação aos materiais utilizados na arquitetura moderna e ao enfrentamento de determinadas questões para a sua revitalização. Ao discorrer sobre a "evolução dos materiais", afirma que esse é um ponto-chave, um "ponto de inflexão", onde estes - a partir da industrialização dos elementos, sua "produção em série", "seu anonimato" e "repetitividade" - são incor- 
porados a uma lógica da arquitetura que tende à homogeneização dos materiais, não sendo mais possível a sua identificação - a exemplo do que era feito antes, onde se podia identificar a madeira, a pedra e o tijolo.

Ainda dentro desse raciocínio, a "intercambiabilidade" é o segundo ponto importante, pois, além da "rápida montagem", ela contém a ideia de que "cada peça já não se repara, apenas se substitui". Esse ponto contém um dos problemas mais recorrentes de muitas das intervenções que, por motivos que não vem ao caso enumerar, optaram pela troca do material original. Essa postura acaba por induzir leituras equivocadas ${ }^{26}$ do patrimônio envolvido.

O último ponto a considerar, é a especialização, sobre a qual Montaner afirma:

"Cada material y cada elemento constructivo servía para una función específica: estructural, aislamiento térmico, aislamiento acústico, impermeabilización, protección contra el fuego, recubrimiento, decoración (...)."27 (MONTANER, 2009, p. 42)

E exemplifica:

"(...) a partir de la cultura del hormigón armado aparece un material que una vez consolidado ya no puede tener una vida en otro lugar: solo puede mantenerse, repararse o derribarse. "28 (MONTANER, 2009, p. 42)

De todo modo, Salvo coloca claramente que devemos olhar para o patrimônio moderno, além dos materiais e patolo- gias existentes, encarando-o como documento histórico a ser preservado, retomando, assim, o argumento de Araujo, e complementando:

"A característica física do moderno, portanto, não deve ser encarada como um defeito a ser corrigido, mas como essenciais formas de expressão e criatividades a serem tuteladas; por conseguinte, reagir ao declínio, refazendo sem meios-termos, implica recorrer a modalidades superficiais e inconstantes de agir, que traem o significado da obra, colocando-se imediatamente fora do campo da restauração." (SALVO, 2008, p. 200)

E nos alerta, de maneira enfática:

“(...) o clima de revisionismo vigente em âmbito internacional e, em particular, a negação dos efetivos méritos da Carta de Veneza, tendem a constringir o debate sobre a preservação a questões de mera natureza técnica (...) Ao desenvolvimento macroscópico do tema, sintoma de uma novidade passageira e não da vontade de aprofundar seu mérito, contrapõe-se um enfraquecimento do debate em torno de questões centrais, tais como o desenvolvimento de adequada historiografia, a busca pela 'veracidade' dos materiais e técnicas construtivas, o estudo de técnicas para o restauro adequadas às obras modernas (...) A penúria de restaurações bem conduzidas e a abordagem teórica metodológica, geralmente fria e pouco fértil, limitaram o crescimento de um real conhecimento material e construtivo da arquitetura do século 20 , que, somente pode ser obtido pela indagação direta da obra, no canteiro, e apenas se as finalidades e intenções forem aquelas de indagar para reconhecer e conservar." (SALVO, 2008, p. 202) 
1.2.4 A PRESERVAÇÃO DO MODERNO: PATOLOGIAS

\section{E OUTRAS QUESTÕES PURAMENTE TÉCNICAS}

Apesar de concordar com a última afirmação de Simona Salvo, nos pareceu importante indicar, mesmo que superficialmente, questão técnicas e patológicas ligadas ao restauro do patrimônio moderno, pois muitos desses problemas estão associados tanto aos seus elementos construtivos, como também aos seus materiais e às suas infraestruturas, ou seja: a presença quase constante da estrutura em concreto aparente ${ }^{29}$, as vedações em caixilhos metálicos, as divisórias leves, as fachadas independentes e as instalações elétricas e hidráulico-sanitárias.

Novas demandas de conforto térmico e acústico, o incremento de maior número de eletrodomésticos e equipamentos tecnológicos que certamente acarretarão na modernização das instalações prediais, a necessidade de adequação às normas de combate a incêndio e à acessibilidade universal, a abundância de componentes industrializados disponíveis para complementação ou substituição de elementos, as patologias tanto nos fechamentos da fachada como nas esquadrias metálicas, muitas vezes tendo sua estanqueidade comprometida e, por fim, as atuações nas estruturas portantes sem comprometer o princípio construtivo original, são alguns dos itens que certamente iremos enfrentar ao nos depararmos com a necessidade de preservação de um patrimônio da arquitetura moderna.

Neste sentido, Moreira esclarece que:

"A dimensão material dos edifícios modernos criou certos empeciIhos à sua conservação. Métodos e materiais tradicionais não foram abandonados, mas usados de novas maneiras ou em combinação com novos materiais. Por exemplo, a pedra, usada por séculos como material de construção, foi empregada em edifícios modernos como revestimento." (MOREIRA, 2010, p. 191-192)

Ainda sobre os novos revestimentos e suas combinações, Moreira comenta sobre o uso de placas de pedra que "reagem com as peças metálicas que servem para conectá-las à construção, causando oxidações e outras reações", ilustrando com um caso específico de patologia na fachada em placas de pedra do Finlândia Hall de Alvar Aalto (1965-1975) [FIGS. 1.23 A 1.24], cujas "placas de mármore Carrara italiano se deformaram" quando submetidas ao rígido inverno finlandês e acabaram por ser totalmente substituídas em 1997.

Sobre o enfrentamento de questões estruturais e de técnicas construtivas nas edificações da arquitetura moderna, temos o relato de Araujo sobre a obra de restauro da Fundação Miró [FIGS. 1.25 A 1.27], projetada por Josep Lluís Sert em 1975, coordenada por J. Freixas e S. Soteras em 2004:

"Las armaduras del edificio sufrieron un proceso de oxidación acelerado debido a la proximidad del mar, el escaso recubrimiento, la excesiva porosidad del hormigón y la inadecuada aplicación de un tratamiento superficial." ${ }^{30}$ (ARAUJO, 2010, p. 11)

Como medida de intervenção, optou-se por se reparar trechos das zonas mais afetadas, com a substituição do concreto por um recobrimento de base polimérica, inclusive sobre as armaduras nos trechos mais danificados. Após essa medida
1.23 e 1.24 Finlândia Hall, Helsinki, Alvar Aalto, 1965-1975
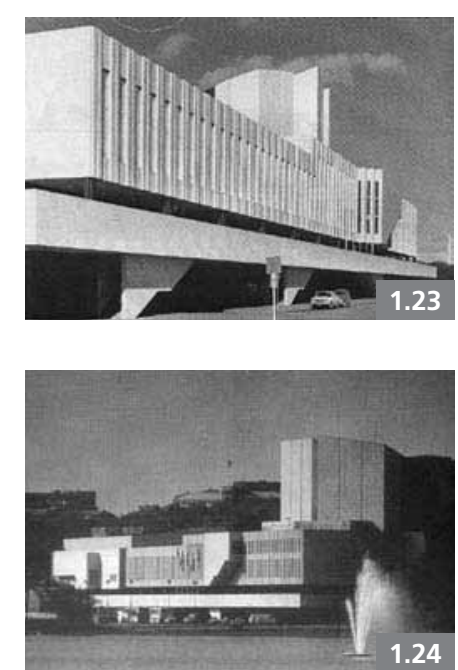

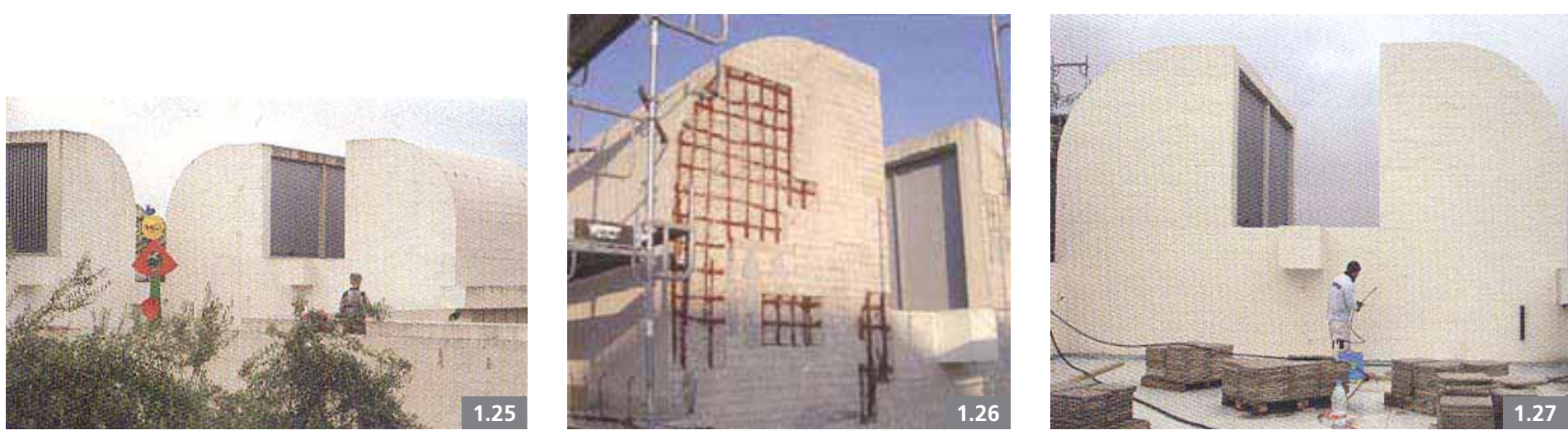

1.25 Fundação Miró, Barcelona, Josep Lluís Sert, 1975 - situação após as obras de restauro, 2004 1.26 Fundação Miró - detalhe do processo de tratamento das armaduras nos trechos mais afetados

1.27 Fundação Miró - imagem durante a aplicação do

revestimento acrílico

invasiva, aplicou-se um revestimento acrílico (que evita a carbonatação), utilizando-se uma forma de tábuas similares à da concretagem original.

Analisando os resultados, não podemos deixar de fazer certos questionamentos quanto à sua legitimidade, perguntando-nos até que ponto ações relacionadas diretamente à estrutura podem auxiliar na preservação e conservação do patrimônio construído e de seu significado ou se apenas configuram medidas de manutenção, buscando as intervenções corretivas. Nesse sentido, evocamos Moreira, que acrescenta: “A manutenção de estruturas de concreto quase sempre altera a sua autenticidade e dá origem a questionamentos que desafiam a teoria da restauração." (MOREIRA, 2010, p. 192)

Outra questão - que pode ser considerada uma das mais significativas - diz respeito às soluções específicas em relação às fachadas e sistemas de fechamentos da arquitetura moderna; não só pelas questões inerentes à própria estanqueidade, mas, sobretudo, devido à grande presença desses elementos componentes que, apesar de manufaturados, tinham como premissa a reprodução seriada e que hoje, com a presença de patologias, são refeitos ou substituídos, acarretando na perda do próprio material autêntico. Sobre esse tema, Araujo ressalta:

"En definitiva, todo apunta a que debemos limitar las transformaciones a las necesarias, casi a las mínimas. Además, una 'excesiva' adecuación acaba implicando mantener poco más que la estructura, caso cada día más habitual, y el coste económico y energético comienzan a equipararse a la sustitución del edificio. El resultado suele conducir no solo a la perdida de la integridad del edificio, sino a una confusa superposición de soluciones, en la que tanto el viejo como la intervención pierden valor." 31 (ARAUJO, 2010, p. 5) 

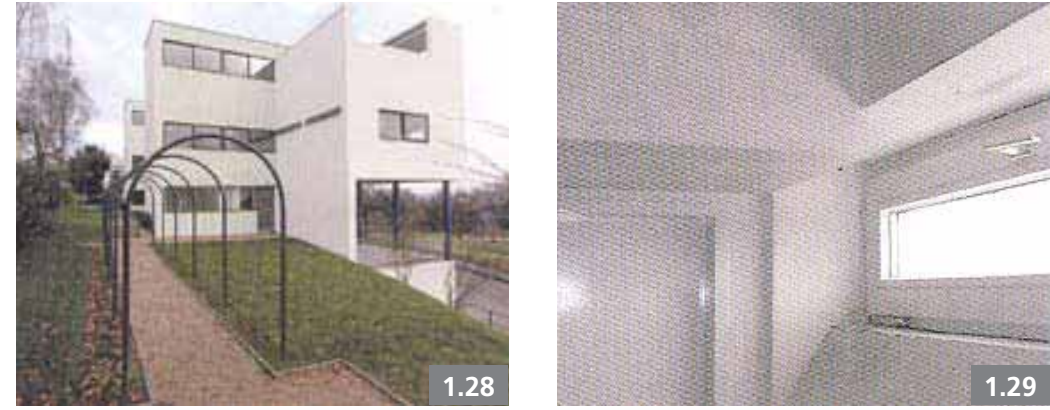

1.29

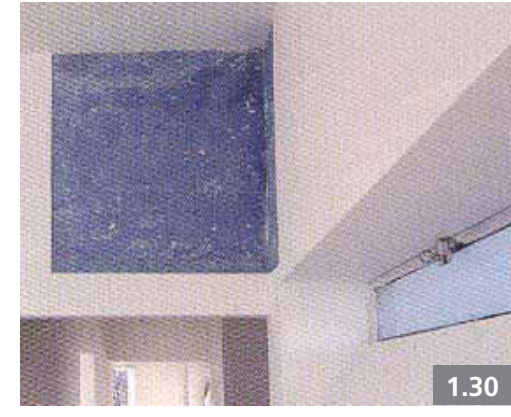

mento, devido tanto aos detalhamentos ingênuos ou pouco aprofundados, quanto à degradação do próprio material, oxidação e corrosão dos elementos metálicos expostos;

- Divisórias leves e fachadas independentes - problemas de estanqueidade de água, dilatações heterogêneas, pontes térmicas, escassez de sistema de drenagem, ventilação deficitária, juntas de dilatação ineficientes;

- Instalações - desgaste e insuficiência da capacidade das instalações elétricas e seus quadros, desgaste e insuficiência das instalações hidráulico-sanitárias;
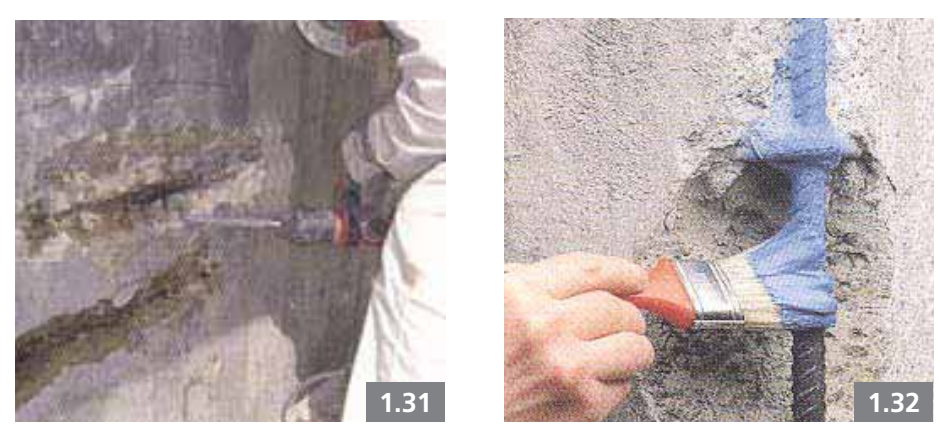

1.28 Doppelhaus, StuttgartWeissenhof, Le Corbusier, 1929 Restaurado por Architekteur 109, 2005 - vista geral

1.29 Doppelhaus - detalhe do caixilho antes da restauração 1.30 Doppelhaus - detalhe do caixilho depois da restauração 1.31 Doppelhaus - detalhe do tratamento de armaduras (processo de eliminação do concreto deteriorado)

1.32 Doppelhaus - detalhe do tratamento de armaduras (aplicação de inibidores de corrosão) 1.33 Doppelhaus - detalhe do tratamento de armaduras (recuperação da superfície em concreto)

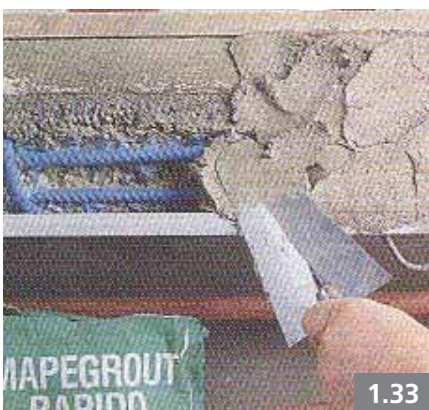




\subsubsection{MUDAR A FUNÇÃO PARA SOBREVIVER}

Além das características ligadas aos materiais e à tecnologia, a arquitetura moderna teve a funcionalidade e o racionalismo como pontos importantes de expressão. Esses atributos resultaram em espaços especializados e mínimas dimensões: "os tetos baixaram ao limite, as medidas dos espaços se ajustaram, especialmente os corredores, que se inspiraram nas formas mais justas dos trens e barcos; os espaços e as peças sanitárias se especializaram e se subdividiram para aumentar a eficácia funcional."35 (MONTANER, 2009, p. 44)

Montaner defende essa afirmação, exemplificando com a Casa Curutchet [FIG. 1.34], projetada por Le Corbusier na cidade de La Plata em 1949, que foi recentemente reconvertida para ser a sede do Colegio de Arquitectos, sem a necessidade de nenhuma nova intervenção.

No entanto, tal afirmação deve se relativizada, como podemos perceber no texto de Johnston, em livro de 2011 , baseado em sua tese de doutorado, que apresenta um estudo minucioso sobre a Casa Curutchet, desde a sua concepção, esclarecendo não só as questões de projeto, como também as relações estabelecidas de Le Corbusier com Amancio Williams durante a construção. Johston descreve que em 1987:

“(...) El Dr. Curutchet alquiló la casa a la Fundación oftalmológica Christmann, quienes encargaron a Luis y Julio Grossman, su restauración total, pues en esa fecha se encontraba 'en estado ruinoso, en especial los interiores'. Estos arquitectos realizaron un cuidadoso levantamiento de la obra construida, reacondicionaron los suelos, falsos techos, revestimientos, carpinterías y pinturas, abriendo la casa al conocimiento del público. Este trabajo realizado con precisión, cuidando de restituir los acabados originales de la casa, no estuvo exento de cierta polémica pues, con el objeto de conseguir un espacio de recepción para la Fundación Christmann cercano de la calle, los arquitectos resolvieron utilizar para esta función el garaje de la casa. Ejecutaron la carpintería de madera y vidrios por tras de la persiana metálica enrollable e intentaron ejecutar una ventana en el muro posterior del garaje, idea que fue rápidamente desechada a la luz de las duras críticas recibidas.

Finalmente, en el año de 1992 la casa fue alquilada por el Colegio de Arquitectos de la Provincia de Buenos Aires, y convertida en Museo en el año 2002. Entre los años de 1992 y 2004 la casa fue objeto de tareas de mantenimiento, que en algunos casos modificaron la obra construida y en otros, con un discutible criterio, alteraron el inapreciable documento histórico que significaba la casa con todas las interpretaciones realizadas." ${ }^{136}$ (JOHNSTON, 2011, p. 177) [FIG. 1.35]

E sintetiza:

"Esta casa tiene una historia ulterior: la de su ocupación por la familia Curutchet, sus usos posteriores, las restauraciones... Ello nos evoca la candente cuestión de la arquitectura contemporánea entendida desde su dimensión patrimonial, y trabajos como este, al reconstruir las vicisitudes de un edificio en toda su complejidad, pueden aportar una inestimable contribución a la urgente tarea de definición de criterios patrimoniales específicos. ${ }^{137}$ Grifo nosso. (JOHNSTON, 2011, p. 13)
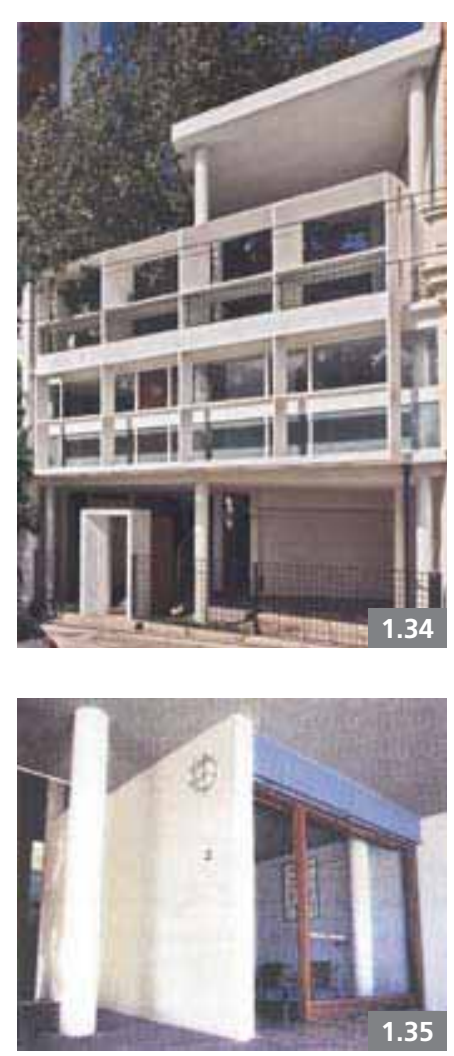

1.34 Casa Curutchet, La Plata Le Corbusier, Charles Edouard Jeanneret e Amancio Williams (projetista e diretor de obra), 1948-1951

1.35 Casa Curutchet - vista interna da garagem onde se encontra o volume edificado na época da restauração para a Fundação Christmann 


\subsection{PRESERVAÇÃO E INTERVENÇÃO: OS CRITÉRIOS TEÓRICO-METODOLÓGICOS}

No presente item, não se pretende fazer uma revisão de todos os critérios de preservação, mas apenas - e de maneira preliminar - elencar os princípios que regem a restauração, os quais irão delimitar as bases necessárias para a realização das análises dos projetos de intervenção feitos no patrimônio arquitetônico moderno.

Entende-se que, ao examinar os critérios metodológicos e suas aplicações no patrimônio recente para garantir a sua salvaguarda, baseados na Carta de Veneza e suas bases teóricas, amplia-se a própria discussão de conceito de bem patrimonial, como esclarece Kühl:

"Há uma contínua ampliação, que se acentuou nas últimas décadas, daquilo que é considerado bem de interesse cultural a ser preservado, estendendo-se a um número cada vez maior, a tipos cada vez mais variados e a um passado cada vez mais próximo." (KÜHL, 2006, p. 20)

E enfatiza: “[os bens culturais] são sempre testemunhos únicos, não repetíveis, que têm de ser analisados com a máxima diligência, fundamentando-se as propostas em rigorosos critérios." (KÜHL, 2006, p. 20)

Essa afirmação, sobre a concepção alargada de monumento, apesar de não especificamente ligada à arquitetura moderna, já figurava nos textos de Brandi:
"Neste ponto se deve especificar que por monumento entendemos qualquer expressão figurativa, seja arquitetônica, pictórica, escultórica e também qualquer complexo ambiental que seja particularmente caracterizado por monumentos singulares ou simplesmente pela qualidade do tecido idílico de que é formado, mesmo se não relacionado a uma só época." (BRANDI, 1975, p. 308 apud KÜHL, 2008b, p. 80)

Acerca dessa discussão é importante destacar que o objetivo da busca do entendimento desse arcabouço teórico relacionado com as cartas patrimoniais ${ }^{38}$ e os referenciais da restauração é reforçar a sua importância junto aos arquitetos, que têm optado por "desconsiderar os referenciais da restauração", seja pela falta de preparo ${ }^{39}$, seja pela ausência de tradição crítica, como aponta Kühl, complementando:

"No Brasil, o debate sobre os princípios teóricos da restauração que deveriam reger a atuação prática nos bens culturais é recente e incipiente. Os trabalhos, de enorme interesse, que se têm acumulado nas últimas décadas se voltam a variados aspectos do problema (...) no entanto, no que se refere às modalidades de intervenção e aos princípios teóricos que deveriam regê-las, existe uma lacuna (...)." (KÜHL, 2008b, p. 29)

\subsubsection{RESTAURO E OUTRAS DEFINIÇÕES}

Entrementes, ainda com relação a esse arcabouço teórico, nos pareceu de suma importância apresentar algumas definições de termos ${ }^{40}$ que irão figurar tanto no presente ca- 
pítulo, como em todo o desenvolvimento do trabalho. Para isso, iniciamos pelo termo preservação no sentido que é utilizado no Brasil. Recorremos a Kühl, que explica:

“(...) possui um sentido lato que abarca vários tipos de ações, tais como inventários, registros, providências legais para tutela, educação patrimonial e políticas públicas. Abrange também as intervenções nos bens, para que sejam transmitidos da melhor maneira possivel ao futuro, que podem assumir a forma de manutenção, conservação, restauração (...)." (KÜHL, 2008b, p. 59)

A fim de objetivar essa discussão, Kühl ressalta a ordem para qualquer procedimento sobre o monumento, que deve ir do menos interveniente, ou seja, da manutenção, ao maior grau de intervenção, que é o restauro. Destaca ainda que a conservação é um processo intermediário e declara que "nas ações de restauro, em geral, opera-se concomitantemente também com procedimentos de manutenção e conservação". Assim, adotamos o termo manutenção como:

“(...) ações cotidianas e periódicas que visam a sanar e reparar problemas que aparecem na edificação assim que surgem, como reparo de um condutor vertical, de fiação inadequada, substituição de telhas e vidros quebrados, de balaústres danificados etc., em que se opera, em geral por analogia, com formas e materiais iguais ou semelhantes aos originais; casos, pois, em que os problemas não se consolidam como uma cisão, no tempo, na obra como imagem figurada (caso houvesse uma cisão, esses mesmos problemas deveriam ser tratados como casos de restauração)." (KÜHL, 2008b, p. 74)
Para os termos conservação e restauração, utilizaremos as definições expressas nos artigos da Carta de Veneza ${ }^{41}$ :

Conservação:

"Art. $4^{\circ}$ - A conservação dos monumentos exige, antes de tudo, manutenção permanente. Art. $5^{\circ}-A$ conservação dos monumentos é sempre favorecida por sua destinação a uma função útil à sociedade; tal destinação é, portanto, desejável, mas não pode nem deve alterar a disposição ou decoração dos edifícios. É somente dentro desses limites que se devem conceber e se podem autorizar as modificações exigidas pela evolução dos usos e costumes. Art. $6^{\circ}-A$ conservação de um monumento implica a preservação de uma ambiência em sua escala. Enquanto sua ambiência subsistir, será conservada, e toda construção nova, toda a destruição e toda a modificação que possam alterar as relações de volumes e de cores serão proibidas." (CURY, 2000, p. 92)

Restauração:

"Art. 90 - A restauração é uma operação que deve ter caráter excepcional. Tem por objetivo conservar e revelar os valores estéticos e históricos do monumento e fundamenta-se no respeito ao material original e aos documentos autênticos. Termina onde começa a hipótese; no plano das reconstituições conjecturais, todo trabalho complementar reconhecido como indispensável, por razóes estéticas ou técnicas, destacar-se-á da composição arquitetônica e deverá ostentar a marca de nosso tempo. A restauração será sempre precedida e acompanhada de um estudo arqueológico e histórico do monumento." (CURY, 2000, p. 93) 
Para concluir esse tópico, utilizaremos o enunciado de Brandi, para complementar a definição do termo restauração:

"A restauração constitui o momento metodológico do reconhecimento da obra de arte, na sua consciência física e na sua dúplice polaridade estética e histórica, com vistas à sua transmissão para o futuro." (BRANDI, 2004, p. 30)

\subsubsection{CARTA DE VENEZA E SUAS BASES TEÓRICAS}

Desde o século XVIII, o entendimento do sentido de bem $\mathrm{cul}$ tural foi sendo alterado, assim como o modo de lidar com o mesmo, "um momento crítico, apontado por vários autores, que dá as bases da preservação hoje, ocorreu na segunda metade do século XVIII." Embora as raízes dessa mudança possam ser encontradas no Renascimento italiano, ela se acentua "em finais do século XVIII devido a vários fatores": o Iluminismo, as reações dos vandalismos maciços da Revolução Francesa e o ritmo acelerado das mudanças da Revolução Industrial. (KÜHL, 2008b, p. 59-60)

Kühl esclarece que a noção de ruptura entre passado e presente foi paulatinamente se intensificando, afastando-se "das ações ditadas por razões pragmáticas" e finalmente "assumindo [uma] conotação fundamentalmente cultural, voltada aos aspectos estéticos, históricos, memoriais e simbólicos dos bens $[e]$ também com fins educativos" (2008b, p. 60) e ressalta:

“(...) as questões de ordem prática deixam de ser as únicas e prevalentes, apesar de dever estar sempre presentes, e passam a ser concomitantes, a ter caráter indicativo, mas não determinante. São empregadas como meio de preservar, mas não como a finalidade, em si, da ação." (KÜHL, 2008b, p. 60)

Apenas no século xx, porém, é que são elaboradas ações, em diferentes países europeus, tais como: "tentativas de inventários sistemáticos, experimentações práticas, formulações teóricas, elaboração de medidas legais e o estabelecimento de órgãos de preservação" (KÜHL, 2008b, p. 60), que iriam contribuir para a teoria e as práticas da conservação de monumentos históricos.

Como precursores das teorias sobre preservação, teremos o inglês John Ruskin (1819-1900) e o francês Eugène Emmanuel Viollet-le-Duc (1814-1879), cujas posturas antagônicas ficaram bastante evidentes: de um lado as "conservativas" de Ruskin e de outro as voltadas ao refazimento de estilo, de Viollet-le-Duc.

Por fim, recorremos à Choay que conclui:

"O monumento histórico entra então em sua fase de consagração, cujo término pode ser fixado por volta da década de 1960 ou, se desejarmos um outro marco simbólico, em 1964, data da redação da Carta de Veneza." (CHOAY, 2001, p. 125)

Antes de discorrermos sobre os princípios da Carta de Veneza, é importante ressaltar que a redação da mesma foi pautada nos princípios do "restauro crítico" entre outros documentos, e que este, por sua vez, foi o resultado de uma releitura das propostas filiadas ao "restauro filológico" ou "científico", de 
Boito e Giovannoni, que se mostravam limitadas em algumas situações ${ }^{42}$.

Conforme elucida Kühl, o que diferenciava o "restauro filológico" de outras posturas era "a grande atenção [dada] aos aspectos documentais das obras e às marcas de sua passagem ao longo do tempo, respeitando as várias fases" (2010, p. 294) e complementa:

"Se houvesse necessidade de inserir novos elementos, deveriam ser diferenciados da obra como estratificada, para não induzir o observador ao engano de confundir a intervenção com a obra (em alguma de suas etapas)." (KÜHL, 2010, p. 294)

A fim de explicitar seus princípios gerais do "restauro científico" para agir em relação aos bens culturais, recorremos à Boito:

"1. diferença de estilo entre o novo e o antigo; 2. diferença de materiais de construção; 3. simplificação das linhas e supressão dos ornamentos; 4. exposição de velhas partes removidas perto do monumento; 5. incisão, em cada uma das peças renovadas, da data de restauro ou de um sinal convencionado; 6. epígrafe descritiva incisa no monumento; 7. descrição e fotografias dos diversos períodos das obras, colocadas no próprio edifício ou próximo a ele, ou descrição por meios impressos; 8. notoriedade". (вогто, 1893, p. 15-24. apud KÜHL, 2008a, p. 354-355)

Em relação ao "restauro crítico", podemos afirmar a importância de seu caráter multidisciplinar, como indica Kühl ao assinalar que: "restaurador, historiador da arte e cientistas tornam-se co-protagonistas (...) não estando mais a ação sujeita ao arbítrio de um único indivíduo" (2008a, p. 358). Por sua vez, Carbonara apresenta, de maneira abrangente as características dessa corrente teórica:

"[O restauro crítico] parte da afirmação de que toda intervenção constitui um caso em si, não classificável em categorias (como aquelas meticulosamente precisadas pelos teóricos do chamado restauro 'científico': completamento, liberação, inovação, recomposição etc.), nem responde a regras prefixadas ou a dogmas de qualquer tipo, mas deve ser reinventado com originalidade, de vez em vez, caso a caso, em seus critérios e métodos. Será a própria obra, indagada atentamente com sensibilidade histórico-crítica e com competência técnica, a sugerir ao restaurador a via mais correta a ser empreendida. Resulta uma estreita ligação da restauração com a história artística e arquitetônica, com a finalidade de obter respostas satisfatórias aos problemas que o restauro, desde as suas origens, coloca: reintegração de lacunas, remoção de adições, reversibilidade e distinguibilidade da intervenção, controle histórico-crítico das técnicas e assim por diante. Problemas que na restauração, porém, requerem, diferentemente da verdadeira atividade historiográfica, respostas não apenas 'verbais', mas também concretamente operacionais e figurativas: digamos, pintando e não apenas falando quando se trata de restauro pictórico, esculpindo e plasmando no restauro escultórico, fazendo arquitetura, e boa arquitetura, no caso do restauro arquitetônico." Grifo nosso. (CARBOnARA, 1997, p. 285-286 apud KÜHL, 2008b, p. 66) 


\section{E Kühl destaca:}

"Mas as especificidades que são reconhecidas para os casos particulares, 'o cada caso é um caso' (em vista da conformação, de seus materiais e de suas vicissitudes ao longo do tempo), não devem ser confundidas com 'cada um faz o que quer'. A intervenção deve seguir princípios fundamentais (e não regras) que norteiam o campo da restauração como um todo, derivados das razões por que se preserva, e que devem embasar o código de conduta dos profissionais envolvidos na área." (KÜHL, 2010, p. 296)

\section{E complementa:}

“(...) na prática os meios empregados variam em função da vertente de pensamento, da realidade de cada obra ou conjunto e obras, de sua constituição física, de seus materiais, de sua configuração e inserção num dado ambiente e de seu particular transcurso ao longo do tempo." (KÜHL, 2006, p. 21)

De modo que, "a restauração assume pra si a tarefa de prefigurar e controlar, justificar e fundamentar essas al terações, respeitando os aspectos documentais, materiais e formais das obras", como coloca Kühl em seu artigo A restauração como campo disciplinar autônomo, indicando a grande relevância de diversos autores, entre eles Cesare Brandi, Roberto Pane, Renato Bonelli e Paul Philippot e cujas proposições atingem "certa posição de consenso internacional na Carta de Veneza, de 1964" (2008a, p. 357) e conclui:
“(...) o restauro passa a ser encarado como ato que deve respeitar as várias fases por que passou a obra e preservar as marcas de sua própria translação no tempo, com consciência de que qualquer ação a modifica e intervém inexoravelmente em sua realidade figurativa." (KÜHL, 2008a, p. 357)

A Carta de Veneza ${ }^{43}$ coloca em condição de igualdade os valores estéticos e históricos e, apesar de “herdeira indireta da teoria brandiana" (KÜHL, 2010, p. 295), é um documento sintético; enquanto esta última [Teoria da Restauração] fornece uma "formulação de maior complexidade e envergadura, oferecendo bases filosóficas de atuação" (KÜHL, 2010, p. 297), como indica Kühl.

Tendo como base a Teoria de Brandi e os princípios de Boito e Giovanonni, Kühl afirma que “a restauração deve seguir princípios ${ }^{44}$ gerais vinculados a uma unidade conceitual e metodológica" (2008b, p. 77), que devem ser "pensados de forma concomitante e não excludente" (2008b, p. 78), pois a restauração "é um ato histórico-crítico ancorado na história e na filosofia" (2008b, p. 77), assinalando os princípios essenciais da Carta de Veneza - "a distinguibilidade da ação contemporânea, a mínima intervenção, a retrabalhabilidade e a compatibilidade de técnicas e materiais" (2010, p. 296) - e que são sintetizados por Brandi, conforme podemos verificar abaixo:

" Distinguibilidade: pois a restauração (que é vinculada às ciências históricas), não propõe o tempo como reversível e não pode induzir o observador ao engano de confundir a intervenção ou eventuais 
acréscimos como o que existia anteriormente, além do dever de documentar a si própria.

- Reversibilidade, que mais recentemente tem sido anunciada, de modo mais preciso, como 're-trabalhabilidade': pois a restauração não deve impedir, tem, antes, de facilitar qualquer intervenção futura; portanto, não poder alterar a obra em sua substância, devendo-se inserir com propriedade e de modo respeitoso em relação ao preexistente e de forma a não impedir ou inviabilizar intervenções futuras que se façam necessárias.

- Minima intervenção: pois a restauração não pode desnaturar o documento histórico nem a obra como imagem figurada, devendo respeitar suas várias estratificações.

- Compatibilidade de técnicas e materiais: deve-se levar em conta a consistência física do objeto, com a aplicação, para seu tratamento, de técnicas compatíveis que não sejam nocivas ao bem e cuja eficácia seja comprovada através de muitos anos de experimentação." (BRANDI, 2004 apud KÜHL, 2008b, p. 78)

Em específico sobre o princípio de distinguibilidade, Kühl reconhece a necessidade de se arbitrar dentro de duas posturas possíveis: a "diferenciação em dissonância" e a "diferenciação em consonância", dependendo das 'condicionantes' impostas pelas preexistências. De qualquer maneira, o arquiteto [ou a equipe responsável] deverá "assumir a responsabilidade projetual de se fazer novos elementos articuladores, sem perder a individualidade e personalidade." (2006, p. 27-28).

Em relação à Teoria da Restauração e a comumente indagação de sua "utilidade" mais como texto teórico do que prático, Kühl nos auxilia a esclarecer esse equívoco:
"A Teoria não é uma simples coletânea de textos que conformam um manual prático de Restauração. Trata-se de uma consistente concepção e formulação do restauro, que oferece uma unidade de método $e$ de conceitos para guiar a atividade prática de restauro (...) é a consubstanciação de décadas de formulações teóricas do autor associadas à sua experiência à frente do Instituto ${ }^{45}$ com repercussões na práxis." (KÜHL, 2008b, p. 72)

Quanto às atuais abordagens de enfrentamento das obras de arquitetura, Carbonara ressalta em seu artigo Brandi e a restauração arquitetônica hoje, que, frequentemente, “as razões do restauro", tais como: "funcionalidade, valorização econômica, reutilização, consolidação e adaptação anti-sísmica, adequação às normas de segurança, acessibilidade e instalações" são previamente estabelecidas, ao invés de precedê-las, ou seja, deveriam derivar "da sua consistência material e figurada, da sua história e estratificação, do estado de conservação e assim por diante". (2006, p. 36)

Vale a pena ressaltar que Brandi volta seus esforços para “afastar a restauração do empirismo e da arbitrariedade e vinculá-la ao método e ao processo histórico-crítico de forma rigorosa" (KÜHL, 2008b, p. 69), conforme podemos perceber na seguinte afirmação:

“[Esse processo de reconhecimento da obra de arte é] duplamente singular, seja pelo fato de dever se efetuado toda vez por um indivíduo singular, seja por não poder ser motivado de outra forma a não ser pelo reconhecimento que o individuo singular faz dele." Grifo nosso. (BRANDI, 2004, p. 27 apud KÜHL, 2008b, p. 69) 
Finalmente, Kühl conclui que esse reconhecimento "da obra como dado cultural" fundamenta "toda e qualquer ação sobre bens reconhecidos como de interesse cultural (inclusive as de manutenção e conservação e aquilo que Brandi denominou restauração preventiva)", através da "abordagem teórico-metodológica, associada ao ato histórico-crítico" que define a restauração como campo disciplinar autônomo. (KÜHL, 2008b, p. 75)

\subsubsection{DESDOBRAMENTOS TEÓRICOS NA ATUALIDADE}

Nas discussões da atualidade ${ }^{46}$, o campo teórico está associado a ações práticas, e alguns autores detectam três tendências principais: 1 - a "crítico-conservativa e criativa"; 2 - a "conservação integral" ou "pura conservação"; 3 - "hipermanutenção-repristinação".

Segundo Kühl, a primeira delas, a "crítico-conservativa e criativa" tem como autores vinculados: Giovanni Carbonara e Miarelli Mariani, baseando-se na "teoria brandiana e na releitura de aspectos do chamado restauro crítico" (2008b, p. 82), tendo como característica a prudência em relação ao restauro, assumindo uma "posição conservativa", mas não com significado de congelamento, como explica a autora:

"[Essa vertente] propõe, quando necessário, o uso de recursos criativos (utilizados, porém, com respeito pela obra e não em detrimento dela) para tratar várias questões (...) envolvidas na restauração, como as citadas remoção de adiçôes e reintegração de lacunas. É pos tura fundamentada no juiz histórico-crítico, na análise da relação dialética entre as instâncias estética e histórica de cada obra, caso a caso, que exclui, na prática, qualquer tipo de interpretação mecânica de relação causa-efeito." (KÜHL, 2008b, p. 82)

A vertente chamada "pura conservação" ou "conservação integral" privilegia a instância histórica e sustenta que a restauração e a conservação são ações opostas. Essa posição polêmica é advinda de textos de Didron, Ruskin, Morris, Boito e Riegl, e contando com importantes contribuições de outros autores como Amedeo Bellini, Marco Dezzi-Bardeschi, Anna Lucia Maromotti e Paolo Torsello, “que fornecem importantes elementos para a reflexão sobre uma realidade sempre mais complexa" (KÜHL, 2008b, p. 83), conforme expressa Kühl:

"É importante salientar que na vertente da conservação integral, a conservação não é mero apêndice do restauro, nem um grau de intervenção. É algo de natureza diversa. Nessa postura não existe uma distinção entre as instâncias histórica e estética, que são fato único e incindivel; ou seja, não se trabalha através de uma relação dialética entre as instâncias, pois a conformação decorre também da passagem do objeto pelo tempo e a historicidade deve ser respeitada de modo absoluto, sendo a matéria preservada tal qual chegou aos dias atuais." (KÜHL, 2008b, p. 83)

\section{E complementa:}

"Segundo a conservação integral, deve-se reconhecer as várias estratificações da obra, que devem ser rigorosamente respeitadas, possam 
apresentar descontinuidades, admitindo-se uma configuração final com conflitos e, mesmo, contradiçóes. Ademais, propõe-se, do ponto de vista metodológico, a separação do momento da conservação propriamente dita, que busca perpetuar integralmente seus aspectos materiais, daquele da inovação - projeto de transformação de um edifício para um novo ou para o mesmo uso-, que se segue à conservação e se assemelha ao projeto do 'novo'". (KÜHL, 2008b, p. 85)

Ambas, contudo, excluem as ações que levam ao mimetismo ou imitações, apesar das diferenças basilares.

A terceira vertente, que tem Paolo Marconi como figura mais conhecida no Brasil, é chamada de "manutenção-repristinação" ou "hipermanutenção" e está fundamentada em um pragmatismo baseado em uma lógica indutiva que provém da própria obra e tende a trabalhar por analogia, como esclarece Kühl:

"[A manutenção-repristinação] propõe o tratamento da obra através de manutenções ou integrações, ordinárias e extraordinárias. Retomam-se formas e técnicas do passado, sendo um modo de se colocar contra o estado fragmentário do bem, mantendo sua configuração e seu significado linguístico." (KÜHL, 2008b, p. 86)

Sobre esta última postura, em relação à arquitetura e sua restauração, sabemos que tem "certa propensão a tratar o restauro arquitetônico como categoria à parte". (KÜHL, 2008b, p. 86)

Devido às controvérsias ligadas ao tratamento de superfícies arquitetônicas, Marconi afirma que só “há duas possíveis opções" para se enfrentar essa questão, conforme relata Kühl:

“(...) acatar a Carta Italiana de Restauração de 1972 e deixar os monumentos à própria sorte [ou] levar em conta os resultados dos estudos científicos feitos e estimular, ou pelo menos não condenar, as práticas de limpeza e proteção das superfícies de pedra e tijolos." (KÜHL, 2008b, p. 87)

Defendendo esta última "como a única a poder salvaguardar, o patrimônio arquitetônico", Marconi sugere utilizar-se do "emprego de técnicas tradicionais". (KÜHL, 2008b, p. 86)

Devemos nos atentar à seguinte informação assinalada por Kühl:

"Os princípios da Carta de 1972, continuam válidos, com alguns textos complementares e integrativos, pois o documento incluía, além de preceitos teóricos, alguns procedimentos técnicos considerados ultrapassados na atualidade. Autores como Cordaro, Carbonara e Basile, através de cuidadosa releitura da Carta de 1972, recomendam que se deva ater ao seu cerne teórico e remeter a capítulos técnicos, que tratem as questões técnicas e operacionais, a serem revistos e atualizados periodicamente." (KÜHL, 2008b, p. 87)

Para concluir, em relação à arquitetura recente, e em específico à arquitetura moderna, existe uma tendência de "tratar a preservação esses bens fora do âmbito disciplinar do restauro" (KÜHL, 2008b, p. 94), acarretando em ações problemáticas em diversos bens, como salienta Kühl: 
“(...) [essa tendência] tem conduzido a uma série de ações nesses bens, com numerosas nuanças, que vão desde a volta ao restauro de repristinação (...) para as obras icônicas, em geral vinculadas ao movimento moderno - em que se chega a extremos de nem mesmo buscar o suposto estado original 'as built' (como de fato construido), mas o estado 'as published', como divulgado através de fotos e projetos da época da construção, ou mesmo de refazer uma obra desaparecida ${ }^{47}$ segundo o projeto original -, até manutenções e modernizações desrespeitosas em relação aos aspectos documentais e formais das obras, algo que acomete sobretudo algumas expressões da arquitetura mais recente, construídas no segundo pós-guerra, ou obras anteriores, não-modernas." (KÜHL, 2008b, p. 94-95) [FIGS. 1.36 A 1.38]
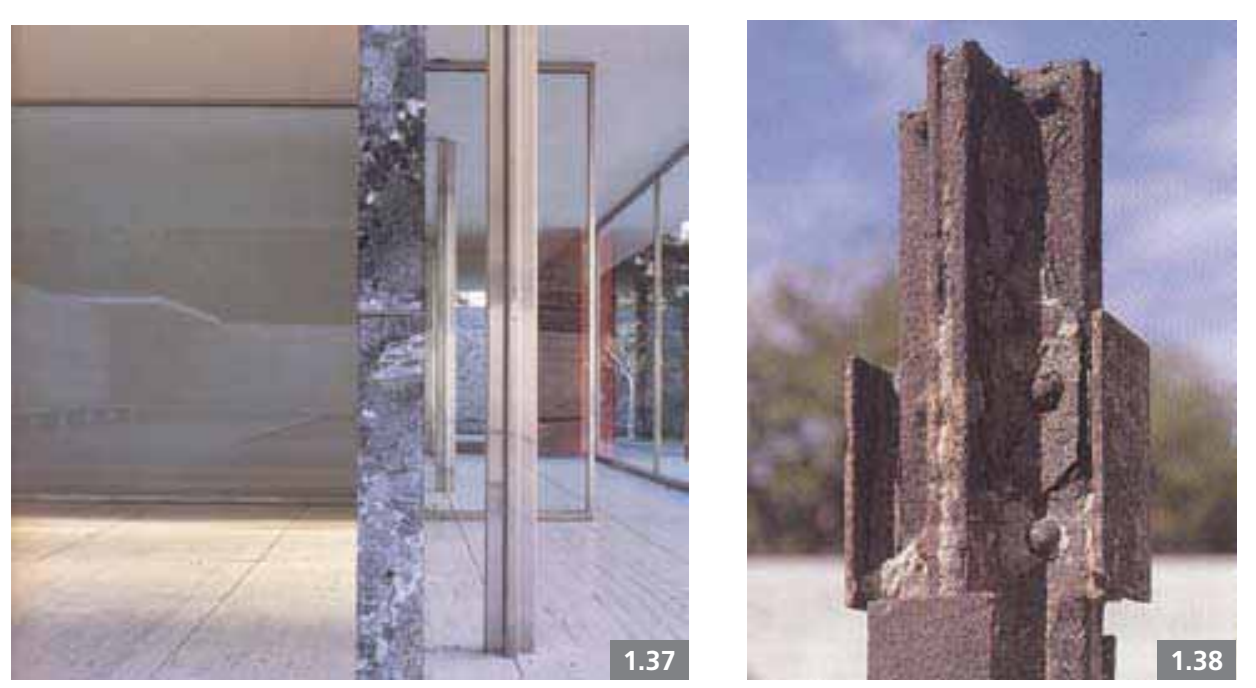

1.36 Pavilhão de Barcelona,

Mies van der Rohe, 1928-1929. Reconstruído, em 1981-1986, tendo como autores: Ignasi de Solá Morales, Cristian Cirici e Fernando Ramos - detalhe do pilar

1.37 Pavilhão de Barcelona - vista parcial

1.38 Pavilhão de Barcelona - restos de um pilar metálico recuperado no subsolo da área do pavilhão 
NOTAS - CAPÍTULO 1

1 Sobre a criação de uma

"arquitetura paulista", Artigas relembra em sua arguição (concurso para professor titular da disciplina de Projeto da FAU-USP realizada em junho de 1984) que Carlos Lemos havia Ihe atribuído essa responsabilidade em seu livro Arquitetura brasileira para maiores informações ver: LEMOS, Carlos Alberto Cerqueira. Arquitetura brasileira. São Paulo: Melhoramentos/Editora da Universidade de São Paulo, 1979, p. 158.

2 Ver: SEGAWA, Hugo. Arquiteturas no Brasil 1900-1990. São Paulo: Edusp - Editora da Universidade de São Paulo, 1997. (Acadêmica, v. 21).

3 Esses princípios (pilotis, planta livre, fachada livre, janela em fita e terraço jardim) são publicados em 1927 na revista L'Esprit Nouveau em Cinco pontos para uma nova arquitetura, são utilizados na Villa Savoye, em Poissy (1929-1931), cujo projeto constitui expressão máxima da estética purista. DARLING Elizabeth. Le Corbusier. São Paulo: Tradução: Luciano Machado. São Paulo: Cosac Naify, 2002

4 "A construção do edifício (iniciada em 1937) arrastou-se ao longo dos anos com dificuldades (...) por volta de 1942, o edifício estava virtualmente completo em seus exteriores e assim foi fotografado pelos norte-americanos para a exposição 'Brazil Builds'".

A inauguração oficial por Getúlio Vargas somente se daria em 1945 (...)." SEGAWA, Hugo. Arquiteturas no Brasil 1900-1990. São Paulo: Edusp - Editora da Universidade de São Paulo, 1997. (Acadêmica, v. 21) p. 92.

5 Em relação a essa negativa, Sergio Ferro na própria entrevista, indica que essa postura foi exposta em artigos "radicais" de Vilanova Artigas contra "um movimento internacional que seria o mesmo em Tóquio, na França ou aqui" e cita o texto "Os caminho da Arquitetura" de 1952, como um dos exemplos. 6 Em seu texto: Brutalismo caboclo e as residências paulistas, Marlene Acayaba esclarece sobre o surgimento desse termo advindo do crítico inglês Reyner Banham, referindo-se a uma obra do arquiteto Peter Smithson de 1954 e descreve as suas características: "Absolutamente austera, essa arquitetura buscou a cada obra a solução estrutural e espacial adequada ao conteúdo ético proveniente das raízes populares. Sua construção era a expressão mais despojada dos materiais, das superficies sem revestimentos, das instalações deixadas aparentes." ACAYABA, Marlene. Brutalismo Caboclo, as residências paulistas. In: Projeto, n. 73, mar. 1985, p. 46
7 Tanto na dissertação de Ruth Verde Zein, como no próprio texto fundante de Yves Bruand, ambos assinalam a existência de duas vertentes do Brutalismo, uma ligada a Le Corbusier e outra ligada ao brutalismo inglês. Ver: ZEIN, Ruth Verde. Arquitetura brasileira, escola paulista e as casas de Paulo Mendes da Rocha. Dissertação (Mestrado) Faculdade de Arquitetura da Universidade Federal do Rio Grande do Sul, Porto Alegre, 2000, p. 16 e BRUAND, Yves. Arquitetura contemporânea no Brasil. 4. ed. Tradução: Ana M. Goldberger. São Paulo: Perspectiva, 2008, p. 295 8 "Do grupo inicial de colaboradores, sete eram arquitetos: Lucio Costa, Oscar Niemeyer, Carlos Leão, José de Souza Reis, Paulo Thedim Barreto, Renato Soeiro e Alcides da Roch Miranda. Entre outros intelectuais, eram presença constante, nas reuniões ao final da tarde, na sala de Rodrigo M. F. de Andrade: Gilberto Freire, Carlos Drummond de Andrade, Manuel Bandeira, Sérgio Buarque de Holanda, Vinícius de Moraes, Joaquim Cardoso." GONÇALVES, Cristiane Souza. Restauração arquitetônica: a experiência do SPHAN em São Paulo, 1937-1975. São Paulo: Annablume/Fapesp, 2007, p. 34.

Serviço do Patrimônio Histórico Artístico Nacional fundado em 1937, atual Instituto da
Patrimônio Histórico e Artístico Nacional (IPHAN)

10 Os dados utilizados para

elaboração dos gráficos apresentados foram extraídos da Tabela comparativa de bens tombados $n$ cidade de São Paulo, entre 1930 e 1979, nos órgãos de preservação (CONPRESP, CONDEPHAAT IPHAN) apresentada no Memorial de Qualificação e que encontra-se disponibilizado nos Anexos do presente trabalho, p. 243

11 Ver SERAPIÃO, Fernando. Projeto Design. São Paulo, n. 294, p. 44-49, ago, 2004

12 O projeto em questão foi recuperado na pesquisa de mestrado da arquiteta Mônica Junqueira de Camargo e posteriormente publicado em um livro de Hugo Segawa, sobre o referido arquiteto. Ver: residência na rua Sofia. In: SEGAWA, Hugo. Oswaldo Arthur Bratke. Projeto editorial Vicente Wissenbach e Hugo Segawa. São Paulo: ProEditores, 1997, p. 29 13 Residência Gilberto Krutman, projetado de 1968. Não foram localizadas fotografias desta obra, apenas os desenhos que se encontram no Acervo da Biblioteca da FAU-USP.

14 Ver matéria: PROTESTO Projeto Design. São Paulo, n. 94,

p. 119, dez, 1986

15 Carta internacional sobre

conservação e restauração de monumentos e sítios, deliberada pelo $\|$ Congresso internaciona de arquitetos e técnicos dos monumentos históricos. Documento base do ICOMOS (International Council on Monuments and Sites), órgão da UNESCO. In: CURY, Isabell (org.). Cartas patrimoniais. 2. ed. revista e aumentada. Rio de Janeiro: IPHAN, 2000. (Edições do patrimônio). 16 Hiper-manutenção ou repristinação. "(...) propõe o tratamento da obra através de manutenções ou integrações, ordinárias e extraordinárias. Retomam-se formas e técnicas do passado, sendo um modo de se colocar contra o estado fragmentário do bem, mantendo sua configuração e seu significado linquístico." KÜHL, Beatriz Mugayar. Preservação do patrimônio arquitetônico da industrialização - problemas teóricos de restauro. Cotia: Ateliê Editorial, 2008b, p. 86 17 O edifício Pirelli projeto pelos arquitetos Gio Ponti, Pier Luig Nervi, Fornaroli, Rosselli, Valtolina e Dell'Orto, e construído entre 1956 e 1961, e foi restaurado em 2004 sob a coordenação de Pietro Petraroia, Maria Antonietta Crippa, Carla Di Francesco e Giovanni Carbonara. 18 O projeto em referência encontra-se disponibilizado no site da empresa de arquitetura: Estudio Lamela. Disponível em: <http:// www.lamela.com>. E figura em 
um dos exemplos comentados no artigo La rehabilitación de arquitectura moderna. Ver: ARAUJO, Ramón. La rehabilitación de la arquitectura moderna. In: Tectónica monografias de arquitectura tecnologia y construcción, Madri ATC Ediciones, n. 33, setembro 2010, p. 4-21.

19 O Estudio Lamela é um escritório espanhol, que tem como um dos seus diretores Antonio Lamela, arquiteto autor do projeto original. 20 A Casa del Fascio foi desenhad pelo arquiteto italiano Giuseppe Terragni e sua construção iniciou-se em 1932 e foi finalizada em 1936 sob o regime de Benito Mussolini. Por iniciativa da Soprintendenza per i Beni Architettonici de Milão, esteve em processo de restauração de 1988 até 1992 sob a coordenação de Alberto Artioli.

21 Tradução nossa. "A construção moderna é em geral mais precária que a tradicional, devido em grande parte a seu progressivo aligeiramento: A massa é uma defesa contra o tempo e a construção leve tem um pio envelhecimento que as de maior peso próprio. Mas também, a arquitetura moderna nasceu ligada ao emprego de tecnologias e materiais novos em seu tempo, que acabaram com o ciclo do sistema de alvenaria. O século XX foi uma contínua experimentação com soluções nem sempre bem sucedidas, mas na maior parte novas, com um comportamento de longo prazo difícil de prever. A soma do aligeiramento e da experimentação produziu uma arquitetura

problemática ao longo do tempo. 22 FERRAZ, Geraldo. Warchavchik e a introdução da Nova Arquitetura no Brasil: 1925 a 1940. São Paulo: MASP, 1965. Apud SEGAWA, Hugo. Arquiteturas no Brasil 1900-1990. São Paulo: Edusp - Editora da Universidade de São Paulo, 1997. (Acadêmica, v. 21), p. 46. 23 Segawa comenta que essa firmação não correspondia à realidade, pois já havia exemplos de casas construídas com terraços construídas em concreto, ver: SEGAWA, Hugo. Arquiteturas no Brasil 1900-1990. São Paulo: Edusp Editora da Universidade de São Paulo, 1997. (Acadêmica, v. 21), p. 46.

24 No original. "El edificio tendrá carências de diferente tipo, pero éstas son muchas veces sus valores, no pueden ser resueltas sin atentar contra ellos."

25 No original. "Parece mejo valorar aquello que de positivo tenga, lo que no es dificil, pues la arquitectura de aquellos años es portadora de muchos elementos $y$ soluciones hoy perdidos, y por tanto revalorizados, y materiales y técnicas hasta hace poco convencionales alcanzan cada día una nueva consideración, sobre todo por conservar aún ciertos valores "artesanales'."

\section{Segundo Brandi podem} ocorrer três casos fundamentais de falsificação. Citamos o segundo: "produção de um objeto (...) com o intuito especifico de levar outros ao engano a respeito da época, da consistência material ou do autor." BRANDI, Cesare. Teoria da restauração. Tradução: Beatriz Mugayar Kühl. Cotia: Ateliê Editorial 2004. (Artes e Ofícios, 5), p. 115

27 Tradução nossa. "Cada material e cada elemento construtivo servia para uma função especifica: estrutural, isolamento térmico, isolamento acústico, impermeabilização, proteção contra incêndio, revestimento ornamentação (. )."

28 Tradução nossa. "(...) a partir da cultura do concreto armado, aparece um material que uma vez consolidado já não se pode ter um uso em outro lugar, só se pode manter, reparar ou demolir."

29 "Embora o concreto armado fosse conhecido desde o final do século XIX, sua aplicação sem revestimento e que negava a

necessidade de qualquer tratamento para colmatar a porosidade superficial (...) potencializou a ocorrência de inúmeras patologias ou não conformidades nos edifícios modernistas no século XX (...)."
OLIVEIRA, Claudia T. da Andrade; PRESTES, Lucinda Ferreira; YURGEL, Marlene; BORTOLLI Jr., Oreste; ROSA, Alexandre Miranda de Almeida. O restauro do moderno: o caso do edificio Vilanova Artigas da FAU-USP. Porto Alegre: Universidade Federal do Rio Grande do Sul, 2007. (Seminário DOCOMOMO Brasil, 7, 22 a 24 outubro 2007, Porto Alegre), p. 3.

30 Tradução nossa. "As armaduras do edificio sofreram um acelerado processo de oxidação devido à proximidade do mar, ao pouco recobrimento, à excessiva porosidade do concreto e à inadequada aplicação de um tratamento superficial."

31 Tradução nossa. "Em suma, tudo aponta para limitar as transformações as mínimas necessárias. Além disso, uma adequação 'excessiva' acaba implicando em manter um pouco mais do que só a estrutura e essa solução está se tornando habitual e o custo econômico e energético começam a se equiparar ao da construção de um novo edifício. $O$ resultado, muitas vezes leva não só a perda de integridade, mas a uma confusa sobreposição de soluções, em que tanto o original como a intervenção perdem o seu valor." ARAUJO, Ramón. La rehabilitación de la arquitectura moderna.

In: Tectónica - monografias de arquitectura, tecnologia y construccion, Madri, ATC Ediciones, n. 33, setembro 2010, p. 5.

32 "No caso de ser poroso ou apresentar trincas e fissuras, ele permite a passagem de água, oxigênio e gás carbônico que vão deteriorando o próprio concreto até atingirem a armadura inicia-se o processo de corrosão." MOREIRA Fernando Diniz. Os desafios postos pela conservação da arquitetura moderna. In: SEGRE, Roberto (org.). Arquitetura+arte+cidade: um debate internacional. Rio de Janeiro: Viana \& Mosley, 2010. (Seminário DOCOMOMO Brasil, $8^{\circ}$, 1 a 4 de setembro de 2009, Rio de Janeiro), p. 192.

33 "As eflorescências são manchas de coloração normalmente branca que surgem frequentemente no concreto e ocorrem devido ao transporte da cal, liberada na hidratação do cimento, através dos poros do concreto em direção à superfície da peça. Esta cal dissolvida ao chega ao chegar à superfície da peça reage com o anidrido carbônico do ar e transforma-se em carbonato de cálcio." BRASIL. DEPARTAMENTO NACIONAL DE ESTRADAS DE RODAGEM. Manual de inspeção de obras-de-arte especiais, 1994, p. 5.

34 O concreto "quando exposto à umidade, inicia um processo natural (...) que ocorre a partir da reação entre um gás carbônico 
do ar e os compostos alcalinos presentes no concreto". MOREIRA, Fernando Diniz. Os desafios postos pela conservação da arquitetura moderna. In: SEGRE, Roberto (org.). Arquitetura+arte+cidade: um debate internacional. Rio de Janeiro: Viana \& Mosley, 2010 (Seminário DOCOMOMO Brasil, $8^{\circ}$ 1 a 4 de setembro de 2009, Rio de Janeiro), p. 192

35 No original. "(...) los techos bajaron hasta el límite; las medidas de los espacios se ajustaron especialmente los pasillos, que se inspiraron en las formas tan ajustadas de los ferrocarriles y barcos; los espacios y piezas del baño se especializaron y s subdividieron para aumentar la eficacia funcional"

36 Tradução nossa.

“O Dr. Curutchet alugou a casa para a Fundação oftalmológoca

Christmann, que encarregou Luiz e Julio Grossman de sua restauração total, pois nesta data a casa encontrava-se em estado decadente em especial os espaços interiores. Estes arquitetos realizaram um cuidadoso levantamento da obra construída, recondicionaram

os pisos, forros, revestimentos, caixilharias e pinturas, abrindo casa ao conhecimento do público. Este trabalho realizado com precisão, cuidando para reconstituir os acabamentos originais, não esteve isento de polêmicas, pois com o intuito de conseguir um espaço para a recepção da Fundação Christmman, perto da rua, os arquitetos resolveram utilizar para esta função a garagem da casa. Executaram uma caixilharia de madeira e vidros por detrás da persiana metálica de enrolar e

tentaram executar uma janela no muro posterior da garagem. Ideia que foi rapidamente abandonada à luz das duras críticas recebidas. Finalmente no ano de 1992 a casa foi alugada pelo Colégio dos Arquitetos da província de Buenos Aires, e convertida em museu em 2002. Entre os anos de 1992 e 2004 a casa foi objeto de manutenção que em alguns casos modificaram obra construída, e em outros, com um critério discutível, alteraram um inestimável documento histórico que a casa significava com todas as interpretações realizadas."

37 Tradução e grifo nossos. "Esta casa tem uma história recente: a sua ocupação pela família Curutchet, seus usos posteriores, sua restauração (...) [Este livro] nos evoca uma questão candente sobre a arquitetura contemporânea [arquitetura do século XX] entendida em sua dimensão patrimonial. Trabalhos como este, ao reconstruir as vicissitudes de um edificio em toda a sua complexidade, podem contribuir para a urgente tarefa de definição de critérios patrimoniais específicos [relacionados à arquitetura moderna]."

38 "As chamadas cartas

patrimoniais são documentos em especial aquelas derivadas de organismos internacionais cujo caráter é indicativo ou, no máximo, prescritivo. Constituem base deontológica para as varias profissões envolvidas na preservação, mas não são receituário de simples plicação." KÜHL, Beatriz Mugayar. Notas sobre a Carta de Veneza, Anais do Museu Paulista, v. 18, p. 287-320, 2010. Disponível em: <http://www.scielo.br/pdf/anaismp/ v18n2/v18n2a08.pdf>. Acesso em 08/02/2013

39 Sobre a discussão da formação do arquiteto no Brasil e suas relações com as bases e conteúdos para tuação em Restauro Arquitetônico. Ver: FARAH, Ana Paula. Restauro arquitetônico: a formação do arquiteto-urbanista no Brasil para preservação do patrimônio edificado - o caso das escolas do Estado de São Paulo. São Paulo: FAU-USP, 2012. Tese (Doutorado)

Faculdade de Arquitetura de

Urbanismo/USP, São Paulo.

$40 \mathrm{Em}$ relação às definições

de termos voltados para a preservação, é importante indicar que Quatremère de Quincy em seus Verbetes, publicados em

1825, já antecipa em suas reflexões algumas das principais vertentes de atuação do século XIX. Ver: KÜHL, Beatriz Mugayar. Quatremère de Quincy e os verbetes Restauração, Restaurar, Restituição e Ruína de sua Encyclopédie methodique. Architecture. Rotunda, Campinas,

n. 2, agosto 2003, p. 100-117. Disponivel em: <http://www.iar. unicamp.br/rotunda/>. Acesso em 01/05/2006.

41 Ver: Cartas Patrimoniais. Rio de Janeiro: IPHAN, 2004, p. 91-95. 42 Sobre esses limites do "restauro filológico". Ver: KÜHL, Beatriz

Mugayar. Notas sobre a Carta de Veneza, Anais do Museu Paulista, v. 18, p. 287-320, 2010. Disponível em: <http://www.scielo.br/pdf/ anaismp/v18n2/v18n2a08 pdf . Acesso em: 08/02/2012.

43 No artigo Notas sobre a Carta de Veneza de Beatriz Kühl, a autora faz uma leitura crítica do documento, contextualizando-a com os postulados teóricos da época e remetendo a uma bibliografia pertinente; Tem como objetivo o auxilio na sua interpretação e utilização nos dias atuais, esclarecendo alguns equívocos e lançando bases para discussões futuras. Ver: KÜHL, Beatriz Mugayar. Notas sobre a Carta de Veneza Anais do Museu Paulista v 18, p. 287-320, 2010. Disponível em: <http://www.scielo.br/pdt/anaismp/ v18n2/v18n2a08 pdf > - Acesso em: 08/02/2012.

44 Sobre esse tema, Silvio Oksman discorre sobre esses princípios apresentando diversas análises de projetos exemplares contemporâneos de intervenção em patrimônio arquitetônico. Ver: OKSMAN, Silvio. Preservação do patrimônio arquitetônico moderno - A FAU de Vilanova Artigas. São Paulo: FAU-USP, 2011. Dissertação

(Mestrado) - Faculdade de

Arquitetura e Urbanismo/USP, São Paulo.

45 Cesare Brandi dirigiu o Instituto Central de Restauração (ICR) em Roma de 1938 a 1960. Ver: BASILE, Gieseppe. Breve perfil de Cesare Brandi. Desígnio - Revista de História da Arquitetura do Urbanismo/FAU-USP, São Paulo, Annablume, n. 6, p. 49-56, setembro 2006.

46 Para se aprofundar sobre as "tendências atuais no restauro", ver: KÜHL, Beatriz Mugayar. Preservação do patrimônio arquitetônico da industrialização - problemas teóricos de restauro. Cotia: Ateliê Editorial, 2008b, p. 81-100

47 Ver: HERNÁNDEZ MARTÍNEZ, Ascensión. La clonación arquitetctónica. Madri: Siruela, 2007. (La Biblioteca Azul - serie mínima, 16). 

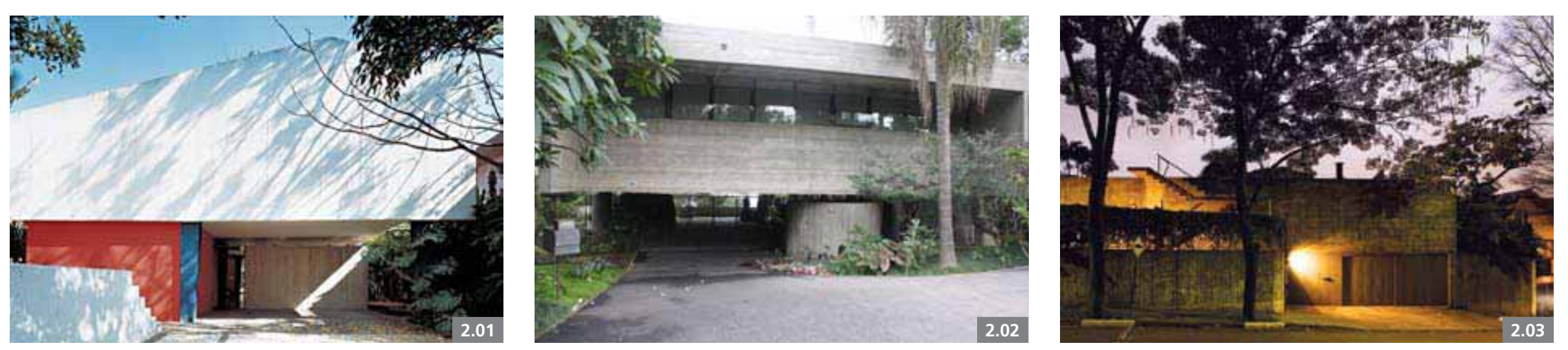


\section{TRÊS CASAS PAULISTAS: COMPREENSÃO E DECOMPOSIÇÃO}

O presente capítulo apresenta cada objeto de estudo individualmente, é descrito o partido arquitetônico e suas particularidades, o sistema construtivo, as especificidades das implantações, as circulações e os fechamentos, das três casas [FIGS. 2.01 A 2.03], no intuito de caracterizar a espacialidade de cada uma delas e auxiliar na compreensão das intervenções, que serão analisadas no próximo capítulo.

Buscando uma discussão ordenada, foram desenvolvidos diagramas, cuja aproximação gráfica analítica, através da operação de decomposição do objeto, tem o intuito de fornecer subsídios para o seu entendimento - sem perder a relação com o todo -, e ainda apoiar a construção do seu "reconhecimento", reforçando a ideia de patrimônio arquitetônico através da sua historiografia, como foi apresentado no capítulo anterior.
2.1 DIAGRAMAS COMPARATIVOS: ACESSOS/

SETORIZAÇÃO DE USOS/ CIRCULAÇÃO /

ESTRUTURA/FECHAMENTOS/SOMBRAS

A seguir serão apresentados diagramas tridimensionais das três residências estudadas (p. 56-59). Os critérios comparativos buscam auxiliar a compreensão dos espaços arquitetônicos e suas relações com a implantação, bem como facilitar um leitura do conjunto analisado. [as notas referentes ao Capítulo 2 encontram-se na p. 70]
2.01 Residência Olga Baeta, São Paulo, Vilanova Artigas, 1956-1957 2.02 Residência Mário Masetti, São Paulo, Paulo Mendes da Rocha 1968-1970

2.03 Residência Fernando Millan, São Paulo, Paulo Mendes da Rocha e João de Gennaro, 1970-1975 


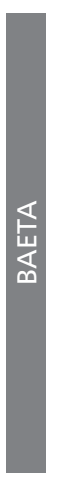
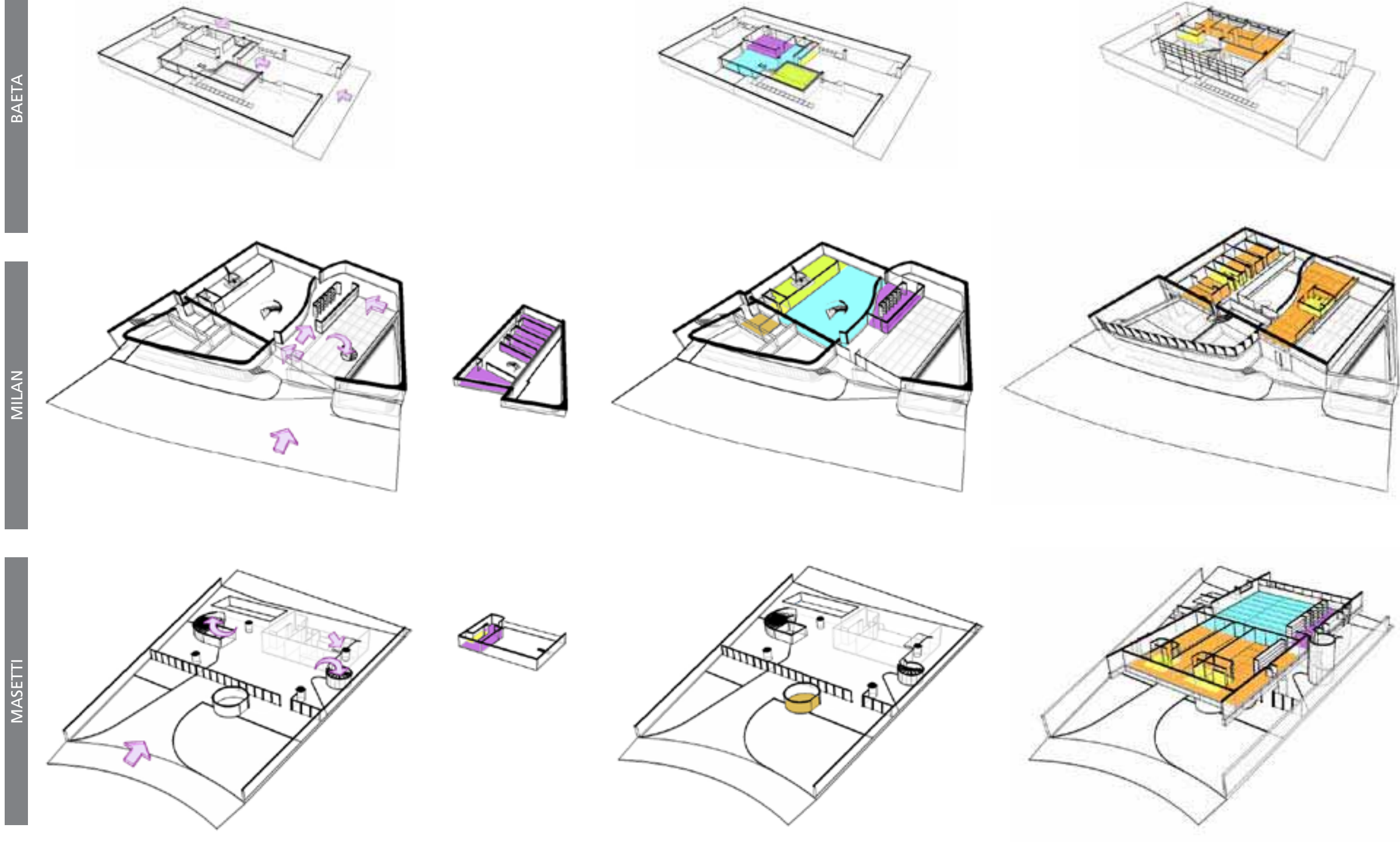

cozinha/serviços estar sanitários biblioteca/estúdio quartos a equipamentos 

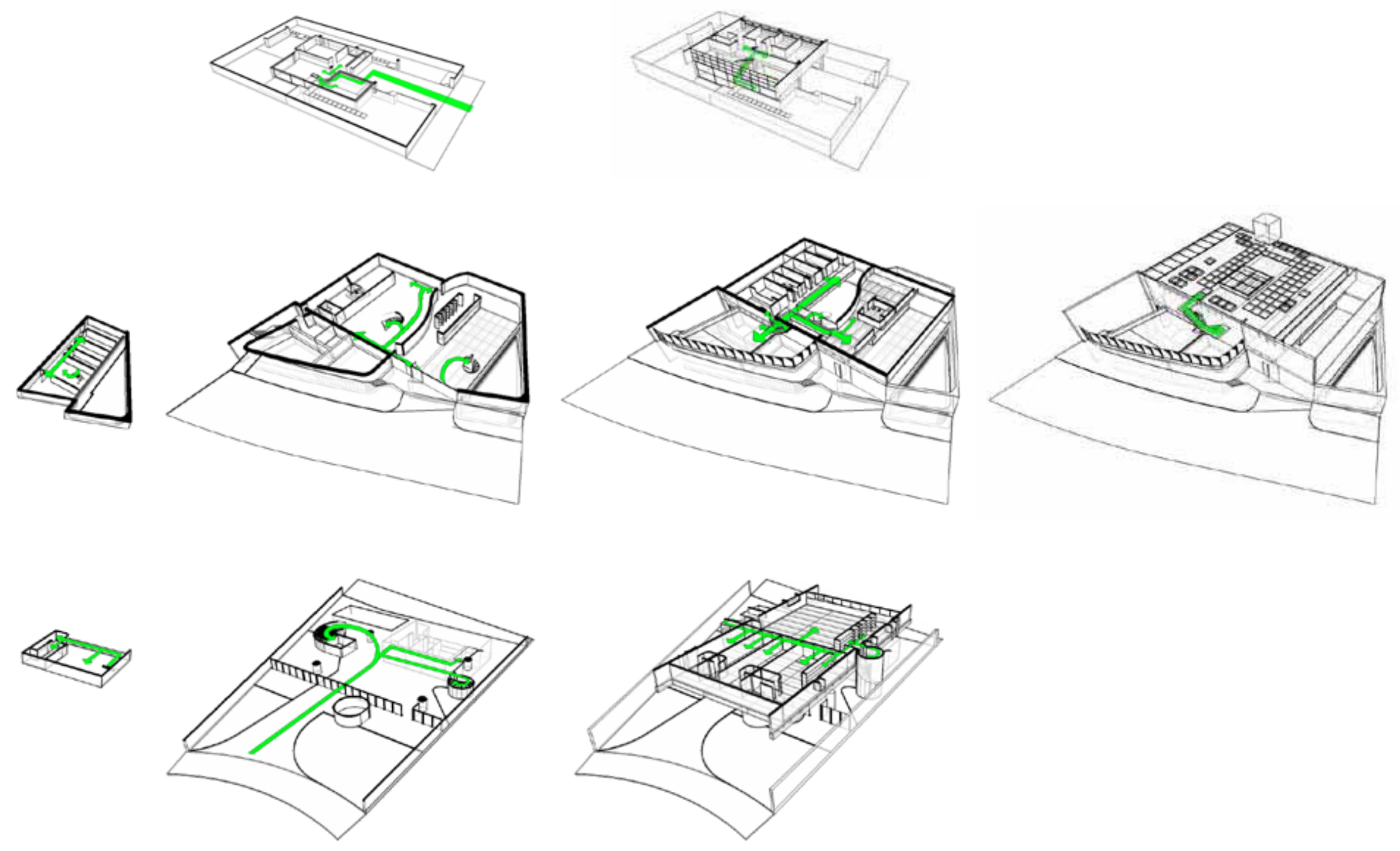

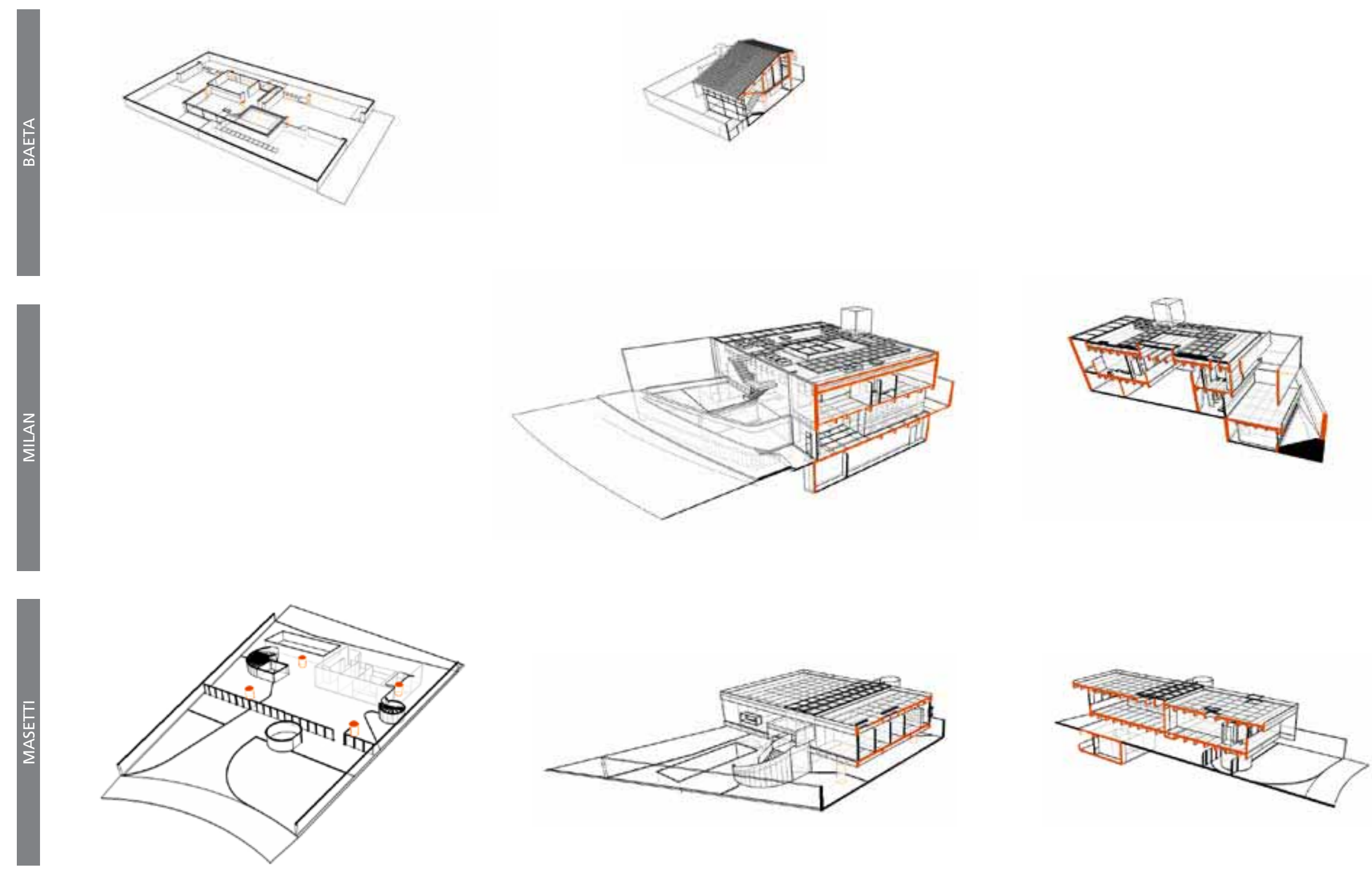

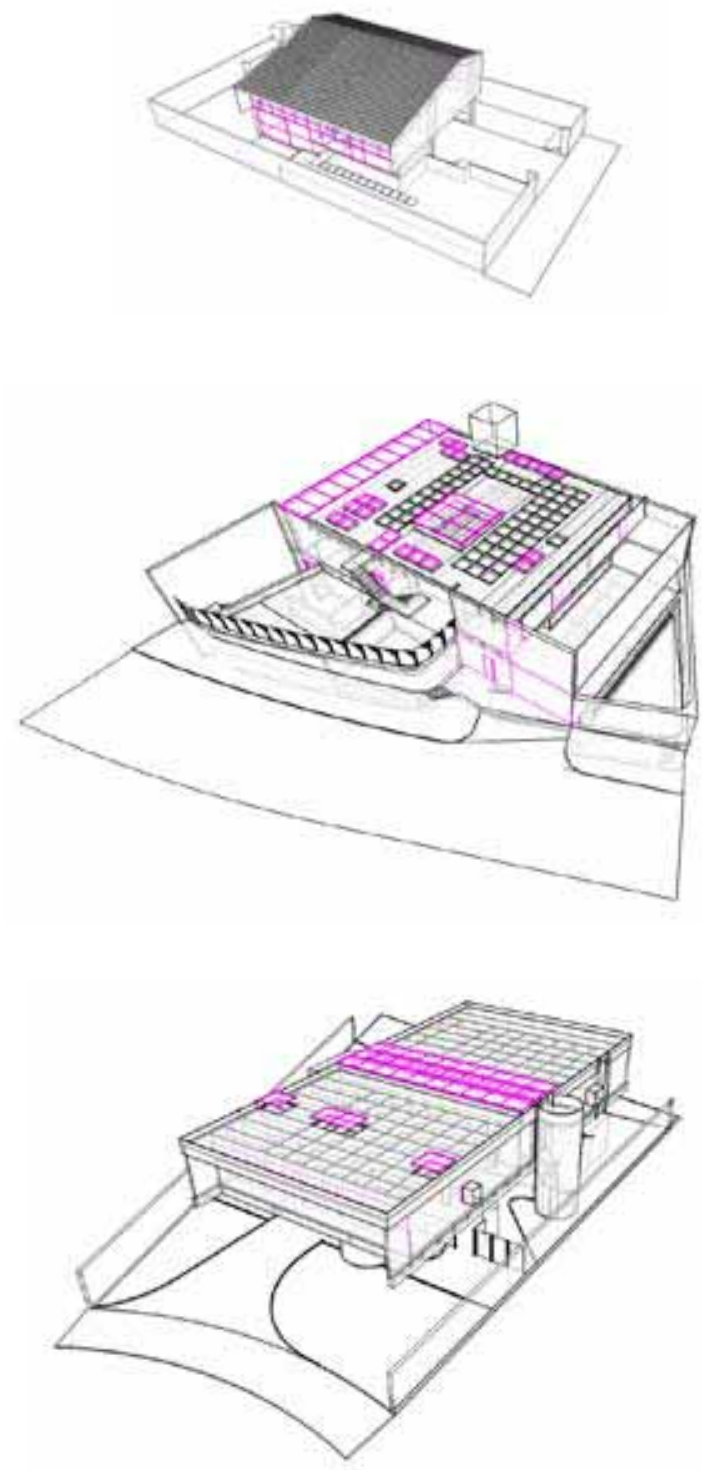
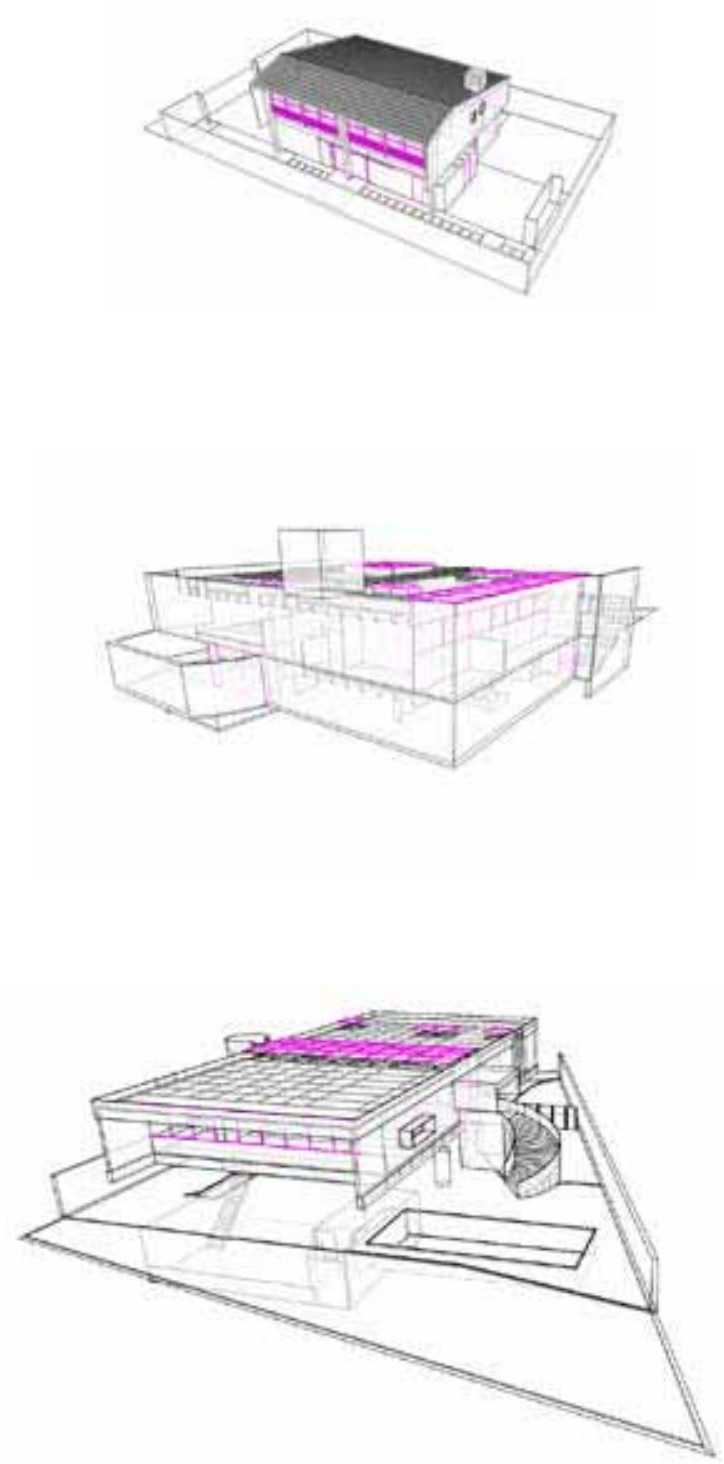
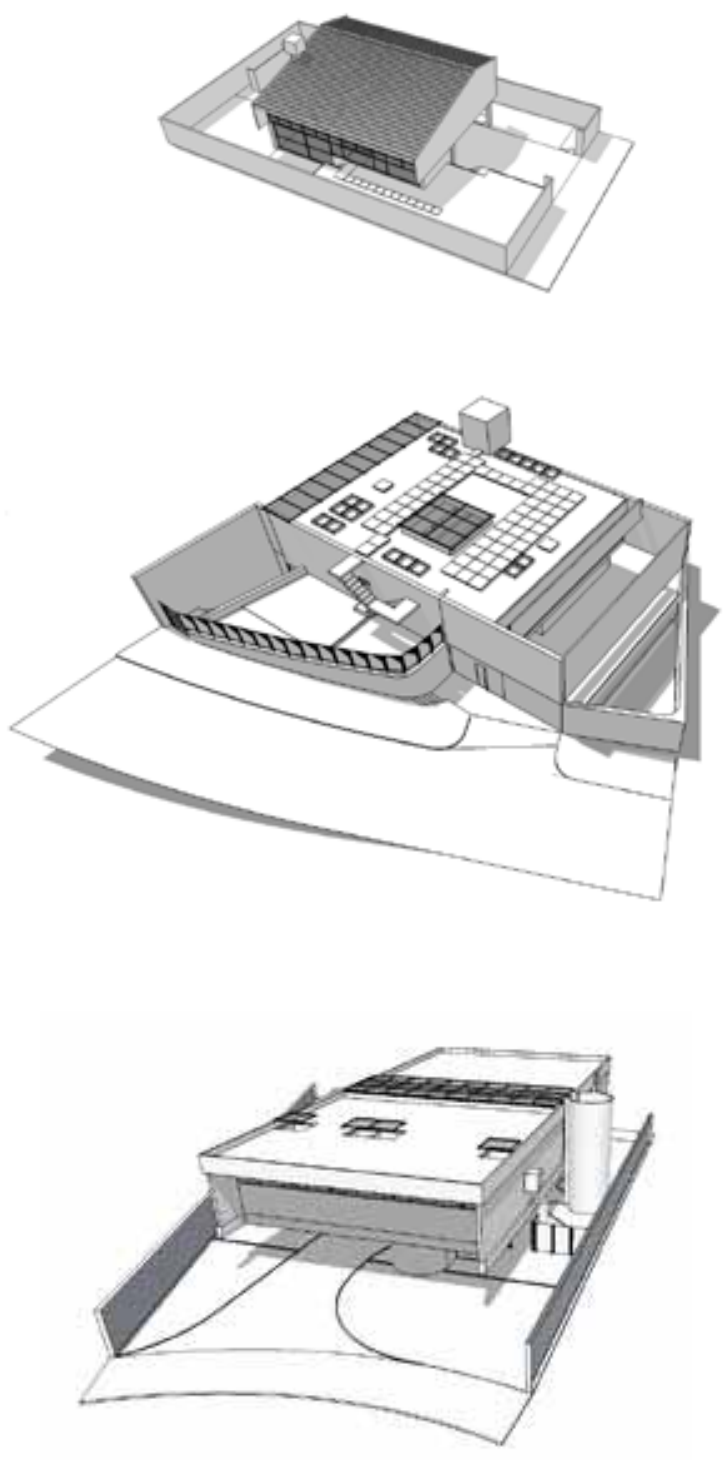


\subsection{RESIDÊNCIA OLGA BAETA}

A residência Olga Baeta ${ }^{1}$ [FIG. 2.04], projetada por Vilanova Artigas e Carlos Cascaldi em 1956 e executada no ano seguinte, teve como arranjo fundamental do programa arquitetônico a divisão em quadrantes, sendo que voltado para a face norte no pavimento térreo, encontra-se o abrigo de veículos e a cozinha, nesses mesmos quadrantes no pavimento superior estão localizados os quartos. Nos quadrantes restantes voltados para a face sul localizam-se a sala, de pé-direito duplo [FIG. 2.05], e o estúdio, que se encontra elevado a um metro do solo, cujo acesso é realizado no patamar intermediário da escada.

"Até por volta de 1940, a típica residência paulista abastada era o sobrado, implantado de modo centralizado, obedecendo passivamente a legislação municipal e seguindo de modo submisso as tendências ecléticas vigentes." (KAMITA, 2004, p. 160)

Podemos observar, pela descrição de Kamita, como estava configurado espacialmente o programa das residências unifamiliares no período anterior ao projeto da Baeta. Entretanto, a mudança nessa tipologia não tardaria a acontecer, como descreve o próprio Artigas:

"Na década de 50, achei que era necessário mudar a tipologia da casa paulistana. Tratava-se de modificar a divisão interna espacial da casa da classe média paulistana, que necessitava se atualizar em relação às modificações sociais que se processavam em nosso país. Ela já não podia continuar imitando a casa tradicional, influen-

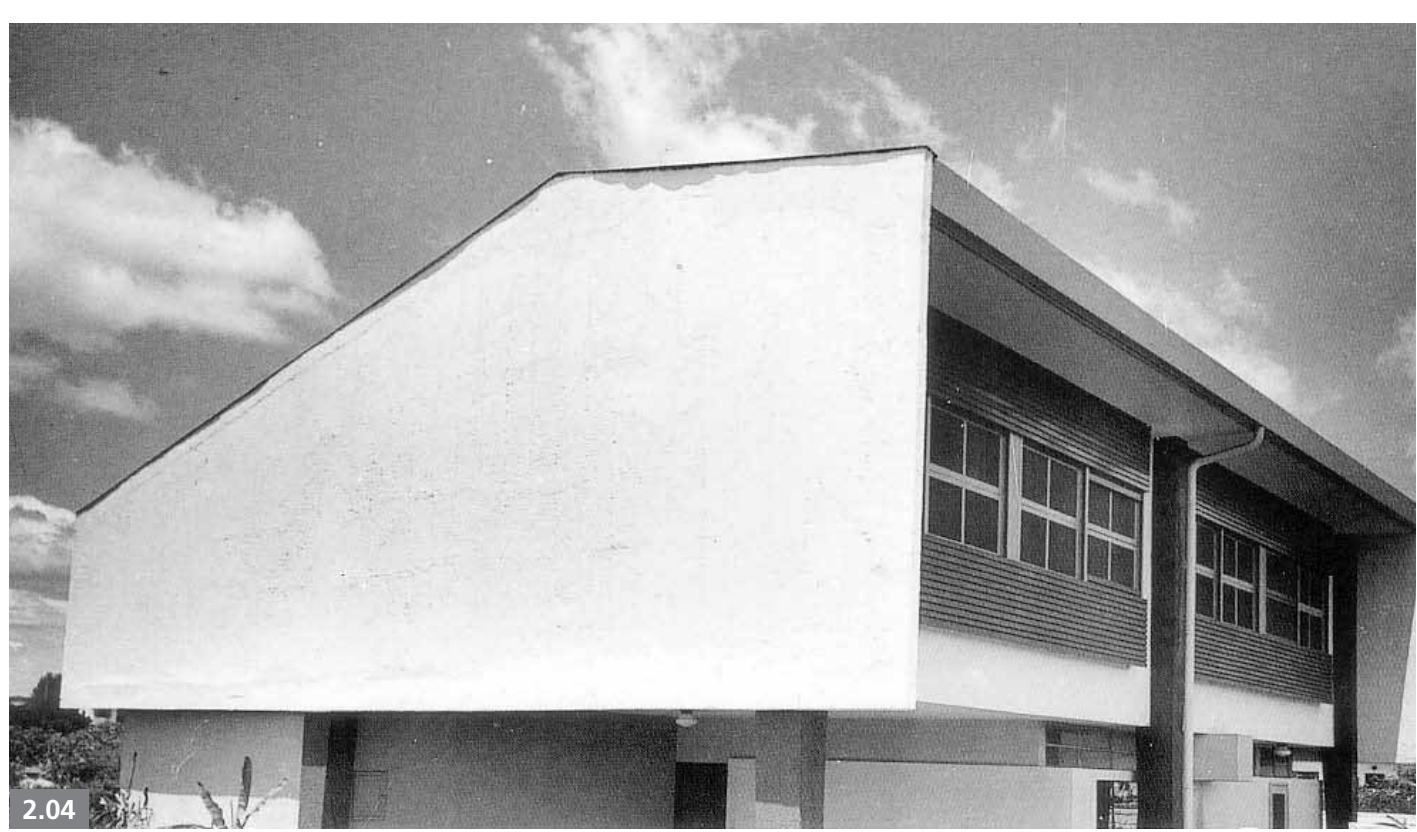

ciada pela vida no campo. Nessa época, por exemplo, era comum as casas manterem a entrada de carro como uma reminiscência da antiga cocheira, com os quartos de criados e o tanque de lavar nos fundos da casa. Para mim, elas deveriam ser pensadas enquanto um objeto com quatro fachadas, mais ou menos iguais, ajustando-se à paisagem, como uma unidade. Assim, tanto a garagem quanto o quarto de empregados e a lavanderia estavam incluídos na unidade. E cada uma dessas casas, com suas características próprias, formaria um conjunto de unidades, resultando um bairro ou cidade mais equilibrada, onde cada um dos elementos falaria sua própria linguagem." (ARTIGAS, 2003, p. 217)

Thomas, por sua vez, assinala a elaboração desse projeto, como ponto de inflexão na produção de Artigas, que havia retomado, em 1956, após dois anos, as atividades no escritório:
2.04 Residência Olga Baeta, Vilanova Artigas e Carlos Cascaldi, 1956-1957 


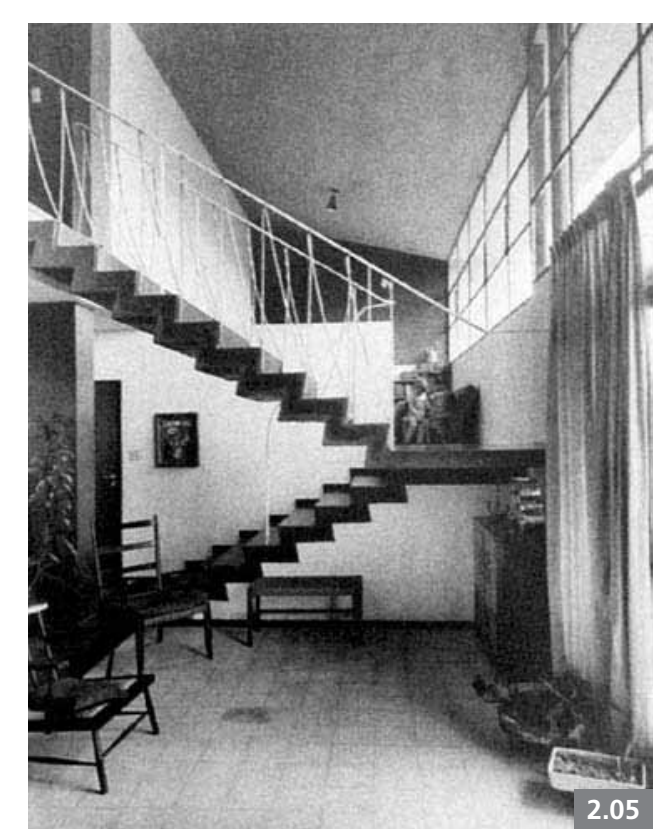

"Talvez envolvido pela nova onda de otimismo, talvez pressionado pelas circunstâncias, ou, quem sabe, refeito do período mais difícil, Artigas, que quase nada produzira desde a 'crise'2, retoma a prática arquitetônica em meados de 1956. Coincidência ou não, a primeira residência projetada por ele após a retomada do trabalho na prancheta, a Casa Olga Baeta, vai revelar um arquiteto mais amadurecido e, sobretudo, firmemente proposto a novamente reformular seu fazer arquitetônico." (THOMAs, 1999, p. 225)

E complementa:

"É nesse sentido que a casa de Olga Baeta representa, a nosso ver, um marco decisivo na transformação do itinerário de Artigas. Ali parecem estar recolocados sonhos e angústias, a experiência do já realizado, mas também o que deixara pra trás, e que poderia ser retomado numa perspectiva de continuidade. O passado, o presente e o futuro lado a lado. Sobretudo, a casa Olga Baeta parece atingir um momento de franca disposição para a abertura mais do que a sintese. Como numa profusão de ideias, Artigas manifesta a intenção de apropriar-se, generosa e criticamente, de um amplo espectro de proposiçoes formais provenientes quer da cultura nacional quer da internacional. Sua atitude projetiva parece apontar em direções diversas, como que tentasse rever com outros olhos o que o satisfizera e o incomodara durante longos anos de debate que haviam precedido e acompanhado sua paralisação profissional como arquiteto."

(THOMAS, 1999, p. 228)

Sua estrutura, composta por seis pilares seção quadrada variável [FIG. 2.05], conformam três pórticos, sendo que o pórtico da frente e o pórtico do fundo incorporam a altura estrutural das empenas de concreto. Estas, que por sua vez, têm um trecho de aproximadamente $4,5 \mathrm{~m}$ em balanço que, jun-

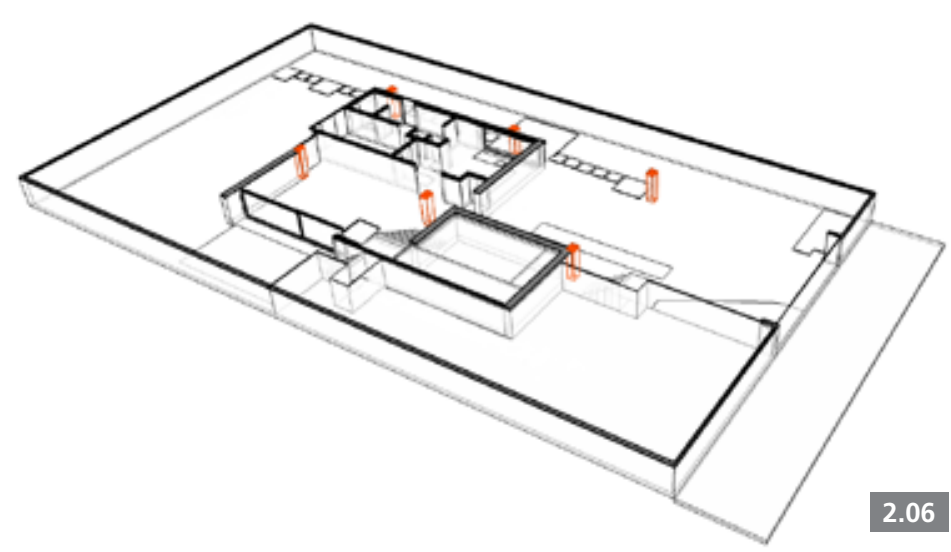

2.05 Residência Olga Baeta - vista intern

2.06 Residência Olga Baeta diagrama tridimensional com a indicação dos seis pilares 
tamente com a inclinação da laje de cobertura, configuram o espaço da sala e do estúdio. No entanto, existe certa particularidade que deve ser observada, como descreve Bucci³:

“(...) no pórtico central essa empena não existe, por isso, Artigas recorreu a uma escora em concreto armado como solução estrutural. Em 57, por problemas na execução da obra, aquela escora acabou por ser substituída por um pilar improvisado em concreto, do lado de fora da casa." (SPBR ARQUITETOS)

Essa informação em relação à escora ${ }^{4}$ foi confirmada por Bucci $^{5}$, que esclareceu essa questão controversa, ao afirmar:

"Aquela escora foi executada. Eu sabia por que era a história que eu tinha ouvido. Mas, depois, você via que ela foi colapsada, porque na laje de cobertura tinha uma cicatriz do ponto em que a escora ancorava na laje. E o capitel, tudo isso eu vi lá (...)." (ANGELO BUCCI São Paulo, 02/09/2011)

Apesar da inspiração assumidamente referenciada às casas de madeira paranaenses ${ }^{6}$, neste projeto, Artigas faz uma releitura dessa imagem e desenha as fachadas frontal e posterior com empenas cegas em concreto, sinalizando as duas águas assimétricas [FIG. 2.07] da cobertura com telhas de barro. Thomas comenta uma possível "reconciliação com os aspectos da casa tradicional brasileira", pois essa solução com telhado "ele [havia] abandonado desde meados de 1944". (1999, p. 226)

Ainda em relação às empenas de concreto, Artigas relata essa experiência inovadora:
"Foi a primeira vez que se fez uma empena desse tamanho. Isso me tirava o sono porque, quando nós tiramos a madeira grossa o que resultou foi um concreto 'desesperado'. Uma coisa 'hedionda!'" 2.07 Residência Olga Baeta - corte ansversal (desenho original digitalizado) (ARTIGAS, 1997, p. 72)

Todavia, a adoção dessa solução, indica um caminho de relacionamento estreito do arquiteto com as questões estruturais e de como elas iriam ser reveladas no próprio partido da arquitetura em diversos de seus projetos, como assinala Petrosino, ao afirmar ser uma característica de Artigas dar

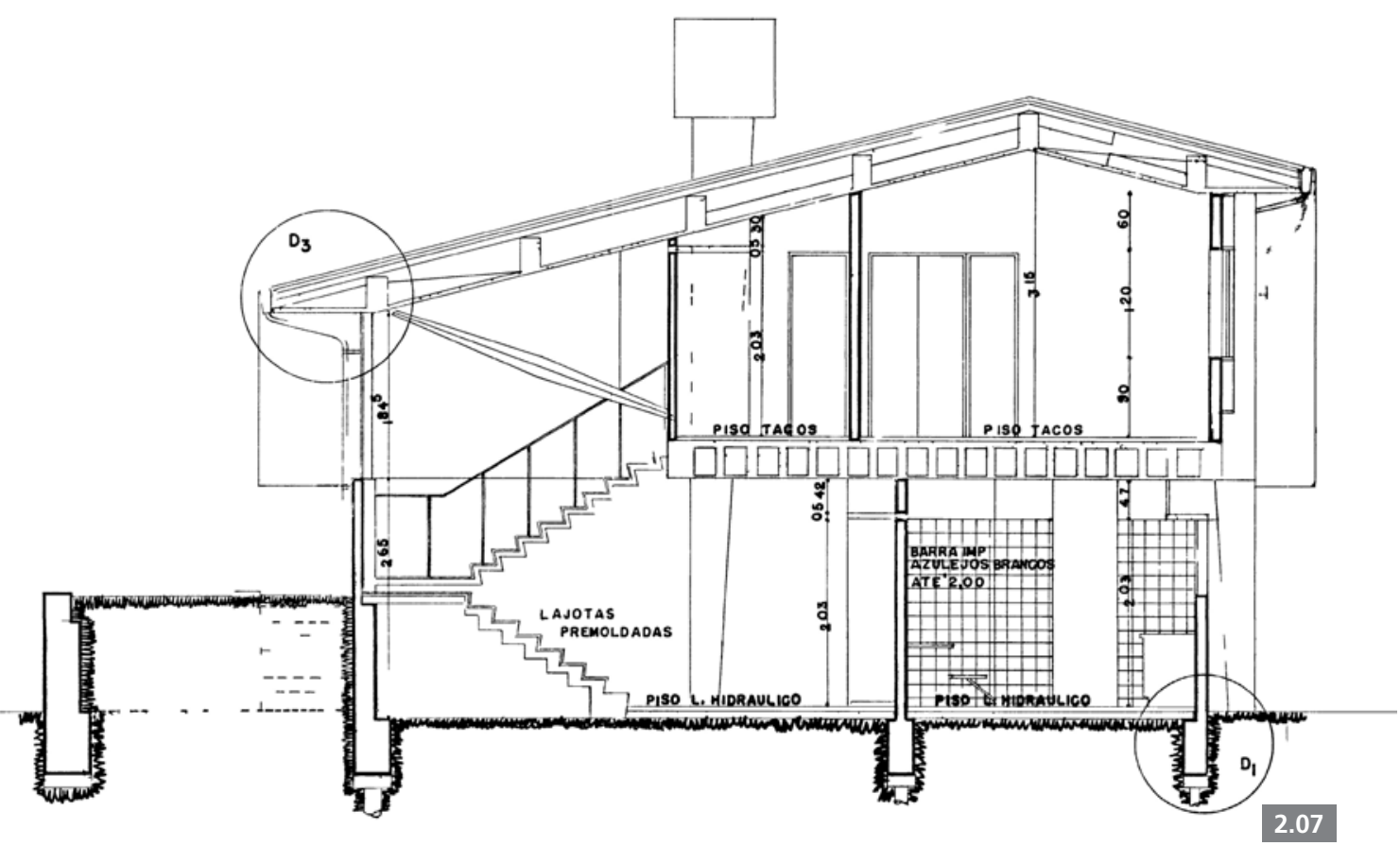


e atribuir "destaque e importância (...) nas resoluções dos apoios técnica e plasticamente". (PETROSINO, 2009, p. 105)

Valentin compartilha dessa ideia, entendendo a residência Baeta como um ensaio de temas a serem estudados por Artigas em projetos futuros:
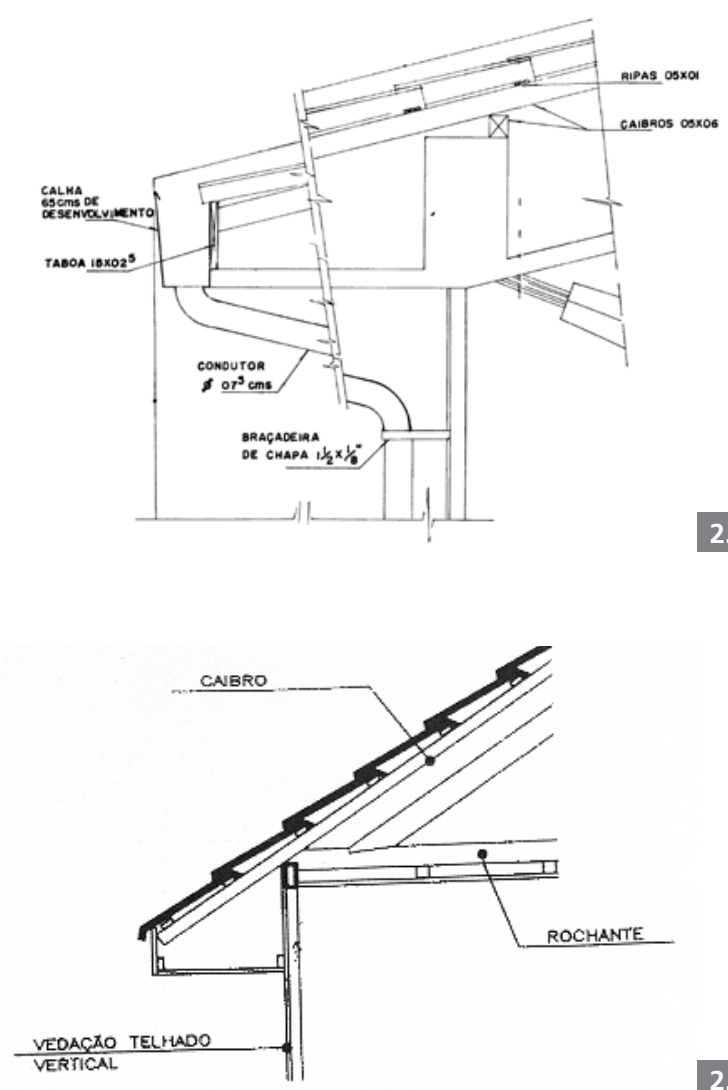

"De certa forma, esta casa contém todos os elementos que serão gradualmente depurados nos projetos seguintes: implantação compacta num único volume; definição da estrutura como elemento expressivo e caracterizador do partido arquitetônico; a distribuição do programa de forma aberta, se valendo de meios-níveis e a integração do estúdio em continuidade ao espaço da sala, aberto, mas resguardado pelo meio-nível." (VALENTIN, 2003, p. 128)

Thomas, todavia, vai mais além:

"A casa Baeta explora o ideário arquitetônico das casinhas simples de madeira do Paraná, como tantas vezes disse Artigas, mas explora ao mesmo tempo, deliberadamente, ideias a respeito do que seja abstrato na forma, na cor, na intenção." (THOMAS, 2005, p. 255) [FIGS. 2.08 A 2.11]

O abstrato na obra de Artigas já havia sido reforçado anteriormente por Thomas, em sua dissertação de mestrado, ao comentar sobre "uma pequena homenagem à Mondrian" (THOMAS, 1999, p. 227) quando o arquiteto utilizou pisos de ladrilhos hidráulicos coloridos separando "o espaço contínuo destinado ao estar e jantar". Essa solução é também apontada como uma "reconciliação com a arte abstrata". ${ }^{7}$

A casa, porém, também iria colocar uma nova questão em relação aos seus espaços internos, como assinala Kamita:

"Apesar do arquiteto ter se empenhado, desde o início da década de 40, na proposição de uma nova divisão dos espaços da casa, visando a integração dos ambientes, é somente na Casa Baeta (1956) que o partido de Artigas se define com clareza." (KAMITA, 2004, p. 160)
2.08 e 2.09 Comparação do detalhe da borda da laje de concreto da residência Baeta e do detalhe do forro beiral das casas paranaenses. Destaque para essa sutil referência adotada por Artigas

2.10 e 2.11 Casas típicas do Paraná caracterizada pela estrutura de madeira e fechamentos em painel de tábua e mata-junta na vertical
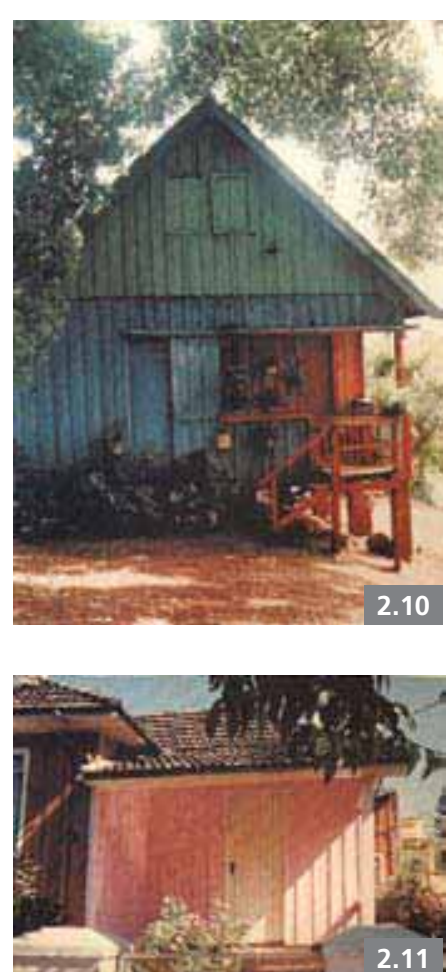
Artigas explica as origens desse 'novo' programa e como ele viria a ajudar na organização do partido, ao afirmar:

"Nessa casa incluí a compreensão de um certo problema da intelectualidade, que sempre quis ter, em sua casa, um recinto que chamavam de escritório. Comecei a perceber que essa intenção não era só pra ter uma sala extra, mas tinha que ter um quarto de uso mais lúdico. Podia ser uma coisa que se chamasse estúdio, onde tinha uma biblioteca, e era possivel se refugiar para determinadas ativi dades. Mas não precisava ter uma porta; o espaço devia ser aberto e múltiplo de maneira que estabelecesse uma relação de visualidade do total do espaço com uma intenção de educação da família." (ARTIGAS, 1997, p. 72)

Outra característica marcante nessa obra é a particularidade na sua implantação, como ressalta Valentin:

"O interessante aqui é a criação de um grande patamar elevado cerca de 1 metro do terreno, que parte das divisas frontais do lote e estende-se sala adentro conformando o estúdio. Artigas cria assim uma nova topografia para o lote plano (...)" (VALENTIN, 2003, p. 129)

Além disso, fica evidente que a força do partido adotado não se situa apenas em sua ligação com a estrutura, mas também na relação desta com o próprio lote, pois “a solução independente" permitiu a adoção dos fechamentos em vidro na fachada sul e caixilhos em madeira com abertura em guilhotina nos quartos que são face norte [FIG. 2.04]. Com isso, Artigas acabou "promovendo mais uma vez a continuidade visual e o prolongamento do espaço para além dos limites da forma arquitetônica", como indica Thomas em sua dissertação. (1999, p. 227)

Essa solução, também é reconhecida por Kamita ao afirmar que, para esta casa, "ampliar o interior e reagir ao exterior constitui o partido poético do arquiteto". Além do que, a adoção desse partido estrutural e do singular arranjo de seus programas internos acaba por fazer com que a casa se relacione com o exterior de maneira inovadora, pois, ao abrir a caixilharia para recuos laterais do lote, “a frente da casa é definida pela grande empena de concreto e pelo vão da garagem". Por sua vez, para o transeunte "não há o menor indício da vida fluente que se desenvolve aquém dos planos opacos". (KAMITA, 2004, p. 162)

Para finalizar, Acayaba sustenta a posição de que a residência Olga Baeta não se transforma em modelo para a arquitetura paulistana, mas já é concebida como tal; afirmação essa que de maneira nenhuma tem a intenção de mitificar a obra, mas sim de reforçar o seu reconhecimento e a sua importância enquanto patrimônio da arquitetura moderna paulista:

"A casa Olga Baeta (1957) é a paixão dos discípulos. Nasceu modelo. Nela alguns moraram, outros ainda guardam o seu desenho. Modelo que mais versões terá na arquitetura paulistana: o espaço único distribuído em meios níveis, a sala com pé-direito duplo, o estúdio a meio-nível e os dormitórios acima." (ACAYABA, 2011, p. 17) 


\subsection{RESIDÊNCIA MÁRIO MASETTI}

A residência Mário Masetti [FIG. 2.12], projetada por Paulo Mendes da Rocha e João de Gennaro em 1968 e executada entre anos de 1968 a 1970, tem como características a sua implantação, cujo terreno está localizado na encosta do vale do Pacaembu e a volumetria paralelepipedal, como um prisma retangular de concreto, flutuando sob quatro pilotis a $2,10 \mathrm{~m}$ do chão. Esses dois pontos associados configuram o térreo asfaltado com funções múltiplas (acesso, abrigo de veículos e estar) "o pilotis, asfaltado como extensão da rua, é uma praça" tendo como ponto de ligação duas escadas, uma social e outra de serviço, como define Acayaba. (2011, p. 287)

Ainda tomando o partido do terreno com declive para os fundos e aproveitando o aterro arrimado que possibilitou a configuração do térreo, o subsolo é ocupado com as dependências de empregada.

Sobre essa singular implantação, Spiro, segundo a versão de Otondo, faz um paralelo com outras três casas de Mendes da Rocha: a casa do próprio arquiteto no Butantã [FIG. 2.19], a residência Fernando Millan [FIG. 2.21] e a casa James King [FIG. 2.20], chamando a atenção para os "espaços não-construídos", resultantes significativas na produção do arquiteto:

"Dependendo do ponto de vista, você sente que faz parte da casa ou do terreno, é um lugar extremamente comunicativo, capaz de conectar as esferas pública e privada. Assim, o limite entre interior e exterior se dissolve, e acabamos por perder a certeza por onde se entra no edifício. No lugar de uma estreita passagem de entrada.

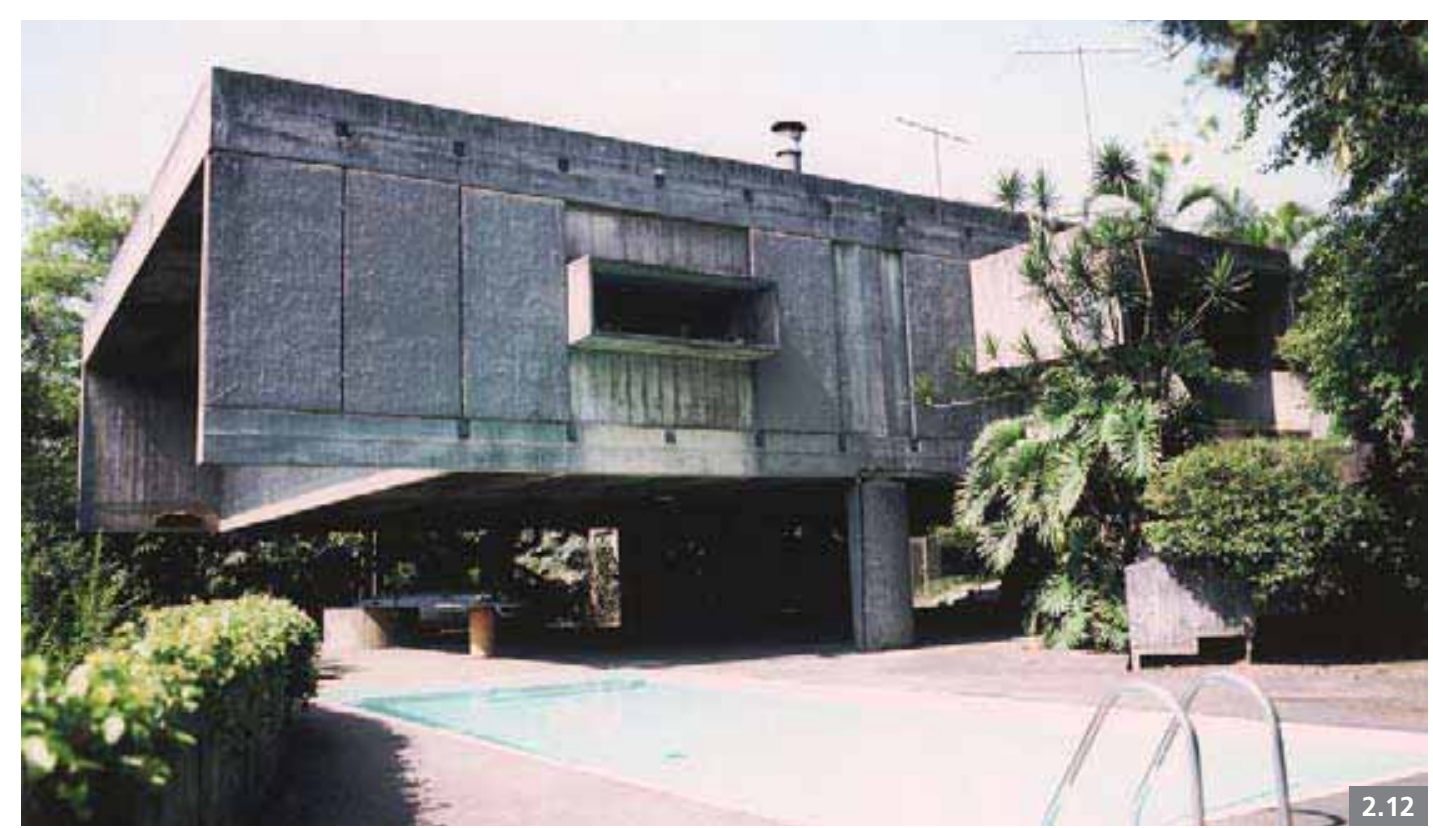

existe um espaço que conecta o terreno com o artefato." (OTONDO, 2009, p. 39)

Essas residências, produzidas entre os anos de 1969 e 1972, denotam muitas similaridades: a adoção do concreto como elemento plástico e estrutural, a "praça" como articuladora dos espaços, a releitura do "alpendre" em diversas situações, a cozinha linear ${ }^{8}$ [FIG. 2.13] e uma atenção especial nas implantações, sempre se relacionando de maneira particular com o terreno.

Especificamente na residência Masetti [FIG. 2.18], percebemos uma concentração do acesso abrigado e do estar, "espécie de alpendre-varanda", como assinala Acayaba (2011, p. 287), e que, por sua vez, organiza internamente a residência, dividindo os espaços sociais e íntimos como
2.12 Residência Mário Masetti, Paulo Mendes da Rocha e João de Gennaro, 1968-1970 - vista da fachada lateral e da área de lazer 

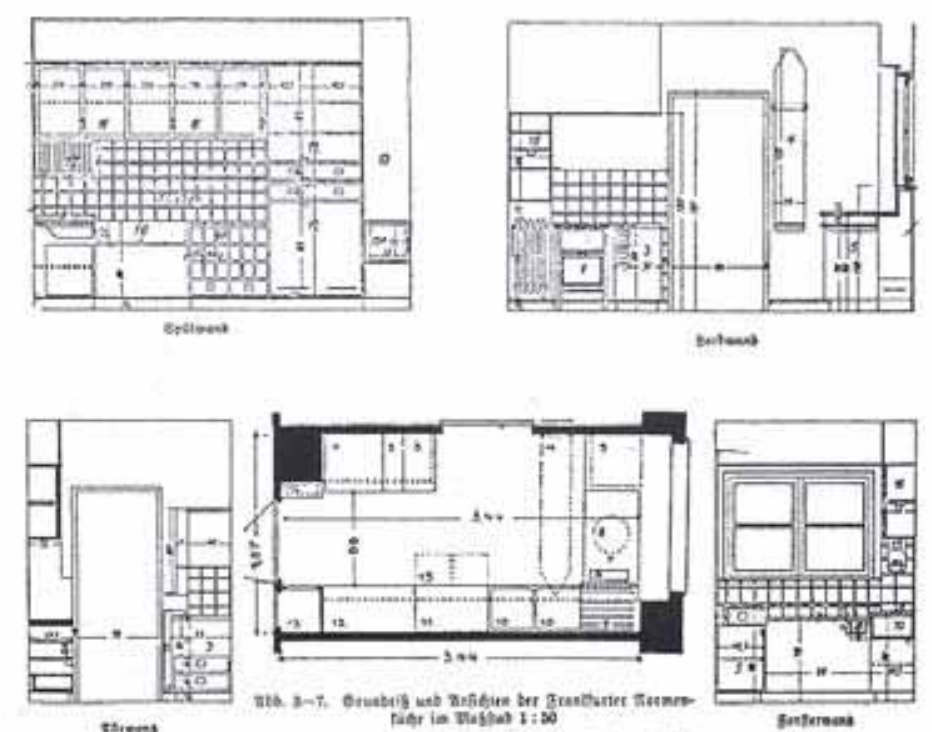

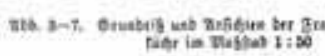

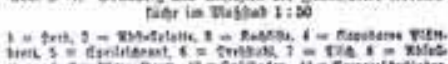

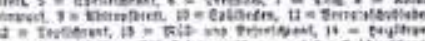

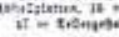

num pátio, cuja iluminação zenital cria um "microclima", que nos remete a um "quintal".

Essa relação interno/externo é observada por Wisnik como uma característica dos projetos da arquitetura moderna paulista desse período, e argumenta:

“(...) o brutalismo paulista vai internalizar uma compreensão territorial de geografia do país e do continente, tragando para dentro dos edifícios os atributos inerentes ao ambiente externo: água, jardins, luz solar. Essa operação se faz mediante uma poderosa integração espacial interna, que acomoda os diversos programas do edifício sob a cobertura única (...)" (WISNIK, 2004, p. 42)

Bastos, por sua vez, faz um paralelo entre a solução da residência Masetti [FIG. 2.14] e as unidades de habitação do CECAP "Zezinho Magalhães Prado" [FIG. 2.15], devido à setorização bem marcada em quadrante social, íntimo, e de áreas molhadas, como podemos perceber nessa descrição:

"(...) certos aspectos de Cumbica relembram a proposta da Residência Mário Masetti no bairro do Pacaembu (...) Mendes da Rocha explora a ideia de 'casa-apartamento' organizada em um pavimento sobre pilotis com acesso por escada externa (o que permitiria, em princípio, seu 'empilhamento' com certa independência de acessos)." (BASTOS, 2010, p. 176)

Esse conceito de "casa-apartamento" é defendido pelo próprio arquiteto Paulo Mendes da Rocha", que vê a verticalização como uma evolução da habitação na cidade, ressaltando que a casa particular em terreno isolado "não faz muito sentido dentro de um plano de cidade (...) desde essa época em que essas casas foram feitas". E reforça essa ideia ao declarar:

"A planta da casa que eu fiz lá no Butantã, que você conhece, uma casa de planta única, rigorosamente de planta única. Está tudo lá num plano só. Se você quiser multiplicar por dez andares, aquilo pode ser um prédio. Ali atrás onde está aquela escada, pode-se colocar o elevador e faz aquilo passar adiante e fazer um prédio de cinco, seis andares (...)." (PAULO MENDES DA ROCHA, São Paulo, 26/09/2011)
2.13 Planta, corte e elevações internas da "cozinha de Frankfort" Grete Schutte-Lihotsky, 1927
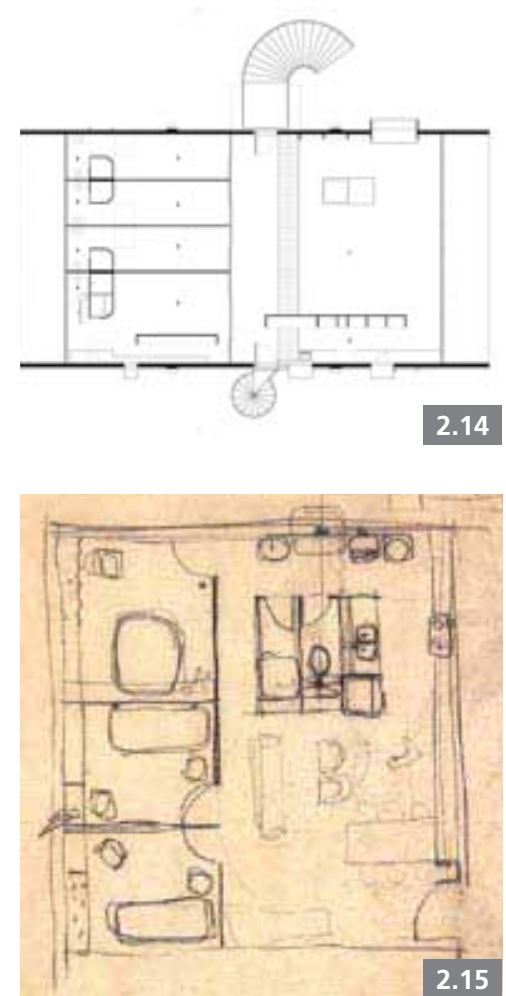
O volume, por sua vez, está definido por um lado, pelas empenas laterais de concreto, e por outro, pelos generosos "beirais" que protegem as fachadas envidraçadas da incidência solar indesejada. Essas empenas de $15 \mathrm{~cm}$ de espessura sofrem um alargamento nos pontos de apoio, cujos quatro pilares se projetam do solo como uma extensão da própria fundação.

Existe uma presença constante de elementos independentes associados a essa estrutura, externamente. Agregados às empenas podemos perceber os painéis de concreto pré-moldados [FIGS. 2.16 E 2.17] que configuram uma proteção extra, assim como a própria caixilharia. Internamente, temos as porta com venezianas em madeira separando a área social dos dormitórios, as alvenarias leves de concreto dividindo todos os ambientes e os componentes elétricos e hidráulicos aparentes reforçando a ideia de industrialização na construção.

Por fim, Spiro, segundo Otondo, declara a sua primeira impressão sobre as casas de Paulo Mendes da Rocha - o que, de certa maneira, também indica a importância patrimonial dessas casas devido à sua singularidade: "Todavia, a noção de 'clássico' aqui é inevitável. Ela surge, porém, menos como uma reflexão analítica e mais como exorbitante sensação, uma rara harmonia entre geometria e proporção." (OTONDO, 2009, p. 39)
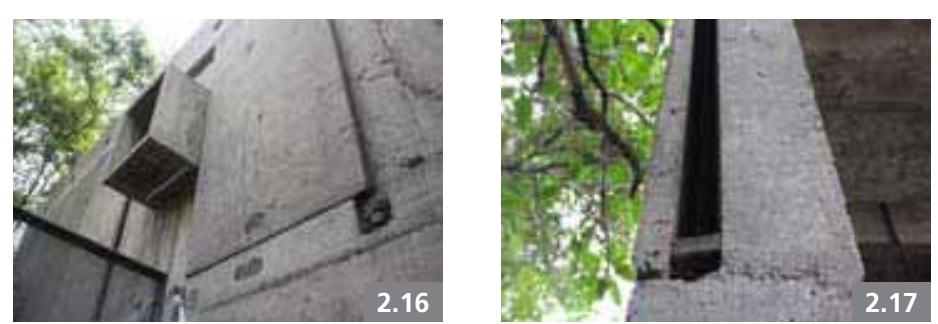

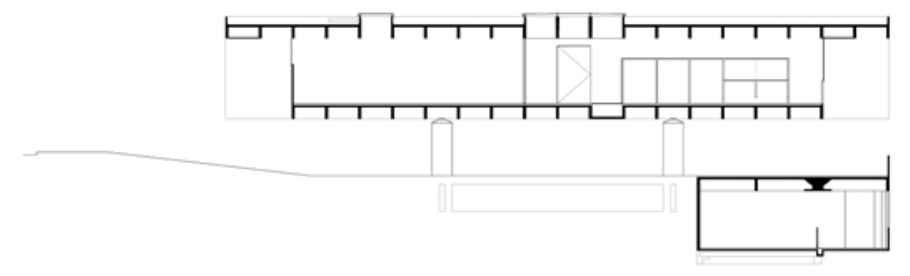

2.18

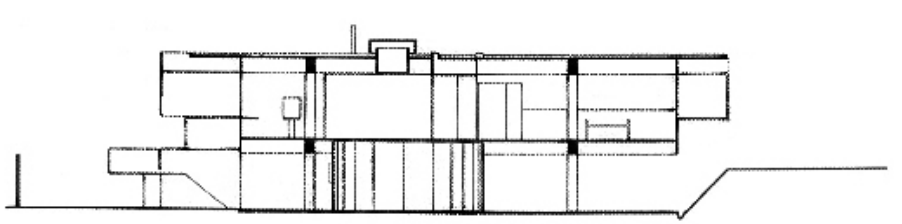

2.19

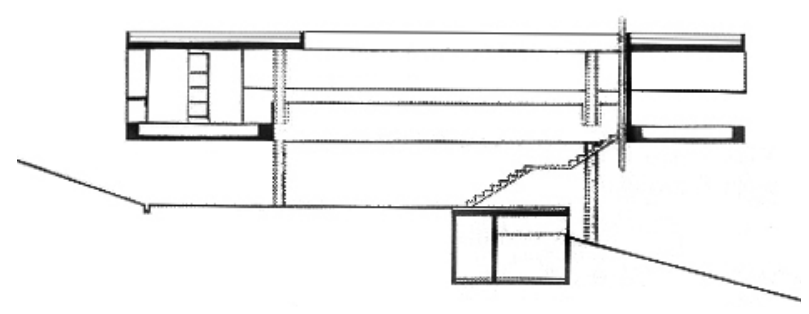

2.20

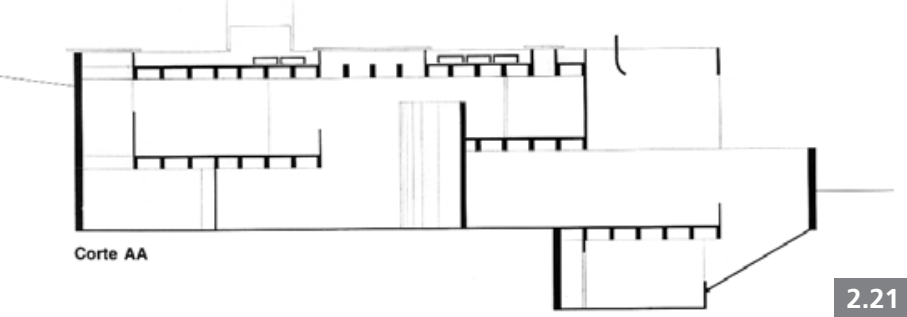

2.14 Residência Mário Masetti -

planta

2.15 CECAP "Zezinho Magalhães

Prado", Guarulhos, Fábio Penteado,

João Vilanova Artigas,e Paulo

Mendes da Rocha; arquitetos

colaboradores: Arnaldo Martino,

Geraldo Vespaziano Puntoni, Giselda

Visconti, Renato Nunes e Ruy Gama,

1967 - croqui de estudo da unidade

habitacional

2.16 Residência Mário Masetti -

vista da fachada lateral. Especial

atenção aos painéis de concreto

pré-moldados com função de

melhorar o conforto térmico

2.17 Residência Mário Masetti -

detalhe do encontro entre as

empenas de $15 \mathrm{~cm}$ de concreto e os painéis pré-moldados

2.18 Residência Mário Masetti -

corte

2.29 Residência Paulo Mendes da Rocha (também conhecida como

Casa do Butantã), São Paulo, Paulo

Mendes da Rocha e João Eduardo

de Gennaro, 1964 - corte

2.20 Residência James Francis King,

São Paulo, Paulo Mendes da Rocha,

1972 - corte

2.21 Residência Fernando Millan,

Paulo Mendes da Rocha,

1970-1975 - corte 


\subsection{RESIDÊNCIA FERNANDO MILLAN}

A residência Fernando Millan [FIG. 2.22], projetada por Paulo Mendes da Rocha em 1970 e executada entre anos de 1970 a 1974, tem como ponto de partida uma história muito particular, como descreve o próprio Mendes da Rocha ${ }^{10}$ :

"O Fernando Millan era um grande amigo meu. E, como todo mundo sabe, irmão de um grande arquiteto, Carlos Millan. E na ocasião que ele me encomendou esse projeto [o Fernando], o Carlos tinha acabado de morrer tragicamente em um desastre. Eu quero dizer que tudo isso está ligado a questões muito pessoais." (PAULO MENDES DA ROCHA, São Paulo, 26/09/2011)

\section{E complementa:}

“(...) Ele [o Fernando] já tinha quatro filhos, e ainda ficou com os dois filhos que ficaram do Carlos, que ficaram sem pai e sem mãe da noite para o dia. Tudo isso deu àquela casa um sentido extraordinário para mim." (PAULO MENDES DA ROCHA, São Paulo, 26/09/2011)

Esse depoimento esclarece, de certa forma, a particularidade desse programa, que tem uma quantidade de quartos aparentemente desproporcional. De qualquer modo, e obviamente, essa casa tem como atributo ímpar a sua implantação, pois, ao encravar a parte inferior da casa no terreno em declive e incorporar os recuos obrigatórios como muros de arrimo, Mendes da Rocha foge das soluções adotadas em outras casas projetadas por ele no mesmo período, enrique-

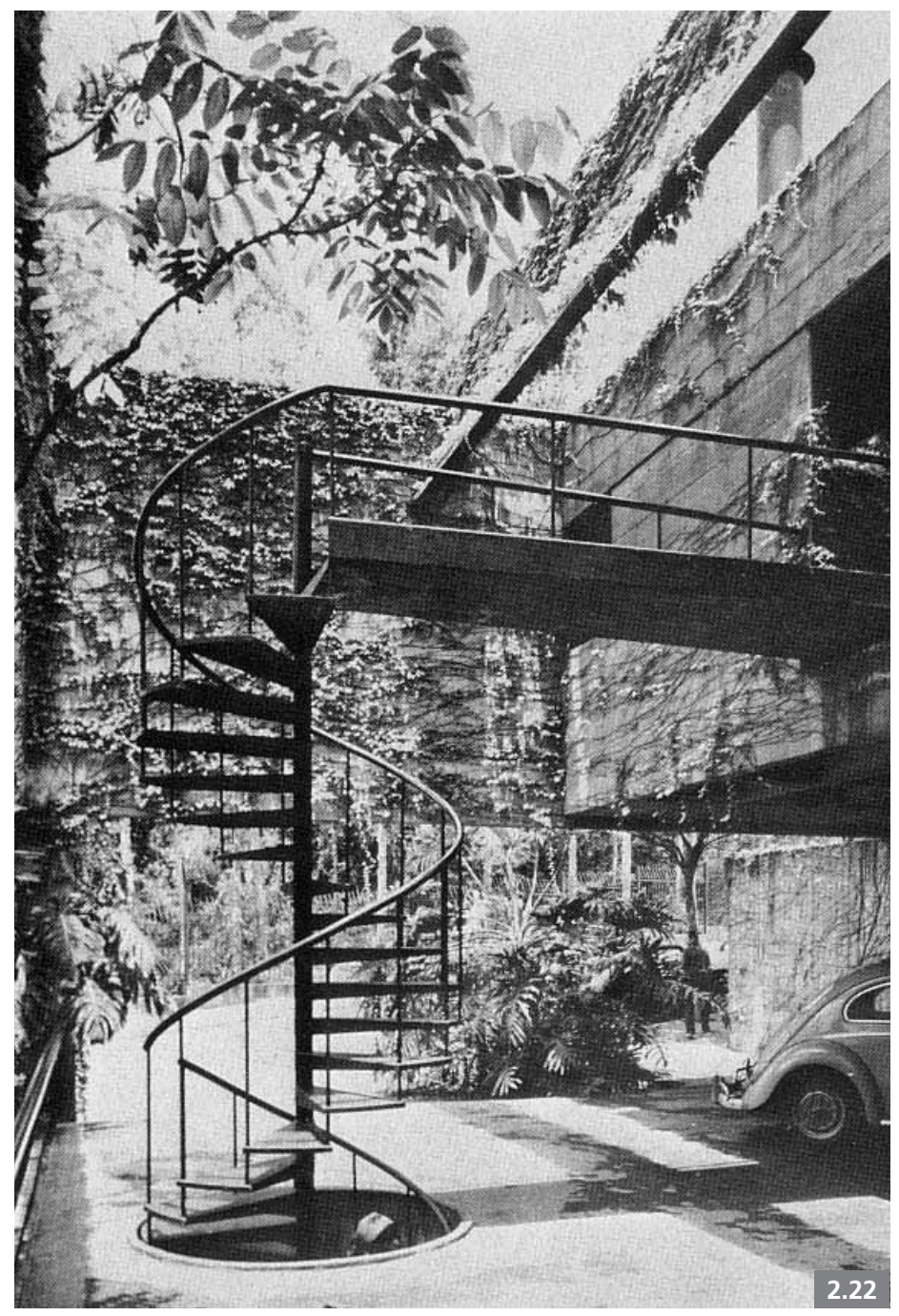


cendo a discussão entre a arquitetura e o território, como expressa Kamita:

"(...) o arquiteto cercou a totalidade do perimetro do lote; em seguida, foi imposta uma decisiva divisão do térreo, materializada por uma parede sinuosa que separa, no nível térreo, o pátio das áreas internas; finalmente, os quartos foram distribuídos em pavilhões suspensos conectados por uma passarela ponte. O inédito dessa ideia consistiu na inserção de volumes num espaço cercado, convencionalmente considerado interno." (KAMITA, 2004, p. 168) [FIG. 2.24]

A implantação no sentido leste-oeste faz referência à casa Baeta com sua empena cega de concreto, que nega as relações visuais diretas com a rua. Aparentemente é uma casa sem janelas. Na fachada principal, a única abertura discreta que se vislumbra é a porta no pátio descoberto da piscina, cuja escada externa faz a interligação com a cobertura, indicando, assim, um possível uso para essa área. Esta, que poderia ser "simplesmente uma cobertura" caracteriza-se como um jardim aéreo [FIG. 2.23], com plantas aquáticas, espelho d'água com vistosas carpas e "passeios flutuantes" em placas pré-fabricadas de concreto, ensejando o seu uso inspirado pela vista e proximidade do Bosque do Morumbi.

Um dado bastante curioso é o fato de o asfalto adentrar no terreno e também na sala, "evidenciando o seu caráter urbano", como indica Acayaba. (2011, p. 335)

Podemos destacar outros dois pontos, também singulares, dessa casa: o primeiro é o pé direito alto no vazio central com iluminação zenital, que organiza todos os ambientes ao seu redor; o segundo é um espaço que faz menção aos

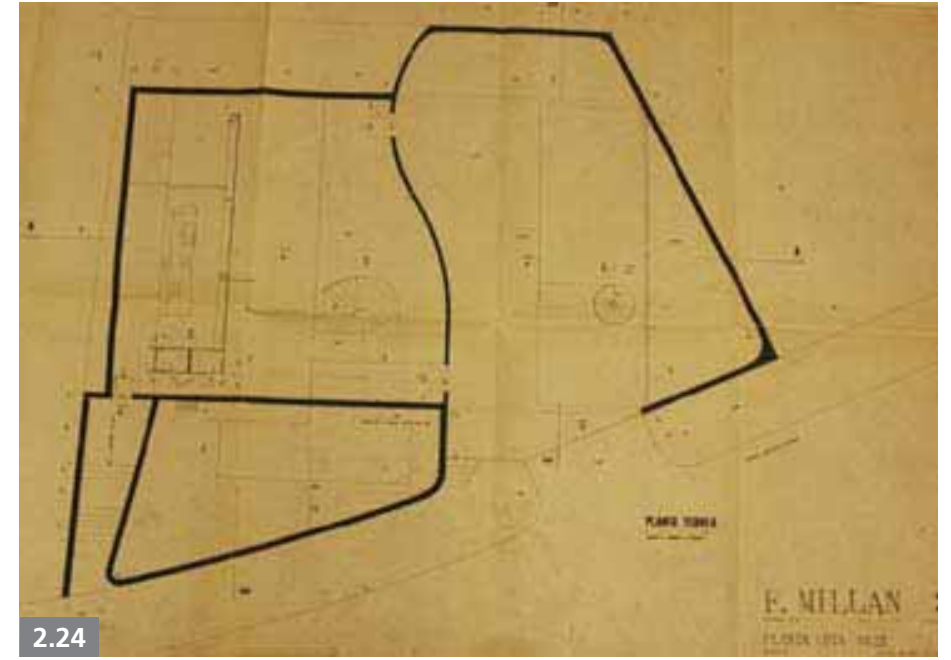

usos da casa tradicional paulista: o alpendre ${ }^{11}$. Essa solução aparece duas vezes nesta residência: localizada sob o volume do quarto e estúdio do casal, espaço este com finalidade de abrigar os veículos junto ao acesso principal e na porção posterior da casa, no ambiente da cozinha, com pé direito duplo, cuja iluminação é feita por meio de pérgulas cobertas.

Ademais de todas essas soluções bastante peculiares, a separação no pavimento inferior entre a área externa e a sala é feita por uma parede sinuosa, aparentemente descompromissada com a solução geral, mas de suma importância para o entendimento da dialética expressa nessa obra, como afirma Acayaba: “Há, neste projeto, uma sobreposição de desenhos, um mais livre formado pelos muros de arrimo e paredes de fecho e o outro ortogonal, definido pelo volume do andar superior." (2011, p. 335)
2.24 Residência Fernando Millan planta do pavimento térreo (desenho original digitalizado) 
Existe uma riqueza geométrica contida nessa complexidade de planos e formas, como indica Zein ao descrever:

"O perímetro da casa definido pela planta do pavimento superior é um retângulo áureo, cujo quadrado de origem é a base dimensional das outras linhas geométricas de definição dos ambientes." (ZEIN, 2000, p. 277)

O espaço coletivo sob uma laje nervurada que, ao vencer o vão, se sustenta nas duas empenas cegas de concreto, é evidenciado por Kamita, que percebe a sua importância na "concentração numa área comum de diversas atividades: estar, jantar, estudar, cozinhar" (2004, p. 168) e entende que possíveis zoneamentos são definidos ou muitas vezes sugeridos pelas divisórias baixas e os mobiliários de concreto.

Todas essas soluções estruturais - associadas a uma precisa execução no encontro de planos, soluções inovadoras e primoroso acabamento do concreto - estão intimamente ligadas à execução da obra pela CENPLA Engenharia e seu importante papel na construção da história da arquitetura moderna paulista, como evidencia Koury em seu artigo Novas Casas de Morar (2): a contribuição da construtora CENPLA:

"O papel da construtora CENPLA na viabilização dos projetos arquitetônicos não apenas explicita um método de trabalho de fundamental importân cia para o entendimento de seu sucesso entre os arquitetos do periodo, mas também representa um momento em que convergiram as expectativas de engenheiros e arquitetos que canalizaram as suas energias criativas para compor, juntos, soluções que representam uma contribuição ao patrimônio construtivo da arquitetura moderna brasileira." (KOURY, 2010)
NOTAS - CAPÍTULO 2

1 Angelo Bucci relata uma

curiosidade em relação ao nome

da proprietária, por qual a casa é

conhecida. "(...) Casa Baeta, tem

uma história, aliás, a gente chama assim, e acho que é uma coisa, não é muito justo, porque o Sebastião Baeta e a Olga Bohomeletz. Eles eram comunistas e nunca ... não sei se casaram, mas ela não tinha o nome dele. Não tinha a Olga Baeta. Tinha o Sebastião Baeta e a Olga Bohomoletz. Eram colegas do Artigas, de partido." Informação fornecida por Bucci em entrevista realizada pelo autor em 02/09/2011. Essa entrevista encontra-se disponível na íntegra nos Anexos do presente trabalho, p. 180

2 Sobre essa "crise", Dalva Thoma especula as possíveis razões desse apontamento encontrado em registros autobiográficos e que acarretaram no afastamento de dois anos prática profissional e rompimento temporário com seu colaborador Carlos Cascaldi. Ver: THOMAZ, Dalva Elias. Um olhar sobre Vilanova Artigas e sua contribuição à Arquitetura Brasileira. São Paulo: FAU-USP, 1997. Dissertação (Mestrado) - Faculdade de Arquitetura de Urbanismo/USP São Paulo, p. 206-237.

3 Informações disponíveis no site oficial do escritório SPBR Arquitetos. Disponível em: <http://www.spbr. arq.br/>. Acesso em: 11/01/2011
4 As informações referentes à escora original e as implicações que levaram ao seu colapso serão abordadas no capítulo Três casas paulistas: recomposição e

intervenção, do presente trabalho, p. 71.

5 Informação fornecida por Bucci em entrevista realizada pelo autor em 02/09/2011.

6 "A arquitetura em madeira foi marcante e predominou nas paisagens paranenses até metade do século XX ( ). "ZANI, Antonio Carlos. Arquitetura em Madeira. Londrina: EDUEL/Imprensa Oficial, 2003, p. 11

7 Sobre essa ligação de Artigas com os "concretistas" e em particular com Waldemar Cordeiro - e sua participação na Família Artística Paulista e no Grupo Santa Helena, ainda como estudante da Politécnica, ver: THOMAZ, Dalva Elias. Um olhar sobre Vilanova Artigas e sua contribuição à Arquitetura Brasileira. São Paulo: FAU-USP, 1997. Dissertação (Mestrado) - Faculdade de Arquitetura de Urbanismo/USP. São Paulo, p. 230; ARTIGAS, Rosa (org.). Vilanova Artigas - arquitetos brasileiros. São Paulo: Instituto Lina Bo e P. M. Bardi/Fundação Vilanova Artigas, 1997, p. 17; ARTIGAS, João Batista Vilanova. Caminhos da arquitetura. 2. ed. São Paulo: Pini/ Fundação Vilanova Artigas, 1986, p. 212-213
8 Nota-se a referência da "cozinha de Frankfurter", projetada pela arquiteta austríaca Grete Schutte-Lihotsky, cujos estudos de funcionalidade e fluxos de atividades, certamente estão presentes nas cozinhas projetadas por Paulo Mendes da Rocha em diversas residências. Ver: BRUNA, Paulo.

Os primeiros arquitetos modernos habitação social no Brasil 19301950. São Paulo: Edusp - Editora da Universidade de São Paulo, 2010, p. 43-44.

9 Informação fornecida por Paulo Mendes da Rocha em entrevista realizada pelo autor em 26/09/2011. Essa entrevista encontra-se

disponível na íntegra nos Anexos do presente trabalho, p. 225

10 Informação fornecida por Paulo Mendes da Rocha em entrevista realizada pelo autor em 26/09/2011 11 Ver: LEMOS, Carlos Alberto Cerqueira. Casa Paulista - história das moradias anteriores ao ecletismo trazido pelo café. São Paulo: Edusp Editora da Universidade de São Paulo, 1999, p. 45-50. 


\section{TRÊS CASAS PAULISTAS: RECOMPOSIÇÃO E INTERVENÇÃO}

Neste capítulo pretendemos analisar os objetos de estudo através de dois tópicos, que nos guiarão ao examinarmos as intervenções específicas de cada projeto:

- projeto, obra e circunstância;

- as intervenções e seus detalhes.

Contaremos com o apoio de diagramas, que nos auxiliarão graficamente, juntamente com desenhos dos projetos executivos de intervenção, assim como fotos - tanto durante as obras quanto posteriores à sua finalização -, na tentativa de responder algumas questões: Quais foram às ações projetuais propostas? Quais foram executadas? Como foi o processo de projeto e obra? Em que estado de conservação se encontrava cada edificação? As vertentes teóricas contemporâneas foram contempladas? Foram utilizados metodologias e conceitos contidos nas Cartas Patrimoniais, tais como: de restauração, de conservação, de adição etc? Como esses três exemplos podem contribuir para uma maior compreensão e valorização da arquitetura moderna e avançar no estudo de intervenção e preservação em patrimônio arquitetônico?

Restauração e preservação são ações distintas. Este é o primeiro pressuposto do qual partimos para esclarecer essas e outras questões - que por ventura poderão surgir no decorrer da argumentação -, apoiando-nos em Boito, como descreve Kühl:

"[вогто] Considera como essencialmente diversas a conservação e a restauração, insistindo que a conservação é, muitas vezes, a única coisa a se fazer, além de ser obrigação de todos, da sociedade e do governo, tomar as providências necessárias à sobrevivência do bem. Concebe a restauração como algo distinto $e$, às vezes, oposto à conservação, mas necessário." (KÜHL, 2003, p. 22-23)

O segundo pressuposto é que tais intervenções visam, mais do que a simples atualização para novas funções, prolongar a vida útil da edificação, respeitando o seu princípio físico, conforme sintetiza Araujo: [as notas referentes ao Capítulo 3 encontram-se a partir da p. 111] 
"Creo que hay una regla de oro em rehabilitación: no alterar el comportamiento físico del edifício sobre el que se interviene: mantener sus reglas, respectar sus princípios, y nunca dejarse llevar por la idea de que nuevas soluciones o técnicas están por encima de esse principio." (ARAUJO, 2010, p. 4)

Em relação ao projeto de restauro, Kühl ressalta que a importância da participação do arquiteto nesse processo não deve se restringir apenas a "produzir um desenho". Seu envolvimento com a obra é elemento sine qua non "nas diversas fases de produção do conhecimento (e do projeto)", ponderando, ainda: “A restauração requer, ademais, grande maestria no que se refere à qualidade do projeto, do próprio desenho." (2006, p. 27)

Essa afirmação é compartilha por Peter Zumthor², importante arquiteto suíço ganhador do Prêmio Pritzker 2009, que além de ter como característica de seu trabalho o detalhamento minucioso, elaborou vários projetos relacionados à preservação de patrimônio histórico:

"De todos os desenhos que os arquitetos produzem, os que mais gosto são os de execução técnica. Estes são específicos e objetivos. Dirigidos aos técnicos que darão ao objecto inventado uma figura material, são livres de qualquer encenação de representação associativa. Já não procuram convencer cativar como os desenhos de projecto. A sua característica é a certeza e a confiança. Parece dizer: 'Vai ser exactamente assim.'" (ZUMTHOR, 2009, p. 18) [FIG. 3.01]

Parece ser senso comum, talvez óbvio apenas para os arquitetos que trabalham com a preservação do patrimônio, que

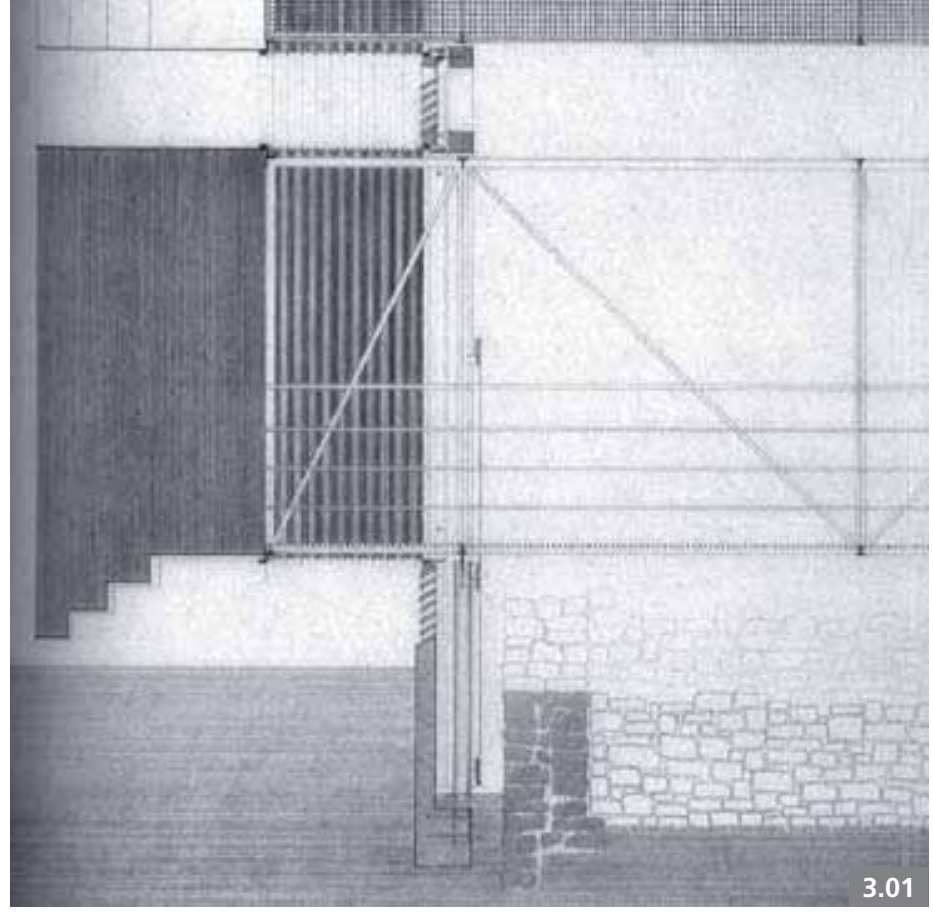

o projeto arquitetônico age como um articulador da restauração, sob a coordenação de um arquiteto, mesmo considerando que a restauração tenha como ponto de partida uma operação onde vários campos disciplinares trabalham conjuntamente. Kühl nos auxilia na compreensão dessa questão ao afirmar:

“(...) a intervenção se resolve também através do desenho, do projeto de restauração, que é um projeto de arquitetura, nada simples, estando presente sempre a dilacerante relação entre o conservar e o
3.01 Abrigo para ruínas

arqueológicas Romanas, Chur, Suiça, Peter Zumthor, 1985-1986 - detalhe do acesso 

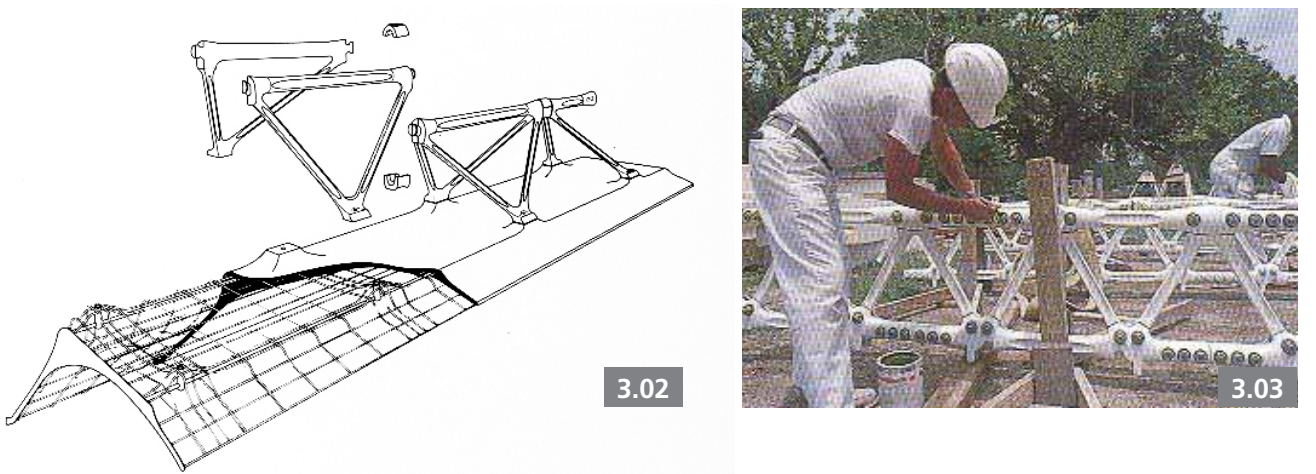

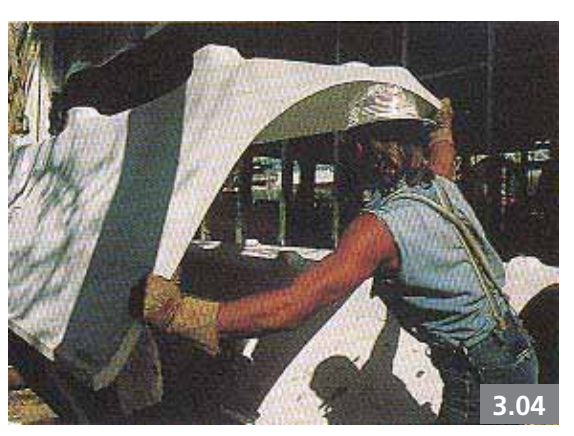

inovar (...) [o projeto] deve se ligar de maneira indissolúvel ao processo de aquisição de dados e análise." (KÜHL, 2006, p. 27)

E ainda reforça:

"O projeto de restauro, que é um tipo particular de projeto arquitetonico, insere-se nesse contexto de discussões [das vertentes contemporâneas de restauração]. Deve ser fruto de compreensão aprofundada da obra, ou conjunto de obras, e do ambiente que estão inseridas, e consequência de esforços multidisciplinares, envolvendo acurada pesquisa histórico-documental, iconográfica e bibliográfica, sensíveis estudos antropológicos, sociológicos e de viabilidade econômica, pormenorizado levantamento métrico-arquitetônico e fotográfico do(s) edifício(s), exame de materiais e técnicas construtivas, de sua estrutura, de suas patologias, e análise tipológica e formal." (KÜHL, 2006, p. 26)

Para discutir questões específicas em relação à obra e seus detalhes executados, recorremos a Zumthor que assinala a sua beleza: "Para cada lugar do objecto, os pormenores devem reflectir a ideia base do esboço: homogeneidade ou separação, tensão ou leveza, fricção, solidez, fragilidade (...)." (ZUMTHOR, 2009, p. 15)

Piano, por sua vez, ressalta a importância do canteiro, mesmo que o projeto tenha sido minuciosamente detalhado: “Não é verdade que tudo está no projeto. É o canteiro de obras que diz quais as hierarquias, as escolhas a fazer para decisões que, no papel, às vezes pareciam irrelevantes." (PIANO, 2011, p. 30) [FIGS. 3.02 A 3.04]

\subsection{DIAGRAMAS COMPARATIVOS: DEMOLIÇÃO / INTERVENÇÃO}

Os diagramas tridimensionais apresentados a seguir (p. 74-75) tem como objetivo mostrar a síntese das ações executadas nas residências estudadas.
3.02 The Menil Collection, Piano e Fitzgerald, Houston, 1981-1986 perspectiva explodida da junção dos elementos da treliça metálica com as abas de fibro-cimento

3.03 e 3.04 The Menil Collection montagem da estrutura metálica e empilhamento das abas no canteiro de obra 


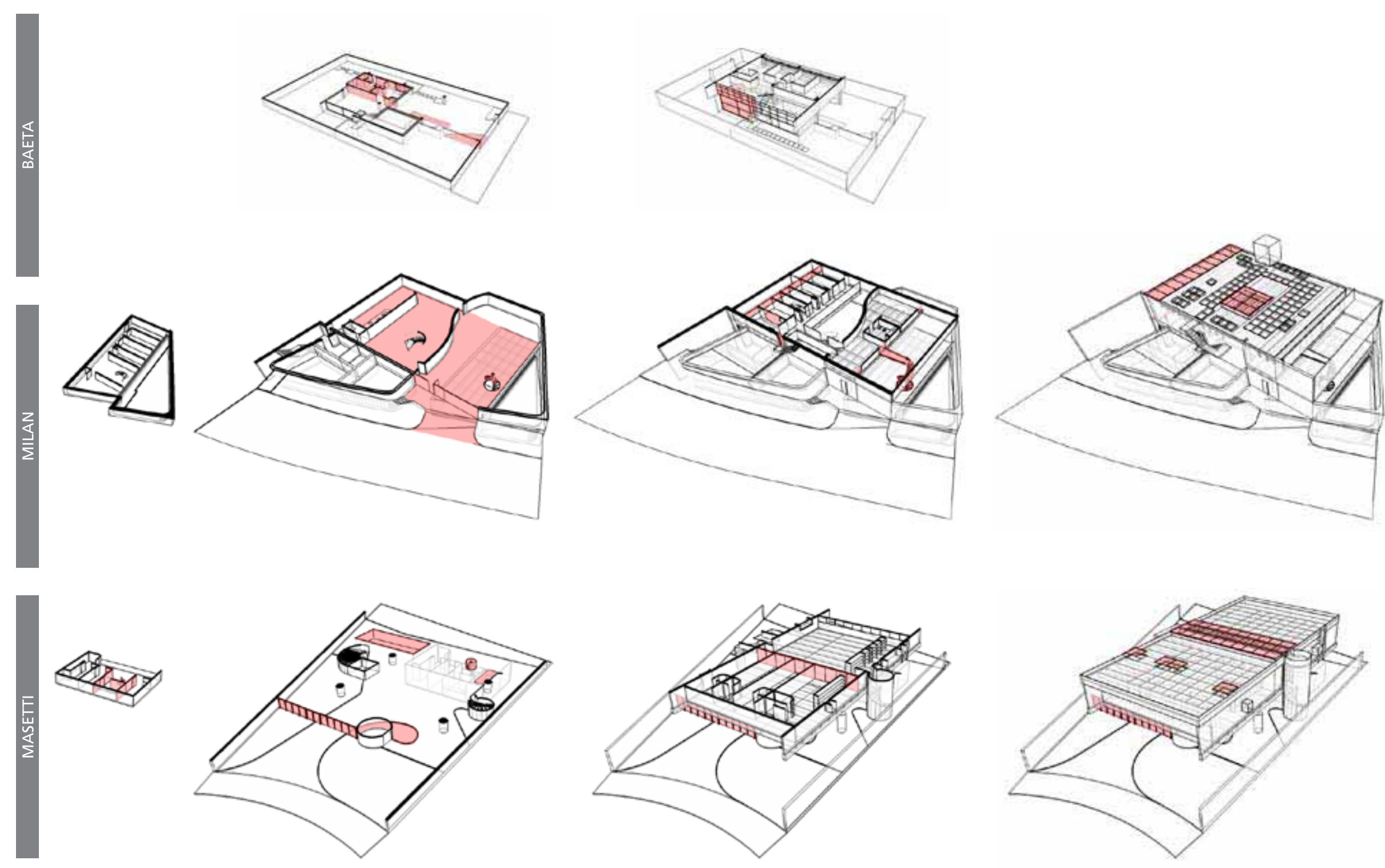




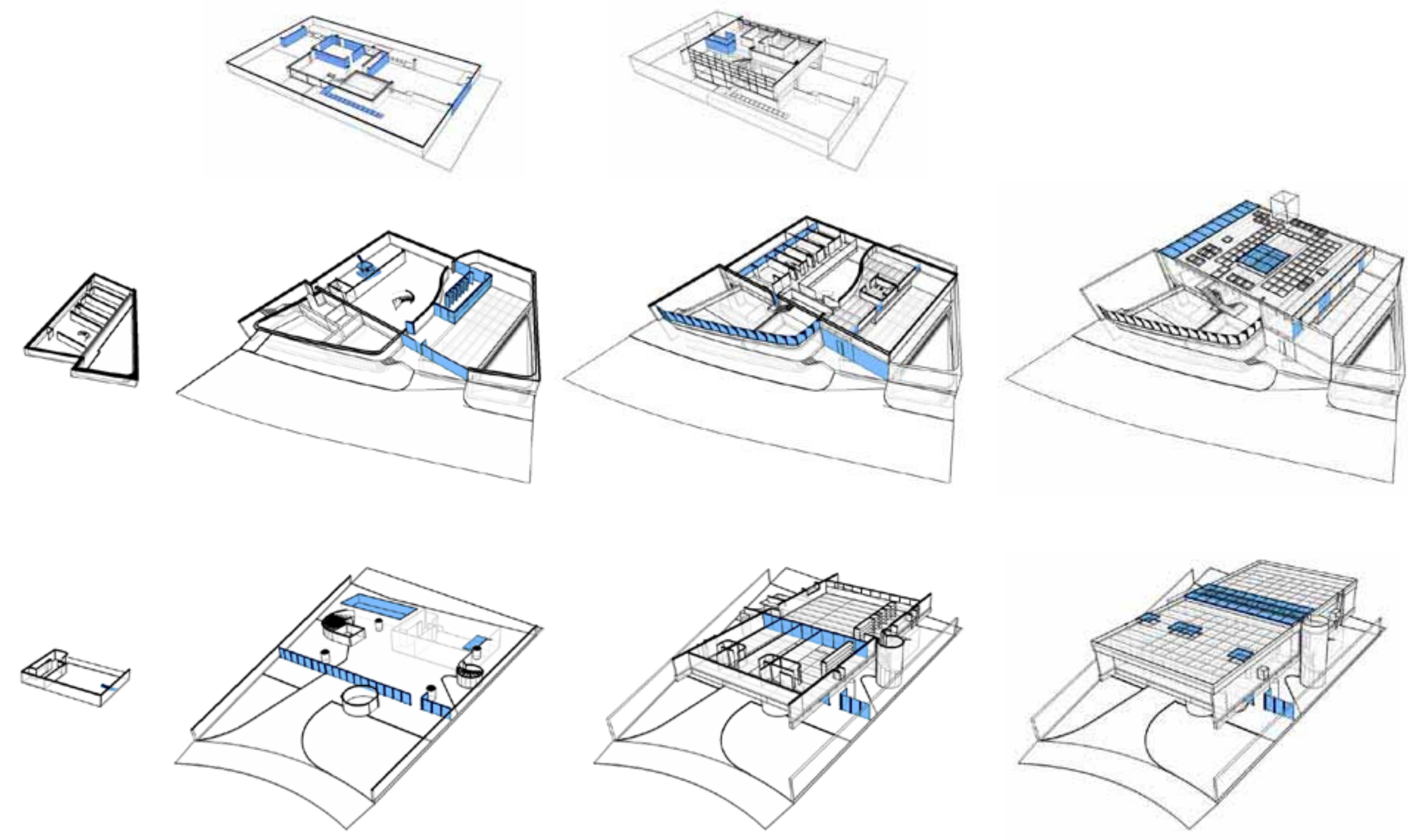




\subsection{PROJETO, OBRA E CIRCUNSTÂNCIA: RESIDÊNCIA OLGA BAETA}

A intervenção da residência Baeta foi elaborada pelo arquiteto Angelo Bucci e a equipe do MMBB Arquitetos ${ }^{4}$, cujo projeto iniciou-se no final de 1996 e a obra em $1997^{5}-$ a qual durou aproximadamente sete meses -, tendo como ponto de partida uma condição muito excepcional, como esclarece Buccí

"A Olga era tia-avó da Maria Paula, que é a minha cunhada. E quando a casa foi posta à venda, ela estava vazia há algum tempo estava meio... estava inteira, estava lá mais ou menos como está.. mas estava com uma cara de uma casa que já sem ocupar há algum tempo. E eles queriam muito vender pra dentro da família, porque assim eles poderiam continuar frequentando a casa e tal. A casa foi avaliada e custava baratíssimo, assim relativamente. Porque ela tinha um programa também modesto, área pequena, não tinha suites, não tinha lavabo. Tinha essas coisas. Então, quando... a lista de programa da casa era modesta e a casa tinha um preço.. precisava de uma boa manutenção... mas tinha um preço ótimo. Aí um dia eles me ligaram, o Eugênio me ligou e falou: "Olha, apareceu essa casa. O que você acha? Porque eu queria muito fazer um projeto com você". Eu falei: "Não! Imagina! Tem que comprar! E vamos lá ver. Mas, é um privilégio!". E daí nós fomos ver a casa. Eles queriam fazer uma reforma. Não era bem uma reforma. Tinha que atualizar algumas coisas da casa. Eles todos gostavam muito da casa. E eu também. E isso. Aí comprou." (ANGELO BUCCI, São Paulo, 02/09/2011
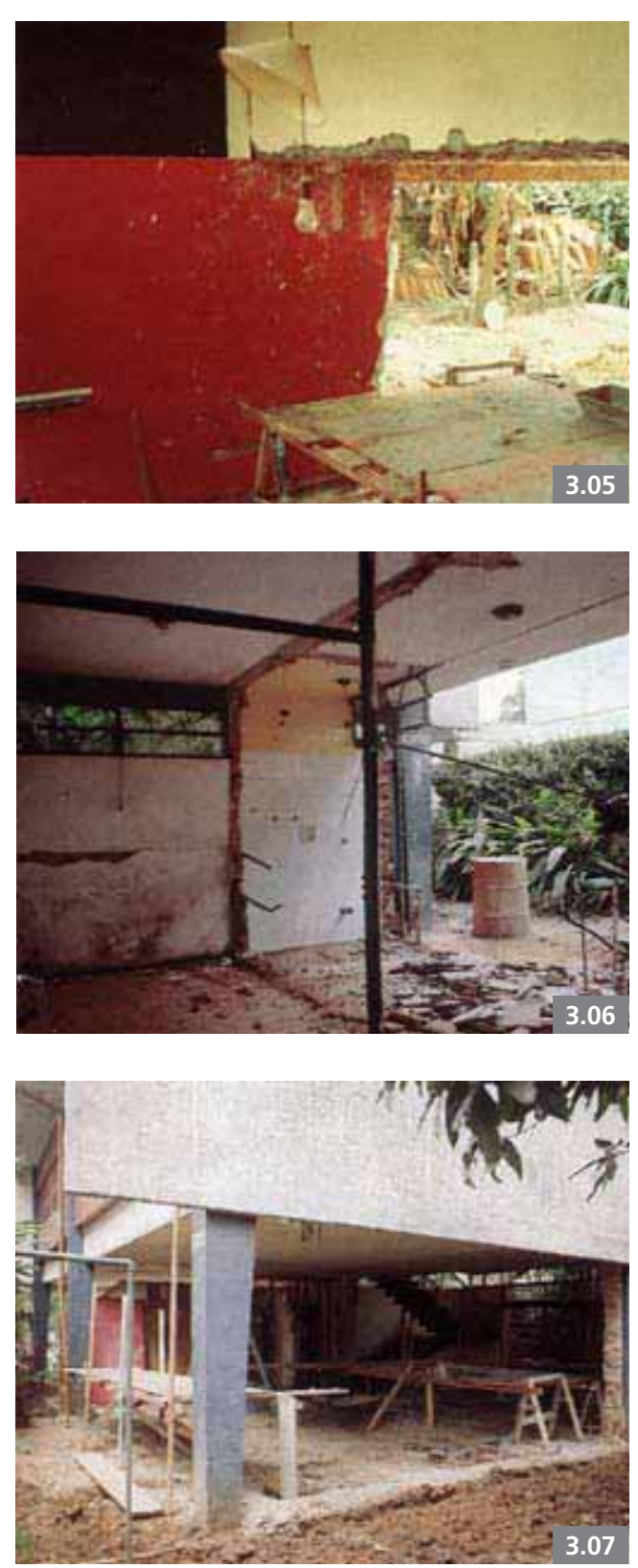

05 e 3.06 Residência Olga Baeta Vilanova Artigas e Carlos Cascaldi, 1956-1957 - vista interna e externa - demolição em andamento da cozinha e áreas adjacentes 3.07 Residência Olga Baeta - vista interna da sala com a demolição já finalizada 
As solicitações iniciais em relação a essa "reforma", estavam principalmente focadas nas atualizações da parte de serviço [FIGS. 3.05 A 3.07]: cozinha, lavanderia, além de toda a fiação elétrica, que deveria ser adequada aos novos equipamentos. Também foi requisitado ao arquiteto um sanitário no pavimento térreo [FIG. 3.08] e a adequação do sanitário no pavimento superior. O desenvolvimento do projeto e de seus detalhes, tendo como referência o projeto original, foi realizado em paralelo com a obra, como esclarece Bucci:

"Foi [o executivo foi feito junto]. Porque nós imaginávamos que o plano de estrutura, o projeto de estrutura estivesse fielmente atendido, mas não estava. Eu tinha os desenhos originais (...) um conjunto de informações lá da Fundação [Vilanova Artigas] muito bom (...) durante o processo de reforma, a gente foi verificando que as coisas que... estrutura que estava prevista inicialmente não tinha sido respeitada fielmente (...) as histórias que eu fui vendo da casa foram aparecendo durante esse processo, como quase que uma arqueologia (...)." (ANGELO BUCCI, São Paulo, 02/09/2011)

É importante ressaltar que o projeto é bastante criterioso, como revela a qualidade dos desenhos e dos detalhes produzidos. Por outro lado, apesar de Bucci afirmar que não tinha conhecimento da Carta de Veneza, é nítida a sua influência, mesmo que "inconsciente", uma vez que revela certa familiaridade com alguns dos preceitos teóricos de restauração, neste caso a distinguibilidade, um dos princípios fundamentais da Teoria Brandiana ${ }^{7}$, e a Carta de Veneza, como podemos perceber em sua argumentação:

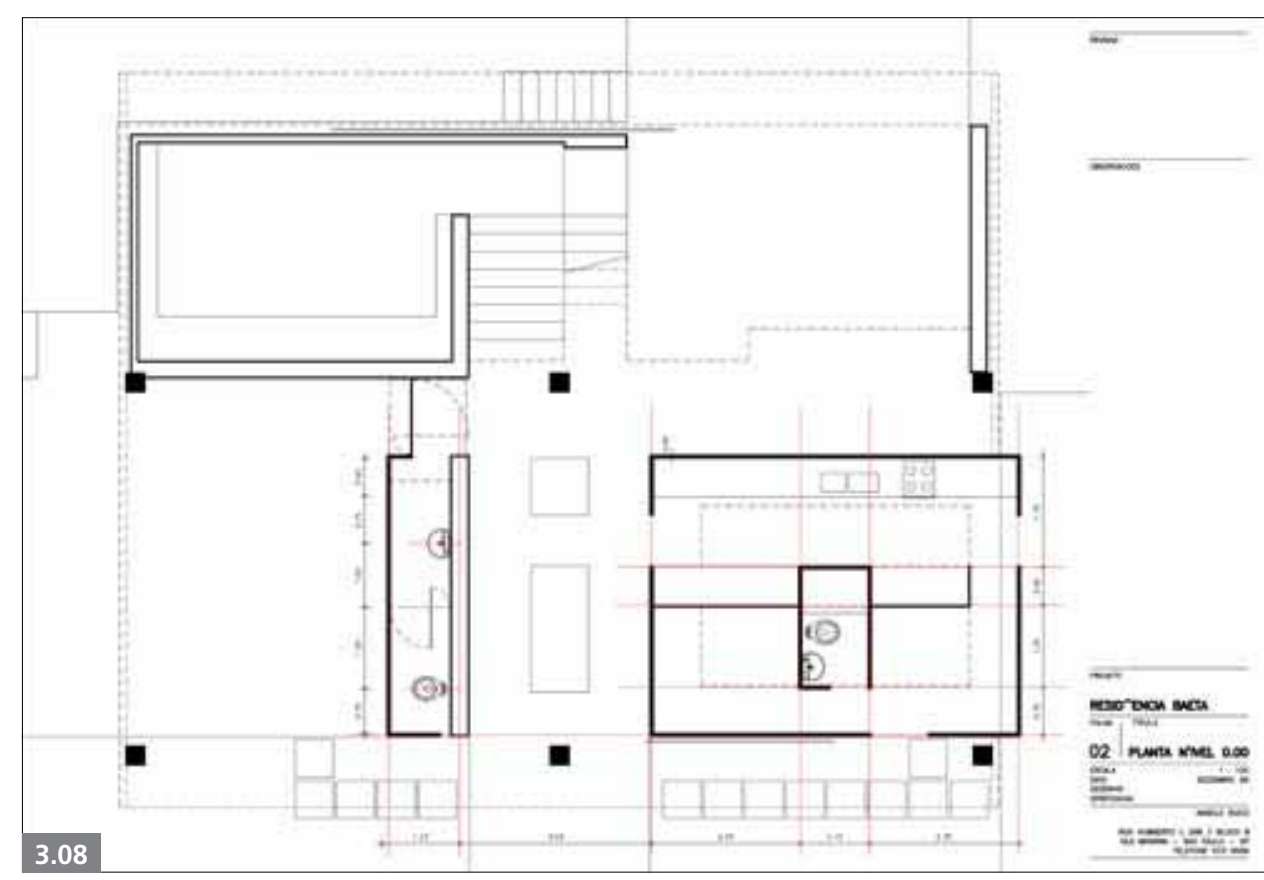

“(...) mas, não é a toa que está lá assim, que você faça um novo que não confunda... Mas, também não é só uma coisa de material. Também não confunda, não toque...não confunde e não se funde. Nenhuma peça nova [de concreto] toca, por exemplo, as lajes, as paredes existentes. Isso é uma coisa que fizemos assim. Eu acho interessante porque a casa toda é estrutura de concreto. A empena é de concreto aparente, mas pintada de branco e o que está feito lá [na intervenção] não é exatamente concreto, porque a armação é simples, então tem argamassa, mas tem essa cara. Então ela tem uma diferença radical de espessura, porque tem cinco centímetros. E tudo que é o novo é aparente, de fato, sem pintura, que foi também um outro modo de distinguir. E daí você olha assim. Segue esses princípios, mas que só depois eu fui conhecer." (ANGELO BUCCI, São Paulo, 02/09/2011)
3.08 Residência Olga Baeta - planta do pavimento térreo - nível 0,00 (prancha original digitalizada, escala original 1:100) 
Em relação ao canteiro [FIGS. 3.09 E 3.10] e suas especificidades, Bucci faz duas observações. A primeira: a obra contou com o acompanhamento minucioso do calculista (Ibsen Puleo Uvo), que "foi se dispondo a ver, verificar, calcular (...) fomos fazendo uma 'prospecção', algumas peças como vigas, pilares, a gente chegou a descascar para ver a armação que tinha dentro". A segunda: a relação com uma equipe de obra já conhecida por ele - o que até poderia ser questionado por não se tratar de uma empresa especializada - revelando a riqueza da proximidade e da confiança estabelecida em uma pequena equipe de obra, como relata Bucci:

"Aqui foi uma obra feita (...) com tão pouca gente. Tinha lá os pedreiros, o Paulinho que ficava um pouco lá. O Jam, pedreiro que depois fez o consultório de odontologia lá em Orlândia. O Persinho. O Dorfo. Tinha cinco pessoas, que era o que cabia no carro. E cinco pessoas fizeram a reforma. Então todas as coisas usadas era o que aqueles cinco ali podiam fazer. Depois veio o marceneiro, que ficava na obra, montou as janelas todas, trocamos cabos de aço. Coisas super domésticas, assim. Serralhei$\operatorname{ros}($...)." (ANGELO BUCCI, São Paulo, 02/09/2011) [FG. 3.11]

\section{E complementa:}

"Ali na Baeta eu tinha [tempo], porque eu ia à obra diariamente ${ }^{8}$, os pedreiros lá também podiam fazer a coisa com tempo, eu conhecia muito bem cada pessoa que trabalhava lá, era legal. o Ibsen, recalcular aquilo a troco de nada, incrível! Foram condições que é muito difícil de ter (...)." Grifo nosso. (ANGELO BUCCI, São Paulo, 02/09/2011)
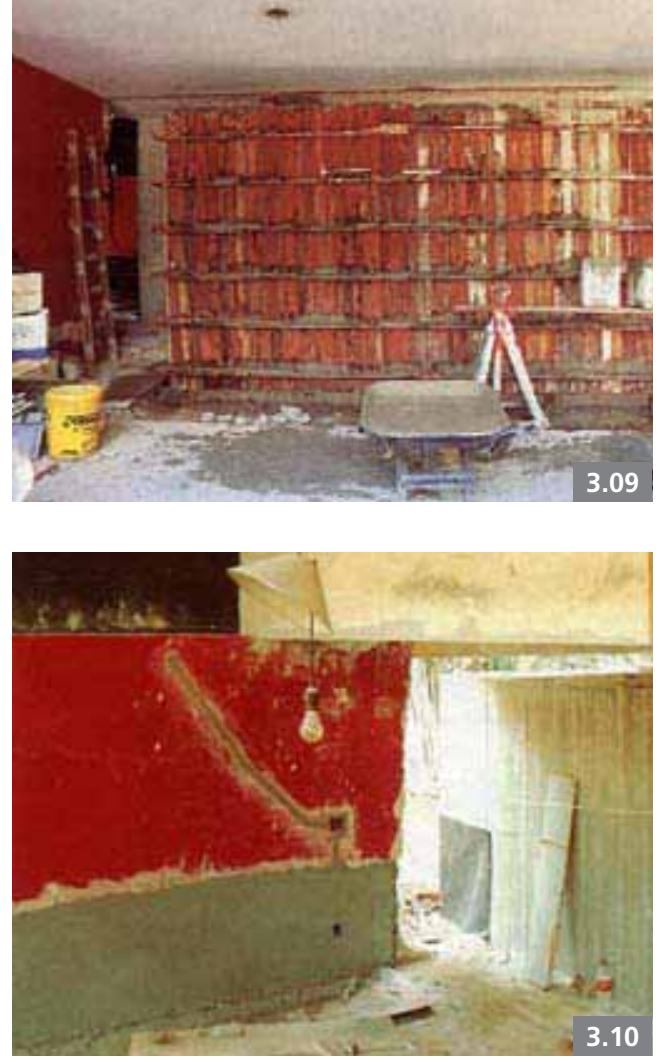

Bucci ainda comenta o "peso" da responsabilidade de fazer uma intervenção numa casa que já figurava na literatura específica com tamanho destaque: "Então a obra era uma coisa que me preocupava muito. Eu sabia que com esta casa não podia acontecer nada, não podia brincar". Por fim, aponta a dicotomia entre fazer apenas uma manutenção ou

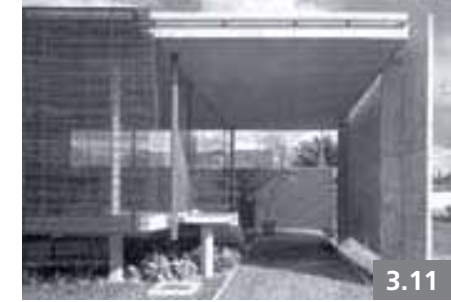

3.09 Residência Olga Baeta - vista do acesso principal. Notar formas de madeira para concretagem da parede de $5 \mathrm{~cm}$ que configurou 0 lavabo

3.10 Residência Olga Baeta - vista interna da sala, nota-se que o volume de serviço está concretado e não encosta nas alvenarias e nem na laje existente

3.11 Clínica de odontologia,

Orlândia, Angelo Bucci, Fernando de Mello Franco, Marta Moreira e Milton Braga, 1998

3.12 Residência Mário Masetti, Paulo Mendes da Rocha e João de Gennaro, 1968-1970 - detalhe da canaleta de drenagem da

piscina (trecho da prancha original digitalizada, escala original 1:5) 3.13 Residência Mário Masetti vista da piscina registrada na vistoria de início do projeto, 15/03/2010 3.14 Residência Mário Masetti vista da piscina registrada após a obra, 15/03/2011 
intervir com propriedade, na medida entre a necessidade e uma "nova identidade", ou seja, aborda o problema do "enfrentamento" em uma obra de patrimônio:

"Eu não gostaria de alterar demais a casa... Tem sempre isso: a medida boa para um projeto, um limite bom, positivo, é sempre o limite dos entendimentos (...) é um ponto super delicado pra mim, muito importante. Como você se coloca diante daquilo ali. Você pega você se limita a espanar paredes? Eu acho o mais respeitoso com o cara que dedicou a vida toda a ser professor e tudo, é você fazer o melhor possível. Para que o diálogo seja se um modo respeitoso ele precisa ter um patamar onde, cada um em uma posição, cada um em um nível - que não é para igualar as qualificações - fale, escolhendo as palavras e tudo. Que seja um diálogo." (ANGELO BUCCI, São Paulo, 02/09/2011)

\subsection{PROJETO, OBRA E CIRCUNSTÂNCIA: RESIDÊNCIA MÁRIO MASETTI}

Na residência Mário Masetti, o projeto de intervenção foi elaborado pelo próprio arquiteto autor do projeto original, Paulo Mendes da Rocha, e o arquiteto Eduardo Colonelli do Escritório Paulistano de Arquitetura, com o projeto executivo e seu detalhamento feitos conjuntamente no decorrer da obra, no ano de 2011 e início de 2012. No entanto, Paulo Mendes da Rocha9 ${ }^{9}$ esclarece que foi desejo do cliente que se "retomasse absolutamente a condição original", devido às diversas substituições feitas ao longo do tempo, e argumenta:
“Já a Casa Mário Masetti, no Pacaembu, o caso é completamente diferente, porque há, ao mesmo tempo, um rigor e uma simplificação da questão muito clara. O cidadão, Houssein [Jarouche], que comprou, me chamou, também - eu não sabia nada do negócio! Que a família tinha vendido, que ele comprou e que ele queria... Porque sabia que uma coisa ou outra tinha sido recomposta na casa, substituída (pelo tempo até da construção dos anos 70, se não me engano, portanto já faz 40 anos e tal)... Se eu queria conferir com ele se estava tudo [bem] (...) Então eu fui lá e, de fato, constatei que isso e aquilo, claraboia, persianas de madeira... E disse literalmente a ele-porque poderia até... -, as persianas tinham sido substituídas por persianas de fibra (pode ser até útil, porque conserva melhor)... Mas, eu disse isso, isso e aquilo e ele mandou consertar tudo." (PAULO MENDES DA ROCHA, São Paulo, 26/09/2011)

Paulo Mendes da Rocha assinala uma modificação que, $a$ priori, não havia sido solicitada pelo cliente: a mudança da cor da piscina [FIGS. 3.12 A 3.14]. Esta, de qualquer forma, teria seu revestimento substituído, assim como sua impermeabilização refeita e seus equipamentos e sistema de drenagem revisados. E comenta:

"Aproveitei pra fazer uma coisa que eu sempre sonhei, que é uma piscina escura, como as águas do mar nas pedras do Arpoador. A pedra é granito escuro, o fundo é de areia clara, e as águas parecem cristalinas. Eu tenho implicância com piscina que fica com cara de aparelho sanitário, tudo de azulejo branco. Mas, é a mesma piscina que está lá, só que tinha mesmo que ser refeita a impermeabilização e etc., aproveitei e pedi pra por uma cor escura. Ele fez isso e ficou
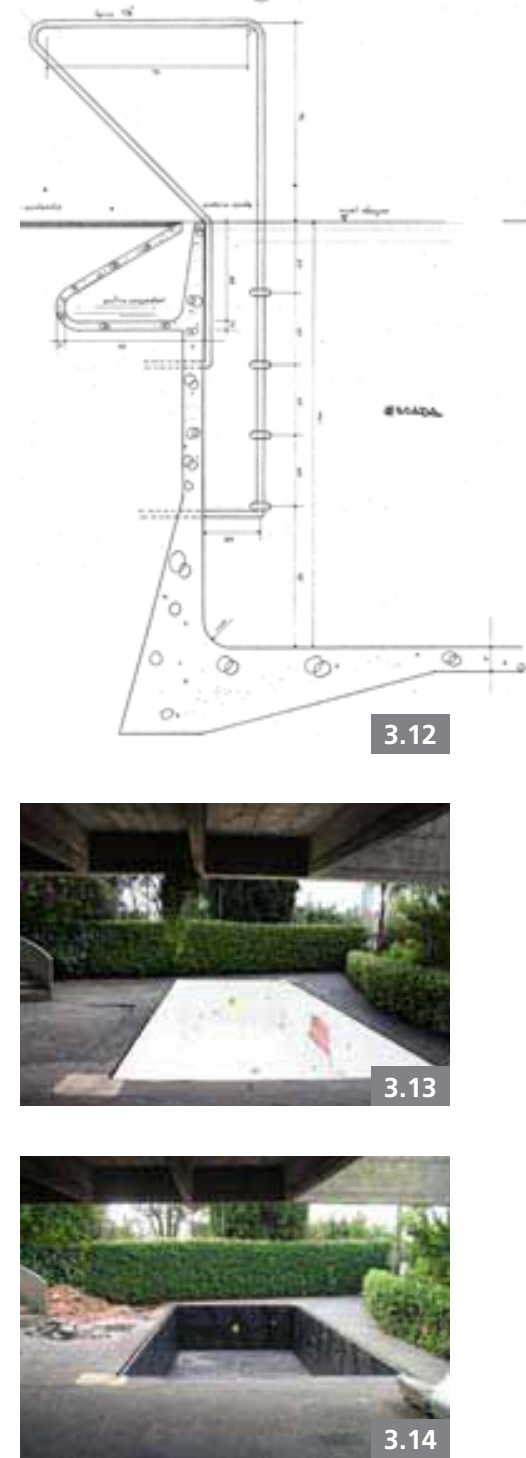
muito bonito. Ele foi muito gentil." (PAULO MENDES DA ROCHA, São Paulo, 26/09/2011)

Em relação às posturas adotadas no projeto, Colonelli $^{10} \mathrm{ar}$ gumenta que se optou por "seguir uma certa metodologia", e relata: "a gente fez de acordo com alguns protocolos", que ao agir, "adotando vários aspectos conceituais", buscamos solucionar questões práticas, e que se não pretendia elaborar nenhuma tese, e reforça: "houve conservação e mesmo adequações", mas "não se buscou uma restauração".

Essa afirmação do arquiteto revela a sua compreensão das diferenças conceituais de cada uma dessas operações. Assim como sua explicação sobre a questão da "continuidade do uso" da edificação, seu conhecimento do campo teórico, cuja afirmação de que 'cada caso é um caso', - ligada à vertente do "restauro crítico" -, é o ponto central:

"No fundo, o mais importante eu acho que é manter o uso, deixar ele vivo. Usá-lo. Deixá-lo como uma coisa viva. É usá-lo plenamente e que ele conserve a sua essência, na sua conceituação, na sua arquitetura. Eu acho que certos ajustes são, às vezes, absolutamente necessários. Não vejo nisso um problema. Agora, que ajustes são esses? Caso a caso!" (EDUARdo COLONELLI, São Paulo, 20/09/2011)

Araujo também se apoia nessa definição de "restauro crítico", ao analisar diversos exemplos de intervenções associadas às posturas técnico-operativas, em seu artigo La rehabilitación de la arquitectura moderna, e comenta: "En realidad, en reha-
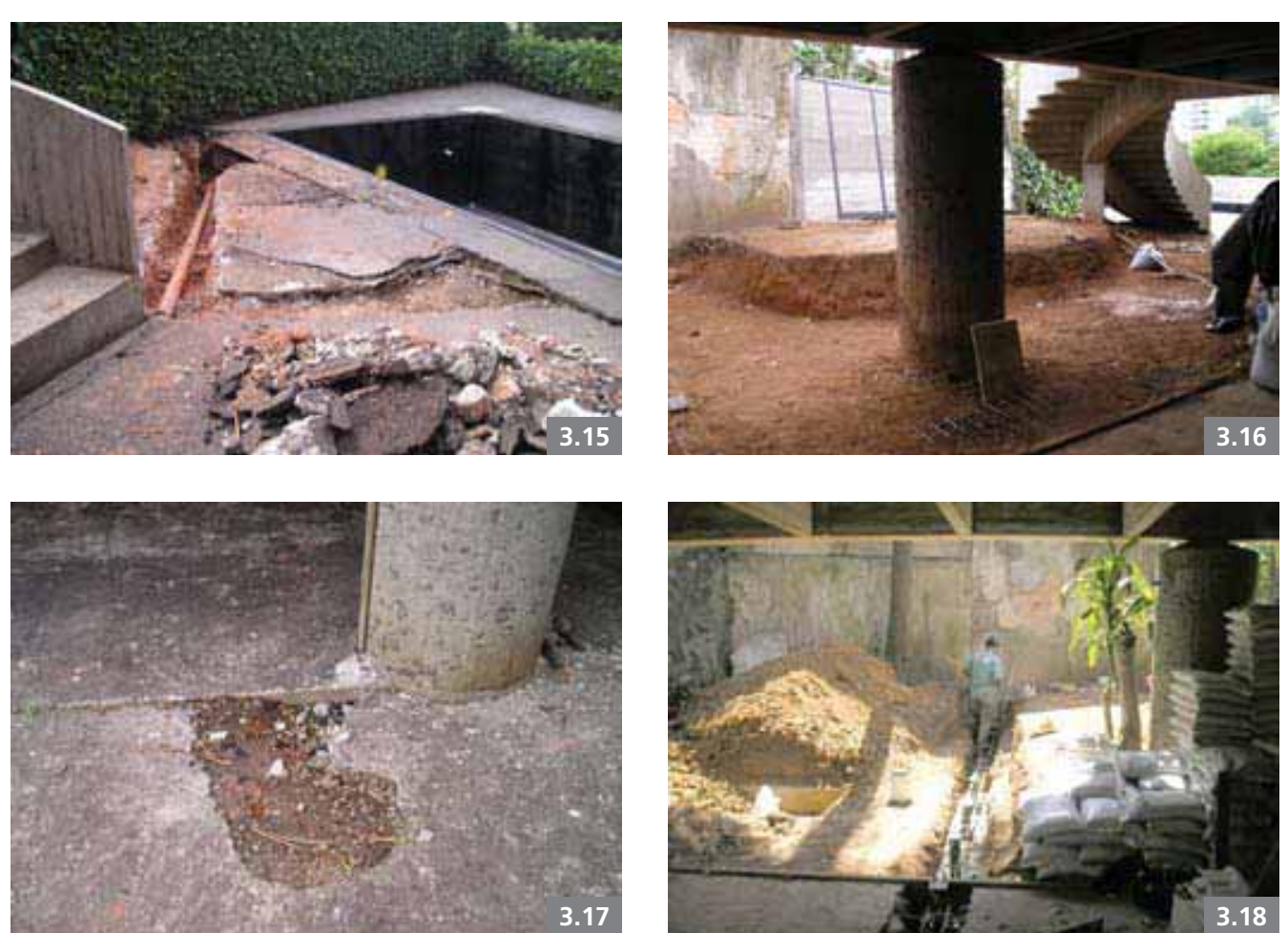

bitación no valen dogmas, y todo ló dicho debe entenderse como una generalid: El edifício manda mucho y cada obra será un caso excepcional." ${ }^{11}$ (2010, p. 8)

Especificamente sobre o processo de obra, Colonelli descreve que após ser chamado por Paulo Mendes da Rocha, e vistoriarem juntos a casa, inclusive com a participação do cliente, foram definidos os pontos principais que deveriam ser recuperados, cujas decisões foram reunidas em um Relatório Preliminar de Serviços. Após essa etapa, Colonelli ficou 


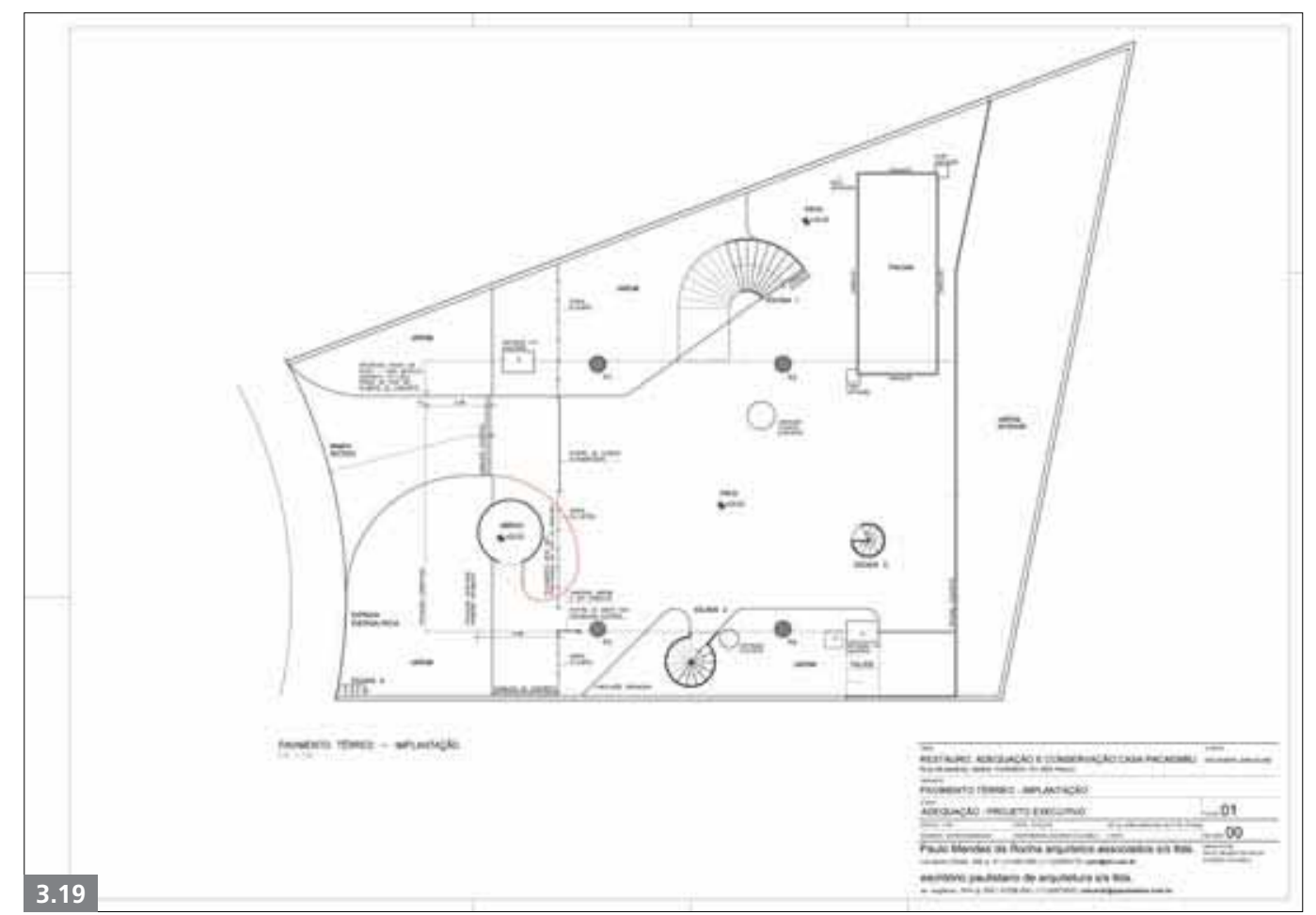

3.15 Residência Mário Masetti detalhe do encanamento de drenagem a ser removido do pavimento térreo - registrado em vistoria de obra - 05/05/2010

3.16 Residência Mário Masetti detalhe da execução de adequações de piso e drenagem no pavimento térreo - registrado em vistoria de

obra - 18/09/2010

3.17 Residência Mário Masetti detalhe da prospecção do piso asfáltico do pavimento térreo - registrado em vistoria de obra 04/08/2010

3.18 Residência Mário Masetti detalhe da execução das fundações para fixação do novo gradil metálico do pavimento térreo - registrado em vistoria de obra - 28/04/2010

3.19 Residência Mário Masetti planta do pavimento térreo

- implantação (prancha original digitalizada, escala original 1:100)

encarregado do desenvolvimento do projeto e acompanhamento da obra, como descreve:

“(...) aí, fiquei fazendo o desenvolvimento, esse trabalho, esse contato. Acompanhei a execução. Acompanhei essa obra, assim, passo a passo, porque, inclusive, muitas coisas tinham que ser vistas, se ficaram boas ou não. Foi uma coisa delicada. Foi esse o processo (...) Eu não cheguei a fazer um memorial de restauro. Nós pegamos os desenhos originais, digitalizamos todos. Aí desenhamos neles as coisas que seriam eventualmente alteradas e depois trabalhamos nos detalhes: desenhei a claraboia, desenhei os caixilhos. Tem um pequeno memorial ${ }^{12}$ inicial de procedimentos com relação ao que fazer, mas não chegou a caracterizar, a formalizar um memorial de restauro, nada disso. Mas, foram instrumentos suficientes para que essa obra fosse feita, controlada. Mesmo porque eu estava presente. Fosse para fazer um pacote para mandar, provavelmente eu teria que fazer isso de outra forma. Foi tudo muito documentado (...)." (EDUARDo COLONELLI, São Paulo, 20/09/201 l) [FIGS. 3.15 A 3.19] 


\subsection{PROJETO, OBRA E CIRCUNSTÂNCIA: RESIDÊNCIA FERNANDO MILLAN}

O projeto de intervenção da residência Fernando Millan foi também elaborado pelo próprio arquiteto autor do projeto original, Paulo Mendes da Rocha, tendo sido desenvolvido conjuntamente com o arquiteto Milton Braga do escritório ммвв Arquitetos, e uma equipe de colaboradores do escritório Bela Vista Arquietos ${ }^{13}$. O desenvolvimento do projeto foi concomitante com a execução da obra nos anos de 2000 e 2001, e teve outra particularidade - além do próprio autor conduzir a transformação na sua obra: a participação do engenheiro Osmar Penteado de Souza e Silva, da empresa CENPLA Construções, Engenharia e Planejamento, que havia executado a obra original na década de 1970.

Tendo em vista a importância da CENPLA, em seu papel singular na execução de obras da arquitetura moderna em São Paulo e, em especial, ao interesse da continuidade metodológica em relação ao canteiro [FIGS. 3.21 A 3.26], mesmo nessa obra recente, destacamos e compartilhamos com Koury o mérito dessa participação tão inusitada, como a autora já havia reforçado em sua dissertação e que pode ser abalizado pelo depoimento do próprio Osmar:

"Nós temos um caderno que contempla e esclarece o detalhamento, os acabamentos. Fica registrado nesse caderno, com croquis, com anotações, com legendas, o que se pretende fazer. Na obra, o nosso princípio éo seguinte: não faça se tiver alguma dúvida. Na falta de instruções ou se não entendeu o que deve ser feito, não faça. Se não está dando certo, não faça, espere até que chegue um engenheiro de obras nosso. Se for só um problema de interpretação de desenho, e ele for capaz de resolver, tudo bem, senão o arquiteto é chamado para esclarecer ou mesmo interferir, modificando o seu próprio projeto para possibilitar a sua construção."14 (KOURY, 1999, p. 220)

Paulo Mendes da Rocha ${ }^{15}$, por sua vez, comenta a situação de ter sido chamado para intervir em uma casa de sua autoria:

"Quando a casa foi vendida, mais tarde - coisa que eu não tenho nada que possa comentar quanto a isso-; mas, entretanto, quem comprou a casa, foi o Eduardo Leme, de uma postura muito simpática, digamos assim, muito positiva, conversou comigo se eu não queria dirigir uma limpeza na casa - que ele precisava fazer - e se era possivel tirar a cozinha dali." (PAULO MENDES DA ROCHA, São Paulo, 26/09/2011)

Sobre essa mudança do lugar da cozinha ${ }^{16}$ [FIG. 3.20], é interessante considerarmos o pedido feito pelo proprietário: por um lado, a situação da cozinha, constante no projeto original, era bastante privilegiada (ambiente de pé direito duplo sob pergolado envidraçado na porção posterior da casa); por outro, sua localização sui generis (proximidade com os quartos, que abrem para um vazio dentro da própria casa), cuja mudança já havia sido aventada pelos proprietários na época da obra, como relata Mendes da Rocha:

“(...) a posição daquela cozinha foi discutida. E, durante a obra, mesmo - já na obra - eu me lembro que foi falado se não era 


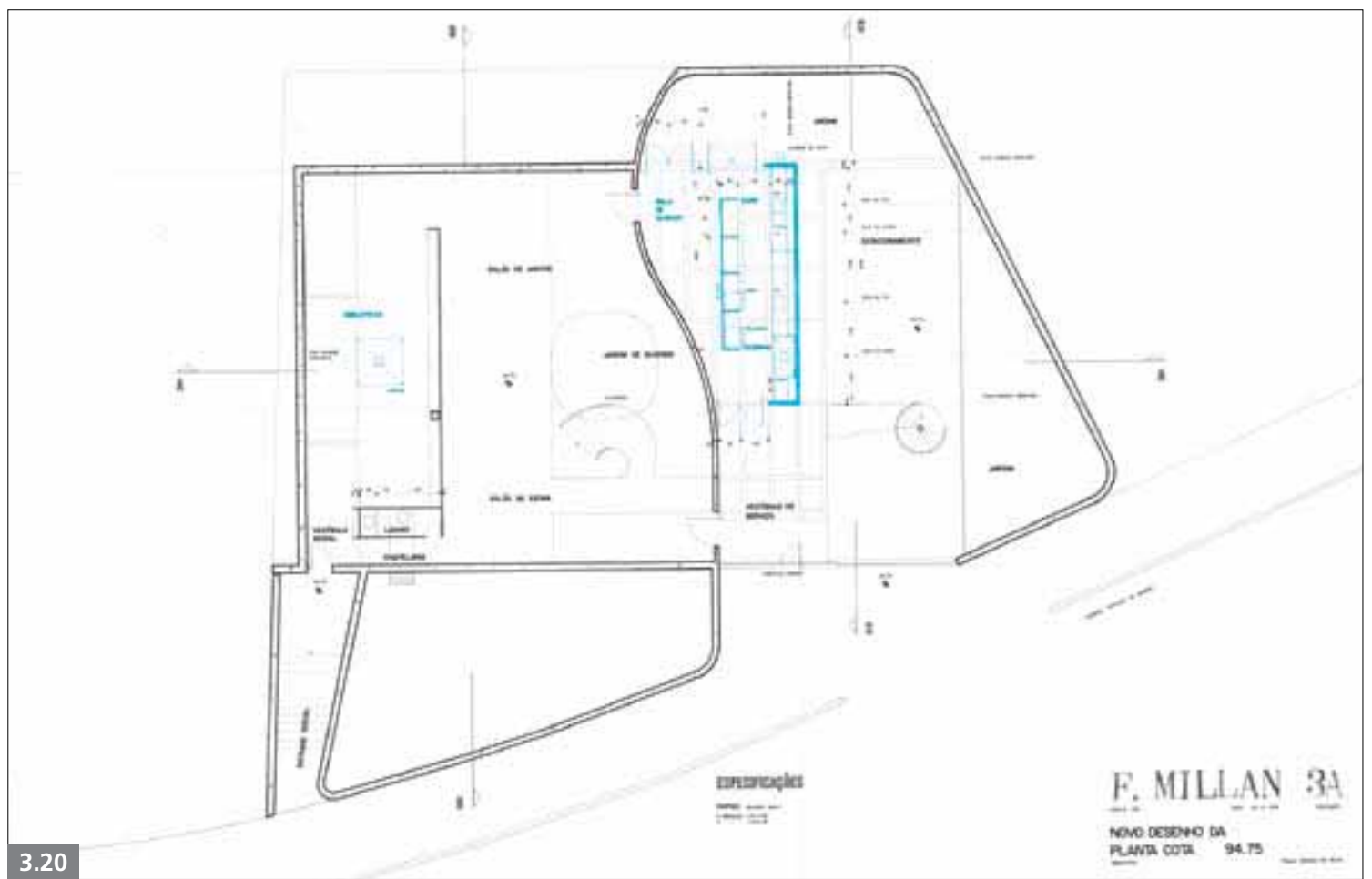

3.20 Residência Fernando Millan, Paulo Mendes da Rocha, 1970-

1975 - planta do pavimento térreo (prancha original digitalizada com a nova locação da cozinha,

23/04/1974). Notar em azul -

intervenção do autor - as mudanças em relação ao projeto original executado

possível aproveitar aquela parte de fora, que era toda só pra estacionamento, etc., passando a cozinha para ali, na área externa. E aproveitando aquela área onde está a cozinha pra mais espaço de estar e coisa do tipo. Fácil de adaptar. Já pro Fernando, mesmo, e a Matilde, a mulher dele, foi conversado isso. Eu falei: 'Bom... eu, por mim, prefiro como está. Mas, não tem problema, vamos fazer isso'. E o Fernando disse: 'Não. Não vamos fazer nada. Vamos deixar assim'." (PAUlO MENDES DA ROCHA, São Paulo, 26/09/2011)
E complementa:

"Como tinha havido já a discussão, eu, sincera e honestamente, pensei no intimo: 'Essa cozinha sempre foi discutida. Principalmente se alguém comprou a casa...' E disse: 'Olha, sempre houve essa ideia. Se você quiser, a gente fecha uma área aqui em baixo, nessa parte que já está coberta pelo andar de cima, e você diz que cozinha você imagina, eu desenho aqui e você vê. E aquela área que era a cozinha passa a ser o que você quiser, biblioteca, você amplia'. E foi 

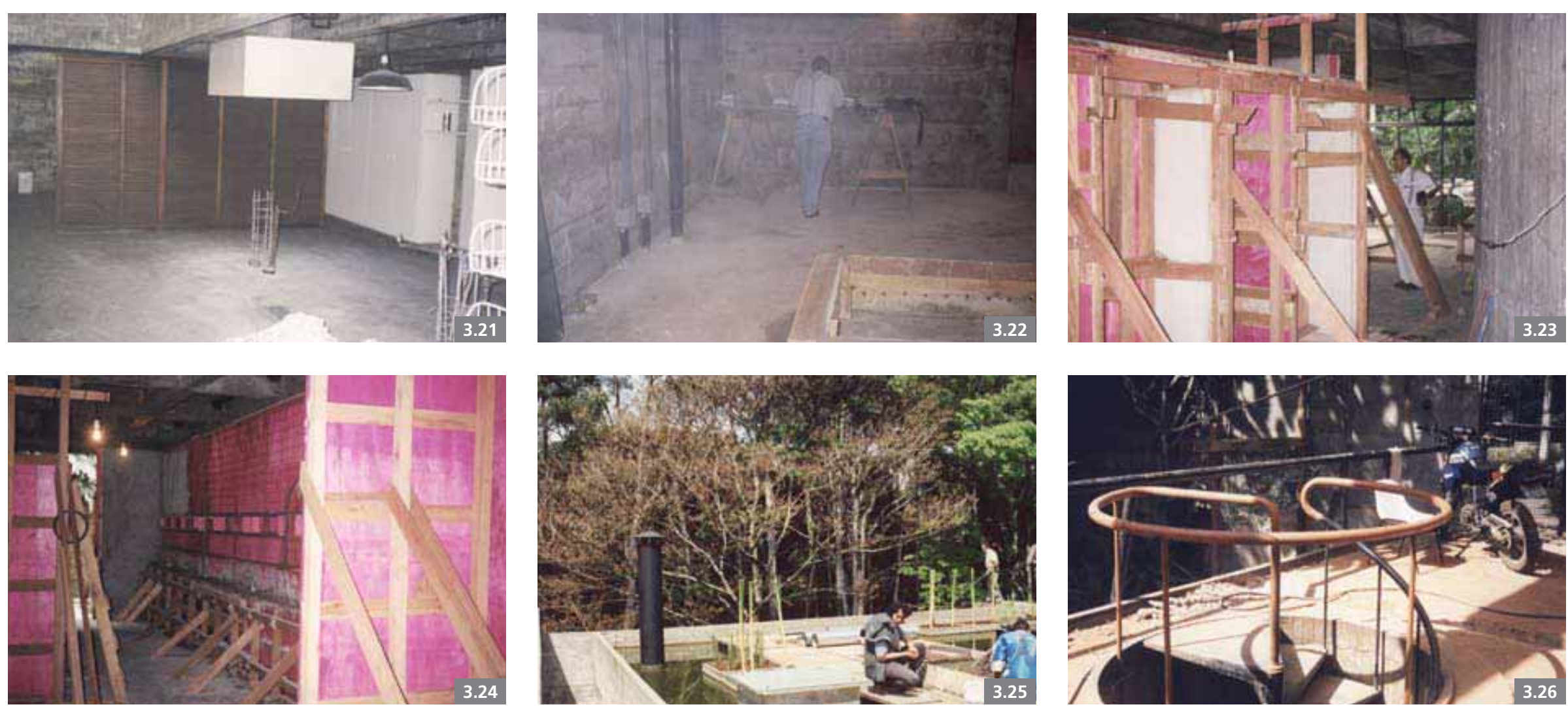

feito isso, simplesmente." (PAULO MENDES DA ROCHA, São Paulo, 26/09/2011)

Ao discutirmos alguns projetos de intervenção com o arquiteto Angelo Bucci, durante a entrevista, e ao exemplificarmos esse caso específico da residência Fernando Millan, Bucci comentou que "a liberdade que o Paulo tem para fazer a intervenção é difícil que outra pessoa tenha", o que traz à tona a controversa discussão sobre a legitimidade ${ }^{17}$ dessas transformações pelas mãos do próprio arquiteto.
3.21 Residência Fernando Millan vista parcial da antiga cozinha em processo de demolição

3.22 Residência Fernando Millan vista parcial da antiga cozinha e base da lareira em execução. Notar ao fundo a "mesa de obra" e a presença do Eng" Osmar da CENPLA 3.23 e 3.24 Residência Fernando Millan - vista parcial da nova cozinha - montagem das formas para concretagem das alvenarias e do armário
3.25 Residência Fernando Millan vista parcial da cobertura em obras de manutenção

3.26 Residência Fernando Millan detalhe do novo arremate do

corrimão metálico após a supressão do trecho da escada de acesso ao primeiro pavimento 


\subsection{AS INTERVENÇÕES E SEUS DETALHES: RESIDÊNCIA OLGA BAETA}

Em relação propriamente às intervenções executadas na residência Olga Baeta, podemos indicar os seguintes itens:

- Novos volumes em argamassa armada devido à reformulação de toda a área da cozinha e serviços, inclusão do lavatório no térreo, sanitário no pavimento superior e um depósito externo paralelo à divisa posterior do lote;

- Eliminação do pilar embutido em tubo metálico no eixo intermediário e dos três pilares ocultos na alvenaria da cozinha;

- Completamento da viga de concreto no eixo intermediário dos pilares;

- Instalação da escora metálica;

- Completamento dos pisos internos em ladrilho hidráulico e em tacos de madeira;

- Reposicionamento da caixilharia de ferro para sua posição original;

- Novo desenho para as áreas externas: piso em mosaico português, banco de concreto, muros e portão de acesso;

- Recuperação dos caixilhos de madeira dos dormitórios;

- Readequação das instalações hidráulicas e elétricas.

- Repintura geral;

- Novo projeto de plantio para o paisagismo.
Sobre essas intervenções, Bucci descreve os serviços de forma bastante simples e objetiva, revelando a existência de uma marcação externa [FIG. 3.27] das grandes mudanças ocorridas no interior da casa:

"O trabalho que era uma coisa objetiva ali, restrita, como foi feito assim, com essa objetividade lá que estava traçada no início, restrito... Aquela faixa de mosaico português que a gente colocou, que começa na calçada e atravessa com a mesma largura... aquela largura marca mais ou menos a área que foi alterada no térreo." Grifos nossos. (ANGELO BUCCI, São Paulo, 02/09/2011)
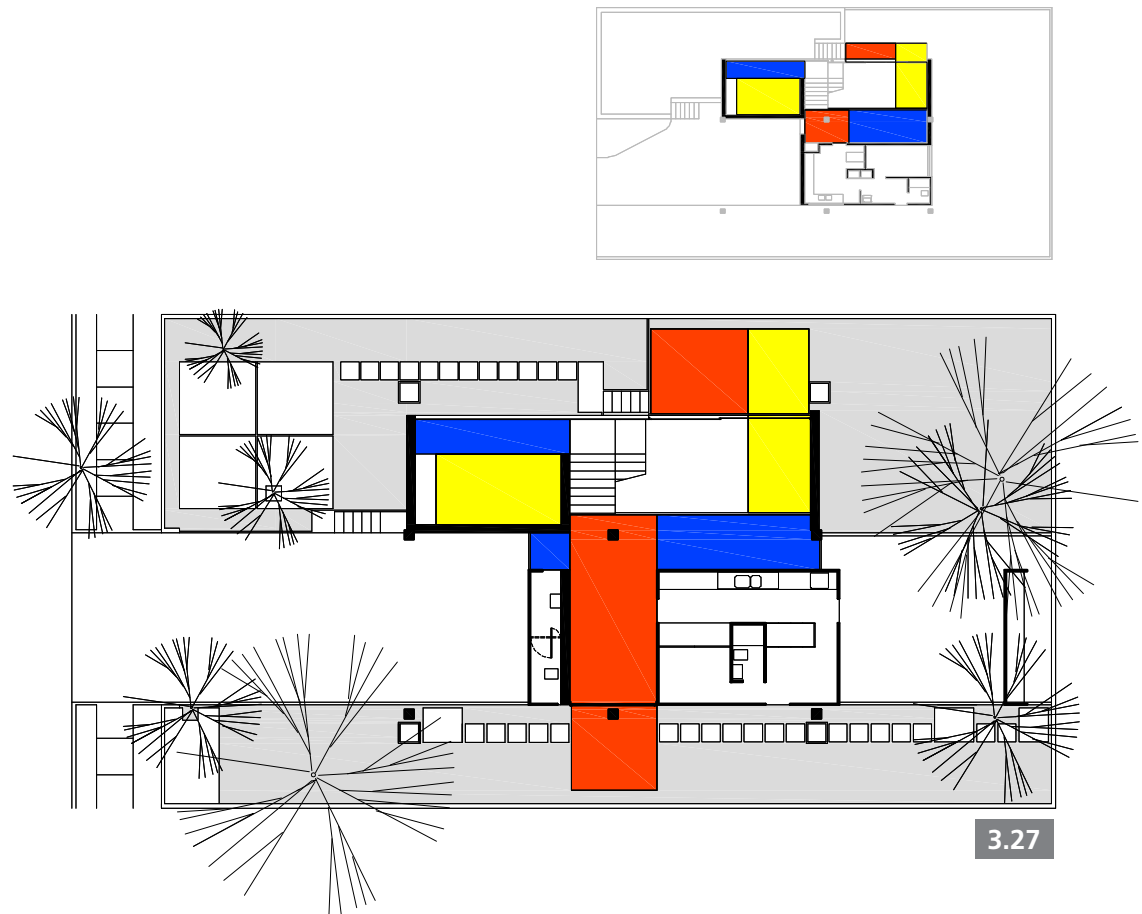

3.27 Residência Olga Baeta, Vilanova Artigas e Carlos Cascaldi 1956-1957 - implantação -

comparação entre o desenho do piso de ladrilho hidráulico original e após a intervenção 
Essas mudanças, que poderiam se restringir a meras adequações de uma simples reforma, acabaram por contribuir tanto para a reorganização de alguns espaços, como para atribuir uma clara distinção ${ }^{18}$ entre o que foi e o que não foi modificado. Por exemplo, a cozinha e área de serviço, que agora se encontram envolvidas por novas paredes de cinco centímetros de espessura em concreto aparente - cujas dimensões foram alteradas e otimizadas com divisórias internas que acomodam armários e equipamentos. Essa solução também foi utilizada para criar um novo lavatório no térreo, junto do acesso principal e no banheiro do quarto no pavimento superior que se transformou em suíte.

Ao modificar as dimensões de alguns ambientes, tais como a cozinha no pavimento térreo [FIGS. 3.28 E 3.29] e o sanitário do pavimento superior [FIGS. 3.30 E 3.31], devemos levar em consideração que a redução de suas dimensões levaria, inevitavelmente, à necessidade de um 'completamento' dos pisos faltantes. Bucci menciona a solução adotada:

"[por] sorte... por exemplo, ainda existia a Ladrilar, que é a mesma fábrica que fez aquele ladrilho hidráulico, então, quando a gente abriu aquele pedaço transversal, para compor ali a sala, fazer a mesa de jantar, a gente usou o mesmo ladrilho. Estendemos um pouco o piso externo para fazer essa coisa da casa estender mais." (ANGELO BUCCI, São Paulo, 02/09/2011)

Levando em conta o princípio da distinguibilidade, sobre esse completamento dos pisos de ladrilho hidráulico no térreo - e mesmo dos tacos de madeira no pavimento supe-
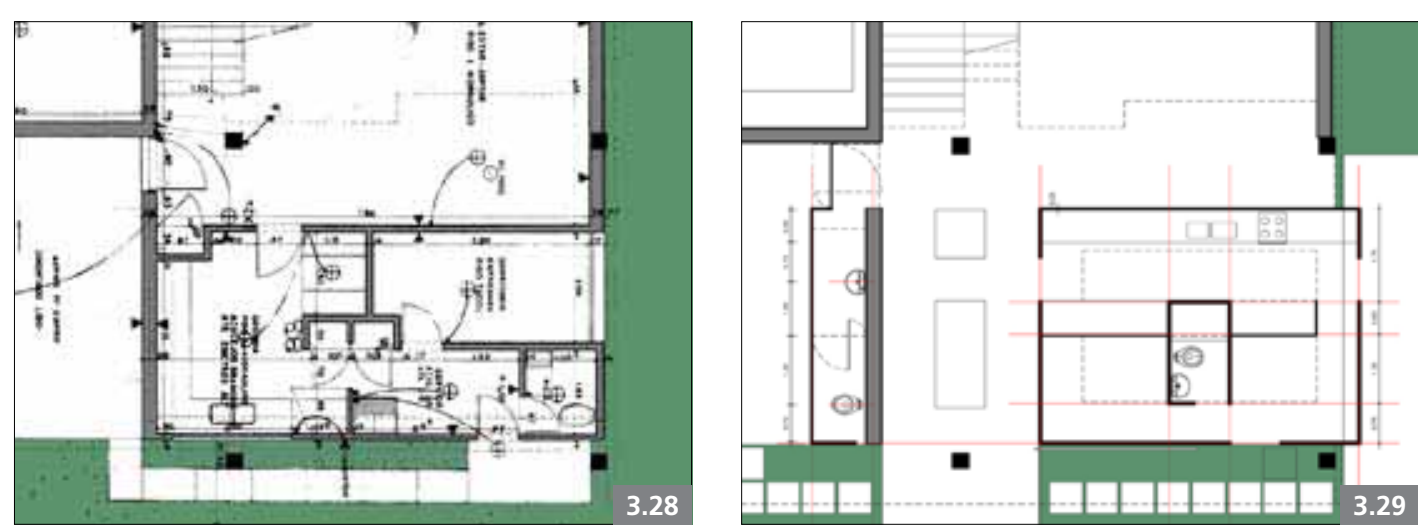

rior -, poderia ter sido adotado algo parecido com a técnica tratteggio $^{19}$ e com o rebaixamento óptico no preenchimento das lacunas. Ou seja, poder-se-ia utilizar um ladrilho hidráulico com a mesma tonalidade de cor, mas adotando-se uma matriz de desenho (como uma retícula de pontos ou linhas) que só seria perceptível ao aproximar-se do piso completado. Brandi exemplifica o significado desse termo utilizado em pinturas:

“(...) a técnica do 'trattegio' com aquarela se diferencia por técnica e por matéria, da técnica e da matéria da pintura integral. Ao fazermos isso, não ultrapassamos os limites da 'époche' que nos impusemos, pois a nossa integração é fenômeno no fenômeno e como tal não se esconde, mas, antes - mais do que se submeter à experiência do outro -, ostenta-se." (BRANDI, 2004, p. 127)

Sobre a questão da mudança de tonalidade das cores adotadas na repintura, Bucci comenta que foi devido às limitações técnico-financeiras e declara ter consciência dessa modificação cromática:
3.28 e 3.29 Residência Olga Baeta planta - comparação da cozinh e adjacências antes e depois da intervenção 

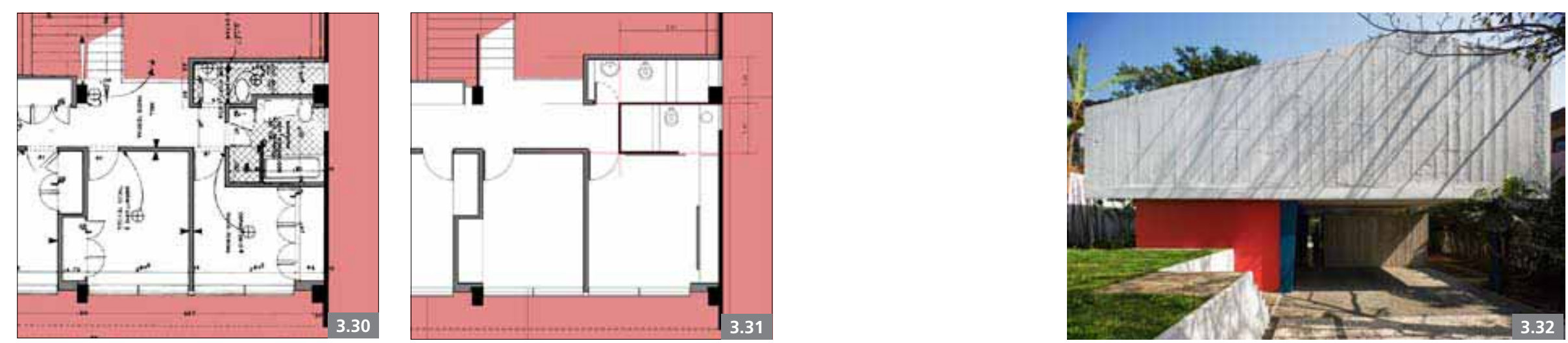

"Ela tinha originalmente as cores... a gente seguiu o que estava original e parte do que estava na casa quando a gente encontrou era muito alterado. Mas eu tinha vontade de fazer o que foi a primeira pintura, que era uma caiação com essas cores Mondrian. Mas, isso era extremamente trabalhoso porque tinha que remover todo o revestimento. Então, a gente acabou deixando a pintura acrílica, mesmo, mas com as cores perto do original, mas não são exatamente as cores do Artigas." (ANGELO BUCCI, São Paulo, 02/09/2011)

Em relação à repintura geral [FIG. 3.32], Wisnik também descreve essa percepção quanto à tonalidade: “Actualmente, la casa se ha reformado y se han alterado los tonos de los colores del interior, que ahora son más vivos que en la version

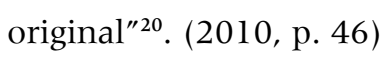

Por outro lado, no decorrer da obra e nas pesquisas realizadas por Bucci, uma informação, até então desconhecida por ele, começou a fazer sentido: a obra havia sido feita por duas equipes de construção ${ }^{21}$ distintas e esse fato tinha reflexos em sua execução, como ele mesmo descreve:
"Aí acho que o Júlio Artigas, uma vez eu fui falar com ele pra tentar saber da história, quem tinha construído a casa e tal, e a história que eu soube (...) é que essa casa teve uma mão de obra que executou as fundações e a laje até o primeiro piso, e uma outra mão de obra que finalizou a casa. Mas que essa finalizou é muita coisa: as empenas de concreto, a estrutura lá em cima, laje de concreto na cobertura e tal. E que essa mão de obra que saiu quando terminou a laje do primeiro piso é que era uma mão de obra que foi substituída porque era muito pouco qualificada. E fizeram muitos erros durante a construção. Mas, os erros não eram tão fáceis de perceber quando a gente olhava a casa agora, porque eram erros de intromissão nas soluções de estrutura, mas escondidos nas paredes." (ANGELO BUCCI, São Paulo, 02/09/2011)

E acrescenta que havia descoberto quatro "pilares intrusos":

"A casa parecia que tinha lá as peças todas, tinha uma coisa muito evidente que era a falta da escora projetada inicialmente. Mas, depois a gente começou a ver, demolindo a parede da cozinha, que tinha um pilar que estava lá embutido, que não estava previsto,
3.30 e 3.31 Residência Olga Baeta planta - comparação dos banheiros e adjacências do primeiro pavimento antes e depois da intervenção

3.32 Residência Olga Baeta - vista externa da fachada principal após a intervenção 


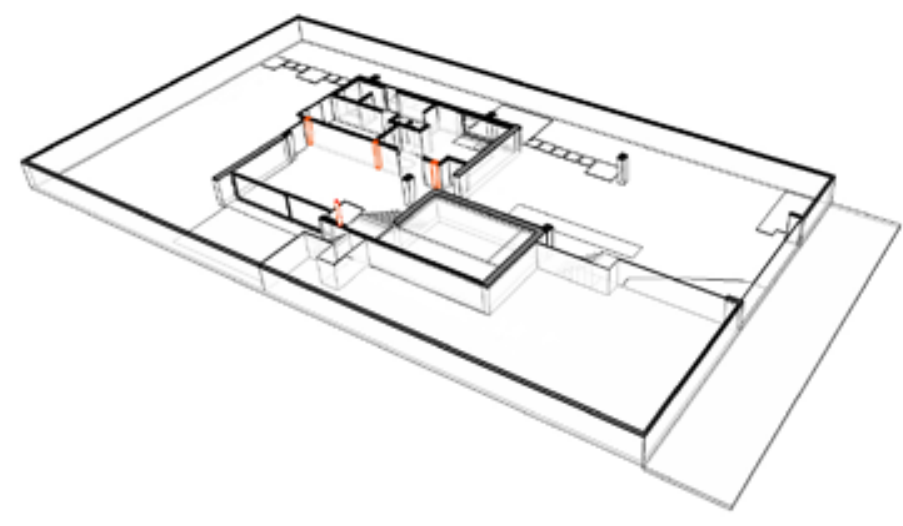

estava lá escondido. Depois outro e outro. Então, havia ali três pilares a mais dentro da parede e mais um lá fora que substituiu a escora que colapsou durante a obra." Grifo nosso. (ANGELO BUCCI, São Paulo, 02/09/2011) [FIG. 3.33]

Sobre esse colapso da escora original, dado também desconhecido na historiografia dessa residência, Bucci considera:

“(...) ela colapsou porque tem 17 toneladas na axial da escora. Só que a escora tem um ângulo extremamente abatido, talvez menos que 30 graus. Quer dizer, a componente horizontal é muito maior que a componente vertical. E quando ela carrega horizontalmente a coluna que não tinha a viga prevista ali pra receber esse esforço, a coluna fletia e a escora colapsava, colapsou. Eu acho que isso aconteceu de um jeito muito... por sorte, ali... suposição... mas imagino que quando eles foram tirando os escoramentos a escora arrebentou e eles mantiveram... e a casa não veio abaixo... a cobertura... tanto não veio abaixo que eu vi a cicatriz da escora lá na laje (...) Quando a escora colapsou, eu acredito que os recursos que eles tinham eram muito contados na época e que não dava... Talvez até, eu imagino, que eles não soubessem exatamente por quê. Porque - como trocou a mão de obra e a mão de obra nova entrou quando a laje já estava feita, e esta viga aqui que não existia um pedaço estava dentro do enchimento da lajetalvez, eles nunca viram, exatamente, o que havia sido o problema (...) a solução que eles encontraram, econômica, era fazer uma coluna aqui, provisória, do lado de fora. Essa coluna era fácil porque, para receber a escora ali, na parte superior na laje, tinha como um capitel embutido lá dentro. Estava tudo preparado. Era só fazer a coluna. E essa coluna foi feita em aço, talvez $150 \mathrm{~mm}$ de diâmetro, preenchida de concreto. Era isso que estava lá. E ficou lá até 96. Então 40 anos basicamente." (ANGELO BUCCI, São Paulo, 02/09/2011)

Sobre a ação estabelecida em relação aos três "pilares intrusos", que haviam sido descobertos embutidos na alvenaria da cozinha, Bucci descreve a sua integração com o calculista [Ibsen Puleo Uvo], uma vez que, juntos, foram avaliando e retirando pilar a pilar. Ao se depararem com um desses pilares alinhados com o eixo de pilares principal, Ibsen reiterou a importância de "achar a viga lá em cima [que] era invertida". Ao realizarem essa "prospecção", surgiu mais uma surpresa, como relata Bucci:

"Aí nós tiramos os tacos lá de cima e achamos esta viga aqui. Só que esta viga morria aqui neste pilar e nos desenhos de estrutura
3.33 Residência Olga Baeta diagrama tridimensional - pilares intrusos 


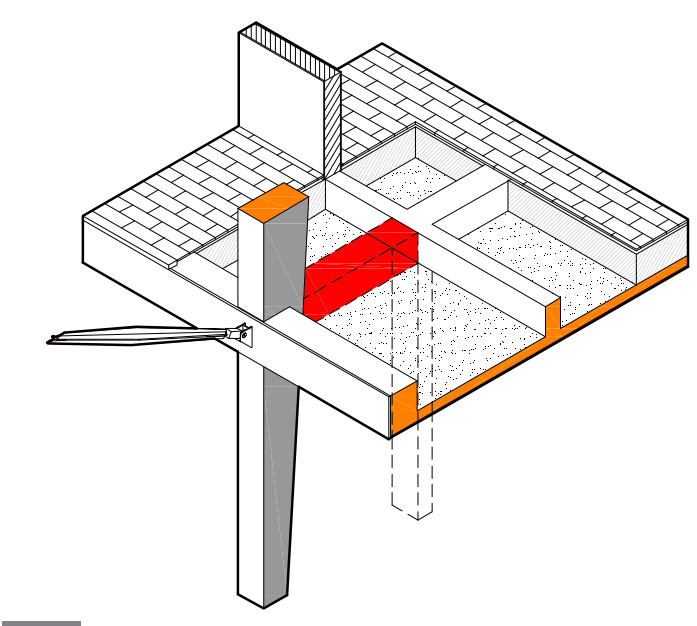

3.34

ela devia chegar até aquele. E ela não foi feita neste trecho (...)." (ANGELO BUCCI, São Paulo, 02/09/2011)

Após essa descoberta, Ibsen, segundo Bucci, dá o veredito: “Não. Esse pilar não pode tirar de jeito nenhum, a não ser que a gente faça o complemento da viga".

Esse complemento [FIG. 3.34] foi executado em concreto; por um lado, devido à sugestão do engenheiro calculista; por outro, devido a certas particularidades em relação ao tipo de aço que viabilizava a execução de solda nas ferragens, como esclarece Bucci:

"Por sorte essa casa feita na década de 50 usava o aço que nós tínhamos, que era o CA25, que era um aço para [o ano de] 96 muito fácil de soldar na obra. Era muito mais difícil, em 96, você soldar

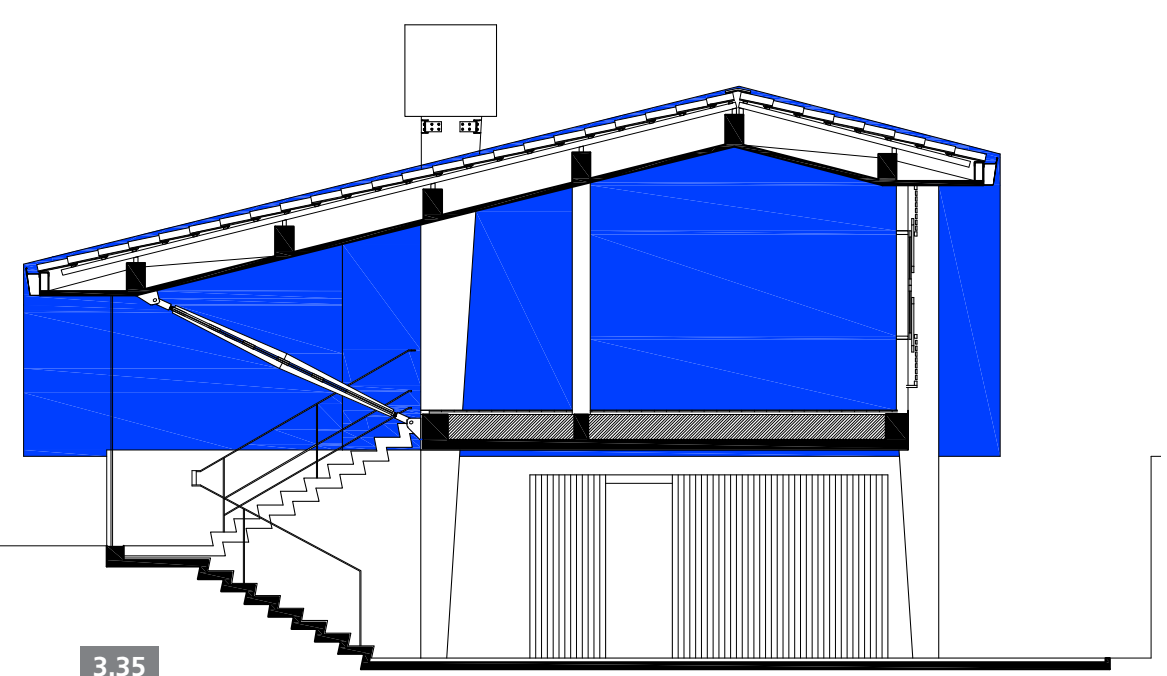

um aço CA50, mas o CA25 não tinha problema. Então a gente furou o pilar, colou os arranques com compound [cola adesiva], quebramos a cabeça da viga, desdobramos aquele final da armação, soldamos e concretamos esse pedaço da viga." (ANGELO BUCCI, São Paulo, 02/09/2011)

Após essa operação, mais um "pilar intruso" foi removido e se constatou que não havia nenhum problema estrutural adicional; Contudo, Bucci esclarece que haveria pequenas acomodações na estrutura, devido a essa nova conformação:

"A questão é que este pilar, que é o pilar previsto no projeto, tem uma fundação; e como este pilar intruso estava aqui, aquela fundação nunca foi carregada inteiramente. Então vai ter uma deformação ali até a reação do solo. Aqui também: esta viga estava feita,
3.34 Residência Olga Baeta perspectiva isométrica de trecho da estrutura. Notar o completamento de parte da viga; o pilar intruso removido e a inclusão da escora metálica

3.35 Residência Olga Baeta - corte transversal com a inclusão da escora 
calculada, não ia ter problema, mas ia ceder um pouco a laje, porque a gente ia carregar a viga aqui, que não tinha sido carregada." (ANGELO BUCCI, São Paulo, 02/09/2011)

Depois de todas essas ações realizadas na estrutura e discussões com o calculista, optou-se por executar novamente a escora [FIGS. 3.35 A 3.41], só que desta vez, metálica. Essa decisão foi integralmente apoiada pelo calculista que ponderou: "E a escora? Vamos por? É gastar muito dinheiro? Agora é o mais fácil. O difícil já está feito". Com isso, a decisão estava tomada, pois "(...) estava tudo preparado para por a escora. A peça que causou a ruína da escora estava resolvida", como sintetiza Bucci. Ademais, relata, de maneira muito generosa, todo o processo da nova escora, desde o seu desenho - que devido à lógica estrutural recupera o mesmo perfil da escora original de Artigas -, até a sua execução e instalação na obra:

"E aí a gente desenhou uma escora em aço, porque - tem um formato parecido com aquela em concreto, mas também porque aquele formato era muito conveniente. Ela aumenta na seção central, onde a flambagem tem maior esforço e afunila nas pontas como aquela - era muito mais simples em aço pela instalação; porque a gente fez a escora como um macaco que, colocada na posição, você ia girando assim e ela ia carregando. Então, foi um momento muito legal porque a gente - as cabeças da escora eram peças independentes -, então, parafusou a cabeça no pilar, parafusou a cabeça no teto, colocou a escora lá em cima, passou o pino de travamento, aí girou a escora assim, botou o pino aqui e aí começou a girar para carregar. E isso foi um momento importante lá da obra. Toda a mão

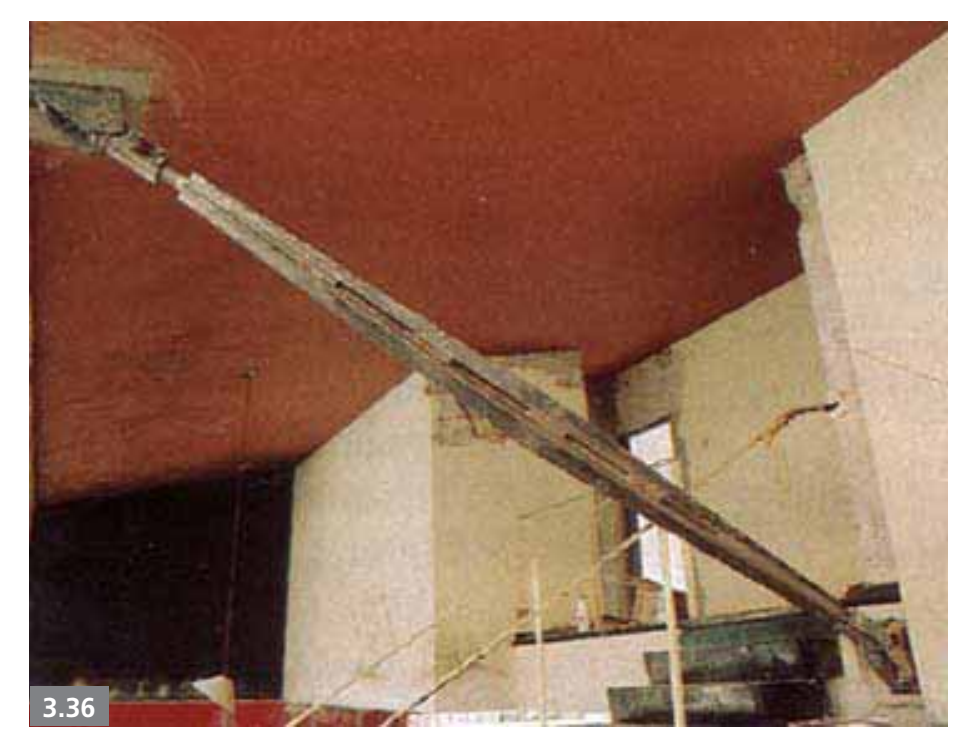

de obra, o Ibsen, eu, acompanhando isso. O pessoal girava a escora com uma alavanca e o Ibsen acompanhando... Aí foi carregando e o Ibsen, assim, no olho, sabe? Porque não tinha torquímetro, nada disso. Aí falou: 'Acho que está bom'. Também porque se estivesse um pouco a mais ou a menos não era um problema. Mas o que foi legal é o seguinte: antes de arrochar a escora, a gente colocou em torno do pilar provisório lá fora, quatro escoras de obra, daquelas que você arrocha também, e colocou na posição, bem apertadas. Aî pôs a escora do projeto. Foi arrochando também até o Ibsen dizer: Tá bom. Daí ele autorizou a cortar a coluna que estava lá fora. Então saiu todo mundo da obra. Falei: 'sai de baixo da laje'. Ficou toda turma lá encostada no muro e o cara com o maçarico veio aqui e cortou o pilar. Quando ele cortou o pilar, aquele escoramento em torno do pilar, as quatro peças, que estavam super apertadas, soltaram, assim... Quer dizer, a laje levantou levemente. Quer dizer, tinha arrochado um pouco mais que o necessário a escora nova." (ANGELO BUCCI, São Paulo, 02/09/2011)
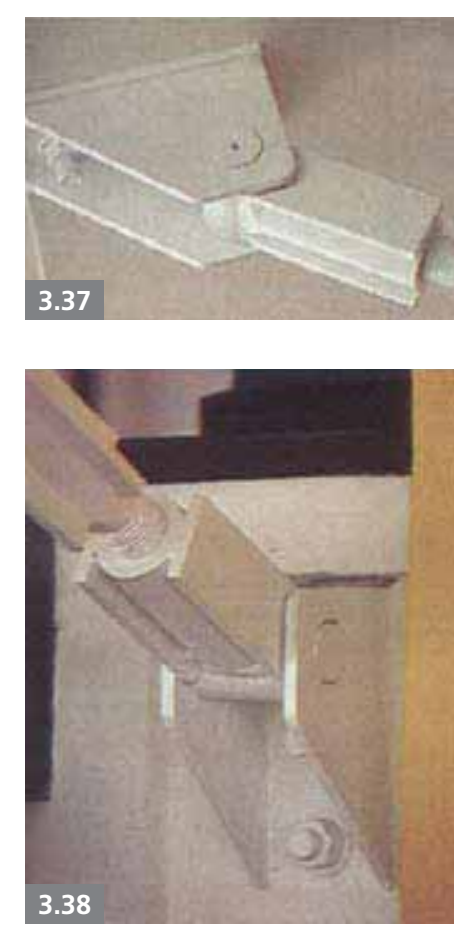

3.36 Residência Olga Baeta - vista interna da sala, detalhe escora metálica após a exeução 3.37 e 3.38 Residência Olga Baeta detalhe dos consolos da escora metálica 


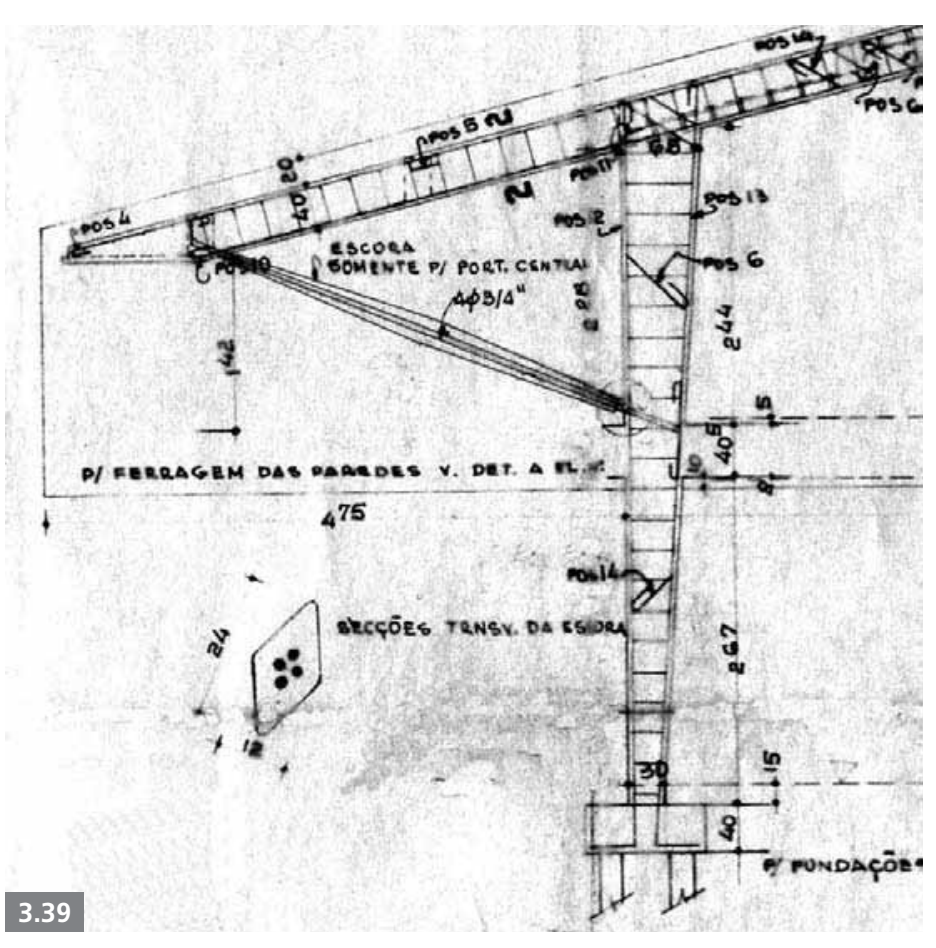

Como consequência da nova escora, alguns ajustes poderiam ser executados, já que pareciam propositadamente fora do lugar, como exemplifica Bucci, ao justificar a mudança do alinhamento do caixilho existente:

"Quando a gente colocou a escora, outra coisa que era possivel fazer era o seguinte: se você olhasse a situação que nós encontramos em 96 isso aqui era assim: e o vidro vinha, desviava, e o pilar provisório estava aqui. Então nós tiramos isso. E este caixilho poderia perfeitamente ser alinhado. Então nós soltamos o caixilho, o mesmo caixilho que encontramos lá e alinhamos ele aqui. A mesma peça." (ANGELO BUCCI, São Paulo, 02/09/2011)
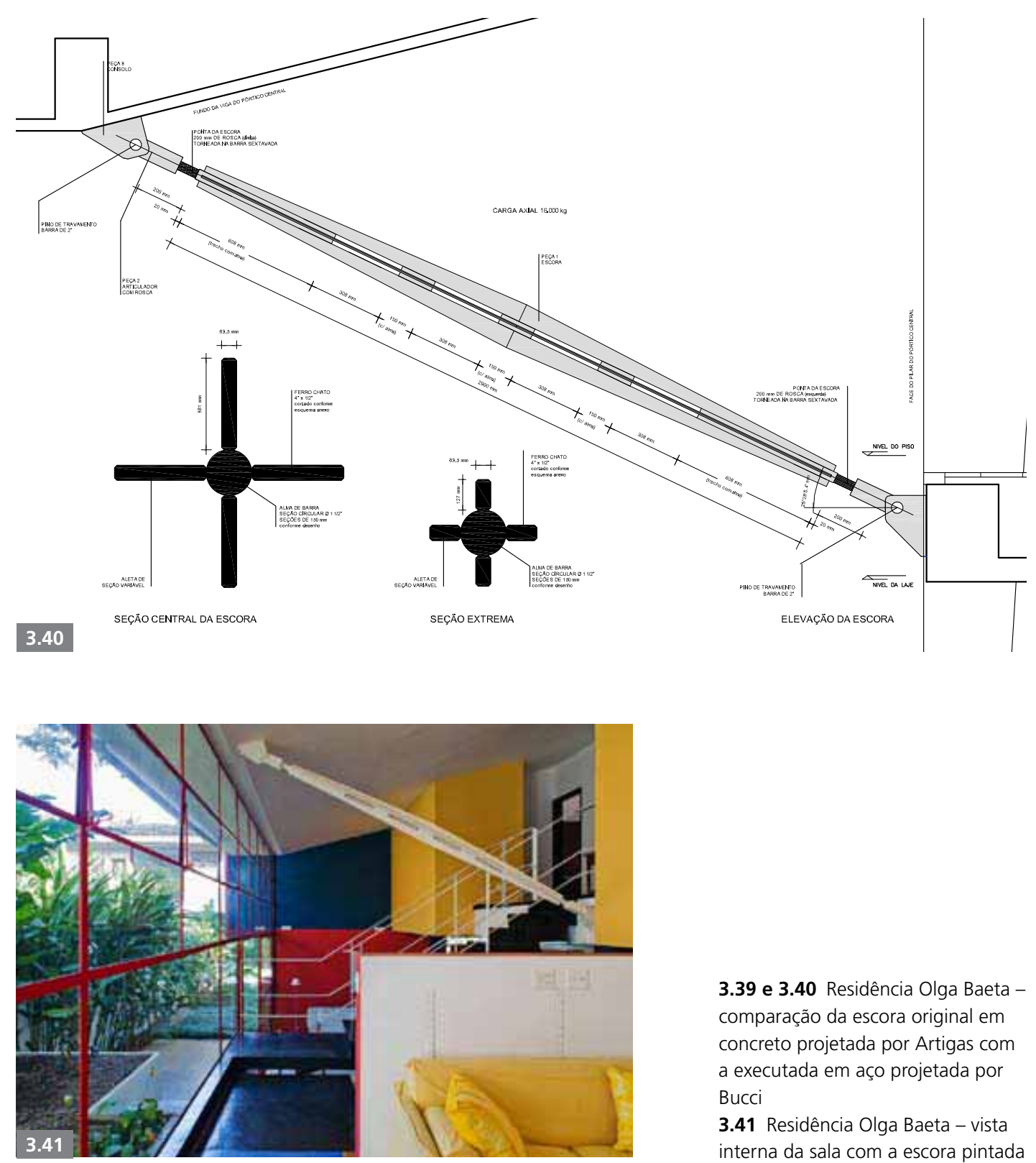

3.39 e 3.40 Residência Olga Baeta comparação da escora original em concreto projetada por Artigas com a executada em aço projetada por Bucci

3.41 Residência Olga Baeta - vista interna da sala com a escora pintada 
Por outro lado, nota-se que essa ação teve consequências, que alguns classificariam de "descaracterizantes", como o fato de ter-se removido um trecho de alvenaria baixa que configurava o estúdio [FIG. 3.42], substituindo-o por um caixilho no mesmo padrão do original, integrando-o visualmente ao jardim. Para validar essa ação e mesmo convencer a proprietária, Bucci utilizou o próprio texto de Artigas, que descreve: “(...) o espaço devia ser aberto e múltiplo de maneira que estabelecesse uma relação de visualidade do total do espaço (...)" (ARTIGAS, 1997). Bucci, porém, apresenta uma justificativa que une uma interpretação do projeto e uma solução para drenagem:

"[o jardim] é uma caixa cheia de terra e tira a possibilidade de você girar o terreno aqui. Eu achei que era possivel fazer isso porque o jardim, então, chegou mais próximo da cota do estúdio e aqui ficou apenas um degrau de desnivel (...) Só que tinha uma parede até 1 m e você não lia esse desnivel (...) E aconteceu uma coisa que, talvez, ao longo dos 40 anos de existência da casa, cuidando de jardim, trazendo talvez adubo, terra vegetal, sei lá... O que tinha lá era que o jardim, em 96, era um pouco mais alto que a casa. Então, quando chovia muito entrava água e tal. Aí a solução que a gente achou foi de rebaixar um pouquinho o jardim, uns $10 \mathrm{~cm}$ em tudo (...) Então fizemos para que, aqui, o jardim e o estúdio ficasse a mesma coisa. Veio tudo muito na consequência..." (ANGELO BUCCI, São Paulo, 02/09/2011)

Através de outra ação ordinária: substituição de calhas e de condutores de águas pluviais [FIG. 3.43], Bucci demonstra o seu
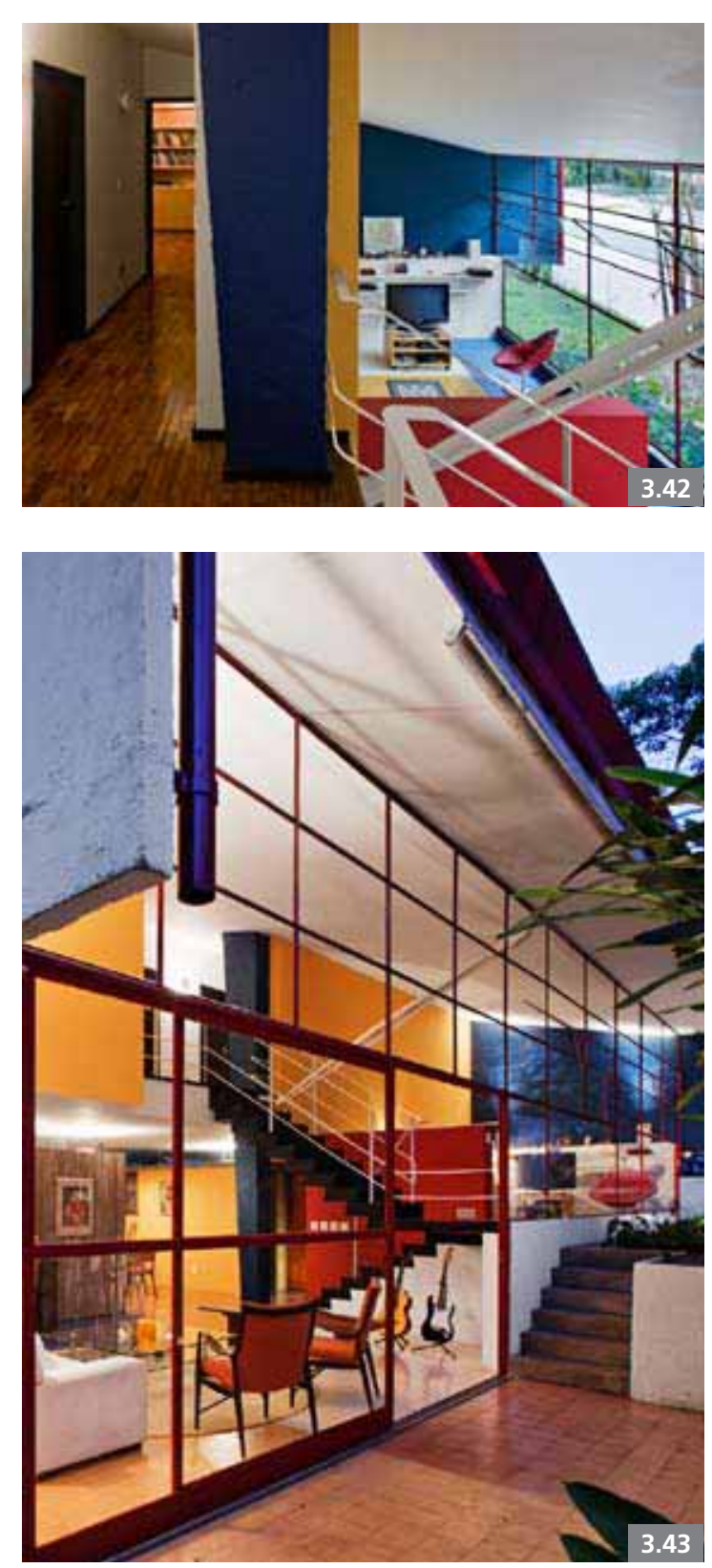

3.42 Residência Olga Baeta - vista parcial do segundo pavimento e estúdio

3.43 Residência Olga Baeta - vista

lateral da casa. Anotar o novo

alinhamento do caixilho após

a retirada do pilar intruso; 0

rebaixamento do trecho de alvenaria

do estúdio e substituição por

caixilhos e a nova dimensão do tubo

de descida de águas pluviais 
cuidado com os detalhes, buscando soluções que, ao mesmo tempo, eliminem as patologias e se coadunem com o espaço e suas qualidades:

"Tivemos surpresas, por exemplo: a calha, nós refizemos de um jeito bacana. Eu achei bacana porque ela arrematava o projeto. As peças todas, não era só a calha d'água, mas a espessura da laje, do telhado, a borda da empena, elas faziam o desenho com muito cuidado (...) Mas, quando nós substituímos a calha, nós substituímos também os condutos verticais de água de chuva. Os que estavam lá chegavam até o chão. Então, era muito estranho, porque os tubos de água de chuva desciam paralelos ao pilar, pareciam outros pilares e você às vezes confundia o que era uma coisa e outra. Então, nós cortamos todos na base da empena. Nenhum tubo de água chuva chega até o chão. A água cai livre." (ANGELO BucCI, São Paulo, 02/09/2011) [FIG. 3.44]

Sobre a escolha de Bucci pela reconstrução da escora metálica, uma conjectura possível é a ideia de resgate de um desejo técnico-artístico de Artigas, revelando a exceção de apoio da laje de cobertura em concreto, não como uma necessidade, mas como um exemplo didático ${ }^{22}$, como exemplifica Ferro, em uma entrevista à Marlene Acayaba, ao lembrar-se de sua época de estudante na FAU-USP, como aluno de Artigas:

"Lembro de certas aulas, onde o Artigas falava da estrutura, considerando que se podia e devia em certos casos exagerar alguns detathes, alguns pilares, não no sentido de enganar, mas ao contrário, para tornar ainda mais explicita a estrutura real, o comportamento real dos materiais. Era quase uma mentira ética, uma mentira didática." (АСАYABA, 1986, p. 68)

Por outro lado, é preciso ponderar que o fato desse apoio "não ter sido executado", conforme estava detalhado em projeto, independente das circunstâncias, é dado factual e histórico; ou seja, fazia parte integrante da preexistência do bem. Podemos considerar que sua alteração atende às recomendações de preservação associadas aos "monumentos antigos"? Conforme expressa Didron citado por Beatriz Kühl, em seu livro Preservação do Patrimônio Arquitetônico da Industrialização:

"Deve-se fazer, para esses edifícios, não apenas os trabalhos apropriados para lhes restituir a fisionomia primitiva e depois assegurar a sua conservação, mas também as obras necessárias para que sejam apropriados ao emprego atual, com os seus desenvolvimentos normais. Deve-se, portanto, repudiar por completo nesse caso a fórmula: conservar, não restaurar. Deve-se conservar, restaurar e, mesmo, às vezes, aumentar (...)." (KÜHL,2008, p.154)

Ainda sobre essa questão: seria correto afirmar que o acréscimo da escora está de acordo ao princípio enunciado por Brandi?

“(...) a restauração deve visar ao restabelecimento da unidade potencial da obra de arte, desde que isso seja possivel sem cometer um falso artístico ou um falso histórico, e sem cancelar nenhum traço da passagem da obra de arte no tempo" (BRANDI, 2004, p. 33)

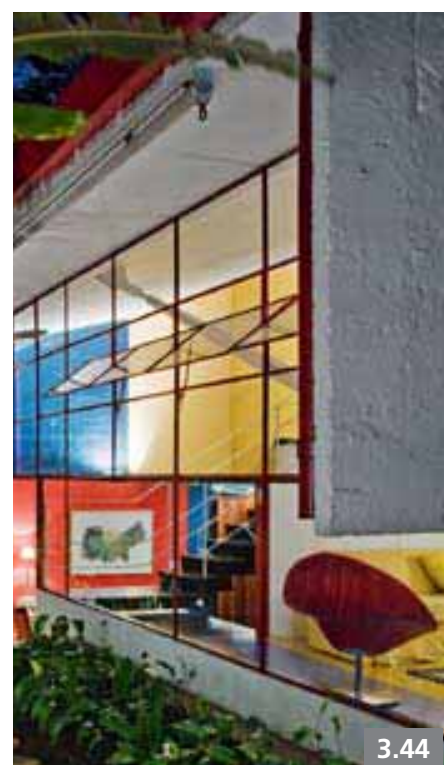

3.44 Residência Olga Baeta - vista lateral da casa. Anotar rebaixamento da alvenaria do estúdio e o novo nível do jardim 

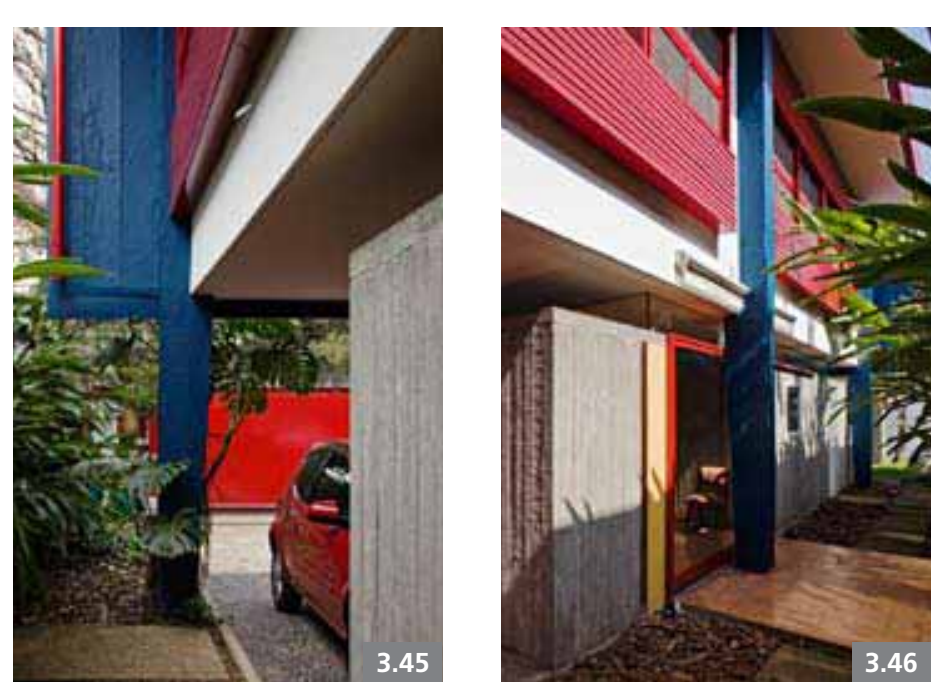

Galino e Sanz, em seu artigo Intervir en Arquitecturas Portantes, respondem essa questão - ao que parece, com base nas anacrônicas ideias de Viollet-le-Duc ${ }^{23}$ : “Reparar es reponer. Devolver al elemento dañado, lesionado o degradado, su capacidad funcional, haciendo que sus características mecánicas (en el caso de la obra portante) vuelvan a ser las que fueron (o debian a haber sido) en su primer momento de existencia." ${ }^{24}$ (GALINO:SANZ, 2005, p. 6)

Bucci, por sua vez, reforça, novamente, o dilema do enfrentamento da intervenção e revela alguns dos seus questionamentos durante a obra:

"(...) o problema são os critérios, quantas coisas você observa pra fazer. Mas, tem uma outra questão que, hoje a gente olha e diz "Ah... não é nada! Uma pequena reforma em uma casa que é incrível...". Mas, na época, eu tinha muita preocupação de qual seria a postura mais adequada. Por exemplo, aquela escora: nunca foi feita! Por que fazer? Por que querer fazer a casa mais
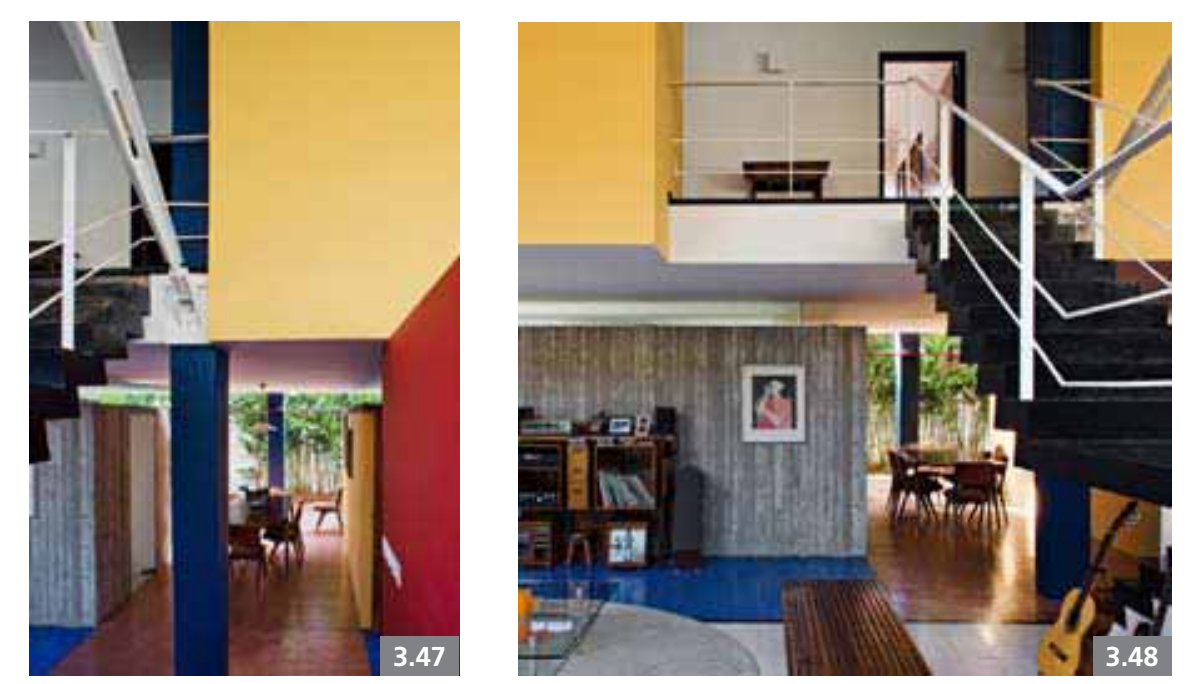

autêntica do que a casa que você encontrou?" (ANGELO BUCCI,

São Paulo, 02/09/2011)

Contudo, entendemos que Bucci, ao fazer a afirmação abaixo, coloca-se em uma posição mais de arquiteto e menos de restaurador; como se, de alguma maneira, um conceito "leduquiano"25 (segundo o qual, na intervenção, deve-se projetar como se fosse o arquiteto autor da obra) estivesse impregnado na sua própria formação - provavelmente fruto da compreensão do objeto e do respeito ao espaço e aos elementos da arquitetura moderna:

"(...) acho bonito como a gente tem um olho que vê o que a gente um pouco quer que seja. Então você via aquela casa no que ela pretendia ser. Eu acho que tem obras que conseguem fazer isso. Às vezes você não consegue realizar por alguma coisa, mas é tão forte a vontade de fazer, que você vê como se estivesse feito." (ANGELO BUCCI, São Paulo, 02/09/2011) [FIGS. 3.45 A 3.48]
3.45 Residência Olga Baeta - vista lateral da casa. Notar o volume de concreto do lavatório à direta 3.46 Residência Olga Baeta - vista lateral da face dos quartos. Notar o destacamento do volume de

concreto da cozinha em relação à edificação, a configuração de uma extensão da sala através do plano de ladrilho hidráulico amarelo e arcabouço em madeira dos caixilhos tipo guilhotina

3.47 e 3.48 Residência Olga Baeta vista interna onde nota-se o novo volume da cozinha e criação de um espaço "vazio" entre a preexistência e a inserção, reforçado pela leitura simultânea dos pilares 


\subsection{AS INTERVENÇÕES E SEUS DETALHES: RESIDÊNCIA MÁRIO MASETTI}

Na residência Mário Masetti' ${ }^{26}$ [FIG. 3.49], em relação às intervenções executadas, podemos indicar os seguintes itens:

- Recuperação e tratamento das patologias do concreto aparente;

- Revisão de todas as instalações hidráulicas e elétricas;

- Substituição do sistema de iluminação;

- Redesenho e novo posicionamento de portão metálico;

- Substituição da estrutura metálica e vidros das claraboias;

- Limpeza dos pisos de ladrilhos hidráulicos;

- Revisão dos sistemas hidráulicos e elétricos da piscina e novo revestimento;

- Revisão e recapeamento parcial do piso asfáltico;

- Adequação das áreas do pavimento inferior para instalação de estúdio musical - remoção de algumas divisórias de ambientes em alvenaria armada e instalação de componentes para proteção acústica;

- Manutenção estrutural (tratamento antioxidante das cabeças dos cabos de protensão [FIG. 3.50] e verificação com aparelhos adequados - da flecha de deformação estrutural);

- Novo projeto de plantio para o paisagismo.

Sobre essa intervenção, de realização recente, Colonelli, descreve mais do que os serviços, a excepcional situação de
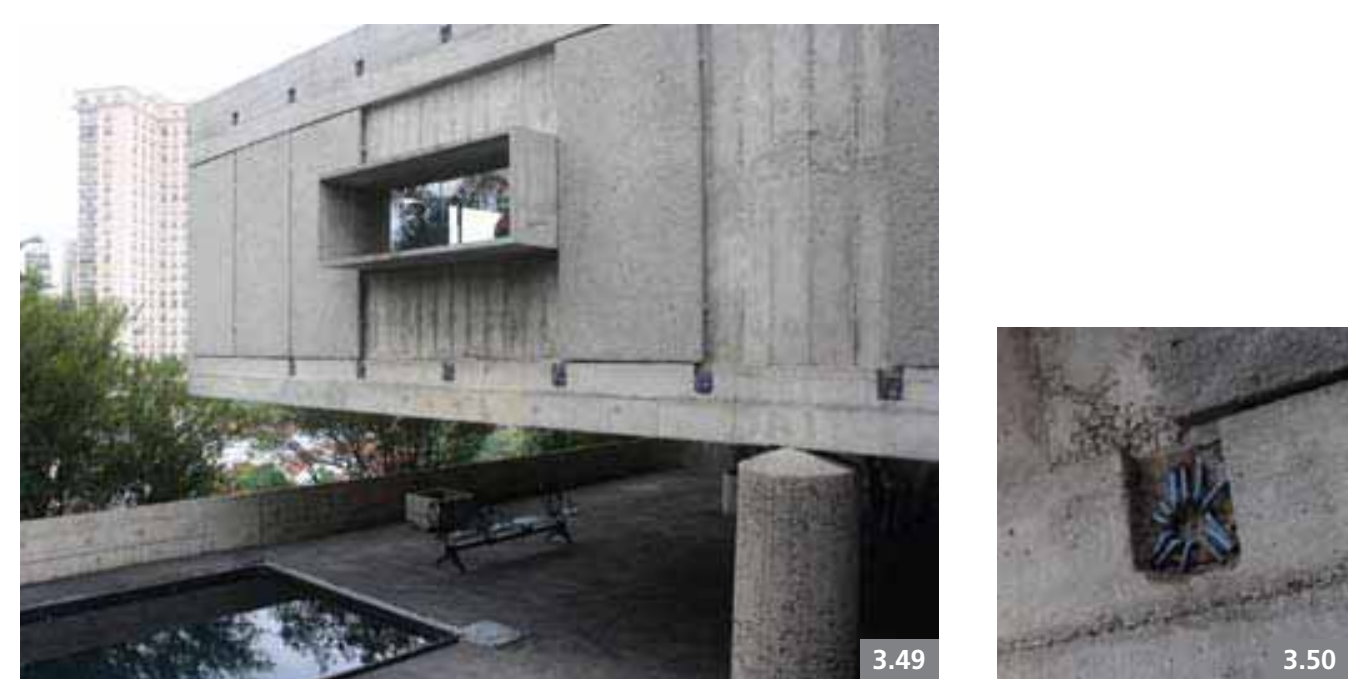

interesse do proprietário em não transformar radicalmente a casa recém-adquirida, e ressalta: “(...) é uma coisa rara, pegar um proprietário que estava interessado em conservar todas as características; mas, também - claro -, adequar às suas necessidades, sem fazer nenhuma alteração essencial."

Com essa demanda de conservação, e se tratando de uma casa toda em concreto aparente, as posturas técnico-operativas associadas a esse material foram uma grande preocupação desde o início, como assinala Colonelli:

"Essa casa tem algumas particularidades que geram algumas dificuldades. Uma das questões, eu acho, que é o concreto aparente. O concreto aparente tem uma certa dificuldade porque ninguém mexe bem. Não tem grandes pesquisas sobre isso. Conversei, quando a gente começou a enfrentar esse problema, conversei com várias empresas que trabalham com restauro de concreto, com restauro de Patrimônio. O pessoal conhece muito a questão das argamassas; tudo lá do século XIX o pessoal desenvolveu bastante. Agora, concreto apa-
3.49 Residência Mário Masetti, Paulo Mendes da Rocha e João de Gennaro, 1968-1970 - vista parcial da residencia e área de lazer após a intervenção - registrado em vistoria de obra 15/03/2011

3.50 Residência Mário Masetti detalhe da cabeça dos cabos de protensão 

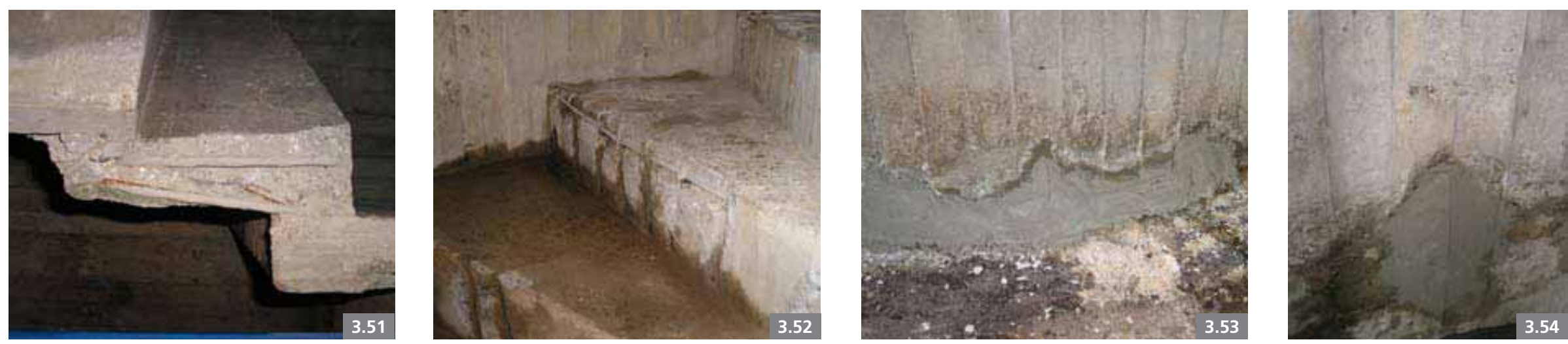

rente... Inclusive, muitos estavam interessados em fazer o trabalho para usar como um laboratório, mesmo. Mas, aí não deu muito certo com algumas empresas, até por questões comerciais etc., porque a escala é pequena. Os caras vão encarar muito como um laboratório! Mas, porque, também, existem poucas... Agora, talvez, é que esteja começando: o caso da FAU tá lá. Tem essa questão presente na FAU. Agora é que é o momento, já que essas obras estão precisando de uma intervenção." (EDUARDO COLONELLI, São Paulo, 20/09/2011)

De todo modo, Colonelli deixa claro que essas dificuldades já estavam implícitas no enfrentamento dessa obra: “Essa casa não é revestimento. E a dificuldade é que, uma vez concretado, como você faz um reparo?". Relata, em relação ao tratamento do concreto [FIGS. 3.51 A 3.55], a busca inicial pela "homogeneização" com o existente, "o problema da textura", da cor, e mais do que tudo, a busca pela coerência na intervenção, assinalando: "essa casa do Paulo (...) é de um concreto bastante bruto. Ele pro si só, já não é homogêneo".

O reparo do concreto ${ }^{27}$ foi um dos pontos cruciais nesse projeto. E para alcançar os resultados obtidos, foi preciso executar diversos testes em situações bem específicas, como por exemplo, nos trechos que o concreto tem a marca das tábuas da concretagem, ou, ainda, quando as ferragens estavam expostas, o que de fato ocorreu de maneira muito localizada nas escadas, como expressa Colonelli:

"Essa casa, ela tem espessuras muito pequenas nas nervuras, nas vigas. Mesmo assim, não havia nenhuma grande exposição de ferros. Só uma coisa muito localizada nas escadas. Nas nervuras, nas paredes, tudo perfeito. Agora, a nervura tem $10 \mathrm{~cm}$ aqui em baixo. Mesmo assim... Precisa tomar um certo cuidado, porque o cobrimento não é muito grande." (EDUARDO COLONELLI, São Paulo, 20/09/2011)

Em relação a esses procedimentos e à postura tomada, Colonelli pondera:

"E é um serviço que o pessoal que faz restauro de concreto, faz restauro de concreto tecnológico. Não tem nada a ver com a questão arquitetônica. Então, é difícil lidar. Mas, eu acho que se conseguiu um resultado bastante razoável, mas, assumindo que o reparo você vai perceber e ponto final. Não tem como igualar." Grifo nosso. (EDUARDo COLONELLI, São Paulo, 20/09/2011)
3.51 a 3.54 Residência Mário Masetti - detalhes das patologias apresentadas na escada e recuperação de trechos danificados no concreto - registrado em vistoria de obra 04/08/2010 3.55 Residência Mário Masetti detalhe de escoamento de águas

pluviais da cobertura, que também recebeu tratamento no concreto registrado em vistoria de obra $15 / 03 / 2010$

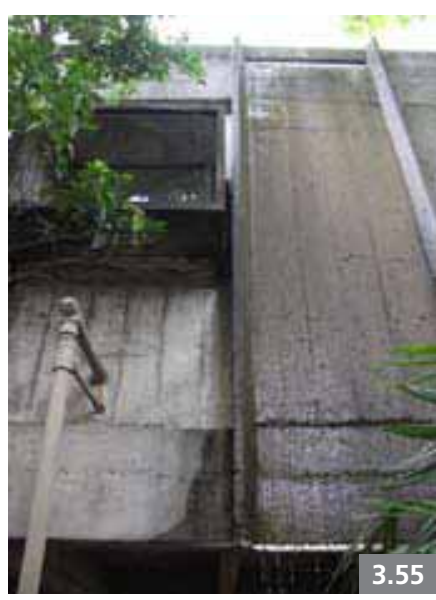


Assumir que esse resultado pode ser observado é, a nosso ver, bastante positivo, pois está baseado na distinguibilidade ${ }^{28}$, cujo princípio é bastante difícil de ser aplicado quando se trabalha com patrimônio recente.

Ainda quanto à recuperação e tratamento do concreto, Colonelli comenta a eficácia de sua limpeza por hidrojateamento e como esse resultado é renovador, mesmo sendo pouco invasivo:

"Ela [a limpeza no concreto] é boa. Eu sou de opinião de que ela é boa. É só uma lavagem. Porque, neste caso, é o material. Você lava o material. É como você pegar a pastilha e lavar a pastilha: jato d'água, faz o rejunte novo; ela fica renovada, mas ela não é nova. E você não tira tudo. Na sua própria origem, o concreto apresenta, às vezes, uma cor (...) um pouco mais amarronzado" (EDUARDO COLONELLI, São Paulo, 20/09/2011)

Por outro lado, ao se examinar o concreto e as patologias apresentadas, nem tudo é uma ciência exata, pelo contrário, algumas perguntas, às vezes, ficam sem respostas, como observa Collonelli: “Teve manchas no concreto que nós não conseguimos tirar. Não sei a origem daquelas manchas. Não é umidade. Não sei. Ficamos desconfiados que fosse alguma reação de origem, de algum produto prá desforma; algum produto aplicado na forma".

E ressalta que, apesar dos bons resultados obtidos apenas com a limpeza e sem recorrer ao lixamento, algumas perguntas persistem:
"Isso [as manchas] eu não tive muita certeza porque nas paredes não apareceu; apareceu só nas lajes de cobertura, sobretudo. A cobertura, na Masetti, tem um filme d'água, mas não era infiltração, entendeu? Não era calcificação, nada disso. Não sei dizer. Lavamos; minimizou um pouco; mas eu não quis aplicar lixas, essas coisas. Não quis lixar. A casa não foi lixada. Foi só hidrojateamento e depois se aplicou um hidrofugante." Grifo nosso. (EDUARDo COLONELLI, São Paulo, 20/09/2011)

Contudo, apesar dos cuidados, em alguns casos, teve-se que adotar medidas mais drásticas para eliminar intervenções espúrias, como foi o caso de uma empena divisória de concreto que havia sido pintada, como explica Colonelli:

"Então, a gente foi se deparando com algumas coisas; fomos lidando com cuidado. Por exemplo: a minha grande preocupação era nunca perder a textura daquele concreto que estava lá. E, às vezes, a própria cor. (...) Teve uma parede grande, em um dos dormitórios, que foi, que sofreu uma pintura, látex, e foi difícil retirar. Quando se tirou, a gente percebeu que o concreto tinha aquelas nuances todas. Então, o concreto absorveu." (EDUARDO COLONELLI, São Paulo, 20/09/2011) [FIGS. 3.56 A 3.57]

Toda essa descrição relacionada ao tratamento do concreto aparente e as complexas decisões que foram tomadas, nos fazem lembrar algumas indagações, expostas por Brandi, de como agir em relação à 'pátina':

“(...) é sempre um juizo de valor que determina a prevalência de uma ou outra instância na conservação ou na remoção das adições.
3.56 Residência Mário Masetti vista parcial dos quartos sem as portas venezianas. Notar pintura verde na divisória de concreto registrado em vistoria de obra 04/08/2010

3.57 Residência Mário Masetti detalhe de teste de remoção da pintura verde na divisória de concreto - registrado em vistoria de obra 04/08/2010
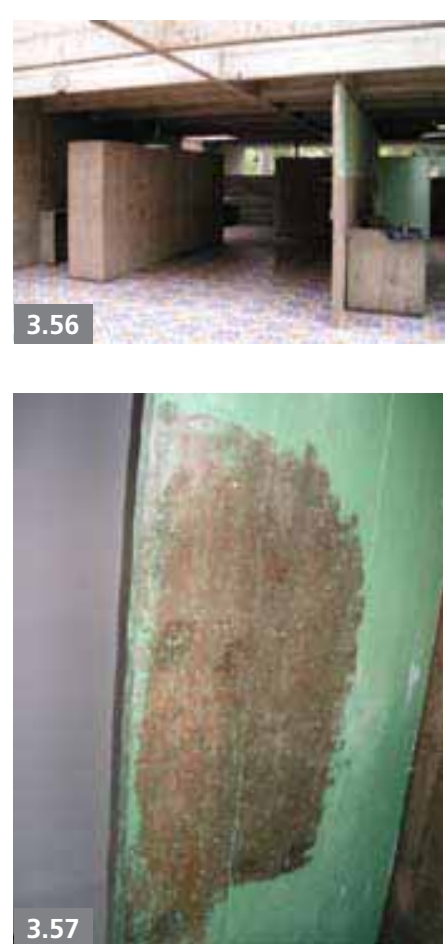


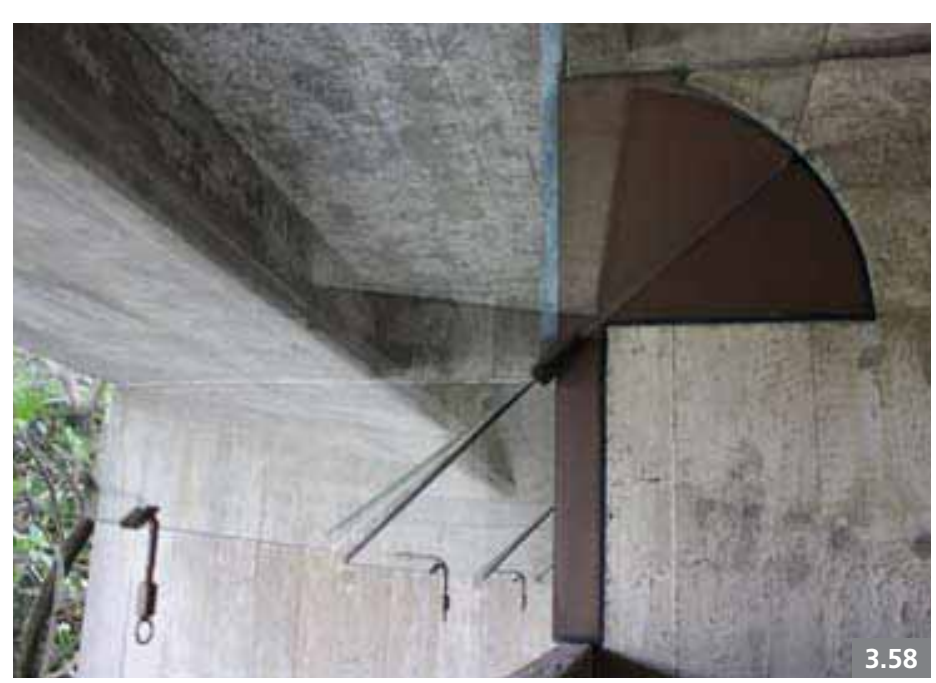

Mas com isso não se exauriu o problema da conservação das adições, dado que mais uma vez devemos examinar a legitimidade ou não da conservação da 'pátina' do ponto de vista estético. Vimos que historicamente, a 'pátina' documenta a própria passagem da obra de arte no tempo e portanto deve ser conservada.Mas a estética é também legítima a conservação?" (BRANDI, 2004, p. 85)

Outra pergunta, comumente formulada, no enfrentamento das intervenções em arquitetura moderna é: como lidar com os 'componentes' tão presentes nesse tipo de arquitetura? Dessa indagação, podemos verificar algumas posturas diversificadas que foram adotadas nessa mesma obra, como descreve o próprio arquiteto: “Nenhuma mudança... Não. No pavimento da casa, propriamente, nenhuma mudança radical. Fizemos alterações de componentes."

Em relação à caixilharia original [FIGS. 3.58 E 3.59], Colonelli afirma: “(...) os caixilhos não se mexeu neles: estão em perfeito estado. Perfeito assim: apresentam desgaste, mas funcio-

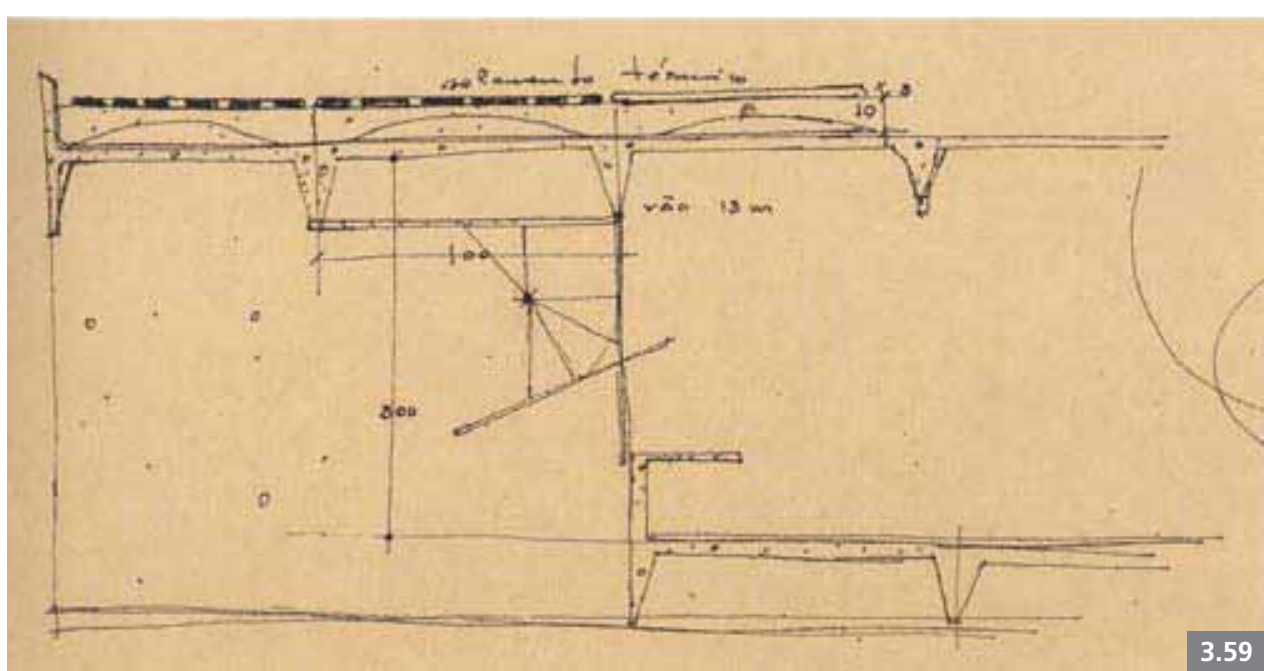

nam perfeitamente. Não se mexeu". Já no caso específico das venezianas de madeira [FIGS. 3.60 A 3.64], buscou-se outra solução:

"Então, todas as portas-venezianas dos quartos para a sala haviam sido substituídas por venezianas de alumínio e nós retornamos à solução original, que era veneziana de madeira. Então isso aqui foi, digamos assim... Voltamos ao componente original. Como é que a gente chegou nesse componente original? Não é original, obviamente. Ele foi refeito. Mas, usou-se como modelo um projeto que o Paulo tinha feito, na mesma época, numa casa em Goiânia e usamos como modelo a própria casa do Butantã do Paulo, que tem essa solução. Mas, a solução era uma solução que havia sido usada nessas três casas, na época. Não posso garantir que o que era na Casa Masetti era igual ao que estava projetado na Odilon Moreira ${ }^{29}$, nem posso garantir que era igual ao que foi executado no Paulo. Sempre pode ter uma diferença. Mas, o conceito, o tipo de veneziana, o tipo de madeira, sim. A própria espessura. O marceneiro queria fazer $3,5 \mathrm{~cm}$ e a gente fez com $2,5 \mathrm{~cm}$, que era a espessura que tinha lá no Paulo. Então, havia
3.58 Residência Mário Masetti detalhe da caixilharia pivotante existente - registrada na vistoria de início do projeto em 15/03/2010 3.59 Residência Mário Masetti croqui original de Paulo Mendes da Rocha para caixilharia dos quartos. Notar preocupação com o sistema de ventilação natural e sombreamento para proteção térmica

3.60 Residência Mário Masetti - vista das portas venezianas em alumínio - registrada na vistoria de início do projeto em 15/03/2010 3.61 Residência Mário Masetti detalhe da porta veneziana em madeira da Casa do Butantã registrada em 2010

3.62 Residência Mário Masetti vista das novas portas venezianas em madeira - registrado em vistoria de obra 15/03/2011 

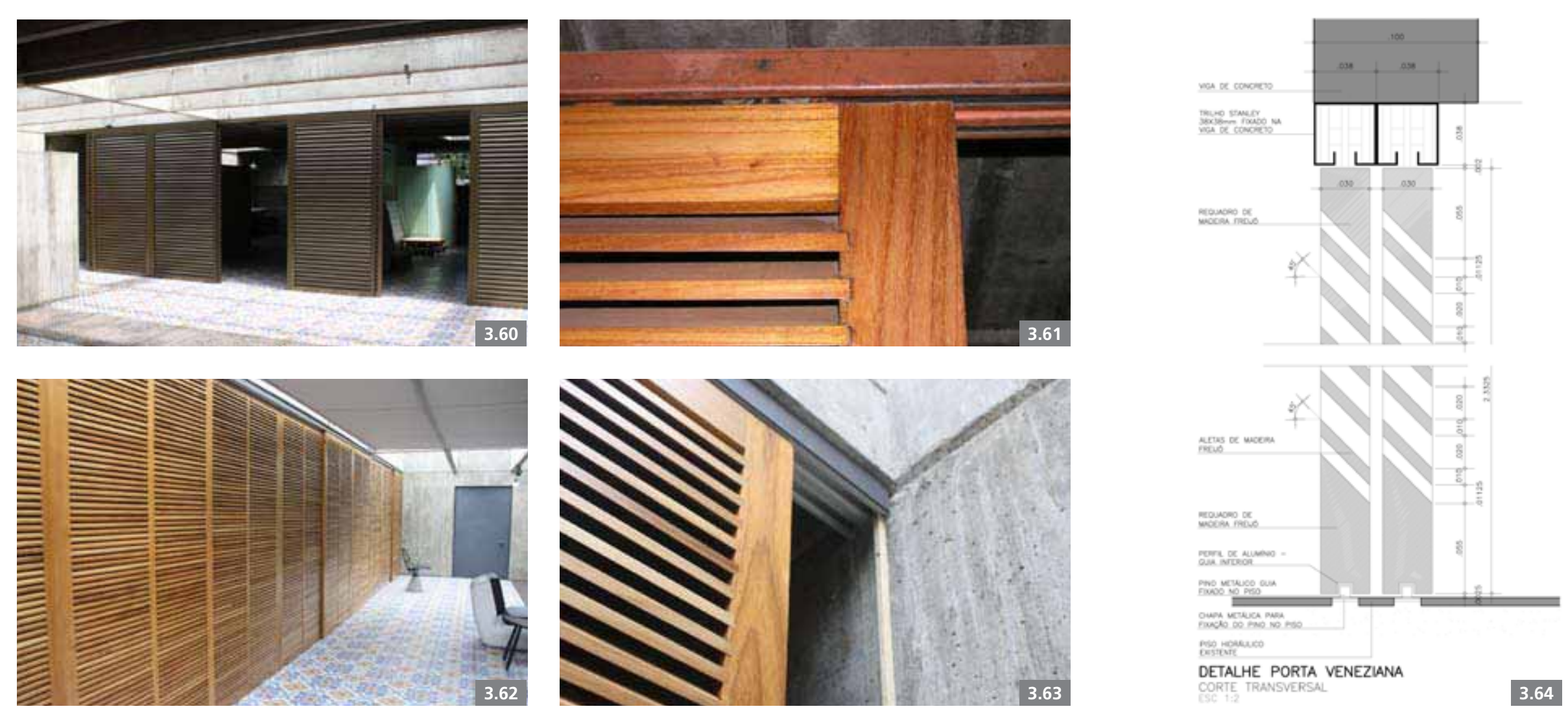

algumas fotos e tal, mas a gente usou alguns projetos de referência, porque, no projeto do Masetti, que a gente tem os desenhos originais, esse detalhamento não aparecia. Talvez nem tenha sido feito, porque essas coisas...: 'Não... Faz igual à casa do Butantã'. O marceneiro vai lá, mede tudo, vai à casa do Butantã e faz igual. Então, pode acontecer assim. Então, nós não encontramos - o Paulo não lembra também - ... Nós não encontramos um detalhamento específico do Masetti. Mas, achamos que era importante ter essa solução da época." (EDUARDO COLONELLI, São Paulo, 20/09/2011)
Também se optou por substituir as claraboias [FIGS. 3.65 A 3.67] ação esta não isenta de controvérsias ${ }^{30}$ - que, por serem em estruturas metálicas, encontravam-se bastante comprometidas, como podemos verificar na descrição de Colonelli,

"Achou-se melhor fazer novamente essa claraboia, e fizemos. Os perfis foram um pouco modificados (...) Eram um pouco pequenos. Continuou de aço, a mesma coisa. A mesma solução de canaleta U, a mesma modulação. Nada disso foi alterado. Mas a gente
3.63 Residência Mário Masetti detalhe das novas portas venezianas em madeira - registrado em vistoria de obra 15/03/2011 3.64 Residência Mário Masetti detalhe da veneziana de madeira (trecho da prancha original digitalizada, escala original 1:2) 


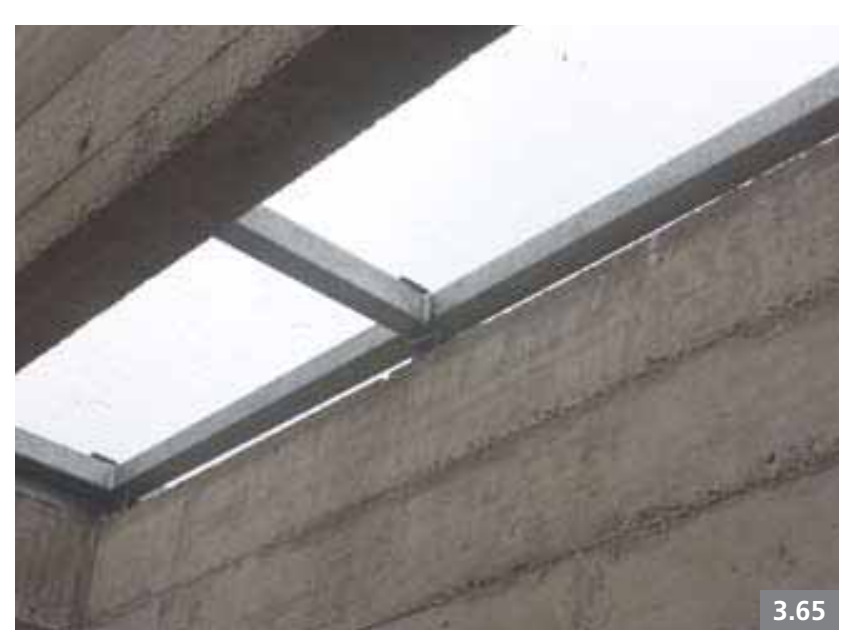

3.65
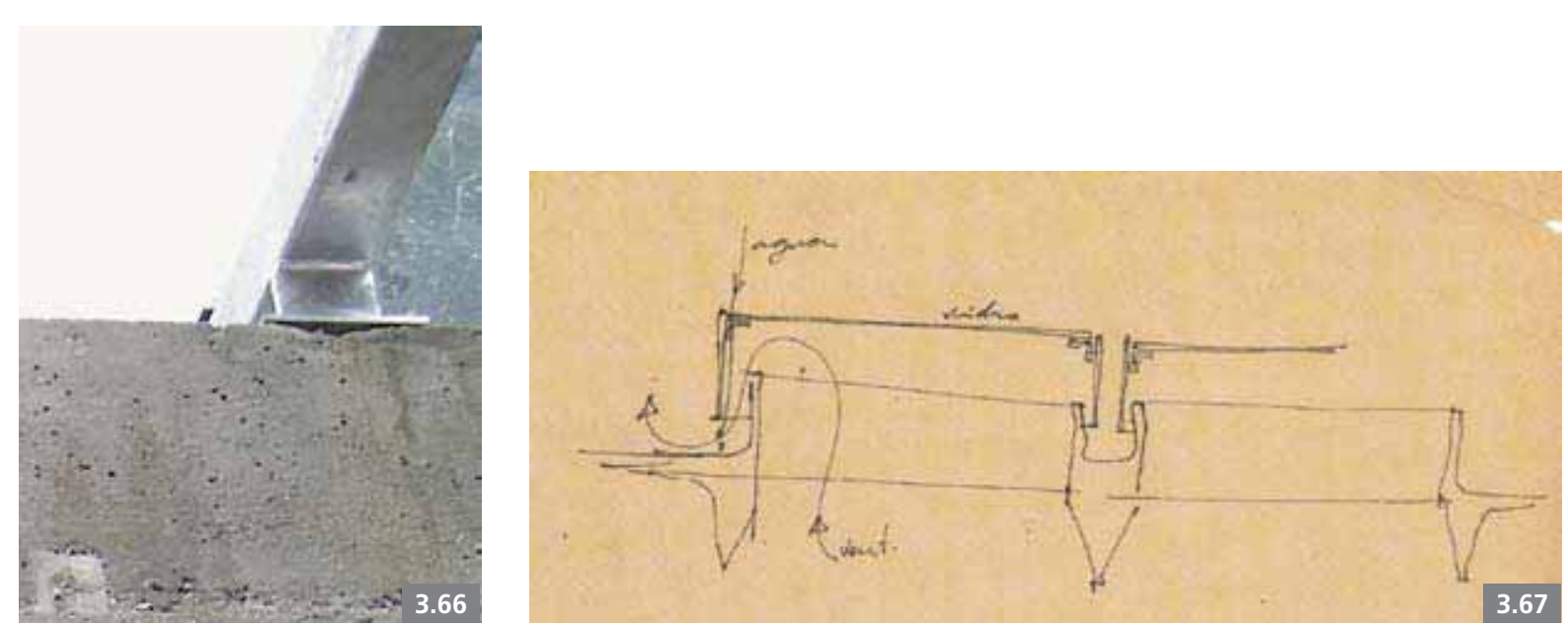

ampliou um pouco a altura dos perfis, para dar maior capacidade contra a chuva e, também, demos uma pequena elevada, porque essa claraboia conserva uma ventilação permanente. E a gente levantou um pouco mais para ampliar, também, a capacidade de ventilação (...) O vidro, originalmente, era um vidro temperado e continuou a mesma coisa. Transparente. (...) Chegamos a cogitar algum tipo de vidro que melhorasse essa questão de transmissão de calor pra dentro, mas, enfim, essas coisas têm toda uma questão financeira envolvida e se optou pelo original, mesmo. Pelo vidro temperado, cristalino (...) sem alterar o conceito, vamos dizer. E fizemos. A fixação é o mesmo sistema. Foi refeito. A peça, em si, não é mais a original. Nem é, exatamente, um fac-símile. Não foi feito igual. Foi feito semelhante." (EDUARDo COLONELLI, São Paulo, 20/09/2011)

Mesmo ao descrever um simples tratamento de recuperação de piso, nota-se a preocupação e o cuidado em relação ao que se considerou "matéria original"; neste caso, as peças de ladrilhos hidráulicos [FIG. 3.71], com padrões coloridos rica- mente decorados, que fazem um contraponto à austeridade do concreto aparente. Colonelli evidencia:

"Piso foi conservado o mesmo que estava lá. Ele foi tratado, lavado. Fez-se uma limpeza com um certo abrasivo, mas sem ofender o ladrilho, para ter uma limpeza. Mas, ladrilho trincado ficou tudo lá, como estava. (...) Lavou-se bastante e depois se fez uma limpeza com um abrasivo, uma espécie de lixa muito fininha, só para tirar essa película de cima e voltar ao ladrilho natural (...) [Depois aplicou-se] Só um hidrofugante. Uma resina, mas uma resina absolutamente inócua." (EDUARDo COLONELLI, São Paulo, 20/09/2011)

É interessante observar que, ao lidar com o assunto das instalações elétricas e de telefonia [FIGS. 3.68 A 3.73], com o intuito de atualizar seu sistema, Colonelli faz uma rica descrição das origens das patologias encontradas e de como a solução adotada incorpora-se de maneira inequívoca, ao se optar também por uma linguagem de componentes industrializados.
3.65 Residência Mário Masetti detalhe das novas claraboias executadas e apoio (estrutura em aço galvanizado e vidros laminados) - registrado em vistoria de obra 15/03/2011

3.66 Residência Mário Masetti etalhe das novas claraboias executadas e apoio (estrutura em aço galvanizado e vidros laminados) - registrado em vistoria de obra 15/10/2010

3.67 Residência Mário Masetti croqui original de Paulo Mendes da Rocha para claraboias. Notar preocupação com o ventilação e iluminação natural

3.68 Residência Mário Masetti detalhe do núcleo de serviços (entrada de energia e descida de esgoto) e conexão com os eletrocalha galvanizada - registrado em vistoria de obra 15/01/2011 

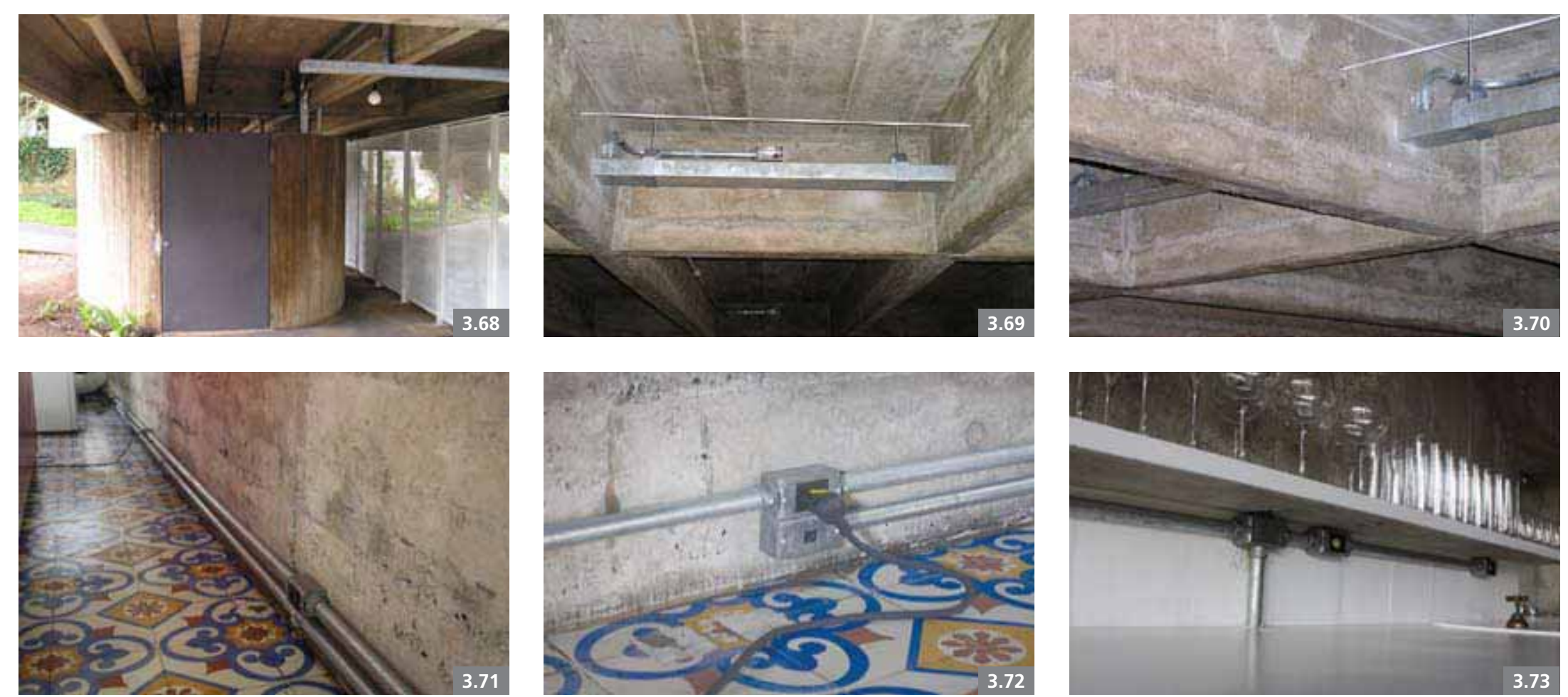

"A casa tinha recebido um monte assim de gambiarras (...) a solução original, a casa está suspensa nos quatro pilares e você tem lá um volume, logo na frente, redondo, onde ficam todas as utilidades. Nem encostam no teto, para liberar a fachada. E a caixa de elétrica e entrada era aqui. Isso subia - a mesma coisa o esgoto... Tudo desce aqui - e corria tudo pelo contrapiso. Bom... Claro que apodreceu todo o conduite, porque eram aqueles conduites metálicos, daquela época. Então, para restabelecer o mesmo tipo de instalação, teria que tirar aquele piso. Priorizou-se, então, manter o piso e estudar uma alternativa para a elétrica. (...) Isso a gente tirou tudo, limpou toda a fachada, e estudou um novo sistema de insta- lação aparente. Então, toda a distribuição de tomadas se faz... Não chega a ser um rodapé, mas funciona quase como um rodapé. Você tem conduites, tanto de elétrica como de informática, que correm paralelos a $15 \mathrm{~cm}$ do chão, $10 \mathrm{~cm}$ entre um e outro, com tubulação aparente de ferro galvanizado. E (...) fizemos três linha de eletrocalhas, que também vêm aparentes por baixo da nervura, e que também são de chapa galvanizada. E fizemos uma interligação da eletrocalha, já por conduites, utilizando algumas furações que as nervuras já tinham. Ficou muito bom. Ficou absolutamente incorporado à casa." Grifo nosso. (EDUARdo ColonelLI, São Paulo, 20/09/2011)
3.69 e 3.70 Residência Mário Masetti - detalhe da eletrocalha galvanizada entre as nervuras da estrutura de concreto - registrado em vistoria de obra 18/10/2010 3.71 e 3.72 Residência Mário Masetti - detalhe de eletroduto galvanizado paralelo ao piso registrado em vistoria de obra 18/10/2010

3.73 Residência Mário Masetti detalhe de eletroduto galvanizado paralelo à bancada da cozinha registrado em vistoria de obra $15 / 01 / 2011$ 
Solução e raciocínio similar foram também adotados para a iluminação [FIGS. 3.74 E 3.75]:

"Originalmente era o seguinte: tinha aqueles aparelhos industriais de pratos esmaltados verdes, que ficavam pendurados (...). E tinham, também, uns conduites que corriam, furando as nervuras, $e$ algumas coisas assim. Sabe aquelas coisas? Fios que ficam pendurados? Um problema dessa iluminação é que ela cria um teto escuro, sabe? Eu acho que já não era uma iluminação adequada. Fora isso, a ideia da eletrocalha dá grande flexibilidade: a partir da eletrocalha vai se instalar qualquer aparelho. Mas, aí compra na esquina. Tem bracinho... Como você quiser. Até pode ser isso. O problema é de onde saiu o ponto. Para não ficar enchendo: "agora põe um ponto aqui". "agora põe um ponto lá". Não! Toda a energia está na eletrocalha. Você pode prender a luminária na própria eletrocalha ou você pode tirar um chicote, tirar uma haste da eletrocalha e colocar o que você quiser. Uma delas corria no eixo da cozinha, a outra no eixo da sala e a outra naquele espaço entre a lareira e a mesa do escritório, onde fica uma espécie de biblioteca. E, depois, em cada quarto corria uma. E fizemos também uma eletrocalha lá no piloti, que era uma maneira de tirar o ponto a partir daquela central e poder correr pela casa toda, para subir para onde você queria. Ficou muito bom! (...) O material se incorporou ao concreto, mas está lá, você vê. É aparente. Incorporou-se ao concreto por causa da cor, por causa do acabamento em si. Um material tão - como eu diria, assim? - tão cru quanto o concreto. Galvanizado. E a tendência é que ele vai escurecendo com o tempo, vai ficar até mais incorporado." (EDUARDo COLONELLI, São Paulo, 20/09/2011)
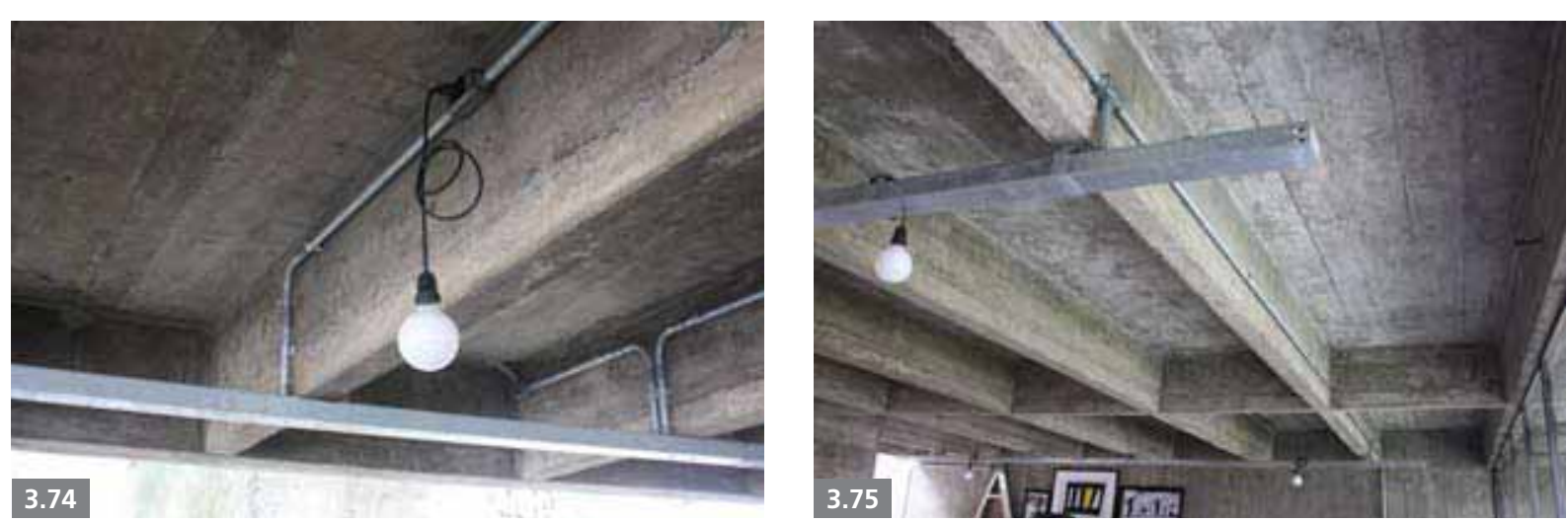

Por fim, Colonelli descreve as ações relacionadas à mudança de uso do pavimento inferior, em cuja área houve mais modificações, que incluíram desde a remoção de divisórias de ambientes em alvenaria armada, até a execução de uma nova escada de acesso - desenhada em chapa metálica. Outras medidas específicas ligadas à proteção acústica foram também necessárias, a fim de acomodar um novo programa para esta área: um estúdio musical, como sintetiza Colonelli:

"Na área de serviço, que tinha lá vários quartos de empregada, ali acabamos fazendo uma intervenção um pouco maior, mesmo na compartimentação. O problema de casa é que há a necessidade do usuário! As famílias se compõem diferentemente; é outra necessidade; é outra estrutura (...) que está se mexendo é naquilo que é divisório. Quer dizer, nenhuma intervenção conceitual. A casa tinha lá três quartos de empregada porque era o que se fazia naquela época. Tinha duas empregadas, outro quarto era a lavanderia.. Mas, se agora você só tem uma empregada e precisa de um salão pra fazer outro tipo de atividade... Então, me parece legítimo isso aí. De qualquer maneira, eram três quartos e ficou um aqui. Aquela
3.74 e 3.75 Residência Mário Masetti - detalhe da solução de luminotécnica associada à eletrocalha e à eletroduto galvanizado - registrado em vistoria de obra 15/03/2011

3.76 Residência Mário Masetti vista lateral com o novo posicionamento do gradil em aço galvanizado

3.77 e 3.78 Residência Mário

Masetti - vista interna do eixo das claraboias. Notar a instalação de fechamento backout em sistema rolô podendo ser utilizado vertical ou horizontalmente

3.79 Residência Mário Masetti - vista da cozinha. Notar que a bancada e os armários receberam uma nova camada de pintura epóxi 3.80 e 3.81 Residência Mário Masetti - vista da área de lazer e piscina com revestimento preto 

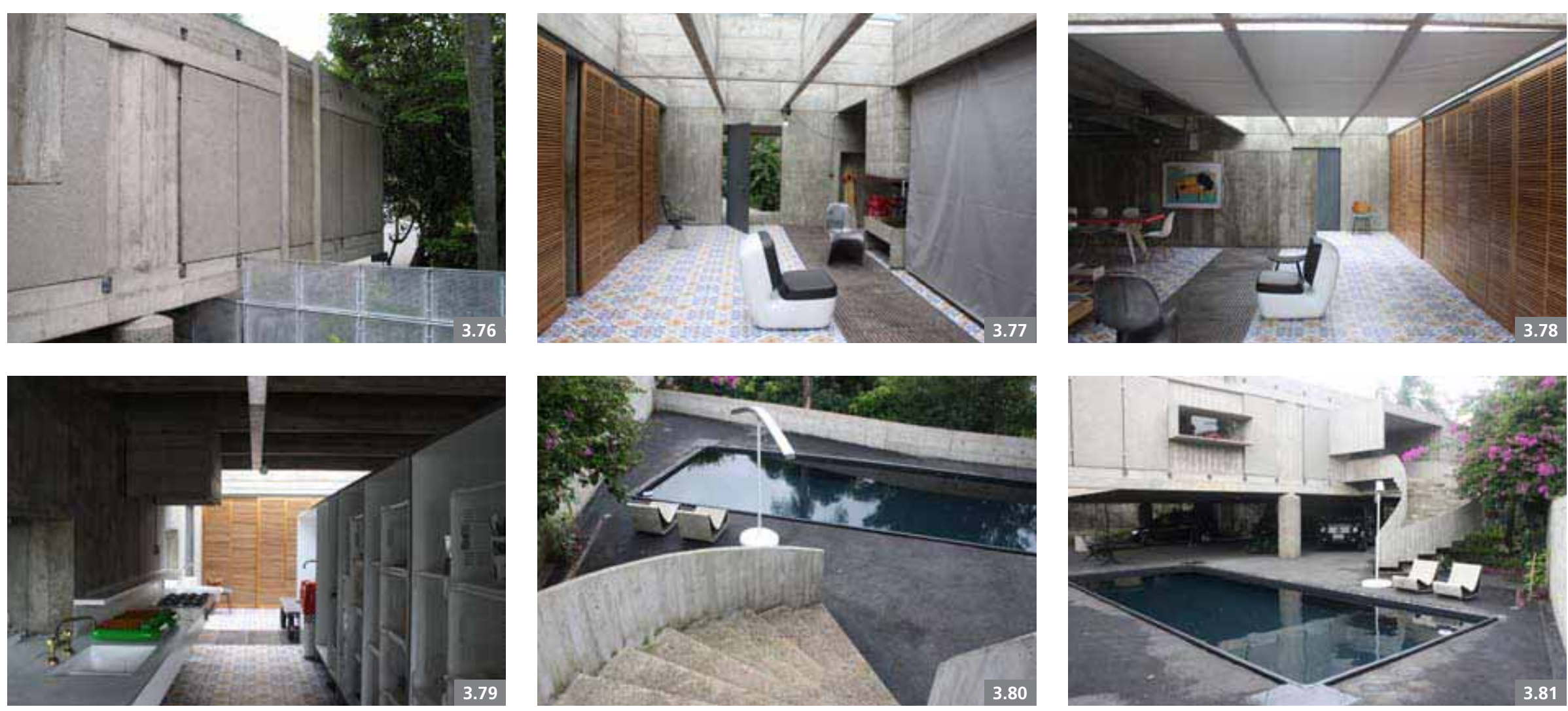

varanda que tem no serviço lá em baixo, tudo isso está conservado. É uma questão da compartimentação daquilo que eram paredes divisórias." (EDUARDo COLONELLI, São Paulo, 20/09/2011)

Colonelli conclui que todas as ações deste projeto buscaram "recuperar o seu aspecto, a sua integridade" [FIGS. 3.76 A 3.81], visando apenas à preservação de um bem cultural, objetivo que ele mesmo reitera: “(...) eu considero que foi feita, assim, uma conservação. Essencialmente uma conservação (...) não acho que seja nenhuma mudança conceitual". Além disso, Colonelli aponta como primordial, em todo esse processo, inclusive como causa do êxito dos resultados, a própria anuência do arquiteto autor do projeto original ${ }^{31}$ : "Claro que tudo isso foi conversado com o Paulo". 


\subsection{AS INTERVENÇÕES E SEUS DETALHES: RESIDÊNCIA FERNANDO MILLAN}

Em relação às intervenções executadas na residência Fernando Millan [FIG. 3.82], podemos indicar os seguintes itens:

- Recuperação e tratamento das patologias presentes no concreto, especial atenção à piscina;

- Inclusão de um novo volume em argamassa armada e vidro para acomodar a cozinha [FIG. 3.83];

- Inclusão de caixilharia nos quartos;

- Inclusão de diversos detalhes elaborados em aço galvanizado: cabideiro ${ }^{32}$ do closet, coifa para nova lareira, portão de acesso, gradil à meia altura junto à piscina e solarium, corrimão da escada de acesso à cobertura e abrigo de gás.

- Substituição da estrutura metálica e vidros das claraboias;

- Substituição de todos os vidros e caixilhos do quarto e estúdio

- Substituição do piso em asfalto por piso de concreto em todo o pavimento térreo;

- Substituição do sistema de iluminação existente por trilho eletrificado;

- Eliminação da escada em espiral metálica, trecho de acesso do térreo ao quarto principal:

- Revisão de todas as instalações hidráulica e elétricas - todos os pontos novos em eletrodutos galvanizados aparentes;

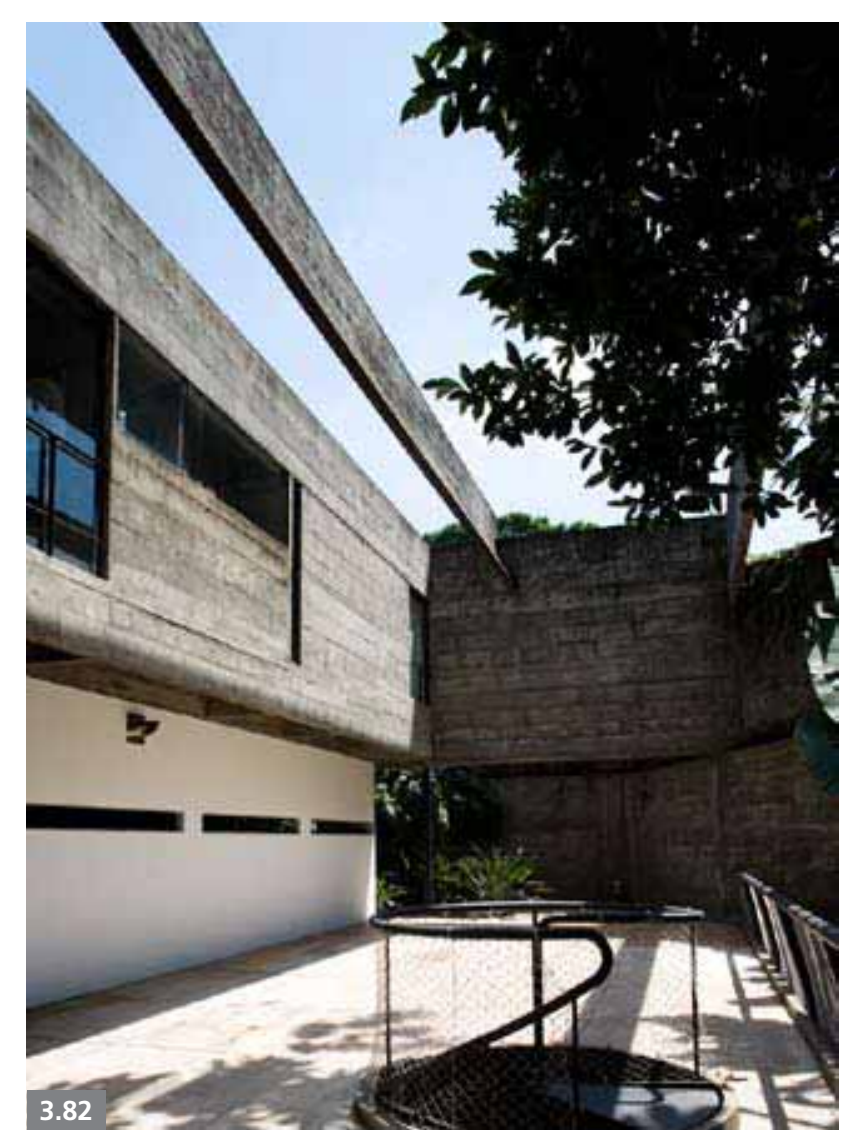

- Aplicação de piso epóxi branco em todo o pavimento superior.

Diferentemente dos casos anteriores, na residência Fernando Millan, a entrevista com Paulo Mendes da Rocha não alimentou explicações e particularidades referentes às posturas técnico-operativas adotadas, assim como com Milton Braga, que comentou não ter nada o que acrescentar no que se referia a esse processo. As escassas informações obtidas de
3.82 Residência Fernando Millan, Paulo Mendes da Rocha, 19701975 - vista do pátio lateral de acesso. Notar o volume da nova cozinha sob o volume preexistente 


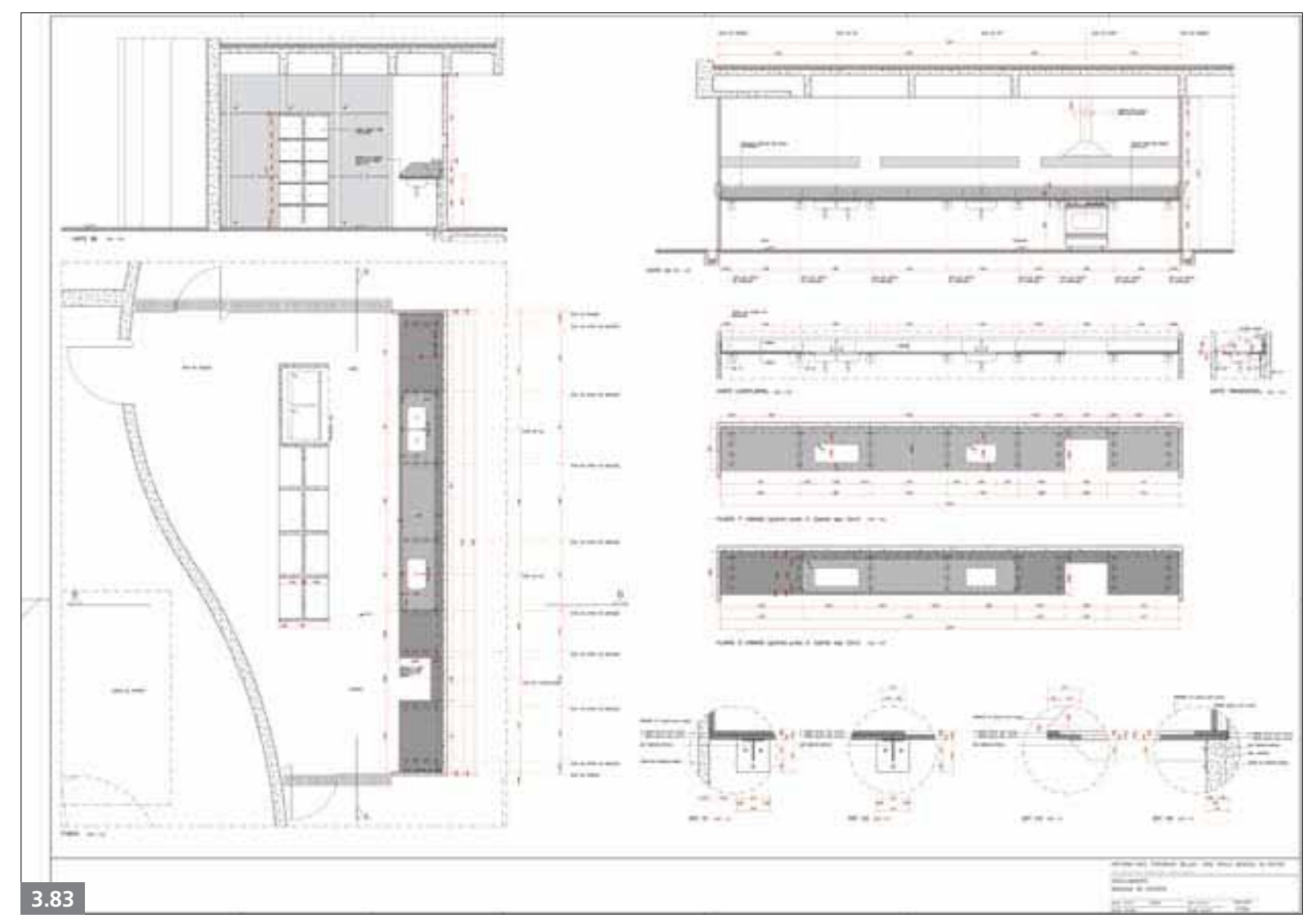

ambos, provavelmente, deram-se pelo fato da intervenção ter ocorrido há mais de uma década.

Sendo assim, muitas das observações referentes aos serviços realizados serão feitas pelo próprio autor do presente trabalho, por ter integrado a equipe que elaborou o projeto de intervenção e por ter participado ativamente de todo o processo da obra, cujos detalhes e descrições foram rememorados através da observação dos desenhos executivos, fotos da obra, parcas anotações e croquis.
Reforçamos aqui, também, a importância da presença do engenheiro Osmar Penteado, da CENPLA, que, com toda a sua experiência, conduziu de maneira exemplar a execução da obra de intervenção. Ademais, com tamanho apreço e cuidado, tanto em relação às minúcias que a obra original exigia, como pelo suporte na elaboração do detalhamento supervisionado pelo próprio Paulo Mendes da Rocha -; e, ainda, pela coordenação magistral de todos os agentes envolvidos naquele processo.
3.83 Residência Fernando Millan ampliação cozinha (prancha original digitalizada, escala original 1:20 


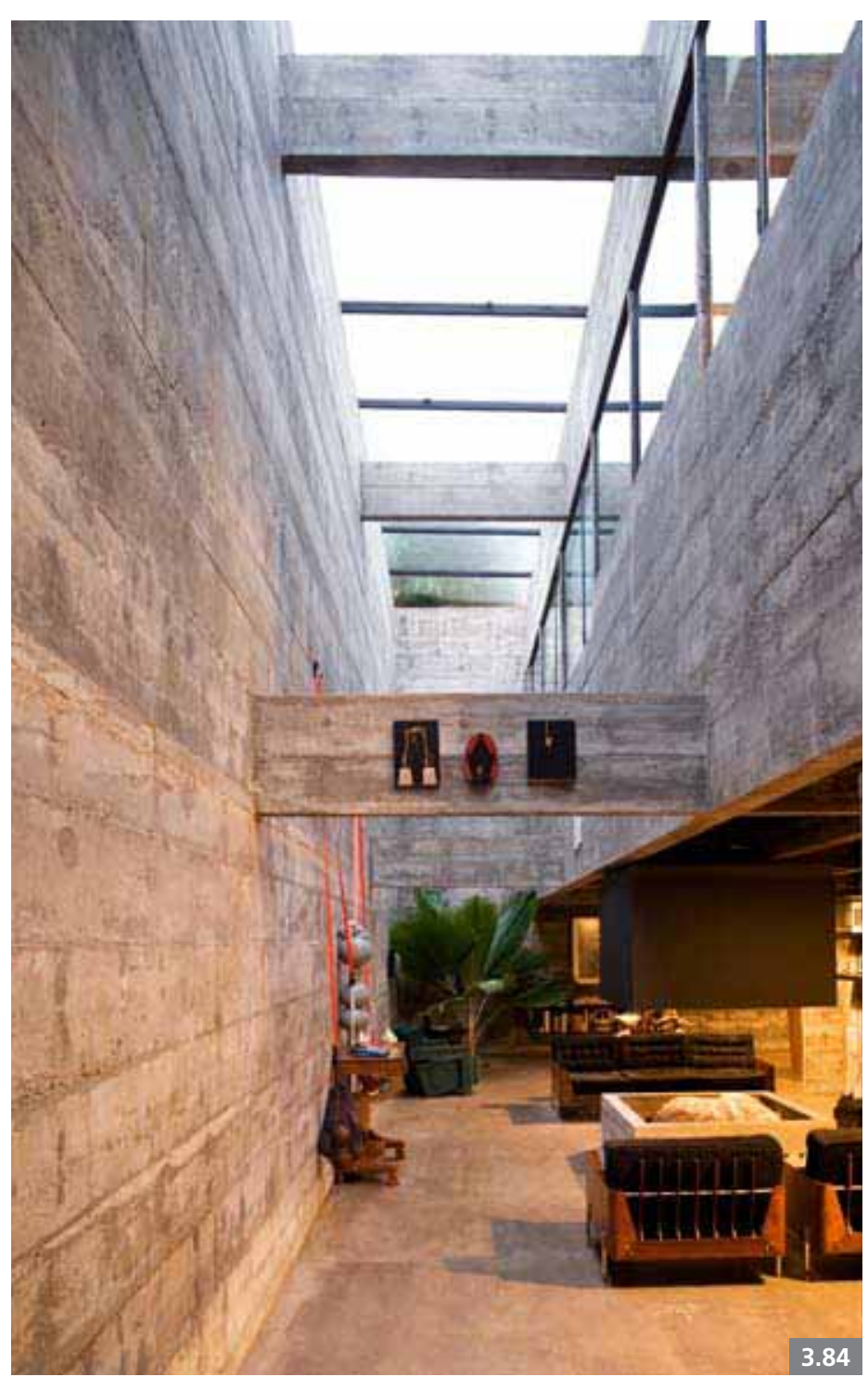

3.84
Ainda como observação preliminar, pareceu-nos importante ressaltar que, diferentemente do que ocorreu na obra de conservação da residência Mário Masetti, neste caso, o arquiteto autor do projeto "resgatou" uma solução que já havia sido apresentada para os proprietários - solução anteriormente comentada em ralação à mudança da cozinha de lugar -, ainda na época de sua construção. Não obstante, consideramos bastante pertinente apresentar e analisar este caso, mesmo correndo o risco de se repetir algumas observações no que se refere às posturas técnico-operacionais. Essa opção está baseada em duas justificativas: a primeira, a própria peculiaridade da situação do "resgate"; a segunda, o fato dessa intervenção não ter sido divulgada nem publicada em nenhuma mídia ou, mesmo, em nenhum trabalho acadêmico.

Assim, focalizaremos as principais modificações realizadas na obra, atendo-nos aos seguintes itens: a mudança das funções de uso da antiga cozinha, suas consequências no espaço construído e suas particularidades construtivas, a substituição de componentes existentes, a inclusão de componentes complementares, as alterações relacionadas às instalações elétricas e luminotécnicas, as ações diretamente ligadas aos pisos existentes e, ainda, uma breve descrição dos serviços relacionados ao tratamento e recuperação estrutural.

Tomando como partida o espaço da antiga cozinha [FIG. 3.84], que teve como programas substitutos biblioteca e estar, optou-se por aproveitar o duto de exaustão existente e instalar uma lareira, com a base em argamassa armada cuja coifa de exaustão foi executada em estrutura metálica, fixada nas nervuras da laje de concreto.
3.84 Residência Fernando Millan vista da biblioteca (antiga cozinha). Notar a caixilharia dos quartos, lareira e coifa executadas na intervenção 
Por sua vez, para a nova cozinha, instalada sob o "alpendre", junto ao acesso principal, optou-se em executar todos os elementos opacos em argamassa armada, que foi posteriormente pintada em tinta epóxi na cor branca - com o intuito de diferenciar essa nova volumetria -, e os demais fechamentos em vidro temperado e laminado incolor, fixado por sistema "Dorma" ${ }^{33}$. Apenas para efeito de registro, aventou-se a possibilidade de execução desses elementos em peças de aço galvanizado com pintura eletrostática a pó; mas, devido às suas especificidades de "área molhada", essa opção foi descartada.

Apesar de se configurar como um "anexo", a cozinha teve como premissa não "encostar" nenhum elemento opaco na parede sinuosa de concreto, sendo esse contato feito pelas peças de vidro, postura que indica certa preocupação tanto com a distinguibilidade como com a reversibilidade ${ }^{34}$. Um volume de armários e equipamentos, também executado em argamassa armada de cinco centímetros de espessura, faz a transição entre o espaço de preparo, cocção e lavagem e o acesso ao espaço social.

Sobre as substituições dos componentes existentes, podemos relatar que tanto as claraboias, quanto a caixilharia foram trocadas por novas, buscando recriar as mesmas aparências contidas nas peças originais, que se encontravam em péssimo estado, devido à corrosão do ferro. Essa postura de substituição integral de peças ou componentes considerados secundários nas obras de arquitetura moderna - fruto, provavelmente, de uma combinação de diversos fatores, tais como: questões financeiras, prazos de execução, busca em melhorar os detalhes executados sanando suas falhas e, ainda, uma crença generalizada de que, ao término do cumprimento de suas funções, o componente deve ser substituído por outro, que atenda de melhor maneira - tem levado à perda significativa de suas "matérias originais", o que remete à necessidade de avaliar cuidadosamente tal solução, bem como de utilizá-la apenas em último caso.

Por sua vez, alguns desses componentes foram irremediavelmente alterados, como é o caso do trecho da escada em espiral, que fazia a conexão direta do acesso com o quarto principal. Após a sua remoção, foi executado um detalhe de arremate no trecho restante que leva ao pavimento inferior. Essa escada, apesar de ter seu uso especificamente ligado a um desejo do proprietário original, como relatou Paulo Mendes da Rocha, fazia parte integrante da casa e de sua imagem. Sua remoção acarretou, assim, a perda irremediável de um detalhe significativo.

Algumas inclusões foram fruto de solicitações do novo proprietário, como é o caso dos seguintes itens: cabideiro [FIGS. 3.85 A 3.87], fechamento e portão de acesso, gradil à meia altura junto à piscina e ao solarium e corrimão na escada de acesso à cobertura.

Em relação ao closet, uso que havia sido previsto em um dos quartos cujo cabideiro iria apenas se apoiar nas paredes de concreto existente, diferente do que consta no projeto de intervenção, dois quartos acabaram por ser unificados, tendo a sua empena divisória de concreto parcialmente seccionada.

Além da coifa de exaustão para lareira, também desenhou-se um abrigo de gás em estrutura metálica, sendo esses dois itens associados unicamente às questões de infra-estrutura. 


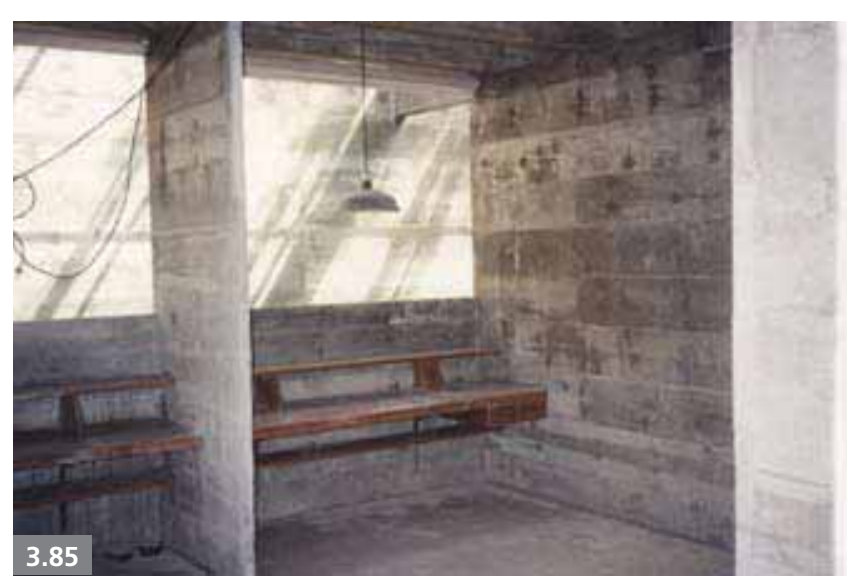

Quanto à revisão de todas as instalações elétricas e substituição do sistema de iluminação existente, adotou-se, como padrão, executar uma nova rede em eletrodutos galvanizados aparentes e trilho eletrificado para alimentação dos novos pontos de iluminação, soluções estas que também foram adotadas posteriormente por Eduardo Colonelli nas intervenções da residência Mário Masetti.

Em relação aos pisos existentes, houve duas posturas dissonantes entre si: na primeira, no pavimento térreo, optou-se por substituir o piso asfáltico original por um novo piso em concreto; na segunda, no pavimento superior, apenas realizou-se a remoção do piso e uma nova aplicação de camada de pintura epóxi, mudando apenas a cor para branco [FIG. 3.88].

Sobre o novo piso em concreto, executado apenas no interior da residência, a metodologia adotada foi a concretagem em damas com juntas de dilatação de PVC na cor cinza tendo como processo de acabamento a utilização de desem-
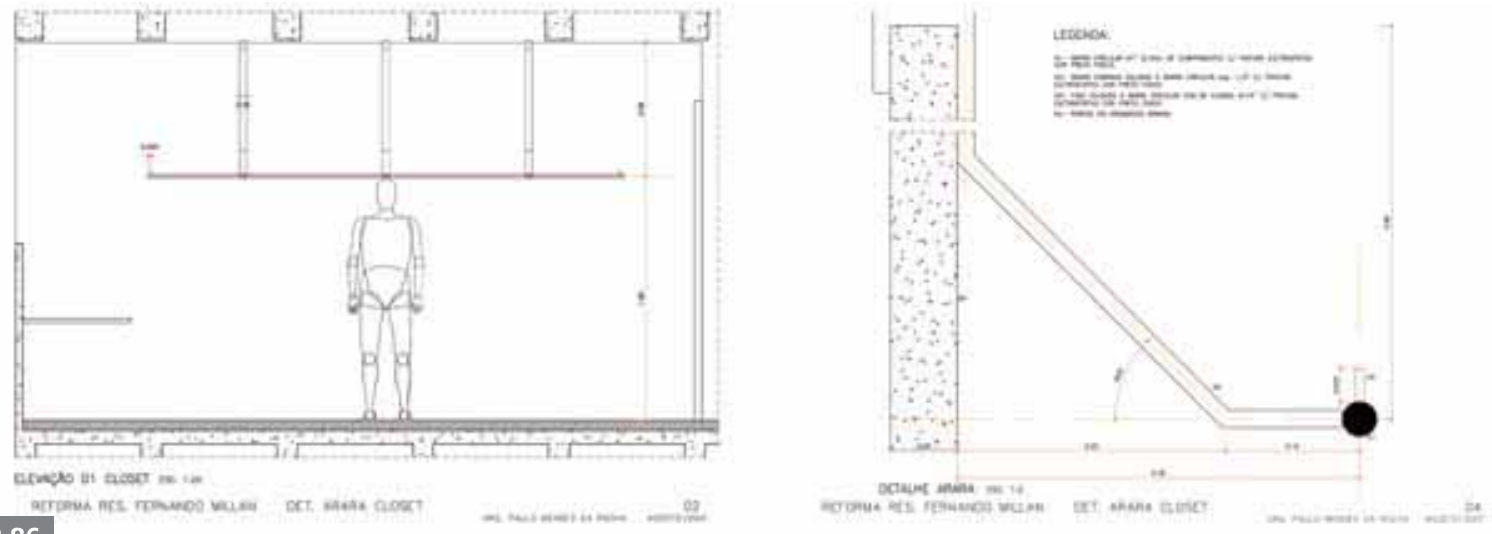

penadeira mecânica circular ${ }^{35}$ e posterior aplicação de resina de poliuretano fosco. Entretanto, apesar da solicitação de mudança desse acabamento ser compreensível devido à sua difícil manutenção do revestimento asfáltico (já na época da entrevista, os proprietários destacaram esse "descontentamento funcional"), ela é um testemunho, entre outros, do estranhamento em relação às novas formas de morar, como relata Santos:

"Não me lembro de muitos elogios às virtudes das casas modernas que visitamos, mas me lembro bem, talvez porque me surpreendessem, das queixas do chão de asfalto na cozinha, da falta de privacidade e de luz, da opressão das grandes estruturas que acomodavam partindo os vidros e negando o aconchego, dos móveis fixos, dos ambientes sombrios em concreto aparente, do frio e do calor quase sempre excessivos e inoportunos." Grifo nosso. (SANTOS, 2011, p. 14)

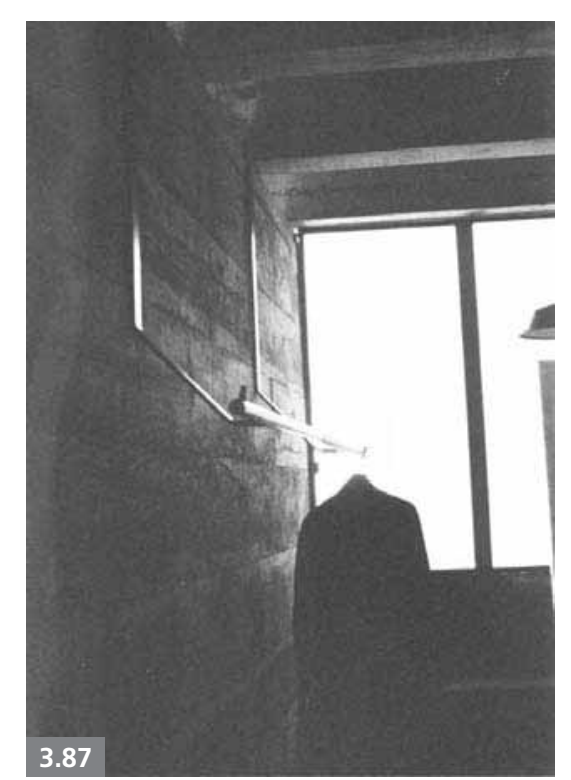


Contudo, poderíamos adjetivar de perversa essa transformação da moradia, conflita não só com uma imagem muito conhecida, - devido ao asfalto adentrar na residência -, mas com a intenção nela contida, como expressa Kamita:

"Como se vê, para Paulo Mendes da Rocha, casas são modalidades de pensamento sobre a arquitetura, um ato de conhecimento que põe em xeque noções habituais sobre programa, implantação, interior e exterior, estrutura e vedação, vão e volume (...) fica claro que para o arquiteto a dimensão pública não se refere simplesmente àquilo que ocorre no espaço exterior e aberto. Pública, no caso, é a legibilidade das relaçôes daqueles que convivem e constituem a sociedade." (KAMITA, 2004, p. 169)
Por fim, sobre a recuperação das patologias presentes no concreto [FIG. 3.89], podemos relatar que foi conduzida de maneira muito pontual, buscando recompor áreas eventualmente corrompidas e com as armaduras expostas. Realizou-se uma preparação da superfície, com tratamento químico das armaduras e completamento com argamassa polimérica e, de maneira geral, executou-se uma limpeza com hidrojateamento ${ }^{36} \mathrm{em}$ alta pressão e posterior aplicação de produto hidrofugante ${ }^{37}$.

Especial atenção foi dispendida na região da piscina, que se encontra em pior estado de conservação devido, obviamente, não só ao seu contato direto com a água; mas, sobretudo, pelo fato de não haver revestimento em sua superfície.
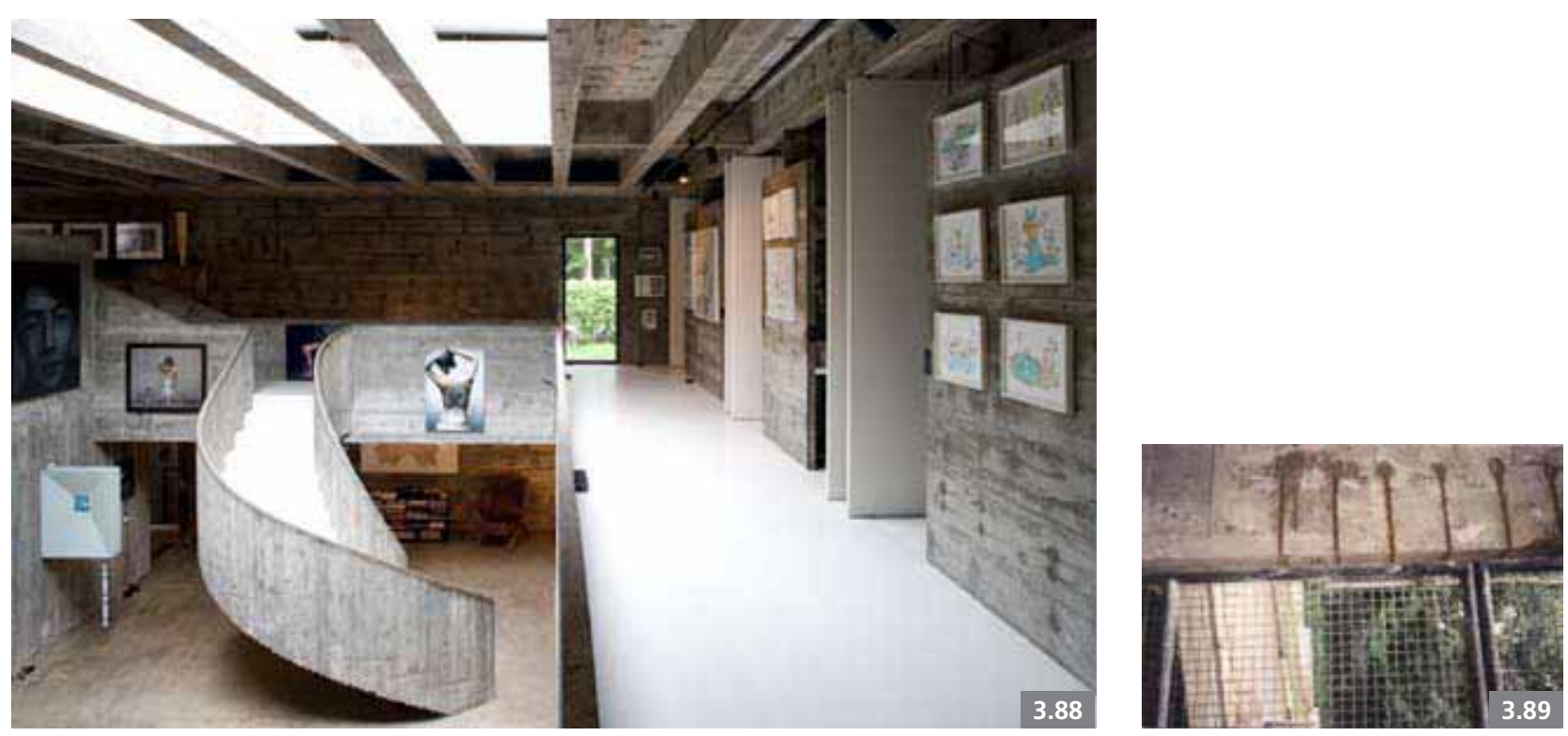

3.85 Residência Fernando Millan detalhe do closet, configurado após o corte de trecho da divisória em

concreto - registrado em vistoria de obra em 2000

3.86 Residência Fernando Millan detalhe da arara metálica apoiada

nas divisórias de concreto (prancha original digitalizada, escala original $1: 20 / 1: 2)$

3.87 Residência Fernando Millan detalhe da arara metálica apoiada nas divisórias de concreto

3.88 Residência Fernando Millan vista da circulação dos quartos e pé direito duplo da sala

3.89 Residência Fernando Millan detalhe de teste de tratamento do concreto 


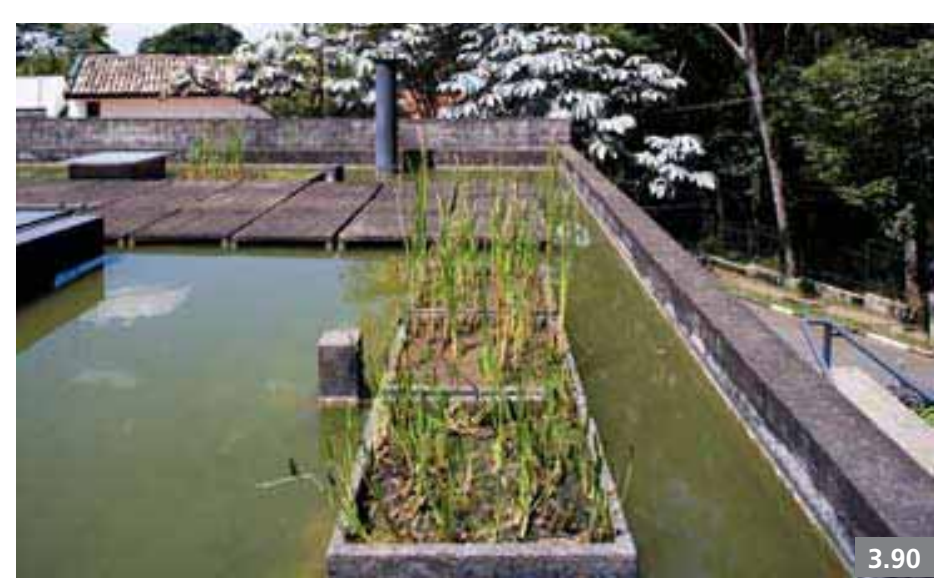

Para a coberta, com seu espelho d'água [FIG. 3.90], foram feitos apenas reparos pontuais na impermeabilização (onde existiam interferências na laje, como por exemplo, a exaustão da lareira), já que, de maneira geral, se encontrava em ótimo estado, devido à proteção térmica da própria camada de água.

Apenas como curiosidade, ao remexermos nossas anotações e cadernos, encontramos um croqui de uma discussão referente à possível locação de uma guarita [FIGS. $3.91 \mathrm{~A}$ 3.93], cujo estudo buscava não acrescentar nenhuma outra volumetria na edificação, mas tentava incorporar na sala de equipamentos da piscina (casa de bomba) esse novo item, tirando partido do próprio desnível da rua. Essa solução não foi levada adiante devido às dificuldades técnicas - exiguidade do espaço a ser compartilhado e outras exigências de segurança predial -, o que, de certa maneira, justifica algumas das soluções adotadas como: fechamento em chapa cega do portão de acesso principal e inclusão do gradil em meia altura.
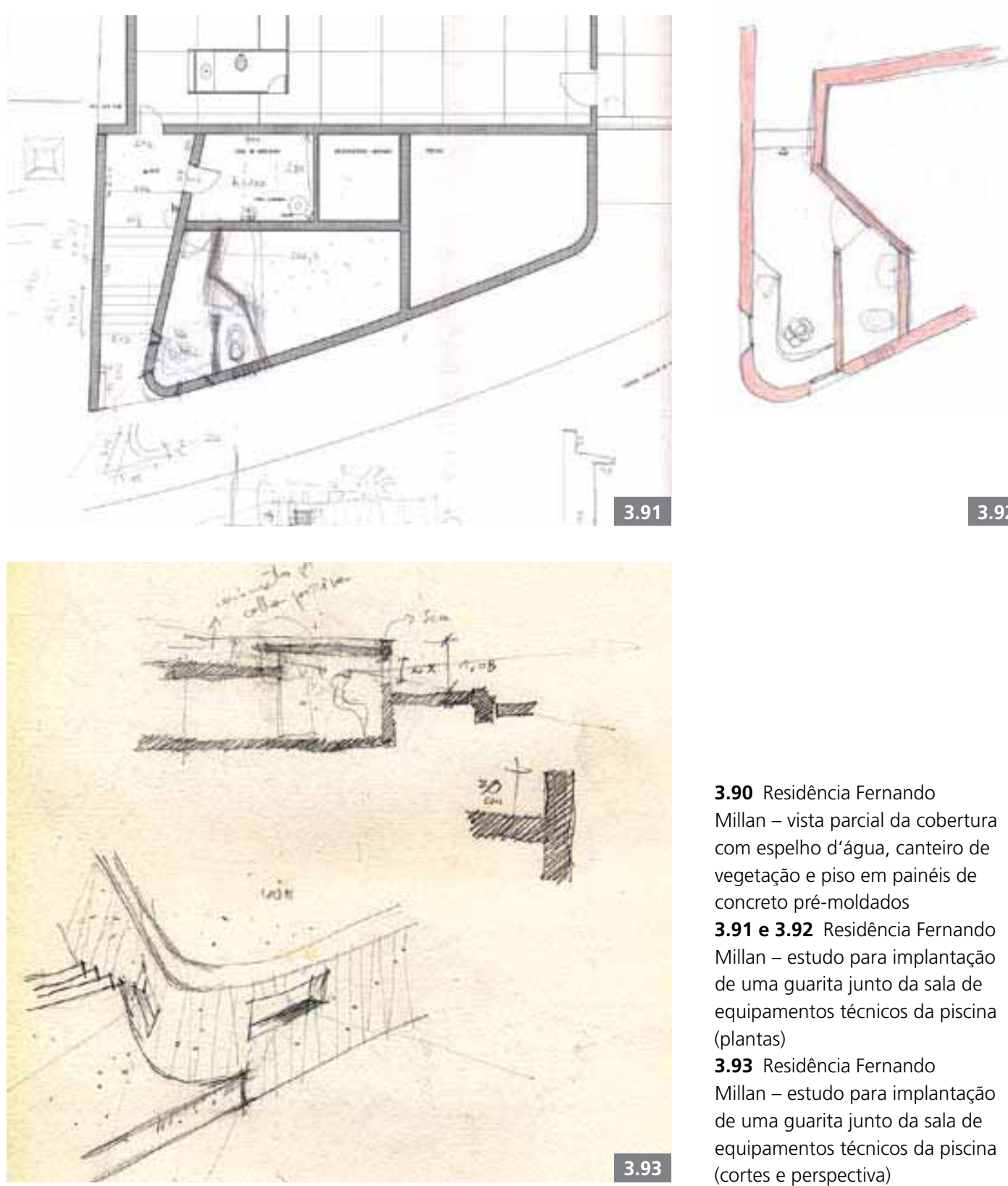

3.90 Residência Fernando

Millan - vista parcial da cobertura com espelho d'água, canteiro de vegetação e piso em painéis de concreto pré-moldados

3.91 e 3.92 Residência Fernando Millan - estudo para implantação de uma guarita junto da sala de equipamentos técnicos da piscina (plantas)

3.93 Residência Fernando

Millan - estudo para implantação de uma guarita junto da sala de equipamentos técnicos da piscina (cortes e perspectiva) 
NOTAS - CAPÍTULO 3

1 Tradução nossa. "Creio que existe uma regra de ouro para restauração: não alterar o comportamento físico do edificio: manter suas regras, respeitar seus princípios e nunca se deixar levar pela ideia de novas soluções ou técnicas, que possam sobrepor esse princípio."

2 Alguns aspectos na formação de Peter Zumthor, como o fato de pertencer a uma família de carpinteiros, ter começado os estudos na Kunstgewerbeschule Basel em 1963 e, em 1966, se transferir para o Pratt Institute em Nova York para estudar arquitetura e design, auxiliaram-nos na compreensão de sua obra, assim como o fato de ter trabalhado como arquiteto, entre de 1968 a 1978,

no Departamento de Manutenção e Preservação de Monumentos do Cantão de Graubüngen, na Suíça.

3 Ver Abrigo para Ruínas

Arqueológicas Romanas

(CHUR, SUIÇA), Corredor de

Conexão Museu de Arte de Chur

(CHUR, SUIÇA), Casa Gugalum

(GRAUBÜNDEN, SUIÇA), Renovação

Urbana de MEELFABRIEK (LEIDEN,

HOLANDA), Museu de Arte de

Kolumba (COLONIA, ALEMANHA.

Ver: ARQUITETURE AND URBANISM.

Peter Zumthor. Tokio: a+u Publishing,

Extra Edition , fev/1998.

4 Angelo Bucci não é mais

integrante do escritório MMBB
Arquitetos desde 2003, atualmente dirige o escritório SPBR Arquitetos.

5 Existe uma discrepância entre a precisão datas de projeto e obra nas informações contidas no site do escritório SPBR, nas datas das pranchas e no depoimento do arquiteto. Como Bucci relatou o processo de procura de um imóvel para o irmão começou no final do ano de 1994, entre essa data e o ano de 1996, o casal adquire o imóvel, pois nas pranchas do projeto consta a data de dezembro de 1996, o que reforça a ideia de que a obra deve ter sido iniciada no ano seguinte, 1997. Concluímos então, que as datas informadas no site estão erradas Projeto de Reforma: 1997; Obra: 1998. 6 Informação fornecida por Bucc em entrevista realizada pelo autor em 02/09/2011.

7 Teoria que se refere à Cesare Brandi, também chamada Teoria da Restauração. Alguns de seus princípios e sua influência na Carta de Veneza foram abordados no presente trabalho no item Preservação e intervenção: os critérios teórico-metodológicos, p. 42 8 O grifo tem a intenção de ressaltar a dedicação e cuidado do arquiteto, provavelmente ja sabendo, por experiência prévia, que surgiriam muitas questões no dia a dia da obra.

9 Informação fornecida por Paulo Mendes da Rocha em entrevista realizada pelo autor em 26/09/2011.

10 Informação fornecida por

Eduardo Colonelli em entrevista realizada pelo autor em 20/09/2011. Essa entrevista encontra-se

disponível na íntegra nos Anexos do presente trabalho, p. 217

11 Tradução nossa. "Na verdade, em restauração não valem dogmas e tudo isso deve ser entendido como generalidade: 0 edificio comanda muito e cada obra é um caso excepcional."

12 Para aferir os itens que constam nesse referido documento, ver: Relatório Preliminar de Serviços -

R.2, elaborado pelo Escritório Paulistano de Arquitetura em: 12/05/2010, que se encontra, em versão reduzida, nos Anexos, p. 216

13 O escritório Bela Vista Arquitetos eve como equipe de colaboradores neste projeto os seguintes integrantes: Apoena Amaral, Carlos Ferrata, Eduardo Ferroni, Pablo Hereñu e Moracy Almeida, que participaram ativamente desde a elaboração do projeto em todas as suas etapas, acompanhamento de obra e desenvolvimento e adaptação do detalhamento.

14 Trecho retirado da entrevista ealizada em 19/02/1999 na sede da Cenpla com o engenheiro Osmar Penteado de Souza e Silva (1928-2008) e é parte integrante dos Anexos do referido trabalho. Ver: KOURY, Ana Paula. Grupo
Arquitetura Nova. São Carlos: EESCUSP, 1999. Dissertação (Mestrado) Escola de Engenharia de São Carlos USP, São Paulo, p. 220-239.

15 Informação fornecida por Paulo Mendes da Rocha em entrevista realizada pelo autor em 26/09/2011

16 Essa informação também pode

ser confirmada ao estudarmos o jogo completo de desenhos originais, cuja folha de número 3A, com a descrição "planta do térreo - alternativa 2" já contém um estudo da mudança da

cozinha para a nova posição.

17 Sobre este tema ver item A presença dos arquitetos autores, vínculos e fatores externos, do presente trabalho, p. 33.

18 A distinguibilidade é um dos princípios da Teoria da Restauração

de Cesare Brandi, que aponta:

"(...) a integração deverá ser sempre facilmente reconhecive (...)" BRANDI, Cesare. Teoria da restauração. Tradução: Beatriz Mugayar Kühl. Cotia: Ateliê Editorial 2004. (Artes e Ofícios, 5), p. 47 19 Sobre esse termo, Kühl comenta que Brandi desenvolveu, para a restauração de pinturas, um método de integração de lacunas "com linhas verticais feitas com aquarela descritas inicialmente como 'filamentos' (1945), e em texto de 1946 assumiria a denominação atual", ver: KÜHL, Beatriz Mugayar. Cesare Brandi e a teoria da restauração. Pós - Revista do programa de pós-graduação em Arquitetura e Urbanismo da FAU-USPI Universidade de São Paulo. São Paulo, n. 21, junho 2007, p. 201 20 Tradução nossa. "Atualmente, a casa foi reformada e se alteraram os tons da cor de seu interior, que são agora mais vivos do que a versão original."

21 Vale a pena ressaltar que, no livro de Marlene Acayaba - Residências em São Paulo, referência inconteste no que tange à pesquisa e informações de diversas casas da arquitetura moderna e cujos redesenhos minuciosos são referências até os dias atuais, na ficha técnica consta apenas a seguinte informação: "Arquitetos dirigiram mestre Agostinho Mallart." ACAYABA, Marlene. Residências em SP. São Paulo: Projeto, 1986, p. 89-94 22 Essa ideia do caráter didático relacionado à reconstrução também é abordada por Oksman: "A reconstrução pode ter um caráter didático, mas não é considerada uma ação de preservação (...) não significa que não tenha um valor

do ponto de vista da comunicação (...) [um edifício] carregado de valores que se julgam importantes de serem transmitidos." OKSMAN Silvio. Preservação do patrimônio arquitetônico moderno - A FAU de Vilanova Artigas. São Paulo: FAUUSP, 2011. Dissertação (Mestrado)

- Faculdade de Arquitetura de Urbanismo/USP, São Paulo, p. 51 
23 "Restaurar um edifício não e mantê-lo, repará-lo ou refazê-lo é restabelecê-lo em um estado completo que pode não ter existido nunca em um dado momento."

VIOLLET-LE-DUC, Eugène Emmanuel. Restauração. Apresentação e tradução Beatriz Mugayar Kühl. 3. ed. Cotia: Ateliê Editorial,

2006, p. 29

24 Tradução nossa. "Reparar é repor Devolver ao elemento danificado, lesionado ou degradado, sua capacidade funcional, fazendo com que suas características mecânicas (no caso de uma estrutura portante) voltem a ser as que foram (ou

deveriam ter sido), em seu primeiro momento de existência."

25 Que se refere à Viollet-le-Duc (1814-1879). Podemos citar um de seus princípios absolutos:

“(...) restaurar não é apenas uma conservação da matéria, mas de um espírito da qual ela é suporte."

VIOLLET-LE-DUC, Eugène Emmanuel. Restauração. Apresentação e tradução Beatriz Mugayar Kühl. 3. ed. Cotia: Ateliê Editorial, 2006, p. 23. 26 A listagem apresentada refere-se apenas aos temas mais importantes. Para uma aproximação mais pormenorizada, ver: Relatório Preliminar de Serviços - R.2 elaborado pelo Escritório Paulistano de Arquitetura em: 12/05/2010, que se encontra, em versão reduzida, nos Anexos, p. 216
27 Ao tratar do assunto do "reparo" do concreto, certamente indagaremos sobre como proceder e se, neste caso, um tipo de "anastilose" poderia ser uma alternativa: "recomposição de partes faltantes, mas desmembradas" cujos "elementos de integração deverão ser sempre reconhecíveis e reduzir-se ao mínimo necessário para assegurar as condições de conservação do monumento e restabelecer a continuidade de suas formas." CURY, Isabelle (org.). Cartas patrimoniais. 2. ed. revista aumentada. Rio de Janeiro: IPHAN 2000. (Edições do patrimônio), p. 95.

28 Sobre esse assunto ver item A Carta de Veneza e suas bases teóricas, do presente trabalho, p. 44. 29 Projeto residência Bento Odilon Moreira - 1963, seus desenhos encontram-se disponibilizados no acervo do arquiteto.

30 Essa postura de substituição das peças originais foi discutida no item As especificidades da preservação da arquitetura moderna, do presente trabalho, p. 35.

11 Os benefícios e contradições decorrentes da presença do próprio autor na intervenção foram abordados no item $A$ presença dos arquitetos autores, vínculos efatores externos, do presente trabalho, p. 33.

2 Verbete definido no dicionário Aulete: "2.Móvel com hastes ou ganchos em que se penduram roupas e chapéus: CABIDEIRO: OMBREIRA (NE) 3.Suporte com hastes que se prega à parede ou atrás de porta, us. para esse mesmo fim" Disponível em: http://aulete.uol.com.br/ cabide\#ixzz2JWMOtzTA. Acesso em: 31/01/2013. Nos desenhos do projeto executivo encontra-se indicado o seu sinônimo: arara.

33 Dorma é a marca de um

fabricante de sistemas de fixação para vidros. Neste caso específico,

utilizou-se um sistema em peças de Alumínio fundido (linha SM), que tem como característica a menor interferência nos panos de vidro. Disponivel em: <http://www dorma. com.br>. Acesso em: 03/02/2013.

34 A reversibilidade é um dos princípios da Teoria da Restauração de Cesare Brandi, que aponta: “(...) prescreve que qualquer intervenção de restauro não torne impossivel, mas, antes, facilite as eventuais intervenções futuras." BRANDI, Cesare. Teoria da restauração. Tradução: Beatriz Mugayar Kühl. Cotia: Ateliê Editorial, 2004. (Artes e Ofícios, 5), p. 48. Esse princípio também é conhecido como retrabalhabilidade, ver: OKSMAN Silvio. Preservação do patrimônio arquitetônico moderno - A FAU de Vilanova Artigas. São Paulo: FAUUSP, 2011. Dissertação (Mestrado) Faculdade de Arquitetura de Urbanismo/USP, São Paulo, p. 58
35 "Máquina portatil provida de colheres de aço instaladas em

braços radiais que giram em torno de um eixo vertical, utilizada para alisar, compactar e dar acabamento a uma superfície de concreto fresco." CHING, Francis D. K. Dicionário visual de arquitetura. Tradução: Julio Fischer. 2. ed. São Paulo: Editora

WMF Martins Fontes, 2010, p. 57 36 Limpeza realizada com

equipamentos que utilizam bombas de alta pressão e cujos jatos d'água são direcionados em determinadas superfícies sem danificá-las. 37 Produto com características químicas que impedem a permanência e acumulação de água nas superfícies em que forem aplicadas. "A hidrofugação tem por objectivo proteger preventivamente as fachadas expostas aos agentes meteorológicos, contra a humidade e contra os danos provocados pela humidade em estruturas arquitectónicas. A impregnação hidrofugante é um tratamento incolor da substância construtiva, sem formação de película, que impede a absorção de água dos seus solutos poluentes por capilaridade, sem obstruir os capilares, pelo que preserva as condições de respirabilidade do substrato." Disponível em: <http://www.wacker. com/cms/media/publications/ downloads/6187 PT.pdf $>$. Acesso em: 06/02/2013. 


\section{CONSIDERAÇÕES FINAIS}

Pretendeu-se, no presente trabalho, discutir temas relevantes para o enfrentamento da questão do conhecimento do patrimônio arquitetônico moderno e de sua preservação. Através dos estudos de caso, procurou-se, de alguma maneira, exemplificar algumas situações referentes a esse enfrentamento, mais do que afirmar que foram procedimentos exitosos em todos os seus aspectos.

Sobretudo, gostaríamos de reforçar a necessidade de aproximação e de conhecimento profundo do objeto a ser trabalhado, a fim de que ele mesmo nos guie através de sua materialidade e nos auxilie nas interpretações dos resultados obtidos, para que possamos "juntos" melhorar o próprio projeto, ou seja, o próprio fazer arquitetônico ${ }^{1}$ associado aos edifícios preexistentes. Como assinala Galino:

"En la base de la restauración deberá pues existir un profundo conocimiento, no solo de la técnica con que se construyó la obra a la restaurar, sino de las leyes arquitectónicas, muchas veces no es- critas, aunque casi siempre construidas y legibles en los edificios coetaneos. ${ }^{\prime 2}$ (GALINO:SANZ, 2005, p. 6)

Moreira, por sua vez, sintetiza essa dificuldade de enfrentamento da intervenção em arquiteturas recentes: "Na conservação da arquitetura moderna é preciso encontrar um equilíbrio entre a autenticidade do espaço e o respeito pela autenticidade material." (MOREIRA, 2010, p. 19)

Especificamente em relação à estruturação do nosso trabalho, cada capítulo teve a premissa de enriquecer essa discussão, mas sempre tendo como foco o rebatimento no projeto. Mais do que classificar cada intervenção analisada quanto ao seu êxito - ou mesmo se chegaram ou não a atingir o patamar de serem consideradas manutenção, conservação ou restauro -, nossa intenção foi a de evidenciar alguns pontos que nos parecem importantes no referido enfrentamento.

Ainda em relação à nossa pesquisa, gostaríamos de salientar que, apesar desta abarcar a "arquitetura moderna" - [as notas referentes às Consideraçôes finais encontram-se na p. 119] 
e em especial a "escola paulista" -, reconhecemos que dentro dessa alcunha ("arquitetura moderna"), em todo território nacional figura uma imensa diversidade de arquitetos cuja produção é bastante extensa e variada, e que, ainda - mesmo a produzida em São Paulo -, teve representantes cujos caminhos divergiram dos exemplos abordados. Podemos citar como exemplo: Miguel Forte, Oswaldo Bratke e Rino Levi. Acreditamos, no entanto, que muitas das nossas abordagens, aproximações e discussões poderão servir para guiar quaisquer outros estudos que tenham como interesse a preservação do patrimônio arquitetônico produzido nesse período.

Podemos, assim, afirmar que os nossos estudos - em que pesem as suas limitações - não se invalidam de maneira nenhuma. Ao contrário: acreditamos que esta nossa pequena produção deva ser somada às já existentes, auxiliando, conjuntamente, no reconhecimento e na preservação da arquitetura moderna brasileira.

Destacamos que esse reconhecimento da arquitetura moderna como patrimônio, tal qual pudemos perceber, dá-se por diversos caminhos - desde o tombamento nos órgãos de preservação, em pesquisas nas instituições de ensino e, até mesmo, no âmbito particular de seus proprietários que consideramos legítimos e válidos. Salientamos, ainda, a importância da historiografia como ferramenta na consolidação não só da imagem, mas do próprio conceito de bem patrimonial. Como exemplo dessa postura de reconhecimento, independente de seu tombamento, podemos citar a intervenção da residência Luis Magalhães Gouveia - projeto original de Carlos Lemos e Eduardo Corona de 1961 - que foi recentemente reformada pelos arquitetos Carlos Leite e Fabiana Stuchi. Em seu depoimento Leite 3 assinala: “Mesmo não sendo tombado, não sendo obrigado a fazer nada disso, mas achei que era de bom tom um pouco de cuidado, de carinho com aquela arquitetura moderna, icônica aqui de São Paulo."

Apenas como nota: durante a pesquisa, ao consultar a historiografia, fazer as entrevistas, estudar os projetos originais e os de intervenção, o processo, ao contrário do que se imaginava, teve um resultado inesperado: uma espécie de desmistificação do "modelo moderno" aprendido na graduação, o que possibilitou uma nova forma de olhar o objeto arquitetônico - com mais acuidade, respeito e buscando superar a mera impressão exógena - assim como a reavaliação dos valores e premissas para o seu reconhecimento.

Vale ressaltar também que, no desenvolvimento do trabalho, ficou mais clara a importância do recorte da pesquisa em intervenções de residências do período, devido não só à pequena quantidade de exemplares tombados - com exceção das residências dos próprios arquitetos -, mas, também, por ser um programa de difícil abordagem, como foi discutido no capítulo Arquitetura moderna e os órgãos de patrimônio: o caso paulista e, ainda, pelas "questões afetivas" envolvidas, como explicita Paulo Mendes da Rocha em seu depoimento:

"A situação toda é comandada por razões de uma lógica muito mais ligada à compreensão do andamento da vida e das situações, ligada muito mais a um plano afetivo do que a qualquer ques- 
tão teórica ou mesmo técnica da Arquitetura. Se é que a questão afetiva não faz parte de tudo isso. Vai ver nós podíamos descobrir uma coisa que sempre foi assim. Principalmente em uma casa." (PAUlO MENDES DA ROCHA, São Paulo, 26/09/2011)

Ao lidarmos com a intervenção propriamente dita, reconhecemos que ações localizadas podem ser positivas desde que estejam baseadas em certos princípios operativos, como os contidos na Carta de Veneza e na Teoria da Restauração de Brandi, com especial destaque para três princípios básicos: distinguibilidade, reversibilidade e mínima intervenção; ou mesmo nas suas dissidências, como os explicitados por nós no item Desdobramentos teóricos na atualidade, onde ressaltamos a importância dos critérios metodológicos para a compreensão do restauro e do seu próprio campo disciplinar. Todavia, embora possam existir muitas soluções para cada um dos problemas apontados, estes devem ser examinados com cuidado, caso a caso, através de critérios e métodos, como afirma o "restauro crítico".

O restauro das obras modernas como campo disciplinar autônomo enfrentará diversas questões, ora de âmbito geral, ora de âmbito específico. Tema extenso e complexo, como apresentamos no capítulo As especificidades da preservação da arquitetura moderna, certamente apresentará um novo desafio para a disciplina, como aponta Salvo:

"A restauração das obras contemporâneas representa, portanto, uma espécie de desafio para a disciplina e, talvez, para a cultura da memória em seu conjunto, pois implica o reconhecimento em tempo real do próprio presente, de seus valores e de sua capacidade testemunhal na vida do homem e também a modulação e adaptação de teorias e métodos a expressões figurativas e suportes materiais rebeldes, sem precedentes na história da arquitetura, além de um enfrentamento no campo aplicativo, algo que o mundo do restauro ainda não experimentou." (SALVO, 2008, p. 210)

Nesse sentido, gostaríamos de citar Montaner, que indica a transformação endógena como um caminho possível para a preservação do patrimônio:

"Los clásicos defensores del patrimônio solo se fijan en los edificios históricos y, a lo sumo, también les interesa la arquitectura del hierro y la arquitectura industrial. Pero en estos momentos, tal como define el Docomomo, la arquitectura moderna emblemática e incluso la más reciente, forman parte de un patrimonio arquitetónico que debe ser conservado y sobre el que debe dedicarse una labor de mantenimiento. Se trata de unos edificios que para prolongar su vitalidad deben crecer, transformarse y cambiar de usos al mismo tiempo que se mantienen sus características formales. "4 (MONTANER, 2009, p. 46)

Em relação às análises das três residências - que se constituíram como estudos de caso -, gostaríamos de salientar a importância de iniciarmos, como aproximação metodológica, com o estudo pormenorizado dos desenhos - tanto do projeto original como dos projetos de intervenção -, culminando nos diagramas tridimensionais apresentados. Essa ideia de análises diagramática da arquitetura tem sido ex- 
plorada desde o século XIX e foi utilizada em projetos da arquitetura moderna, por Geofrey Baker, que se dedicou com especial atenção às obras de Alvar Aalto, Richard Meier e Le Corbusier ${ }^{5}$.

Essa predileção pelo "sentido da visão - e em especial à perspectiva - foi discutida por Pallasma, que buscou suas origens históricas e filosóficas ao assinalar:

"Na cultura ocidental, a visão tem sido historicamente considerada o mais nobre dos sentidos, e o próprio pensamento é igualado à visão (...) durante a Renascença, considerava-se que os cinco sentidos formavam um sistema hierárquico no qual a visão está no topo, e o tato, na base (...) a invenção da representação em perspectiva tornou os olhos o ponto central do mundo perceptual (...) a representação em perspectiva em si própria se tornou uma forma simbólica, que não apenas descreve, mas também condiciona a percepção." (PALLASMA, 2011, p. 15-16)

A decomposição em diversos diagramas buscou sintetizar uma leitura sistematizada da obra original e dos resultados das intervenções realizadas, como se pudéssemos capturar e traduzir, novamente em imagem, o próprio processo do "fazer arquitetônico", ou seja, o processo de projeto, cuja dificuldade de "descrição de sua natureza e a compreensão de sua relevância na maneira de projetar" já havia sido explanado por Katakura, que acrescenta:

"A qualidade dos espaços e volumes é resultado dessa reflexão racional, de ideias amadurecidas e criativamente iluminadas. A intuição no processo de invenção diferencia-se da inspiração por exigir esse preparo anterior. Antes que o projeto se revel por completo, há um trabalho árduo que só a lógica organiza. Esse trabalho capacita-nos e sensibiliza-nos à descoberta. Embora não existam fórmulas secretas ou técnicas que assegurem bons projetos, sua qualidade pode ser encontrada no processo que o conduz." (KATAKURA, 1997, p. 35)

Sobre os resultados obtidos das três casas analisadas, uma vez que seu detalhamento já está à disposição nos respectivos capítulos, iremos elencar um tópico chave para cada uma delas, cujo enfoque demonstre a postura adotada na intervenção e que, em comparação com as demais, a defina individualmente.

Na residência Olga Baeta, a postura de intervenção de Bucci encontra-se entre a inovação arquitetônica - nata postura do enfrentamento de um novo projeto arquitetônico - e o restauro, que faz as transformações necessárias para preservar a edificação preexistente. Essa bipolaridade se dá, preliminarmente, pelo fato de se ter "reconstruído" a escora, em contraponto a uma série de ações projetuais que demonstram clara preocupação com pelo menos um dos princípios brandianos: a distinguibilidade. Apesar disso, nos colocamos frente a essa questão com duas possíveis hipóteses: a de um completamento "leduquiano" ou de uma postura radical, mas necessária, frente às questões colocadas pelo próprio patrimônio no momento de sua intervenção.

A linha entre essas duas hipóteses é tênue. Sobre o completamento, com certeza podemos afirmar que é uma ideia tentadoramente cativante para nós arquitetos, por vermos 
"o que a gente quer que seja" ou ainda ver "como se estivesse feito", como afirmou Bucci em seu depoimento. Contudo, é preciso ponderar que tal pensamento não é de fato inusitado, como podemos perceber ao nos debruçarmos sobre um fragmento dos diálogos entre Fedro e Sócrates, no livro Eupalinos ou $O$ arquiteto, que contém esse mesmo raciocínio, como expressa Paul Valéry:

"Nada nos seduz, nada nos atrai; nada desperta nosso ouvido, e nada cativa nosso olhar; nada por nós é escolhido na profusão das coisas, e nada pode abalar a nossa alma, que não esteja, de algum modo, ou preexistindo em nosso ser, ou secretamente sendo almejado pela nossa natureza. Tudo quanto vimos a ser, mesmo por breve tempo, já estava preparado." (VALÉRY, 2006, p. 101)

Essa mesma ideia foi expressa recentemente por Zumthor: "Há uma bela expressão antiga: as coisas encontraram-se, estão em si. Porque são, o que querem ser." (ZUMTHOR, 2009, p.69)

Já na residência Mário Masetti, identificamos uma postura conservativa, mas não na sua totalidade; ou seja: apesar de, neste caso, as ações de intervenção demonstrarem clara preocupação também com a distinguibilidade e a mínima intervenção no tratamento das patologias do concreto, ao lidar com os vários componentes de fechamento originais essas premissas não foram respeitadas, uma vez que tais elementos foram substituídos inadvertidamente, sem nenhum tipo de consideração a possíveis alternativas a essa solução. Apesar disso, por se tratar de elementos "secundários" em relação ao partido, não é algo que se nota à primeira vista.
Quanto a residência Fernando Millan, a postura de plena transformação é efetivada pelo próprio autor do projeto original - sendo esse dado já bastante singular. Apesar dessa situação (a presença do próprio autor nas intervenções em bens patrimoniais recentes) ser bastante discutida, neste caso ela também é modificadora dos espaços, embora não parta de uma nova premissa, mas sim do prosseguimento de um raciocínio curiosamente iniciado ao término do processo de obra.

Contudo, as intervenções perpetradas demonstram a consciência de alguns dos princípios de restauro, com especial atenção à distinguibilidade e à reversibilidade, principalmente ao inserir novos elementos ao léxico arquitetônico existente. Neste caso, porém, também houve substituições significativas de componentes de fechamentos, resultando na perda da "matéria original".

Para concluir, gostaríamos de conduzir a discussão para o campo do reconhecimento do patrimônio cultural enquanto obra construída, do reconhecimento de sua memória e de sua transformação como recurso de preservação. Todas as estratégias apresentadas configuram um arcabouço referencial importantíssimo para a arquitetura contemporânea associada ao enfrentamento de questões ligadas à preservação do bem cultural, em especial à arquitetura moderna paulistana. Porém, ao invés de respostas, incluímos mais algumas indagações: Seria correto afirmar que a própria estratégia de projeto e a compreensão das qualidades arquitetônicas intrínsecas ao bem edificado poderiam ser consideradas como patrimônio imaterial? ${ }^{6}$ 
Ou seria esse um pensando herdeiro direto das origens do tombamento de exemplares da arquitetura moderna ${ }^{7}$, cujo reconhecimento de sua importância como bem cultural é colocado como um dado a priori?

Por considerarmos digna de nota, gostaríamos de apontar uma informação que, se não curiosa, certamente deve ser considerada em discussões futuras: das três casas que foram objeto de estudo, apenas a residência Olga Baeta teve seu projeto amplamente publicado, seja diretamente associado à produção geral do arquiteto Angelo Buccis ${ }^{8}$, seja em recente publicação da obra de Vilanova Artigas9. Contudo, nenhuma revista de arquitetura de cunho teórico ou projetual publicou o projeto ou obra de intervenção através do foco do restauro. Por sua vez, duas delas $\left(\right.$ Baeta $^{10} \mathrm{e}$ Masetti ${ }^{11}$ ) figuraram em revistas de cunho decorativo, cujo tema da arquitetura é muitas vezes visto como apenas um coadjuvante. Curiosamente não foi esse o caso da residência Olga Baeta, que teve até o seu processo de obra documentado pelo fotógrafo Dario de Freitas, para uma matéria especial descrevendo a sua transformação após quatro décadas. Por fim, a residência Fernando Millan, que não foi publicada em nenhuma mídia, figurou, recentemente, como objeto de ensaio fotográfico realizado por Leonardo Finotti ${ }^{12}$, que tem registrado um grande número de obras do arquiteto Paulo Mendes da Rocha.

Alguns leitores atentos, possivelmente, poderão afirmar que muitas das perguntas elaboradas inicialmente não foram respondidas a contento. Quanto a isso, queremos deixar aqui registrado que não era nossa intenção fazer de nossos estudos exemplos a serem seguidos, mas sim buscar, através de nossas análises, possíveis caminhos para o enfrentamento da questão do conhecimento do patrimônio arquitetônico moderno e de sua preservação. E, sobretudo, com um olhar voltado também para os que "apenas projetam", utilizar esses exemplos práticos, que foram executados dentro do dia a dia de cada um dos escritórios, no intuito de cativar novos adeptos para essa disciplina tão rica e peculiar que é o restauro arquitetônico.

Se não como restauradores, esperamos que como plenos arquitetos possam, através da mudança do olhar, encontrar pistas e caminhos que os guiem para soluções passíveis de resgatar as qualidades - muitas vezes ocultas - dos edifícios em que estiverem trabalhando; e, ainda, que compreendam, de coração, a importância dos bens culturais e sua preexistência.

Para encerrar, nos apoiamos novamente em Boito:

"Para bem restaurar é necessário amar e entender o monumento, seja estátua, quadro ou edifício, sobre o qual se trabalha (...) que séculos souberam amar e entender as belezas do passado? E, nós. hoje, em que medida sabemos amá-las e entendê-las?" (вогто, 2003, p. 31) 
NOTAS

1 Essa ideia do "fazer arquitetônico" é discutida por Paula Katakura em sua dissertação de mestrado, que faz uma observação quanto à expressão: "el que hacer arquitetônico", utilizada entre arquitetos latino-americanos, ver: KATAKURA, Paula. O processo do projeto arquitetônico. São Paulo: FAUUSP, 1997. Dissertação (Mestrado)

Faculdade de Arquitetura de

Urbanismo/USP, São Paulo.

2 Tradução nossa. "Na base de uma restauração deverá existir um profundo conhecimento, não só da técnica com que se construiu a obra a ser restaurada, mas das leis arquitetônicas, muitas vezes não escritas, ainda que quase sempre construídas e legíveis nos edificios coetâneos."

3 Informação fornecida por Carlos Leite em entrevista realizada pelo autor em 23/09/2011. Essa entrevista encontra-se disponível na íntegra nos Anexos do presente trabalho, p. 195

4 Tradução nossa. "Os clássicos

defensores do patrimônio

arquitetônico só se fixam nos edifícios históricos [anteriores ao século XX] e na melhor das hipóteses, também Ihes interessa a arquitetura do ferro e a arquitetura industrial. Mas nestes momentos, tal como defende o Docomomo, a arquitetura moderna emblemática, inclusive a mais recente, fazem parte de um patrimônio arquitetônico que deve ser conservado e é a ele que se deve dedicar um trabalho de conservação. Trata-se de edifícios que para prolongar a sua vitalidade devem crescer transformar-se mudar de usos ao mesmo tempo em que mantêm suas características formais." MONTANER, Josep Maria. Intervenciones em la arquitectura Moderna. Paradojas tecnológicas, funcionales y simbólicas: fragilidad, precisión funcional e innovación. In: COMAS, Carlos Eduardo Dias; PEIXOTO, Marta; MARQUES, Sergio M. (org.). O Moderno já passado, o passado no moderno: reciclagem, requalificação, rearquitetura. Porto Alegre: Editora UniRitter, 2009 (Cadernos de Arquitetura, Ritter dos Reis, v. 6), p. 45-46.

5 Ver: BAKER, Geoffrey H. Le

Corbusier: uma análise da forma. Tradução: Alvamar Helena Lamparelli.

São Paulo: Martins Fontes, 1998

6 Segundo informação que

consta no site do IPHAN, a Unesco define como Patrimônio Cultural

Imaterial "as práticas, representações, expressões, conhecimentos e técnicas - junto com os instrumentos, objetos, artefatos e lugares culturais que Ihes são associados - que as comunidades, os grupos e, em alguns casos, os indivíduos reconhecem como parte integrante de seu patrimônio cultural." O Patrimônio Imaterial transmitido de geração em geração e constantemente recriado pelas comunidades e grupos em função de seu ambiente, de sua interação com a natureza e de sua história, gerando um sentimento de identidade $e$ continuidade, contribuindo assim para promover o respeito à diversidade cultural e à criatividade humana.

Disponível em: <http://portal.jphan. gov.br/portal/montarPaginaSecao.d o? id=10852\&retorno=paginalphan $>$ Acesso em: 31/01/2013.

7 Sobre esse assunto, ver: OKSMAN Silvio. Preservação do patrimônio arquitetônico moderno - A FAU de Vilanova Artigas. São Paulo: FAUUSP, 2011. Dissertação (Mestrado) - Faculdade de Arquitetura de Urbanismo/USP, São Paulo, p. 62-65.

8 Ver: Reformada casa Olga Baeta.

Monolito, São Paulo, n. 1, p. 56-63, fevereiro/março 2011

9 Ver: CASA BAETA - 1956-1957. 2 G International Architecture Magazine, Barcelona, ano II, n. 54, p. 46-51, 2010. 10 Ver: TEIXEIRA, Cristiane e BAVA, Cristina. Dos anos 50 aos 90 Arquitetura \& Construção. São Paulo, 3, p. 28-37, mar/1998.

11 Ver: ROSSETTI, Beatrice. Propost concreta. Casa Vogue. São Paulo,

310, p. 144-153, jun/2011.

12 Disponível em: <http://

leonardofinotti.com/projects/filter/ architect/paulo-mendes-da-rocha> Acesso em: 23/09/2011. 



\section{REFERÊNCIAS BIBLIOGRÁFICAS}

AB'SABer, Aziz Nacib. O sítio urbano inicial da aglomeração paulistana. In: Acrópole, São Paulo, ano xxv, n. 295/6, jun. 1963. Edição comemorativa do $25^{\circ}$ aniversário.

ACAYABA, Marlene. Brutalismo caboclo, as residências paulistas. In: Projeto, n. 73, mar. 1985, p. 46-48.

Reflexões sobre o brutalismo caboclo. In: Projeto, São Paulo, n. 86, abr. 1986, p. 68-70.

. Residências em SP. São Paulo: Projeto, 1986.

ANDREOLI, Elisabetta e FORTY, Adrian. Arquitetura moderna brasileira. Londres: Phaidon, 2004.

ANTINUCCI, Paolo. Introduzione. In: BRANDI, Cesare. In Situ. Viterbo: Sette Città, 1966. Apud KÜHL, Beatriz Mugayar. A restauração como campo disciplinar autônomo. Anais do Museu Histórico Nacional. Rio de Janeiro, v. 40, 2008a.

AQUINO, Paulo Mauro Mayer de (org.). Gregori Warchavchik - acervo fotográfico v. I e v. II. São Paulo, edição Família Warchavchik, 2005 e 2007.

ARAUJO, Ramón. La rehabilitación de la arquitectura moderna. In: Tectónica - monografias de arquitectura, tecnologia y construcción, Madri, ATC Ediciones, n. 33, setembro 2010, p. 4-21.
ARGAN, Giulio Carlo. Projeto e destino. São Paulo: Ática, 2004. (Série Temas, v. 71).

ARQUITETURE AND URBANISM. Peter Zumthor. Tokio: a+u Publishing, Extra Edition, fev. 1998.

ARTIGAS, João Batista Vilanova. Caminhos da arquitetura. 2. ed. São Paulo: Pini/Fundação Vilanova Artigas, 1986.

Depoimento. In: XAVIER, Alberto (org.). Depoimentos de uma geração - arquitetura moderna brasileira. Edição revista e ampliada. São Paulo: Cosac Naify, 2003, p. 217-226

ARTIGAS, Rosa (org.). Vilanova Artigas - arquitetos brasileiros. São Paulo: Instituto Lina Bo e P. M. Bardi/Fundação Vilanova Artigas, 1997.

BAKER, Geoffrey H. Le Corbusier: uma análise da forma. Tradução: Alvamar Helena Lamparelli. São Paulo: Martins Fontes, 1998.

BASILE, Gieseppe. Breve perfil de Cesare Brandi. Desígnio - Revista de História da Arquitetura e do Urbanismo/FAU-USP, São Paulo, Annablume, n. 6, p. 49-56, setembro 2006.

BAstos, Maria Alice Junqueira; ZeIN, Ruth Verde. Brasil - arquitetura após 1950. São Paulo: Perspectiva, 2010.

BOITO, Camillo. Os restauradores - conferência feita na Exposição de Turim em 7 de junho de 1884. Tradução: Beatriz Mugayar Kühl e 
Paulo Mugayar Kühl. 2. ed. Cotia: Ateliê Editorial, 2003. (Artes e Ofícios, 3).

Questioni pratiche delle belle arti. Milão: Hoepli, 1893

p. 15-24. apud KÜHL, Beatriz Mugayar. A restauração como campo disciplinar autônomo. Anais do Museu Histórico Nacional. Rio de Janeiro, v. 40, 2008, p. 354-353.

вотеY, Josep Maria. Oscar Niemeyer. Barcelona: Editorial Gustavo Gili, 1996.

BRANDI, Cesare. Teoria da restauração. Tradução: Beatriz Mugayar Kühl. Cotia: Ateliê Editorial, 2004. (Artes e Ofícios, 5).

BRASIL. DEPARTAMENTO NACIONAL DE ESTRADAS DE RODAGEM. Manual de inspeção de obras-de-arte especiais. 1994.

BRUAND, Yves. Arquitetura contemporânea no Brasil. 4. ed. Tradução: Ana M. Goldberger. São Paulo: Perspectiva, 2008

BRUNA, Paulo. Os primeiros arquitetos modernos - habitação social no Brasil 1930-1950. São Paulo: Edusp - Editora da Universidade de São Paulo, 2010

Buchanan, Peter. Renzo Piano Building Workshop. Londres, Nova York: Phaidon Press, v. 1, 2005.

CAMARGO, Mônica Junqueira. Residências modernas: patrimônio ameaçado. Porto Alegre: Universidade Federal do Rio Grande do Sul 2007. (Seminário Docomomo Brasil, 7º, 22 a 24 outubro 2007 Porto Alegre).

CARBONARA, Giovanni. Brandi e a restauração arquitetônica hoje. Tradução: Beatriz Mugayar Kühl. Desígnio - Revista de História da Arquitetura e do Urbanismo/FAU-USP, São Paulo, Annablume, n. 6, p. 35-47, setembro 2006.

CASA BAETA - 1956-1957. 2 G International Architecture Magazine, Barcelona, ano II, n. 54, p. 46-51, 2010.

CHING, Francis D. K. Dicionário visual de arquitetura. Tradução: Julio Fischer. 2. ed. São Paulo: Editora WMF Martins Fontes, 2010.
CHOAY, Françoise. A alegoria do patrimônio. Tradução: Luciano Vieira Machado. São Paulo: Estação Liberdade e Unesp, 2001.

CLÍNICA de odontologia. ELARQA, Montevidéu: Dos Puntos, n. 39 p. $50-53$, set/2001.

COMAS, Carlos Eduardo Dias; SANTos, Cecília Rodrigues dos; ZEIN Ruth Verde. Autoridades, emendas, paradoxos e peculiaridades da preservação do patrimônio arquitetônico moderno. Salvador: Faculdade de Arquitetura da Universidade Federal da Bahia, 2008. (Seminário Dосомомо Brasil N-Ne, 2º, 04 a 07 junho 2008 , Salvador). Disponível em: <http://www.docomomobahia.org/ Comas_Santos_Zein.pdf> Acesso em: 26/02/2009.

CURTIS, William J. R. Arquitetura moderna desde 1900. Porto Alegre: Bookman, 2008.

CURY, Isabelle (org.). Cartas patrimoniais. 2. ed. revista e aumentada. Rio de Janeiro: IPHAN, 2000. (Edições do patrimônio).

CZAJKOWSKI, Jorge (org.). Jorge Machado Moreira. Rio de Janeiro: Centro de Arquitetura e Urbanismo do Rio de Janeiro, 1999.

DARLING, Elizabeth. Le Corbusier. Tradução: Luciano Machado. São Paulo: Cosac Naify, 2002.

DEDECCA, Paula Gorenstein. Sociabilidade, crítica e posição: o meio arquitetônico, as revistas especializadas e o debate do moderno em São Paulo (1945-1965). São Paulo: FAU-USP, 2012. Dissertação (Mestrado) Faculdade de Arquitetura de Urbanismo/USP, São Paulo.

FARAH, Ana Paula. Restauro arquitetônico: a formação do arquiteto-urbanista no Brasil para preservação do patrimônio edificado - o caso das escolas do Estado de São Paulo. São Paulo: FAU-USP, 2012. Tese (Doutorado) - Faculdade de Arquitetura de Urbanismo/UsP São Paulo.

FLEIG, Karl. Alvar Aalto. São Paulo: Martins Fontes, 1994.

FRAMPTOM, Kenneth. História critica da arquitetura moderna. Tradução: Jefferson Luiz Camargo. 2. ed. São Paulo: Martins Fontes, 2008. 
GONÇALVES, Cristiane Souza. Restauração arquitetônica: a experiência do SPHAN em São Paulo, 1937-1975. São Paulo: Annablume/ Fapesp, 2007.

GUERRA, Abilio. A moderna morada paulista. Resenhas online, São Paulo, 01.001, Vitruvius, jan $2002<\mathrm{http}$ //Www.vitruvius.com.

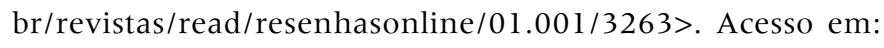
28/01/2013.

HERNÁNDEZ MARTíNEZ, Ascensión. La clonación arquitetctónica. Madri: Siruela, 2007. (La Biblioteca Azul - serie mínima, 16).

INVANOMото, Denise. Futuro do Pretérito: historiografia e preservação na obra de Gregori Warchavchik. São Paulo: FAU-USP, 2012. Dissertação (Mestrado) - Faculdade de Arquitetura de Urbanismo/ USP, São Paulo.

KAMITA, João Masao. A Casa moderna brasileira. In: ANDREOLI, Elisabetta; FORTY, Adrian. (org.) Arquitetura Moderna Brasileira. Londres: Phaidon, 2004, p. 142-169.

KATAKURA, Paula. O processo do projeto arquitetônico. São Paulo: FAU-USP, 1997. Dissertação (Mestrado) - Faculdade de Arquitetura de Urbanismo/UsP, São Paulo.

KOURY, Ana Paula. Grupo Arquitetura Nova. São Carlos: EESC-USP, 1999. Dissertação (Mestrado) - Escola de Engenharia de São Carlos/usp, São Paulo.

. Novas casas de morar 2: a contribuição da construtora CENPLA, p. 79-83, 2010. (Apresentação de Trabalho/Comunicação). Disponível em: <ftp://ftp.usjt.br/pub/revint/79_60.pdf>. Acesso em: 09/01/2013.

KÜHL, Beatriz Mugayar. A restauração como campo disciplinar autônomo. Anais do Museu Histórico Nacional. Rio de Janeiro, v. 40, p. 351-373, 2008a.

. Cesare Brandi e a teoria da restauração. Pós - Revista do programa de pós-graduação em Arquitetura e Urbanismo da FAU-USP/
Universidade de São Paulo. São Paulo, n. 21, p. 198-243, junho 2007.

. Notas sobre a Carta de Veneza. Anais do Museu Paulista, v. 18, p. 287-320, 2010. Disponível em: <http://www.scielo.br/pdf/ anaismp/v18n2/v18n2a08.pdf>. Acesso em: 08/02/2012.

. Preservação da arquitetura moderna e metodologia de restauro. Pós - Revista do programa de pós-graduação em Arquitetura e Urbanismo da FAU-USP/Universidade de São Paulo. São Paulo, n. 13, p. 198-210, junho 2003. Disponível em: <http:// www.usp.br/fau/public/pos/13/revistapos 13.pdf>. Acesso em: 11 janeiro de 2011.

. Preservação do patrimônio arquitetônico da industrialização - problemas teóricos de restauro. Cotia: Ateliê Editorial, 2008b.

. Quatremère de Quincy e os verbetes Restauração, Restaurar, Restituição e Ruína de sua Encyclopédie methodique. Architecture. Rotunda, Campinas, n. 2, agosto 2003, p. 100-117. Disponível em: <http://www.iar.unicamp.br/rotunda/>. Acesso em: 01 maio 2006.

. Restauração hoje: método, projeto e criatividade. Desígnio - Revista de História da Arquitetura e do Urbanismo/FAU-USP, São Paulo, Annablume, n. 6, p. 19-34, setembro 2006.

LE GOFF, Jacques. História e Memória. 3. ed. Campinas: Unicamp, 1994.

LEMos, Carlos Alberto Cerqueira. Arquitetura brasileira. São Paulo: Melhoramentos/Editora da Universidade de São Paulo, 1979.

. Casa paulista - história das moradias anteriores ao ecletismo trazido pelo café. São Paulo: Edusp - Editora da Universidade de São Paulo, 1999.

. História da casa brasilieria. São Paulo: Contexto, 1989.

MERRO JOHNSTON, Daniel. El autor y el interprete: Le Corbusier y Amancio Williams em la casa Curutchet. Buenos Aires: 1:100 Ediciones, 2011. 
MONTANER. Josep Maria. Intervenciones em la arquitectura moderna. paradojas tecnológicas, funcionales y simbólicas: fragilidad, precisión funcional e innovación. In: COMAs, Carlos Eduardo Dias; РЕIХOTо, Marta; MARQUES, Sergio M. (org.). O Moderno já passado, o passado no moderno: reciclagem, requalificacão, rearquitetura. Porto Alegre: Editora UniRitter, 2009. (Cadernos de Arquitetura, Rit ter dos Reis, v. 6).

MOREIRA, Fernando Diniz. Os desafios postos pela conservação da arquitetura moderna. In: SEGRE, Roberto (org.). Arquitetura+arte+cidade: um debate internacional. Rio de Janeiro: Viana \& Mosley, 2010. (Seminário росомомо Brasil, $8^{\circ}$, 1 a 4 de setembro de 2009, Rio de Janeiro).

OKSMAN, Silvio. Preservação do patrimônio arquitetônico moderno - A FAU de Vilanova Artigas. São Paulo: FAU-USP, 2011 . Dissertação (Mes trado) - Faculdade de Arquitetura de Urbanismo/UsP, São Paulo.

OLIVEIRA, Claudia T. da Andrade; PRESTES, Lucinda Ferreira; YURGEL, Marlene; BORTOLLI Jr., Oreste; ROSA, Alexandre Miranda de Almeida. O restauro do moderno: o caso do edifício Vilanova Artigas da FAU-USP. Porto Alegre: Universidade Federal do Rio Grande do Sul, 2007. (Seminário Dосомомо Brasil, $7^{\circ}, 22$ a 24 outubro 2007, Porto Alegre)

отоNDo, Catherine. Você sempre entra por uma porta e sai por outra - versão para o português do texto de Annette Spiro. Pós Revista do programa de pós-graduação em Arquitetura e Urbanismo da FAU-USP/Universidade de São Paulo. São Paulo, v. 16, n. 25 , p. 34-55, junho 2009.

PALLASMAA, Juhani. Os olhos da pele: a arquitetura e os sentido. Tradução: Alexandre Salvaterra. Porto Alegre: Bookman, 2011.

PETROSINO, Maurício Miguel. João Batista Vilanova Artigas: residências unifamiliares: a produção arquitetônica de 1937 a 1981. São Paulo: FAU-USP, 2009. Dissertação (Mestrado) - Faculdade de Arquitetura e Urbanismo/usP, São Paulo. 493 p.
PIANo, Renzo. A responsabilidade do arquiteto - conversas com Renzo Cassigoli. Tradução: Maurício Santana Dias. São Paulo: BEI Comunicações, 2011.

PRADO JR., Caio. Evolução política do Brasil e outros estudos. São Paulo: Brasiliense, 1933.

PRUDON, Theodore H. M. Preservation of modern architecture. Nova Jersey: John Wiley \& Sons, Inc., 2008.

RosSETTI, Beatrice. Proposta concreta. Casa Vogue. São Paulo, 310 p. 144-153, jun/2011.

RUSKIN, John. A lâmpada da memória. Tradução: Maria Lucia Bressan Pinheiro. Cotia: Ateliê Editorial, 2008. (Artes e Ofícios, 7).

SALVo, Simona. A intervenção na arquitetura contemporânea como tema emergente do restauro. Tradução: Beatriz Mugayar Kühl. Pós - Revista do programa de pós-graduação em Arquitetura e Urbanismo da FAU-USP/Universidade de São Paulo. São Paulo, n. 23, junho 2008. Disponível em: <http://www.revistasusp.sibi.usp. br/scielo.php?script=sci_arttext\&pid=S1518-9554200>. Acesso em: 05 dezembro de 2010

. Arranha-céu Pirelli: crônica de uma restauração. Tradução: Beatriz Mugayar Kühl. Desígnio - Revista de História da Arquitetura e do Urbanismo/FAU-USP, São Paulo, Annablume, n. 6 , p. 69-86, setembro 2006 .

. Restauro e "restauros" das obras arquitetônicas do século 20: intervenções em arranha-céus em confronto. Revista CPC, São Paulo, n. 4, maio/outubro 2007, p. 139-157. Disponível em: <http://www.usp.br/cpc/vl/php/wf07_revista_interna. php?id_revista $=88$ id_conteudo $=218$ tipo $=7>$. Acesso em: 05 dezembro de 2010.

; KÜHL, Beatriz Mugayar. A intervenção na arquitetura contemporânea como tema emergente do restauro. Pós - Revista do programa de pós-graduação em Arquitetura e 
Urbanismo da FAU-USP/Universidade de São Paulo. FAU-USP, São Paulo, n. 23, jun. 2008 . Disponível em <http://www.revistasusp.sibi.usp.br/scielo.php?script=sci_arttext\&pid=S1518 $955420080001000158 \operatorname{lng}=$ ptgnrm=iso $>$. Acesso em: em $16 / 01 / 2013$

; KÜHL, Beatriz Mugayar. Preservação da arquitetura moderna e metodologia de restauro. Pós - Revista do programa de pós-graduação em Arquitetura e Urbanismo da FAU-USP/Universidade de São Paulo. São Paulo, n. 13, p. 198-210, junho 2003. Disponível em: <http://www.usp.br/fau/public/pos/13/revistapos13. pdf $>$. Acesso em: 11/01/ 2011.

SEGAWA, Hugo. Arquiteturas no Brasil 1900-1990. São Paulo: Edusp Editora da Universidade de São Paulo, 1997. (Acadêmica, v. 21). SERAPIÃo, Fernando. A revista Acrópole. Projeto, São Paulo, n. 312 , fevereiro 2006. Disponível em: < http://www.arcoweb.com.br/ artigos/fernando-serapiao-a-revista-06-03-2006.html>. Acesso em: 07/02/2013.

Sutis modificações revelam diálogos entre as gerações. Projeto Design. São Paulo, n. 294, p. 44-49, agosto/2004.

SPBR ARQUITETOS. Reforma da casa Olga Baeta. Disponível em: <http:// www.spbr.arq.br/>. Acesso em: 11/01/2011.

SPIRO, Annette. Paulo Mendes da Rocha: bauten und projekte. Sulgen: Nigli, 2002.

SuMA, Stefania. Le Corbusier. Tradução: Wally Constantino. São Paulo: Folha de São Paulo, 2011.

TAGLIARI, Ana. Frank Lloyd Wright: princípio, espaço e forma na arquitetura residencial. São Paulo: Annablume, 2011.

TECTÓNICA - MONOGRAFIAS DE ARQUITECTURA, TECNOLOGIA Y CONSTRUCCIÓN, Madri, ATC Ediciones, n. 18, março 2005.

TECTÓNICA - MONOGRAFIAS DE ARQUITECTURA, TECNOLOGIA Y CONSTRUCCIÓN, Madri, ATC Ediciones, n. 33, setembro 2010
TEIXEIRA, Cristiane e BAVA, Cristina. Dos anos 50 aos 90. Arquitetura $\theta$ Construção. São Paulo, 3, p. 28-37, mar/1998.

THOMAZ, Dalva Elias. Artigas: a liberdade na inversão do olhar - modernidade e arquitetura brasileira. São Paulo: FAU-USP, 2005. Tese (Doutorado) - Faculdade de Arquitetura de Urbanismo/UsP, São Paulo.

. Um olhar sobre Vilanova Artigas e sua contribuição à arquitetura brasileira. São Paulo: FAU-USP, 1997. Dissertação (Mestrado) - Faculdade de Arquitetura de Urbanismo/UsP, São Paulo.

TOLEDo, Benedito Lima de. São Paulo: três cidades em um século. 4. ed. rev. São Paulo: Cosac Naify/Duas Cidades, 2007.

VAlentin, Fábio Rago. Casas para o ensino: as escolas de Vilanova Artigas. São Paulo: FAU-USP, 2003. Dissertação (Mestrado) - Faculdade de Arquitetura de Urbanismo/usP, São Paulo.

VAlÉRY, Paul. Eupalinos ou $O$ arquiteto. Tradução: Olga Reggiani. 2. ed., 1. reimpressão. Rio de Janeiro: Editoa 34, 2006.

VIOLLET-LE-DUC, Eugène Emmanuel. Restauração. Tradução Beatriz Mugayar Kühl. 3. ed. Cotia: Ateliê Editorial, 2006.

WISNIK, Guilherme. Lucio Costa. São Paulo: Cosac Naify, 2001. (Espaços da arte brasileira).

. 2G International Architecture Magazine. Barcelona, 54, $\mathrm{jul} / 2010$.

Modenidade congênita. In: ANDREOLI, Elisabetta; FORTY, Adrian. (org.) Arquitetura moderna brasileira. Londres: Phaidon, 2004, p. 22-55.

WOLFF, Silvia Ferreira Santos. Arquitetura moderna paulista - a preservação oficial. Texto apresentado ao $1^{\circ}$ Dосомомо/Vale do Paraíba, realizado na residência Olivio Gomes, São José dos Campos, 1998. apud OKSMAN, Silvio. Preservação do patrimônio arquitetônico moderno - A FAU de Vilanova Artigas. São Paulo: 
FAU-USP, 2011. Dissertação (Mestrado) - Faculdade de Arquitetura de Urbanismo/usp, São Paulo, p. 66.

XAVIER, Alberto; LEMOS, Carlos; CORONA, Eduardo. Arquitetura moderna paulista. São Paulo: PINI, 1983.

ZANI, Antonio Carlos. Arquitetura em madeira. Londrina: EDUEL/Imprensa Oficial, 2003.

ZEIN, Ruth Verde. Arquitetura brasileira, escola paulista e as casas de Paulo Mendes da Rocha. Porto Alegre: UfRgS, 2000. Tese. Programa de Pós Graduação da Faculdade de Arquitetura da Universidade Federal do Rio Grande do Sul, Porto Alegre, 2000.

. Residência: a moradia como laboratório experimental. In:

ZEIN, Ruth Verde. A arquitetura da escola paulista brutalista, 1953

1973. Porto Alegre: Propar-UfrgS, 2007, p. 221-248. Tese. Programa de Pós Graduação da Faculdade de Arquitetura da Uni-

versidade Federal do Rio Grande do Sul, Porto Alegre, 2007.

ZIMMERMAN, Claire. Mies van der Rohe 1886-1969: a estrutura do espaço.

Köln: Taschen, 2006.

zUMTHOR, Peter. Arte Sagrado - Museu Kolumba en Colonia, Alemanha. Madri: Arquitetura Viva, SL, Revista AV, n. 116, 2007, p. 38-45 Atmosferas. Barcelona: Editorial Gustavo Gili, SL, 2009. 


\section{SITES CONSULTADOS}

ANAIS DO MUSEU PAULISTA Www.scielo.br/anaismp

ARCHDAILY WWw.archdaily.com

ARCHITECTHUM www.architecthum.edu.mx

ARCOWEB Www.arcoweb.com.br

BASF - THE CHEMICAL COMPANY WWW.constructionsystems.basf-cc.es

CONDEPHAAT WWw.condephaat.sp.gov.br

CONPRESP wWw.conpresp.sp.gov.br

DICIONÁRIO AULETE aulete.uol.com.br/

DOCOMOMO www.docomomo.org.br

DORMA WWW.dorma.com.br

ESCRITÓRIO PAULISTANO www.epaulistano.com.br

ESCRITÓRIO SPBR WWw.spbr.arq.br

ESTUDIO LAMELA WWw.lamela.com

FDR FOUR FREEDOMS PARK Www.fdrfourfreedomspark.org

GOOGLE MAPS maps.google.com.br

ICOMOS www.icomos.org.br

ÍNDICE DE ARQUITETURA BRASILEIRA www.usp.br/fau/fau/secoes/

biblio/on_line/index
INFORMATIVO FAU-USP Www.usp.br/fau/fau/secoes/espacos_fisicos/

IPHAN www.iphan.gov.br/

LEONARDO FINOTTI leonardofinotti.com

MUSEU HISTÓRICO NACIONAL WWw.museuhistoriconacional.com.br PLATAFORMA ARQUITECTURA WWw.plataformaarquitectura.cl

PONTO REVISTA DIGITAL WWw.ponto.org

REVISTA CPC WWw.usp.br/cpc

REVISTA PÓs www.usp.br/fau/public/pos/index

REVISTA RISCO Www.arquitetura.eesc.usp.br

REVISTA ROTUNDA Www.iar.unicamp.br/rotunda

SCIELO WwW.scielo.br

THE ARCHITECTS NEWSPAPER archpaper.com

VITRUVIUS www.vitruvius.com.br

VSL - POST-TENSIONING $\&$ SPECIALTY REINFORCEMENT SYSTEMS

www.vsl.net/NEWS/ARTICLES/tabid/73/Default.aspx

WACKER www.wacker.com/cms/media/publications/

downloads/6187_PT 



\section{SIGLAS E ABREVIAÇÕES}

CECAP Caixa Estadual de Casas para o Povo

CIAM Congrès Internationaux d'Architecture Moderne (Congressos Internacionais da Arquitetura Moderna)

CONDEPHAAT Conselho de Defesa do Patrimônio Histórico, Arqueológico, Artístico e Turístico

CONPRESP Conselho Municipal de Preservação do Patrimônio Histórico, Cultural e Ambiental da Cidade de São Paulo

Dосомомо International working party for Documentation and Conservaion olf builds, sites and neighbourghoods of the Modern Movent

DPH Departamento do Patrimônio Histórico

FAU-USP Faculdade de Arquitetura e Urbanismo da Universidade de São Paulo

FAUS Faculdade de Arquitetura e Urbanismo de Santos - Unisantos

FDE Fundação para o Desenvolvimento da Educação
FIESP Federação das Indústrias do Estado de São Paulo

GEGRAN Grupo Executivo da Grande São Paulo

ICOMOS International Council on Monuments and Sites (Conselho Internacional de Monumentos e Sítios)

IPHAN Instituto do Patrimônio Histórico e Artístico Nacional

IPT Instituto de Pesquisas Tecnológicas

IPTU Imposto sobre a propriedade predial e territorial urbana

MEC Ministério da Educação (antigo MESP)

MESP Ministério da Educação e Saúde Pública

SPHAN Serviço do Patrimônio Histórico e Artístico Nacional TFG Trabalho Final de Graduação

UNESCO United Nations eEducational, Scientific and Cultural Organization (Organização das Nações Unidas para a Educação, a Ciência e a Cultura)

USP Universidade de São Paulo 



\section{CRÉDITO DAS IMAGENS}

\section{INTRODUÇÃO}

i.1 Jorge Hirata (ACAYABA 1986 , p. 89

i.2 José Moscardi (XAVIER, 1983, p. 106)

i.3 autor não identificado (Acervo Paulo Mendes da Rocha Arquitetos Associados)

\section{CAPÍTULO 1}

1.01 Alexandre Wollner (SERAPIÃO 2006)

1.02 Acervo Jorge Machado Moreira (CZAJWOWSKI, 1999, p. 99)

1.03 Arquivo Nacional (WISNIK 2001, p. 64)

1.04 Hugo Zanella (Coleção Gregori Warchavchik)

1.05 Cartão-postal. Ed. Colombo (TOLEDO, 2007, p. 179)
1.06 Nelson Kon (WISNIK, 2010, p. 52)

1.07 Nelson Kon (WISNIK, 2010, p. 58)

1.08 Fundation Le Corbusier (SUMA, 2011, p. 52)

1.09 Oscar Niemeyer (BOTEY, 1996, p. 159)

1.10 Acervo Família Millan, 2005 (CAMARGO, 2007, p. 10)

1.11 Nelson Kon (SEGAWA 1997, p. 29)

1.12 Nelson Kon (SERAPIÃO, 2004, p. 44)

1.13 Acervo Biblioteca da FAU-USP (plantas, escala original 1:100 728.3 GK folha 2)

1.14 Acervo Biblioteca da FAU-USP (corte, escala original 1:100 728.3 GK folha 2)

1.15 Acervo Biblioteca da FAU-USP (fachada, escala original 1:100 - 728.3 GK folha 2)

1.16 Alexandre Delijaicov e Vera Domschke (PROTESTO contra a demolição de uma casa de Vilanova Artigas, Projeto,

São Paulo, 94, dez/1986, p. 119)

1.17 Simona Salvo (SALVO 2006, p. 70)

1.18 Renzo Piano Building Workshop e John Hewitt (BUCHANAN, 2005, p. 55)

1.19 autor não identificado

(TECTÓNICA - MONOGRAFIAS DE ARQUITECTURA

TECNOLOGIA Y CONSTRUCCIÓN, Madri, ATC Ediciones, n. 33, set/2010, p. 19)

1.20 A. Baltanás (TECTÓNICA MONOGRAFIAS DE ARQUITECTURA, TECNOLOGIA Y CONSTRUCCIÓN, Madri, ATC Ediciones, n. 33, set/2010, p. 19)

1.21 Estudio Lamela (TECTÓNICA MONOGRAFIAS DE

ARQUITECTURA, TECNOLOGIA Y CONSTRUCCIÓN, Madri, ATC Ediciones, n. 33, set/2010, p. 19)
1.22 Alessandra Cerroti (SALVO, 2008, p. 10)

1.23 autor não identificado (FLEIG 1994, p. 54)

1.24 autor não identificado (PRUDON, 2008, p. 492)

1.25 autor não identificado (TECTÓNICA - MONOGRAFIAS DE ARQUITECTURA TECNOLOGIA Y CONSTRUCCIÓN, Madri, ATC Ediciones, n. 33, set/2010, p. 11)

1.26 BASF (TECTÓNICA MONOGRAFIAS DE ARQUITECTURA, TECNOLOGIA Y CONSTRUCCIÓN, Madri, ATC Ediciones, n. 33, set/2010, p. 11)

1.27 BASF (TECTÓNICA MONOGRAFIAS DE ARQUITECTURA, TECNOLOGIA Y CONSTRUCCIÓN, Madri, A TC Ediciones, n. 33, set/2010, p. 11)
1.28 T. Wolf (TECTÓNICA MONOGRAFIAS DE ARQUITECTURA, TECNOLOGIA Y CONSTRUCCIÓN, Madri, ATC Ediciones, n. 33, set/2010, p. 7)

1.29 A. Fentzloff (TECTÓNICA MONOGRAFIAS DE ARQUITECTURA, TECNOLOGIA Y CONSTRUCCIÓN, Madri, ATC Ediciones, n. 33, set/2010, p. 7)

1.30 A. Fentzloff (TECTÓNICA MONOGRAFIAS DE ARQUITECTURA, TECNOLOGIA Y CONSTRUCCIÓN, Madri, ATC Ediciones, n. 33, set/2010, p. 7)

1.31 Sika (MONOGRAFIAS DE ARQUITECTURA, TECNOLOGIA Y CONSTRUCCIÓN, Madri, ATC Ediciones, n. 33, set/2010, p. 10)

1.32 Mapei (MONOGRAFIAS DE

ARQUITECTURA, TECNOLOGIA Y CONSTRUCCIÓN, Madri, ATC Ediciones, n. 33, set/2010, p. 10) 
1.33 Mapei (MONOGRAFIAS DE ARQUITECTURA, TECNOLOGIA Y CONSTRUCCIÓN, Madri, ATC Ediciones, n. 33, set/2010, p. 10)

1.34 Daniel Merro Johnston (MERRO JOHNSTON, 2011, p. 51)

1.35 Daniel Merro Johnston (MERRO JOHNSTON, 2011, p. 176)

1.36 Mies van der Rohe (TECTÓNICA - MONOGRAFIAS DE ARQUITECTURA, TECNOLOGIA Y CONSTRUCCIÓN, Madri, ATC Ediciones, n. 18, mar/2005, p. 5)

1.37 Lluís Casals (TECTÓNICA MONOGRAFIAS DE ARQUITECTURA, TECNOLOGIA Y CONSTRUCCIÓN, Madri, ATC Ediciones, n. 18, mar/2005, p. 5)

1.38 Lluís Casals (TECTOONICA MONOGRAFIAS DE ARQUITECTURA, TECNOLOGIA Y CONSTRUCCIÓN, Madri, ATC Ediciones, n. 18, mar/2005, p. 4)

\section{CAPÍTULO 2}

2.01 Nelson Kon (Acervo)

2.02 autor não identificado (Acervo Escritório Paulistano de Arquitetura, 15/03/2011)

2.03 Leonardo Finotti @ 2011 photo@leonardofinotti.com
2.04 Fundação Vilanova Artigas (ARTIGAS, 1997, p. 73)

2.05 Acervo Biblioteca da FAU-USP (ANDREOLI:FORTY, 2004, p. 161)

2.06 produzida pelo autor

2.07 Acervo Biblioteca da FAU-USP (prancha de cortes e planta do telhado, escala original 1:50 código 728.3 OB folha 4)

2.08 Acervo Biblioteca da FAU-USP (prancha de cortes e planta do telhado, escala original 1:50 - código $728.3 \mathrm{OB}$ folha 4

2.09 Antonio Carlos Zani (ZANI, 2003, p. 72)

2.10 Antonio Carlos Zani (ZANI 2003, p. 45)

2.11 Antonio Carlos Zani (ZANI 2003, p. 45)

2.12 autor não identificado (Acervo Paulo Mendes da Roch Arquitetos Associados)

2.13 Grete Schutte-Lihotsky (BRUNA, 2010, p. 44)

2.14 Acervo Paulo Mendes da Rocha Arquitetos Associados

2.15 Escritório Técnico da CECAP (ARTIGAS, 1997, p. 145)

2.16 autor não identificado (Acervo Escritório Paulistano de Arquitetura, 15/03/2011)

2.17 autor não identificado (Acervo Escritório Paulistano de Arquitetura, 15/03/2010)

2.18 Acervo Paulo Mendes da Rocha Arquitetos Associados
2.19 Acervo Paulo Mendes da Rocha Arquitetos Associados (OTONDO, 2009, p. 39)

2.20 Acervo Paulo Mendes da Rocha Arquitetos Associados (OTONDO, 2009, p. 41)

2.21 redesenho Rogério Pfutzenreuter (ACAYABA 1986, p. 338)

2.22 Jorge Hirata (ACAYABA, 1986, p. 339)

2.23 autor não identificado (Acervo Paulo Mendes da Rocha Arquitetos Associados)

2.24 Acervo Biblioteca FAU-USP (planta térrea - cota 94.75 escala original 1:50 Folha 3 , data 17/07/1970)

\section{CAPÍTULO 3}

3.01 Peter Zumthor (ARQUITETURE AND URBANISM. Peter Zumthor. Tokio: a+u Publishing, Extra Edition, fev/1998, p. 43)

3.02 Renzo Piano Building Workshop (BUCHANAN, 2005, p. 152)

3.03 Shunji Ishida (BUCHANAN, 2005, p. 153)

3.04 Shunji Ishida (BUCHANAN, 2005, p. 153)

3.05 Dario de Freitas (TEIXEIRA, 1998, p. 32)

3.06 Dario de Freitas (TEIXEIRA, 1998, p. 30)

3.07 Dario de Freitas (TEIXEIRA, 1998 , p. 30)
3.08 Acervo Angelo Bucci (planta do pavimento térreo - níve 0,00 , escala original 1:100 Folha 2, data dezembro 1996)

3.09 Dario de Freitas (TEIXEIRA 1998, p. 36)

3.10 Dario de Freitas (TEIXEIRA 1998, p. 32)

3.11 Nelson Kon (CLíNICA de odontologia. ELARQA Montevidéu: Dos Puntos, n. 39, set/2001, p. 53)

3.12 Acervo Paulo Mendes da Rocha Arquitetos Associados (execução detalhe piscina, escala original 1:50 / 1:5 Folha 27, data 28/06/1969)

3.13 autor não identificado (Acervo Escritório Paulistano de Arquitetura, 15/03/2010)

3.14 autor não identificado (Acervo Escritório Paulistano de Arquitetura, 15/03/2011

3.15 autor não identificado (Acervo Escritório Paulistano de Arquitetura, 05/05/2010)

3.16 autor não identificado (Acervo Escritório Paulistano de Arquitetura, 18/09/2010)

3.17 autor não identificado (Acervo Escritório Paulistano de Arquitetura, 04/08/2010)

3.18 autor não identificado (Acervo Escritório Paulistano de Arquitetura, 28/04/2010)

3.19 Acervo Escritório Paulistano de Arquitetura Associados (pavimento térreo implantação, escala

original 1:100 - Folha 01 data 19/05/2010)

3.20 Acervo Paulo Mendes da Rocha Arquitetos Associados novo desenho da planta cota 94.75, escala original 1:50 Folha 3A, data 23/04/1974)

3.21 autor não identificado (Acervo Bela Vista Arquitetos, 2000)

3.22 autor não identificado (Acervo Bela Vista Arquitetos, 2000)

3.23 autor não identificado (Acervo Bela Vista Arquitetos, 2000)

3.24 autor não identificado (Acervo Bela Vista Arquitetos, 2000)

3.25 autor não identificado (Acervo Bela Vista Arquitetos, 2000)

3.26 autor não identificado (Acervo Bela Vista Arquitetos, 2000)

3.27 Acervo Angelo Bucci

3.28 produzido pelo auto [intervenção sobre arquivo digitalizado do Acervo Biblioteca FAU-USP (728.3 OB folha 3) da planta do pavimento térreo, escala original 1:50 Folha $s / n$ data 1957

3.29 produzido pelo autor [intervenção sobre arquivo digital do Acervo Angelo Bucc (148ARQ02) da planta do pavimento térreo - nível 0,00, escala original 1:100 Folha 2 , data dezembro 1996

3.30 produzido pelo auto [intervenção sobre arquivo 
digitalizado do Acervo Biblioteca FAU-USP (728.3 OB folha 3) da planta do primeiro pavimento, escala origina 1:50 Folha s/n, data 1957

3.31 produzido pelo autor

[intervenção sobre arquivo digital do Acervo Angelo Bucci (148ARQ03) da planta nível

3,00 escala original 1:100

Folha 3, data dezembro 1996]

3.32 Nelson Kon (Acervo)

3.33 produzido pelo autor

3.34 produzido pelo auto

3.35 Acervo Angelo Bucc

3.36 Dario de Freitas (TEIXEIRA 1998, p.34)

3.37 Dario de Freitas (TEIXEIRA 1998, p.34)

3.38 Dario de Freitas (TEIXEIRA 1998, p.34)

3.39 Acervo Biblioteca FAU-USP (concreto armado laje de forro postigos, escala original 1:50 Folha s/n, data 1957)

3.40 Acervo Angelo Bucci (escora metálica, escala original 1:2 Folha $1 / 2$, s/data)

3.41 Nelson Kon (Acervo)

3.42 Nelson Kon (Acervo)

3.44 Nelson Kon (Acervo)

3.45 Nelson Kon (Acervo)

3.46 Nelson Kon (Acervo)

3.47 Nelson Kon (Acervo)

3.48 Nelson Kon (Acervo)

3.49 autor não identificado (Acervo Escritório Paulistano de Arquitetura, 15/03/2011)
3.50 autor não identificado (Acervo Escritório Paulistano de Arquitetura, 15/03/2010)

3.51 autor não identificado (Acervo Escritório Paulistano de Arquitetura, 04/08/2010)

3.52 autor não identificado (Acervo Escritório Paulistano de Arquitetura, 04/08/2010)

3.53 autor não identificado (Acervo Escritório Paulistano de Arquitetura, 04/08/2010)

3.54 autor não identificado (Acervo Escritório Paulistano de Arquitetura, 04/08/2010)

3.55 autor não identificado (Acervo Escritório Paulistano de Arquitetura, 15/03/2010)

3.56 autor não identificado (Acervo Escritório Paulistano de Arquitetura, 04/08/2010)

3.57 autor não identificado (Acervo Escritório Paulistano de Arquitetura, 04/08/2010)

3.58 autor não identificado (Acervo Escritório Paulistano de Arquitetura, 15/03/2010

3.59 Paulo Mendes da Roch (SPIRO, 2002, p. 73)

3.60 autor não identificado (Acervo Escritório Paulistano de Arquitetura, 15/03/2010)

3.61 autor não identificado (Acervo Escritório Paulistano de Arquitetura, 2010)

3.62 autor não identificado (Acervo Escritório Paulistano de Arquitetura, 15/03/2010
3.63 autor não identificado (Acervo Escritório Paulistano de Arquitetura, 15/03/2010)

3.64 Acervo Escritório Paulistano de Arquitetura (portas venezianas dormitórios e detalhes, escala original 1:2 - Folha 08 , data 05/05/2010)

3.65 autor não identificado (Acervo Escritório Paulistano de Arquitetura, 15/03/2011)

3.66 autor não identificado (Acervo Escritório Paulistano de Arquitetura, 15/10/2010)

3.67 Paulo Mendes da Roch (SPIRO, 2002, p. 72)

3.68 autor não identificado (Acervo Escritório Paulistano de Arquitetura, 05/01/2011)

3.69 autor não identificado (Acervo Escritório Paulistano de Arquitetura, 18/10/2010)

3.70 autor não identificado (Acervo Escritório Paulistano de Arquitetura, 18/09/2010)

3.71 autor não identificado (Acervo Escritório Paulistano de Arquitetura, 18/10/2010)

3.72 autor não identificado (Acervo Escritório Paulistano de Arquitetura, 18/10/2010)

3.73 autor não identificado (Acervo Escritório Paulistano de Arquitetura, 15/01/2011)

3.74 autor não identificado (Acervo Escritório Paulistano de Arquitetura, 15/03/2011)
3.75 autor não identificado (Acervo Escritório Paulistano de Arquitetura, 15/03/2011)

3.76 autor não identificado (Acervo Escritório Paulistano de Arquitetura, 15/03/2011)

3.77 autor não identificado (Acervo Escritório Paulistano de Arquitetura, 15/03/2011)

3.78 autor não identificado (Acervo Escritório Paulistano de Arquitetura, 15/03/2011)

3.79 autor não identificado (Acervo Escritório Paulistano de Arquitetura, 15/03/2011)

3.80 autor não identificado (Acervo Escritório Paulistano de Arquitetura, 15/03/2011)

3.81 autor não identificado (Acervo Escritório Paulistano de Arquitetura, 15/03/2011)

3.82 Leonardo Finotti () 2011 photo@leonardofinotti.com

3.83 Acervo Paulo Mendes da Rocha Arquitetos Associados (ampliação cozinha, bancada e detalhes, escala original 1:20 / 1:5 - Folha 05A, data 15/05/2001)

3.84 Leonardo Finotti @ 2011 photo@leonardofinotti.com

3.85 autor não identificado (Acervo Bela Vista Arquitetos, 2000)

3.85 Acervo Paulo Mendes da Rocha Arquitetos Associados (arara, escala original 1:20/ 1:2 Folhas de obra 04 e 05, data agosto 2001)
3.87 autor não identificado (Acervo Bela Vista Arquitetos, 2000)

3.88 Leonardo Finotti @ 2011 photo@leonardofinotti.com

3.89 autor não identificado (Acervo Bela Vista Arquitetos, 2000)

3.90 Leonardo Finotti @ 2011 photo@leonardofinotti.com

3.91 autor não identificado (Acervo Bela Vista Arquitetos, 2001)

3.92 autor não identificado (Acervo Bela Vista Arquitetos, 2001)

3.93 produzido pelo autor (caderno de campo, 2001)

DIAGRAMAS TRIDIMENSIONAIS

(56-59, 74 e 75), GRÁFICOS

(p. 28 e 29) E TABELAS (p. 162-

164, 188-190, 201, 232, 242

245) produzidos pelo autor 



\section{ANEXOS}

A disponibilização de grande parte do material coletado durante a pesquisa foi sugerida pela Banca de Qualificação o que nos pareceu de grande importância em virtude de não ser de fácil acesso, como, por exemplo, a reprodução das pranchas originais dos projetos executivos - constantes nos acervos dos próprios escritórios -, as entrevistas - que não são objetos de publicações, além dos diagramas tridimensionais produzidos.

Somando-se a esses motivos, consideramos que as duas casas ausentes nas análises (Residência na rua Itápolis - 1930, também conhecida como "Casa Modernista", de autoria de Gregori Warchavchik e residência Luis Eduardo Magalhães Gouveia de autoria de Carlos Lemos e Eduardo Corona, projetada em 1961) deveriam figurar no material apresentado como possível contribuição ou ponto de partida para outros pesquisadores que tenham essas residências como objeto de estudo.

Sobre a intervenção na residência da rua Itápolis, gostaríamos de ressaltar que o fato da casa pertencer à família War- chavchik há mais de 80 anos ocasionou diversas intervenções realizadas por três gerações de arquitetos da própria família $1^{a}$ geração: Gregori; $2^{a}$ geração: Maurice; $3^{a}$ geração: Carlos -, o que não só dificulta a elaboração de uma leitura mais precisa do que foi ou não alterado, mas coloca em xeque o próprio conceito de originalidade, visto que as primeiras mudanças foram executadas pelo próprio Warchavchik. Sobre a última intervenção, Carlos assinala que foi se envolvendo aos poucos e que não tinha intenção de fazer um "restauro"1. Pretendia realizar apenas pequenas atualizações de instalações elétricas e a impermeabilização da varanda. Seu processo de descoberta e pesquisa está documentado na entrevista realizada, do mesmo modo que o apoio e incentivo ${ }^{2}$, no decorrer de toda a obra, de Paulo Mauro Mayer, curador do acervo da família Warchavchik, que culminou na assinatura de um Termo de Ajustamento de Conduta junto ao IPHAN e na exposição "Modernista: 80 anos" em março de 2010.

Já para a residência Luis Eduardo Magalhães Gouveia, elaborou-se, inicialmente, um projeto executivo completo e [as notas referentes aos Anexos encontram-se na p. 136] 
aprovação na prefeitura, para depois dar início às obras que duraram cerca de dois anos ${ }^{3}$. Apesar dessa casa não figurar em nenhum órgão de tombamento, o escritório Stuchi \& Leite Projetos Ltda, adotou a postura de reconhecê-la como um patrimônio arquitetônico paulista, tanto pela sua autoria quanto pelo partido arquitetônico, respeitando a preexistência ao utilizar o princípio da "distinguibilidade" para os novos elementos. Como ações projetuais positivas, podemos assinalar desde a recuperação cuidadosa do concreto aparente, o não desvirtuamento do partido original, até o envolvimento de especialistas para documentar e restaurar o painel artístico de Lula Ayres - identificado a posteriori pela arquiteta Fernanda Craveiro, responsável por seu restauro. Contudo, o fato de não termos localizado nenhuma prancha do projeto executivo original ${ }^{4} \mathrm{e}$ também por não termos acesso ao projeto executivo, acabamos por eliminar essa residência dos estudos de caso que iriam ser analisados.

Para finalizar, reforçamos que o fato dessas duas casas não terem sido incluídas no estudo pormenorizado deste trabalho, em hipótese alguma se relaciona com a qualidade ou postura das intervenções realizadas. Acreditamos que a inclusão, nos Anexos, do material referente a elas, reitera a sua significância no que diz respeito ao patrimônio arquitetônico moderno paulista.

\section{NOTAS}

1 Informação fornecida por Carlos Warchavchik em entrevista realizada pelo autor em 08/09/2011. Essa entrevista encontra-se disponível na íntegra nos Anexos do presente trabalho, p. 145.

2 Informação fornecida por

Paulo Mauro Mayer em entrevista

realizada pelo autor em 08/09/2011

Essa entrevista encontra-se

disponível na íntegra nos Anexos do presente trabalho, p. 152

3 Informação fornecida por Carlos Leite em entrevista realizada pelo autor em 08/09/2011.

4 Foi localizada apenas uma versão reduzida da planta original, ver: XAVIER, Alberto; LEMOS, Carlos; CORONA, Eduardo. Arquitetura moderna paulistana. São Paulo: Pini, 1983, p. 68. 


\section{RESIDÊNCIA}

\section{RUA ITÁPOLIS - "CASA MODERNISTA"}

Endereço: rua Itápolis, 961, Pacaembu, São Paulo, SP

Área do terreno: 496,09 $\mathrm{m}^{2}$

Área da construção: $176,60 \mathrm{~m}^{2}$ (principal); $81,59 \mathrm{~m}^{2}$ (edícula)

Data do projeto original/obra: 1928 / 1928-1930

Autor: Gregori Warchavchik

Data do projeto de intervenção/obra: 2008-2010

Escritório responsável: Warchavchik Arquitetura Ltda

Autor: Carlos Eduardo Warchavchik

Colaboradores: Thiago Amado e Flora Campanatti

Pesquisa iconográfica: Carlos Eduardo Warchavchik e Paulo Mauro de Aquino

Obra: João Bosco (mestre de obra); Adilson Roberto de Oliveira (impermeabilização);

Pedro Alves da Silva (pintura)

Luminárias: Serman Serralheria

Marcenaria: Wagner Alves Martins

Fotos: Coleção Gregori Warchavchik, Kelly Naguissa e Marisa Nagumo
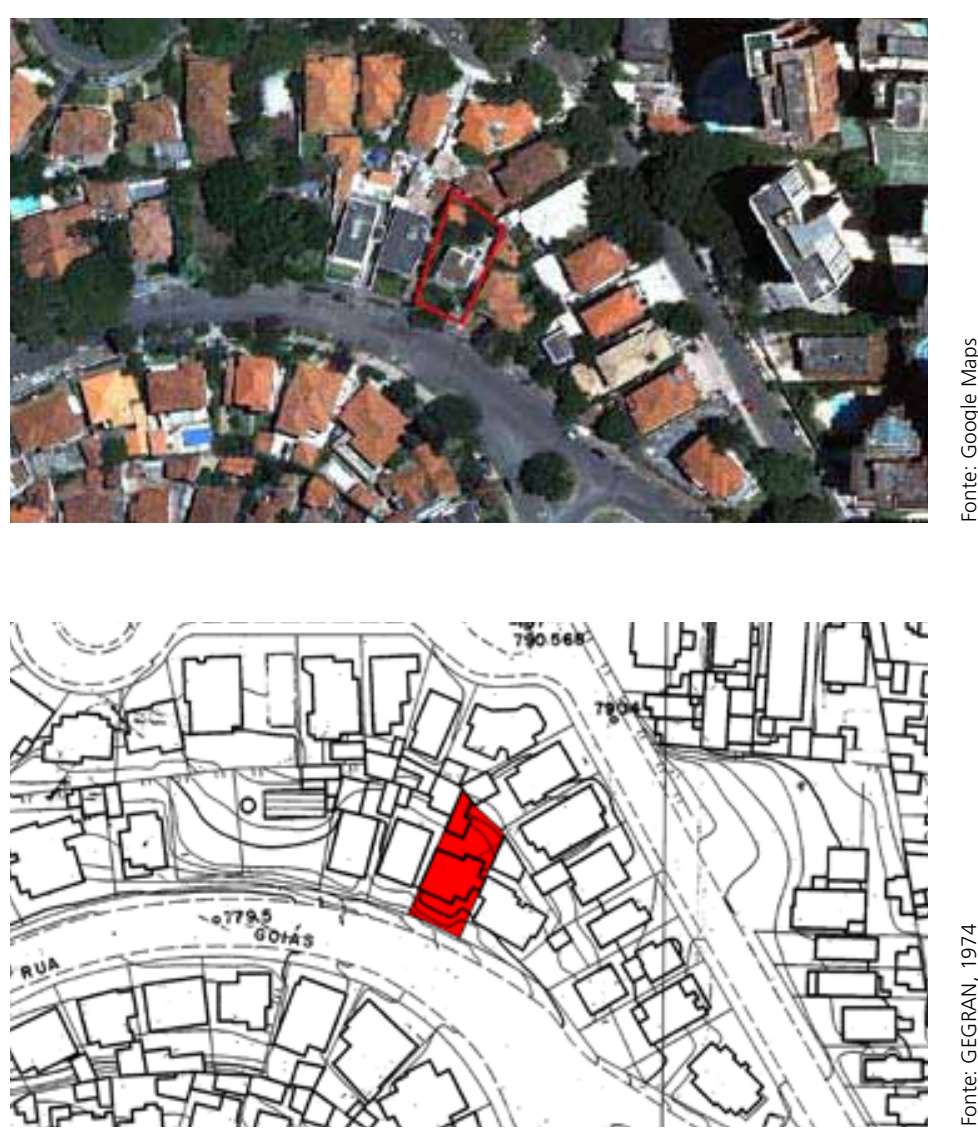


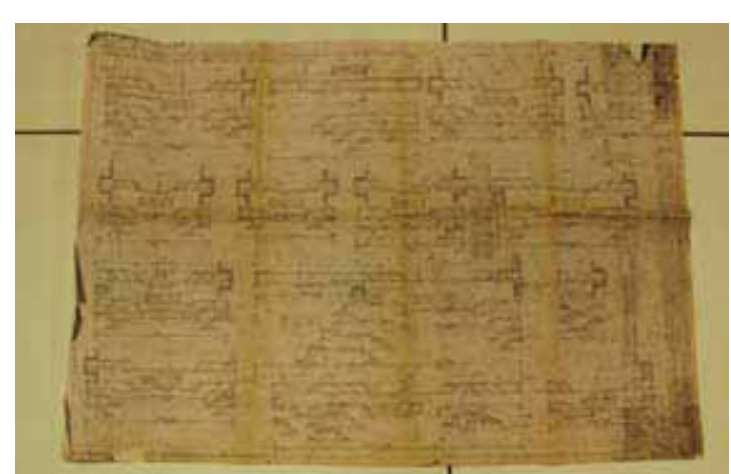

Detalhes em concreto armado (escala 1:20)

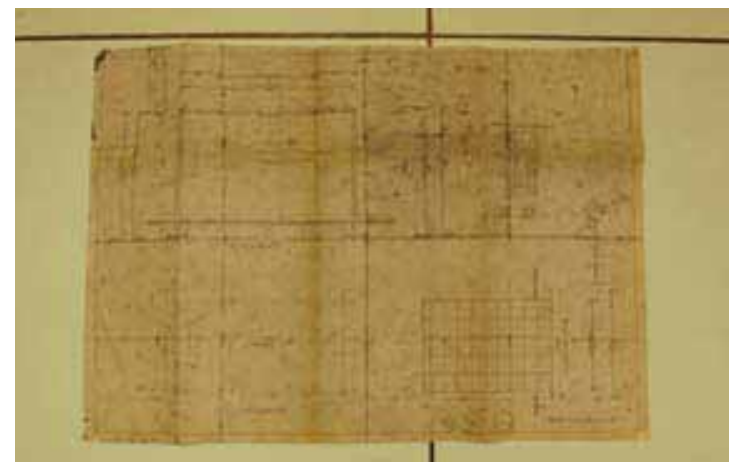

Detalhes de armação (escala 1:20)

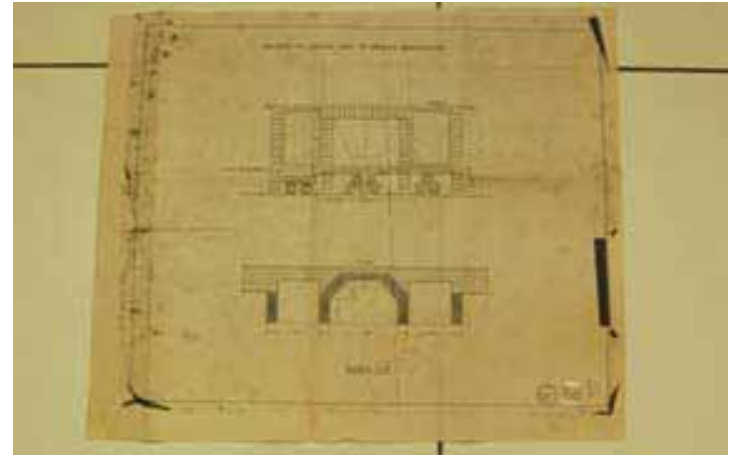

Detalhe da lareira (escala 1:10)

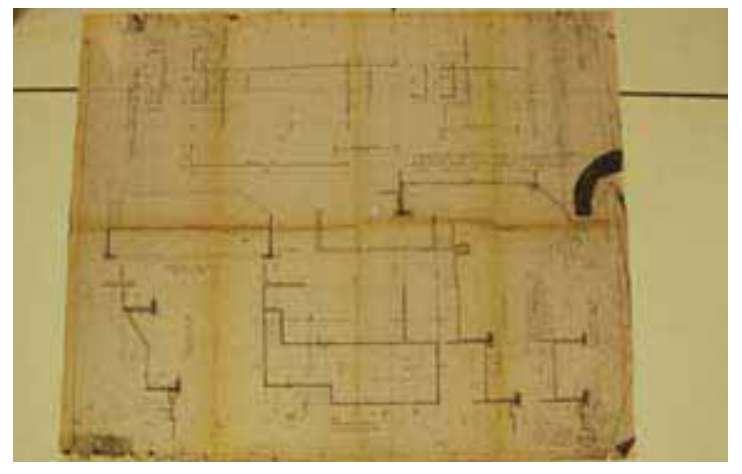

Muro de arrimo em concreto armado (escala 1:50)

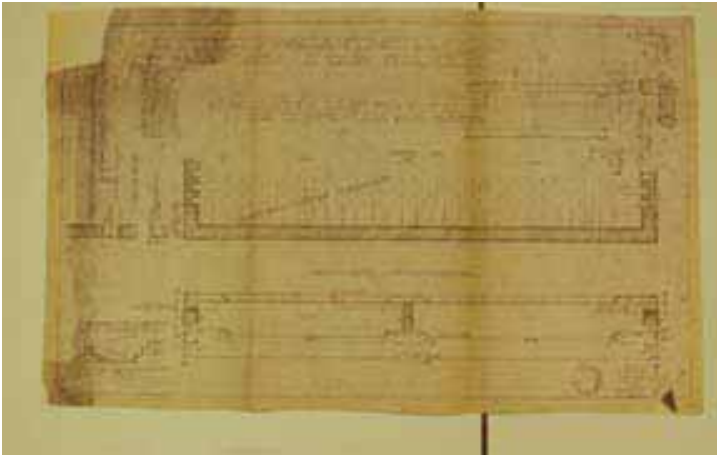

Armação da laje em tijolos da cobertura (escala não identificada)

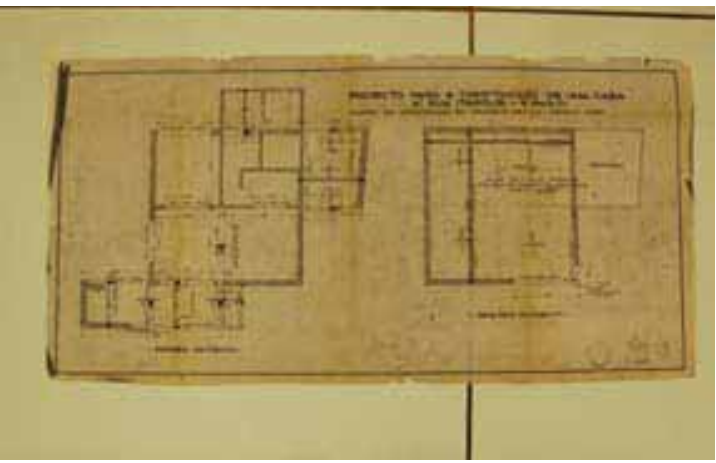

Planta da construção em concreto armado (escala 1:50)

Planta de aprovação na Prefeitura (escala não identificada)

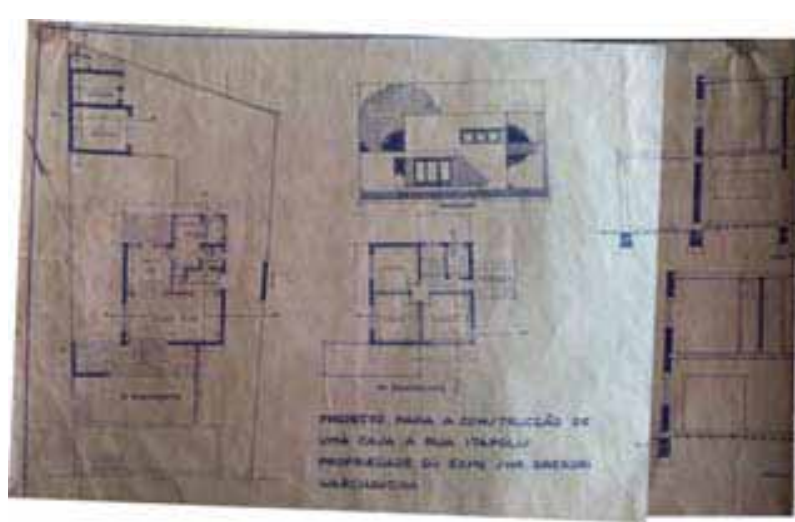



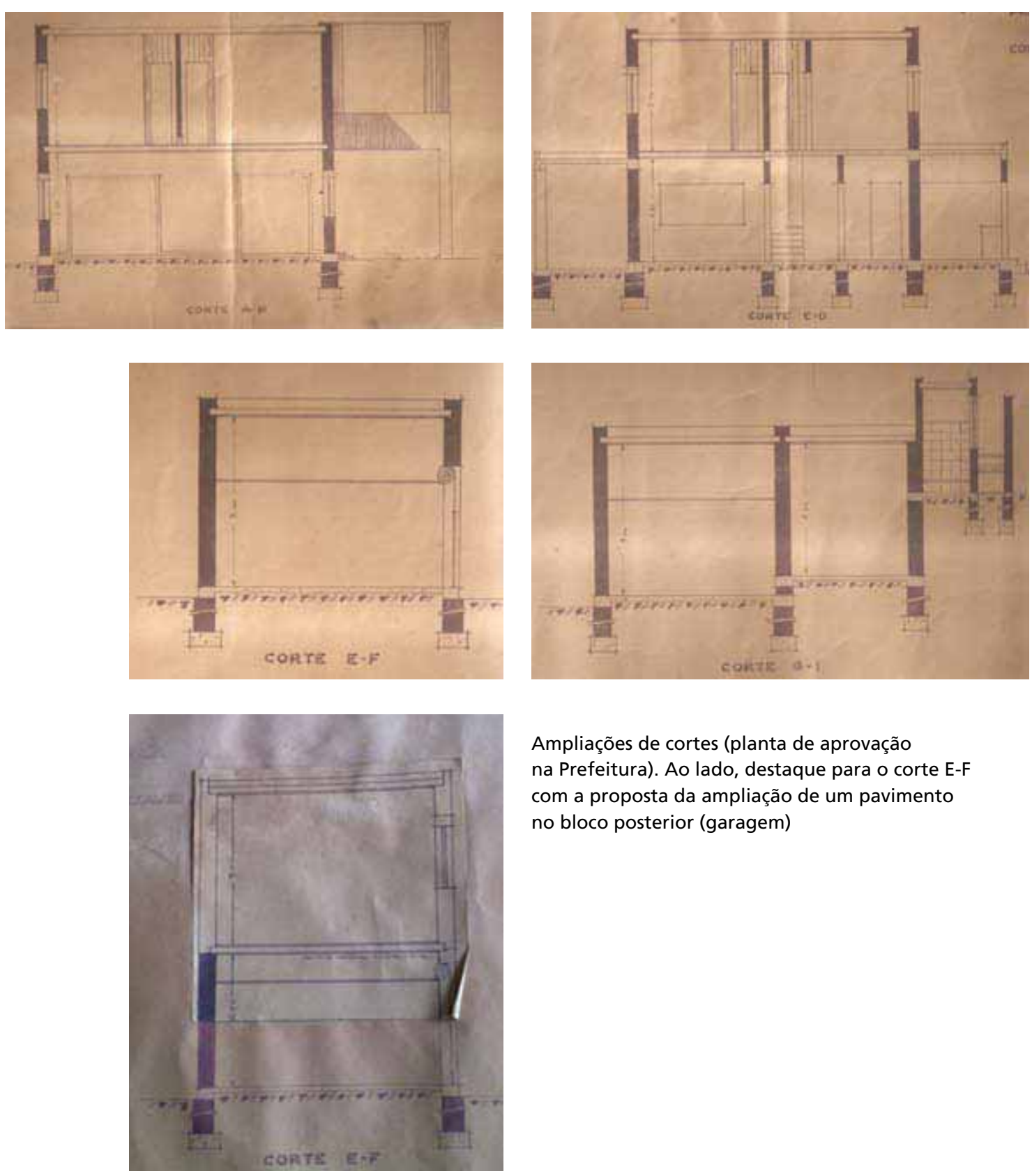

Ampliações de cortes (planta de aprovação

na Prefeitura). Ao lado, destaque para o corte E-F

com a proposta da ampliação de um pavimento

no bloco posterior (garagem)

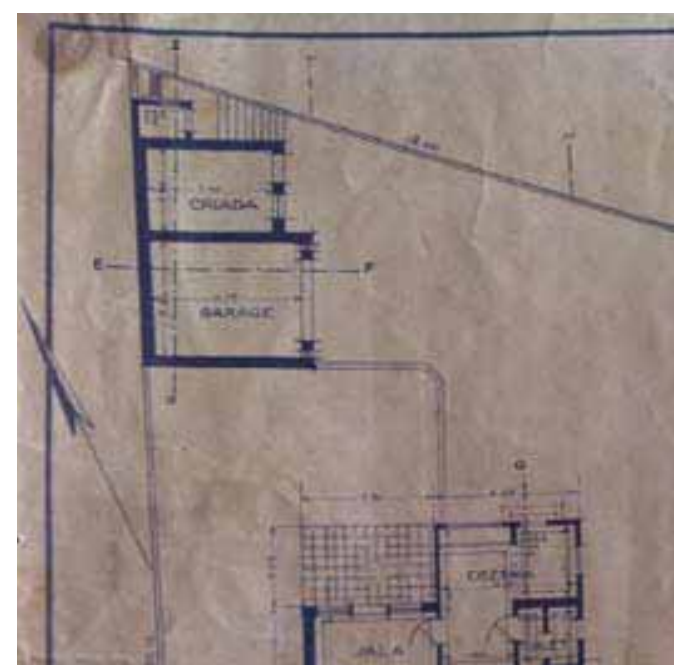

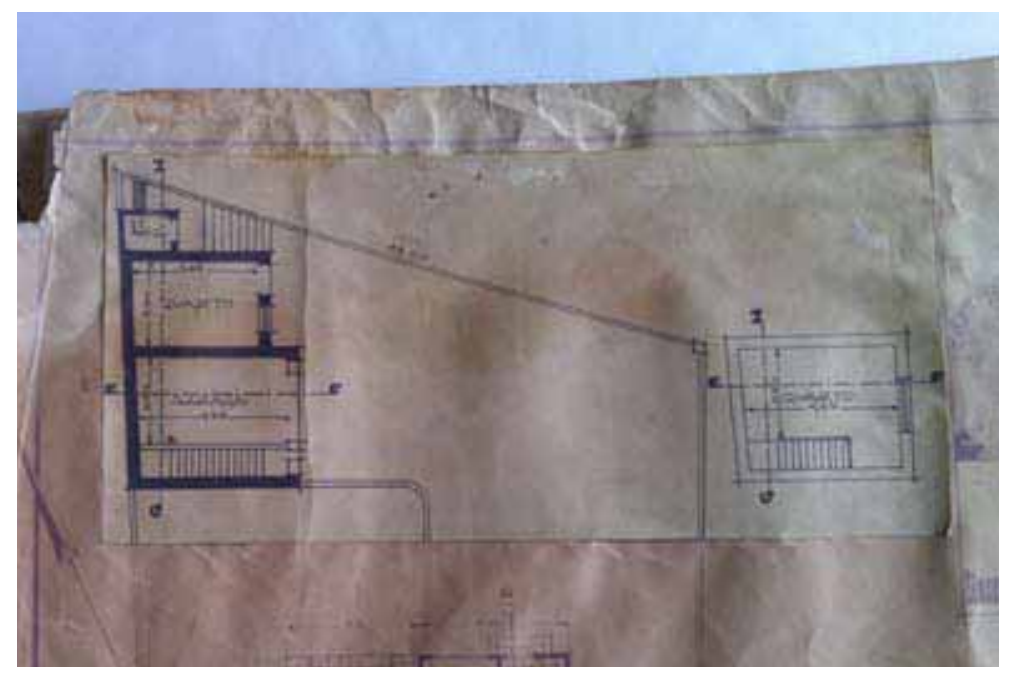

Ampliações das plantas do bloco anexo (planta de aprovação na Prefeitura). Embaixo, destaque para a planta com a proposta da ampliação de um pavimento no bloco posterior (garagem) 

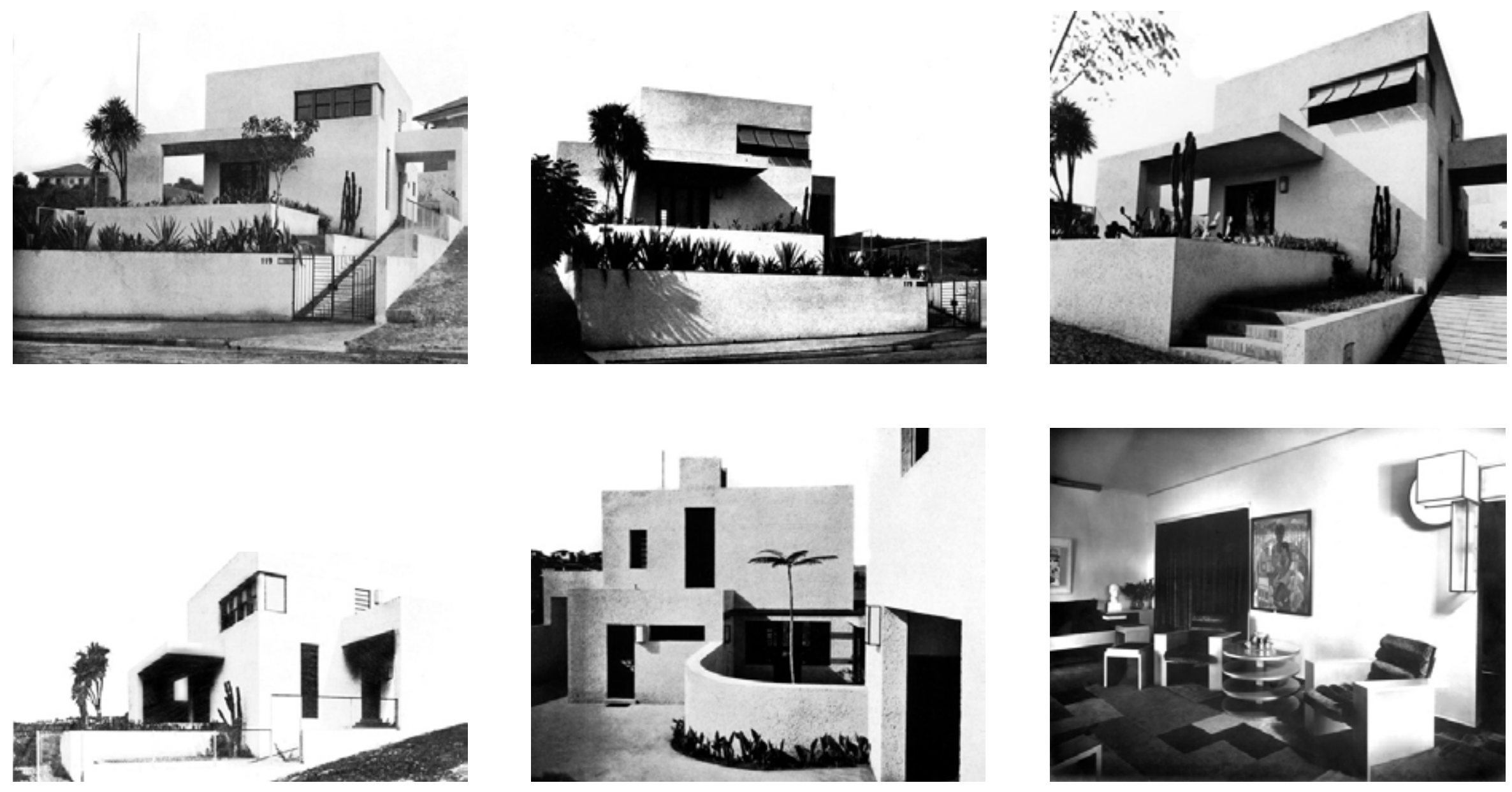


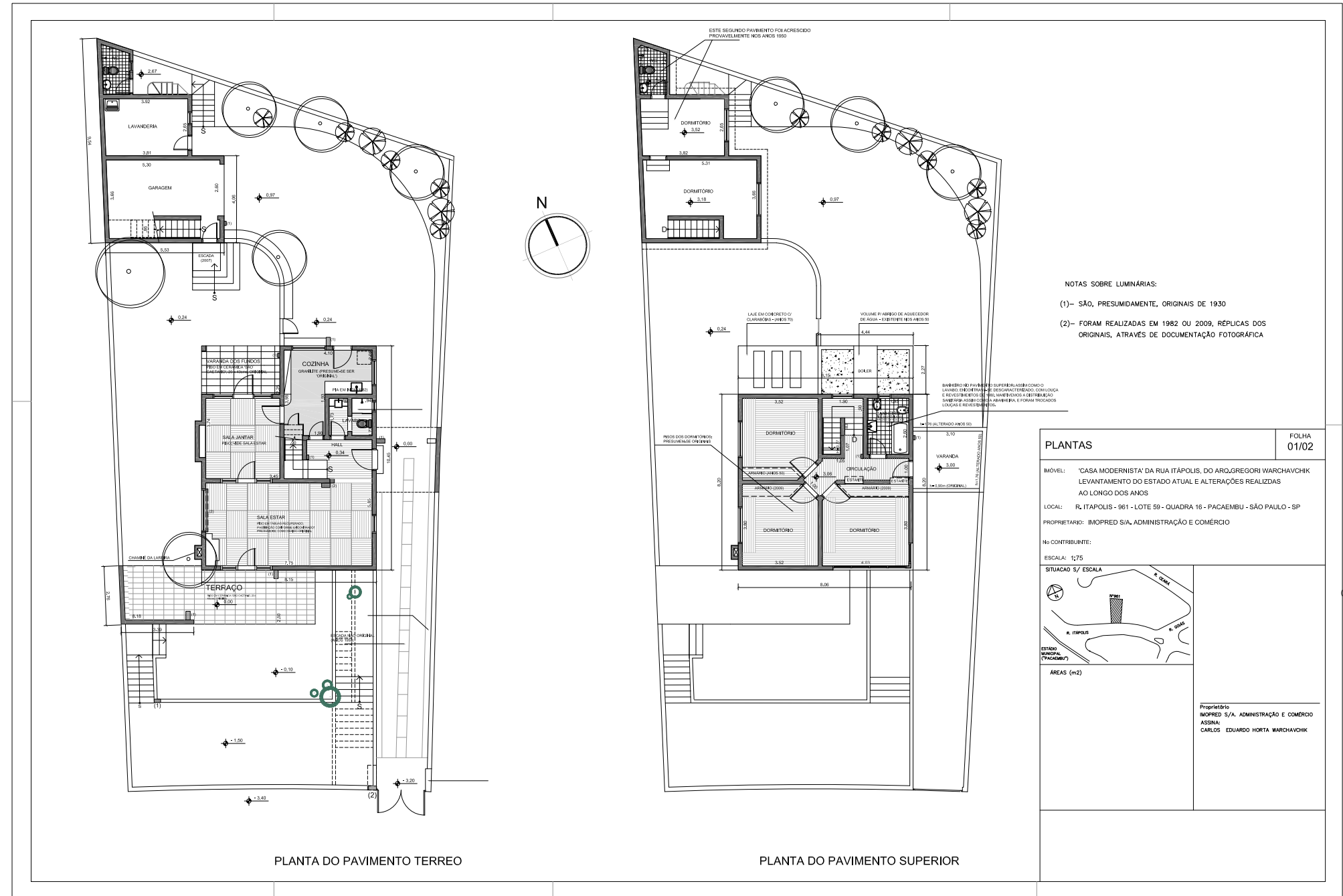

Plantas do térreo e do primeiro pavimento (escala 1:75) 


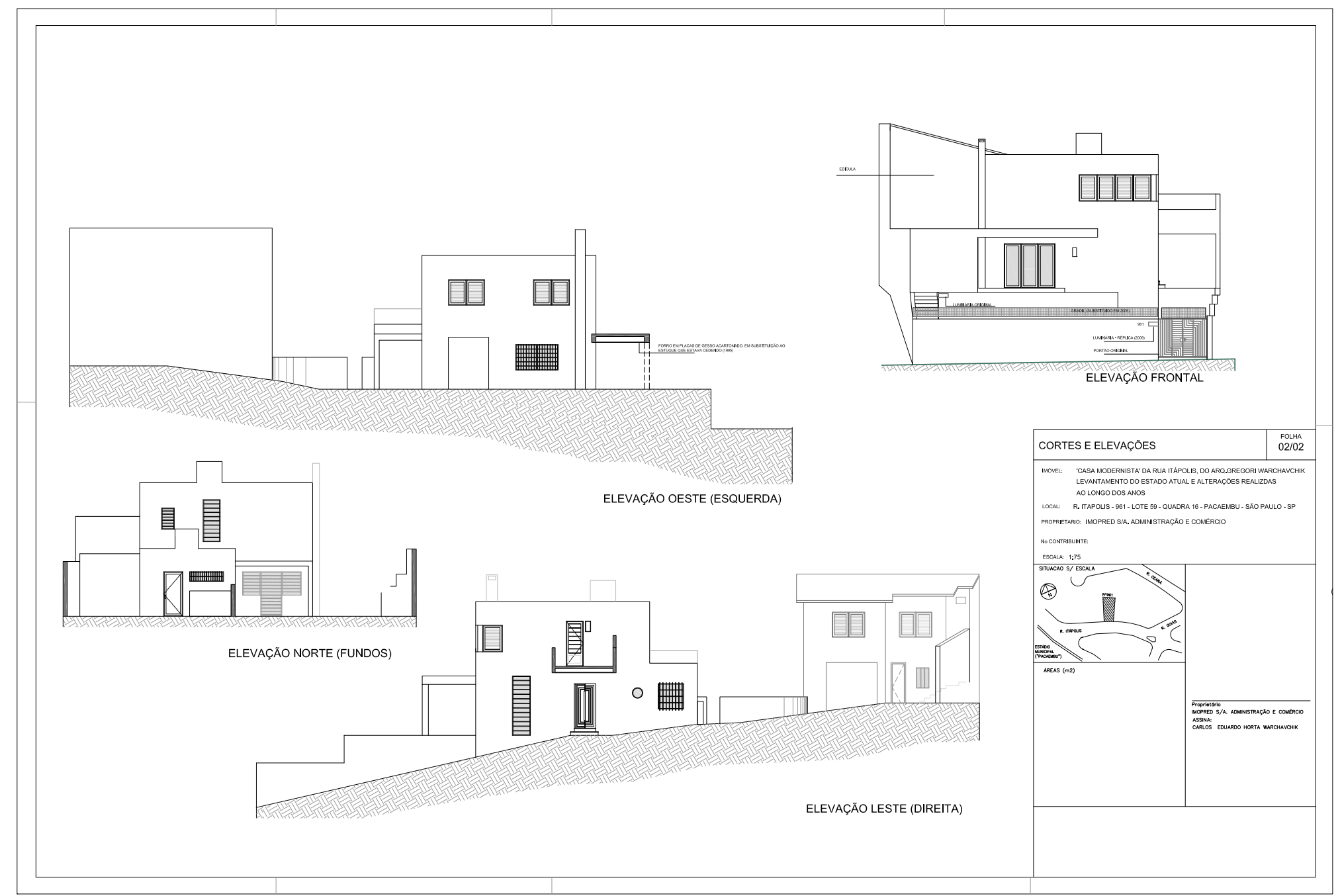

Elevações (escala 1:75) 

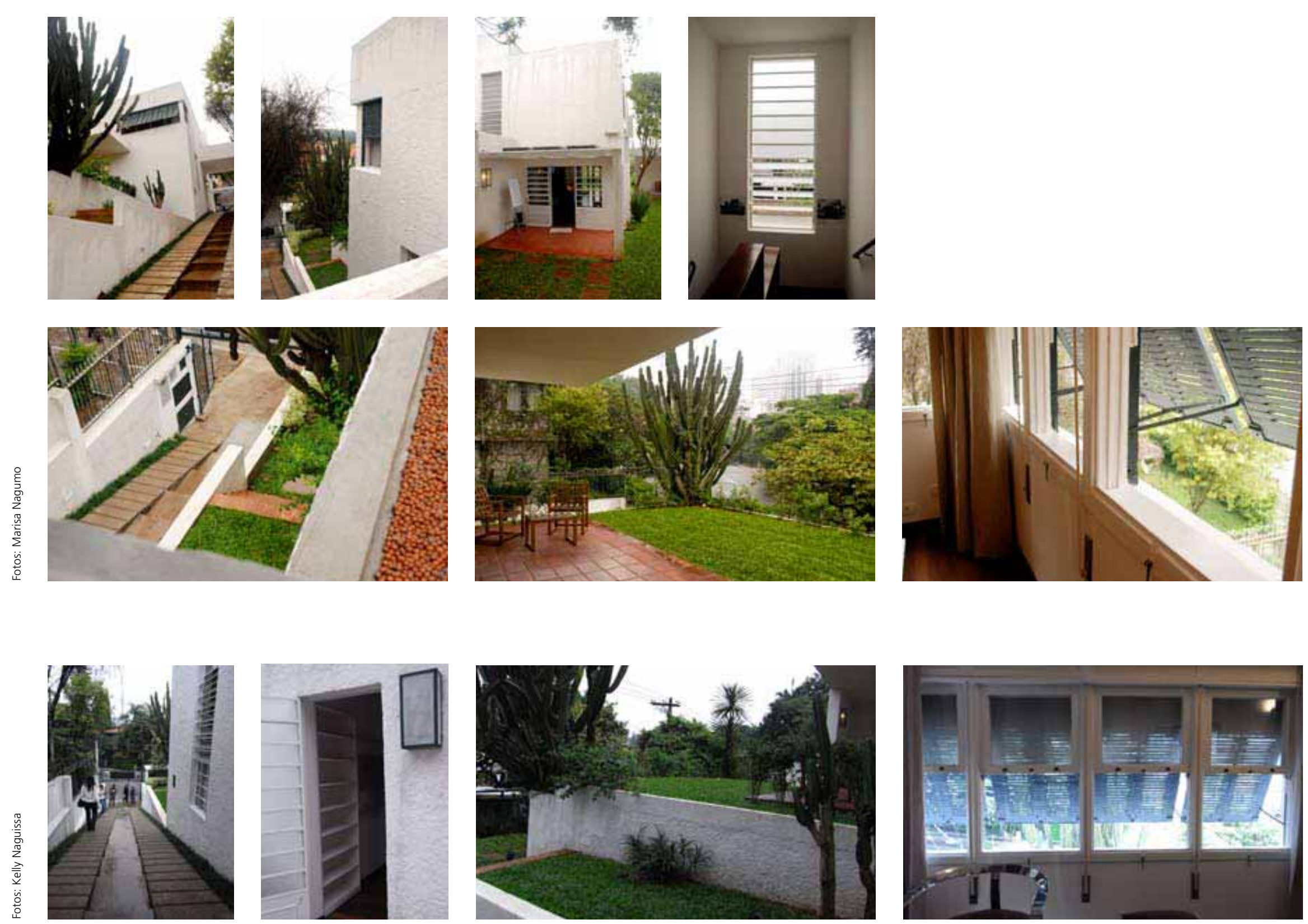

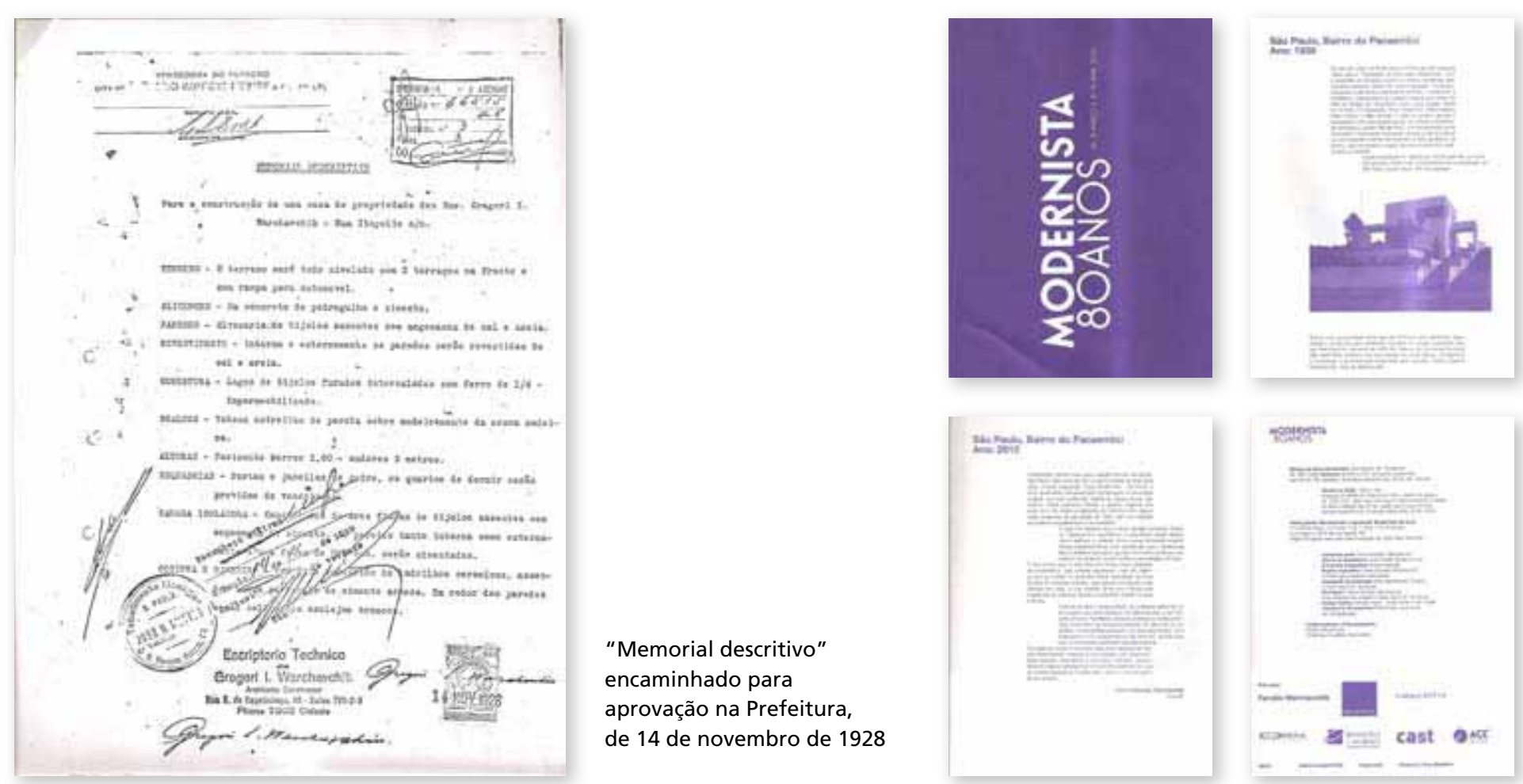

"Memorial descritivo"

encaminhado para

aprovação na Prefeitura,

de 14 de novembro de 1928
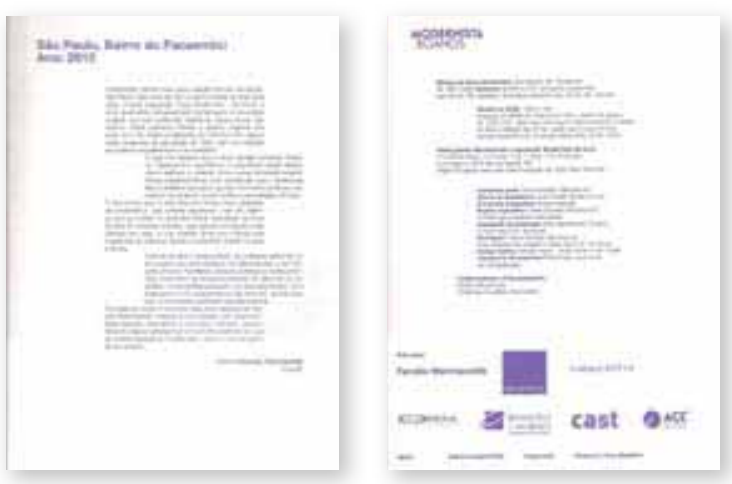

Catálogo da exposição

"Modernista 80 anos",

de 26 de março

a 21 de abril de 2010
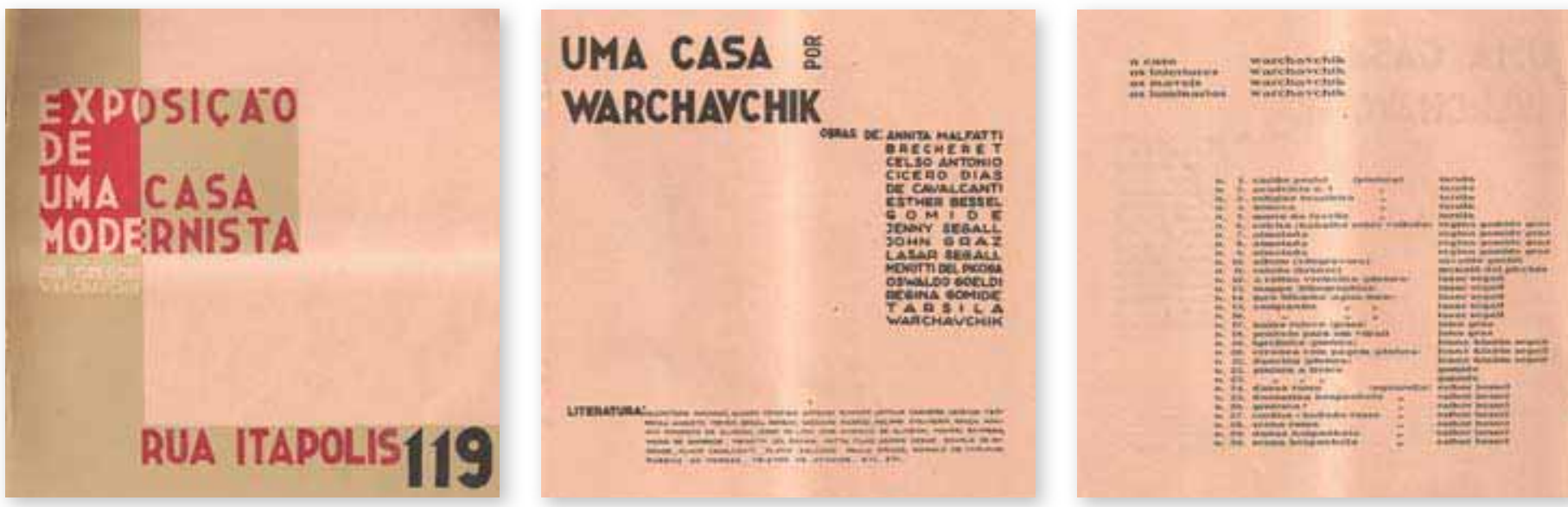
[APOENA AMARAL] Então, estou estudando a intervenção no patrimônio moderno e a gente acabou usando as residências para estudo de caso. Pareceu oportuno. Porque, dentro do patrimônio moderno, você tem, em São Paulo particularmente, residências e as obras institucionais, escolas. Mas, pouca coisa consolidada. Pode-se dizer " a FIESP [Federação das Indústrias do Estado de São Paulo] é um caso", mas muito de exceção. Principalmente no caso das instituições, tem projeto, mas não tem obra, ou nem tem projeto. Você vê a FAU [FAU-USP, Faculdade de Arquitetura e Urbanismo da Universidade de São Paulo] do jeito que está... Aí as casas acabam sendo uma feliz coincidência. O Angelo [Bucci] já tinha feito há alguns anos a reforma da Baeta, o Paulo [Mendes da Rocha] tinha feito a Millan em 2000, 2001, aí as coisas foram surgindo... Essa do [Carlos] Lemos concluiu o ano passado... Mais a da Itápolis. Aí a gente achou que casa era um exemplo bom.

[CARLOS WARCHAVCHIK] Casas que foram restauradas ou mexidas. Atualizadas.

[AA] Eu estava querendo pegar esse foco, mesmo, que é a metodologia de projeto. Pensando como é que foi. Em alguns casos... A Baeta, por exemplo, não fez projeto antes. Foi fazendo junto. Também pela particularidade de ser o irmão [Eugênio Bucci] que comprou a casa. Então, eu queria saber um pouquinho dessa história. Como é que foi.

[CW] É curiosa essa história desse restauro, digamos assim, porque eu não tinha um projeto, junto com uma indefinição de vida minha também. Separado, não sabia... Tinha acabado de mudar de casa. Se eu soubesse que essa casa estivesse vaga, talvez tives- se vindo pra cá quando eu separei. Aí ficou aquela coisa meio "o que é que eu faço da minha vida, o que é que eu faço com a casa". Foi uma coincidência, assim. Aí o primeiro impulso eu quis atualizar a casa para colocá-la no lugar. 0 que a gente fez foi problemas de pequenas patologias, coisinhas assim: água, água quente, fissurinhas, infiltrações. Isso era uma coisa que estava ocorrendo um pouquinho na laje de cobertura. Aí eu achei que era bom atualizar a parte elétrica, coisas assim, que não ia mudar em nada... Aí quando entrou naquela mini obra, coisas assim, eu comecei a mergulhar no projeto. Como tinha essas plantas aqui, comecei a estudar um pou co. Só aí que eu percebi que estava completamente alterada esta frente. Eu nunca tinha atentado para esse detalhe desse projeto, os pequenos detalhes. Mas, aqui, toda essa jardineira, esta parte aqui, eu não conseguia entender porque este portão estava mais alto do que o muro, sendo que ele sempre teve esse alinhamento, essa composição. Falei "esse portão foi trocado. Deve ser outro portão". Tive a pachorra de, numa foto mais próxima, contar todas as horizontais Aí falei: "não, é idêntico. É o mesmo portão. Como é que ele está. . Alguém quebrou esse muro, demoliu o muro. Que coisa bizarra pra se fazer!" . Aí percebi que esta escada aqui estava demolida, tinha uma outra escada que vinha aqui debaixo, de concretão, cimento, uma escada muito mal feita, vinha aqui e quebrava toda essa volumetria. Eu disse: "Você quer saber? Vou fazer toda essa atualização aqui e vou fazer na raça esse negócio" . Aí peguei e refiz esta escada esta aqui com tijolo laminado, igual... Tinha uma escada origina nesse lado aqui com tijolo laminado. Aí vi que era muito parecido com o tijolo de hoje, não ia mudar nada, refiz esta escada aqui. E no meio desse processo, minha vida também foi mudando. Eu já estava quase noivo, já estava com uma pessoa e ia alugar pra ela a casa... O melhor dos mundos! Vou alugar a casa para a Alessandra minha namorada, e eu fico aqui cuidando, fico em cima... Enfim, estava dando certo. Mas, aí ela veio: "Isso aqui... Vai pintar aqui?" . Aí eu disse: Será que isso vai dar certo? Minha cliente... "Isso aqui não vai pintar. Isso aqui está bom assim!". Aí começou umas briguinhas normais de arquiteto com cliente. Aí eu disse: Quer saber? "Talvez ela não vá ter dinheiro pra pagar esse aluguel também... Melhor esquecer essa história" . No meio disse eu queria era morar com ela, mesmo. Vamos morar nós dois nessa casa e vamos "casar" ... bem, enfim, não importa, vamos vir morar aqui.

Como eu tinha feito esse restauro aqui da frente, falei: Antes de voltar pra essa casa, podia abrir essa casa ao público pra refazer... Vai fazer 80 anos da exposição de 30. Vamos fazer mais um evento, uma coisa e tal. Aí chamei o Piratininga, que são amigos, me ajudaram a levantar os fundos e fazer. Eles mesmos acabaram bancando uma parte. Eu e eles. Enfim, fizemos aquela exposição. Acabou, então, tudo se casando. Falando muito em casamento... E depois fiz a minha festa de casamento. Acabei casando, mesmo, mais formalmente. Depois da exposição, fechamos de novo a casa com tudo e casamos aqui.

Mas, voltando aqui à parte mais física. Acabei descobrindo que, o que aconteceu, é que, por algum motivo, a rua subiu, sei lá... Calçamento, alguma coisa aqui da calçada e esse portão foi posto mais pra cima. E tinha também aqui uma entrada de luz. Esse poste aqui. Antigamente você sentava aqui ou aqui, não sei... Estava entrando bem aqui. Então tinha aqui um volume que atrapalhava toda a leitura da geometria. Então, mudei isso pra cá (estamos em "flash back", voltando pra antes da decisão de casar...). Mudei isso pra cá, a entrada de luz, livrei isso aqui. Aí, o que eu fiz? Eu subi esse muro aqui, já que o portão não podia baixar mais, por que só se ele ficasse abaixo da terra... E, depois, você olhando 
você vê que tem uma rampinha de leve, mas, se eu quebrasse essa rampinha, primeiro o carro ia fazer assim... E, depois, acho que mesmo assim não seria suficiente. Teria que baixar quase $20 \mathrm{~cm}$. Então eu subo uma fiadinha de tijolo aqui, pra ficar no nível. Aí eu vejo que acabei alterando essa relação aqui. Isto aqui ficou menor do que era. Aí eu disse: "Será que eu fiz burrada? Devia ter feito o negócio mais certo, mais consultado... " Aí eu não tive dúvida: levantei esse aqui também pra voltar ao que era. Aí agora eu mexi... Tinha um degrau muito chato aqui, desse... Não sei se cedeu essa terra... Mas um degrauzinho que pessoa com um pouco mais de idade já tinha que segurar alguma coisa... Tinha uns $22 \mathrm{~cm}$, mais ou menos. Eu estava com dor no joelho, pra descer aqui era ruim. Então eu subi esse muro aqui, ficou tudo na mesma proporção, e aqui ficou com uns cinco centímetros de desnível... Ficou nivelado. Única coisa é que isto daqui alterou e essa distância daqui pra cá alterou, mas isso é uma coisa que você acaba nem percebendo.

Outra coisa que alterou é que isto daqui estava... Quando subiu esse muro aqui, ele ficou mais alto, neste ponto zero aqui de encontro não existia mais. Só que isto daqui estava tudo arrebentado, estava feia essa rampa... Aí o que eu fiz? Havia uma escada aqui, nesse central, uma escada de água e também para as pessoas. Mas essas jardineiras laterais estavam cimentadas. Eu refiz, então, por cima da rampa, eu refiz uma rampa igual à original, mas eu mantive a escada, porque eu achei que na rampa, uma senhora, alguém com salto, na chuva... Enfim, quem fez a escada deve ter feito por um motivo prático. Então eu refiz essa rampa, com esse desenho, com as duas jardineiras laterais e voltou a ter esse ponto zero aqui.

Então, na verdade, foi um restauro, mesmo. Voltei a ter esse movimento das janelas de abrir assim, que não serve pra muita coisa, serve só pra tirar foto, quando alguém quiser tirar essa foto, eu abro...
[AA] No fundo, também, o que é a imagem da casa pras pessoas, a imagem consolidada, também faz diferença. Porque você diz "a janela não importa", aí muitas vezes as mudanças começam assim... Nada é importante...

[CW] Mas, você vê, quando eu comecei a casa nem projeto de projeto eu tinha. Vou trocar os fios aqui que está precisando, vou ver o não sei quê da... Troquei - como é que chama? - a impermeabilização de cima... Porque a Dulce [Vainer] até falava - a Dulce era moradora, ex-mulher do André Vainer, morou 20 anos na casa - "Seu avô é que sabia fazer impermeabilização" - essas mitologias - "Eu falei pro André". A casa deles sempre dá problema, porque não tem laje, porque trinca, porque vaza... Esta casa tem 70 anos, 80 anos e não vaza". 0 mês que ela resolveu ir embora ficou tudo preto. Coincidência... Mas, acho que isso aí não é mérito do meu avô, a impermeabilização já devia ter sido refeita ao longo desses anos. Acho que é uma coincidência. Meu pai, ele deu uma bela restaurada antes da Dulce entrar. Aqui atrás que tinha... Aqui... Não dá pra ver direito na foto, mas isso aqui é um pergoladinho de madeira... Meu pai fez um pilar de alvenaria e uma laje... É bonitinho até... Tipo pergoladinho, mas de alvenaria, laje... Então tá lá. Isso eu mantive.

Outra coisa que tem, que eu desconfio que foi até o meu avô mesmo que fez, aqui, tem um voluminho que é do boyler, mas ele conversa bem com este volume aqui da caixa d'água, está bem na geometria. Isto aqui eu mantive também. E que mais? Eu troquei todo este piso aqui. Quer dizer, eu mantive o piso, mas ele estava muito... Os barrotes, embaixo, estavam podres, completamente. Sabe aquele piso que você andava assim e ficava balançando? Eu tirei, refiz, perderam alguns e eu tive que repor no meio, mas mantive a paginação que era tipo damas, assim, interessante.
Aí eu refiz essas partes, porque me empolguei com a coisa do restauro. Fui olhar todas essas luminárias que eram parte integrante da casa. E refiz. Mas, aí foi assim: pegava a régua aqui media, mesmo.

[AA] Não tinha os desenhos...

[CW] Não tem nenhum desenho. Essa foi mais difícil, porque você vê que ela tem uma geometria estranha. Tem um círculo do outro lado. Ela é bem complicada. Aí eu descobri essa... Você vê por aqui, que é mais escura... Nós descobrimos lá essa cor de parede meio vinho. Você foi à exposição? Então, estava lá. Descobrimos aqui, depois, um verde. E aqui, em algum lugar do texto, diz que tinha um verde claro. E a gente refez o verde claro, porque a gente achou um mini fragmento, um pigmento do verde... E aí foi uma grande pena porque, num destes andares aqui, o pedreiro descobriu, o pintor aliás, uma cor original, amarela assim. Achei curioso, na hora não falei nada assim... Aí passou o fim de semana, quando fui ver, ele descascou tudo, perdeu... Só lembro na minha cabeça.

Essas cores aqui... Não era o branco que a gente acha... Era super colorida a casa. Acho que por fora era mais branquinha, mas por dentro... Que mais?

A edícula foi um caso mais diferente, aqui... Eu tive momentos mais preservacionistas, em que eu pensava naquela coisa do restauro, na exposição e outros momentos mais... "Não. Vamos atualizar. Essa casa tem que ser vivida...". Então, em um desses momentos assim, eu fiz uma pequena abertura aqui. Porque quando você vê aqui essa... São coisas que você pode voltar ao que era facilmente. A casa tinha uma coisa que era bem antiga ainda, que era essa coisa dos fundos e frente. Está aqui a área de serviço. Não há comunicação. A edícula é enorme. Tem dois quartos aqui em cima. E o jardim, proporcionalmente, não é tão grande. 
Então eu fiz esta pequena abertura aqui e a gente consegue passar da cozinha, passar com coisas pra cá. A gente usa muito este portão. Integrou mais a casa. E aqui eu abri uma portinha, que aqui já estava toda alterada mesmo e aqui fez uma sala de TV moderna, home theater. E aqui em cima eu fiz um quarto pro meu filho. Quando ele está lá ele dorme aqui. E aqui ficou o quarto de empregada, que já é suficiente.

Então, você vê: tem esses momentos de atualização, outros de restauro, outros só de coisas técnicas, de botar em funcionamento. Aqui, essa foto da edícula. Eu não entendo muito esta foto. Esta coisa aqui atrás. Eu imagino que seja o vizinho lá de trás. Eu não sei. Está difícil de ver. Mas, o que tem hoje lá é um telhadinho. Então, já está bem ferrada essa edícula. 0 certo era voltar a ter esta coisa quadrada aqui. Hoje em dia aqui tem uma portinha. Uma escadinha. Também é uma coisa que, se um dia alguém quiser restaurar, demole a escada e fecha a porta. Não é nada que...

0 resto são coisas que eu acabei restaurando, como essas luminárias. Fui descobrindo uma e outra e tal. Tinha umas que eram originais e estavam lá.

No meio do processo teve até umas decepções com a casa. Tinha coisas que eu jurava que eram de um jeito e eram de outro. Por exemplo, aqui, eu jurava que a casa era de concreto. Óbvio. o Carlos Lemos já tinha aquela teoria dele que a casa da Santa Cruz, modernista, é uma casa de transição, casa "meio do caminho", híbrida. A última casa de tijolos, digamos assim. Toda despida de ornamentos, mas ela ainda é tradicional. Tem o telhadinho escondido. Tem assoalho, estuque... Todas aquelas coisas bem tradicionais. A única diferença é que ela é... Inclusive assimétrica, a fachada, as concessões estéticas assim... E essa aqui não. Essa aqui, tudo bem, pode ser considerada... Tem alguma coisa com 0 meu avô o Carlos Lemos... Mas... "Aquela lá se quiser considerar, tudo bem". Alguma coisa assim. Porque já tem uma planta mais livre, o concreto... Para a família, esta era a "casa modernista", que meu avô chamava assim. A outra era a casa dele. A da Vila Mariana era a casa que ele morava. A gente nunca dá muita bola pra casa que a gente mora. Enfim, eu achava que tudo era concreto e vim descobrir que é tudo estuque aqui, tudo madeira, tudo assoalho. Viga de madeira com assoalho e estuque em baixo. De concreto aqui só tem a laje de cobertura, este terracinho aqui, isto aqui que é a cobertura da cozinha e a varanda da frente. Inclusive está desenhado errado nesta planta aqui. 0 que tem é uma viga chata que sai aqui e vem pra essa ponta e aqui tem outra viga chata, em baixo desta parede central. Então estas duas vigas estão travadas pelas paredes que estão em cima delas. Essas vigas que sustentam mesmo uma capinha de concreto, em cima. Aqui está faltando um pedacinho, que avança pra cá, que dá toda a diferença.

[AA] Ah... eu tinha visto na foto. Está alinhada com o primeiro módulo do caixilho...

[CW] Isso. Ela está mais... la ficar mais sem graça aqui. Mas, enfim, tem essas duas vigas aqui. Inclusive a gente pendurou uma escultura, outro dia, que pesa 180 quilos, do Nelson Felix [Nelson Tavares Felix de Oliveira], aí eu até chamei o engenheiro: "Posso pendurar nesta viga aqui?" Porque é a única viga em balanço. Ele disse "Pode. Nós temos as plantas estruturais aqui". Ele ficou olhando... "Lembra que esse ferro aí tem 80 anos e era outra tecnologia". Mas, está lá.

Essas janelas eu também descobri que já estavam modificadas. Alguém trocou no meio do caminho. Uma pena, porque são muito mal feitas. Que mais?

Aí apareceu o IPHAN [Instituto do Patrimônio Histórico e Artístico Nacional], bravo comigo, porque eu fiz tudo isso sem falar com eles... Eu entendo os caras... Mas, sabe, quando eu fui fazer, se eu for falar com eles vou ficar um ano aqui, sentado, esperando... Porque os caras são devagar... Mas, eles apareceram lá... Pediram pra eu mandar uma planta... Já que eu já tinha feito besteira, avançado os faróis sem falar com eles. Então, "manda uma planta com tudo o que você fez" ... Para adequar... Espécie de um TAC [Termo de Ajuste de Conduta]... Parece "um termo de adequação de conduta" ... Tá bom. Mandei a planta, mas por algum motivo não chegou a planta... Consultei... Ah! Deixei com a menina, que ela ligou... 0 cara estava de férias. Recebi uma cartinha dos caras depois de uns seis meses: "Tem 48 horas para apresentar aqui a planta, se não, não sei quê..." . Aí mandamos. Aí veio outra cartinha, que eles foram fazer inspeção lá. Aí apareceram uns quatro caras. Ficaram lá passeando. Aí tudo bem. Eles estavam como falando "Nós estamos cuidando... A gente sabe que você é arquiteto, neto, que você tem direito... A gente sabe que você não está querendo ferrar...".

[AA] É... Eu até estava falando com o Paulo [Mauro Mayer]. Você poderia ter uma... Enfim... É uma feliz coincidência de ser o neto, mas...

[Cw] Eu poderia estar fazendo alguma besteira...

[AA] Você poderia estar radicalizando... Até porque existe essa corrente onde o novo é o novo e eu não quero... Quer dizer, modifica só, retorna só as coisas que foram mudadas de maneira muito grosseira, mas incorporam outras e propõe coisas novas bem radicais. E é aceito no meio, no metiér dos restauradores, etc., etc.. Poderia... Mas, fico pensando: como as pessoas reagiriam? Nossos órgãos de patrimônio são um pouco... Travados... Não sei... Eu tenho essa impressão. Impressão. Você vê: tudo o que você fez, você faria... Quer dizer... Eu estava falando com o Paulo: Se você não fosse neto, como seria? Ele falou: Não sei! 
[CW] Não é só questão de ser neto. A casa está com a família desde sempre... Então, ia ser estranho... Até uma pessoa do IPHAN falou isso: "A casa sempre foi de vocês... A gente fica até meio assim...". Enfim, eu entendo, acho que os caras também têm que... 0 gozado é que o CONDEPHAAT [Conselho de Defesa do Patrimônio Histórico, Arqueológico, Artístico e Turístico] e o DPH [Departamento do Patrimônio Histórico] caem fora quando tem o IPHAN no meio. Vai pra esfera federal...

\section{[AA] Aí eles decidem...}

[CW] É essa coisa federalista de quem manda... Teve algumas dificuldades. Por exemplo, o revestimento. Muito interessante. Tudo assim rugoso, cheio de volumes, de caroços... Dá uma luz bonita. A gente não conseguiu refazer isso direito de jeito nenhum. Fica assim... Eu pus ar condicionado split pra não ficar aquele troço... Mas aí teve que passar o tubinho. Ficou a cicatriz. Nós não conseguimos refazer esse negócio direito. 0 cara do IPHAN falou, foi tão complicado... Ele falou: "Vai in loco, mesmo. Não, você tem que fazer isso, com cal, vai e passa, tira, põe..." . Enfim, eu acabei..

[AA] Então, manda por e-mail... Esse esquema da receita de bolo... Se é tão complexo, não dá pra fazer assim... Difícil... Depois, também... Um processo de dois anos, mais ou menos, entre começo e... ? É um processo, mesmo. Não é uma coisa assim: faz um projeto lá, uma semana, faz um projetinho... É uma coisa que é a própria descoberta do que é.

[CW] Teve uma outra coisa curiosa. Quando eu comecei a mexer na casa, estava bem no começo, ainda estava naquela coisa que eu estava pensando de só dar um jeitinho na casa pra alugar, apareceu tudo alagado. Inclusive na sala de jantar entrou água.
Um dia de chuva. Lá pelo fim de ano. Aí não estava drenando nada este jardinzinho aqui. Aí a gente pegou e fez uma drenagem nova jogando pra rua, aproveitando a queda. Aí esse piso aqui super legal, cerâmica São Caetano e tal... Se quebra alguma coisa... Tinha um quebrado na escada, eu arranjei um parecido, num cemitério de azulejo. Achei um mais ou menos. Aí eu cheguei um dia e os caras estavam quebrando o jardim pra passar... Bem aqui. Pela varanda e joga aqui na rua. Cheguei aqui e o cara arrancou aqui essa fiada... "Você é louco! Isso aqui não tem mais, não sei quê...". Ele falou assim: "Compra outro". Eu falei: "Você tá louco. Como vou comprar outro? Isso não existe mais!". E ele: "Mas tá velho. Faz um outro piso". Aí começou dar bronca no outro cara... Ele arrancou, por uma felicidade, sem quebrar nenhuma! Passou a Makita [serra circular] e tirou a fiada inteira da cerâmica São Caetano. 0 cara sabia que a casa era tombada, estava zoando comigo.

\section{[AA] Mas na hora...}

[Cw] Ele resolveu tirar uma com a minha cara! Mas, teve uns episódios engraçados. Não sei como conseguiu tirar sem quebrar nenhum! Às vezes, você vai arrancando e chega na última que estava mais grudada...

[AA] De fato é difícil... Às vezes, até um defeito interno...

[CW] Mas, mesmo assim, entre mortos e feridos, foi uma experiência bem legal, bem interessante. Agora estou fazendo uma coisa bem parecida lá na Barão de Limeira, do meu avô. Mas esse é tombado apenas pelo CONPRESP [Conselho Municipal de Preservação do Patrimônio Histórico, Cultural e Ambiental da Cidade de São Paulo]. Estou fazendo aprovado e tal.
[AA] E o processo?

[CW] Nossa! É demorado!

[AA] E lá você chamou pra fazer prospecção pictórica?

[CW] Não. Acho que lá sempre foi um prédio mais simples... Baixa renda, média renda. De pintura não tinha nada de excepcional assim. Mas, o restauro lá está sendo mais... Tem muita madeira que é bonita... muita sucupira. Isso está fácil de refazer. Ainda tem. Os mármores travertinos, que por sorte ainda se encontra. Mas, é um processo parecido, assim.

Eu sempre gostei de restauro, mas nunca pensei... Sempre achei que também é um tanto limitador...

[AA] Essa sua conclusão, que é muito interessante... Você começa a estudar... Também para mim foi meio por acaso a escolha. Hoje em dia tem disciplinas. Na nossa época não tinha nada disso. No fundo, o restauro é um conjunto de ações em que você preserva coisas e altera outras... Porque sempre se acha que o restauro é deixar o original... Na verdade, o restauro engloba todos esses procedimentos. Como você estava falando: em dado momento você se deparou com a necessidade de modernizar, em outro momento...

[Cw] Claro que, mesmo no momento de modernizar, não ia fazer uma burrada, descaracterizar... Mas, você sempre fica meio... Quanto você vai...

[AA] É que tem uma vertente que diz que você deve deixar apenas a marca do seu tempo. Mesmo que você vá voltar à volumetria você deveria fazer com uma outra tecnologia. Se foi em tijolo, fazer em concreto. E deixar visível... 
[CW] Como em São Luís do Paraitinga... O Carlos [Lemos] estava falando da igreja que vão reconstruir. Que não deviam fazer a besteira que fizeram no Pátio do Colégio.

[AA] É um assunto complexo. Essas bases teóricas... Não é uma coisa simples. Discute-se isso de maneira bastante aprofundada. Mas, a arquitetura moderna tem um porém. Essa proximidade temporal, que é bom e ruim. Todo material é mais disponível. Se encontra plantas, se encontra tudo. Por outro lado, com a proximidade temporal, toda a tecnologia, a técnica construtiva é a mesma que a gente usa hoje. Não tem nada de... Ah... O cara tinha um tipo de técnica com pedras... Não. É a técnica que a gente tem hoje. É como a gente faz a casa hoje.

[CW] Mas, quanto à fachada eu não consegui. Deve ter... Difícil de achar.

[AA] Mas, se você tem lá a capa original, em dado momento, se precisar. .

\section{[cw] Alguém consegue.}

[AA] Por exemplo, eu sei que tem um pessoal do IPT [Instituto de Pesquisas Tecnológicas] que só cuida de argamassa pra fachada. Os caras, você vai lá e os caras vêm com uns aparelhos, extraem... Coisa de laboratório. Tem como fazer. Óbvio que tem um custo. Mas, se não remover o original, em algum momento... Um pouco o que eles falam da Arqueologia, hoje. Eles nãos escavam tudo. Eles escavam um pedaço. A ideia é que daqui a 100 anos as pessoas terão técnicas mais avançadas que irão danificar menos. Então, acho que o restauro hoje passa um pouco por esse... Você vai tentando não fazer bobagem. Tudo requer um certo cuidado. É claro que é diferente de qualquer reforma, por ser um patrimônio. Mas, você acha que seria tão diferente se fosse fazer o restauro de uma casa do século XIX, do século XVIIII? Teria que se usar o mesmo cuidado. Metodologicamente seria parecido. 0 que se tem visto... Numa literatura super recente, na verdade. Se você pensar a Carta de Veneza é dos anos 60 e aqui chegou em 70. Tudo um pouco demorado. Os textos de arquitetura moderna então... Na Itália o pessoal está escrevendo agora, há uns 20 anos. É muito recente! É duro porque questionam: Quais são as bases teóricas? Mas, é tudo muito recente! Na verdade, como as coisas começam a ter que ser restauradas agora, é agora que as pessoas estão se deparando com todo esse problema. Então, não há um procedimento já consolidado.

[CW] Acho que começou - lembra? - há uns 15 anos, 20... Que começou uns cursos de restauro de arquitetura moderna.

[AA] Há uns anos atrás teve uma "onda" ... Acho que uma certa coincidência...

[Cw] Villa Savoye [de Le Corbusier] foi restaurada nos anos 80 ou 90 ..

[AA] Depois aqui teve a Pinacoteca [do Estado de São Paulo], que não é moderna... Mas, depois o Paulo fez a FIESP... Então, né? Muita coisa que acabou despertando até pras escolas, que hoje faz parte do currículo, tem disciplina específica. Diferente da nossa época... Enfim... a ideia era um pouco essa...

[CW] Uma coisa que eu não falei muito é banheiro, cozinha e lavabo. Não há nenhuma foto registrada. Nada. Então, cozinha a gente deixou do jeito que estava. Tinha um azulejo que não era original. Nem a pia era original. Mas eu acabei preservando a pia. Azulejo eu troquei, pus novo. Uns armários - que eu acho que têm cara de ser coisa do meu avô - eu mantive, até completei um pedaço que faltava. Agora, o banheiro de cima foi uma opção estranha. Eu tinha a planta dele só, a posição das peças. Nem achei muito boa, mas, enfim, coincidia com o que estava lá, então eu falei: Isso daí é o original. Mantive a banheira, pintei pra ficar menos velhinha... Tinha um piso plástico... Vinílico. Aí arranquei que estava meio velho e botei uma pastilhazinha meio anos 40, pastilha jatobá mesmo... Mas, foi da minha cabeça. Uma coisa pra ficar com cara de anos 40. E comprei uma pia de coluna. Uma coisa mais antiquadona. A que estava lá era uma celitezinha anos 70. Aí pus uma mais parrudona, cara de antiga, que a Celite tem até hoje. Aí foi mais uma brincadeira. Brincando de ser antigo.

[AA] Se não tem foto, não tem informação... Fica difícil.

[CW] Depois que eu fiz... Falta de comunicação com meu pai... Ele lembrou que era granilite o piso e a parede, aquela barra hidráulica de granilite. Não lembrava... Depois ele lembrou. Acho que foi até ele que talvez fez aquela cerâmica feia anos $70,80 \ldots$

Devia estar velho. Acho que nos anos 70 granilite era uma coisa assim muito... Acho que as coisas se deterioram com o tempo. É igual carro também. Quando o carro tem 20, 30 anos de idade... De repente, quando você vê o restaurado, fica bom de novo. Tira aquela aura... A mesma coisa aquele tijolo de vidro. Aquele que é riscadinho assim. Eu só conheci, na minha infância, velho, torto, quebrado. Aí começou aqueles onduladinhos novos. Ah! Este aqui é legal. Tijolo de vidro novo é legal. De repente, ficou bonito de novo aquele que era caneladinho. Porque está novo, bonito. Quer dizer, não era ele que era ruim, era que estava velho. 
Só conhecia o velho. Então, com o granilite acho que passou um pouco por isso também. Acho que com todos os materiais. Acho que nos anos 60, 70 era só coisa velha que tinha.

[AA] 0 ladrilho hidráulico teve essa fase...

[Cw] Exatamente. Aí volta, volta com outro preço também, mas com outra qualificação. Engraçado isso.

Aí o lavabo estava com uma cerâmica horrorosa, que eu descobri que era a mesma que estava na Barão de Limeira. Quer dizer, meu pai mesmo que fez. Então, o assoalho chegava e terminava num azulejo horrível, anos 70. Quem sabe daqui uns 30 anos, azulejo "anos 70" vai ser...

[AA] Vai ser difícil...

[CW] Aí tinha também uma piazinha muito chinfrim... Aí falei: Quer saber? Aqui vou dar uma modernizada também. Aí fiz uma piazinha de concreto. Fiz bem anos 2000 assim. Cimentinho à vista, com aquela pia cuba, de sobrepor. Aí fiz o meu projeto na cabeça... Teve vários momentos da casa que eu acabei mudando. Aí fiz um chuveiro, porque quando estão meus dois filhos lá... Ter só um chuveiro, um banheiro da casa dentro... No fim, meu filho acabou indo pra edícula. Fiz um outro banheiro lá pra ele. Talvez não precisasse. Mas acabei fazendo um chuveirinho em baixo do lavabo. Questão prática.

Então, o lavabo, realmente, dei uma modernizada total.

[AA] 0 que a gente tem visto é que casa é diferente de uma instituição. Por exemplo, a FAU. A FAU tem lá uma coisa ou outra, mas, as salas de aula... O programa não mudou. A casa precisa de adequações mais radicais.
[CW] As famílias mudam também. Às vezes está virando uma casa que é só um casal. Às vezes é um casal com três filhos... Bom, se você tem três filhos, talvez não devesse peitar... Também tem isso...

Agora, a FAU pode mudar também. De repente eles podem fazer um curso para 250 alunos, aí não vai caber mais.

Agora, a casa cabe bem na minha vida. Quando estão os dois filhos lá, cabem. Agora, a maior parte do tempo estamos só eu e a minha mulher, então... A casa está ótima...

[AA] Uma coisa pra te perguntar: por que as pessoas ficam aumentando tanto o programa?

[CW] É... Não sei. Eu achei divertida a coisa do banheiro lá de cima. Porque eu falei "Bom... Tem que fazer esse banheiro bem.. Ele é grande, não é? Poderiam ser dois banheiros, pelo espaço que ele tem. Mas, não tem bancada... Minha mulher e meu filho usando o mesmo banheiro... Três pessoas... Quatro. A edícula ficou pronta só neste ano. Quase seis meses ficamos quatro. Aí enchi de armarinhos e coisinhas. Tudo organizadinho. 0 banheiro é bem... Projeto de interiores quase. Toda essa linguagem bem antiguinha.

\section{[AA] Pra funcionar...}

[Cw] Aqui é armário, aqui é de remédio, aqui é de não sei quê... Aquela bancada moderna que tem hoje, além de ter em cima, em baixo você guarda coisa. Ali não tem nada disso. Deu certo. No fim acabou atendendo.

[AA] Casa tem essas particularidades. Ela tem essas micro transformações. Um pouco até de casos específicos. Vai pra lá e faz umas modificaçõeszinhas " $X$ ". Coisas que precisam. Você acha que, metodologicamente, quando você for reformar uma outra casa, mais contemporânea, você vai olhar com "outro olhar"?

[CW] Eu acho que sim. Você vai aprendendo. É impossível não absorver alguma coisa.

Ah, aqui acho que o Paulo deve ter te falado. Aqui ele fez uma janela e a lareira. 0 curioso é que, quem reparou foram uns franceses que foram visitar lá a casa. Eu estava mostrando as plantas. "Esta janela aqui não é original". Aí eles olharam... É que a planta tinha, a planta da prefeitura tinha a janela, é que não fo feita. Na exposição que a gente montou 0 ano passado, a gente fechou com tapume.

[AA] Ah... Quando ele falou da janela, eu até pensei que ele estava falando de outra janela... Quando ele mostrou a da prefeitura que eu...

[Cw] Esta marquise passa um pouquinho da janela, acho que pra dar um desenho mais simpático. Aqui, depois, o vizinho construiu a janela olhando pra cá direto. 0 meu avô aumentou essa parede aqui detrás. Uma pequena alteração que houve também. Bacana que, durante a exposição, apareceu um cara que morou lá antes da Dulce. Um cara que morou nos anos 60 , um pouquinho dos anos 70, eu acho. Morou criança. Morou com 10 anos, 15 anos. Ele lembrava bem da casa. Ele foi me dizendo as coisas... Aí eu falei "Eu demoli a escada que estava aqui". E ele: "Que escada? Sempre foi assim", ele falou. Acho que eu fiz um bom trabalho de restauro, porque sempre foi assim! Aí ele falou "Sabe o que está diferente?". Era o pergoladinho que eu te falei que meu pai fez. E umas madeiras que tinham aqui na frente, neste terracinho aqui. Como subiu este muro aqui, ele disse que o pai dele botou umas madeiras assim, porque tinha medo que o filho caísse lá 
de cima. Eu cortei fora essas madeiras. Ele disse que meu avô ia lá bastante, assim. Qualquer alteração ele reclamava. "Seu avô aparecia bastante. Ele vinha aqui. Cuidava. Não deixava mexer em nada!" . Aí que eu comecei a ver o histórico da casa. Meu avô morreu em 72. Aí estava alugada para um cara que estava entre a Dulce e esse cara aí. E esse cara, então, que eu acho que fez a escada, fez um monte... Fechou a varanda com caixilho. Porque meu avô não estava mais aí pra "torrar as paciências" ... E ele fez umas alterações lá. Aí esse cara foi embora em 80 e aí meu pai entrou e terminou de ferrar algumas coisas.

[AA] É um processo vivo, de transformações, de retornos, de acertos...

[CW] E aí a Dulce, a única coisa que ela fez, foi umas duas ou três daquelas luminariazinhas, que o André Vainer refez... Olhando fotos ele fez. Aí eu terminei de fazer as outras que faltavam.

Eu restaurei um pouco desse caminho que tinha, está vendo? Por esse lado aqui. Como tinha aquela escada horrível aqui, seccionava isso. Realmente não é muito prático. Você tem que vir por aqui, pra vir aqui e fazer aqui, aquele ponto zero. Você tem que fazer tudo isso. Não é muito prático. Mas, é legal porque faz este circuitinho aqui pro jardineiro, cachorro. Pessoas circulam. Seres.

Refiz. Tinha uma luminária aqui, bacaninha. Aqui e aqui, nessa da entrada, que era bem simpática. Deixa ver se aparece aqui. Está aqui. Pequenininha. Uma luminariazinha de canto assim. Eu refiz.

[AA] E a serralheria, assim, em geral? Teve muita coisa que estava oxidada ou não? Teve que mexer?

[CW] Tinham coisas, sim. Mas, são coisas que se usa ainda hoje. Então, é diferente de uma coisa...
[AA] Mas, teve que retirar, por exemplo, caixilho inteiro, mandou pro serralheiro e voltou? Ou era coisa bem pontual?

[CW] Mas Não. Era coisa pontual. Essa porta aqui não existia mais assim... Eram duas portas. Uma de madeira maciça mexicana. Nada a ver! E por fora uma grade. É que a Dulce... Teve um evento qualquer lá de assalto, roubo... Aí ela entrou na paranoia e encheu de grade na casa. Mais do que já tinha. Eu tirei umas dessas grades e aí restaurei... Eu voltei... Este caixilho aqui eu fiz meio chutando como ele devia ser, porque estas fotos não são muito claras... Mas, esse cara que foi lá disse que lembrava: "Era isso mesmo. A porta, tal.". Uma porta bem modernista, Gropius, ferrinho assim.

Agora, uma das coisas mais difíceis foi o serralheiro fazer isto daqui assim. 0 caixilho abrindo... "Não é possivel, isto daqui é um braço articulado. Isto daqui não vai dar certo". Fiquei dois meses. Ele levou um velhinho lá...

[AA] Mas tem tanto na cidade...

[CW] É... Eu não me lembro qual era a justificativa. Mas, enfim, resolveu fazer. Era meio cabeça dura. Ficou legal. Acho que não abre tanto quanto esta, mas quase tanto.

[AA] Então... Felizes coincidências...

[CW] É... 
ENTREVISTA PAULO MAURO MAYER DE AQUINO, 08/09/2011, SÃO PAULO [CURADOR DA "COLEÇ̃̃O GREGORI WARCHAVCHIK"]

[PAULO MAURO] Quando a casa voltou para a mão da família, o que aconteceu? O Carlos [Warchavchik] ... a primeira coisa que ele tinha que fazer... Foi assim... Não é restaurar. Seria reformar. Reformar a casa. A ideia inicial era reformar. Por quê? Porque na verdade era um grande problema... Aí é que eu falei pra você que pessoas não sabem o que falam em relação àquela casa: "Ah! Aquela casa é modernista, etc. e tal, mas tem um telhado". Não. A casa não tem telhado embutido, como é o caso da casa da Santa Cruz. Aquela casa... é uma laje e tem problema de infiltração, como qualquer casa que só tem laje. Aí o Carlos falou "Então tá bom. Vamos lá, vamos restaurar a casa. Vou reformar. Vou fazer o conserto da infiltração". Então, à medida que o Carlos foi trabalhando com a casa, foi também pegando gosto pela casa. É claro! Ela é um ícone da arquitetura moderna.

Uma coisa que eu defendo nessa casa, e que não é uma defesa só minha, mas é uma defesa como curador do acervo do Gregori [Warchavchik], é assim: a casa da Santa Cruz é a primeira manifestação modernista, mas ela não é a casa modernista para o Gregori. Você tem aquela questão... o repórter falando "Ah! A casa modernista! A primeira casa modernista". Essa é o que 0 repórter colocava, o que a manchete do jornal colocava. Mas, a casa modernista para o Gregori é a da rua Itápolis. Tanto que ele coloca a expressão "de uma casa modernista". Então, ele nomeia a casa como sendo "a casa modernista".

Além disso, o que a gente pode ficar muito claro, claro... assim.. se você pegar e ler o Manifesto Modernista de 25, reler, você vai ver que aquela casa é a interpretação do Manifesto. Então, tudo que ele edita no Manifesto, como clareza na fachada, e uma série de coisas mais legais, a linha, a volumetria, você vai ver que aquela casa contempla isso. Coisa que a casa da Santa Cruz ela é mais simétrica, ela se porta de uma maneira muito organizada. Eu acho que é uma das coisas. Além disso, o próprio telhado, que é mesmo um telhado embutido.

Vamos voltar à questão da casa. Então o Carlos pegou, restaurando a casa, reformando a casa, "Ah! Vamos fazer uma prospecção para tentar ver a pintura que tinha na época". Foi fazendo isso e foi descobrindo cores da casa. Pegava livros, pegava um documento, tentava ver, algumas coisas batiam, outras não batiam, outras coisas, por exemplo, o próprio Gregori já tinha reformado a casa. Porque aquela casa, quando ela foi inaugurada, ela não tinha janela no fundo, onde tinha um quadro da Tarsila do Amaral. Em fotografias, no livro, você vê que tinha um quadro, depois passou a ter uma janela. E não tinha uma lareira.

A casa, então, foi ganhando essa questão de deixar de reformála para restaurá-la. Então, diante disso, começamos a observar uma série de coisas: o que é, o que foi e o que o próprio Gregori também modificou.

Diante disso, então está bom, o Gregori modificou isso, na própria reforma que ele já faz quando ele vai morar lá na casa... Por que ele vai morar lá na casa? Porque está reformando a casa da Santa Cruz.

[APOENA AMARAL] Ah! Então ele vai morar lá enquanto está reformando...

[PM] É. Aquela casa para o Gregori? Não necessariamente. Por que não necessariamente? Por que é assim: Por que a casa foi construída lá no Pacaembu? Lembra que Companhia City dava isenção de imposto, dava algumas coisas, melhorias; um milheiro [mil tijolos]; saco de cimento? Era uma coisa... uma coisa que acontece hoje, aliás, que era essa questão de incentivos. Então o Gregori como tinha o terreno. Se fizesse uma casa lá tinha o incentivo de ganhar o material ou alguma coisa - não que necessariamente precisasse - mas era um incentivo e ele fez a casa. Então, não foi uma casa necessariamente pensando num cliente. Foi a casa pensando no Modernismo, isso eu te garanto. Ou pensando no Manifesto, pela forma que você lê a casa. Então, essa casa... o Carlos, na medida que ele foi vendo, a gente foi restaurando. A própria entrada da casa. A escada... tem a rampa da subida ali do carro, não tinha uma escada lateral. Na verdade, você passava pela entrada para sair para o jardim da frente. Então, coisa desse tipo... A gente tirou a escada que fo feita posteriormente, devolveu o aspecto antigo dela e aí fo tentando fazer algumas coisas. Algumas coisas foram restauradas? Foram. Seguindo o padrão da imagem do que a gente tinha como informações.

[AA] Iconografias?

[PM] Iconografias! Baseada aonde? É, bem colocado. Baseada em iconografias.

[AA] As plantas, não?

[PM] Plantas sim

[AA] Só os primeiros desenhos...

[PM] Sim. Até da reforma. Da reforma a gente também tinha o desenho. ... Na própria edícula ele faz um segundo pavimento 
que na primeira planta não tinha o segundo pavimento, só tinha o primeiro. Depois ela passa a ter um segundo pavimento, que é onde a empregada vai dormir. Porém, o quarto da empregada dá pra garagem, porque em baixo, na edícula era a garagem. 0 que acontecia com a empregada, quando você ligava seu carro? Matava a empregada sufocada, brincadeira à parte... Isso foi um dos alvos de aprovação da casa, dessa reforma. "Não pode ser aprovada porque precisa resolver o problema da porta". Aí ele tira a porta da posição que ela estava e modifica a porta para outra posição, para não mais ter interferência da garagem com o quarto da empregada, digamos assim, uma ligação direta. Então, há uma série de coisas assim, que foram sendo feitas algumas melhorias, dentro do processo.

Mas, voltando à questão agora, atual, eu acho que tudo foi decorrente, não teve um estudo prévio, não foi feita uma análise, que a gente falou assim: "Vamos restaurar". Por que eu falo "vamos" ? Porque aí é uma questão minha que enche o saco um pouco, eu falava "Vamos fazer tal coisa" e insistia um pouco, porque para mim aquela casa é um ícone. Para mim aquela casa deveria virar um instituto, ou uma fundação, ou alguma coisa ligada à família Warchavchik. Então, com isso, o Carlos tem essa coisa e a gente vai buscando informações.

Outra coisa importante, a gente tem uma luminária, dentro da sala de estar, que é muito bonita, que a gente tinha apenas o desenho dela via planta ou via fotografia, fotos, imagem. Nem via planta, via fotografia. Aí o que a gente fez? Pegou, também, pela escala da parede, grossura, largura, conseguimos reproduzir essa luminária. Então, essa luminária foi refeita. Uma série de coisas que a gente conseguiu ir refazendo, nós tentamos buscar o máximo para ser fiel à casa. E, então, com isso, fazer com que ela voltasse a ser 0 máximo possível... Sem necessariamente fechar parede... Porque, o que o Gregori fez, digamos assim, o que ele fez nós mantivemos, o que foi feito posterior pela própria necessidade do momento atual, a gente então retrocedeu. Seria um pouco assim. Por aí a ideia. Foi uma série de voltas. Acho que as principais foram a fachada, uma parte mais... dessa escada da entrada e o restante foi manutenção. E pintura, um pouco. Pintura acho que pegamos um pouco. Mas, não chegamos a pintar exatamente com as corres que foram pintadas. Não na casa inteira. Porque você tinha parte que era verde. A laje, o forro era verde. Ela tinha uma pintura, a Duco [nome comercial de pintura automotiva desenvolvida pela DuPont em 1920]. Pintura Duco é uma pintura tipo essa de carro. Mas, no caso, a gente não chegou a fazer tanto, mas tentou volta algumas cores, pintar próximo. Então, não existia uma metodologia não foi uma coisa pensada desde o começo, mas foi atendendo às necessidades, dentro daquilo que era possível voltar às origens.

[AA] Verificando esses detalhes... É. Um projeto desse tipo é muito sujeito a modificações. Você faz na prancheta, mas depois, quando chega lá, há muitas coisas que você não previu.

[PM] Tem uma coisa também... A casa, apesar de ter 80 anos... Mas, o mundo de lá pra cá... Hoje você tem computador, freeze uma série de equipamentos e eletrodomésticos que você vai ter que adequar essa casa. Afinal, o mundo continua, você vai ter novos equipamentos, até para melhorar serviços necessários hoje. Esse tipo de coisa o Carlos pensou. Sim. Tentar que a casa ganhe mais 80 anos, pelo menos.

\section{[AA] Então a parte elétrica foi refeita.}

\section{[PM] Uma boa parte.}

[AA] Inserção de novas tomadas... Uma casa viva...
[PM] É. Uma casa viva. Não é só uma máquina de habitar. É uma casa de morar e de contemplá-la. Quer dizer, você tem que fazer com que a casa tenha argumentos para ter valor, se não ela perde. É engraçado falar "argumentos" ... Porque tem uma coisa que eu falo muito em relação a essa casa... Uma coisa que eu descobri, uma coisa que foi bacana. As pessoas perguntam: "Os móveis modernistas...". Por exemplo, uma coisa que foi muito bacana, que as pessoas perguntavam... Isso é uma coisa que também desenvolve, porque é assim: Se o móvel - quando você para pra pensar que no período da era moderna você vai fazer tudo em série... Então, os móveis modernistas são em série? Não. Não necessariamente. Por que não necessariamente eles são em série? Porque na casa modernista não vem inseridos, necessariamente, móveis fabricados industrialmente. Esses móveis são fabricados de modo artesanal, porque o Gregori precisou mandar fazer esses móveis, ou ele fabricou esses móveis na própria firma, na própria marcenaria que ele mantinha. Então, esses móveis eram, na sua maioria, feitos para aquela casa. Então, cada casa modernista tinha um tipo de mobiliário. Ou, até, uma necessidade de mobiliário. Claro que tinha outras mobílias que você poderia fabricar em série e aí poderiam caber em qualquer casa, mas pela quantidade de recortes da casa, o jeito da casa, como a luminária que foi mencionada... Essa luminária é só para essa casa. Não caberia em mais nenhuma outra casa. Até pelo quintal você vê. Tem em outras casas, até casas que não são nem do Gregori, mas tem material que é específico da casa. Eu estou tentando me lembrar de uma frase que eu uso muito para essa casa... Mas me fugiu. É uma frase... Já sei! Eu coloco muito assim: que o Manifesto Modernista é o croqui da casa. Ou, que a casa é o resultado do Manifesto. Em suma seria isso. A casa é o resultado do Manifesto. Mas é também o que eu falei. 0 Manifesto é, mesmo, o croqui da casa. Ele já vai desenhando a casa através de uma literatura, digamos assim. 
Eu acho que isso é algo que eu consegui desenvolver na minha cabeça, de entender a ligação de uma com a outra.

[AA] Isso é legal... Mas, quer dizer que esse processo foi bem intuitivo... Do momento que você vai lá, olha cada item, etc., etc... Aí a Dulce sai e daí ia alugar de novo ou não...

[PM] Eu não sabia. Não sabia se alugava de novo ou não alugava. Para alugar eu tinha que dar aquela reformada que eu te falei. Por causa da infiltração. Tinha que pintar a casa novamente. Dar uma garibada. Aí você começa a garibar, começa a melhorar e começa a se apaixonar. Aí junta uma coisa com a história, e sabe o valor, e a casa já estava pra completar 80 anos, então... até que todo esse trabalho culminou com a exposição "80 anos da Casa Modernista". Que aí o Carlos organizando, a gente organizando - que eu cuido da parte do acervo... Tudo que ele pedia eu trazia, em termos de informações, porque aí eu tinha as informações ou sabia aonde obter as informações, juntávamos tudo, fazíamos a análise de vez em quando e depois íamos mandando bala na casa. Por isso que a casa demorou um bom tempo... pra gente conseguir, eu e o Carlos, digamos assim, finalizar a casa, demorou um bom tempo, porque, entre acertos e erros e estudos, tempo necessário da maturidade foi o tempo que a gente precisou pra essa casa ficar pronta. Tanto é que hoje o Carlos mora lá, já faz um tempinho, com a família.

[AA] E esse tempo entre a Dulce sair e começar a mexer e finalizar e que culminou com a exposição, foi quanto tempo mais ou menos?

[PM] Uns dois anos, mais ou menos.

[AA] É... pelo tempo, é realmente um processo. É diferente de uma casa "do zero" ou de uma reforma onde você...
[PM] ... sabe o final dela. A gente não sabia o final dessa casa. 0 quanto ela iria ser reformada ou restaurada. Porque, na verdade, o que acontece? Como é uma casa tombada, você teria que entrar com uma série de documentos para reformá-la. Pedir licença para CONPRESP [Conselho Municipal de Preservação do Patrimônio Histórico, Cultural e Ambiental da Cidade de São Paulo], CONDEPHAAT [Conselho de Defesa do Patrimônio Histórico, ArqueológiCO, Artístico e Turístico], IPHAN [Instituto do Patrimônio Histórico e Artístico Nacional] e assim vai. Então, como cada um é um órgão e havia uma certa dificuldade... Quer dizer, não é que nós somos pessoas boazinhas e fizemos uma coisa boazinha pra casa... É que a gente sabia que estava fazendo uma coisa que voltava pra origem da casa. Ninguém podia, praticamente, contestar. Afinal de contas a gente estava tentando fazer a casa voltar ao que ela era. Então a gente foi meio... arriscando, mesmo. Sabendo esse pouco risco. Mas, também, se qualquer pessoa que se colocasse à frente do não fazer, era também ir contra o processo de voltar a casa ao que era, de restaurá-la. Quer dizer, de uma certa maneira, seria uma propaganda negativa para a própria pessoa que se colocasse contra o que a família estava fazendo. E o que foi realmente é que eu melhorei muito a casa.

[AA] E foi feita alguma consulta nos órgãos? Informalmente?

[PM] Informalmente. Informalmente foram feitas consultas. Teve essa preocupação. Mas, a questão é que se fosse esperar toda uma documentação e qualquer coisa... Por exemplo... Quer ver um exemplo bem claro disso? Tinha uma árvore apoiada na laja em balanço. Tinha sido feito o pedido para a retirada daquela árvore. Ah, não... precisa o pedido em cinco vias, dois memorandos, um parecer do papa e um do presidente da república Jânio Quadros. Então, está bom... não ia ter parecer nenhum, só numa mesa espírita. - Nesse ponto fica aí a minha manifestação. - Então, aquele terraço em balanço, aquela árvore apoiada no balanço e você esperando cair o balanço pra depois falar: "Nossa! Mas, não cuidaram da casa!". Você vê: uma situação idiota! E aí o que é que foi feito? Tira-se a árvore e paga pra ver. $\mathrm{E}$ a árvore estava podre, velha e apoiada no balanço... Então, de um dia pra outro... Eu não sei nem como é que foi feito isso. Só sei que de um dia pra outro a árvore desapareceu. Desencantou. Ah! Que bom! A árvore foi abduzida. Melhor do que deixar cair a casa. Isso é o que a gente sempre brinca: os órgãos que tombam, tombam, mesmo, pra valer.

[AA] Acho que é o grande problema... Tem uma visão para o público, talvez equivocada. Mas, o processo burocrático não ajuda...

[PM] Não ajuda, nem incentiva. Porque, por exemplo, as pessoas perguntam: Aquela casa paga IPTU [Imposto Predial e Territoria Urbano]? Paga IPTU! E IPTU igualzinho a qualquer inquilino do lado, morador, residência do lado. Quer dizer, você não tem o incentivo financeiro, você não pode mexer numa casa que é sua e você para tirar uma porcaria de uma árvore que você está vendo que está danificando a sua casa, você precisa pedir autorização pro Papa, é demais! Realmente é muita burocracia para pouco conteúdo. Então, deixa cair, deixa morrer, como tudo.

[AA] É. O problema é que não tem mecanismos ágeis, nem processos de exceção, quer dizer, não dá para dizer que essa casa é igual a outra casa com uma árvore apoiada. Se você não cria mecanismos ágeis..

[PM] Se você não dá a cara à tapa, muitas vezes, aí cai naquilo que eu te falei: quem vai contestar? Vai lá e conteste que você 
estava modificando, descaracterizando a casa! Ao contrário, você estava re-caracterizando a casa. Vai lá contestar! Dá a cara à tapa! Eu dei a minha cara à tapa nesse ponto. Eu fui um cara que briguei com muita gente. Um dia eu briguei com uma pessoa e falei assim... e ela concluiu: muitas vezes se cria dificuldades para ganhar facilidades. Que é a grande verdade. Então, essa é que é a questão. E o Carlos também deu muito a cara à tapa. Então, acho que é assim. Mas, foi legal. Acho que valeu a pena. 0 processo foi muito gostoso. Ver a casa e ver hoje o resultado que ela deu. E se amanhã vai ser um instituto, como eu gostaria que fosse, ou não... Se ela vai ser um instituto eu não sei, mas, valeu a pena. Ganhamos... não nós só. Mas a população, e aí São Paulo, e aí a casa ganhou não sei quantos anos de vida. Então, eu, pelo menos, já estou com o dever cumprido. $E$ acho que o Carlos, também já... dos 80 anos... vamos poder comemorar daqui a 20 anos os 100 anos da Casa Modernista.

[AA] Com ela inteira...

[PM] Com ela inteira e não com a laje quebrada porque depende dos órgãos públicos para poder tirar a planta do jardim. Então, aí... Coisa que é legal, também: o jardim. Foi todo idealizado pela Mina [Klabin], esposa do Gregori. Logicamente ela trabalhou um pouco em cima das plantas características de um jardim tropical. Mas, também, os moradores, filhos da Mina e do Gregori, contam que também foi feito assim de um modo empírico: "Essa planta não ficou bem nesse lugar. Então, vamos tirar. Vamos colocar outra planta". Então, esse jardim também teve vida, não é uma coisa que foi uma fotografia colocada ali e vamos colocar o standard do jardim tropical. Não é isso. Tinha alguma coisa de um jardim tropical, mas também adequando às necessidades da família, aos que iriam viver lá durante esse tempo, pelo menos, durante a reforma da casa da Santa Cruz, e, depois, aos próximos moradores. Mas, principalmente... de novo, pensar que a casa ela é um elemento vivo pra quem mora na casa. Mas, quando é um bem tombado que vira uma peça de museu, aí você pode fotografá-la e ela vira uma peça. Mas, não é o caso. Todas as casas com jardim, jardim tropical, vai ter a muda do jardim tropical, vai ter o passarinho que suja o jardim tropical e aí por diante. Como a gente vê muito questionamento na casa da Santa Cruz, nesse sentido. Que o jardim tinha menos árvores, depois começou a ter muita árvore e hoje tem uma quantidade bem maior. E o jardim foi perdendo um pouco, aquele jardim tropical... Mas, também, uma casa.. como é que você faz? Você fala para as árvores serem tombadas? Tombar aquela imagem? Não vai tombar! Então, dentro disso, o que falta é manutenção, mesmo. E um pouco deixar que a natureza cuide, não tem jeito. Mas, não deixar que a natureza cuide de quebrar a casa..

[AA] Buscar um equilíbrio...

[PM] É, um equilíbrio... Na verdade, nem bem um equilíbrio. . Na verdade é coerência ou bom senso. Uma coisa é você querer tombar um jardim, que é um ser vivo. Outra coisa é você quere tombar uma casa, um imóvel, que dá pra você tombar. Mas, muitas vezes eu vejo o pessoal criticar o jardim, que já não tem mais aquela característica de um jardim concebido em 1930. Ou seja: Não dá, né? Os moradores de lá cresceram e até morreram e..

[AA] 0 caso das áreas externas é um tema bem controverso na parte do patrimônio, justamente por isso. Vai fazer o quê, também? Vai cortar tudo e replantar as mesmas espécies? Talvez, se tivesse um projeto... Na Europa eles têm até levantamento arqueológico de sementes... Aí o cara diz: "Aqui tinha uma plantação de determinada espécie há 300 anos atrás". Eles têm esse levantamento e especialistas nessas áreas. $\mathrm{E}$ a gente não tem nada. É difícil basear... Quer dizer, você tem a foto, tem a iconografia, às vezes tem projetos, às vezes não tem... Não sei se tinha lá.. .

[PM] Não. Não tem projeto. Não existe desenho da Mina Se existiu, eu nunca vi também. Então, o que acontece é o seguinte, por exemplo... Aí é uma posição minha... Pode ser até uma posição só minha, mas é uma coisa assim: Quando eu falo que não tem como você manter um jardim, é porque o jardim é um ser vivo. Uma planta vai crescer, vai dar arbusto, vai florescer e vai morrer. Se você trocar sempre pelo mesmo tamanho de arbusto, tipo aquele que foi na década de 30, quando foi inaugurada a casa, isso fica uma coisa muito fictícia... Seria a mesma coisa que tentar colocar as pessoas numa mesma idade, com 10 anos, o Dr. Maurice [Warchavchik] com 5 e assim seja... Isso é... por esse lado é que eu falo que é inviável... Já a casa não. A casa você consegue. Mas, mesmo assim, a casa tem que ser adaptada, ou re-adaptada, para os padrões atuais de uma nova cozinha, de uma nova garagem que já não é mais um carro do tipo... eu até esqueci... não é o Karmann-Ghia... tinha um carro tão pequeno que passava no portão... Tem um portão na minha casa que passava carro. 0 portão é da década de 30. Art Nouveau. Passava carro. Hoje já não passa quase nenhum carro. Mas ele está lá. É bonito, mas inadequado pra garagem. Então ele é só bonito.

[AA] Alguns elementos vão sofrer em detrimento de outros... Esse elemento, por exemplo, tem uma funcionalidade muito clara..

[PM] Não dá pra você falar... Se não, como é que eu ponho, estaciono meu carro dentro da garagem, então? Só se eu colocar ele como enfeito e depois... Olha, um exemplo bem claro disso: 
Vamos imaginar o prédio do Ramos de Azevedo, que é o do Hospital das Clínicas ali, a Faculdade, ele é tombado, aquele prédio. Você vê que tem aquela cerquinha totalmente em volta, bonitinha, baixinha, que devia cercar para não roubar carro. Hoje ela não adianta mais nada. Hoje ela só está lá... Ela foi tombada, porque existe uma cerca no fundo. Então, essa é a realidade, você não precisa tirar... Mas, você, muitas vezes, tem que modificar porque a realidade é outra. Só por essa razão. Os ladrões de ontem não são mais os ladrões de hoje... a quantidade... os veículos... Era a Romi-Isetta! Agora lembrei. Era a Romi-Isetta o carro que entrava naquela garagem. E hoje a Romi-Isetta, com aquela largura, já não existe mais... e só que eu tive que modificar o portão, aumentar um pouco pra poder passar o carro.

Mas... a casa, eu acho bem legal nesse sentido: é uma casa que está ganhando sobrevida, agora. Com essa atitude que 0 Carlos teve. E nesse ponto eu agradeço à família... Porque a casa não é só do Carlos, não é só do pai do Carlos, é da tia do Carlos também. Então, é uma casa que ainda pertence à família Warchavchik, ao pai e à tia, que são os filhos do Gregori e da Mina, e é uma casa que merecia esse destaque e o que puder se fazer, vai estar sempre sendo feito.

\section{[AA] E agora o Carlos está lá?}

\section{[PM] Agora o Carlos está lá.}

[AA] Ele já tinha morado lá?

[PM] Não. Não, porque quando o Carlos... eu não sei te falar onde ele nasceu, como é que foi, etc e tal, mas, digamos assim, ele só veio morar agora, nessa casa. Então, se você pega, 20 anos da Dulce, mas, não sei quantos anos da inquilina anterior, se foi, foi uma passagem... Se o Carlos passou ali algum dia foi, realmente, uma passagem, não foi nenhuma "morada", digamos. Porque hoje é que realmente ele está morando lá.

[AA] E nesses dois anos, nesse processo todo, vocês chegaram a procurar alguma referência específica de outros projetos de restauro?

[PM] Um pouco, sim. Nós chegamos a buscar outros processos de restauro. Por exemplo: por conhecer algumas outras casas do próprio Gregori... eu, por exemplo, trabalhei com a casa do Flávio de Carvalho em Valinhos. Aí já é um trabalho meu. Um outro arquiteto modernista que eu tinha fixação... e eu falo que a gente vai namorando... Na medida que a gente vai conhecendo os arquitetos, a gente vai descobrindo um leque maior. Então, já tinha feito um trabalho anterior com a casa do Flávio, que eu já conhecia um pouco... Já tinha conversado com algumas pessoas que restauraram casas modernas... Mas, é que não existe uma escola. Não existe uma escola da arquitetura moderna no Brasil... Ainda não existe para restaurar... A gente fala muito em restauro de Art-Nouveau, Art-Déco, Barroco, Neo-Clássico, mas você não fala em arquitetura moderna, uma escola realmente de restauro. Mas, você pode se basear, dentro daquilo que foi comentado agora a pouco, que é: planta, iconografia, textos, como, por exemplo, pintura, o que usava, como usava, a questão de terraço, a cerâmica São Caetano que foi uma cerâmica importantíssima durante esse período, que forneceu para muitas dessas casas. E depois, uma dificuldade: como muitas coisas eram trazidas de fora, algumas coisas mais da parte de metais eram trazidas de fora, e depois, por exemplo, vou te dar um exemplo bem claro disso: carrinho de chá que o Gregori desenhou. A parte de ferro foi trazida de fora. E a parte do design de madeira foi feita pelo Gregori. Então, quando há essas coisas vindas de fora, fica difícil, porque você não tem a informação de onde é que vinham. De que empresa vinha essa material. Você tem uma pseudo-ideia ou alguém diz "Eu escutei falar que era...". Eu não trabalho com "escutei falar", eu trabalho com fatos. É. É preciso trabalhar com documentação, não... Lógico, ela serve de início... Mas, no final, se eu quiser realmente fazer... Por exemplo, a Casa Modernista, no caso do Gregori, eu teria que ter a Cerâmica São Caetano à venda, pra comprar uma cerâmica. Graças a Deus não foi necessário, mas teria que ir atrás de azulejos antigos ou de alguém que fizesse algo semelhante. Então isso teria um custo muito elevado pra se fazer $\mathrm{X}$ número de peças. $\mathrm{E}$ de qualquer modo sempre fica com cara de réplica. 0 melhor se você tivesse a oportunidade de pegar o já usado, de alguma casa que já foi destruída, porque aí a idade seria semelhante. Acho que algumas preocupações dentro disso o Carlos levou em consideração. Algumas foram casuais. Umas, realmente, deram certo. Então, teve de tudo um pouco. Ora se baseando pela leitura, ora conversando com pessoas que já tinham feito algum trabalho semelhante e o meu próprio conhecimento, com as coisas que eu fui fazendo. Então foi um trabalho de peito, mesmo.

[AA] Existe, hoje, já consolidada, uma vertente, que diz que se deve marcar com mais distinção aquilo que se mexeu. Menos 0 mimetismo. Vocês chegaram em algum item, em algum momento a se deparar com isso e ter essas duas escolhas?

[PM] Não. Nós não tivemos esse tipo de problema, não. Por exemplo, no que se refere à pintura, ninguém tentou fazer aquela pintura, aquela cor exata...

[AA] Mas se chegou a fazer a prospecção? 
[PM] Se fez um pouco de prospecção. Porque para fazer uma boa prospecção, precisava de um profissional pra fazer... Aí é muito engraçado porque, algumas pessoas dizem "Olha, você pode pegar tal pessoa, que trabalha pra prefeitura ou pro estado, que faz". "Ah, tá. Ele pode vir agora?". Ah... ele nunca pode, porque está viajando agora para Milão, depois o ano que vem ele vai para o Japão e depois ele vai para o Ceilão (que já não existe mais, tudo bem... é o atual Sri Lanka). A piadinha é o seguinte: todos os órgãos querem que você faça um trabalho ímpar, mas não te dão estrutura pra isso. 0 governo cobra tanta bobagem, mas não dá respaldo pra certas situações.

Então, nós tentamos nos deparar com menos problemas, porque já era uma dificuldade fazer a casa. Já era comprar uma briga, dentro de algumas coisas.

A sua pergunta, de tentar fazer algum restauro, que a gente deixou claro que houve uma mudança, acho que não houve isso, porque as mudanças já tinham ocorrido. Nós voltamos ao que era a casa. Como a gente também não tinha todas as informações, mas sabia a posição, por exemplo, de portas que foram aquelas que eu te falei, da edícula, nós só fizemos voltar para aquela origem antiga dela. Hoje quem olha aquela casa vai pensar que a casa não teve essa reforma, vai pensar que ela é igualzinha àquela casa de 1930 E não vai saber que em 1970 ou em 1900 e alguma coisa ela foi mudada pelo próprio arquiteto... Como é o caso daquela janela que eu te falei, daquela janela do lado da lareira. A gente não mudou. Não tiramos a janela e botamos uma parede. Mantivemos a janela. Uma questão... Isso foi interessante! Eu acho que agora dentro do que você está falando. Chegou uma pessoa lá, talvez um professor, agora não me lembro, e falou: "Por que vocês não tampam a janela com uma folha só de madeira, só pra tampar, pra ficar mais próxima da casa de 1930?". Aí ele falou: "Tudo bem. Posso tampar só com uma placa, só pra ter aquele caráter da expo- sição, etc. e tal de como foi em 1930". Mas, depois, como a própria reforma havia sido feita pelo próprio arquiteto, não se justificava voltar. A alteração tinha sido feita pelo próprio arquiteto!

Aliás, uma coisa muito interessante... Isso é uma das coisas que eu também noto, diante dessas coisas de reforma e restauro.. Você vai entender bem claro. A casa da Santa Cruz. Pegando um exemplo ótimo, porque a casa da Santa Cruz ela é a primeira. E por ser a primeira ela teve também todos os acertos e erros. Mas uma coisa bem interessante: quando o Gregori manda reformar a casa de 35, não a casa de 35, a casa da Santa Cruz, por que ele manda reformar? Tinha aquelas janelas, se você olhar no livro do Geraldo Ferraz [Warchivchik e a introdução da nova arquitetura no Brasil, 1925-1940], você vai ver que eram três janelas, que depois muda e faz outro tipo de janela. Acontece o seguinte, segundo a própria família, a Dona Mina não poderia ter filhos. Aí teve primeiro filho, que é o Doutor Maurice, que aí chega... Ele pode ter um quarto, que é o quarto de costura ou outro quarto, um segundo quarto. Aí ele vai lá, mora, e tem um espaço pra essa criança. Vem um segundo filho, que é a Sônia. Aí sim, quando a Sônia vem, precisa reformar a casa. Na verdade, o que é que fez a mudança da casa? Se você perguntar para um especialista, ou para um professor, ele vai dizer assim: "A narrativa do arquiteto modernista vai querer contemplar a onipotência da obsolescência...". Vai encher de palavras bonitas, mas vai esquecer de uma coisa simples: a casa tinha mais morador. Precisava reformar. Não fez um puxadinho, mas dividiu um quarto grande em dois quartos, aumentou em tal ponto, diminuiu a varanda de um lado e foi contemplando para o outro... Então, existe uma coisa que é assim: "o arquiteto pensou na narrativa...", pensou é na necessidade! E quando eu falei da casa da Santa Cruz, é uma coisa até engraçada. Porque o CONPRESP tombou a casa da Santa Cruz, a casa de 27, e o CONDEPHAAT a casa de 35. Ou vice-versa. Um tombou uma data, outro tombou outra. As duas casas são do Gregori. As duas atenderam a uma necessidade em um momento: uma sem os filhos e a outra depois com os filhos. Isso eu sei de cara. Mas, se você pegar num livro, um professor, ele vai tentar fazer que isso vire uma narrativa bonita. É uma coisa meio troncha, meio idiota, dizer que por causa de filho ele teve que fazer uma reforma. A casa, de novo, como ser vivo precisa parecer sempre um objeto de arte? Não. Não é. Deixou de ser um pouco objeto de arte.

Então, nesse sentido, o que nós nos deparamos em relação a alguns momentos, era se contemplava a casa de 1930, no caso da Itápolis, ou se contemplava a casa reformada pelo próprio Gregori, diante das necessidades de ser uma região meio fria, porque é uma região meio alta ali, com muita árvore, ele vai e faz uma lareira. Então, vamos fazer o quê? Mantém. Aquela casa que o próprio arquiteto fez com a vida dela. Dela, da casa. Da vida dele, residindo na casa e contemplando as necessidades que se tinha naquele momento. Então, nós não criamos nenhum mimetismo, nem nenhuma figura de linguagem, é aquela casa, é aquilo e só recuperamos aquilo que dava pra ser recuperado, pra voltar o mais próximo da origem dela.

Não sei se eu falei até demais, se eu me embolei... Mas, eu acho que fica clara essa questão... Eu vejo muita gente fazendo "narrativas". E outros um "chutismo", um "achismo"... Aí eu posso falar pra você: nem o Carlos, nem eu, nem algumas pessoas que participaram, a maior parte do tempo não era "eu não acho". Era "eu vou atrás da informação", quando se tratou do jardim, quando se tratou da porta, quando se tratou da pintura, quando se tratou de uma série de coisas que foram sendo colocadas em questão, em cheque. Quando era colocado em cheque, ia atrás da informação. Quando não tinha a informação, muitas vezes não se mexeu, ou se mexeu apenas pela necessidade de manutenção do fato ou do ocorrido. Só por isso. 
[AA] Eu tinha mandado perguntas pra você e para o Carlos... Mas, talvez nem seja preciso, se ele for repetir tudo... A não ser que ele tenha uma outra visão... Porque, no fundo, foi feito muito em conjunto...

[PM] Muito! Quer ver uma coisa? Quando nós montamos a exposição, o Carlos escolheu o [José Tavares Correia de] Lira como a pessoa para escrever um texto sobre a casa. Eu escolhi a Ilda Castelo Branco pra fazer a parte do museu. E escolhi o Ricardo Mendes, que é um fotógrafo, que o Gregori tinha um hobby que era a fotografia. Eu escolhi o Ricardo Mendes também porque é uma pessoa ímpar como fotógrafo e como crítico de fotografia, para fazer a curadoria da parte fotográfica. 0 Carlos é o curador principal, geral, e eu sou o assistente, digamos assim, a pessoa também de produção. Mas, na discussão, como eu que sabia, como eu que faço a pesquisa aqui no escritório, eu tinha praticamente todas as informações... Quando surgia uma dúvida: Paulo, onde está a planta tal? Paulo, onde está isto? E, muitas vezes, parava e discutia.

Você perguntou se é a mesma coisa, falar com o Carlos e falar comigo? Eu acho que a diferença está na visão como "neto", tá bom? Mas, na casa em si, no processo... ah! Nós já várias vezes conversamos a respeito... Porque você não é a primeira pessoa que pergunta. Então a gente discute coisas...

Pergunta tua: 0 fato de ser Warchavchik, influenciou na casa? Uma pergunta tua. Sim e Não. Sim, porque a casa é do avô dele. É o neto que queria fazer a casa, voltar um pouco a casa como o avô fez e nada mais que lógico alguém da família ter o aval de si mesmo, da família. Talvez, então, o Carlos foi a pessoa mais adequada pra poder fazer também isso. Porque qualquer pessoa que fizesse e que não fosse da família, não teria 0 aval de toda a família. Eu, graças a Deus, não posso falar nada, porque eu tenho um super aval do pai do Carlos. 0 pai do Carlos é muito legal comigo. Ele me deu muita entrada. Ele me protege. Ele sabe que eu sou o chato da turma. Eu faço o papel de chato e não tenho dolo de fazer o papel de chato. Por causa disso. Porque eu sou o cara que vou lá, mexo, descobri fotografias recentes... Eu organizei... Então, nesse sentido, ser Warchavchik ajudou? Ajudou! Porque foi alguém da família a fazer.

[AA] Talvez o processo fosse outro, não só no sentido metodológico, mas teria que ter um pré-projeto já um pouco mais claro, pra apresentar pra família inteira... Seria muito diferente.

[PM] Eu trabalhando aqui no escritório há muitos anos e já tendo uma espécie de reconhecimento por parte da família, talvez, se eu fizesse, eu não tivesse problemas com a família, mas talvez com os órgãos governamentais. Já o Carlos, nesse ponto, é o neto... A casa é dele! Vamos dizer assim... É dele também. E tudo estava sendo feito em prol... Até é engraçado, porque eu falo assim "O inferno está cheio de boas intenções". Eu brinco, porque eu digo que eu não sei se amanhã eu vou estar no inferno ou não. Ou o Carlos e outras pessoas que eu conheço, que são tão cheias de boas intenções, não sei... Mas, uma coisa é certa: ninguém pode criticar que ninguém tenha feito alguma coisa realmente pensando no melhor. Porque eu vejo que há pessoas que nem pensam, nem no melhor, nem no pior. E se exime de qualquer responsabilidade. E foi uma coisa... eu me expus e briguei com pessoas que vinham, porque falavam, que era melhor "se fosse assim"! Melhor se fosse assim? Mas, nunca fez nada! Então, estou bem. Quero ver, quem vai estar no inferno, quem vai estar no céu. Vamos ver! Estou pagando pra ver!

Essa é a minha briga, aliás. Essa é a minha briga, independente... Esse sou eu. Não é só com o Gregori. Não é só com o Flávio.
É na minha vida também. Eu vejo gente chegar falando de "narrativas". Narrativa é uma narrativa. É palavra. Fazer é outra coisa. Botar a mão na massa é outra coisa. Eu posso narrar a construção de uma parede. Mas, põe a mão na massa!

[AA] Você sendo o curador de todo o acervo, você convive com isso diariamente.

[PM] Diariamente. Eu trabalho aqui de $3^{\mathrm{a}}$ a $5^{\mathrm{a}}$, mas é uma vida. Hoje... A prova disso é que quando foi aberta a exposição, o Dr. Maurice estava lá. Eu falei pro Dr. Maurice: Dr. Maurice vou falar pro Sr. o quanto eu estou feliz! Ele olhou pra minha cara e deu uma risada... porque ele sabia o quanto... E eu falei pra outras pessoas que me conhecem, outras pessoas também curadoras: Hoje eu posso ir embora. Hoje eu estou com o meu dever cumprido..

Isso eu acho que foi uma coisa legal... O Carlos, por exemplo. o Carlos não tinha um envolvimento grande, quando eu vim trabalhar aqui. Ele me contratou e tudo, mas ele não tinha um envolvimento com o avô dele. Mas, à medida que a gente vai, trabalha, começa, concentra, e o pai dele me apoia, e a tia dele me apoia, e as coisas vão acontecendo, e a própria maturidade dos fatos - porque a gente amadurece, graças a Deus a velhice serve para alguma coisa, não só para dar mais idade, mas para a gente amadurecer nas nossas atitudes - o Carlos também foi amadurecendo. E hoje ele não tem mais aquela coisa de "ser neto do Gregori". 0 Gregori é o Gregori, o Carlos é o Carlos, são dois arquitetos, um contemporâneo, o outro um arquiteto moderno, modernista. E na verdade são arquitetos de temperamento diferentes, levam o mesmo nome e só isso. Mas, o Carlos amadureceu hoje. Ele tem muito mais visão. E trata o avô dele não como uma parte do sangue só, mas como uma parte de uma memória, de um 
memorial, de uma pessoa qualificada, que teve muita qualidade naquele momento. 0 próprio Gregori se sentia, muitas vezes, pelo fato de ser estrangeiro, com dificuldades com alguns arquitetos nacionais, mesmo com quem tinha muito mais abertura... 0 que pode ser ou não uma justificativa do Gregori. Mas, era um pouco como ele se sentia. Então, não importa, se ele está correto ou não está correto. Mas, se você se colocar na posição dele, é aquilo que ele sente e acabou. 0 seu questionamento não interfere em nada na posição dele. Pode até questionar, porque ele se sentia estrangeiro já que ele se naturalizou brasileiro, casou com a Mina que era brasileira... Mas, não é isso. É como a pessoa se sente. Então, pronto. Acabou. Não se discute. Ou se aceita...

Tem um colega que fala muitas vezes sobre a "escola carioca" e a "escola paulista", que se o Gregori estivesse no Rio era diferente. E eu falo assim: E se os cariocas estivessem em São Paulo, também seria diferente. Grande coisa! Leva a algum lugar? Só fica na narrativa. Aí é que entra a narrativa da coisa. Não adianta! Se eu nascesse em berço esplêndido, será que eu ia ser um marchand ou será que eu ia ser um São Francisco?

[AA] Não dá pra saber... Há algumas especulações que são pertinentes, mas há outras que são.

[PM] É... meu pai fala uma coisa... Especula de rodinha... Ficar especulando e nada! Se fosse, se não fosse... Não chega a lugar nenhum. Acho que o principal é isso. Então, o Carlão vai ver isso daqui... Se o nome valeu pra alguma coisa. Sim. Valeu porque teve 0 aval da família e 0 aval também de um órgão público que... Eu acho... Eu acho, não. É que quando eu falo "eu acho" eu tenho certeza. Umas coisas foram feitas muito bem feitas, através de estudos iconográficos, de estudo. Não foi "a galega", mas foi realmente... Quem ia questionar, ainda mais sendo neto? Tendo o pai que ia servir como fonte primária, a tia como fonte primária e outras pessoas próximas.

0 pai dele não é o Gregori, mas é filho e viveu naquela casa morou, correu e se machucou naquela casa. Então, isso é fonte primária. Fonte primária é a pessoa que sabe... Quando nós pe gamos alguns moradores da casa, são moradores que vão dizer: "Olha, o lustre da sala não era esse. Era tal lustre". Ele traz a fotografia, ele viveu na casa. "Era esse o lustre. Mas, quando meus pais saíram daqui, eu tinha saído antes, por exemplo, eu já tinha casado..." . Aí o pai e a mãe morreram e a casa foi alugada pra Dulce ou pra alguém aí. (Ah! 0 arquiteto era o Samuel Vainer [correção: André Vainer], que era marido da Dulce.) Aí ele trouxe as fotos e mostrou: Está aqui a casa. Está vendo aquela varanda como era? Tinha assim... Aquela borda ainda não tinha madeira" Então, na exposição de 30. Mas, depois ela vai ter uma madeira por quê? Porque tem criança. Era muito baixo o peitoril. Podia cair. Então, vamos colocar umas madeiras pra passar. Aí depois o Carlos tirou a madeira e aumentou um pouco mais o peitoril. Porque ele também tem filho. Porque ele também queria um pouco de privacidade. Coisa que naquela época não tinha... Hoje você tem um prédio que está tão próximo da sua casa que te vê nu. Então, essas são as adequações às novas realidades. E como não dá pra manter aquela casa como uma coisa realmente fotográfica ela teve que realmente se adequar. Há um morador lá que precisa morar, que precisa ter suas necessidades atendidas. Então, acho que é isso. E voltando mais uma vez à sua pergunta acho que facilita, sim. É facilitador ser da família.

[AA] De qualquer maneira, fica essa discussão: se não fosse 0 Carlos é óbvio que seria diferente, mas teria que saber "como"... Há inúmeras situações... Também o fato de se ter o Carlos como arquiteto, a família ainda, de certa maneira, envolvida, o Maurício
Segall... Mesmo que sejam outras vertentes, a arquitetura está muito presente na família, o que facilitou muito a permanência da casa na família. Porque poderia ser uma casa construída por um arquiteto " $X$ " e em algum momento a família vai vender... É outra situação.

[PM] Sim, veja... Meu pai é engenheiro, ele que construiu a casa, ele que projetou... Mas, de lá pra cá, eu não moro mais em Brasília, eu moro em São Paulo, voltei pra São Paulo e a casa de Brasilia, que pros padrões de Brasília é uma casa, mas para os padrões de São Paulo é uma mansão, vamos dizer assim, hoje eu já não sei mais quem é o dono, quem é o proprietário. A casa não foi nenhum impacto em relação à arquitetura moderna, não teve esse impacto que essa casa realmente gerou. E além disso, o que essa casa vale pra mim, hoje, é a saudade daquilo que eu tive na casa. Já essa casa do Gregori, não. Essa casa teve um impacto social, um impacto cultural e ainda bem que ficou na família! Porque se não tivesse ficado, poderia ter alguém lá achado "Esta casa tá muito velha. Vou aproveitar o terreno". E ter demolido a casa. E pronto, acabou a história.

[AA] 0 programa das residências é um programa realmente muito delicado, pensando na arquitetura moderna. Se é uma instituição, tudo bem... Sai uma instituição e entra outra. Não tem modificações de programa muito específicas. É um prédio institucional. Agora, uma casa, uma residência, é viva..

[PM] Uma casa é sempre muito viva. Por exemplo, se você pegar aquela casa da Santa Cruz hoje, ela é uma parte Centro Cultural. Isso porque deram a ela essa utilidade. Se não, ia ficar abandonada. Ou ia virar delegacia de polícia. Como aquelas casas dos Campos Elíseos, de arquitetura clássica, ou eclética, com vitrais 
franceses, que hoje é uma delegacia de polícia. Isso, infelizmente, é o cara não saber pra que serve aquele vitral e ele simplesmente joga uma parede na frente. Não tem ideia do valor daquele vitral. Mas, mesmo aquela casa da Santa Cruz ela ainda é muito abandonada, muito largada. Mas, melhor do que estava antes. Muito melhor. Hoje ela está ganhando maturidade até das pessoas que, graças a Deus, estão cuidando dela. Talvez ela até chegue ao que a gente quer que chegue.

[AA] É... eu estive lá, quando ela estava bem abandonada... quando se cogitou da Escola da Cidade ir pra lá... Eu fui lá ajudar no levantamento. Ela estava bem...

[PM] Ela estava bem judiada! Aquele mendigo que morou lá dentro. Teve um mendigo que morou lá dentro. Acho que era Renato ou Ricardo o nome dele. Ele botou fogo num bando de coisa lá dentro. Mas, aí, qual foi a necessidade dele? Estava passando frio, não estava? Eu não vi, mas quem me disse foi a Bea. Acho que você conhece a Bea, Ana Beatriz. Parece que ela comentou alguma coisa. Mas, as coisas foram sendo queimadas. 0 Mário Grégio que tinha ali um grupo de escoteiros, também contou. 0 Mário conta direitinho desse mendigo.

\section{[AA] 0 grupo ainda está lá, não?}

[PM] Não sei. Precisa até descobrir isso. Também foi um problema. 0 grupo ia, não ia, ia, não ia... Eles, por um lado, mantiveram a casa limpa, o terreno limpo, etc. e tal, mas, ao mesmo tempo, também tinham problemas com a Secretaria de Obras, com a Secretaria A, B, C... Então... algumas pessoas gostam de criar facilidades, outras gostam de criar dificuldades... Porque é aquela história que a gente vê no poder público, o prefeito não dá conti- nuidade ao que o prefeito anterior fez, e aí refaz ou vem com uma proposta... e aí nunca acaba, fica pela metade.

\section{[AA] E a casa da Santa Cruz, quem é o proprietário?}

[PM] É o Estado. Quer dizer, hoje é o Município. Quem comprou foi o Estado. Comprou da família. Aí quem tocou foi o Município, porque o Estado passou pra mão do Município. E foi uma coisa que, dentro da família, não dá pra falar muito. É uma coisa que foi imposta. Uma coisa meio... Logicamente tinha aquela questão de vender... Não boicotar. Não teve a família Segall. Museu Lasar Segall. Que foi legal, eu não sou nada contra isso. Mas, as coisas como o Estado faz, que é aquela questão de comprar e pagar aquele dinheiro que você sabe que não paga, não cobre e te enfia goela a dentro. Nesse sentido, acho que ficou, pro pessoal da $2^{\text {a }}$ geração (já que a $1^{\text {a }}$ seria o Gregori), ficou... Como é que se diz, quando você engole... engole a seco!

[AA] É... mal resolvida.

[PM] É uma coisa que eu também nem me conformo tanto... Acho que é bobagem, mesmo. Não tem porquê. Foi feito. Tem um bando de jornal que conta... Os jornais, geralmente, da época, em 84 , contam bem a história como foi. Os sobressaltos e problemas que causaram.

Mas, eu acho assim: da casa, foi muito legal ver, participar. Eu, como uma pessoa curadora da parte do acervo, foi muito gostoso. Foi aquilo que eu te falei, acho que o Carlos também curtiu bastante.

[PM] Uma coisa que é interessante, porque é assim: correntes da exposição. Correntes da exposição. Não necessariamente precisa citar nomes. Mas, tinha gente que falava assim: a casa deveria ser reaberta ao público sem nada. 0 arquiteto deveria entrar aqui, sentar no chão e dizer "Venha, Gregori"... Do tipo: sentir a espiritualidade da casa. Outras pessoas achavam que a exposição deveria ser uma retrospectiva da exposição de 1930. Quer dizer, teoricamente... Porque não seria tão viável assim: 0 caso da Tarsila, o caso da escultura do Lasar Segall, e o que fosse... Brecheret... E refazer aquela exposição. Teria que ir atrás de todos os proprietários, de quem ficou com o quê... 0 que seria inviável. Por quê? Porque você precisaria de muita segurança, hoje, para aquela casa... Teria que, a janela que eu te falei anteriormente que estava aberta, que em 30 estava fechada e tinha um quadro da Tarsila na parede, tinha que ser fechada, mesmo que fosse de uma maneira falsa... Então, essa era a corrente que fazia a casa uma retrospectiva igual à casa e uma outra corrente, que eu fazia parte e o Carlos também, que a gente acreditava, que era comemorar 80 anos da Casa Modernista.

[AA] A $1^{\text {a }}$ já foi..

[PM] Isso! Já pensou se toda vez que se fizesse uma exposição do Picasso tinha que voltar ao que foi a $1^{\mathrm{a}}$ exposição do Picasso? Ou do Brecheret? Não justifica! Você vai ter vertentes, olhares, retratos diferentes de cada momento. Lógico que quando você tem exposições de grandes artistas, você vai ter quadros clássicos. Há um repeteco da linguagem. Afinal de contas vai continuar sendo filho do mesmo pai, da mesma mãe. Mas, não se justificava fazer um olhar passado, quando depois já foi agregado tanto valor ao próprio arquiteto. Porque na exposição da casa, a gente não expôs só a casa da Itápolis, em planta. A gente expôs o Gregori fotógrafo, autor de outros projetos no Pacaembu, de outras residências, ele também tem projetos de uso popular, de 
habitação coletiva. E outras coisas mais que a gente conseguiu juntar, amealhar, além do Gregori como designer. Aí tudo bem porque ele já era desenhista de móveis antes, mesmo, da casa da Itápolis. Já na casa da Santa Cruz ele já havia feito alguns mobiliários. Mas, ali, agregou-se toda uma vivência do Gregori. E, além disso, todo um olhar da família. Família levando material, emprestando material. Assim, tudo que foi colocado, foi colocado: "Acervo família Warchavchik". Pra quê? Pra não ficar: aquele é dono da cadeira, aquele é dono do sofá, o outro é dono da poltrona... Não. 0 coletivo era o Gregori, era a família Warchavchik. Então, vamos colocar isso como uma coisa só. Logicamente, um agradecimento mais específico, mas também interessante nesse sentido. Então, aquilo que eu te falei. Na exposição, teve essa discussão de qual exposição seria feita e, no fim, nós optamos por uma exposição daquilo que a gente tinha como material. Sem inventar moda. Sem mimetismo. Se não, teria que pegar e fazer uma cópia do quadro da Tarsila pra enfeitar aquela parede.

[AA] Poderia até ser uma opção, nesse sentido criar um mock-up numa Bienal, como fizeram pro Zezinho Magalhães Prado [Conjunto Habitacional CECAP]... Eles fizeram lá... Construíram um ambiente, fac-símile, pro pessoal conhecer o que era a unidade. Aí tem outro foco.

[PM] Certo. Aí fica a ideia de uma exposição fac-símile. Não a Exposição 80 anos da Casa Modernista, mas a Exposição fac-símile da Casa Modernista.

[AA] Quer dizer, até dá. É óbvio que se tratando de uma casa, e não de uma instituição, entra nessa discussão da disponibilidade de material. E de espaço propriamente dito. Não pode ter ninguém morando, etc.
[PM] Também mais essa! Não tem que estar ninguém morando. Bem colocado! Só deu certo porque o Carlos ainda não tinha mudado pra lá. É quando chegou ao final da reforma, ele disse: Agora a casa está tinindo. Vamos aproveitar? A exposição foi, na verdade, decorrente. Ela foi consequência de todo esse trabalho feito na casa.

[AA] E a Renata [Semin] e o Zé [José Armênio de Brito Cruz]...

[PM] Como é que eles entraram? Eles entraram bem no finalzinho, como co-patrocinadores da exposição. Mas, do processo não participaram em nada. Quando o Carlos, quando nós resolvemos... Realmente somos bem mais "nós", porque nós conversamos muito... quando isso aconteceu... Porque o Carlos tem a sobrinha dele que também é arquiteta, que é a Mirna. Que também participou da parte já da exposição. Então, o que é que acontece? A primeira coisa que a gente fez, eu e o Carlos já conversando, foi convidar algumas pessoas. 0 Lira já estava com o livro dele, também muito empenhado em fazer as coisas. A Ilda Castelo Branco já tinha feito uma trabalho muito bom sobre o Gregori. E faltava, também, ela fechar um pouco a vida dela.. enquanto estava forte, com saúde... Ela é daquele tipo de senhora que luta pelas coisas: "Aí eu já fiz...". Quer dizer, fez mundos e mundos e faltava um fechamento bacana. Pra mim foi legal, dar a oportunidade e convidá-la. Ela cedeu muito material pra gente, até, de fotografias, porque ela também tinha algumas que ela juntou, o que facilitou pra gente em relação à exposição da casa, porque a gente foi lá, pegou esse material e o Ricardo Mendes já havia feito a exposição do Gregori nos 100 anos, no centenário do Gregori. Também já tinha um grande conhecimento. Então, na verdade, todas essas pessoas, cada uma na medida do seu valor tem, primeiro, o Ricardo Mendes, que é o mais antigo, depois
Ilda e depois o Lira. Em relação a ordem dos mais antigos para os mais novos, digamos assim. Mas, todas elas foram sendo convidadas. Talvez tenha faltado alguém ligado ao paisagismo. Mas, uma pessoa que também tivesse mais engajamento na coisa. Porque precisaria de um estudo maior. Apesar que aí também falaria: você tem projeto? Não tem projeto. Nem na FAU tem. Ninguém tem projeto. Não sei se a Mirna...

[AA] Alguém que estudou a partir da iconografia... 0 negócio não é fácil!

[PM] E tudo isso foi gratuito. Foi uma doação de todo mundo. Do tempo dessas pessoas. Por que então o Piratininga entra? Ele entra como co-patrocinador no momento em que a família bancou tudo... Tudo até o momento que começa a se falar assim: quem vai pagar o seguro da casa, para as coisas que vão ser colocadas? Porque algumas coisas precisam de seguro. Segurança. De uma certa logística. Quem vai dividir algumas coisas da logística? Ah! Então vamos ver quem é que poderia dividir... Ah... tal empresa. E aí, sendo amigos, sendo também da Escola [da Cidade], eles entram. Acho que até teve coisas que eles pisaram um pouco, mas acho que nada tão sério. Nada que não foi resolvido. 


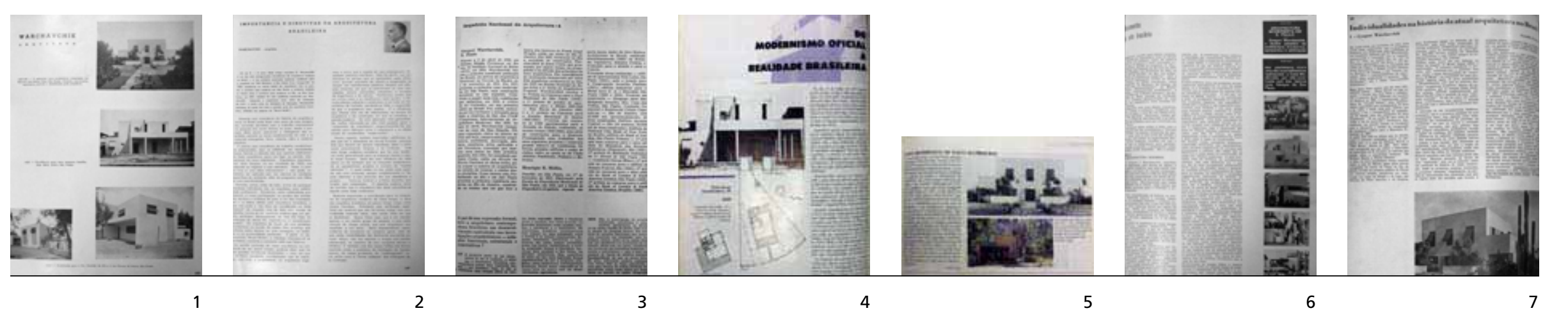

\begin{tabular}{|c|c|c|c|c|c|c|c|c|c|}
\hline & TIPO & NOME & EDITORA & CIDADE & DATA & $\mathrm{N}^{\circ}$ & AUTOR(ES) & TÍTULO & PÁG. \\
\hline 1 & revista & Acrópole & $\begin{array}{l}\text { Técnicas } \\
\text { Brasileiras } \\
\end{array}$ & São Paulo & $\mathrm{jan} / 1954$ & 184 & - & Warchavchik, arquiteto & $163-167$ \\
\hline 2 & revista & Acrópole & $\begin{array}{l}\text { Técnicas } \\
\text { Brasileiras }\end{array}$ & São Paulo & $\mathrm{fev} / 1958$ & 232 & WARCHAVCHIK, Gregori & Importâncias e diretivas da arquitetura brasileira & $149-150$ \\
\hline 3 & revista & Arquitetura & $\begin{array}{l}\text { Editora } \\
\text { Itambé }\end{array}$ & $\begin{array}{l}\text { Rio de } \\
\text { Janeiro }\end{array}$ & $\begin{array}{l}\text { jan-fev/ } \\
1962\end{array}$ & 4 & - & $\begin{array}{l}\text { Inquérito nacional de arquitetura, 4: Gregori } \\
\text { Warchavchik e Henrique Mindlin [entrevista] }\end{array}$ & $12-14$ \\
\hline 4 & revista & Arquitetura e Urbanismo & Pini & São Paulo & $\begin{array}{l}\text { out-nov/ } \\
1992\end{array}$ & 44 & $\begin{array}{l}\text { SOUZA, Ricardo Forjas } \\
\text { Christiano de }\end{array}$ & Do modernismo oficial à realidade brasileira & $78-90$ \\
\hline 5 & revista & Arquitetura e Urbanismo & Pini & São Paulo & $\begin{array}{l}\text { out-nov/ } \\
2001\end{array}$ & 98 & WOLF, José & Casa modernista: de volta ao princípio & 21 \\
\hline 6 & revista & Habitat & $\begin{array}{l}\text { Editora } \\
\text { Habitat }\end{array}$ & São Paulo & $\begin{array}{l}\text { jan-mar/ } \\
1951\end{array}$ & 2 & - & $\begin{array}{l}\text { Acerca da arquitetura moderna/Documentos da Arte } \\
\text { Brasileira }\end{array}$ & $51-52$ \\
\hline 7 & revista & Habitat & $\begin{array}{l}\text { Editora } \\
\text { Habitat }\end{array}$ & São Paulo & $\mathrm{mar} / 1956$ & 28 & FERRAZ, Geraldo & $\begin{array}{l}\text { Individualidades na história atual da aquitetura no } \\
\text { Brasil: Gregori Warchavchik }\end{array}$ & $40-48$ \\
\hline 8 & revista & Projeto & Arco & São Paulo & $\mathrm{fev} / 1984$ & 60 & SEGAWA, Hugo & $\begin{array}{l}\text { Warchavchik, Silvia Telles, Flávio de Carvalho e Rino Levi: } \\
\text { trajetórias do modernismo }\end{array}$ & $20-29$ \\
\hline 9 & revista & Óculum & $\begin{array}{l}\text { FAU } \\
\text { PUCCAMP }\end{array}$ & São Paulo & set/1992 & 02 & $\begin{array}{l}\text { FARIAS, Agnaldo Aricê } \\
\text { Caldas }\end{array}$ & $\begin{array}{l}\text { Gregori Warchavchik: introdutor da arquitetura mo- } \\
\text { derna no Brasil }\end{array}$ & $08-22$ \\
\hline
\end{tabular}




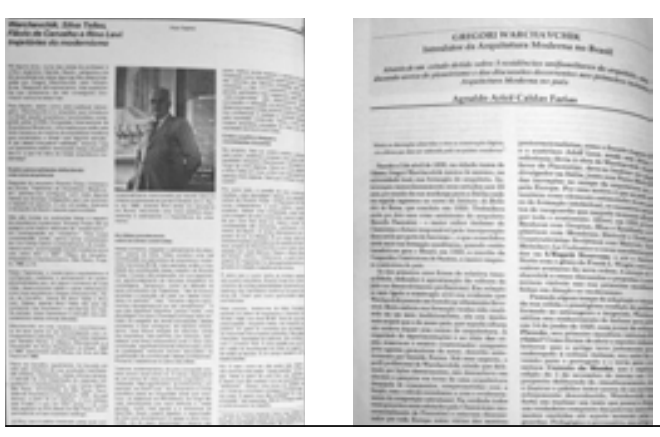

8

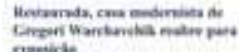

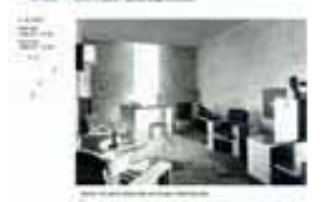

플

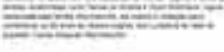

10

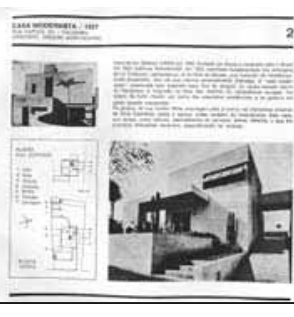

11

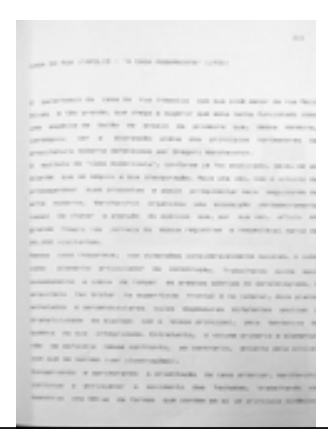

12

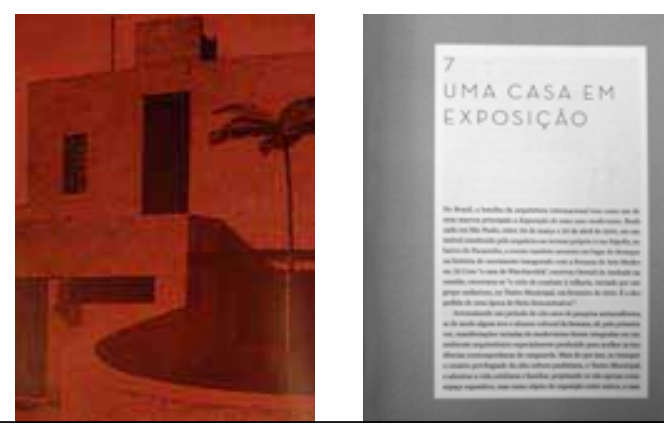

13

\begin{tabular}{|c|c|c|c|c|c|c|c|c|c|}
\hline & TIPO & NOME & EDITORA & CIDADE & DATA & $\mathrm{N}^{\circ}$ & AUTOR(ES) & TÍTULO & PÁG. \\
\hline 10 & $\begin{array}{l}\text { jornal/ } \\
\text { web }\end{array}$ & O Globo & O Globo & $\begin{array}{l}\text { Rio de } \\
\text { Janeiro }\end{array}$ & $\begin{array}{l}01 / 04 / 2010 \\
\text { às } 13 \mathrm{~h} 44 \mathrm{~m}\end{array}$ & - & - & $\begin{array}{l}80 \text { Anos - Restaurada, casa modernista de Gregori } \\
\text { Warchavchik reabre para exposição }\end{array}$ & - \\
\hline 11 & livro & Arquitetura moderna paulista & Pini & São Paulo & 1983 & - & $\begin{array}{l}\text { XAVIER, Alberto; LEMOS, } \\
\text { Carlos; CORONA, Eduardo }\end{array}$ & Casa modernista, 1927 & 02 \\
\hline 12 & tese & $\begin{array}{l}\text { A arquitetura eclipsada - notas sobre } \\
\text { história e a arquitetura a propósito } \\
\text { da obra de Gregori Warchavchik, } \\
\text { introdutor da arquitetura moderna } \\
\text { no Brasil }\end{array}$ & - & Campinas & 1990 & v. 2 & $\begin{array}{l}\text { FARIAS, Agnaldo Arice } \\
\text { Caldas }\end{array}$ & Casa da rua Itápolis (1930) & $211-215$ \\
\hline 13 & livro & Guia da arquitetura 1928-1960 & Aeroplano & $\begin{array}{l}\text { Rio de } \\
\text { Janeiro }\end{array}$ & 2001 & - & CAVALCANTI, Lauro & Casa modernista, 1930 & $114-117$ \\
\hline 14 & livro & Warchavchik fraturas da vanguarda & $\begin{array}{l}\text { Cosac } \\
\text { Naify }\end{array}$ & São Paulo & 2011 & - & LIRA, José & Uma casa em exposição (cap. 7) & $195-215$ \\
\hline 15 & livro & $\begin{array}{l}\text { Warchavchik e a introdução da nova } \\
\text { arquitetura no Brasil: 1925-1940 }\end{array}$ & $\begin{array}{l}\text { Museu de } \\
\text { Arte }\end{array}$ & São Paulo & 1965 & - & FERRAZ, Geraldo & Exposição da casa modernista [contexto 1930] & $32-37$ \\
\hline 16 & livro & $\begin{array}{l}\text { Warchavchik e a introdução da nova } \\
\text { arquitetura no Brasil 1925-1940 }\end{array}$ & $\begin{array}{l}\text { Museu de } \\
\text { Arte }\end{array}$ & São Paulo & 1965 & - & FERRAZ, Geraldo & A casa modernista de São Paulo & $83-99$ \\
\hline 17 & livro & Arquitetura contemporânea no Brasil & Perspectiva & São Paulo & 1997 & 3. ed. & BRUAND, Yves & Parte I-2.3. As outras obras de Warchavchik & $68-71$ \\
\hline
\end{tabular}




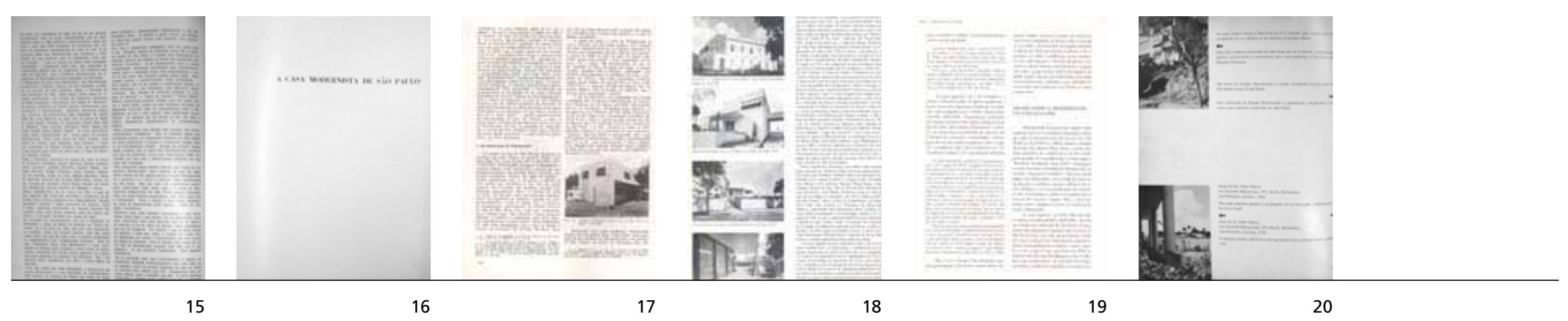

\begin{tabular}{l|l|l|l|l|l|l|l|l|l}
\hline $\mathbf{1 8}$ & TIPO & NOME & EDITORA & CIDADE & DATA & N $^{\circ}$ & AUTOR(ES) & TíTULO \\
\hline $\mathbf{1 9}$ & livro & Arquitetura moderna no Brasil & $\begin{array}{l}\text { Aeroplano } \\
\text { Editora/ } \\
\text { IPHAN }\end{array}$ & $\begin{array}{l}\text { Rio de } \\
\text { Janeiro }\end{array}$ & 2000 & 2. ed. & MINDLIN, Henrique Ephim & - \\
\hline $\mathbf{2 0}$ & livro & $\begin{array}{l}\text { Brazil builds - architeture new and } \\
\text { old, 1652-1942 }\end{array}$ & $\begin{array}{l}\text { The } \\
\text { Museum } \\
\text { of Modern } \\
\text { Art }\end{array}$ & $\begin{array}{l}\text { Nova } \\
\text { lorque }\end{array}$ & 1943 & - & GOODWIN, Philip L. & - & Proselismo e modernidade em Warchavchik \\
\hline
\end{tabular}




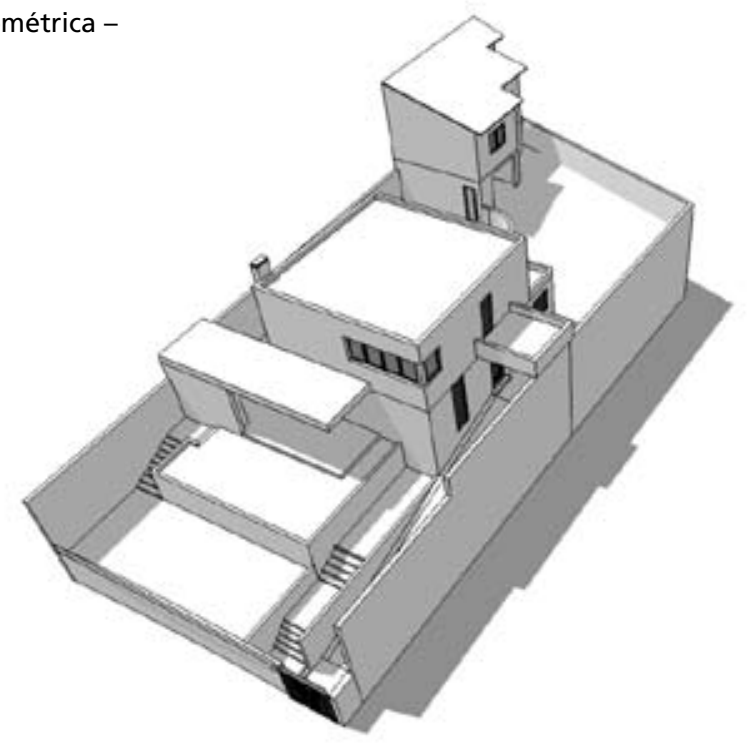

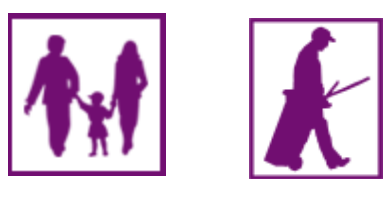

Acesso social

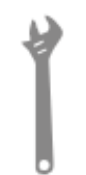

Usos -

equipamentos técnicos

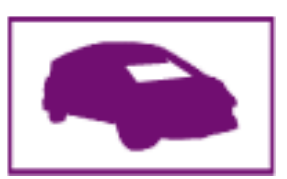

Acesso veículos

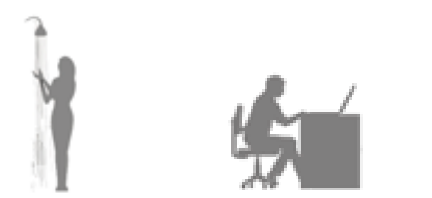

Usos -

Usos -
sanitários

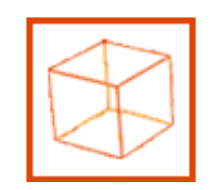

Estrutura

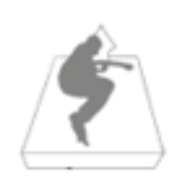

Usos dormitórios

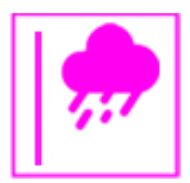

Fechamentos

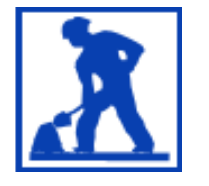

Intervenções

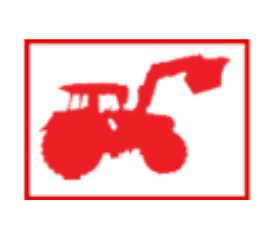

Demolições

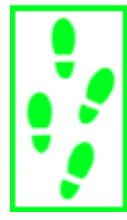

Circulação

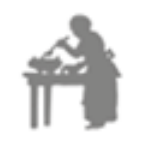

Usos cozinhas

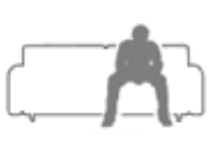

Usos - 
Perspectiva isométrica -

áreas de intervenção

(térreo)

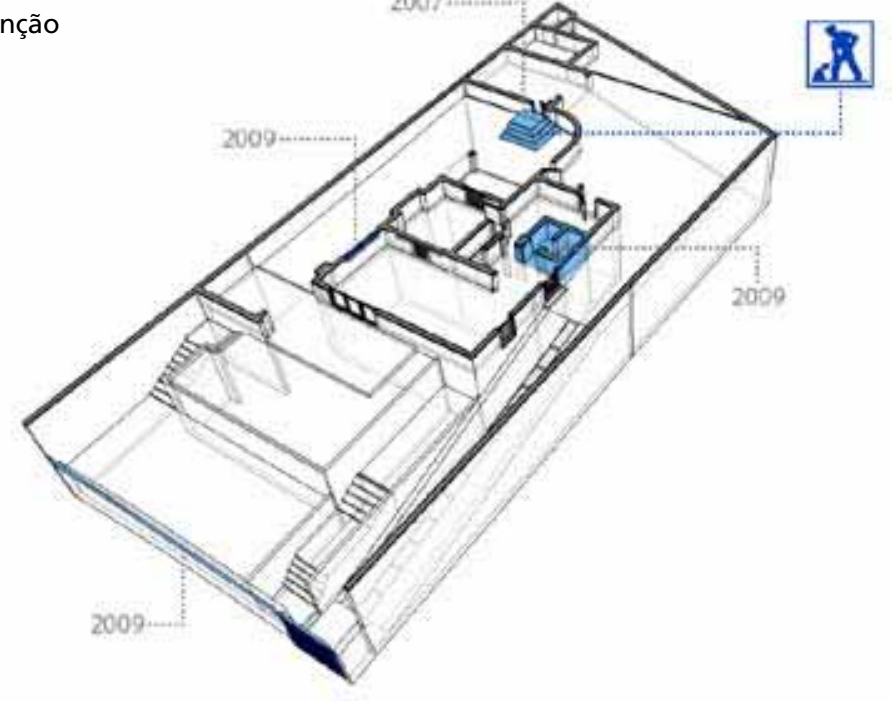

Perspectiva isométrica -

áreas de intervenção

(primeiro pavimento)
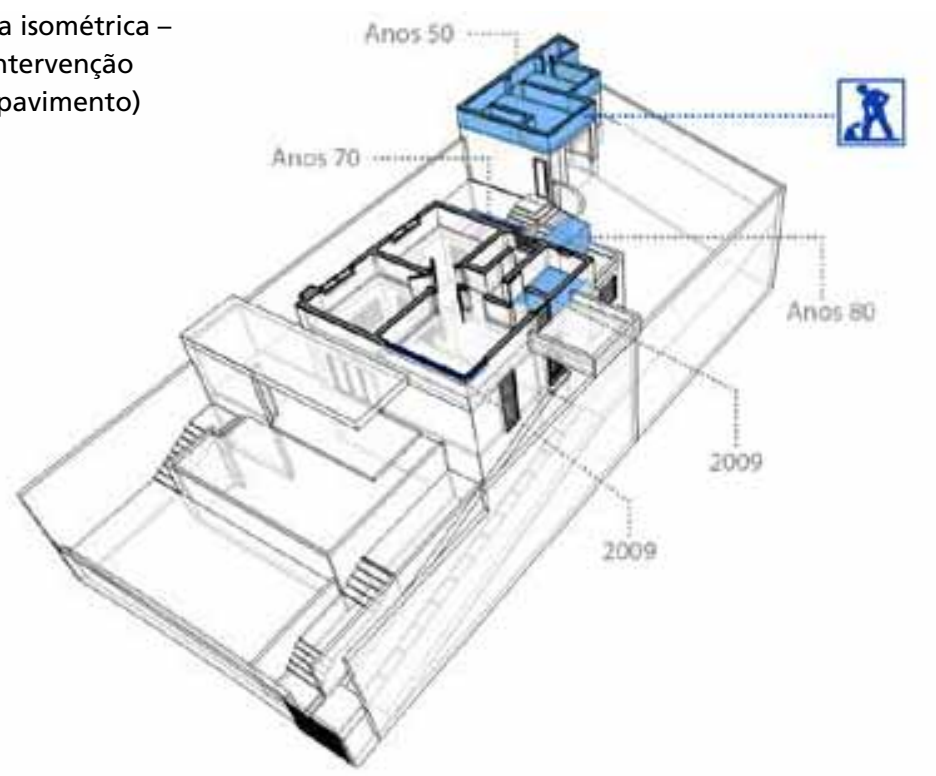

Perspectiva isometrica -

áreas de intervenção

(cobertura)

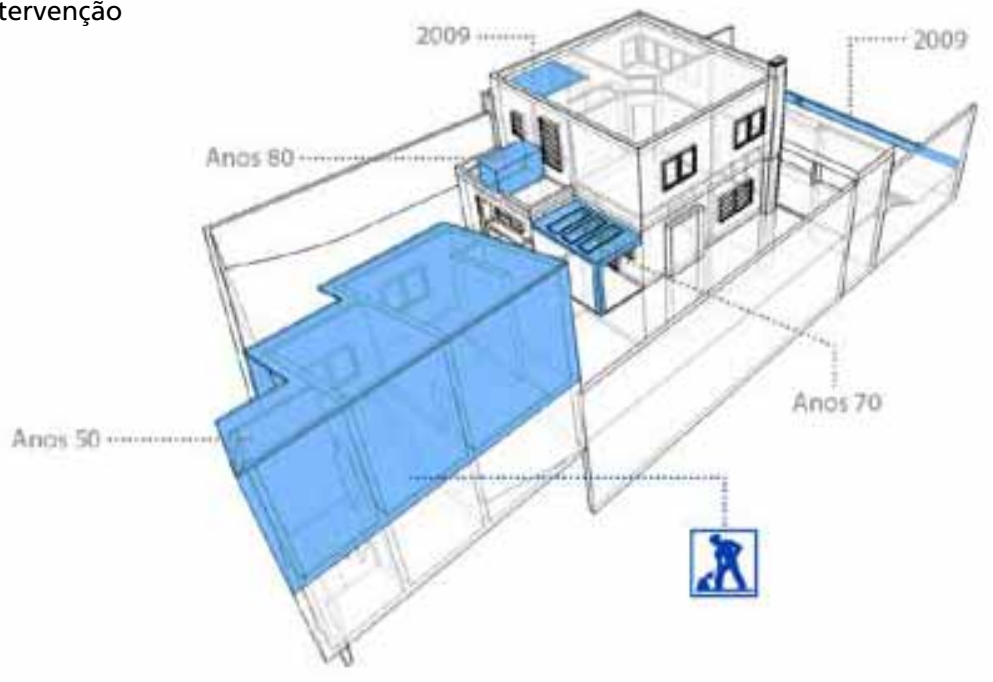


Perspectiva isométrica -

acessos (térreo)

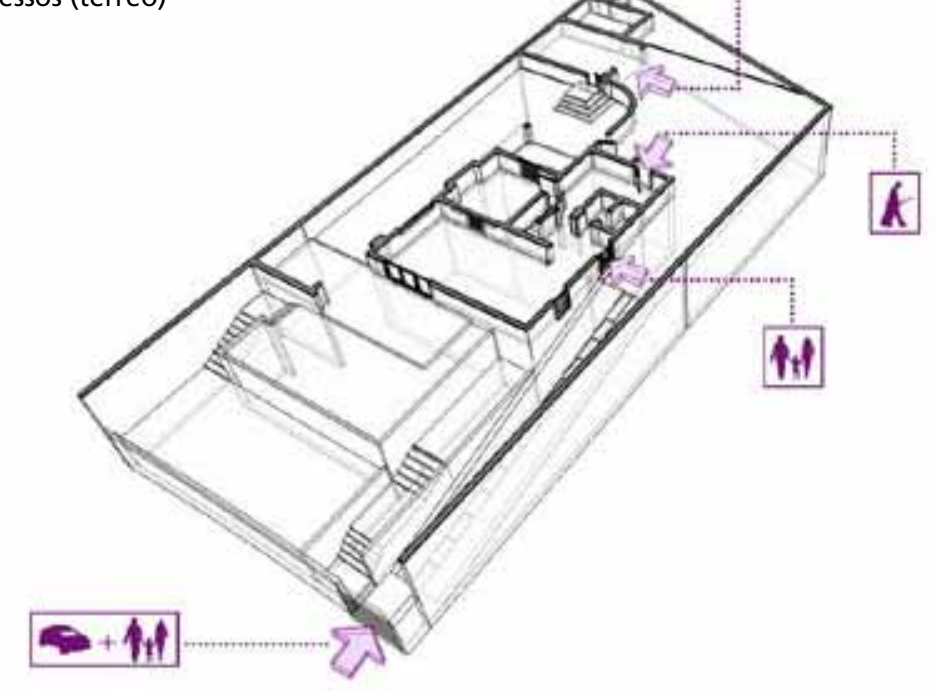

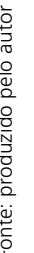

Perspectiva isométrica -

circulação (térreo)
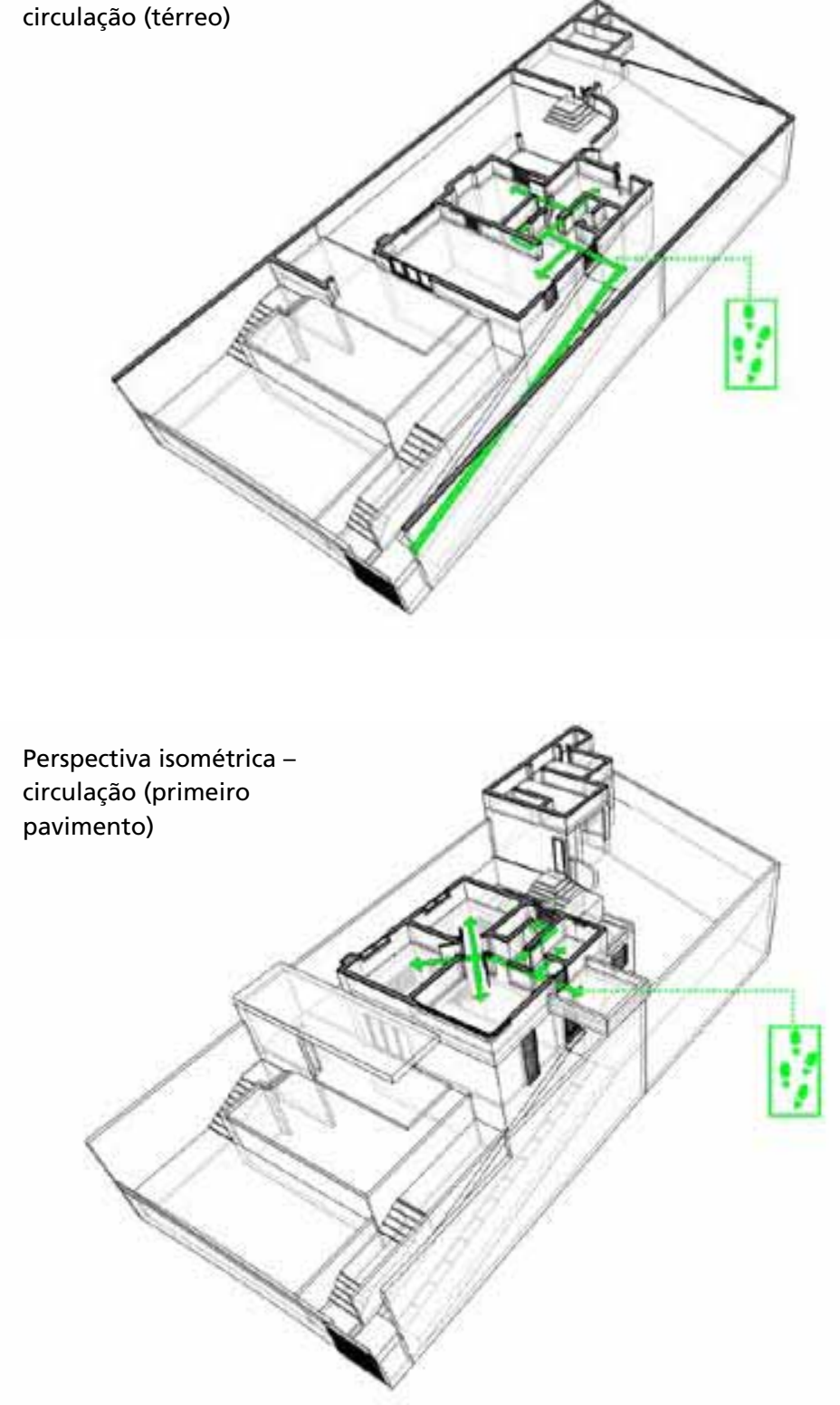
Corte longitudinal estrutura

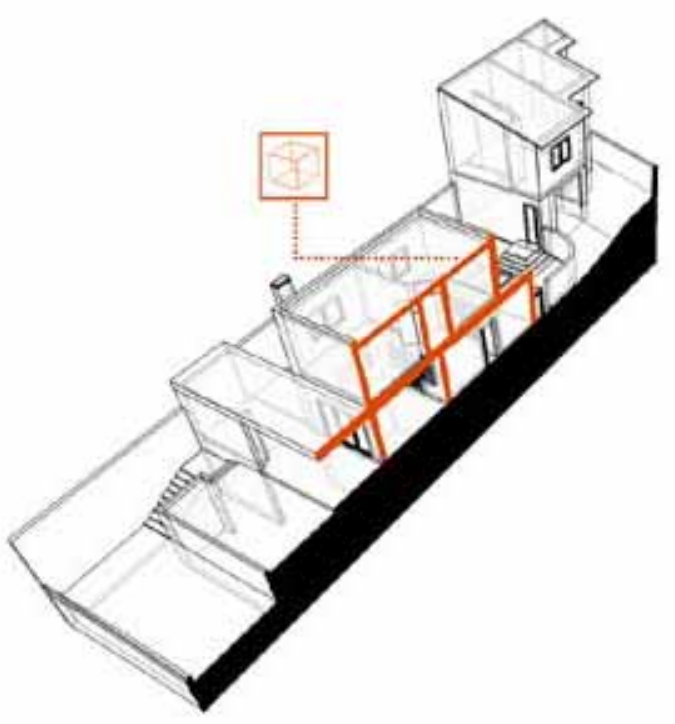

Corte transversal estrutura

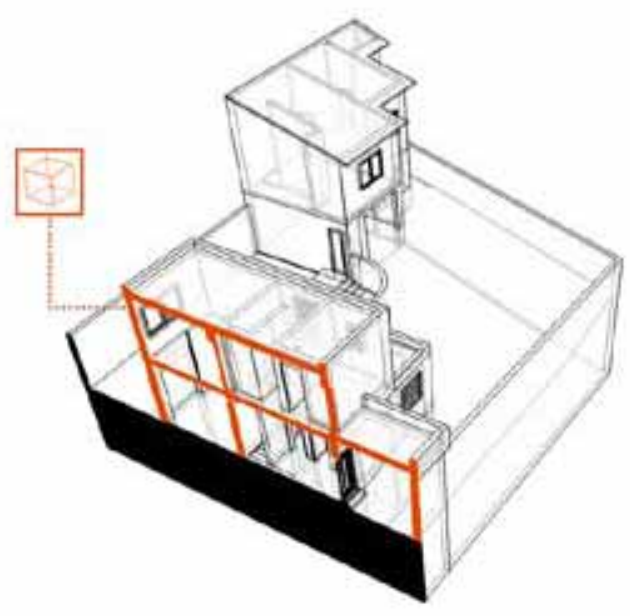

Perspectiva isométrica -

estrutura (térreo)

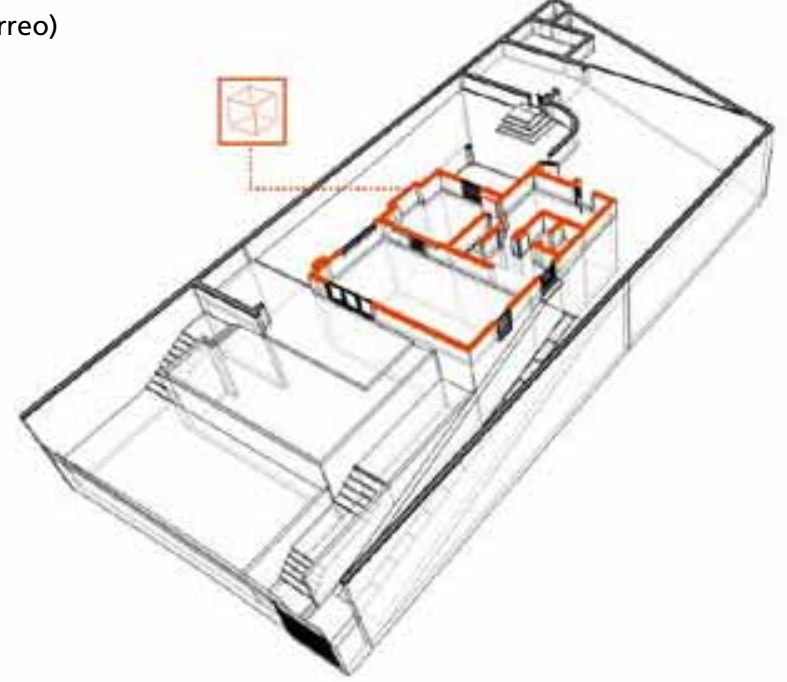

Perspectiva isométrica -

estrutura (primeiro

pavimento)

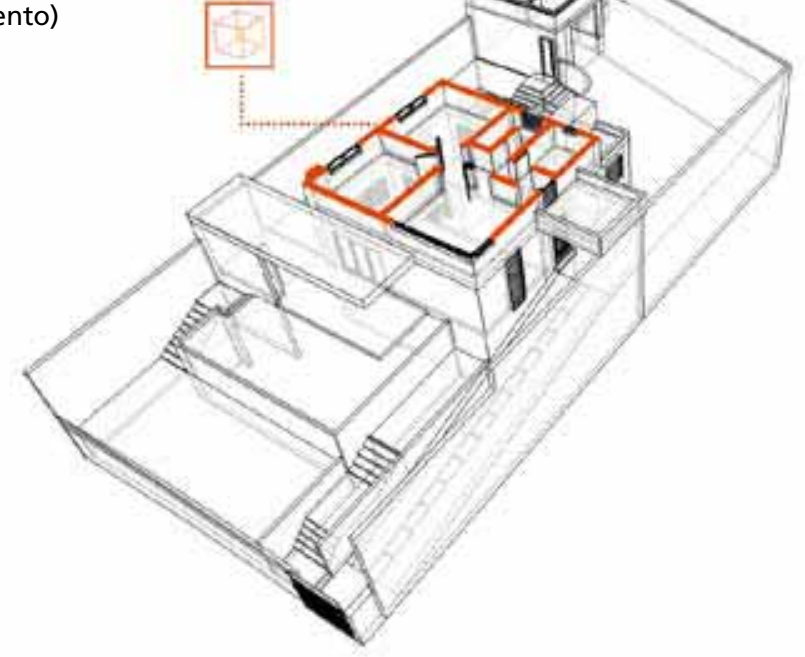


Perspectiva isométrica -

fechamentos

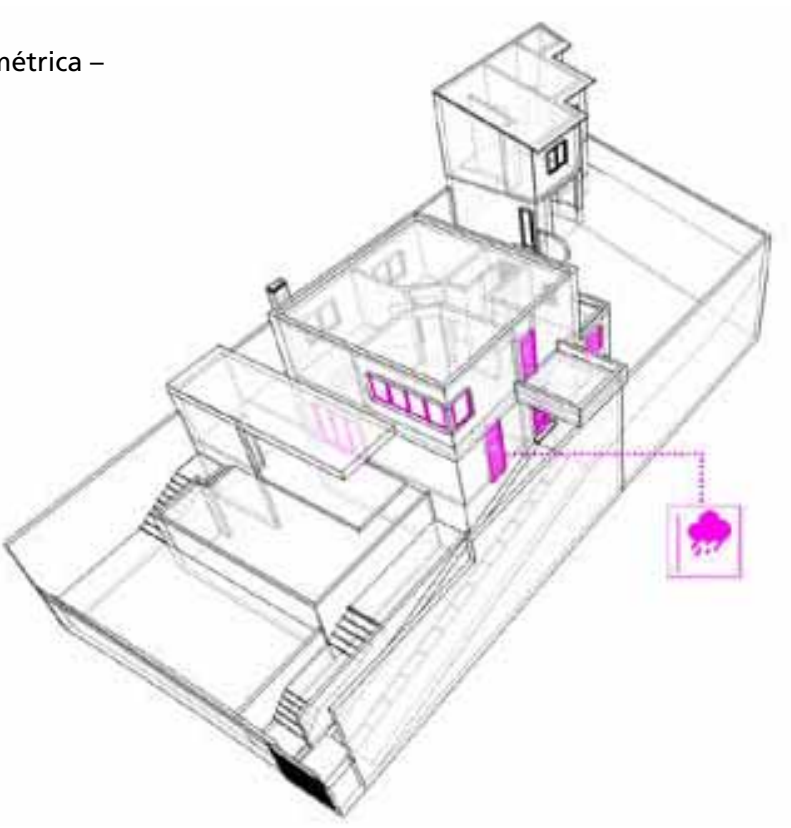

Perspectiva isométrica -

fechamentos

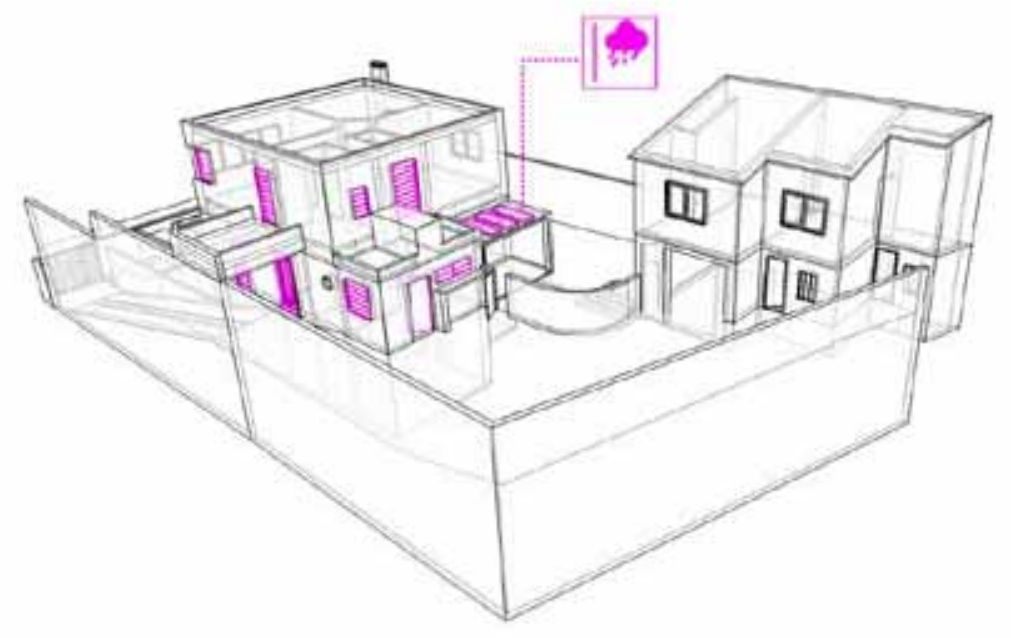

Perspectiva isométrica -

fechamentos

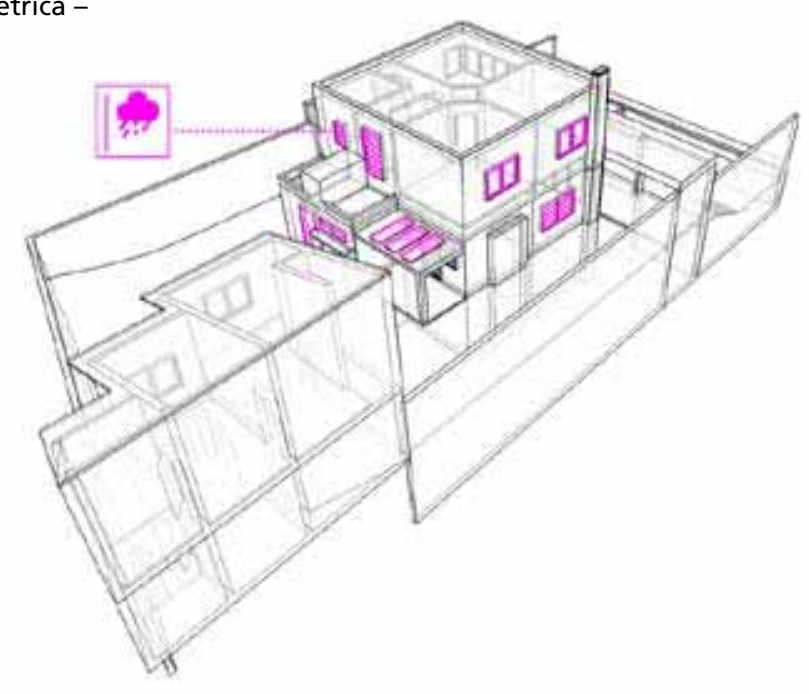


Perspectiva isométrica -

usos (térreo)

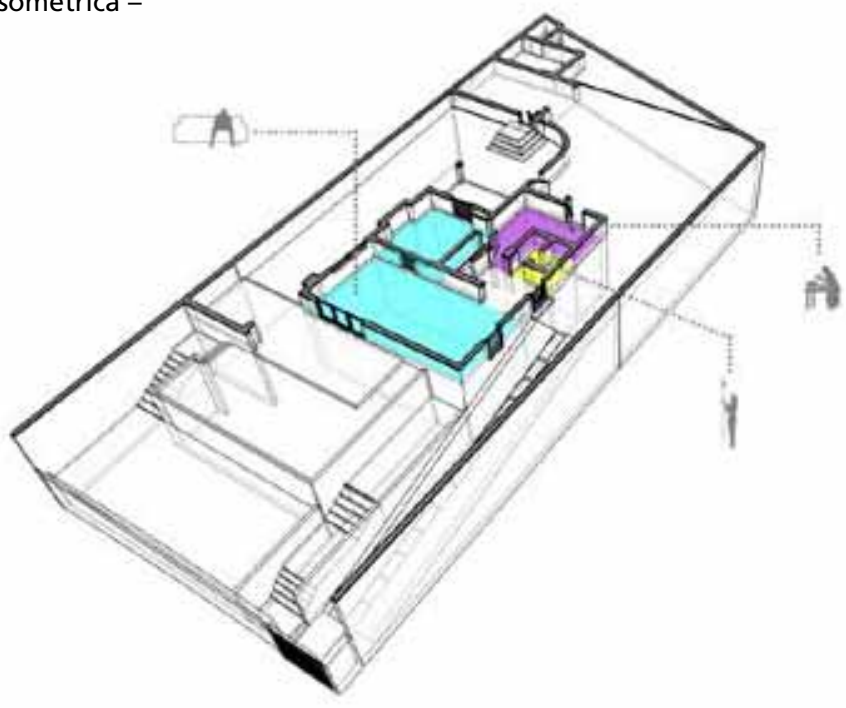

Perspectiva isométrica -

usos (primeiro pavimento)

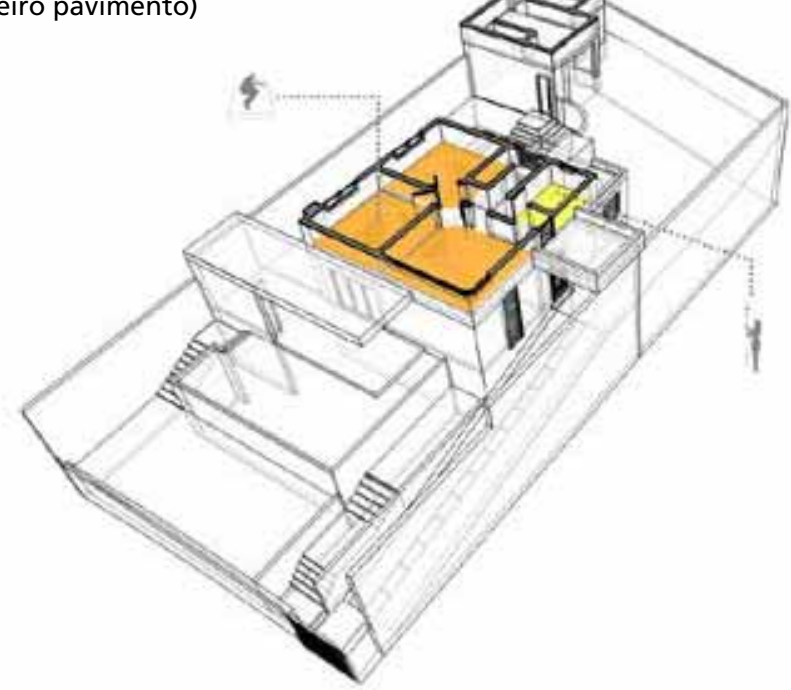




\section{RESIDÊNCIA OLGA BAETA}

Endereço: rua Gaspar Moreira, 271, Butantã, São Paulo, SP Área do terreno: $480,00 \mathrm{~m}^{2}$

Área da construção: $240,00 \mathrm{~m}^{2}$

Data do projeto original/obra: 1956 / 1957 Autor: João Vilanova Artigas e Carlos Cascaldi Obra: Agostinho Mallart (mestre de obra)

Data do projeto de intervenção/obra: 1996/1997 Escritório responsável: MMBB Arquitetos

Autor: Angelo Bucci

Colaboradores: Fernando de Mello Franco, Marta Moreira, Milton Braga, Alvaro Puntoni, Carmen Morais e Luciana Itikawa

Cálculo de estrutura: Ibsen Puleo Uvo

Paisagismo: Marta Espírito Santo e Beatriz Espírito Santo

Obra: Construmet - Paulo Balugoli (mestre de obra); Jean Carlos dos Santos e Adolfo Keles (pedreiros); Persidônio da Silva e Gerson Adenísio (ajudantes); Amador Jesus Galerani (eletricista e encanador); Vanderlei Borges (pintor)
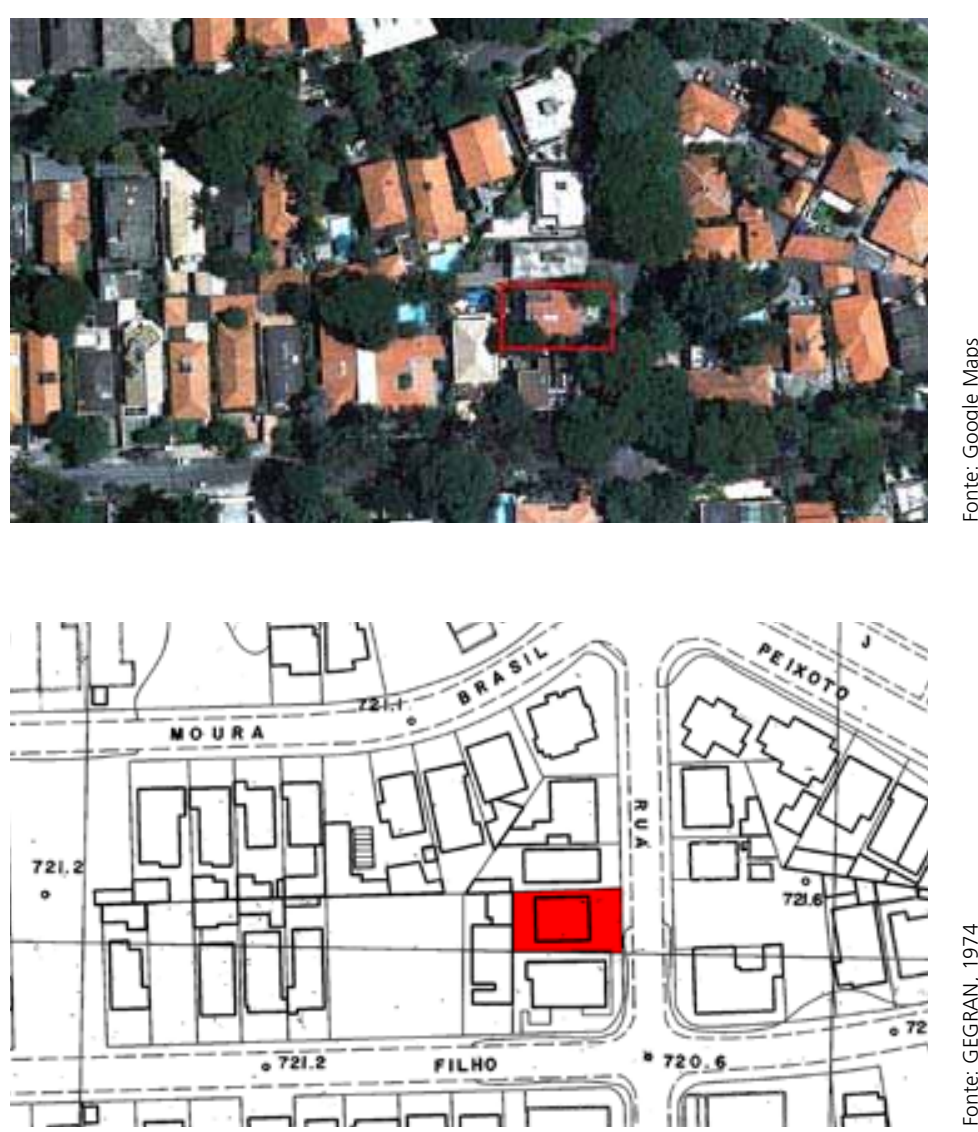


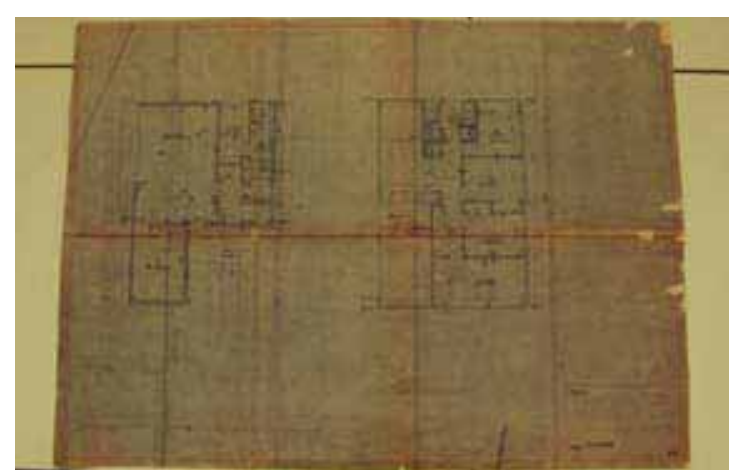

Plantas (escala 1:50)

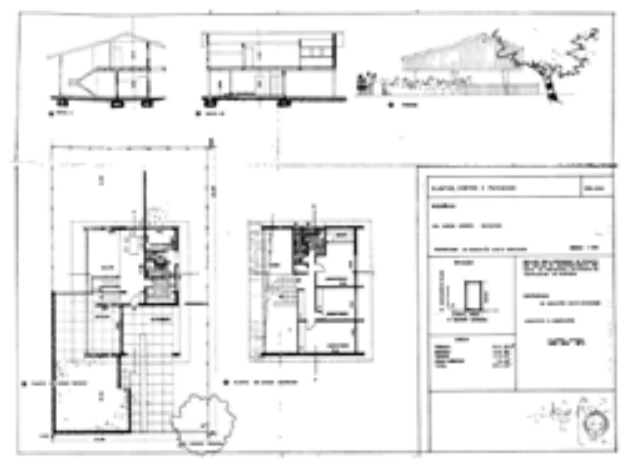

Planta de aprovação na Prefeitura (escala 1:100)

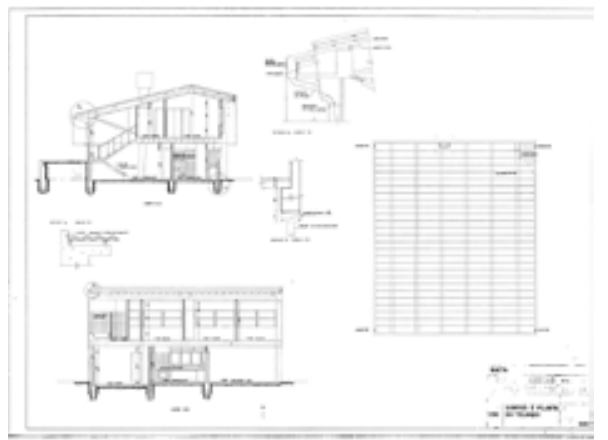

Cortes e plantas do telhado (escala 1:50) - tratada

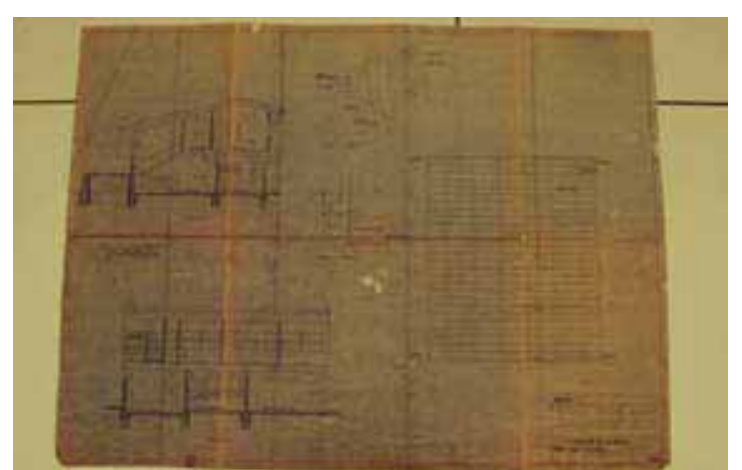

Cortes e plantas do telhado (escala 1:50)

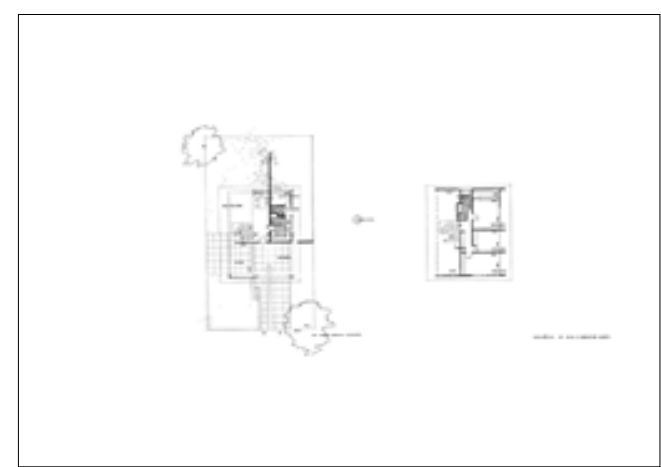

Planta do térreo e primeiro pavimento (escala não identificada)

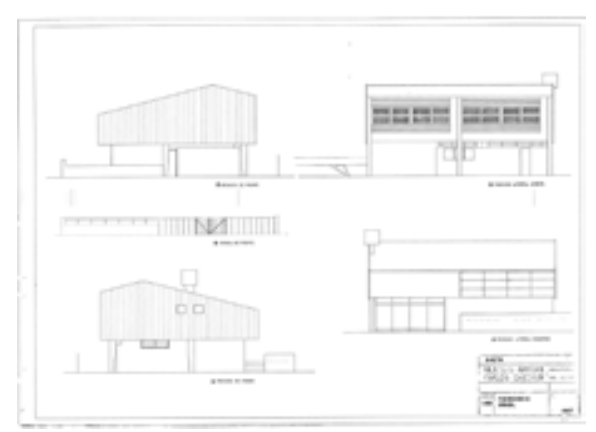

Fachadas e gradil (escala 1:50)

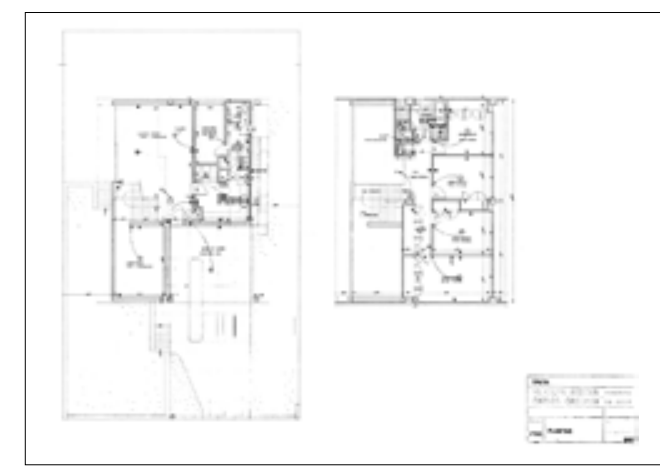

Plantas (escala 1:50) - tratada

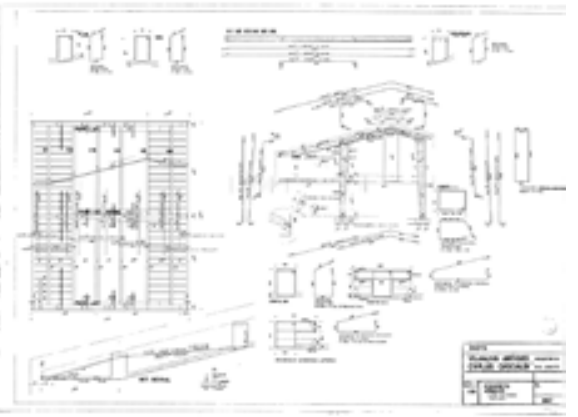

Concreto armado - laje de forro (escala 1:50) 


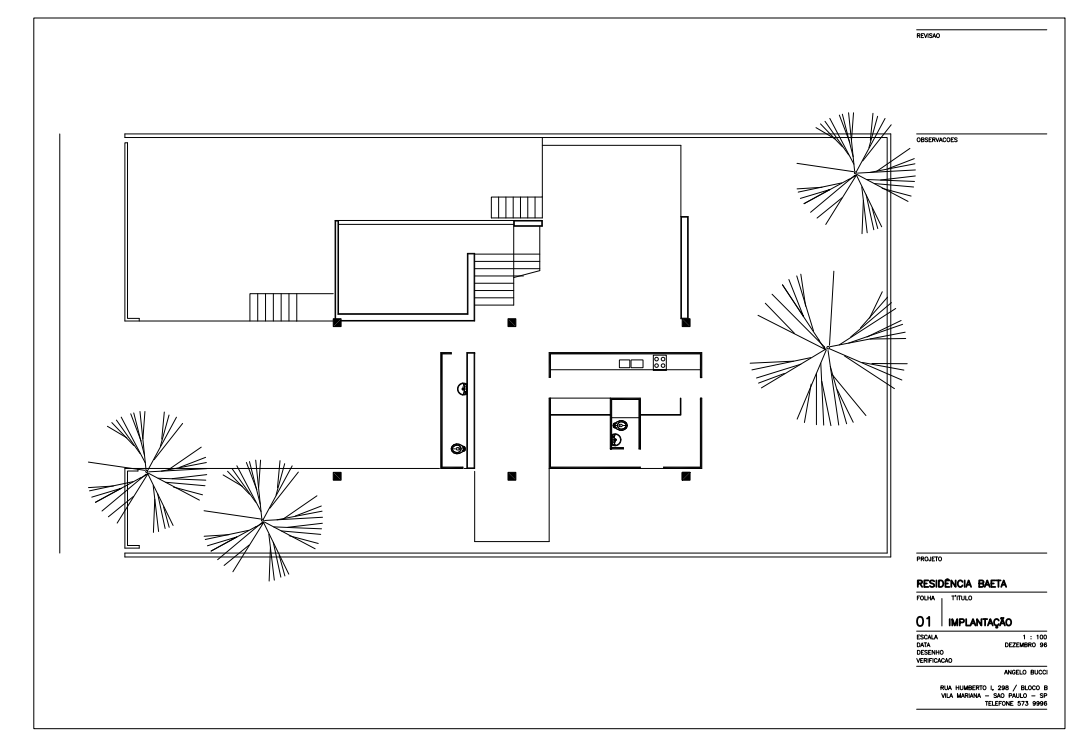

Implantação (escala 1:100)

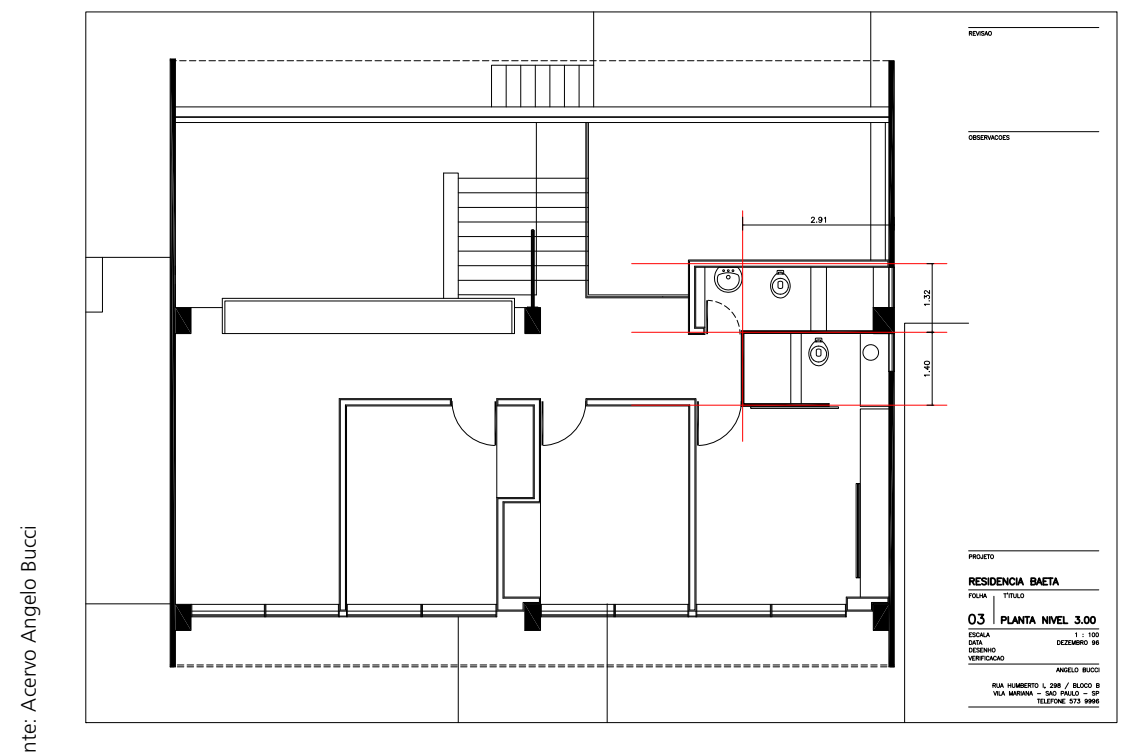

Planta do primeiro pavimento (escala 1:100)

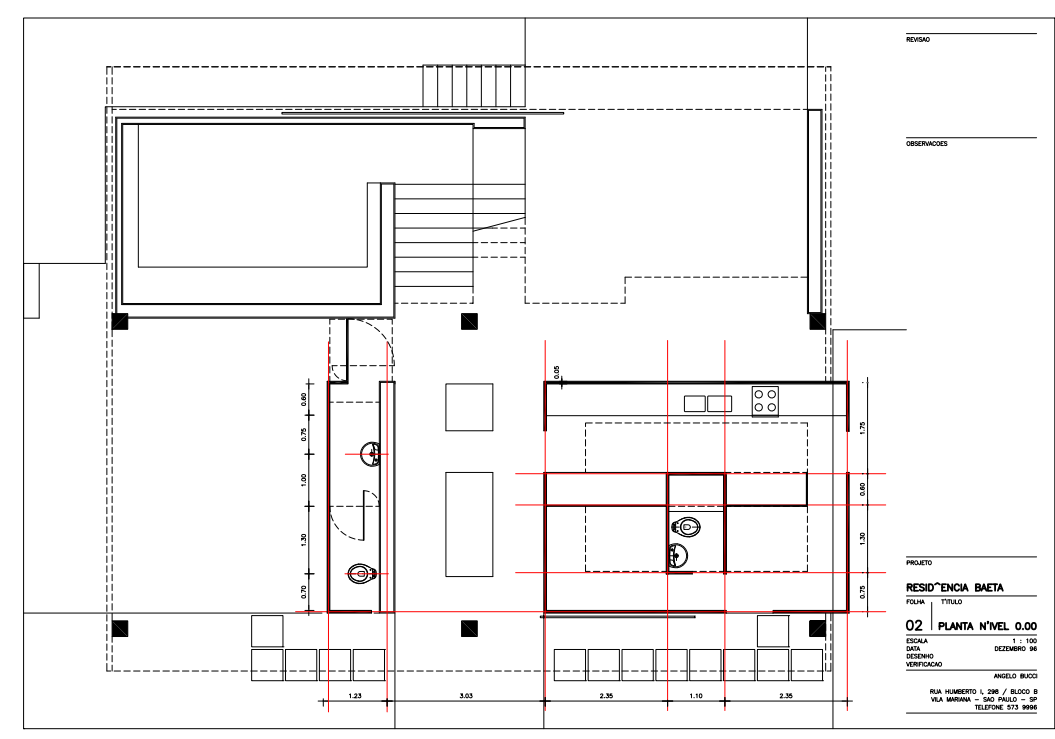

Planta do térreo (escala 1:100)

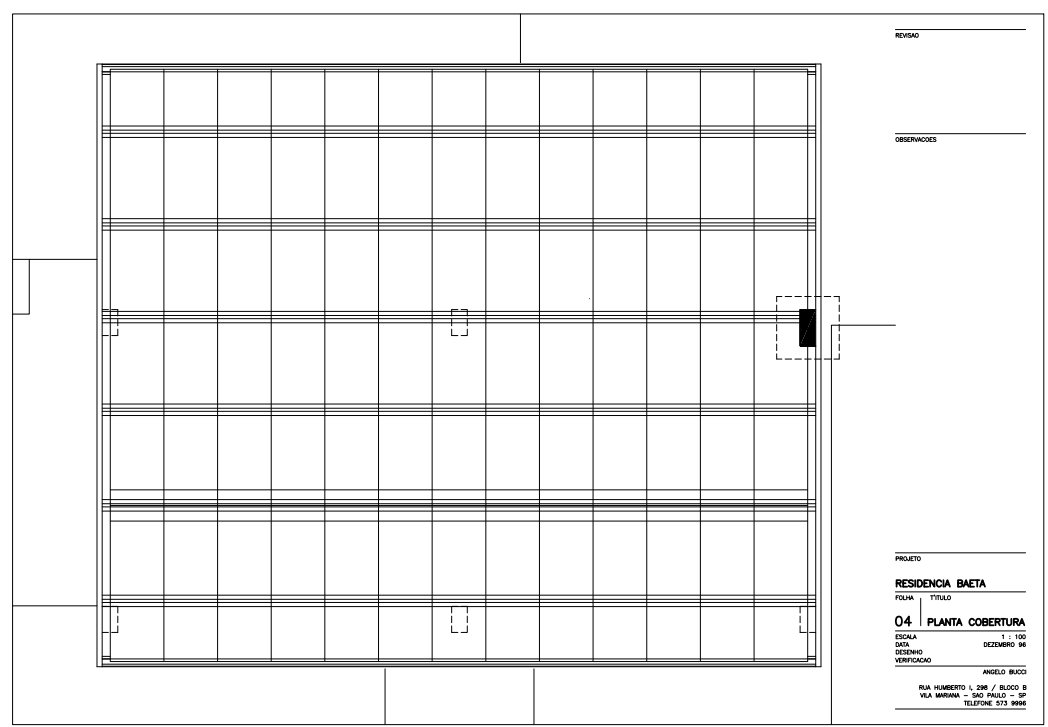

Planta da cobertura (escala 1:100) 


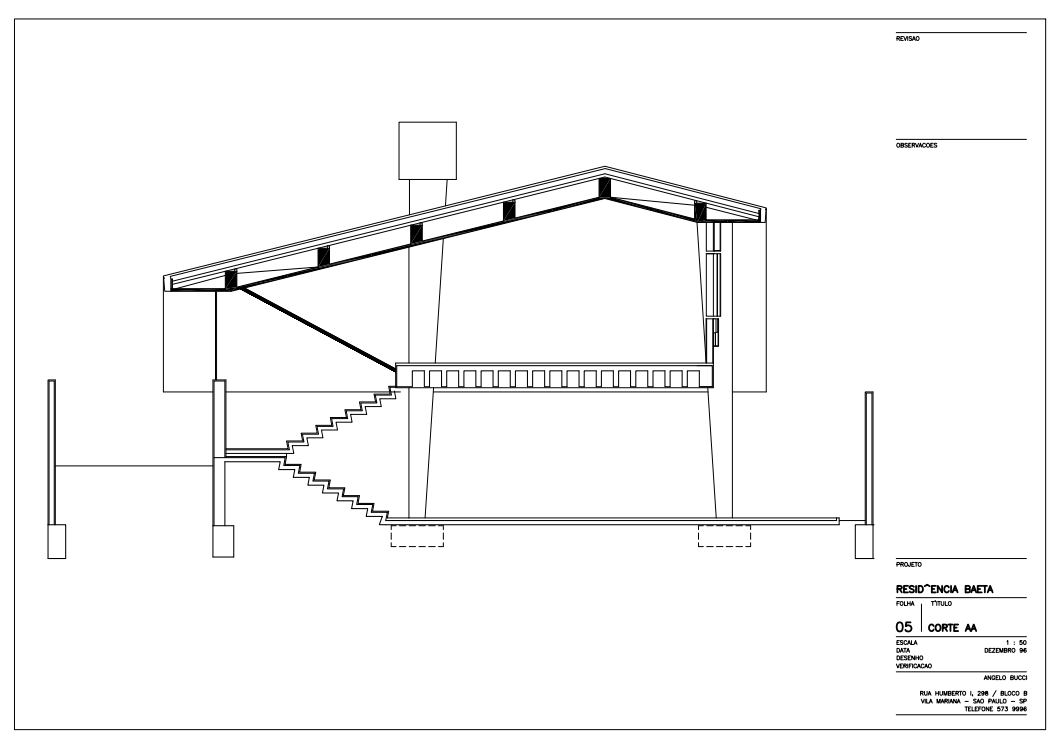

Corte transversal AA (escala 1:100)

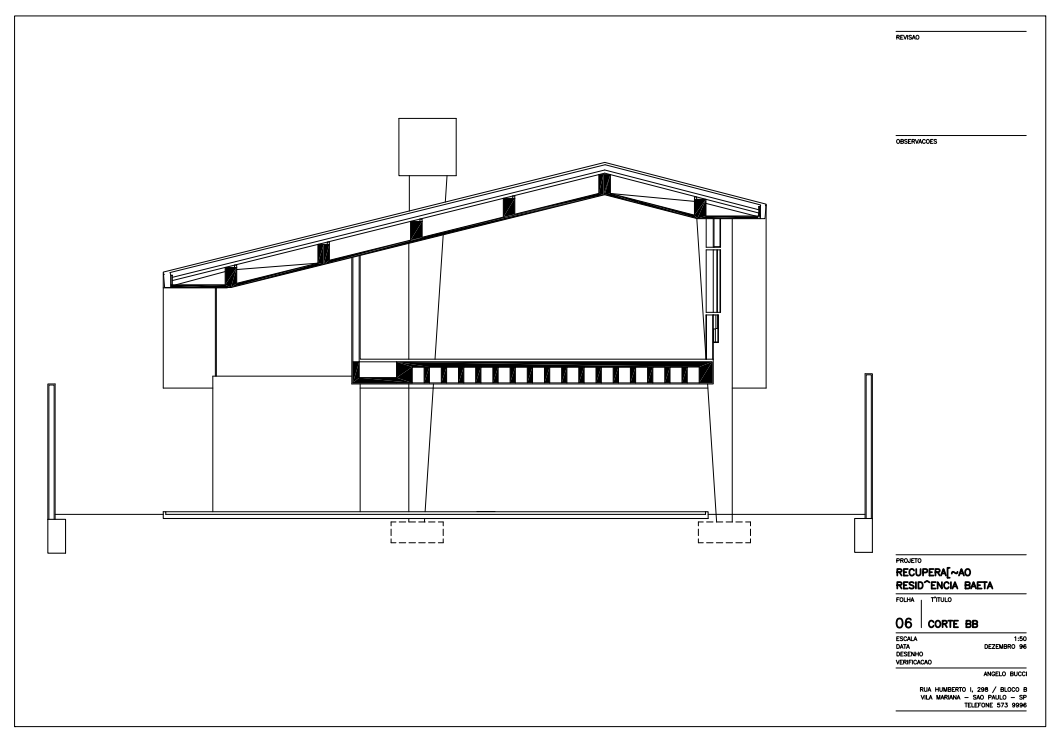

Corte transversal BB (escala 1:100)

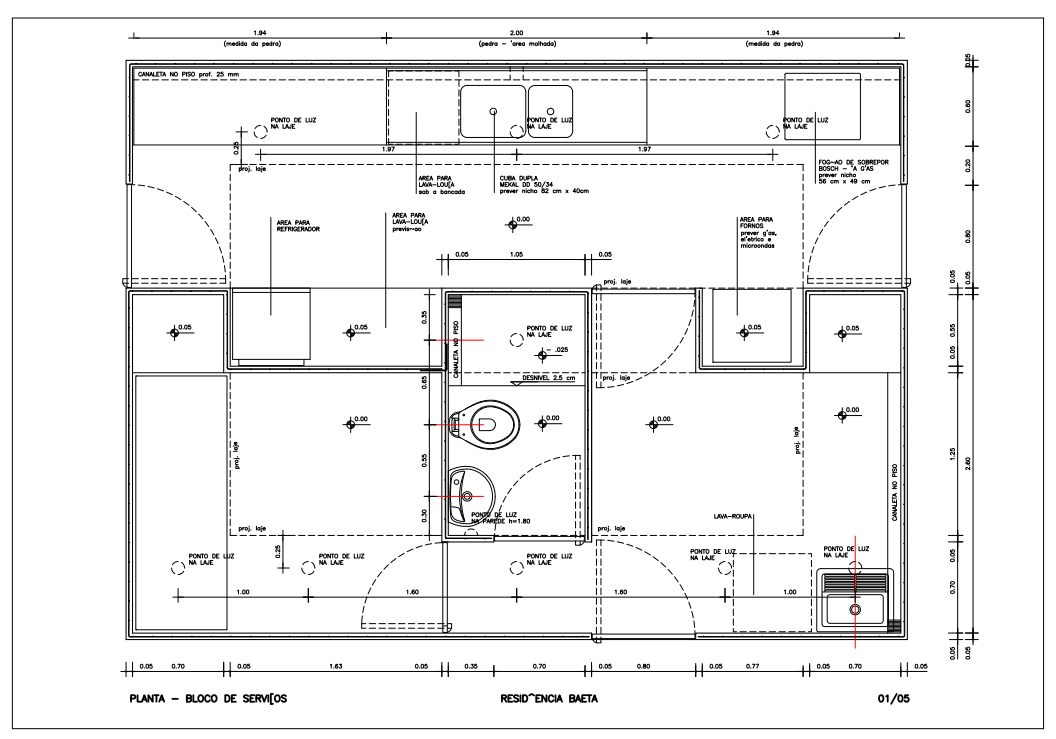

Ampliação do bloco de serviços (escala não identificada)

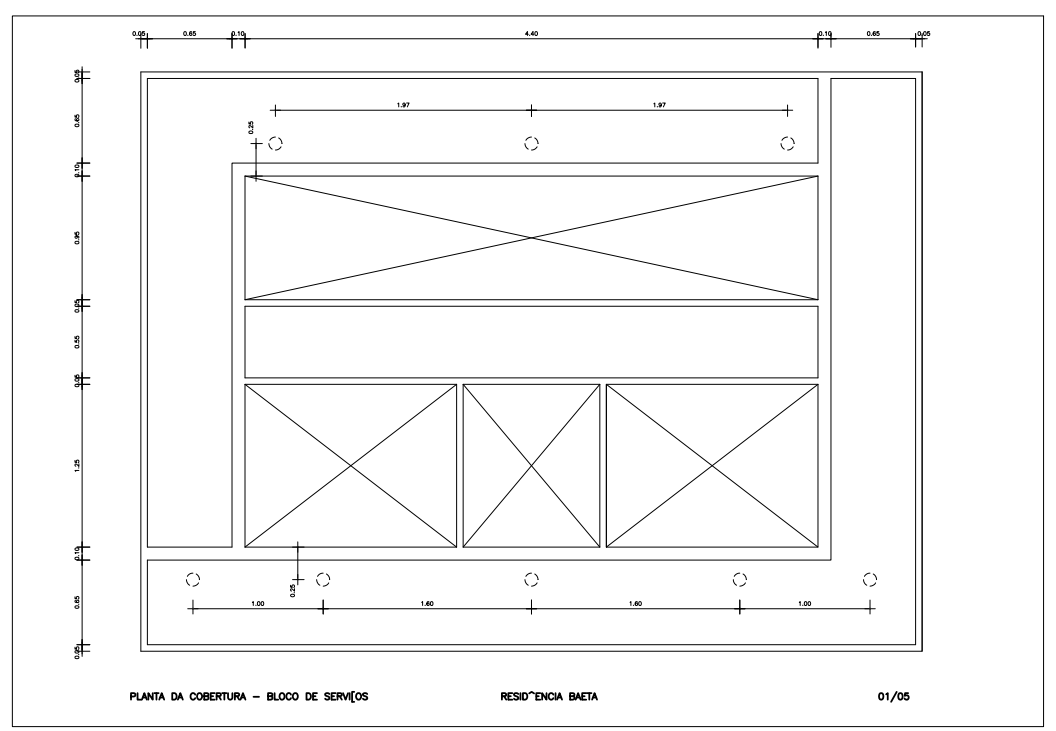

Planta de cobertura do bloco de serviços (escala não identificada) 


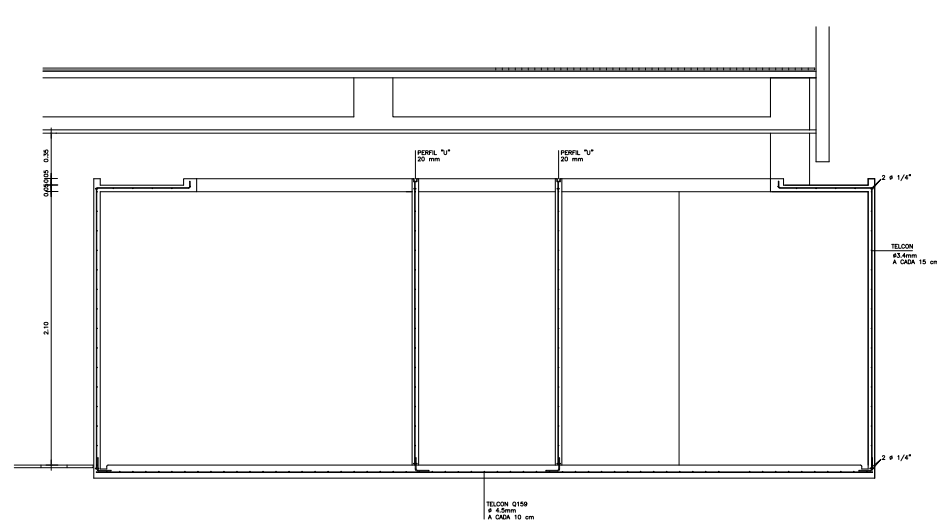

CORTE AA

Corte AA do bloco de serviços (escala não identificada)

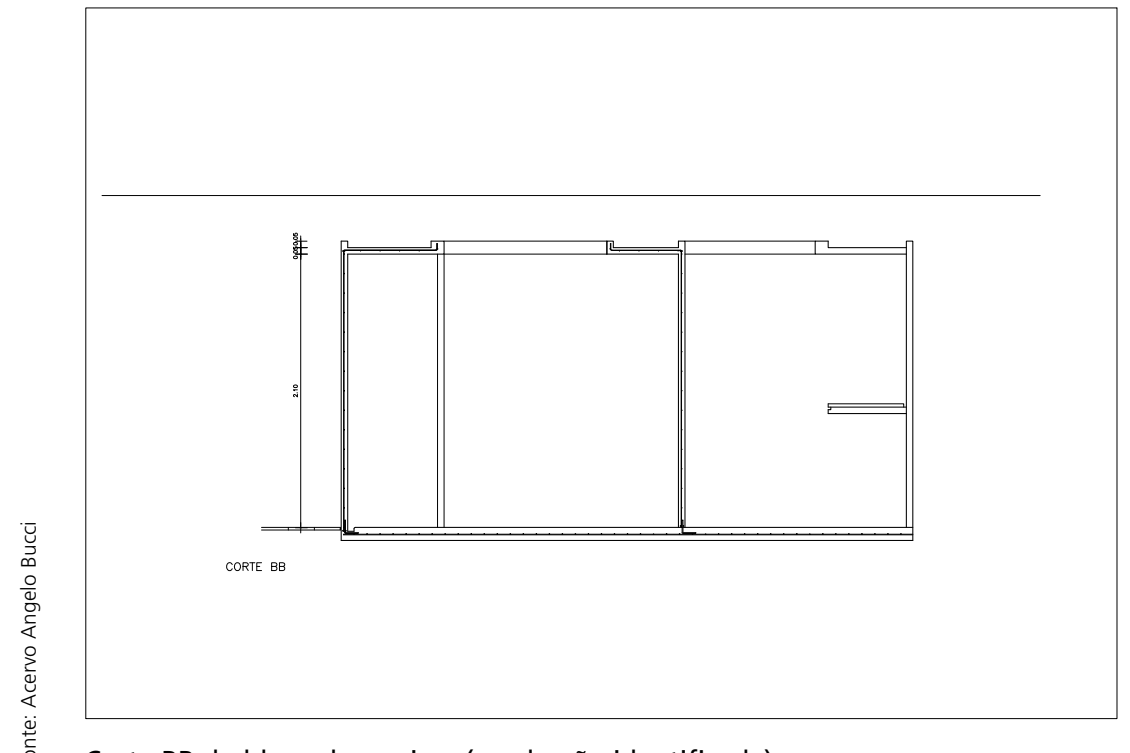

Corte BB do bloco de serviços (escala não identificada)

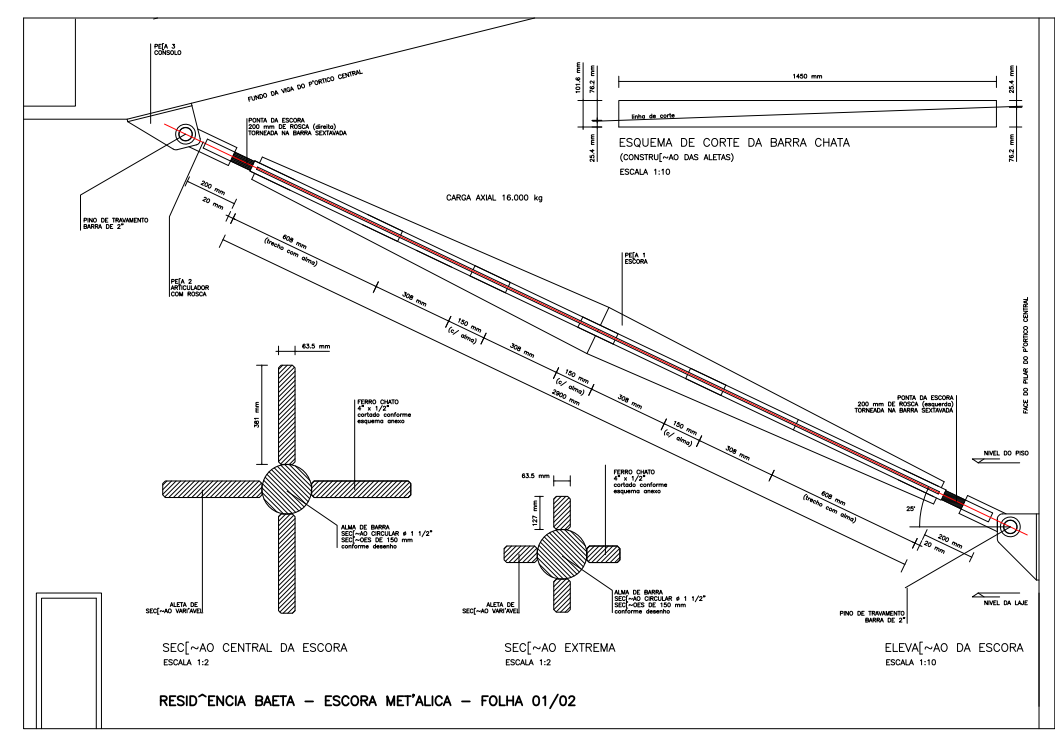

Detalhe escora metálica (escalas 1:2 / 1:10)

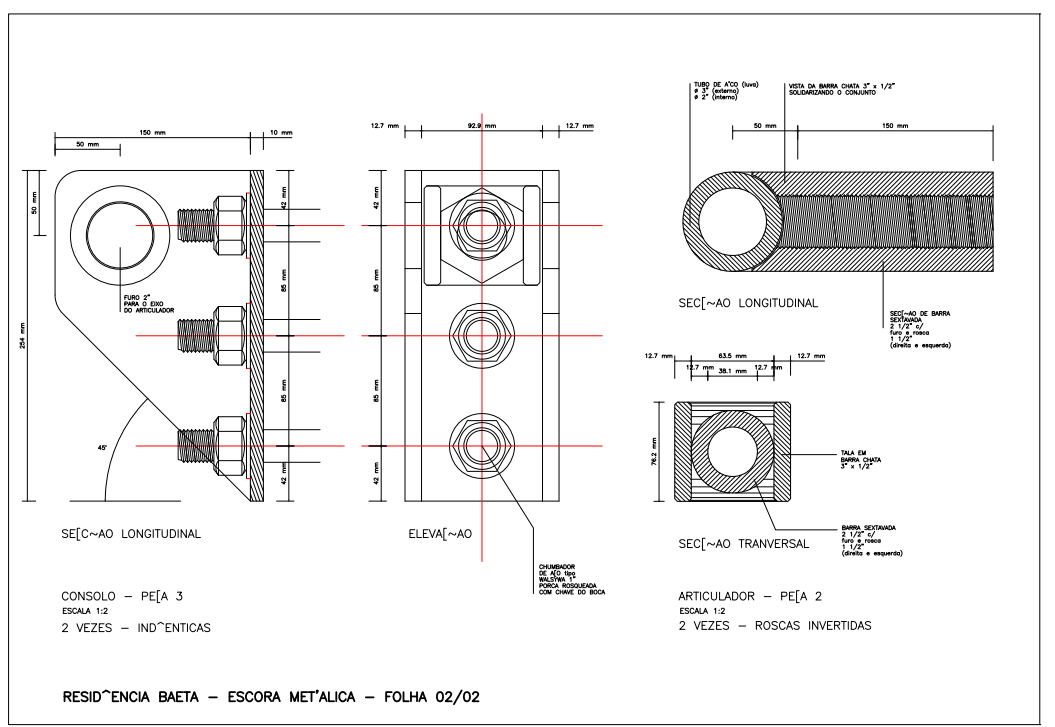

Detalhe escora metálica (escala 1:2) 


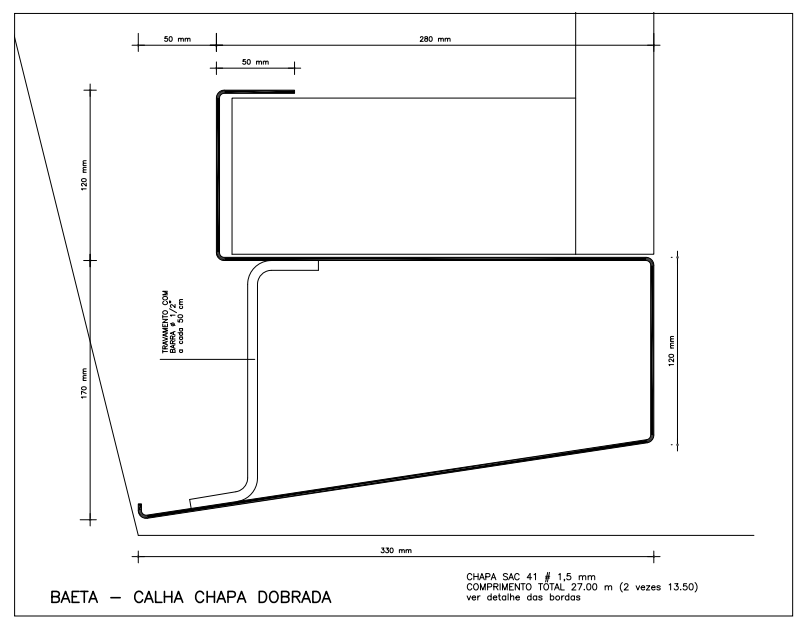

Detalhe da calha em chapa dobrada (escala não identificada)
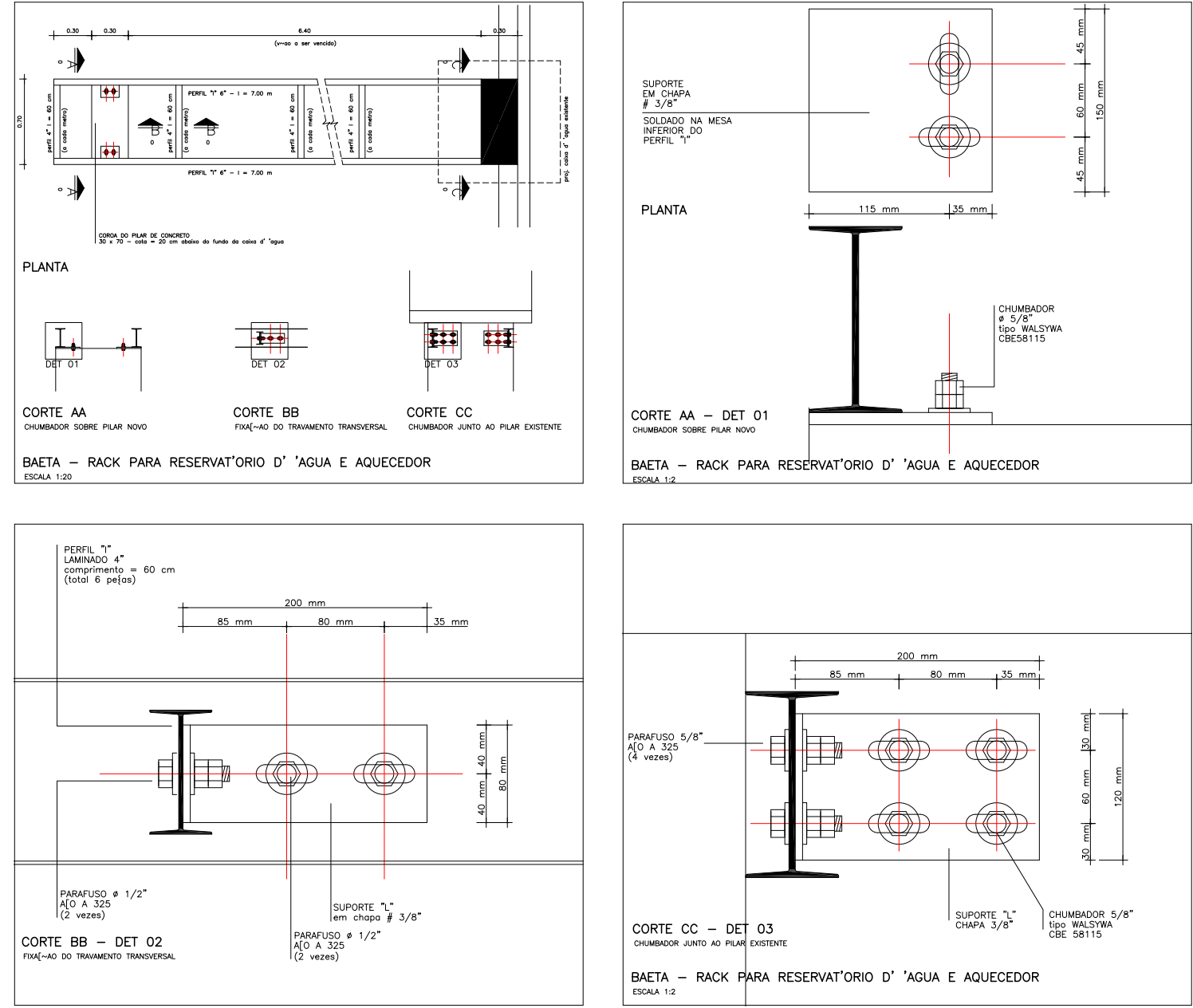

Detalhes do "rack" para reservatório de áqua e aquecedor (escalas 1:2 / 1:20) 


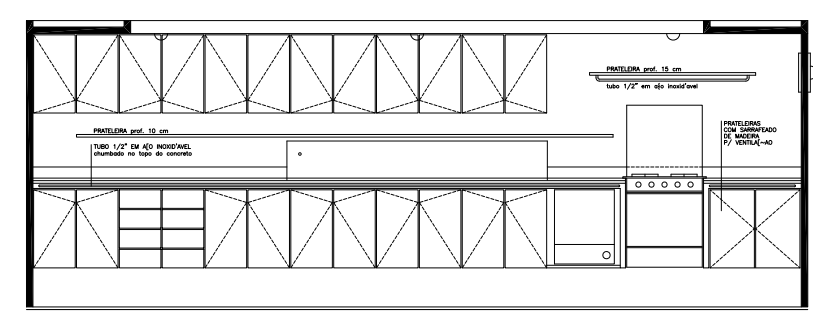

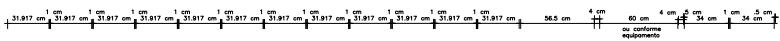

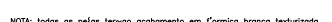

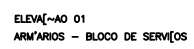

Ressobich Beren

$02 / 08$

Elevação 01 - armários do bloco de serviços (escala não identificada)

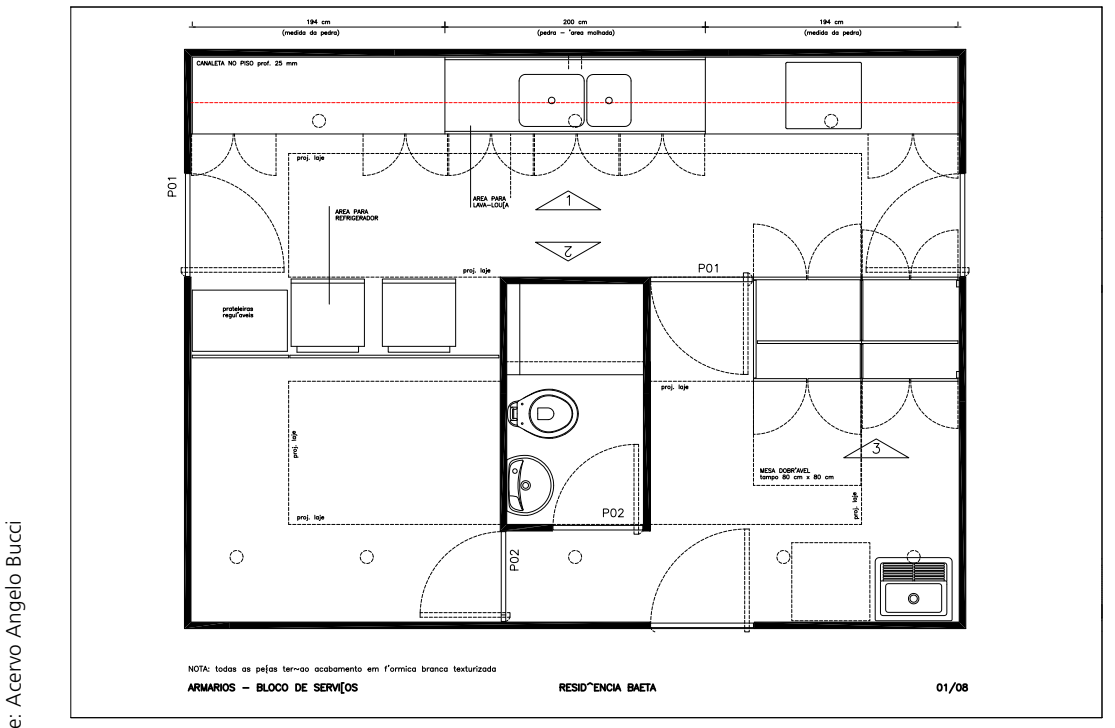

Planta do bloco de serviços (escala não identificada)

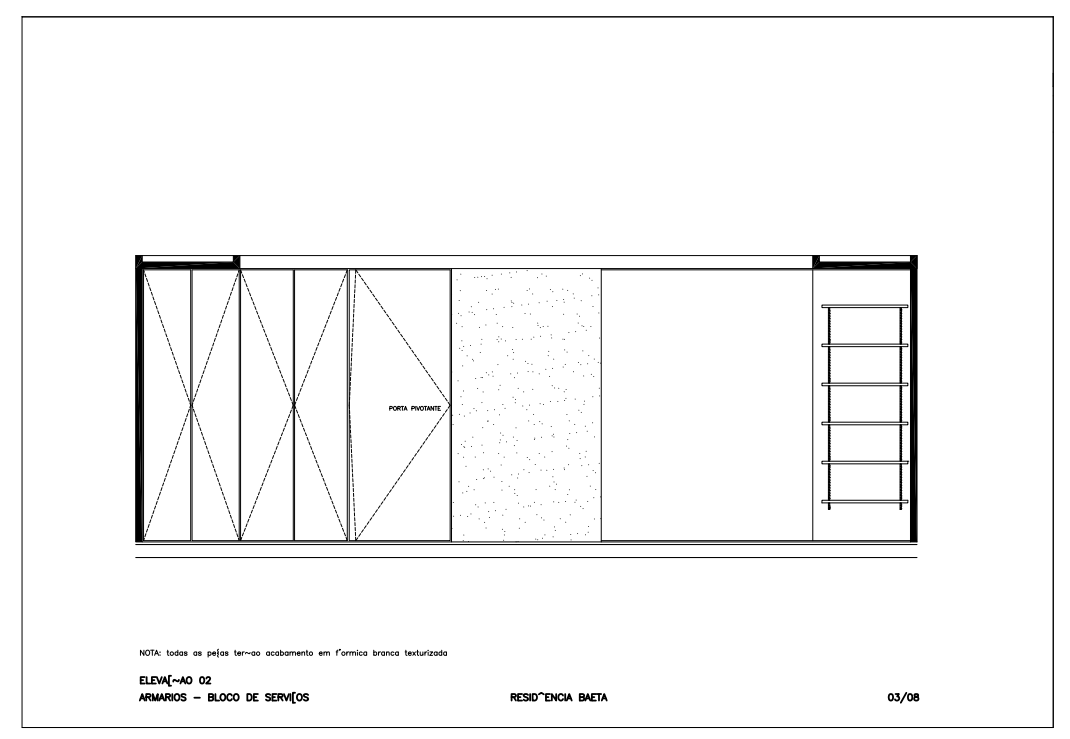

Elevação 02 - armários do bloco de serviços (escala não identificada)

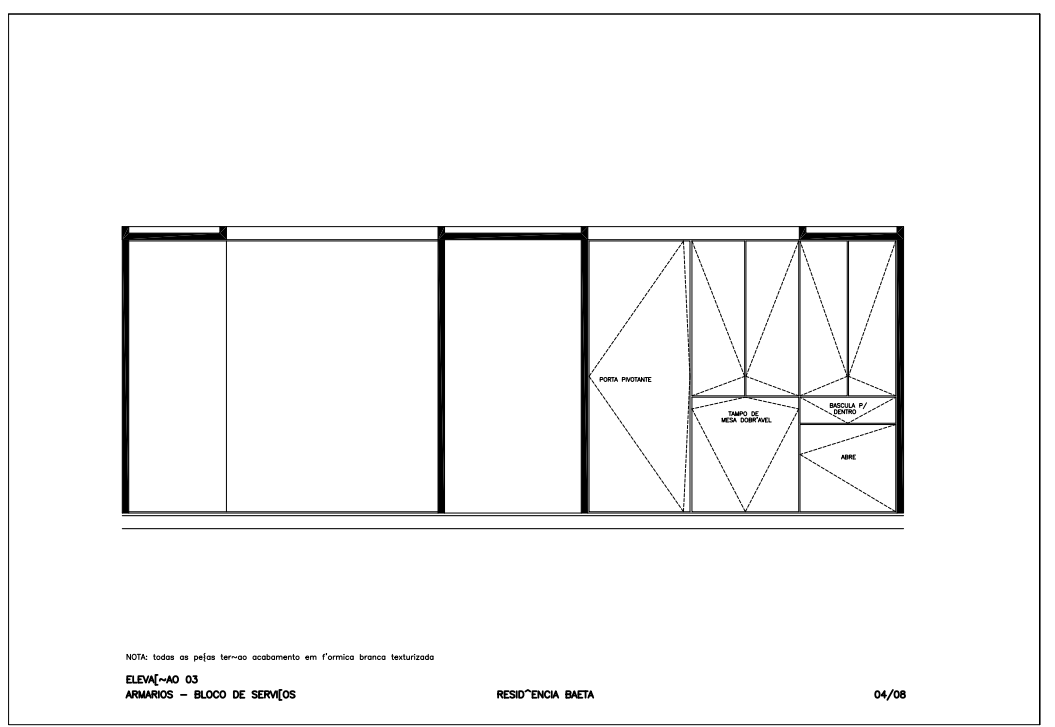

Elevação 03 - armários do bloco de serviços (escala não identificada) 


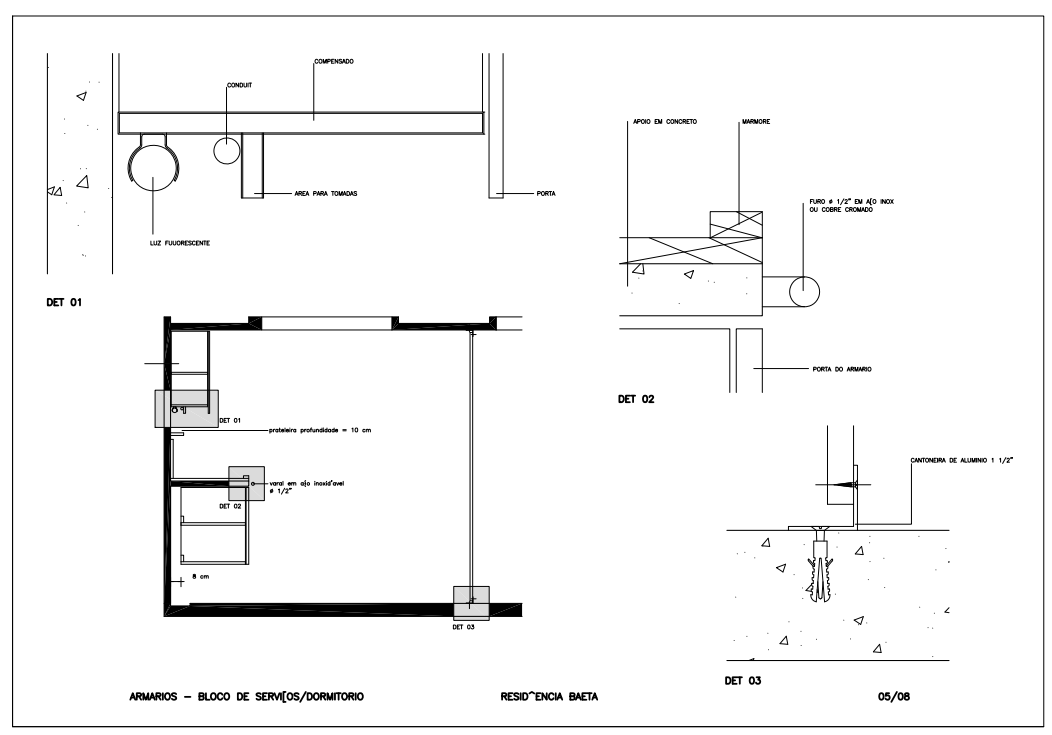

Detalhes - armários do bloco de serviços (escala não identificada)

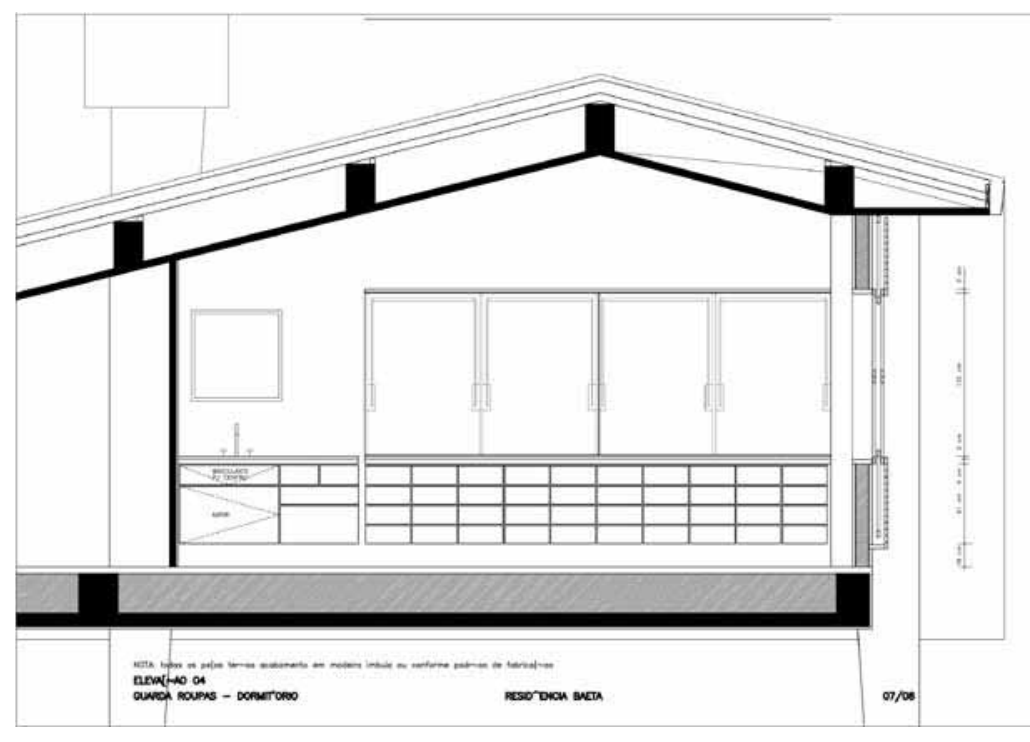

Elevação 04 - guarda-roupas do dormitório (escala não identificada)

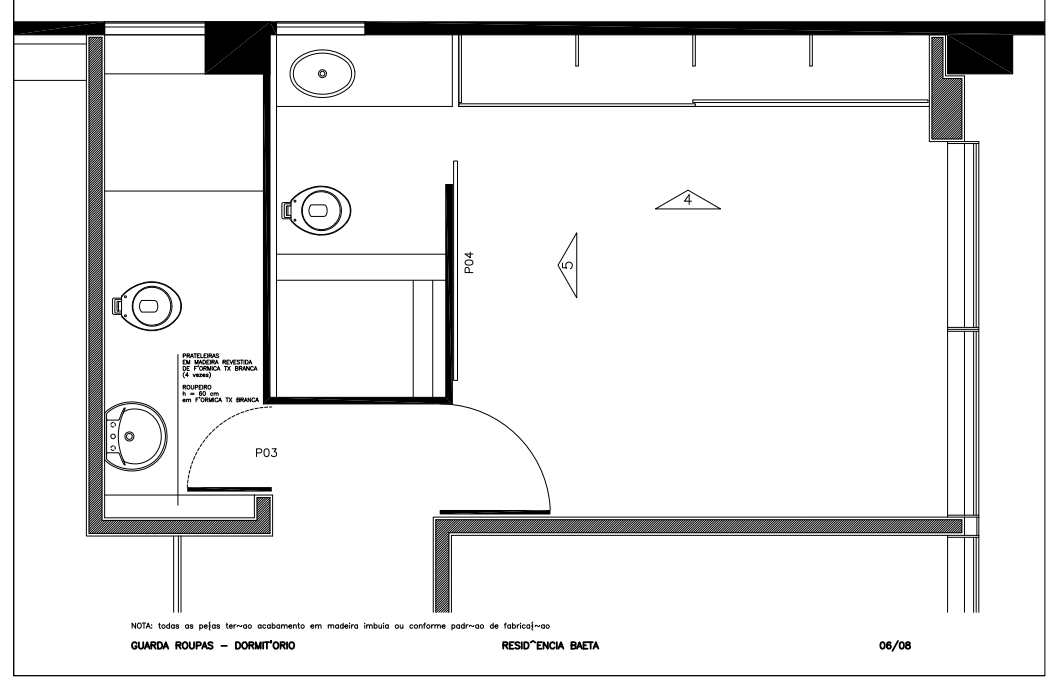

Planta - guarda-roupas do dormitório (escala não identificada)

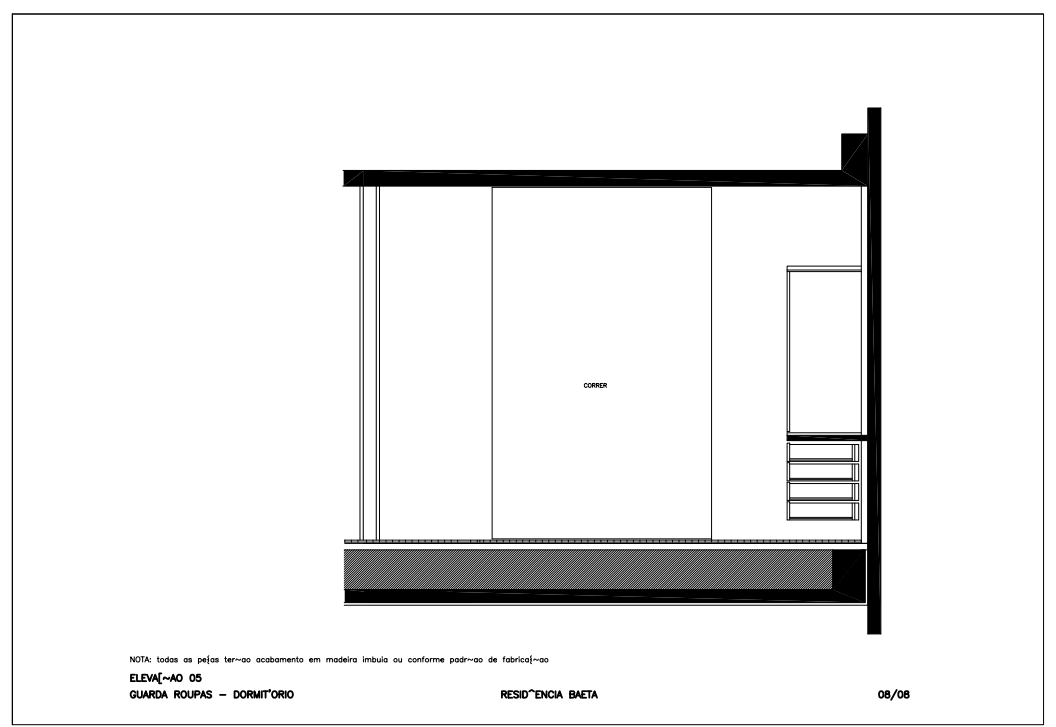

Elevação 05 - guarda-roupas do dormitório (escala não identificada) 


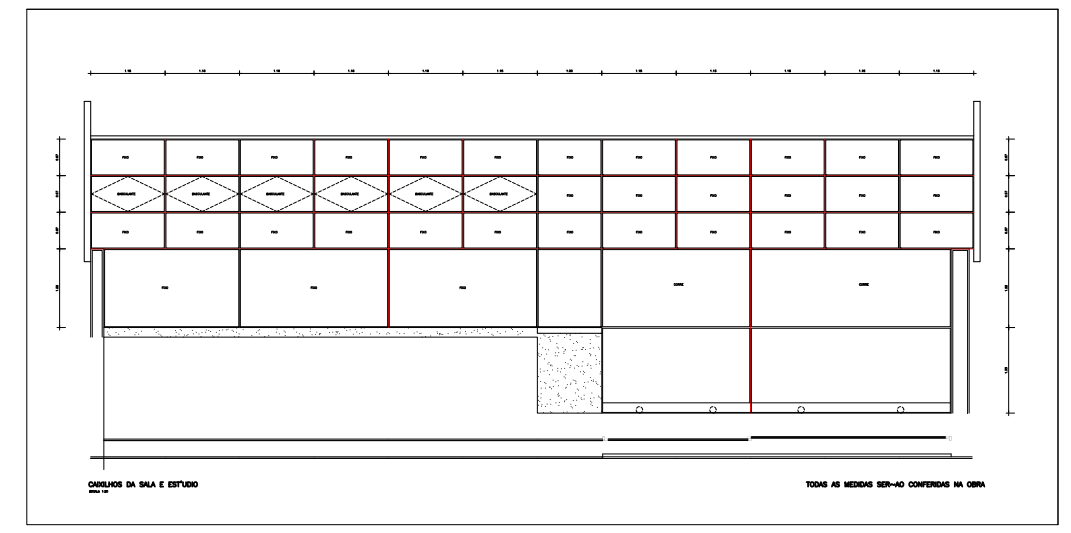

Elevação - caixilhos da sala e estúdio(escala não identificada)

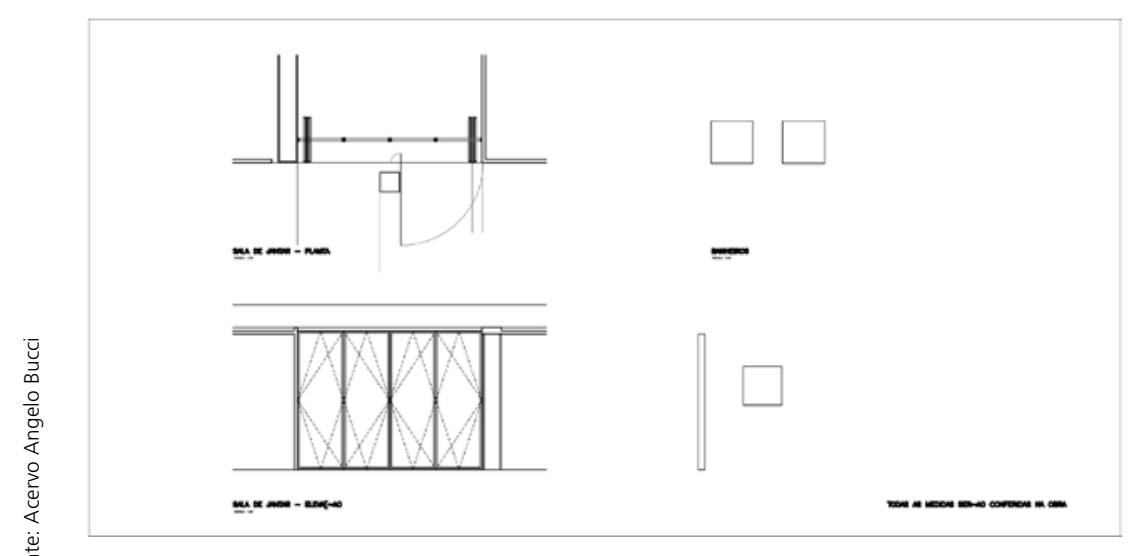

Planta e elevação - caixilho sala de jantar (escala não identificada)

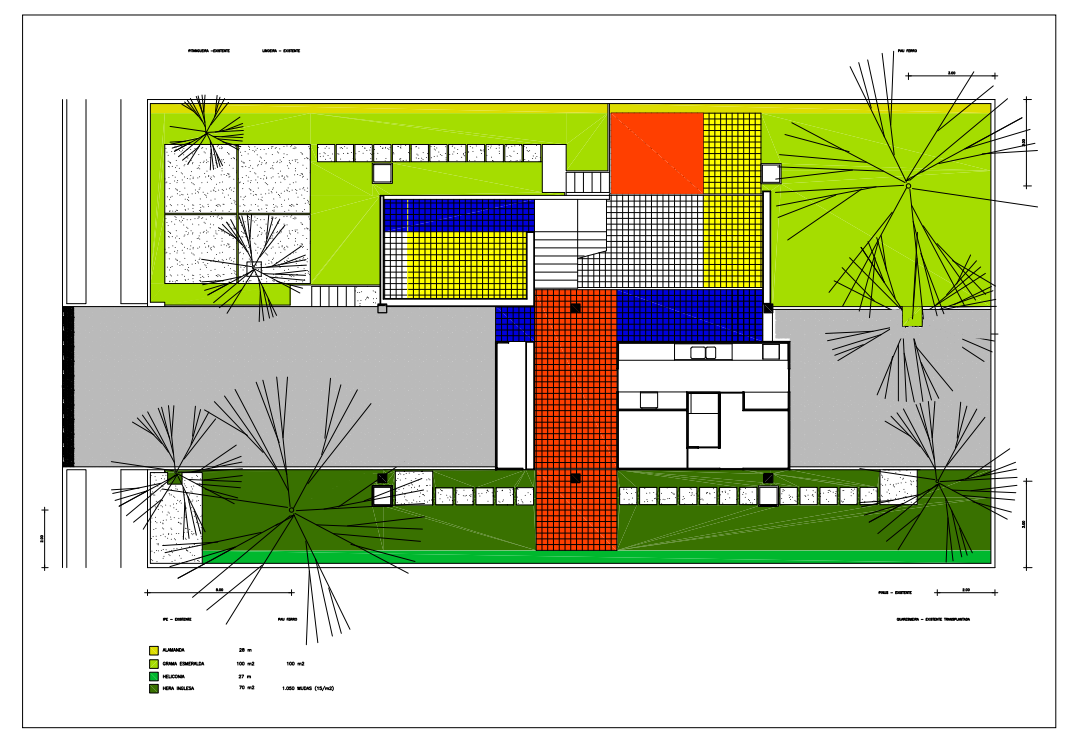

Planta do projeto de paisagismo (escala não identificada)

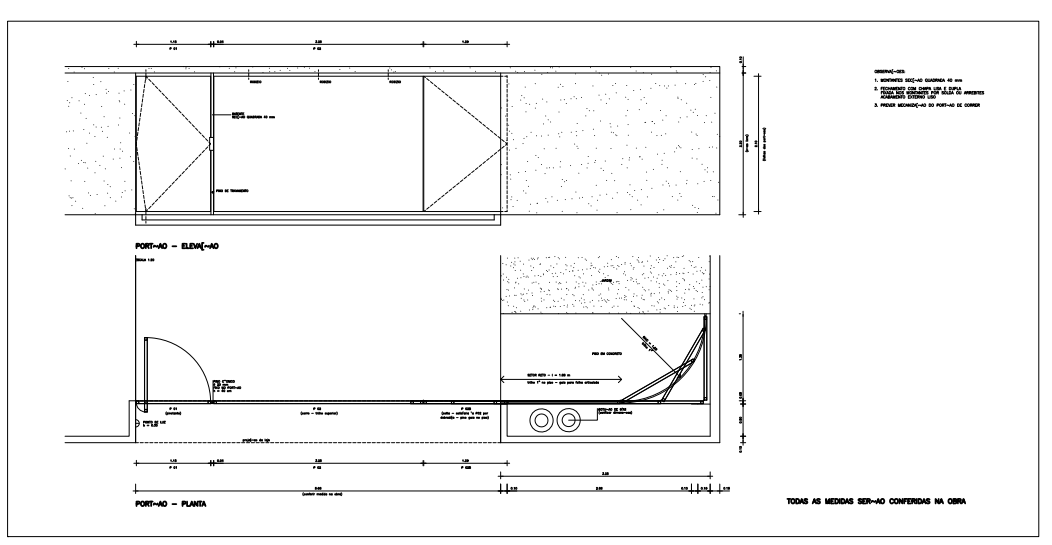

Planta e elevação - portão (escala não identificada) 
ENTREVISTA ANGELO BUCCI, 02/09/2011, SÃO PAULO [AUTOR DO PROJETO DE INTERVENÇÃO]

Apoena explica o recorte de sua pesquisa.

[ANGELO BUCCI] 0 que eu acho legal, embora as casas sejam de períodos diferentes, o que eu acho significativo em São Paulo, as casas - e casas, assim, relativamente modestas em um período. . é como... a arquitetura que a gente reconhece em São Paulo foi se forjando com obras pequenas. Aquele bairro perto da USP, a quantidade de obras que têm ali, de casas, tudo, e são significativas... [Gregori] Warchavchik é uma exceção - é um pouco outro período, Artigas é um pouco antes...

Eu acho que esses arquitetos que hoje são os mais reconhecidos como formadores disso que é a arquitetura hoje em São Paulo, fizeram a formação da obra de arquitetura deles com as casas. É uma coisa que é marcante. Não havia concursos, não havia grandes projetos de modo sistemático, significativo. Acho muito legal esse recorte.

[APOENA AMARAL] Também surgiu esse interesse pela intervenção. Essa intervenção posterior, tratando a arquitetura moderna como patrimônio, independente se ela é tombada ou não...

[AB] Todas essas que você pega tiveram intervenções?

[AA] Tiveram intervenções nos últimos anos...

[AB] A do Masetti quem fez?

[AA] A do Masetti quem está fazendo é o [Eduardo] Colonelli.

[AB] Só ele ou junto com o Paulo [Mendes da Rocha]?
[AA] Junto com o Paulo.

[AB] Aí é uma intervenção diferente. Porque a liberdade que o Paulo tem pra fazer a intervenção é difícil que outra pessoa tenha.

[AA] O que dá um exemplo bom, bem característico

A priori eu tinha pensando em um programa mais público, até 0 exemplo das escolas... tem escolas incriveis, mas não tem nenhum projeto bacana de restauro que tenha sido levado a cabo pelo FDE [Fundação para o Desenvolvimento da Educação]. Inicialmente eu pensei em focar na metodologia de projeto, discutir...

[AB] Metodologia de projeto o quê? Do restauro?

[AA] Isso. Para a intervenção no patrimônio. No sentido do Moderno, dessa proximidade temporal e tecnológica, ela tem seus prós e contras.

[AB] Interessante que isso... é engraçado... patrimônio, eu acho. Eu vi uma loja que eles compram móveis todos de um mesmo período e restauram... Então compraram do [hotel] Ca d'Oro... e acabaram fazendo um acervo. Essas obras acho que é um pouco assim. Acho que pegar as casas para contar essa história é muito significativo porque é em São Paulo. Isso é que me parece interessante. Se fosse no Rio de Janeiro, no mesmo período, você não pegaria as casas.

[AA] A ideia, agora, é que você contasse um pouco como foi o processo da Baeta.
[AB] No ano de 95, talvez no final de 94 meu irmão, Eugênio [Bucci], estava a fim de comprar um terreno para fazer uma casa. Muitos fins de semana nós saímos para ver um terreno ou outro. Ele queria que eu fizesse um projeto. E era muito difícil achar um terreno. Ė muito difícil. É uma tarefa... você já viu alguém comprar um terreno aqui em São Paulo é uma loucura, não é fácil, tem tantas coisas... mas é difícil você realizar. Então começou a virar uma rotina. Final de semana a gente falava, saía para ver uma coisa e outra.

Numa dessas, um dia ele me ligou e disse "Olha, tem uma casa aqui que ofereceram pra gente". Ofereceram pra gente porque, a Casa Baeta, tem uma história, aliás, a gente chama assim, e acho que é uma coisa, não é muito justo, porque o Sebastião Baeta e a Olga Bohomoletz. Eles eram comunistas e nunca... não sei se casaram, mas ela não tinha o nome dele. Não tinha a Olga Baeta. Tinha o Sebastião Baeta e a Olga Bohomoletz. Eram colegas do [Vilanova] Artigas, de partido e tal. Pra quem o Artigas desenhou a casa. A Olga era tia-avó da Maria Paula, que é a minha cunhada. E quando a casa foi posta à venda, ela estava vazia há algum tempo, estava meio... estava inteira, estava lá mais ou menos como está... mas estava com uma cara de uma casa que já sem ocupar há algum tempo. E eles queriam muito vender pra dentro da família, porque assim eles poderiam continuar frequentando a casa e tal.

A casa foi avaliada e custava baratíssimo, assim relativamente. Porque ela tinha um programa também modesto, área pequena, não tinha suítes, não tinha lavabo. Tinha essas coisas. Então, quando... a lista de programa da casa era modesta e a casa tinha um preço ... precisava de uma boa manutenção... mas tinha um preço ótimo. Aí um dia eles me ligaram, o Eugênio me ligou e falou: 
"Olha, apareceu essa casa. 0 que você acha? Porque eu queria muito fazer um projeto com você". Eu falei: "Não! Imagina! Tem que comprar! E vamos lá ver. Mas, é um privilégio!". E daí nós fomos ver a casa. Eles queriam fazer uma reforma. Não era bem uma reforma. Tinha que atualizar algumas coisas da casa. Eles todos gostavam muito da casa. E eu também. E isso. Aí comprou.

Na ocasião acho que eu estava dando aula em Mogi [das Cruzes], talvez. 95. Até 98 eu estava lá. Então eu estava muito em contato com o Alvaro [Puntoni]. A gente já não tinha mais escritório juntos, porque 94 o Alvaro foi trabalhar com o Ciro [Pirondi], depois eu fui trabalhar com o Eduardo [de Almeida]... Depois fiquei sozinho um período, até que eu fosse lá e me juntasse com o Milton [Braga], o Fernando [de Mello Franco] e a Marta [Moreira] e fizesse o MMBB [Arquitetos]. Estava nesse período meio de transição. 0 Alvaro era muito envolvido com a Fundação Vilanova Artigas desde a época da faculdade e daí eu comentei com ele. Ele ficou superentusiasmado. Nós estávamos, talvez, terminando - porque demorou muito - o projeto daquela pousada de Juqueí. E eu acho que talvez tenha sido lá numa dessas visitas à obra de Juqueí que nós fomos conversando sobre a Baeta. E o Alvaro me garantiu que a Fundação Vilanova Artigas tinha todos os desenhos de estrutura. Então um dia eu fui à Fundação e peguei os desenhos de estrutura da casa. Aí fiz uma conversa com eles, com o Eugênio e a Maria Paula, para fazer os ajustes lá, que era o caso. E o caso era principalmente atualizar, digamos assim, a parte mais de serviço, que era cozinha, lavanderia e tal. E a gente tinha um conjunto de informações lá da Fundação muito bom.

Mas... e aí o trabalho que era uma coisa objetiva ali, restrita como foi feito assim, com essa objetividade lá que estava traçada no início, restrito... Aquela faixa de mosaico português que a gente colocou, que começa na calçada e atravessa com a mesma largura... aquela largura marca mais ou menos a área que foi alterada no térreo. Ela era uma modificação que tinha essa previsão de atualizar as instalações... não é só o que está embutido, trocar cano e fio - mas as instalações no sentido de cozinha, de lavanderia, fazer isso. eles queriam um sanitário no piso térreo, que não tinha. Foram essas as coisas que guiaram.

0 que aconteceu depois é que durante o processo de reforma, a gente foi verificando que as coisas que... a estrutura que estava prevista inicialmente não tinha sido respeitada fielmente. A casa parecia que tinha lá as peças todas, tinha uma coisa muito evidente que era a falta da escora projetada inicialmente. Mas, depois a gente começou a ver, demolindo a parede da cozinha que tinha um pilar que estava lá embutido, que não estava previsto, estava lá escondido. Depois outro e outro. Então, havia ali três pilares a mais dentro da parede e mais um lá fora que substituiu a escora que colapsou durante a obra. E aí foi muito interessante porque o Ibsen [Puleo Uvo], que era o calculista que estava acompanhando, ele foi se dispondo a ver, verificar, recalcular... Fomos fazendo uma prospecção, algumas peças como vigas, pilares, a gente chegou a descascar pra ver a armação que tinha dentro, ele refazer as contas e tal. Então, tinha um caso grave - se eu for contando assim, tudo bem? Você sabe tudo, né? - Porque a casa tem um esquema estrutural que é aquele: dois pilares e a viga que faz o balanço lá, que é a empena de concreto. Aí aqui no meio, dois pilares, no fundo dois pilares e repete a solução da fachada, a mesma viga. Interessante porque então é um vão de $5 \mathrm{~m}$ e meio e um balanço de $4 \mathrm{~m}$ e meio mais ou menos. A parede de concreto, essa empena, faz o balanço desproporcional em relação ao vão, mas tem escalas tão tranquilas... e depois tem uma coisa que é interessante que é a laje do primeiro pavimento que só existe no pedaço do vão, não no balanço, equilibra um pouco essa desproporção, mas é um balanço de um lado só, mas são escalas tão pequenas em relação a altura da parede de concreto tudo tranquilo, tipo confortável de fazer... 0 interessante é que, no meio, não poderia existir a parede.

Então aqui ele desenhou aquela escora lá que você conhece. Eu acho muito curioso. Eu te conto isso porque eu tenho curiosidade depois de saber. Porque toda a literatura da casa, uma casa tão visitada, porque ali do lado da USP, já na época em que o Abrahão Sanovicz morava lá... E a casa teve essa história, foi feita pra Olga e pro Sebastião, aí eles viveram lá até por volta de 68 , 69. E com a ditadura militar eles precisaram sair do país. Acho que veio Dalmo Dalari que era casado então com uma sobrinha da Olga, veio uma noite, porque sabia que a polícia ia procurá-los e os tirou dali na hora H. E eles acabaram tendo que sair do país e foram pra Rússia e moraram lá um tempo. E é nesses anos que o Abrahão Sanovicz ficou morando, alugou a casa deles. E depois quando eles voltaram, depois de um tempo voltaram pra casa e ficaram lá o tempo todo.

Aí as histórias que eu fui vendo da casa foram aparecendo durante esse processo, como quase que uma arqueologia pra descobrir a estrutura original, o que estava lá que não era pra estar, porque estava, se era seguro e possível tirar e tal.

Mas, o que eu ia comentar, o que eu tenho curiosidade, é o seguinte: a literatura dessa casa, o que se escreveu sempre, a casa dos seis pilares, da empena de concreto, a empena cujas formas imitam, ou remetem - não imitam, mas remetem às casas construídas em madeira no Paraná, na região do Artigas. São expressões que a gente conhece bem de ver o que se escreveu.

E a casa dos seis pilares, a casa dos seis pilares e a casa dos seis pilares é uma coisa que sempre se diz. São três pórticos, dois, um na frente e um no fundo com essa empena de concreto que faz o balanço e um pórtico central onde a empena não existe e que a estrutura era um absurdo sem a escora. Tinha que ter um outro pilar. E o pilar esteve lá sempre. Mas... é como... eu acho isso 
interessante aparecer na literatura assim. Interessante porque me estranha não comentar, mas tb acho bonito como a gente tem um olho que vê o que a gente um pouco quer que seja. Então você via aquela casa no que ela pretendia ser. Eu acho que tem obras que conseguem fazer isso. Às vezes você não consegue realizar por alguma coisa, mas é tão forte a vontade de fazer que você vê como se estivesse feito. Eu acho interessante esse aspecto

Aí acho que o Júlio Artigas, uma vez eu fui falar com ele pra tentar saber da história, quem tinha construído a casa e tal, e a história que eu soube, sempre assim de uma conversa ou outra, é que essa casa teve uma mão de obra que executou as fundações e a laje até o primeiro piso, e uma outra mão de obra que finalizou a casa. Mas que esse finalizou é muita coisa: as empenas de concreto, a estrutura lá em cima, laje de concreto na cobertura e tal. E que essa mão de obra que saiu quando terminou a laje do primeiro piso é que era uma mão de obra que foi substituída porque era muito pouco qualificada. E fizeram muitos erros durante a construção.

Mas, os erros não eram tão fáceis de perceber quando a gente olhava a casa agora, porque eram erros de intromissão nas soluções de estrutura, mas escondidos nas paredes. Então, quando começamos a demolir e os pilares aparecerem, a gente foi perguntando - a entrada era aqui e aqui tinha uma parede - e aqui apareceu o primeiro pilar - eu já te contei, você sabe mais ou menos - esse é o pórtico central, antes, nesse ponto, embutido na parede, um pilar. Outro pilar aqui. Outro pilar aqui. Esses eram os três. 0 que acontece: esse pilar não fazia nada, não trabalhava nada, o lbsen viu, procuramos a viga, eu disse: pode tirar. Tiramos o pilar. Este pilar: avaliou e disse: pode tirar. Mas tiramos este um pouco depois. Este pilar ele falou: precisamos achar a viga lá em cima. Aí a viga era invertida. Aí nós tiramos os tacos lá de cima e achamos esta viga aqui. Só que esta viga morria aqui neste pilar e nos desenhos de estrutura ela devia chegar até aquele. E ela não foi feita neste trecho.

Então ele falou: Não. Esse pilar não pode tirar de jeito nenhum, a não ser que a gente faça o complemento da viga. Ah! Como faz? De aço? Não - ele falou. Fazemos de concreto. Por sorte essa casa feita na década de 50 usava 0 aço que nós tínhamos, que era 0 CA25, que era um aço para [0 ano de] 96 muito fácil de soldar na obra. Era muito mais difícil, em 96, você soldar um aço CA50, mas o CA25 não tinha problema. Então a gente furou o pilar, colou os arranques com compound [cola adesiva], quebramos a cabeça da viga, desdobramos aquele final da armação, soldamos e concretamos esse pedaço da viga. Aí falou: Pode tirar o pilar. Tiramos o pilar. Aí tiramos esse aqui. Quando nós tiramos este pilar aqui, ele falou: Não tem nenhum problema estrutural. A questão é que este pilar que é o pilar previsto no projeto tem uma fundação e como este pilar intruso estava aqui, aquela fundação nunca foi carregada inteiramente, então vai ter uma deformação ali até a reação do solo. Aqui também: esta viga estava feita, calculada, não ia ter problema, mas ia ceder um pouco a laje, porque a gente ia carregar a viga aqui que não tinha sido carregada. Então a casa teve algumas acomodações. Aqui, o caixilho, que era existente, começou a quebrar uns vidros.

Então a obra era uma coisa que preocupava muito. Eu sabia que com esta casa não podia acontecer nada, não podia brincar. Aqui era assim. Essa aqui era outra curiosidade. Então o que nós fizemos: tiramos estes três pilares. Aí existia um pilar aqui. Este pilar o que é que era? Quando a escora colapsou, eu acredito que os recursos que eles tinham eram muito contados na época e que não dava... Talvez até, eu imagino, que eles não soubessem exatamente porque. Porque como trocou a mão de obra, e a mão de obra nova entrou quando a laje já estava feita, e esta viga aqui que não existia um pedaço estava dentro do enchimento da laje, talvez eles nunca viram, exatamente, o que havia sido o problema.

Eu não sei também o quanto o próprio Artigas pode acompanhar essa casa. 0 Júlio me disse que, no início, ele não acompanhou a obra. Não sei se ele estava fora. Não foi o momento em que ele estava nos Estados Unidos. Não. Foi depois. Então, a solução que eles encontraram, econômica, era fazer uma coluna aqui, provisória, do lado de fora. Essa coluna era fácil porque, para receber a escora ali, na parte superior na laje, tinha como um capitel embutido lá dentro. Estava tudo preparado. Era só fazer a coluna. E essa coluna foi feita em aço, talvez $150 \mathrm{~mm}$ de diâmetro, preenchida de concreto. Era isso que estava lá. E ficou lá até 96. Então 40 anos, basicamente.

\section{[AA] Eles chegaram a fazer a escora que estava desenhada?}

[AB] Sim. Sim. Chegaram. Aquela escora foi executada. Eu sabia porque era a história que eu tinha ouvido. Mas, depois, você via que ela foi colapsada porque na laje de cobertura tinha como a cicatriz do ponto em que a escora ancorava na laje. E o capitel tudo isso eu vi lá. E ela colapsou porque tem 17 toneladas na axial da escora. Só que a escora tem um ângulo extremamente abatido, talvez menos que 30 graus. Quer dizer, a componente horizontal é muito maior que a componente vertical. E quando ela carrega horizontalmente a coluna que não tinha a viga prevista ali pra receber esse esforço, a coluna fletia e a escora colapsava, colapsou.

Eu acho que isso aconteceu de um jeito muito... por sorte, ali... suposição... mas imagino que quando eles foram tirando os escoramentos a escora arrebentou e eles mantiveram... e a casa não veio abaixo... a cobertura... tanto não veio abaixo que eu vi a cicatriz da escora lá na laje. 
Só que... nós tínhamos tirado essas três colunas de dentro da parede e, no final, o Ibsen falou, perguntando: "E a escora? Vamos por? É gastar muito dinheiro? Agora é o mais fácil. 0 difíci já está feito", ele dizia. Porque agora é só por a escora lá. Estava tudo preparado para por a escora. A peça que causou a ruína da escora estava resolvida.

E aí a gente desenhou uma escora em aço, porque... tem um formato parecido com aquela em concreto, mas também porque aquele formato era muito conveniente. Ela aumenta na seção central, onde a flambagem tem maior esforço e afunila nas pontas como aquela, mas era muito mais simples em aço pela instalação, porque a gente fez a escora como um macaco que, colocada na posição, você ia girando assim e ela ia carregando. Então foi um momento muito legal porque a gente... as cabeças da escora eram peças independentes, então parafusou a cabeça no pilar, parafusou a cabeça no teto, colocou a escora lá em cima, passou o pino de travamento, aí girou a escora assim, botou o pino aqui e aí começou a girar para carregar.

E isso foi um momento importante lá da obra. Toda a mão de obra, o lbsen, eu, acompanhando isso. 0 pessoal girava a escora com uma alavanca e o lbsen acompanhando... Aí foi carregando e o Ibsen, assim, no olho, sabe? Porque não tinha torquímetro, nada disso. Aí falou: "Acho que está bom". Também porque se estivesse um pouco a mais ou a menos não era um problema. Mas o que foi legal é o seguinte: antes de arrochar a escora, a gente colocou em torno do pilar provisório lá fora, quatro escoras de obra, daquelas que você arrocha também... e colocou na posição, bem apertadas. Aí pôs a escora do projeto. Foi arrochando também até o Ibsen dizer: Tá bom. Daí ele autorizou a cortar a coluna que estava lá fora. Então saiu todo mundo da obra. Falei: sai de baixo da laje. Ficou toda turma lá encostada no muro e o cara com o maçarico veio aqui e cortou o pilar. Quando ele cortou o pilar, aquele escoramento em torno do pilar, as quatro peças, que estavam super apertadas, soltaram, assim... Quer dizer, a laje levantou levemente. Quer dizer, tinha arrochado um pouco mais que o necessário a escora nova.

Mas, teve essas coisas... Quando começou a estourar vidros, os pedreiros ligavam preocupados... E eu, naturalmente, com uma preocupação enorme porque era essa casa, tão emblemática e tudo tinha que estar tudo muito certo, além de eu gostar muito da obra. Outra coisa que era interessante, que eu achei, assim... isso aqui, olha... eu tenho muita curiosidade: é uma caixa cheia de terra e tira a possibilidade de você girar o terreno aqui. Eu às vezes acho que isso foi feito também por uma razão econômica, sabe? Às vezes eu tenho a impressão que isto foi como fazer um "bota-fora" dentro do terreno. Construiu aqui uma caixa, tinha que acertar o nível, botou a terra aqui, ficou um jardim e estava tudo resolvido. Depois fez estúdio no meio do caminho, no patamar da escada e era isso.

Agora, isso era difícil de ser percebido porque aqui a parede separava, aqui você não lia, e aqui tinha também uma parede até $1 \mathrm{~m}$ de altura... E aconteceu uma coisa que, talvez, ao longo dos 40 anos de existência da casa, cuidando de jardim, trazendo talvez adubo, terra vegetal, sei lá... 0 que tinha lá era que o jardim, em 96, era um pouco mais alto que a casa. Então, quando chovia muito entrava água e tal. Aí a solução que a gente achou foi de rebaixar um pouquinho o jardim, uns $10 \mathrm{~cm}$ em tudo. Então gente usou este "bota-fora" aqui. Aumentamos aqui uns $20 \mathrm{~cm}$ coube toda a terra que tiramos dali.

Eu achei que era possível fazer isso porque o jardim, então, chegou mais próximo da cota do estúdio e aqui ficou apenas um degrau de desnivel. Era legal. Só que tinha uma parede até $1 \mathrm{me}$ você não lia esse desnível. Então, também, depois... Quer dizer tudo isso foi uma consequência de ter encontrado uma escora dentro da parede.
Quando a gente colocou a escora, outra coisa que era possível fazer era o seguinte: se você olhasse a situação que nós encontramos em 96 isso aqui era assim: e o vidro vinha, desviava, e o pilar provisório estava aqui. Então nós tiramos isso. E este caixilho poderia perfeitamente ser alinhado. Então nós soltamos o caixiIho, o mesmo caixilho que encontramos lá e alinhamos ele aqui. A mesma peça. E aí também a seção que tinha uma parede em baixo nós podíamos fazer caixilho também. Então fizemos para que aqui o jardim e o estúdio ficasse a mesma coisa. Veio tudo muito na consequência..

Depois, a obra, você vê que é super simples. Tem uma coisa que aqui a gente fez a cozinha como uma caixa que não toca a construção. A parede que existia lá ia até o teto e aí virava aqui, não existia esta passagem... Esta passagem aqui eu acho que é muito legal porque, mesmo lá da rua você tem a possibilidade, se o portão está aberto, ou sem portão talvez, de ler os três pórticos por aqui. Aqui como nós abrimos pra cá, que era fechado, ficou aqui uma sala de jantar, além de ganhar esta largura do terreno, a extensão do jardim, quando você olha daqui você vê também o pórtico central inteiro. $E$ como a cozinha não toca 0 teto, a laje, você está subindo lá para os quartos e pode ver os seis apoios, sabe..

Então eu acho que a casa foi aparecendo como ela estava descrita lá na literatura e que era ao mesmo tempo descrição que não olhava a estrutura que tinha estado lá funcionando. Principalmente aqui, aquele pilar lá fora como ele era um pilar em aço, seção de 150 [mm de diâmetro], se não olhasse com conhecimento e atenção talvez parecesse um tubo de água de chuva, coisa assim. Mas, era evidente que era uma coluna.

[AA] Estavam com você a Luciana [ltikawa] e a Carmen [Morais], não é? 
[AB] Sim. A Carmen. A Luciana acho que ficou um pedacinho lá. Você não estava lá, estava?

[AA] Eu não estava mas fui algumas vezes.

[AB] Você não estava mais acompanhou várias vezes. Você viu quando tirou a escora?

[AA] Não. Eu não estava nesse dia. Eu fui um outro dia, quando estava o pessoal da "Arquitetura \& Construção" fazendo uma matéria.

[AB] É. Eles fotografaram o processo.

[AA] E você tem essa matéria?

[AB] Tenho. Mas se você falar com a Lívia Pedreira... Eu tenho, você pode copiar se quiser... Mas se você falar com a Lívia Pedreira, talvez ela te arrume as imagens originais. Você fala para que é... Você conhece? A Lívia é editora da "Arquitetura \& Construção". Eu te mostro a matéria aqui, se você quiser ver.

[AA] Acho bonito eu ter acompanhado, mas ainda muito jovem, não enxergava tudo isso que você descreveu. Mas, o que eu percebo no seu jeito de projetar que é esse cuidado, que muita gente não tem. A força do desenho, ela tem que ser tão radical, que para uma obra do zero é importante, mas para uma obra preexistente a radicalidade exige muito cuidado.

[AB] É difícil... Eu não gostaria de alterar demais a casa... Tem sempre isso: a medida boa para um projeto, um limite bom, positivo, é sempre o limite dos entendimentos. Você precisa fazer.
Cada coisa custa. Os moradores, proprietários da casa têm que estar de acordo. 0 engenheiro calculista precisa estar seguro do que vai fazer. São coisas que vão guiando, balizando muito. Eu acho importante o cuidado... Mas talvez a maior prova... Não prova, porque depende de como se faz tudo... Mas, é tempo... Eu sinto muito isso, Apo. Essa coisa de projetos que são feitos com uma falta de tempo absoluta! A elaboração de um projeto demanda tempo. Tempo de conversa, de entendimento com as pessoas. Com croquis você pode até construir... Mas a obra vai parecer um pouco isso..

Aqui foi uma obra feita, você vai lembrar, com tão pouca gente. Tinha lá os pedreiros, o Paulinho [Paulo Balugoli] que ficava um pouco lá. 0 Jean [Carlos do Santos], pedreiro que depois fez o consultório de odontologia lá em Orlândia. O Persinho [Persidônio da Silva]. 0 Dorfo [Adolfo Keles]. Tinha cinco pessoas, que era o que cabia num carro. $\mathrm{E}$ cinco pessoas fizeram a reforma. Então, todas as coisas usadas era o que aqueles cinco ali podiam fazer. Depois veio um marceneiro, que ficava na obra, montou as janelas todas, trocamos cabos de aço. Coisas super domésticas, assim. Serralheiros...

Tivemos surpresas, por exemplo: a calha, nós refizemos de um jeito bacana, eu achei bacana porque ela arrematava o projeto. As peças todas, não era só a calha d'água, mas a espessura da laje, do telhado, a borda da empena, elas faziam o desenho com muito cuidado. E a calha era especificada uma calha de aço Corten [aço patinável] com uma pintura epóxi. E a calha que nós recebemos não era Corten e a pintura também não era epóxi, então aquilo ali estragou rapidamente. E como depois os proprietários foram morar lá em Brasília, a casa foi alugada e precisou trocar a calha. E o inquilino, tudo de acordo lá, trocou a calha por uma solução... fez sem o mesmo cuidado, sem olhar os desenhos, então não é o que estava lá.

Mas, quando nós substituímos a calha, nós substituímos também os condutos verticais de água de chuva. Os que estavam lá che- gavam até o chão, então era muito estranho, porque os tubos de água de chuva desciam paralelos ao pilar, pareciam outros pilares e você às vezes confundia o que era uma coisa e outra. Então, nós cortamos todos na base da empena. Nenhum tubo de água chuva chega até o chão, a água cai livre. Então, tem uma série de coisinhas assim. Mas, sorte... por exemplo, ainda existia a Ladrilar que é a mesma fábrica que fez aquele ladrilho hidráulico, então quando a gente abriu aquele pedaço transversal, para compor ali a sala, fazer a mesa de jantar, a gente usou o mesmo ladrilho, estendemos um pouco o piso externo para fazer essa coisa da casa estender mais.

Ela tinha originalmente as cores... a gente seguiu o que estava original e parte do que estava na casa quando a gente encontrou era muito alterado. Mas eu tinha vontade de fazer o que foi a primeira pintura, que era uma caiação com essas cores Mondrian. Mas, isso era extremamente trabalhoso porque tinha que remove todo o revestimento. Então, a gente acabou deixando a pintura acrílica, mesmo, mas com as cores perto do original, mas não é exatamente as cores do Artigas.

[AA] E essa legibilidade? Porque tem a caixa de concreto da cozinha, o lavabo, acaba ajudando a ler o que é novo. Porque quando se lê a Carta de Veneza isso é super claro. Em algum momento você chegou a... você deu uma olhada?

[AB] Não. Eu não conhecia a Carta de Veneza. Mas, não é a toa que está lá assim, que você faça um novo que não confunda... Mas, também não é só uma coisa de material. Também não confunda, não toque... não confunde e não se funde. Nenhuma peça nova toca, por exemplo, as lajes, as paredes existentes. Isso é uma coisa que fizemos assim. Eu acho interessante porque a casa toda é estrutura de concreto. A empena é de concreto aparente, mas 
pintada de branco e o que está feito lá não é exatamente concreto porque a armação é simples, então tem argamassa, mas tem essa cara. Então ela tem uma diferença radical de espessura, porque tem cinco centímetros. E tudo que é o novo é aparente, de fato, sem pintura, que foi também um outro modo de distinguir. E dai você olha assim. Segue esses princípios, mas que só depois eu fui conhecer.

[AA] Mas é engraçado porque quando eu vi a obra, fazia muito sentido. Eu fui ver isso dez anos depois, fazendo o TFG [Trabalho Final de Graduação], porque na FAU [FAU-USP, Faculdade de Arquitetura e Urbanismo da Universidade de São Paulo] até então eu não tinha tido contato com isso. Mas, parece que intuitivamente, uma pessoa com cuidado, com respeito nesse sentido de reconhecer o valor daquilo, não só culturalmente, mas justamente como objeto manufaturado. E aí você vai com calma, vai com delicadeza. Parece que, a impressão que eu tenho da Carta é que ela é fruto justamente desse raciocínio.

[AB] Mas, é uma posição possível. É uma outra ordem de coisas. Como você não faz uma barbaridade? Não é fácil! Assim, dizer. . você sempre espera não fazer. Mas, o problema são os critérios, quantas coisas você observa pra fazer. Mas, tem uma outra questão que, hoje a gente olha e diz "Ah... não é nada! Uma pequena reforma em uma casa que é incrivel...". Mas, na época eu tinha muita preocupação de qual seria a postura mais adequada. Por exemplo, aquela escora: nunca foi feita! Por que fazer? Por que querer fazer a casa mais autêntica do que a casa que você encontrou? É um assunto. É uma pergunta que se pode fazer. Essa é um tipo de pergunta e que eu acho que cabe. Mas, eu acho que uma boa resposta pra isso, uma coisa que me tranquilizava era: eu não parti com um plano de colocar aquela escora, não era essa a mi- nha meta. 0 que nos surpreendeu é que... eu não queria "fazer" aquela casa. Não parti com esse plano e muito menos o de faze aquela casa melhor do que o Artigas tivesse feito ou coisa assim. 0 que eu queria era tratar a obra. Que postura você coloca? Pega uma obra dessas... 0 que é mais respeitoso com o autor? Voce deixar o que está inadequado ou você tratar aquilo? Eu acho que o mais respeitoso é você tratar com a maior seriedade, com arquitetura, na função que a coisa precisa desempenhar, procurando compreender como aquilo foi concebido, porquê e tal.

Então, pra mim, isso é significativo. Eu pensava assim: a meta não era por uma escora. Não foi esse o ponto de partida. 0 que aconteceu no processo é o que nos surpreendeu. É uma coluna que não poderia ter existido, um pedaço de viga que faltava, que eu acho que ninguém sabia que faltava. Eu acho que o mestre que terminou a obra não entendeu porque a escora colapsou, porque aquilo que faltava estava escondido no enchimento do piso. E nós fomos ali, por uma contingência de uma pequena reforma, descobrindo e recuperando um modo de funcionar. E quando fizemos uma coisa, outra, outra, a gente estava apto totalmente a colocar a peça que colapsou. Então aquela peça era como... Ela marca o sucesso de uma sucessão de surpresas e de soluçõe bem sucedidas no processo, sabe? Você culmina com aquilo e daí pode fazer o que não poderia ter sido feito antes. Isso é uma coisa interessante.

[AA] Foi desenhado tudo, longe do objeto? Falou: Tem que ser assim. Ou não, o executivo foi feito junto?

[AB] Foi. Porque nós imaginávamos que o plano de estrutura, 0 projeto de estrutura estivesse fielmente atendido, mas não estava. Eu tinha os desenhos originais... Mas, não era! Aí eu comecei a pensar assim, que tinha que estar lá. Aquela escora que a gente quase que via sem estar ali, ela agora era uma obrigação. Quase que não importava se era bonita ou feia, porque agora ela tinha todas as condições para existir ali e a estrutura funcionar de um modo razoável, com todos os elementos que estavam ali. Um pouco assim eu achava que valia a pena.

Teve noite de acordar com telefonema porque estourou o vidro. Teve lá o Ibsen de madrugada... Então, sabe, cada um desses episódios foi o que, no final, nos permitiu fazer a escora. 0 engraçado que a escora foi feita por uma fábrica - Não sei se você conheceu lá. Você foi ver onde estavam fabricando a escora? - É uma fábrica que fazia isso e quando eu fui lá, o dono da fábrica, era uma oficina, era proprietário de uma casa desenhada pelo Paulo [Mendes da Rocha] ali na 9 de Julho, perto do Sacre Coeur, ali naquele pedaço. Foi ele que fez aquela peça lá. E a gente chamou uma empresa, aquela Engefuros pra chumbar as peças no concreto. Então eu pensava isso, que essa era um postura respeitosa, sabe? Você tratar com dignidade, mas também considerar cuidadosamente as questões que cabiam naquele momento.

[AA] Naquele momento você tinha alguma referência de projeto específica, que você já tivesse visto? Porque anos depois você foi tocar junto com o Paulo a obra da FIESP [Federação das Indústrias do Estado de São Paulo].

[AB] É. Mas foi quase ao mesmo tempo. A Baeta começou antes. Começou nós não tínhamos começado ainda o MMBB [Arquitetos]. Então a Baeta começou eu acho que em 94 e terminou em 96.96 é o ano da FIESP. A FIESP é uma obra que eu acho incrivel também. Diferente... outra escala, outras condicionantes... tudo

[AA] Uma força que precisava... A força da intervenção. 
[AB] E você vê como é difícil resistir. Você olha hoje lá. É muito duro isso aí. Duro assim... Não, tudo bem... Não é duro... Mas, é uma pena perder, jogar fora tanta oportunidade assim. Eu digo, o que a FIESP fez com o projeto alguns anos depois. A Baeta está melhor... O que eu digo é que os moradores da Baeta têm melhor discernimento que os diretores da FIESP.

[AA] É verdade. Mas... era isso. Bacana conhecer essas histórias! Enxergar...

[AB] É. Mas você já acompanhava. Mas... essa coisa, que eu não falei muito hoje, mas é um ponto super delicado pra mim, muito importante. Como você se coloca diante daquilo ali. Você pega, você se limita a espanar as paredes? Eu acho que o mais respeitoso com o cara que dedicou a vida toda a ser professor e tudo é você procurar fazer o melhor possível. Para que o diálogo seja de um modo respeitoso ele precisa ter um patamar onde, cada um em uma posição, cada um em um nível - que não é para igualar qualificações - fale, escolhendo as palavras e tudo. Que seja um diálogo. Ali cabia esse diálogo porque tinha essa coisa das instalações que tinham ficado inadequadas. E recuperar era difícil. Eu acho que o principal daquela casa ali era a coisa da estrutura, isso é o que aparece mesmo, bem. Depois, você lembra? Foi no final do meu mestrado. Foi muito legal porque foi o Paulo, foi o Abrão que morou lá.

[AA] Para mim caíram umas fichas engraçadas... Porque eu fui trabalhar com o [Alvaro] Razuk e ele estava restaurando a casa do Ernesto, na rua Ceará, do arquiteto Jamie Fonseca Rodrigues. Aí parecia que essa coisa da arquitetura moderna, esse contato posterior... estava crescendo... Eu acabei trabalhando na obra de Itanhaem, em cima do projeto básico do Alvaro; a gente fez o restauro de uma escola em Guarulhos, do Artigas, pelo FDE, uma escolhinha dentro do CECAP [Caixa Estadual de Casas para o Povo]; recuperando todos os elementos vazados que nunca tinham sido feitos, mas às vezes a obra precisa voltar a ser plena, quer dizer, é duro, porque vão falar "Ah! Mexeu!", mas, tudo bem... se o cara não quiser chamar de restauro eu não ligo, mas, parece que para o lugar, aquilo é que faz todo o sentido: recuperar alguns elementos onde a obra ganhe integridade. É entender a obra como um todo. Às vezes pode estar faltando alguma coisa que para a obra é fundamental.

[AB] É... difícil... Você vê agora a Oca, aquele prédio lá do Ibirapuera, o outro... É um assunto... você faz um recorte exatamente nisso: o Moderno virou patrimônio, virou continuidade...

\section{[AA] Então, não é engessar?}

[AB] Algumas coisas talvez sim, se não há razão pra mudar, você consegue manter. Se uma casa atende perfeitamente ao programa, não há razão pra mudar. É claro que o assunto de preservar é muito sério, eu acho. Porque sobra sempre um debate: 0 direito de você poder voltar pras coisas que conheceu, que eram de um jeito. Pode não ter muita razão. Pode ser uma casa que seja um lixo, pelo critério arquitetônico erudito. Mas, é a casa onde o cara passou a infância. Não importa! Ele pode ter uma relação com a vida onde voltar para aquilo seja fundamental. Mas, isso você faz em uma escala... em uma escala pessoal de possibilidades é possível fazer, como tem gente que guarda coisas... Mas, então, você preservar certos legados, certos ambientes do que foi a vida em determinado momento, é interessante. Por sinal, tem uma força que é, assim, arrasadora. Mas, depende também das condições do momento, como as condições econômicas... 0 que é bom é ter critérios, conversar cada situação quando se trata das questões urbanas. E quando é um pequeno projeto, eu acho que também é assim. Você tem que ter critérios e disposição de conversar cada assunto, que é, talvez, um pouco disso que você chama de "cuidado", sabe? Trabalhar ali. Porque, às vezes, é condição... não é um ou outro arquiteto, um ou outro projeto... Às vezes, o que você tem condição de fazer é olhar um assunto e dizer "Vamos fazer assim", e o que pode acontecer é de você nunca mais poder voltar para aquilo. Como a Casa Curutchet em Buenos Aires pode ser tão bem feita, tão precisa, com a distância; com os poucos desenhos que ele [Le Corbusier] mandou para o Amâncio Williams. O Amâncio Williams é um respeito, e ao mesmo tempo uma grandeza, porque não é um respeito totalmente servil, porque você vê coisas ali que são soluções que ele propõe, porque o lugar e tal, sempre muito conversável, muito... Mas, é uma diferença importante. Essa é uma. Mas, há obras assim. Você pega o Carpenter Center do Le Corbusier em Boston, lá em Cambridge coisa impressionante..

[AA] No fundo, o que você falou: requer tempo e aproximação. É realmente caso a caso. Não tem saída. E esse é o dilema das obras institucionais públicas para conservação de edifícios: você não tem tempo, não tem a condição..

[AB] Mas é o dilema da Vida esse aí. Você chega... é mais velho poderia ter outras coisas. Mas, não dá mais tempo. Você vê, o cara começa mais jovem, quando tem tanto tempo, às vezes, pra fazer as coisas... se angustia porque gostaria de fazer muitas coisas e não desfruta esse tempo que tem, naquele momento, pra fazer as coisas com outra densidade... Depois, o momento pra faze essas coisas na vida nunca mais vai existir. Mas, é bom que seja assim porque... faz sentido. Porque depois, o que se espera, é que 
você tenha respostas. Não prontas. Mas, com maior vivência, elas podem ser mais rápidas, num certo sentido.

Agora, você não pode ir pra China numa reunião, fazer dois croquis e voltar três meses depois e ter um prédio de 50 andares construído e achar que você está ali, sabe? Eu acho que não está! Mas... é difícil! Também não sei: você pode recusar uma coisa dessas? Quando uma situação dessas se apresenta, você enfrenta ou desiste?

[AA] Tenta criar as melhores condições dentro das possibilidades.

[AB] É... São dilemas da época, também. Não tem nada a ver, necessariamente, com ganância, com... sabe? É uma época que faz coisas assim. Se você está nesse drama, é porque você está em posição de ter esse dilema. Então, é muito difícil, eu acho.

Mas, ter o tal do tempo é um grande privilégio. Ali na Baeta eu tinha, porque eu ia à obra diariamente, os pedreiros lá também podiam fazer a coisa com tempo, eu conhecia muito bem cada pessoa que trabalhava lá, era legal. 0 Ibsen, recalcular aquilo a troco de nada, incrível! Foram condições que é muito difícil de ter...

[AA] Tudo alinhado para acontecer.

[AB] A confiança do meu irmão.

[AA] Essa relação de proximidade é boa e é ruim..

[AB] É... Mas tinha as trocas... Era mais a minha cunhada que acompanhava. Mas, tem correspondências. Tem umas coisas muito engraçadas. Quando decidimos, quando ela topou que podíamos baixar esta parede, foi um evento! Muito engraçado! 


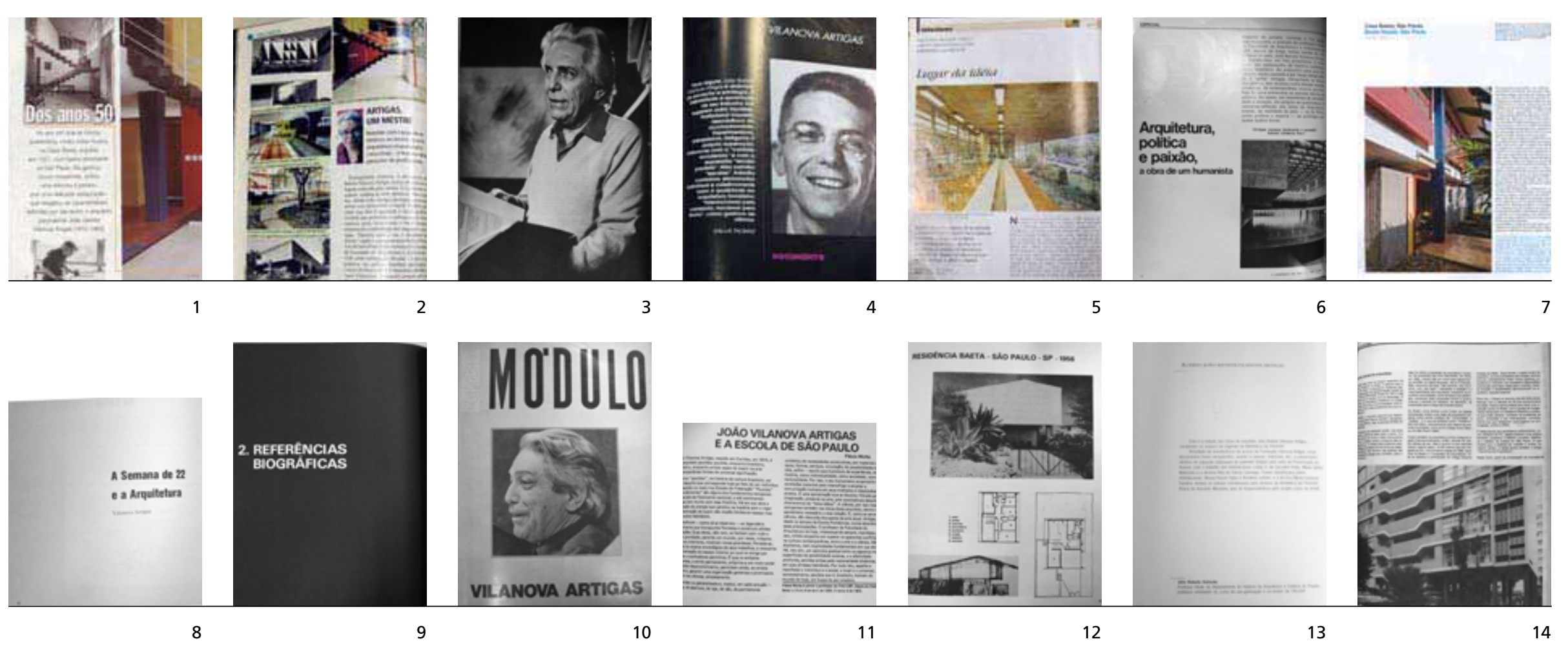

\begin{tabular}{|c|c|c|c|c|c|c|c|c|c|}
\hline & TIPO & NOME & EDITORA & CIDADE & DATA & $\mathrm{N}^{\circ}$ & AUTOR(ES) & TÍTULO & PÁG. \\
\hline 1 & revista & Arquitetura \& Construção & Abril & São Paulo & $\mathrm{mar} / 1998$ & 03 & $\begin{array}{l}\text { TEIXEIRA, Cristiane; } \\
\text { BAVA, Cristina }\end{array}$ & Dos anos 50 aos 90 & $28-37$ \\
\hline 2 & revista & Arquitetura \& Construção & Abril & São Paulo & set/2003 & 09 & BARACUHY, Joana L & $\begin{array}{l}\text { Artigas, um mestre: rebelde com causa, ele se } \\
\text { dedicou ao ensino de uma arquitetura responsável } \\
\text { e consciente - e formou várias gerações de } \\
\text { profissionias }\end{array}$ & 24 \\
\hline 3 & revista & Arquitetura e Urbanismo & Pini & São Paulo & jan/1985 & 01 & $\begin{array}{l}\text { ARTIGAS, João Batista } \\
\text { Vilanova Artigas }\end{array}$ & $\begin{array}{l}\text { Arquitetura, política e paixão: a obra de um } \\
\text { humanista [entrevista a Lívia Álvares Pedreira] }\end{array}$ & $22-29$ \\
\hline 4 & revista & Arquitetura e Urbanismo & Pini & São Paulo & $\begin{array}{l}\text { out-nov/ } \\
1993\end{array}$ & 50 & THOMAZ, Dalva & Vilanova Artigas & $77-90$ \\
\hline 5 & revista & Arquitetura e Urbanismo & Pini & São Paulo & $\begin{array}{l}\text { out-nov/ } \\
1998\end{array}$ & 80 & MACUL, Márcia & Lugar da ideia & $52-55$ \\
\hline
\end{tabular}




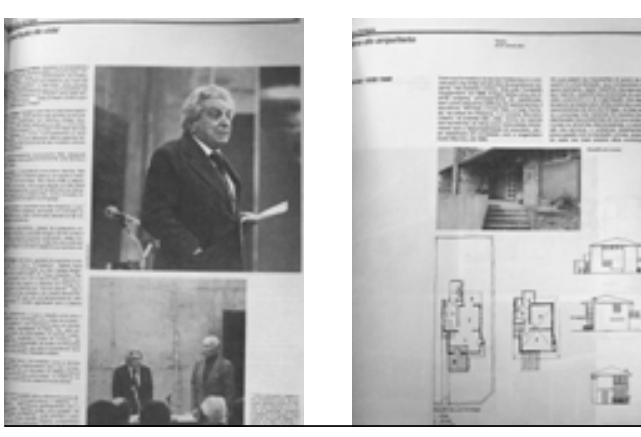

15

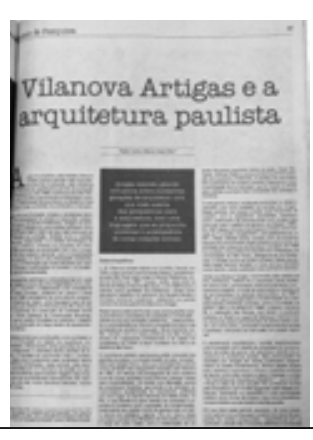

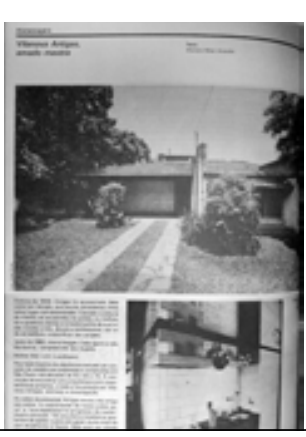

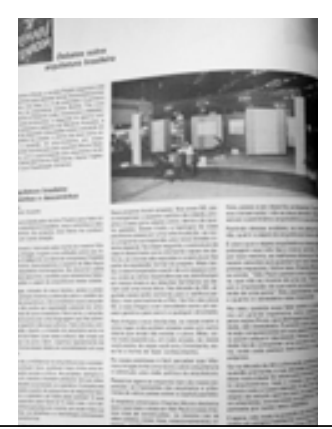

18

19

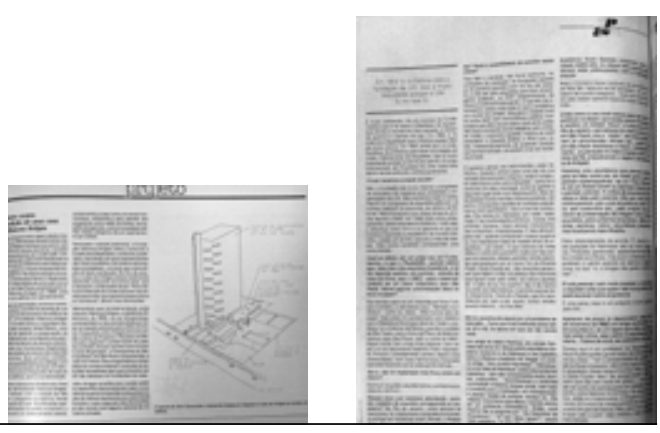

20

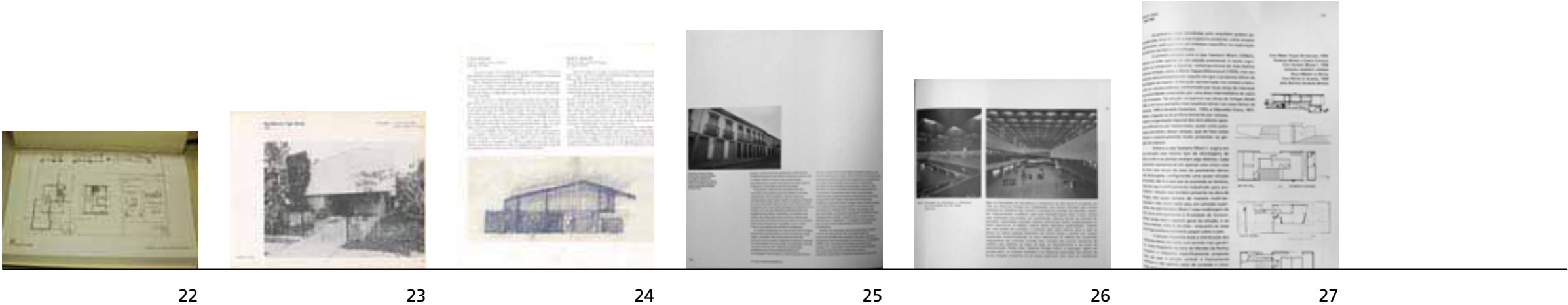

\begin{tabular}{|c|c|c|c|c|c|c|c|c|c|}
\hline & TIPO & NOME & EDITORA & CIDADE & DATA & $\mathrm{N}^{\circ}$ & AUTOR(ES) & TÍTULO & PÁG. \\
\hline 6 & revista & A Construção São Paulo & Pini & São Paulo & set/1984 & 1910 & $\begin{array}{l}\text { ARTIGAS, João Batista } \\
\text { Vilanova Artigas }\end{array}$ & $\begin{array}{l}\text { Arquitetura, política e paixão: a obra de um } \\
\text { humanista [entrevista a Lívia Álvares Pedreira] }\end{array}$ & $14-22$ \\
\hline 7 & revista & $\begin{array}{l}\text { 2G International Architecture } \\
\text { Magazine }\end{array}$ & $\begin{array}{l}\text { Editoril } \\
\text { Gustavo } \\
\text { Gili }\end{array}$ & Barcelona & $\mathrm{jul} / 2010$ & 54 & WISNIK, Guilherme & Casa Baeta, São Paulo 1956-1957 & $46-51$ \\
\hline 8 & revista & Módulo & $\begin{array}{l}\text { Avenir } \\
\text { Editora }\end{array}$ & $\begin{array}{l}\text { Rio de } \\
\text { Janeiro }\end{array}$ & $\begin{array}{l}\text { abr-mai/ } \\
1977\end{array}$ & 45 & $\begin{array}{l}\text { ARTIGAS, João Batista } \\
\text { Vilanova Artigas }\end{array}$ & A semana de 22 e a arquitetura & $20-23$ \\
\hline 9 & revista & Módulo & $\begin{array}{l}\text { Avenir } \\
\text { Editora }\end{array}$ & $\begin{array}{l}\text { Rio de } \\
\text { Janeiro }\end{array}$ & 1985 & $\begin{array}{l}\text { especial Vilanova } \\
\text { Artigas }\end{array}$ & - & Referências bibliográficas & $24-36$ \\
\hline 10 & revista & Módulo & $\begin{array}{l}\text { Avenir } \\
\text { Editora }\end{array}$ & $\begin{array}{l}\text { Rio de } \\
\text { Janeiro }\end{array}$ & 1985 & $\begin{array}{l}\text { especial Vilanova } \\
\text { Artigas }\end{array}$ & - & Cronologia dos projetos [Artigas] & $37-43$ \\
\hline
\end{tabular}




\begin{tabular}{|c|c|c|c|c|c|c|c|c|c|}
\hline & TIPO & NOME & EDITORA & CIDADE & DATA & $\mathrm{N}^{\circ}$ & AUTOR(ES) & TÍTULO & PÁG. \\
\hline 11 & revista & Módulo & $\begin{array}{l}\text { Avenir } \\
\text { Editora }\end{array}$ & $\begin{array}{l}\text { Rio de } \\
\text { Janeiro }\end{array}$ & 1985 & $\begin{array}{l}\text { especial Vilanova } \\
\text { Artigas }\end{array}$ & MOTTA, Flávio & João Vilanova Artigas e a escola de São Paulo & 23 \\
\hline 12 & revista & Módulo & $\begin{array}{l}\text { Avenir } \\
\text { Editora }\end{array}$ & $\begin{array}{l}\text { Rio de } \\
\text { Janeiro }\end{array}$ & 1985 & $\begin{array}{l}\text { especial Vilanova } \\
\text { Artigas }\end{array}$ & $\begin{array}{l}\text { ARTIGAS, João Batista } \\
\text { Vilanova Artigas }\end{array}$ & Residência Baeta [São Paulo, SP, 1956] & 63 \\
\hline 13 & revista & PÓS & FAU-USP & São Paulo & dez/2005 & 18 & KATINSKY, Julio Roberto & $\begin{array}{l}\text { Acaervo Vilanova Artigas [relação das obras do } \\
\text { arquiteto constantes no arquivo de originais da } \\
\text { FAU-USP }\end{array}$ & $196-211$ \\
\hline 14 & revista & Projeto & Arco & São Paulo & ago/1984 & 66 & $\begin{array}{l}\text { ARTIGAS, João Batista } \\
\text { Vilanova Artigas }\end{array}$ & A função social do arquiteto & $73-74$ \\
\hline 15 & revista & Projeto & Arco & São Paulo & ago/1984 & 66 & $\begin{array}{l}\text { ARTIGAS, João Batista } \\
\text { Vilanova Artigas }\end{array}$ & Uma lição de vida & $75-78$ \\
\hline 16 & revista & Projeto & Arco & São Paulo & ago/1984 & 66 & ZEIN, Ruth Verde & A obra do arquiteto [João Vilanova Artigas] & $79-91$ \\
\hline 17 & revista & Projeto & Arco & São Paulo & ago/1984 & 66 & $\begin{array}{l}\text { VIEIRA FILHO, Carlos } \\
\text { Alberto }\end{array}$ & Vilanova Artigas e arquitetura paulista & $97-101$ \\
\hline 18 & revista & Projeto & Arco & São Paulo & jun/1985 & 76 & $\begin{array}{l}\text { ACAYABA, Marlene Milan } \\
\text { de Azevedo }\end{array}$ & Vilanova Artigas, amado mestre & $50-54$ \\
\hline 19 & revista & Projeto & Arco & São Paulo & out/1985 & 80 & $\begin{array}{l}\text { ACAYABA, Marlene Milan } \\
\text { de Azevedo }\end{array}$ & Arquitetura brasileira: caminhos e descaminhos & $66-67$ \\
\hline 20 & revista & Projeto & Arco & São Paulo & $\mathrm{dez} / 1986$ & 94 & - & $\begin{array}{l}\text { Protesto contra a demolição de uma casa de } \\
\text { Vilanova Artigas }\end{array}$ & 119 \\
\hline 21 & revista & Projeto & Arco & São Paulo & $\mathrm{abr} / 1988$ & 109 & $\begin{array}{l}\text { ARTIGAS, João Batista } \\
\text { Vilanova Artigas }\end{array}$ & $\begin{array}{l}\text { As posições dos anos } 50 \text { [entrevista a Aracy Abreu } \\
\text { Amaral] }\end{array}$ & 95-102 \\
\hline 22 & livro & $\begin{array}{l}\text { Projetos digitalizados de João Batista } \\
\text { Vilanova Artigas v. } 4\end{array}$ & FAU-USP & São Paulo & 2010 & residências 4 & YURGEL, Marlene (coord.) & Residência Baeta & 703-729 \\
\hline 23 & livro & Residências em São Paulo 1947-1975 & Projeto & São Paulo & 1986 & - & ACAYABA, Marlene & Residência Olga Baeta 1957 & $89-94$ \\
\hline 24 & livro & Vilanova Artigas & $\begin{array}{l}\text { Inst. Lina } \\
\text { Bobardi }\end{array}$ & São Paulo & 1997 & - & FERRAZ, Marcelo (org.) & Casa Baeta & $72-73$ \\
\hline 25 & livro & Arquitetura moderna brasileira & Phaidon & Londres & 2004 & - & $\begin{array}{l}\text { ANDREOLI, Elisabetta; } \\
\text { FORTY, Adrian }\end{array}$ & Casa Baeta & $160-161$ \\
\hline 26 & livro & Arquitetura moderna brasileira & Projeto & São Paulo & 1982 & - & $\begin{array}{l}\text { FICHER, Sylvia; } \\
\text { ACAYABA, Marlene Milan }\end{array}$ & - & $51-52$ \\
\hline 27 & tese & $\begin{array}{l}\text { Arquitetura brasileira, escola paulista } \\
\text { e as casas de Paulo Mendes da Rocha }\end{array}$ & - & $\begin{array}{l}\text { Porto } \\
\text { Alegre }\end{array}$ & 2000 & - & ZEIN, Ruth Verde & - & $181-183$ \\
\hline
\end{tabular}




\section{RESIDÊNCIA}

\section{LUIS EDUARDO MAGALHÃES GOUVEIA}

atual residência $\mathrm{G}+\mathrm{A}$

Endereço: rua João Moura, 1.723, Jardim das Bandeiras, São Paulo, SP

Área do terreno: $973,78 \mathrm{~m}^{2}$

Área da construção: $621,11 \mathrm{~m}^{2}$

Data do projeto original/obra: 1961 / 1961-1971

Autor: Carlos Lemos e Eduardo Corona

Data do projeto de intervenção/obra: 2007-2009

Escritório responsável: Stuchi \& Leite Projetos Ltda

Autores: Carlos Leite e Fabiana Stuchi

Colaboradores: Ricardo Ramos, Marina Malagonini e Renata Gouveia

Desenho de mobiliário: Carlos Leite e Fabiana Stuchi

Restauro do painel artístico: Fernanda Craveiro Cunha e Mariana Carraco Palos

Paisagismo: Carlos Leite e Via Verde Paisagismo

Obra: FGE Engenharia

Fotos: Ana Mello e Wanderley Bailoni
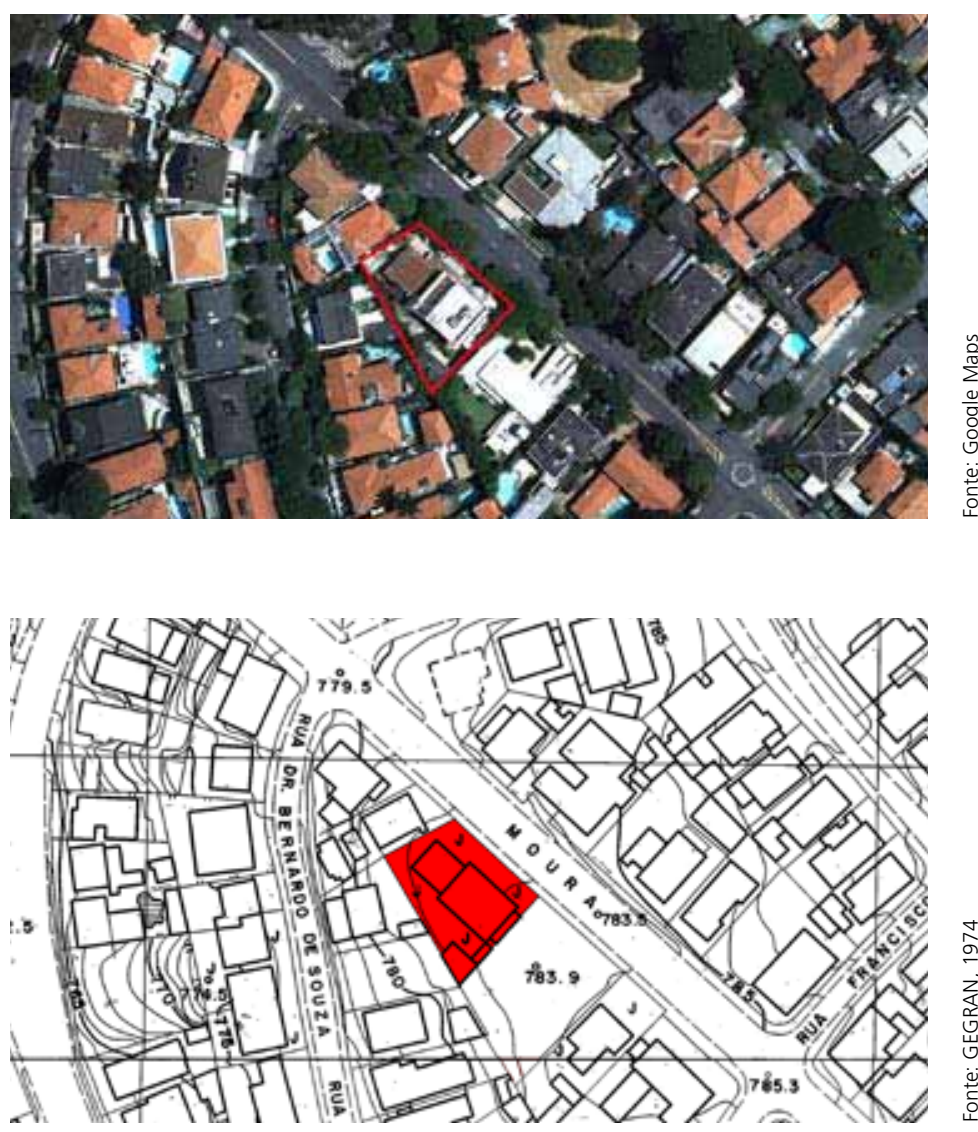

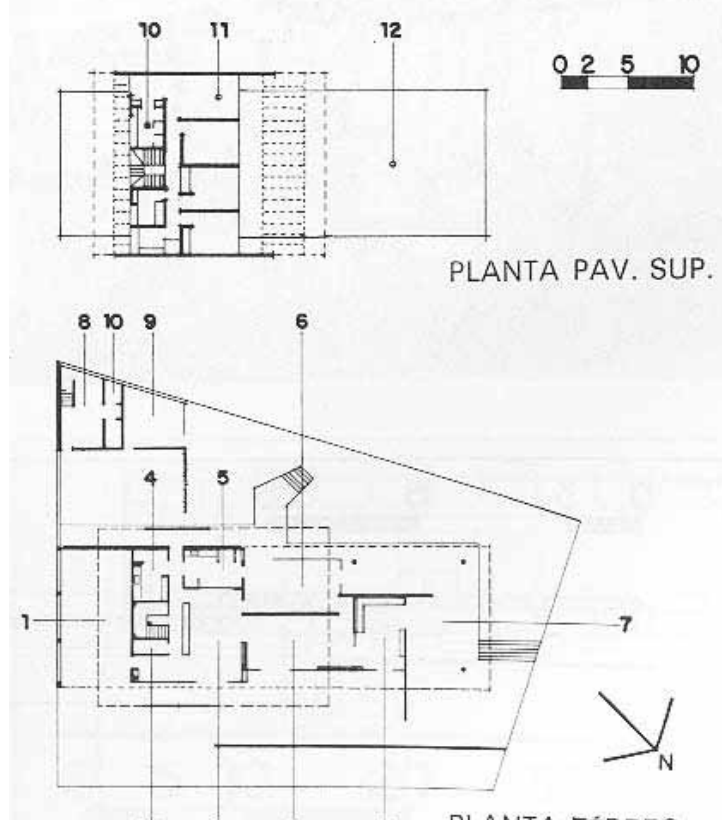

1. Abrigo para carros

2. Estar

3. Biblioteca

4. Cozinha

5. Copa

6. Jantar

7. Varanda

8. Lavanderia

9. Jogos

projeto original não foi localizado

izou-se como referencia o livro

11. Quarto

Arquitetura moderna paulistana, de Alberto

12. Jardim
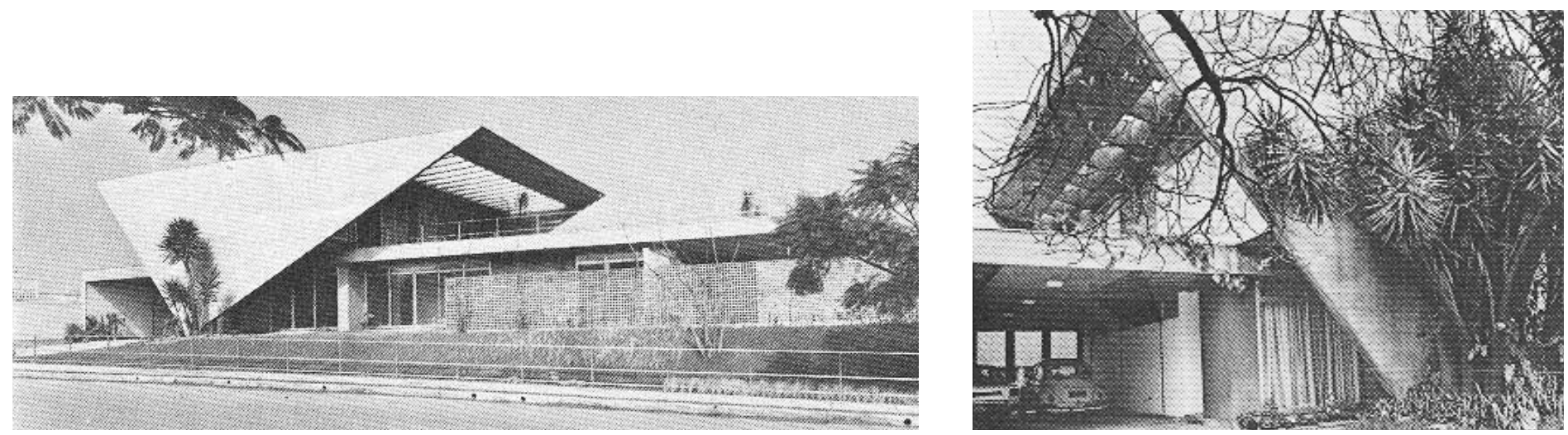


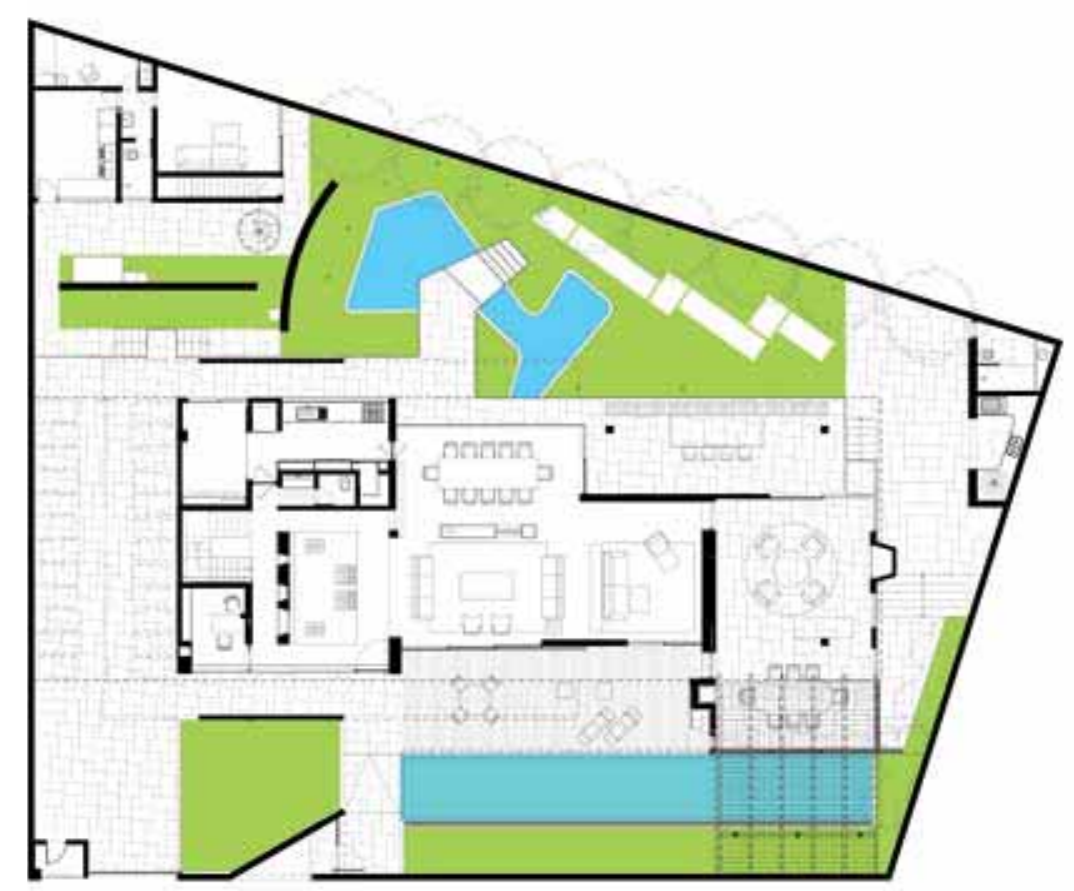

Planta do térreo (escala não identificada)

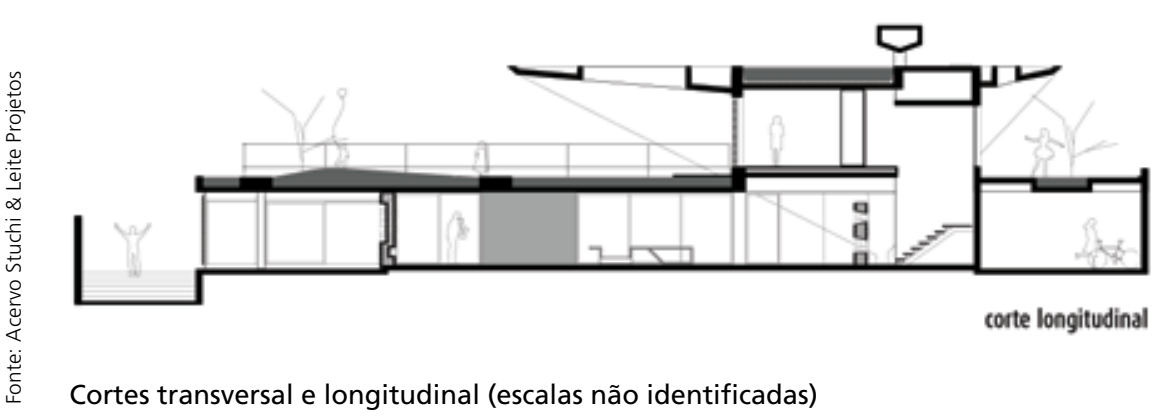

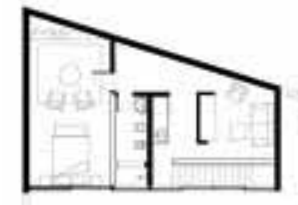

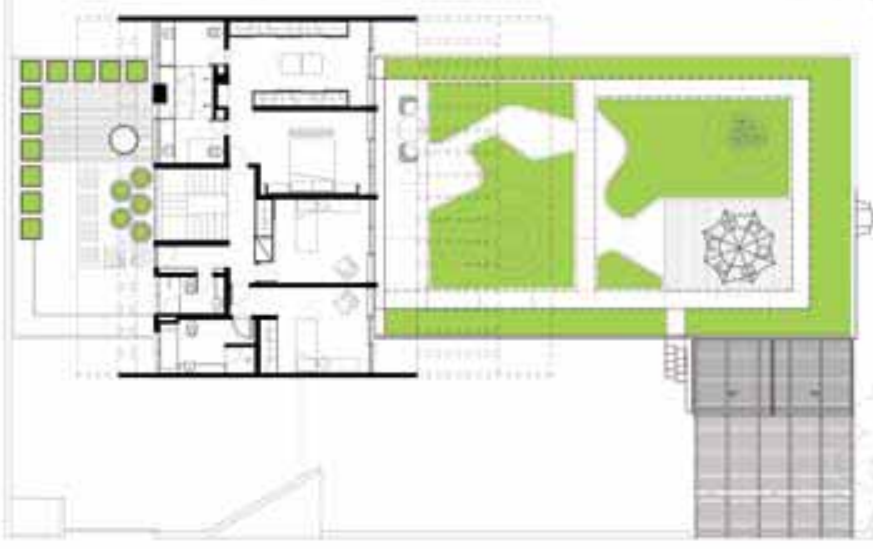

Planta do primeiro pavimento (escala não identificada)

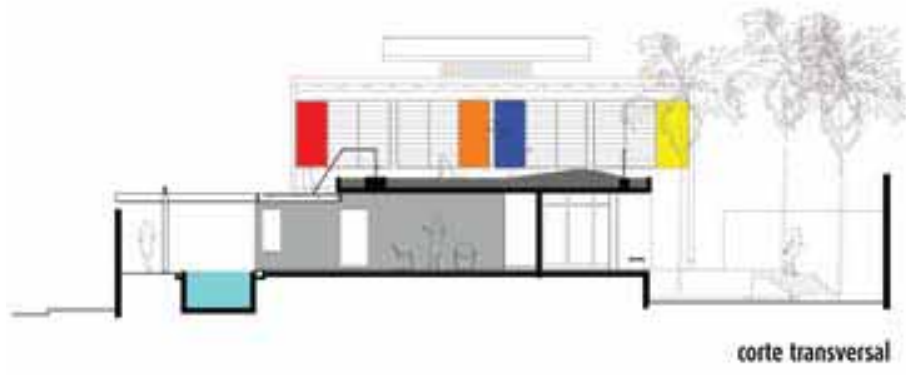



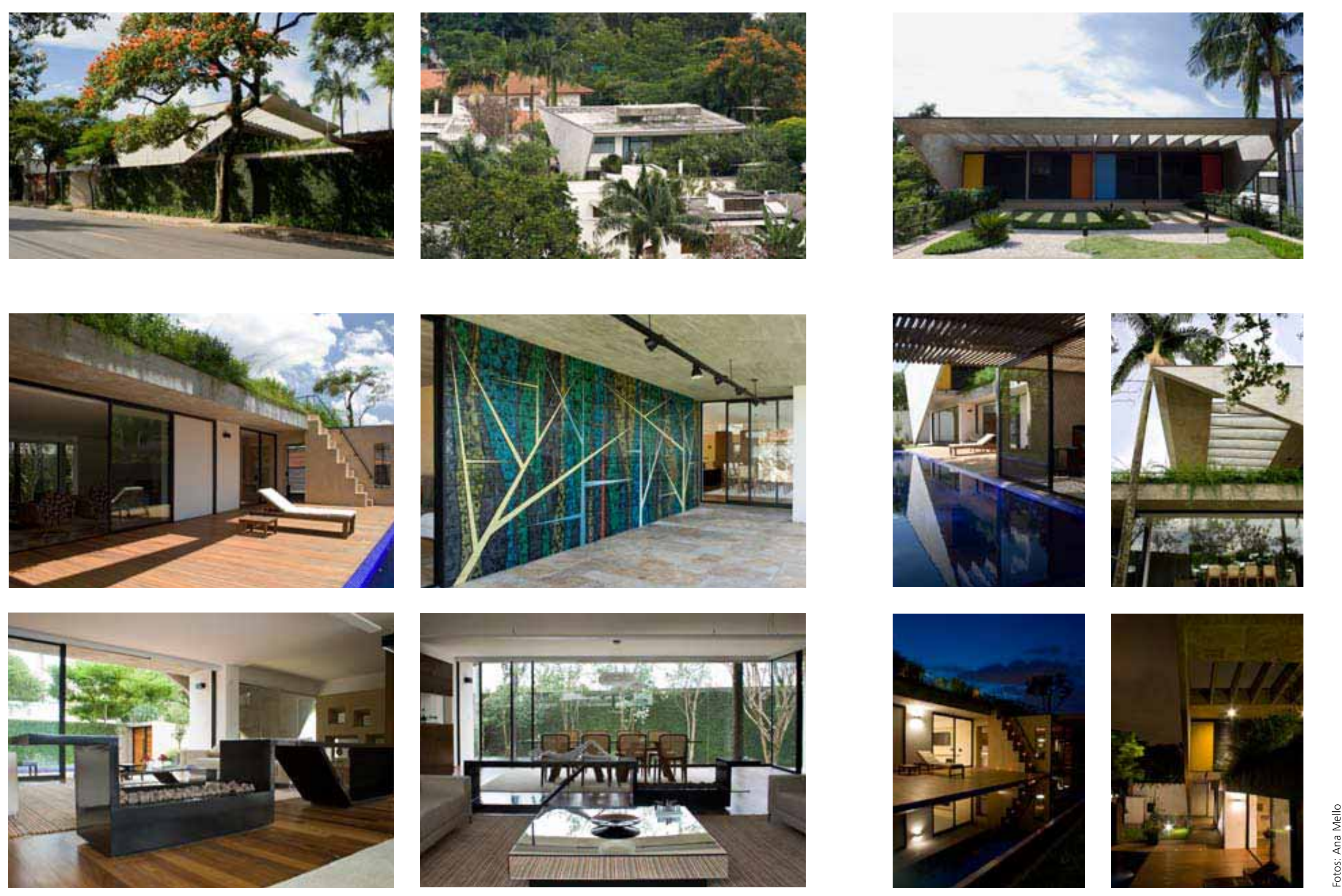
ENTREVISTA CARLOS LEITE, 23/09/2011, SÃO PAULO [AUTOR DO PROJETO DE INTERVENÇÃO]

[CARLOS LEITE] Essa casa... O Gilberto que é meu amigo, que é advogado - é um casal de advogados... Ele estudou comigo no Vera Cruz, é amigo de infância... Ele frequentou a casa. Bastante. Ele era amigo do filho do Magalhães Gouveia. O Magalhães Gouveia tinha dois filhos. Ele era construtor. Trabalhou bastante com o [Carlos] Lemos e com alguns outros arquitetos modernos daquela época. Fez ali mesmo, naquela rua, se você for, tem outra casa do Lemos que foi ele que fez. $E$ ali naquela pracinha tem mais duas casas do Magalhães Gouveia. Então, ele era... - além de ser uma família quatrocentona - um cara culto, erudito, além de rico - era um construtor. Então ele contratou vários arquitetos. E o Giba, esse meu amigo, ele frequentou a casa. Já era um apaixonado pela casa, porque era amigo do filho do Magalhães Gouveia. E esse cara morreu muito cedo. Acho que com 42 anos. Teve um ataque cardíaco. Ficou só uma filha, Adriana. Aí quando ele morreu, o Giba, que era amigo da família, cuidou do inventário. Porque aí tinha lá uma certa disputa de bens, entre a viúva e a filha, Adriana. Aí passou. A casa ficou fechada cinco anos. Eles iam de vez em quando cuidar da casa e tal. Mas ela ficou fechadona durante cinco anos. Aí quando saiu enfim o inventário e a casa pode ser vendida, a Adriana, filha, conversou com o Giba e disse: "Olha, resolveu tudo, está tudo em ordem. Obrigada. E a casa está à venda". Ele chegou e disse: "Compro já. Quanto é?". Isso foi um papo que eles tiveram no Paulistano, num sábado, e aí no sábado mesmo, à noite, ele me ligou. "Carlos, sabe aquela casa da João Moura, do Lemos?". "Lembro. Nunca entrei. Lembro das aulas de história da arquitetura. De livro". "Então... Comprei. Vamos lá amanhã?". E aí a gente foi lá no domingo.

Ele era apaixonado pela casa. Mesmo não sendo arquiteto, era um cara apaixonado pela casa. Tinha frequentado a casa. Então, tinha uma história legal, um certo carinho dele pela casa. A esposa, não. A esposa era muito resistente. Não é de São Paulo. Um pouco de aversão, segurança, morar em casa. Não queria. Mas, ele apaixonadérrimo pela casa.

Aí nós fomos lá no domingo. E essas fotos eu vou te mandar. Têm algumas minhas e, depois, tem algumas de uma estagiária minha, que foi logo na $2^{\mathrm{a}}$ ou $3^{\mathrm{a}}$ feira seguinte. A gente andou lá e ela registrou.

A casa estava assim, relativamente em bom estado. A casa devia ter quase 40 anos. Ela ficou pronta... 0 projeto é de 61. A casa ficou pronta dez anos depois, 71

(Depois eu te conto a historinha do Lemos, que é legal você ver se pega um depoimento. Ele mora aqui, na rua de cima. Na Baronesa de Itu. Você tenta falar com ele. Te dou o telefone.)

Então, andando, achei a casa em bom estado. Concreto, a estrutura da casa. Precisando de algum cuidado, manutenção. E eles tinham feito uns acréscimos, ao longo desses 40 anos de vida. Basicamente, lá atrás, onde era uma laje com o salão de jogos aberto, eles fecharam. Caixilharia feia, de alumínio. Tinha virado um salão de festas. Então, era o que mais chamava a atenção enquanto intervenção que não pertencia à casa original. E o Giba me contou que eles, várias vezes, faziam festinhas lá, iam lá, bailinhos, danças... De fato, foi fechado depois, sem nenhum projeto. $E$ algumas paredes internas que, ao longo do tempo, foram construindo, pra fechar... 0 proprietário tinha uma biblioteca com umas coisas meio raras e fechou depois de um tempo. Basicamente era isso. Não era muita coisa. Ela estava relativamente bem conservada, perto do projeto original.

Aí o que eu falei pro Giba na época: "Vamos fazer, com o maio prazer. A única condição é a seguinte: vamos ligar pro professor
Lemos. A gente não pode sair mexendo na casa, mesmo ela não sendo tombada oficialmente, nem nada. É o mínimo de respeito com ele. Foi meu professor. 0 cara está aí. Tá vivo. Atuante ainda. E a casa é patrimônio arquitetônico". E eu liguei pro Lemos e ele: "Carlos, faça o que quiser!". Ele é um gentleman. Super lúcido até hoje. "Faça o que quiser. Quando estiver pronto você me chama". "Mas, além disso, o senhor tem algum material?". "Não tenho nada. Passou. Faça o que você quiser.".

E daí, assim, a gente começou um processo, que eu achei que foi legal, entre trazer a arquitetura do Lemos e do Corona. Porque, segundo o Lemos, é só dele.

(Depois eu te conto essa historinha. Quando a casa ficou pronta, o jantar que a gente fez lá pra ele. Ele contou um monte. A noite inteira tomando vinho e contando as histórias. Dentre elas, essa. Diz ele que a casa, o projeto é só dele.)

$E$, enfim, tentar não mexer muito na casa, mas tentar atender às necessidades de uma família de hoje. De advogados. Nenhum deles é arquiteto. 0 marido e a esposa, um filho que mora com eles e um outro, do Giba, do primeiro casamento, que frequenta bastante a casa. São demandas de um cliente de classe média alta de hoje. Área de lazer, piscina aquecida, parte toda de closet - monte de roupas -, coisas que não tinham naquela época. A família dela não é daqui e ela queria, sempre quis ter um quarto de hóspedes. A gente acabou fazendo lá atrás, no que era aquele corpo auxiliar lá atrás. Acabamos fazendo um... Eu apelidei lá de "Maison Curutchet". Ficou um voluminho bem bonitinho. Um prisma puro. Legal. A gente acabou fazendo a casa de hóspedes. Então ela está sempre recebendo gente lá. Parentes dela e tal.

Então, foi um pouco assim, esse exercício de você trazer para os dias de hoje, para um cliente de hoje, uma família de hoje, usos 
que fazem parte de uma vida de hoje, que há quarenta anos não tinham, tentando, sempre que possível, manter a força fantástica da casa. Espaços muito generosos, poucas paredes e tal.

Então, as primeiras providências que eu fiz, foi limpar aquelas gorduras, tirar aquelas paredes que tinham sido feitas ao longo do tempo, que não pertenciam à casa, as paredes internas, aquele apêndice que tinha sido feito de vidro, de caixilho de alumínio, que não pertencia ao original e que não adornou bem. Estava muito feio. Visivelmente feito... Chamaram um caixilheiro qualquer pra fazer aquilo ali. Tiramos aquilo. E aí começou um pouco esse exercício de inserir essas coisinhas novas. Então, entrou uma nova raia. 0 Giba, ele joga, profissionalmente não vou dizer, mas joga pôquer, todas as 2as. e 5as. à noite, num esquema quase profissional, doze pessoas, uma mesona... Então a gente tinha que fazer esse espaço dessa salona de jogos. Tinha que mexer nesse anexo e fazer o que era a demanda dela, da Alessandra, de receber a família dela. E no fundo era trazer, fazer todo um trabaIho... Ah, sim! 0 jardinzão lá em cima, ele, por todos os relatos que eu peguei, nunca foi usado! Muito gozado, porque você tem os quatro quartos abrindo pra lá. E a vista é fantástica. Hoje em dia você vê toda a Vila Madalena. Muito legal você olhar lá de cima. E pelo que o Lemos contou, o próprio Giba que frequentou muito a casa, ninguém nunca usou. E sempre foi... Mas, isso é fantástico. Então, a gente logo colocou isso como uma coisa.. Vamos fazer um jardim aqui, voltar a usar isto aqui.

E aí vão acontecendo algumas coisinhas que são de obra. Eu acompanhei bastante a obra. Não faço muito projeto, o escritório é muito pequenininho. Minha vida é basicamente padrão. Então, as poucas coisas que eu tenho, eu vou. Eu mergulhei nisso daí com o maior tesão, paixão. Acompanhei bastante. la lá duas vezes por semana, na obra. Acompanhei a obra do começo até o fim. Aí algumas coisinhas foram aparecendo também na obra.
Um dia, a gente andando lá nesse jardinzão - tivemos metade do dinheiro de obra foi para recuperar essa casa: recuperar o concreto, toda a parte hidráulica... Uma casa de 40 anos. Toda parte elétrica. Tiramos todo aquele volume de terra, para impermeabilizar tudo, trocar todas as coisas. Pusemos captação de água nesse jardinzão para um pouco reusar essas águas. Então teve um trabalhão grande. Aí um dia, andando, estava em obra, eu e ele, ele ia bastante, o Giba, um apaixonado pela casa, vestiu a camisa, ia lá... (Depois, agora, virou um aficionado. Cheguei lá na casa, tinha comprado a coleção completa do Le Corbusier. "Pra mim é o pai de todos!". Então, virou um apreciador.) Então, nesse dia, a Ale, que não ia muito, chegou meio de surpresa e eu a convidei pra subir lá no jardim, pra ver. E ela: “Nossa! Ficou legal! Mas, me fala uma coisa, Carlos. Será que não dá pra gente acessar este jardim superior sem ser pelos quartos, pela área privada? Será que não dá pra por uma escada, alguma rampa - ela falava assim - Uma rampa que contorne tudo e ligue o térreo, o jardim lá de fora?". "Não. Não dá." Mas, ela insistiu. "Não dá. Nunca fez parte. Vai ficar esquisito". Mas eu fiquei com aquilo na cabeça. Ela me perguntou umas duas vezes. E aí, já na hora que eu estava indo embora, eu olhei aquilo lá assim e "Nossa! Tive uma ideia! A única coisa que, talvez, caiba aqui! Fazer uma escadinha Santos Dumont." . Aí eles arregalaram o olho: "0 que é isso?". Eu disse: "Mais uma boa invenção que dizem... creditam ao Santos Dumont, além do avião e do relógio". Aí expliquei: "Não é uma escada confortável. Pesada. Você tem que pensar pra subir, pensar pra descer. Mas, tem essa imensa vantagem que ocupa pouquíssimo espaço. Então, se você olhar agora como ficou, tem o corpo da casa, aí você tem o jardim da frente, tem a raia aqui, uma raia grande de $18 \mathrm{~m}$, e aqui tem todo um deck de madeira. Eu disse: "Caberia direitinho aqui no deck". Fiz uma conta ali. Chamei o Joaquim, que é o pedreiro, a gente puxou a trena junto, tal, tal, tal.
Eu disse: "Olha, acho que vai dar. Eu volto para o escritório agora, peço para a Fabi desenhar e tal e a gente vê isso aí". E encaixou direitinho. E aí foi bem legal, porque agora eles usam sempre, as crianças usam, às vezes estão lá em cima. A gente botou um ombrelone. Aí tem uma área que ele fica ali, fica até a noite. Já fui lá... Eu frequento bastante a casa. Somos amigos. Às vezes a gente toma lá uma vinho à noite, as crianças sobem, descem... Ficou uma coisa legal. E era uma coisa que não tinha. Você só acessava o jardim de cima pelos quartos, que também abrem lá.

Então, foram umas coisinhas assim, que foram andando. Legal aparecer, porque eu acho que interferiu pouco na geometria, no desenho da casa, mas que trouxe uma coisa legal deles. Mesmo a Ale, que é uma pessoa resistente a usar a casa, você vê que hoje, esses ganhos aí, poder estar lá à noite, sentar, numa noite de verão, tomar um vinho com o marido, num jardim externo, são coisas que apareceram. Foram aparecendo em dois anos de obras, que a gente fez... Teve quase dois anos de obra, entre projeto e obra. Teve um momento lá, de uns oito meses, que eles pararam por uma questão de fluxo de caixa, de dinheiro. Então, demorou dois anos.

Então, foram coisinhas legais, que eu acho... Que algumas coisas aconteceram e foram intervenções. Com relação ao aspecto mais de arquitetura, assim, tentei, sempre que possível, a gente fazer as poucas intervenções de hoje com uma cara nova, com uma materialidade nova. Então, tudo que entrou lá, ou seria de madeira ou de pedra, pra não concorrer... Pra deixar um pouco claro o que era de hoje, o que era antigo. Mesmo não sendo tombado, não sendo obrigado a fazer nada disso, mas achei que era de bom tom, um pouco de cuidado, de carinho com aquela arquitetura moderna, icônica aqui de São Paulo.

A pedra no meio do caminho: o cliente resistiu, resistiu... Então, no fim, acabou virando alvenaria com todo o revestimento, nas 
poucas paredes novas, de Fulget [revestimento]. Mas, pelo menos fica diferenciado do que são as alvenarias e o concreto originais. E a madeira. Fizemos, trouxemos lá da Amazônia, certificada. Fui escolher, tudo com a maior... Isso o Giba sempre me apoiou. Tudo que a gente queria, hoje, em termos de fazer uma coisa que ficasse um pouco de sustentabilidade... Com carinho... Foram coisas legais que foram acontecendo. Então a gente colocou que era uma demanda deles, o que seria inevitável para um casa com essas posses - tudo ar condicionado. Então eu abri um dia, eu e o engenheiro fizemos uma simulação, mostramos pra ele o colchão de amortecimento que ele teria entre a laje, mais $55 \mathrm{~cm}$ de terra, pra mostrar pra ele que a gente poderia lá em baixo não ter ar condicionado. Fizemos algumas simulações. Coloquei todos os painéis de aquecimento solar lá em cima. Usamos essa água pra captar, assim como também consegui convencer a gastar um pouquinho mais e comprar madeira certificada. Então foram coisinhas interessantes, legais que foram aparecendo e eu ia sempre fazendo "meio aulinhas" com eles. Levava o laptop no apartamento deles à noite, tomando um vinho. Eles iam gostando. Virou um apaixonado. la contando as histórias da casa, de arquitetura, e a gente foi conseguindo..

\section{[APOena AMARAL] Pedagógico...}

[CL] É. Foi bem pedagógico. Mas foi super prazeroso. Eles recebiam bem. Vinho, jantar. E eu fazia minhas aulinhas. Sou professor... Então, a gente foi montando esse quebra-cabeça.

Aí tivemos o jantar com o Lemos, que foi bem legal, quando acabou. Aí aconteceu uma coisa gozada, porque estava acabando a obra e, um dia, tocou lá a campainha a Lívia [Pedreira], que é editora da revista "Arquitetura \& Construção". E passou lá na frente, disse que tinha acompanhado a obra toda. Aí entrou. Eu nem estava lá. $O$ Engenheiro deixou entrar. E aí ela já queria publicar a casa. Não estava nem pronta ainda. E já tinha gente lá. E daí o Giba falou: "Carlos, vamos fazer logo o jantar para o Carlos Lemos, antes de o pessoal começar a falar desta casa...." Então, uma das primeiras coisas que a gente fez, um dos primeiros jantares deles lá na casa foi pra receber 0 arquiteto original da casa, o Lemos. E aí foi bem legal. Ele jantou lá com a gente. Fizemos um tour pela casa. Ele já está, eu acho, com mais de 80. Está bem lúcido. Ele contou um monte de história da casa, do Magalhães, do proprietário, das outras casas que ele fez lá pra família. Contou que ele e o [Eduardo] Corona, na verdade, nunca tinham trabalhado juntos. O Magalhães Gouveia pediu pra ele, Lemos, por causa de um relacionamento pessoal com ele, fazer um estudo para aquela casa. E, paralelamente a isso, procurou [o Eduardo Corona], porque também tinha relacionamento com o Magalhães Gouveia independentemente, não tinha nenhum contato com o Lemos. E o Magalhães Gouveia... Segundo o Lemos, era meio notívago, não cumpria prazo, ficou demorando, demorando, demorando... O Lemos entregou o dele. Aí o Magalhães Gouveia, disse: "Puxa! Muito bom! É isso mesmo! Mas, olha... Não dá pra vocês tentarem trabalhar juntos aí? Se não vai ficar uma coisa meio chata, eu pedi pra ele também...". E, segundo as histórias do Lemos, o projeto foi meio assim. Ambos assinaram e, segundo ele, o projeto é dele. Essa é a historinha que ele contou. Contou lá pra gente nesse dia. Diz ele que fez várias outras casas pro Magalhães Gouveia, pra construtora dele, pra família dele. A Adriana foi no jantar também. Eu vi ali. Eles foram bem próximos. Bem próximo da família. E fo super legal. Rever o Lemos acho que depois de doze anos que eu não via. Gostou da casa. Elogiou. Disse que tinha ficado melhor do que antes. É um gentleman. Super generoso. Enfim, pra mim foi legal porque, primeiro, eles estão lá, estão gostando da casa; segundo, que sempre dá um medinho a gente mexer na casa de um mestre. E, principalmente pra mim, que não faço muitos projetos. Faço apenas alguns poucos aí. Uns dois por ano. E esse aí foi um projetão grande. Teve muita visibilidade, foi publicado. O Lemos foi lá e gostou. Então foi bem legal ter esse retorno dele. Esse carinho. Andou lá comigo pela casa. Gostou. Depois a Lívia, da revista, fez um... Ela também apaixonou pela casa. Publicaram. Saiu na capa da revista. Depois fizeram um outro livro, que eles publicam sempre, de casonas, de casas de sonho. Você já viu um? Te mostro. Está ali. Eles publicam as maiores, por ano, casonas. E aí eles fazem uma premiação, todo ano, lá... Esse ano foi no Memorial da América Latina. Na premiação anual da revista... Aí fizeram. Me ligou pra fazer também... Encerrar a noite, fazer um depoimento pro Lemos. Enfim, a casa acabou sendo super exposta, publicizada. Eles não gostam muito, o Giba, a Ale, principalmente ela. Mas, faz parte. Compraram uma casa que... Bom, ele sempre frequentou, sabia disso... Que tinha aí uma coisa bem especial. Acho que é isso! Que eu me lembre... Das histórias. .

[AA] Você estava falando lá, do concreto. Estava, em geral, em bom estado?

[CL] 0 concreto estava. Estava. Nenhum problema de ferragem, de nada. Foi só 40 anos de uso. Então, a gente lixou tudo. Bastante coisa. Aquelas duas empenonas. As duas faces delas. Laje toda. Bastante coisa. Basicamente foi só lixar quase tudo. Uma ou outra coisinha ali que a gente... Gerente de obra, também, um cara excelente, Eduardo Taunay. Se você quiser conversar um dia com ele, um cara muito legal. 0 irmão dele está fazendo o atual projeto do Santa Cruz, acho que pelo Una. Fazendo a obra. Um cara bem legal, eu não o conhecia, foi o Giba que me indicou, amigo dele. Eduardo Taunay. Eu te dou o telefone, se você quiser. Foi ele que fez a obra inteirinha. Teve essa paradinha no meio, depois voltou. 
Um cara bem cuidadoso. Bem legal. Tudo que tinha ali ele ligava. A gente foi indo sempre junto. Foi bem legal também.

[AA] Você fez o projeto todo antes e depois foi pra obra ou foi feito meio em conjunto?

[CL] Não, não. Fiz o projeto inteiro, executivo. Aprovou. Aí a gente começou. E, durante a obra, acho que de mudança... Que eu me lembre... É. Essa edícula lá atrás, esse corpo lá atrás, talvez tivesse sido uma decisão que talvez tenha tido uma mudança, pra ficar como ficou, do jeito que ficou hoje. Talvez tenha sido na obra. Mas, fora isso... E essa coisa da escadinha Santos Dumont, que liga lá em cima. Fora isso acho que não. Fizemos o projeto executivo completo. Nessa época a Fabiana já estava... Foi ela que fez, acho, todo o executivo. Acho que foi tudo, enfim, como manda o figurino. Tudo direitinho. Pagou tudo direitinho. Nós fizemos tudo direitinho. Não teve grandes dramas.

Teve um surtão, na época. Ele parou lá, o Giba. Um domingo lá, surtou. Ele era ansioso. Cliente ansioso. Acompanha bem tudo. Todo dia ia lá. Não lembro se ele não estava super ocupado.. Ele é vice-presidente de uma empresa de importação-exportação. Viaja muito. Mas, o cara ia lá direto na obra. Então, teve um domingo que ele mandou todo mundo embora. Surtou, assim. "Meu dinheiro está acabando. Esses caras... Tá demorando muito...!". Deu um surtão lá. E falou que ia fazer tudo sozinho, sem engenheiro. Nossa! Ficou louco! "Carlos!". Me ligou. Num domingo! "Mandei o Taunay embora. Mandei todo mundo embora. Essa coisa não anda!..." . Deu os cinco minutos. A mulher dele me ligou chorando. "Carlos! O Giba ficou louco!". "É. Ficou. Ficou porque tem, no mínimo, uns oito meses de obra pela frente. 0 Giba não vai fazer isso sozinho. Ninguém faria!". Mas, aí deu seis meses lá... Se eu já ia, passei a ir mais lá. Respira fundo...
[AA] É duro, porque se você não teve nunca contato com obra desse porte, você assusta. A gente está treinado, de certa maneira, para respirar fundo e saber que uma hora acaba. Agora, o cliente, ele olha e fala: "Não vai acabar! Não vai dar certo!".

[CL] 0 cara vai vendo o dinheiro sair. E tem uma hora ali... Dá pra entender!

[AA] Aquela hora que nada aparece e já gastou muito.

[CL] E uma casa dessas. Uma reformona. 0 cara botou metade do dinheiro em coisas que não vê. Aquilo que é infra-estruturai na casa. Aí o cara não vê. 0 cara vai ficando maluco. Ele quer ver o piso novo. Ele quer ver o novo! $E$ não o velho recuperado. Aí demora. 0 concreto demora pra lixar. Aí uma coisa amarra a outra... Tudo atrasa... O tempo passando e o dinheiro do cara indo... Aí ele surta!

Mas, tinha um pedreiro fantástico, o Joaquim. Um cara maravilhoso, esse menino! Trinta e poucos anos. Super preciosista. Fantástico! Ele ficou nesses seis meses. Único cara que o Giba deixou lá. "O Joaquim assume". "Ah, sei. Você vai transformar o Joaquim em engenheiro de obra." . "É, é! Vou aumentar um pouco o salário dele. Você passa a ir lá três vezes por semana e a minha secretária vai fazer todas as compras. Vamos economizar. Vamos tirar o Taunay. Estou cancelando minhas viagens nos próximos seis meses". Ele queria ir até o fim assim. Passaram-se seis meses e ele ligou pro Taunay: "Vamos voltar".

[AA] Seis meses durou mais... Com essa etapa, ficou mais lenta...

[CL] É! Esses seis meses ficou devagar. Imagina! A coitada da secretária do cara, nunca tinha comprado... Enfim, ele viu a di- ferença que é ter um engenheiro de obra. Isso no dia que ele me ligou, eu falei: "Olha, estou fora! Eu sei o que é, cara! Já fiz. Estou fora. Não vai dar certo! Você vai quebrar a cara!". "Ah, não! Vamos tentar!". Aí faz parte...

[AA] Parece que é pouca coisa, quando você vê lá pronto. E nesse processo, logo quando você começou... Porque é interessante o que você disse: uma casa que é ícone, referência...

[Interrupção]

[CL] Isso daí foi bem legal. No dia em que eu entrei lá - Acho que não tem uma foto aqui. Mas, no PowerPoint que eu te mandei tinha, no pdf? - ele estava, aqui neste cantinho, com umas oito peças prestes a cair, mas por sorte estava tudo lá, integral. Aí, no dia seguinte, eu fui lá com a estagiária e a gente meteu umas fitonas, só pra segurar. Aí eu falei pro Giba: "Nossa, cara! Isso daqui eu não sei de quem é, mas isto daqui é super importante! Temos que recuperar". Aí eu chamei uma menina da FAU [FAUUSP, Faculdade de Arquitetura e Urbanismo da Universidade de São Paulo], não sei se você conhece, Fernanda Craveiro Cunha. Ela fez FAU e deve estar formada há uns oito anos, talvez. E ela sempre trabalhou, sempre gostou de restauro, patrimônio. Ela fez algum curso, não sei se na Itália, em Veneza, em uma dessas escolas boas de restauro e patrimônio. E começou a trabalhar um pouco com isso. Ela tinha trabalhado com o Piratininga. Até foi a Fabi que me indicou. "Olha, chama a Fernanda. Legal que ela é arquiteta". Aí eu chamei a Fernanda e a Fernanda fez toda a recuperação. Foi bem legal. Mapeou tudo. Como manda o figurino. Peça por peça.

[AA] Soltou tudo? 
[CL] Não. Algumas peças. Mas aí fizeram todo trabalho direitinho, de mapear tudo, de catalogar tudo isso. Deu pra mim e pro Giba um livrão. Contou toda a história do Lula Ayres. A Casa Conrado. A história do cara... O livro está lá, na casa do Giba, guardado. Esse aí foi feito especialmente. Aí o Lemos, quando foi lá, contou do Lula, que era amigo dele. Na verdade, mais amigo do dono, do proprietário, Magalhães Gouveia. E aí a gente recuperou tudo isso e, por sorte, nesses anos todos, não tinha perdido nenhuma peça. E agora está tudo lá, marcadinho, peça por peça. Mapeado catalogado. Se precisar, algum dia, recuperar, a Fernanda hoje... Eu tenho também, material aí. Tudo guardado. Então isso foi bem legal. Ficou bonitão. Ficou lindo. Você vai ver lá. Aí a gente botou esse trilho aqui. Aí a noite ele fica iluminado. Fica bem legal. Hoje eles têm uma mesona aqui, de comer aí fora. Ficou bem legal esse espação aí. Ele tem uma presença legal, esse painel nesse volume de concreto.

[AA] E nesse processo, logo quando você começou a fazer o projeto, alguma... Porque a referência de intervenção na arquitetura moderna é um tanto escassa... Você partiu um pouco dessas referências básicas, Carta de Veneza, legibilidade?

[CL] É... Na verdade, assim: eu sempre soube que tinha pouca coisa a fazer aí. Não teria nenhuma grande intervenção na casa. Então, na verdade, foi meio assim o básico. Um pouco, assim, tentar o que eu podia recuperar do original da casa. $E_{\text {, }}$ depois, deixar um pouco marcado, separado, em termos de linguagem e de estética, do que era a intervenção de hoje. Então, se você for ver, em termos de construção nova, de alteração, é pouca coisa. Eu diria que a única coisa que eu não consegui fazer concessão - sempre há... O cliente... - são as cores desses painéis lá em cima, que eu queria colocar exatamente como era. E um dia ele chegou lá, pintou e falou assim: "Não fala nada. Você não vai concordar, mas está feito". Eu disse: "Está bom".

[AA] Também está lá... Se quiser raspar um dia..

[CL] Está lá. Está fotografado. A Fernanda também tirou as amostras.

[AA] Ah! Ela fez a prospecção da casa toda, não só do painel?

[CL] Fez. Fez. Foi bem legal. Isso está documentado.

[AA] Estava vendo o corte e estava com uma dúvida. Porque tem este corpo aqui - aquele corte que você mandou, da planta mesmo. Aí esta sala, ela já se pronunciava originalmente?

[CL] Aí a gente tem uma parede. Esta parede vinha até aqui. Não foi executada. Nunca foi executada, mas estava no projeto original dele, do Lemos. 0 Lemos também não lembrava. Quando entrei na casa, estava morrendo aqui. E no projeto original, essa parede vinha até aqui. Então, na verdade, eu quis resgatar. Uma coisinha que foi, olhando o projeto original e um pouco pela demanda dele, ele queria transformar o volume para a tal sala de jogos, a a gente - eu e a Fabi [Fabiana Stuchi] - a gente resgatou essa geometria. 0 desenho é outro, mas a implantação dessa parede é onde era o projeto original, que não foi feito.

\section{[AA] E aquela caixilharia, originalmente, parava...?}

[CL] Originariamente até aí. Quando eu entrei lá, vinha mais ou menos até aqui. De alumínio e vidro.
[AA] E eles tinham feito uma lajezinha?

[CL] Não. Vidro também. Alumínio. Uma coisa bem rústica. Devem ter chamado um caixilheiro de alumínio lá e fizeram de vidro, as duas laterais e em cima. Um salãozinho de dança dos adolescentes, acho.

[AA] A Fabi acho que estava fazendo, no Piratininga, há alguns anos atrás, um projeto numa casinha do Artigas, não?

[CL] É. Legal isso aí. Mas não saiu. Pena. Eram aquelas quatro, na Sampaio Vidal. Era o Frederico Lorma, o dono. Ele vendeu. Não fez. Acabou não fazendo. Comprou a casa. Mudou de ideia no meio do caminho.

[AA] Ela falou que tinha também trocentas versões...

[CL] Cinquenta milhões... Essa historinha também é boa pra você falar com a Fabi um dia. Ela que cuidou disso. Ela direto com o José Armênio [José Armênio de Brito Cruz]. Ela que fez as cinquenta milhões de reuniões com o cara, Frederico. Lembro bem dela falar do cara: Frederico Lorma. Mas, ela me contou outro dia: o cara desistiu e vendeu a casa. Acho que vendeu. Um milhão. Bom, o mercado está doidão! Vai ver que foi mais de um miIhão, sei lá! Eu cheguei a ir lá naquelas casas. Já entrou lá? Bem legaizinhas aquelas casas! Eu fui antes disso, bem antes. Tinha um amigo que morava lá, que até é amigo do Zé Armênio tb. 0 Felipe. Cara da FAU. Colega do Zé Armênio. Ele... Quando entrei lá, faz tempo, faz uns quinze anos. Casinhas são bem legais. Eram bem pequenas. A escada deve ter uns $70 \mathrm{~cm}$, você sobe. Casinhas de aluguel. Classe média baixa, que o Artigas fez. Eram quatro casinhas. Numa morava esse cara, na outra morava o Alexandre 
Machado, esse que é jornalista. E uma, por incrivel que pareça, o cara detonou a casa. Filho da [jornalista] Marília Gabriela. 0 cara detonou. Pintou de amarelo. Fez muro. Acabou com a casa. Acho que era do lado dessa que o Frederico tinha... Eram quatro, né? Quando eu fui lá esse cara tinha comprado a terceira... Não, a quarta. Não sei qual era a do Frederico. Essa do Frederico é interessante você ver lá. É interessante. 0 Zé Américo fez uma lajezinha lá atrás. Porque é comprido. 0 terreno é compridão. São dois terrenos. É uma linguicinha, assim, mas tem um jardim legal lá. Eu lembro que... o que é que era? Pena que a Fabi não está aí. Tinha alguma coisa que o cara queria... Não sei se ele tocava piano... Uma sala de música meio enterrada lá atrás, que o Zé Armênio fez. É interessante. Um bloco. Uma coisa assim. Legal essa história. Mas, de fato, eles fizeram cinquenta milhões... E essa era tombada! Essa era tombada, teve que aprovar, voltar. Daí o cara aprovou. Daí o cara mudou tudo de novo. Uma novela! Essa daí foi uma novela!

[AA] 0 cara pega uma casinha... Ah! É uma casinha... MaraviIha! Como se...

[CL] É. Um cara sozinho. Solteirão. Cheio da grana. Aí deu a louca no cara. Saiu do mercado. Trabalhava no mercado financeiro e resolveu estudar Artes em Londres. Sei lá! Uma coisa assim. Deu uma novela! Eles surtaram! Tinha que aprovar e daí o cara mudava tudo de novo... É uma boa história essa aí do Frederico.

[AA] É. Estava na minha lista, mas adiantaram a qualificação...

[CL] É. Casinha do Artigas. Essa é boa. Tinha até que saber quem está lá nessas quatro casas. Essa uma aí, não sei que fim levou. A casa do filho da Marília Gabriela: o cara acabou com a casa! Pelo menos por fora. Eu não entrei.
[AA] Acho que era isso... Deixa eu ver se faltou alguma coisa.

[CL] Então, as fotos, liga pra Ana, pede pra ela. Porque aí ela te dá direto. Agradece. Vê que crédito ela quer que ponha lá. 0 nome dela direitinho. Ela vai te dar, com certeza. Ela tem em alta resolução, em baixa. Você vê lá. Tem bastante. Tem de dia. Fizemos à noite. São legais.

[AA] Você já tinha feito alguma outra obra de patrimônio?

[CL] Nunca. Pessoalmente, não. Trabalhei sete anos com o Paulo Bastos. Naquela época ele tinha recém saído... - Logo que eu me formei. Não... Antes dele se desprender do CONDEPHAAT. E depois, também. Fiquei um período lá que ele foi. Então, naquela época fizemos um monte. Mas aí era ele. Era Paulo Bastos. Fizemos bastante. Fizemos bastante coisa. Quando eu estava saindo de lá ele estava começando... - Eu saí. Essa eu não fiz. Ele estava pegando a Sé. A igreja. A catedral. Deve ser um trabalhão. Gigante. Mas isso eu não participei. Mas fizemos vários.

[AA] A priori, pensam que há uma diferença - o que eu não enxergo como diferença... Mas, a arquitetura moderna, como se fosse mais fácil...

[CL] Não! Eu acho que não!

[AA] ...pelas técnicas serem mais próximas... Parece que todo mundo mexe meio à vontade... Não encara! Não importa se é tombada! Você reconheceu o arquiteto. Mas, poderia nem ser um arquiteto... 0 que importa é ter qualidade! Não vou deturpar! Pensando em patrimônio, tem a opção... o partido direto... Fala: "Quero deixar a minha marca também!". De maneira radical.
[CL] Não! Aí, sinceramente... Até acho que... Vai ser curioso acompanhar o seu trabalho! Vai ser interessante! Eu não sei o que acham dessa intervenção aí na casa. Eu acho super modesta, pequenininha. Pode ser que tenha gente que se ofenda: " 0 cara mexeu na casa! Botou umas coisas que não tinha!". Faz parte. Mas, nunca tive essa vontade! Ele sempre que... A casa, ela é muito grande! São $1000 \mathrm{~m}^{2}$ de terreno e acho que $660 \mathrm{~m}^{2} \mathrm{de}$ casa! Para um casal e um filho e mais um que vai de vez em quando! Então, você entra lá, naquele domingão que eu ande lá, você não precisa fazer mais coisas nessa casa! E ele mesmo sabia! Eu falei pra ele: "Você está comprando uma casa... Você sabe! Você frequentou. A casa não é tombada, mas tem história, tem arquitetura!" " Não, cara! É só recuperar. Trazer para o tempo de hoje!". Falei do Lemos e ele: "Claro! Pode ligar! Liga já! Faço questão! Traz ele aqui!". Porque a gente nunca sabe, falei. 0 cara está vivo. Pode ser que ele... Então, foi legal. Ele, enquanto cliente, um cara muito tranquilo. Respeitoso, sempre. A única coisa que eu me lembro foi essa das cores lá de cima. Cheguei lá, um dia, o cara já tinha chamado o pintor. Estava morrendo de medo de mim né? De brigar comigo... Já foi avisando: "Eu sei que você não vai gostar, mas está feito e eu não vou voltar atrás".

[AA] Será que a gente consegue o material em pdf dessa prospecção?

[CL] Ah! Conseguimos! Podemos! Com a Fernanda. Você podia até falar com ela. Acho que isso seria legal pra você. Ah! Ela vai adorar, a Fernanda! 


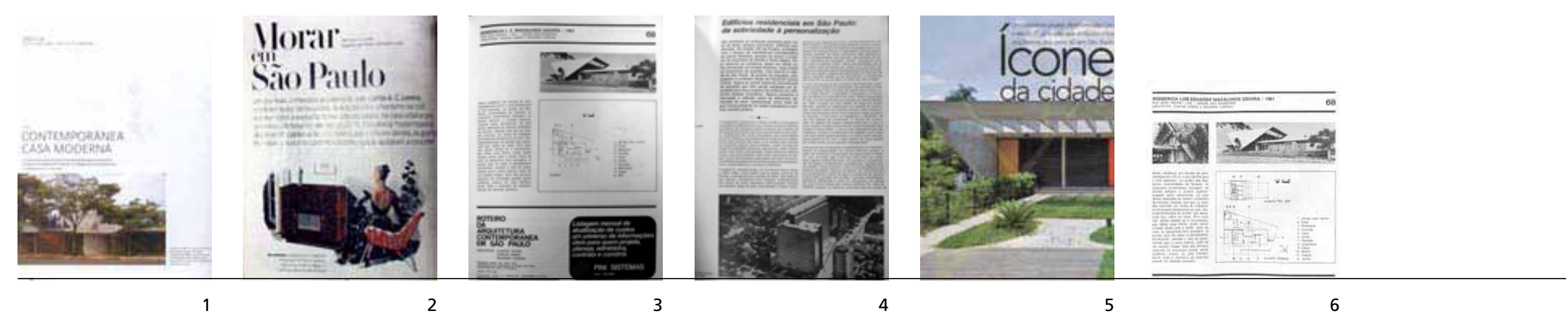

\begin{tabular}{l|l|l|l|l|l|l|l|l|l} 
& TIPO & NOME & EDITORA & CIDADE & DATA & No & AUTOR(ES) & TíTULO \\
\hline $\mathbf{1}$ & revista & AU & Pini & São Paulo & abril/2010 & 193 & SAYEGH, Simone & Contemporânea Casa Moderna \\
\hline $\mathbf{2}$ & revista & Casa \& Jardim & Abril & $\begin{array}{l}\text { Rio de } \\
\text { Janeiro }\end{array}$ & jun/2003 & 581 & $\begin{array}{l}\text { LEMOS, Carlos Alberto } \\
\text { Cerqueira }\end{array}$ & Morar em São Paulo \\
\hline $\mathbf{3}$ & revista & A Construção São Paulo & Pini & São Paulo & set/1981 & 1755 & $\begin{array}{l}\text { LEMOS, Carlos Alberto } \\
\text { Cerqueira; CORONA, } \\
\text { Eduardo }\end{array}$ & Residência L. E. Magalhães Gouvêa \\
\hline $\mathbf{4}$ & revista & Projeto & Arco & São Paulo & jul/1990 & 133 & $\begin{array}{l}\text { LEMOS, Carlos Alberto } \\
\text { Cerqueira }\end{array}$ & $\begin{array}{l}\text { Edifícios residênciais em São Paulo: da sobriedade à } \\
\text { personalização }\end{array}$ & 57-58 \\
\hline $\mathbf{5}$ & revista & Arquitetura \& Construção & Abril & São Paulo & abr/2010 & 276 & $\begin{array}{l}\text { MEDINA, Eliana; } \\
\text { BARRETO, Vera }\end{array}$ & $\begin{array}{l}\text { Ícone da cidade: um cuidadoso projeto de reforma } \\
\text { traz para o século 21 uma casa que simboliza a boa } \\
\text { arquitetura do anos 60 em São Paulo }\end{array}$ \\
\hline $\mathbf{6}$ & livro & Arquitetura moderna paulistana & Pini & São Paulo & 1983 & - & $\begin{array}{l}\text { XAVIER, Alberto; LEMOS, } \\
\text { Carlos; CORONA, Eduardo }\end{array}$ & Residência Luís Eduardo Magalhães Gouvea 1961 & 68 \\
\hline
\end{tabular}



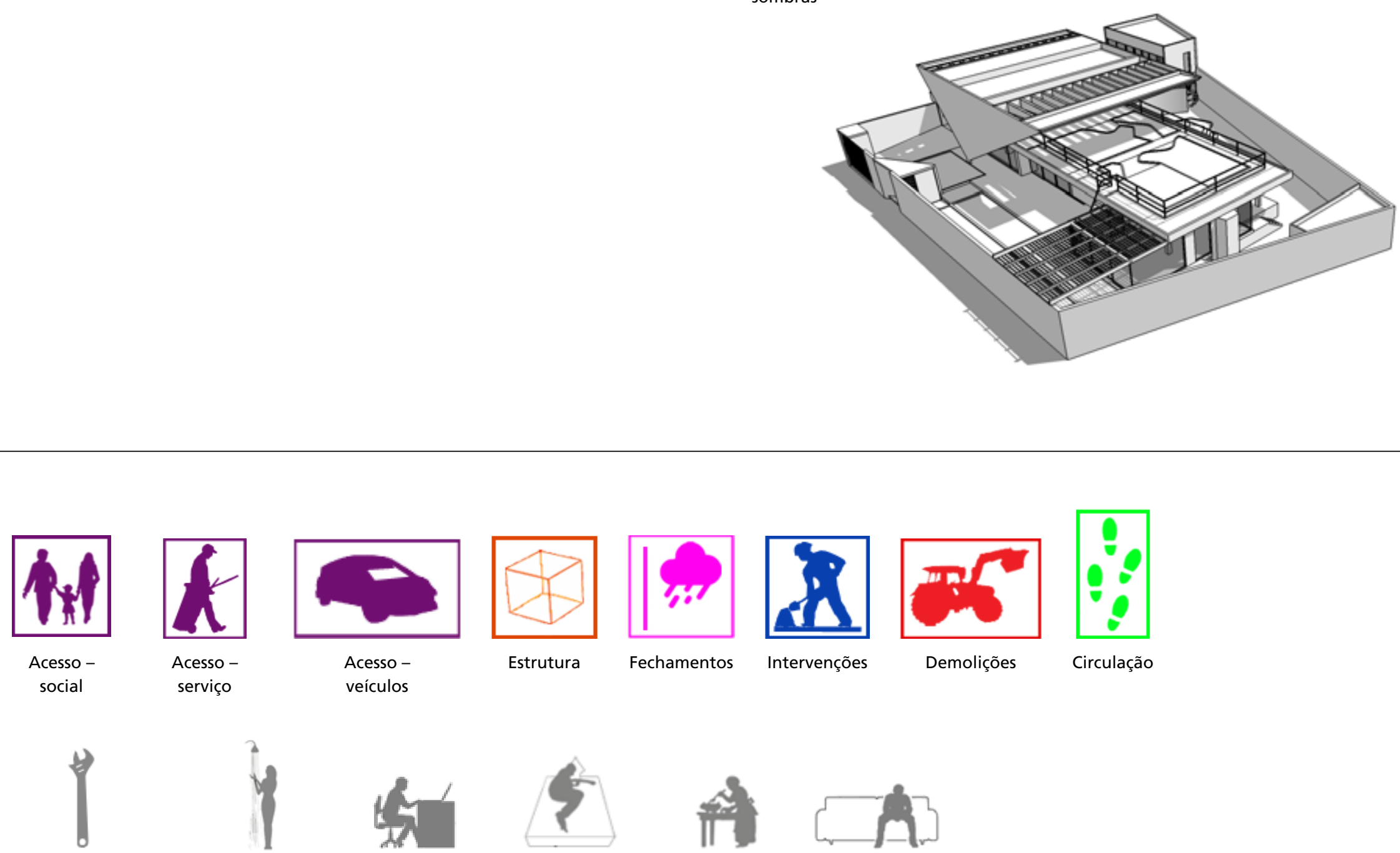

Usos -

Usos -

sanitários

Usos -
escritório

Usos -
dormitórios

Usos -

cozinhas

Usos -

salas 
Perspectiva isométrica -

demolição (térreo)

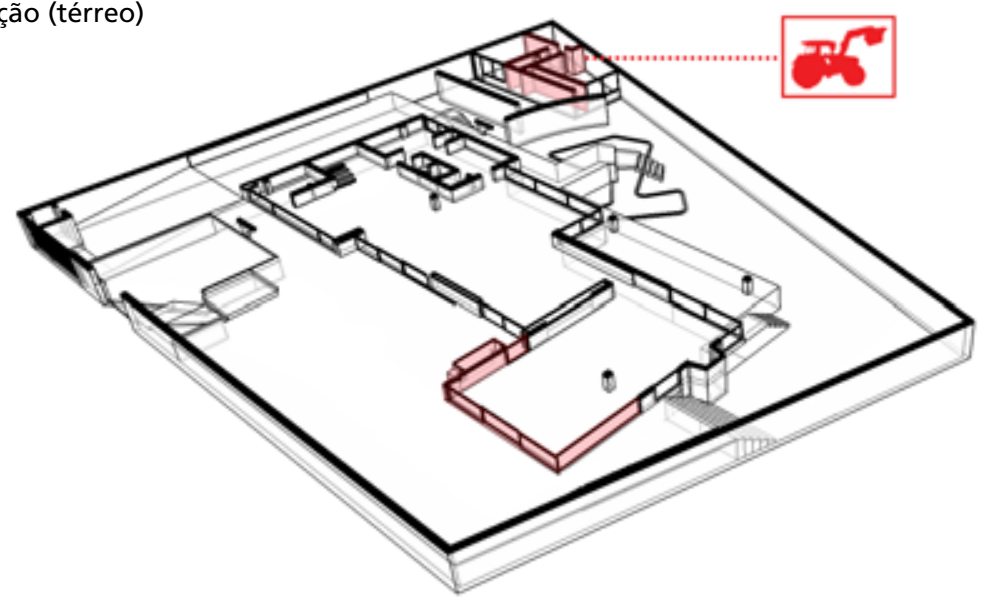

Perspectiva isométrica -

demolição

(primeiro pavimento)

$$
\text { iro pavimento) }
$$

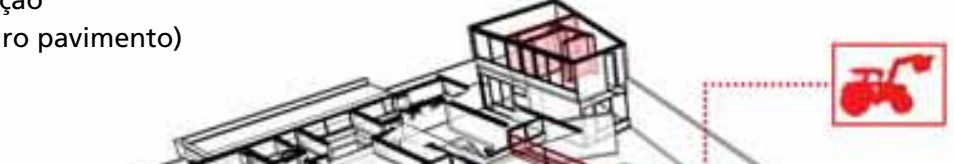

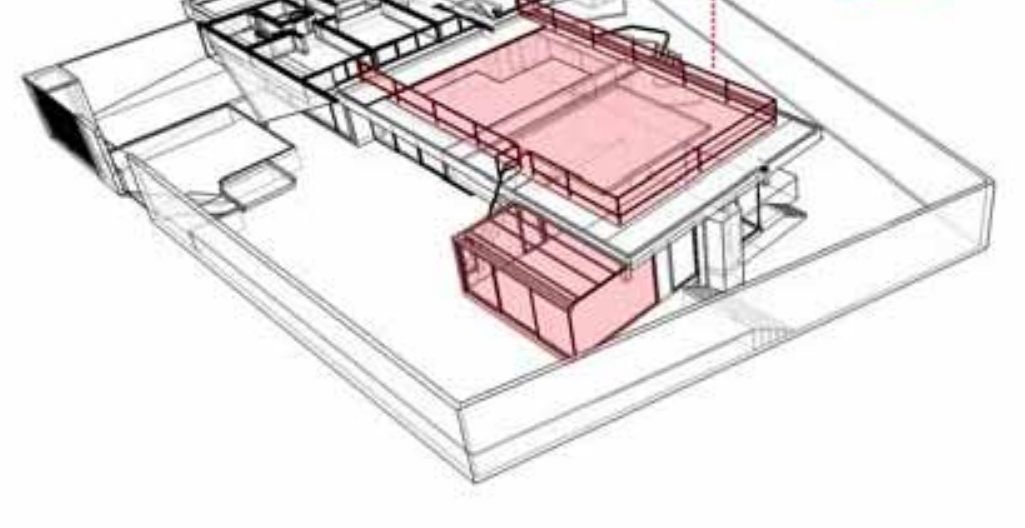

Perspectiva isométrica -

áreas de intervenção (térreo)

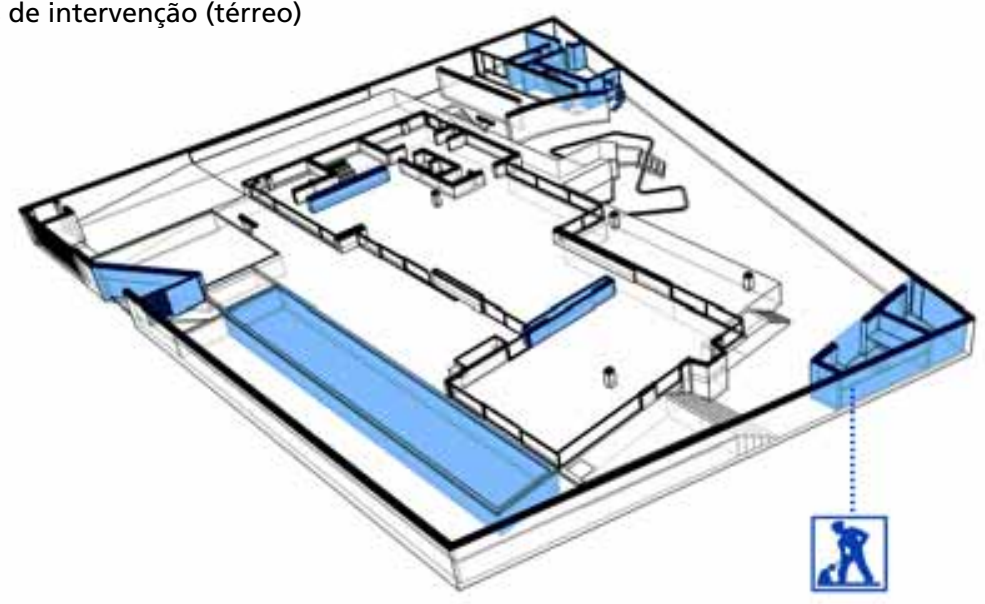

\section{Perspectiva isométrica -}

áreas de intervenção

(primeiro pavimento)

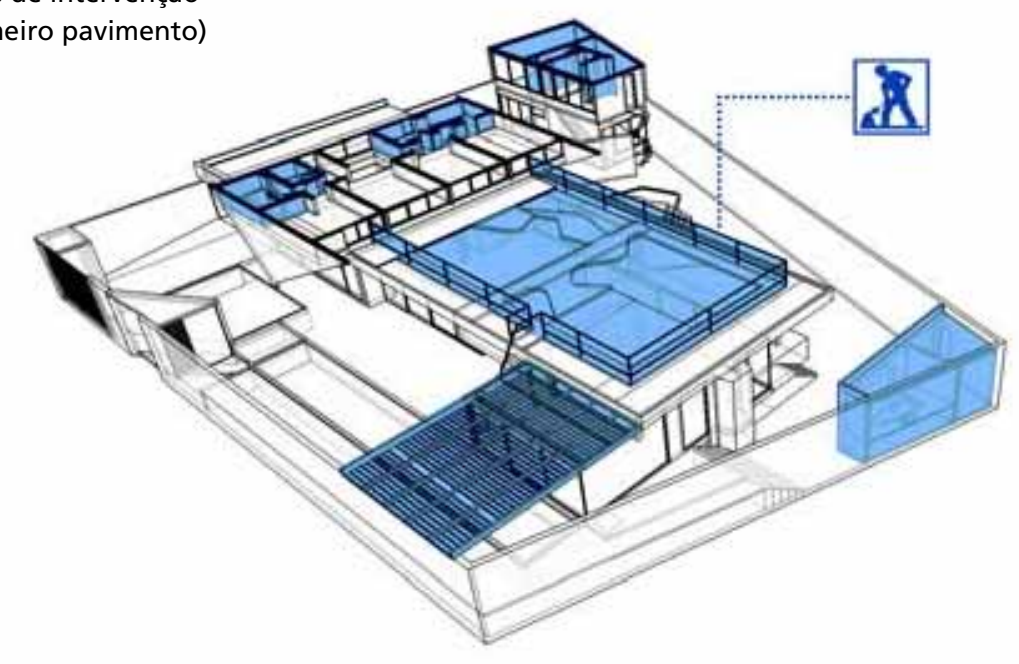


Perspectiva isométrica -

acessos (térreo)

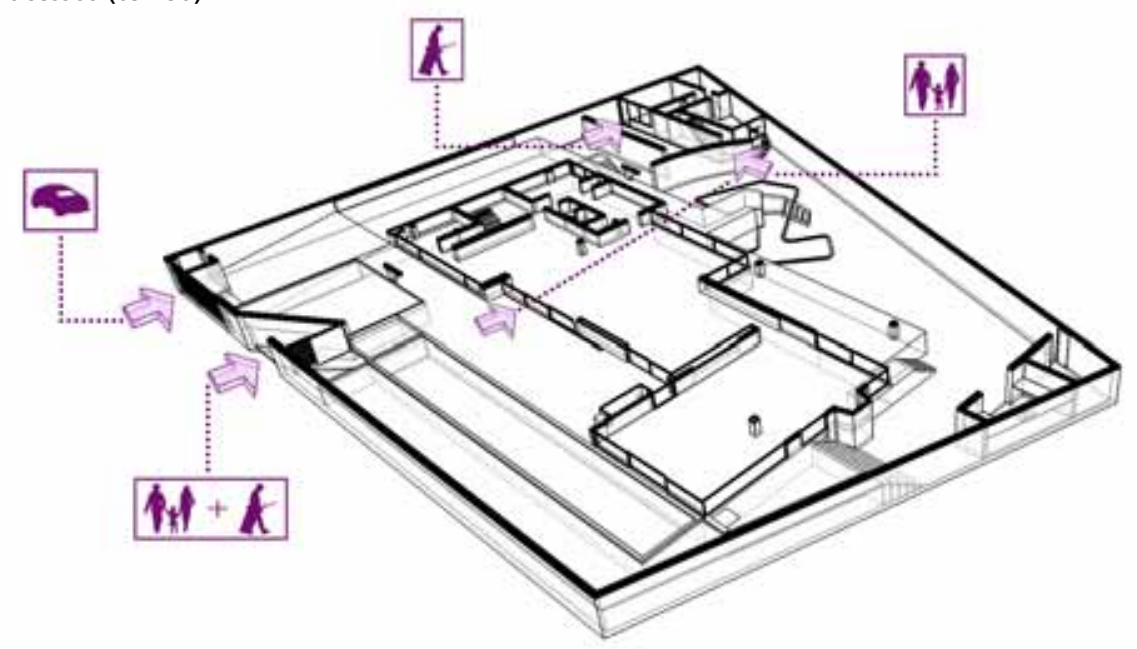

Perspectiva isometrica -

criculação (térreo)

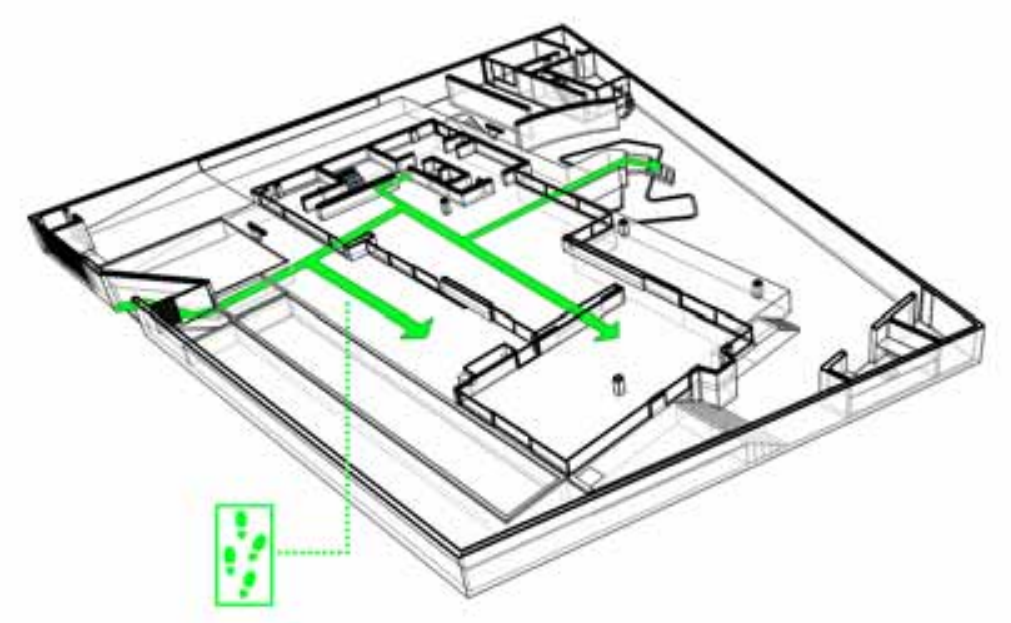

Perspectiva isométrica -

criculação

(primeiro pavimento)

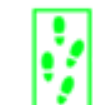

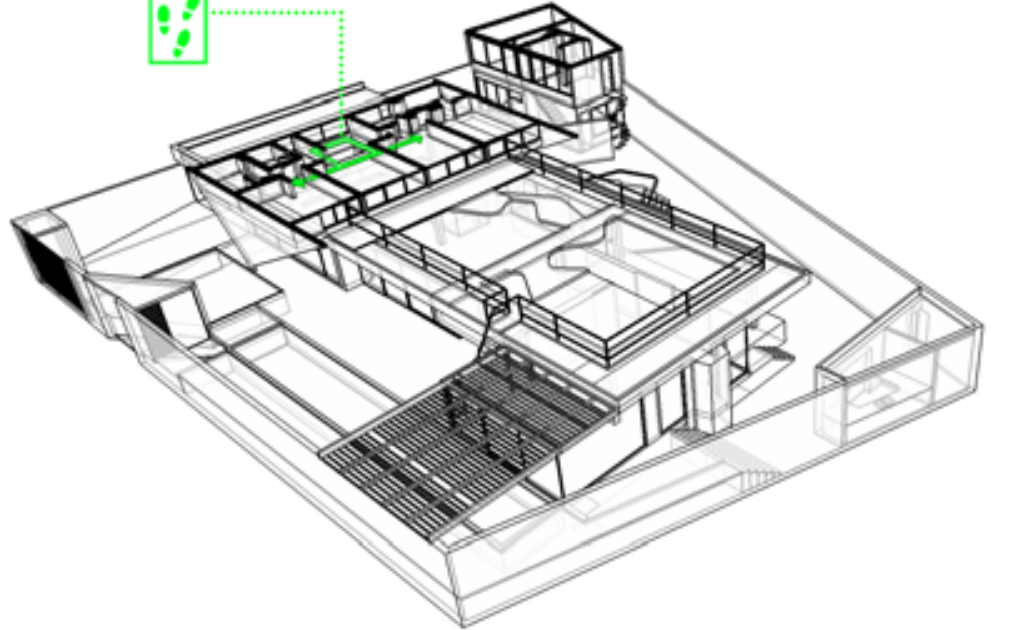


Perspectiva isométrica -

estrutura (térreo)

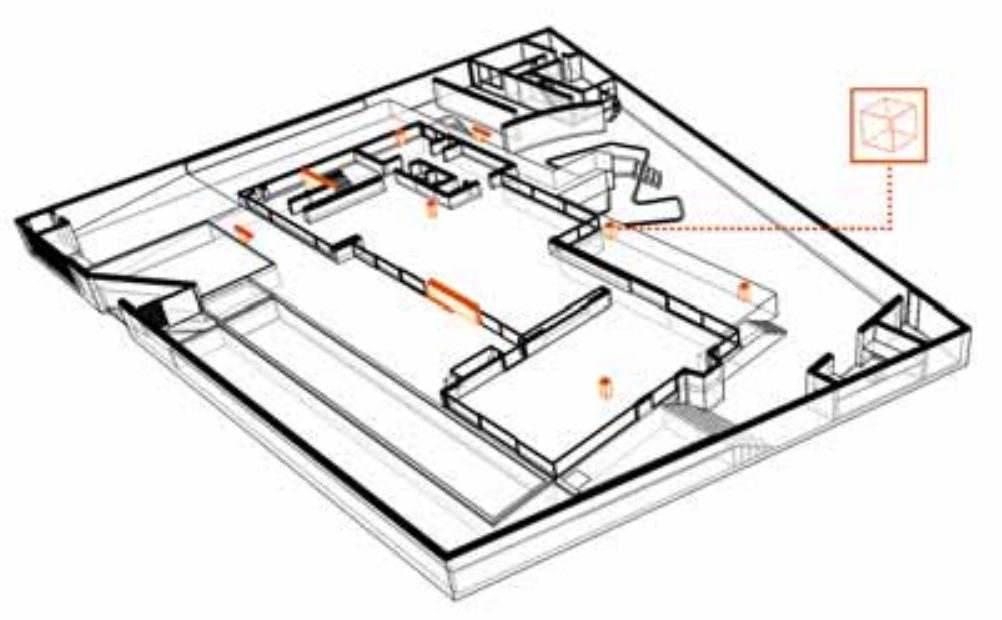

Corte longitudinal -

estrutura

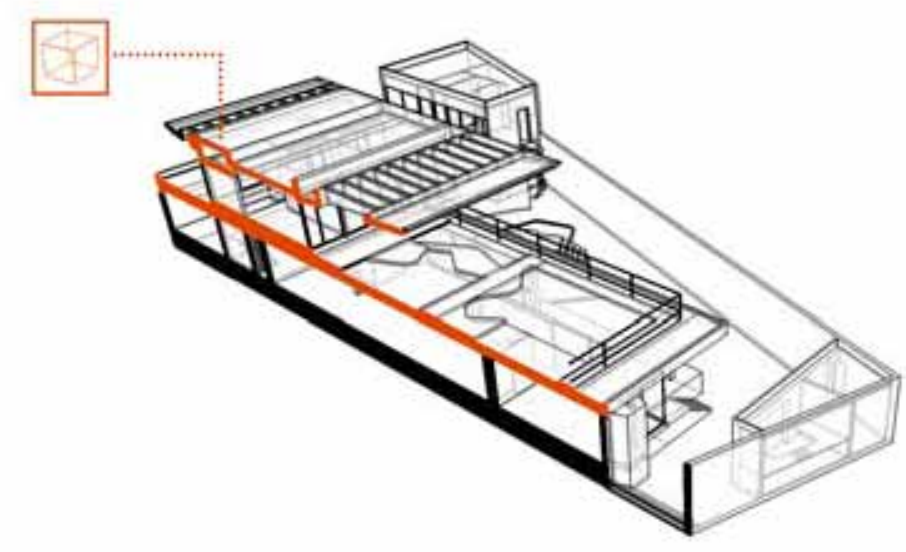

Corte transversal -

estrutura

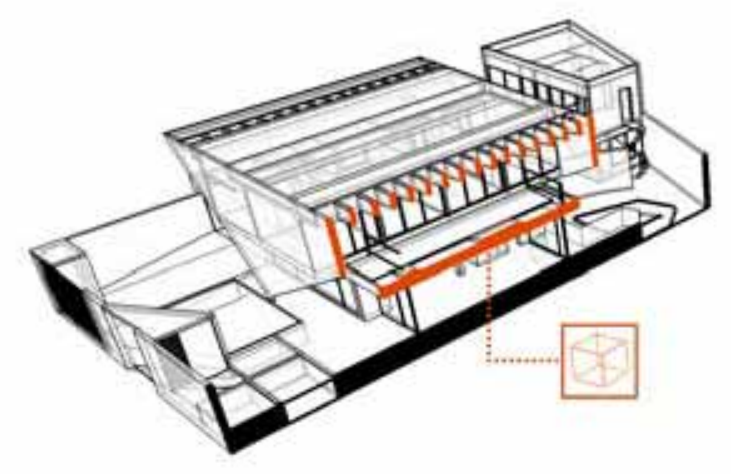


Perspectiva isométrica -

fechamentos

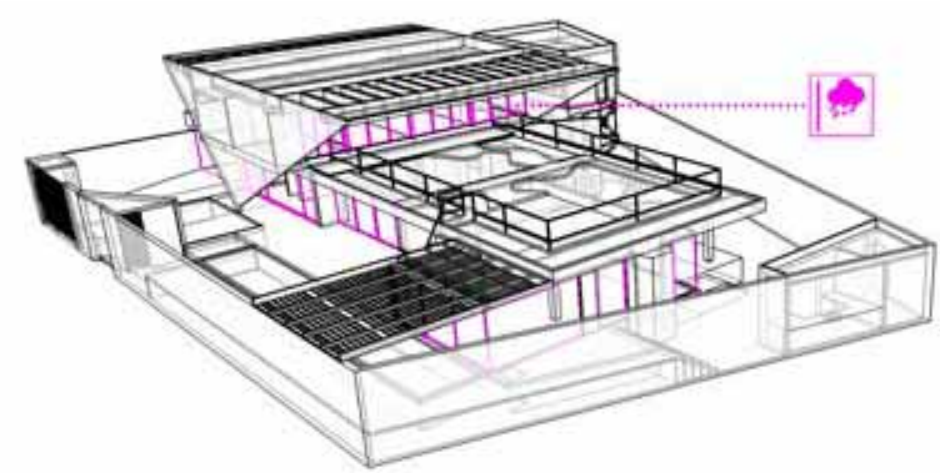

Perspectiva isométrica -

fechamentos

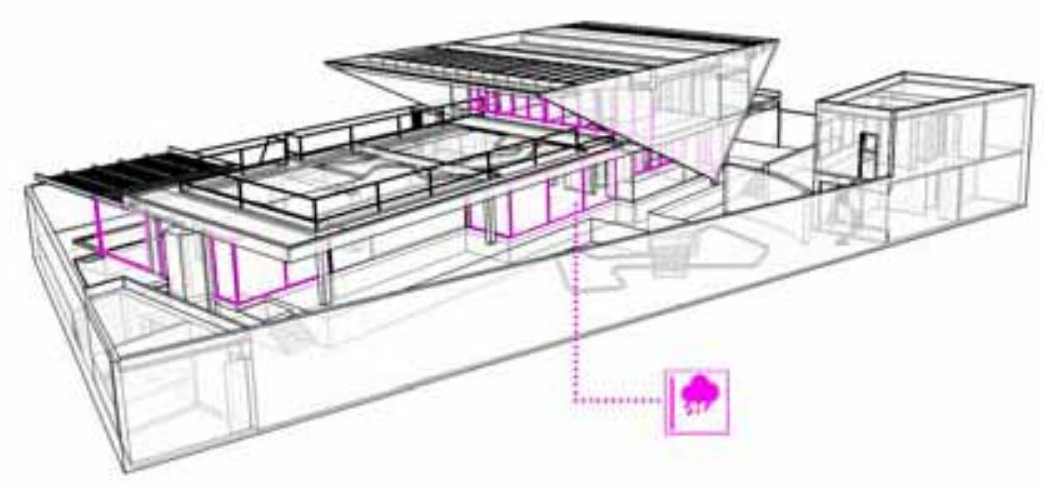

Perspectiva isométrica -

fechamentos

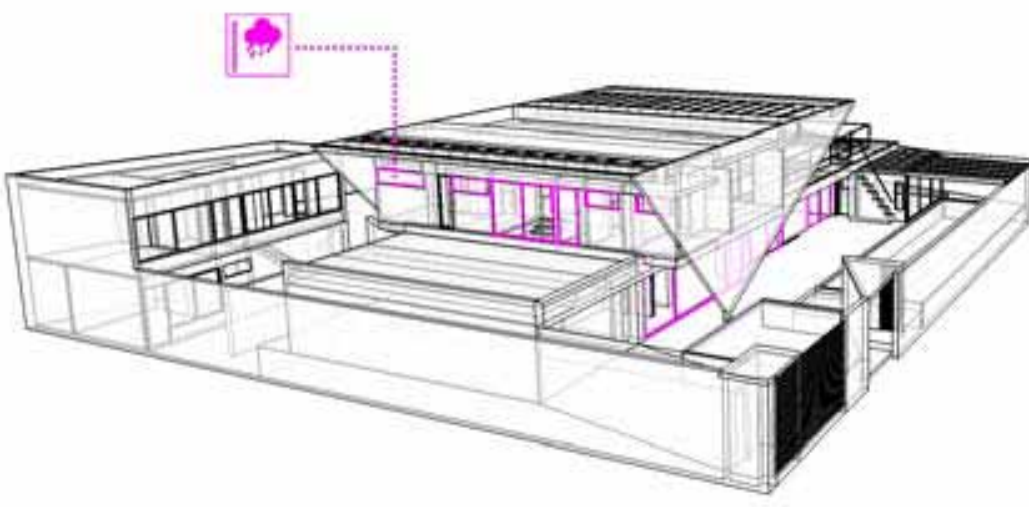


Perspectiva isométrica -

usos (térreo)

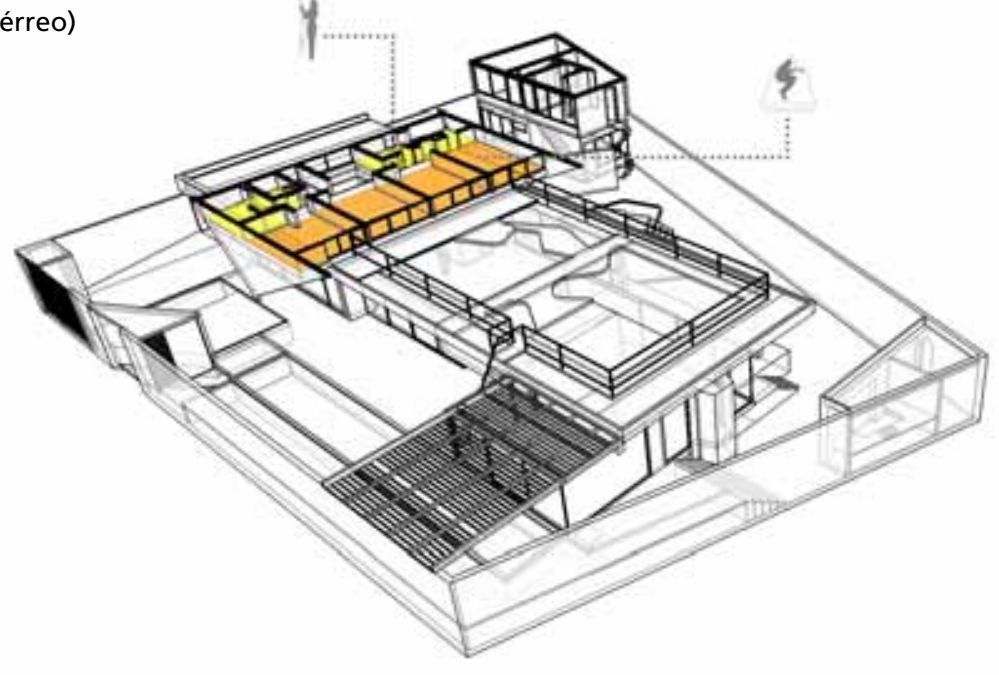

Perspectiva isométrica -

usos (primeiro pavimento)

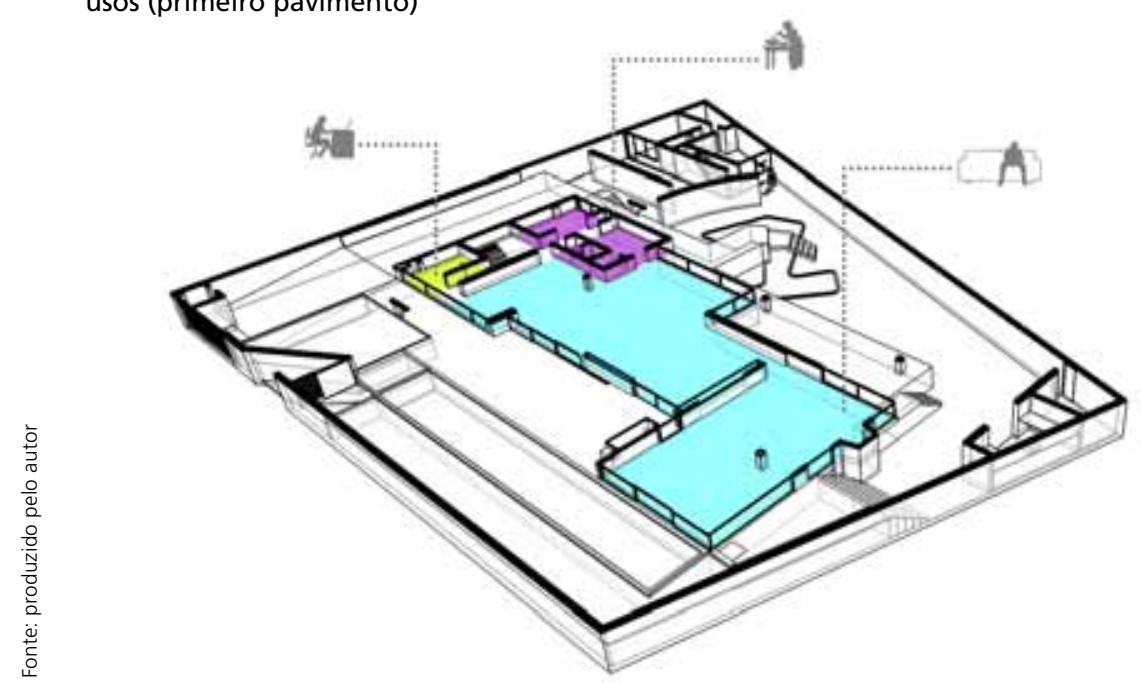





\section{RESIDÊNCIA MÁRIO MASETTI}

atual residência Houssen

Endereço: rua Dr. Manuel Maria Tourinho, 771, Pacaembu, São Paulo, SP

Área do terreno: $752,60 \mathrm{~m}^{2}$

Área da construção: $657,00 \mathrm{~m}^{2}$

Data do projeto original/obra: 1968 / 1968-1970

Autor: Paulo Archias Mendes da Rocha

Colaborador: Yoshio Arakawa (estagiário)

Cálculo das estruturas de concreto armado e fundações: Escritório Técnico Feitosa e De Luca

Cálculo das instalações elétricas, hidráulicas: Masetti e Marinho

Obra: Masetti e Marinho

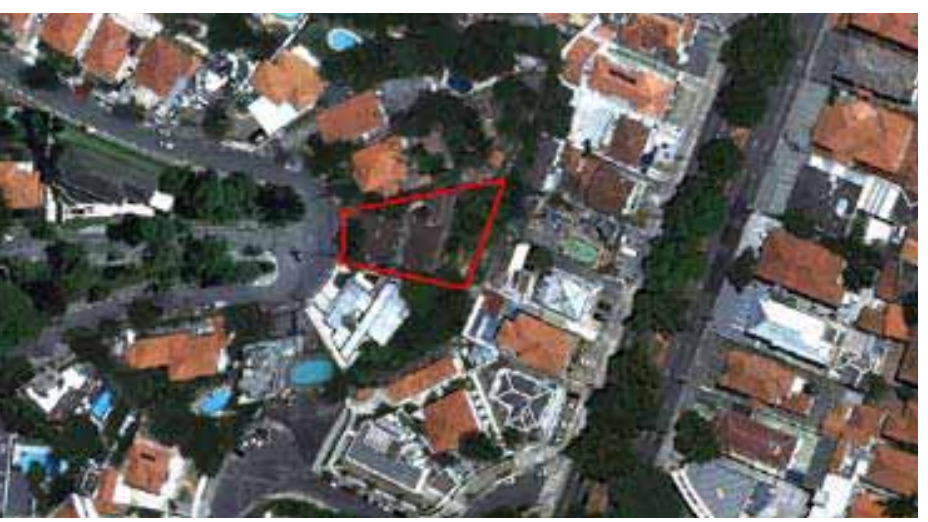

Data do projeto de intervenção/obra: 2011-2012

Escritório responsável: Paulo Mendes da Rocha Arquitetos Associados e Escritório Paulistano de Arquitetura

Autores: Paulo Mendes da Rocha e Eduardo Argenton Colonelli

Consultoria estrutural: Escritório Técnico Feitosa e Cruz

Projeto de instalações elétricas: Sandretec

Paisagismo: Klara Kaiser

Acústica: Alberto Paim da Costa

Ar condicionado: Coldexpress

Esquadrias metálicas: Araújo \& Farsoni

Serviços de recuperação de concreto: Equilibrata Engenharia

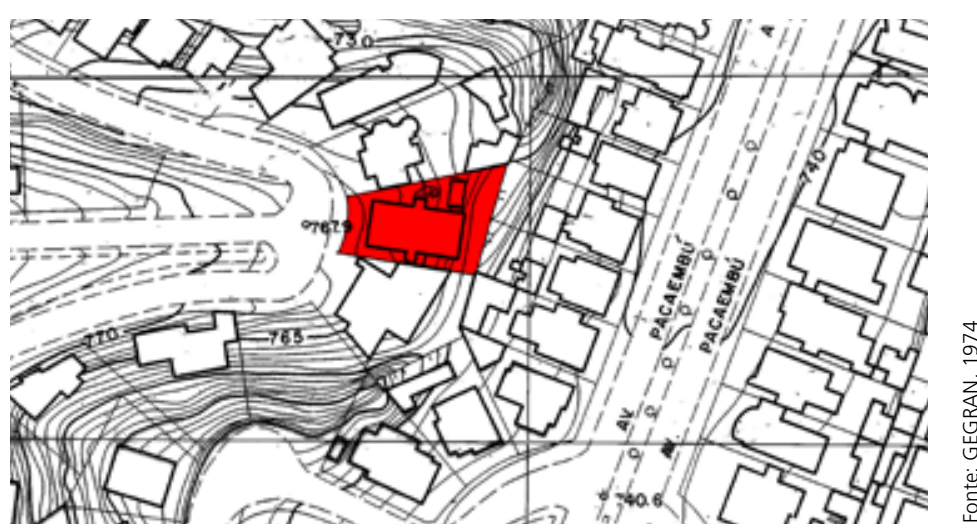




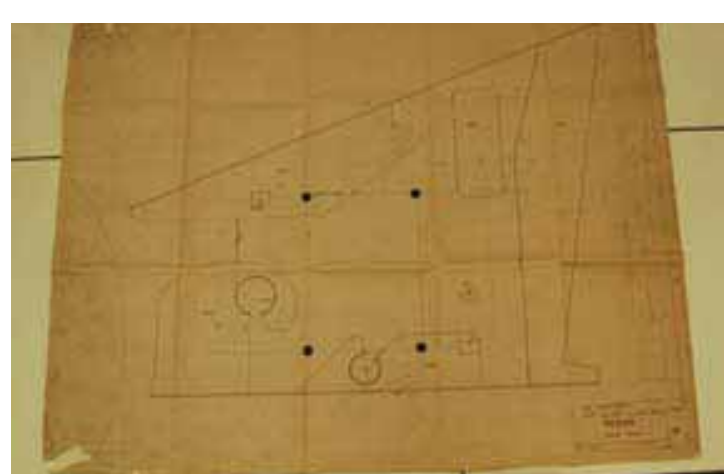

Planta do térreo (escala 1:50)

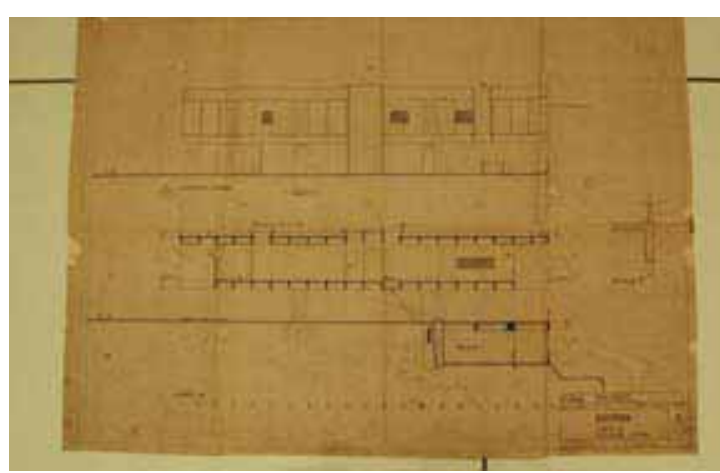

Corte AA e elevação lateral (escala 1:50)

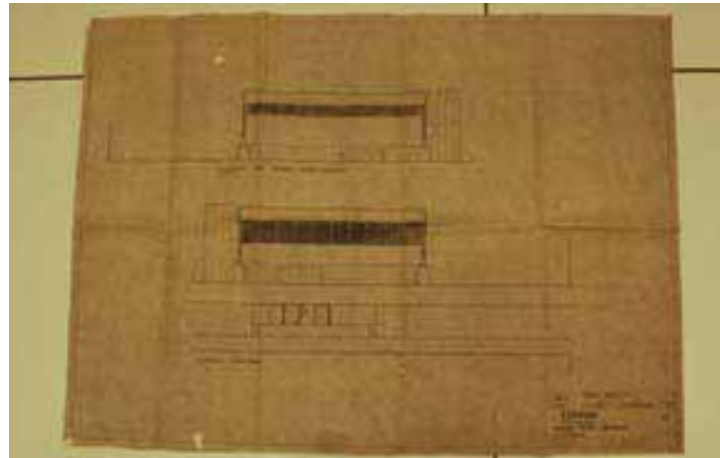

Elevações frontal e posterior (escala 1:50)

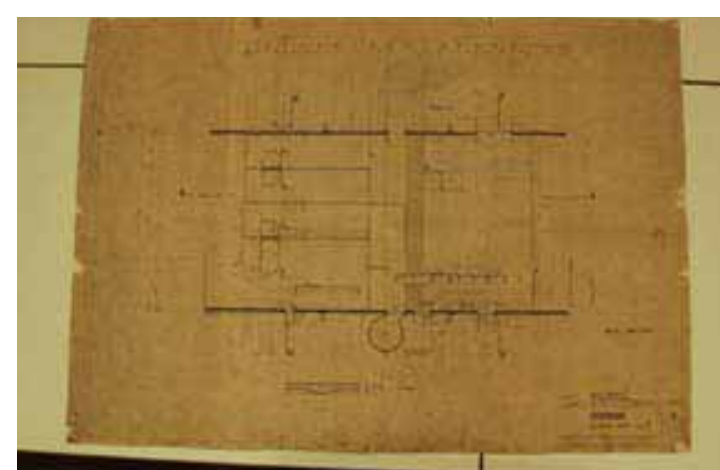

Planta do primeiro pavimento (escala 1:50)

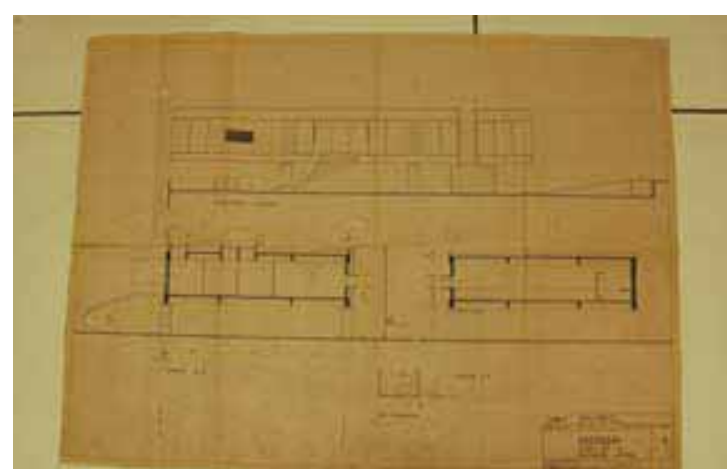

Corte BB, CC e elevação lateral (escala 1:50)

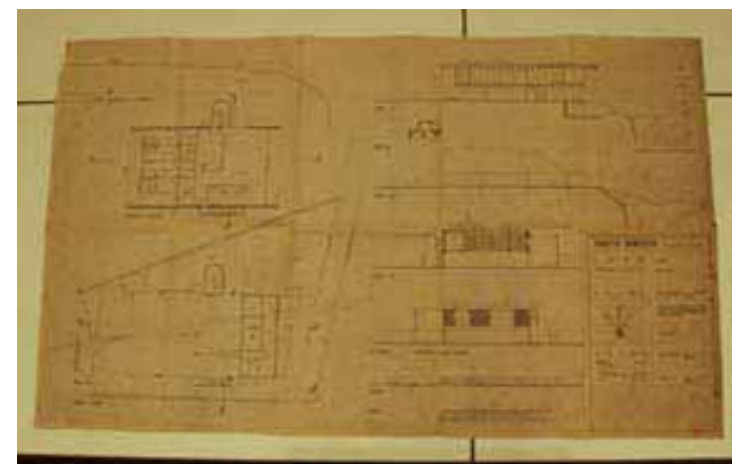

Planta de aprovação na Prefeitura (escala 1:100) 


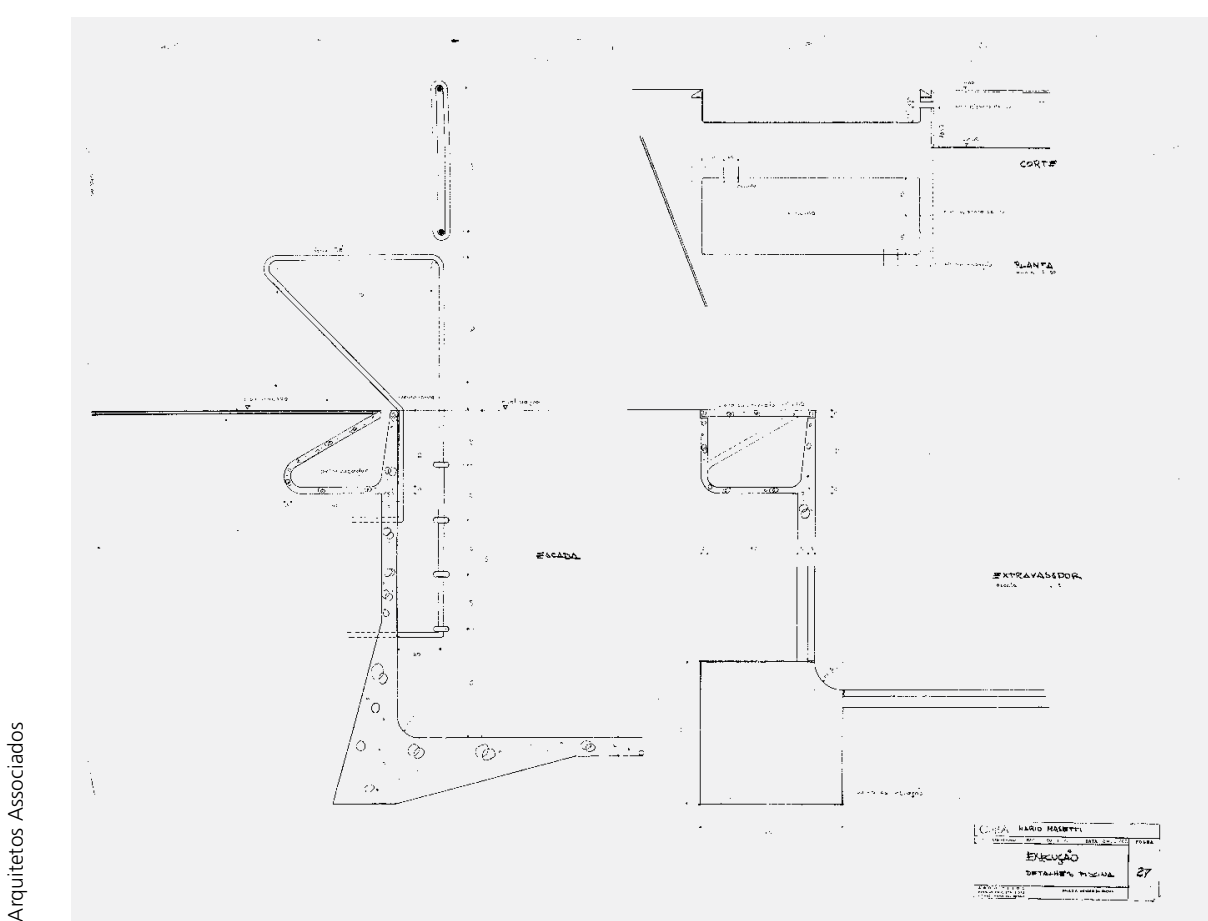

Detalhe da borda da piscina (escala indicada)

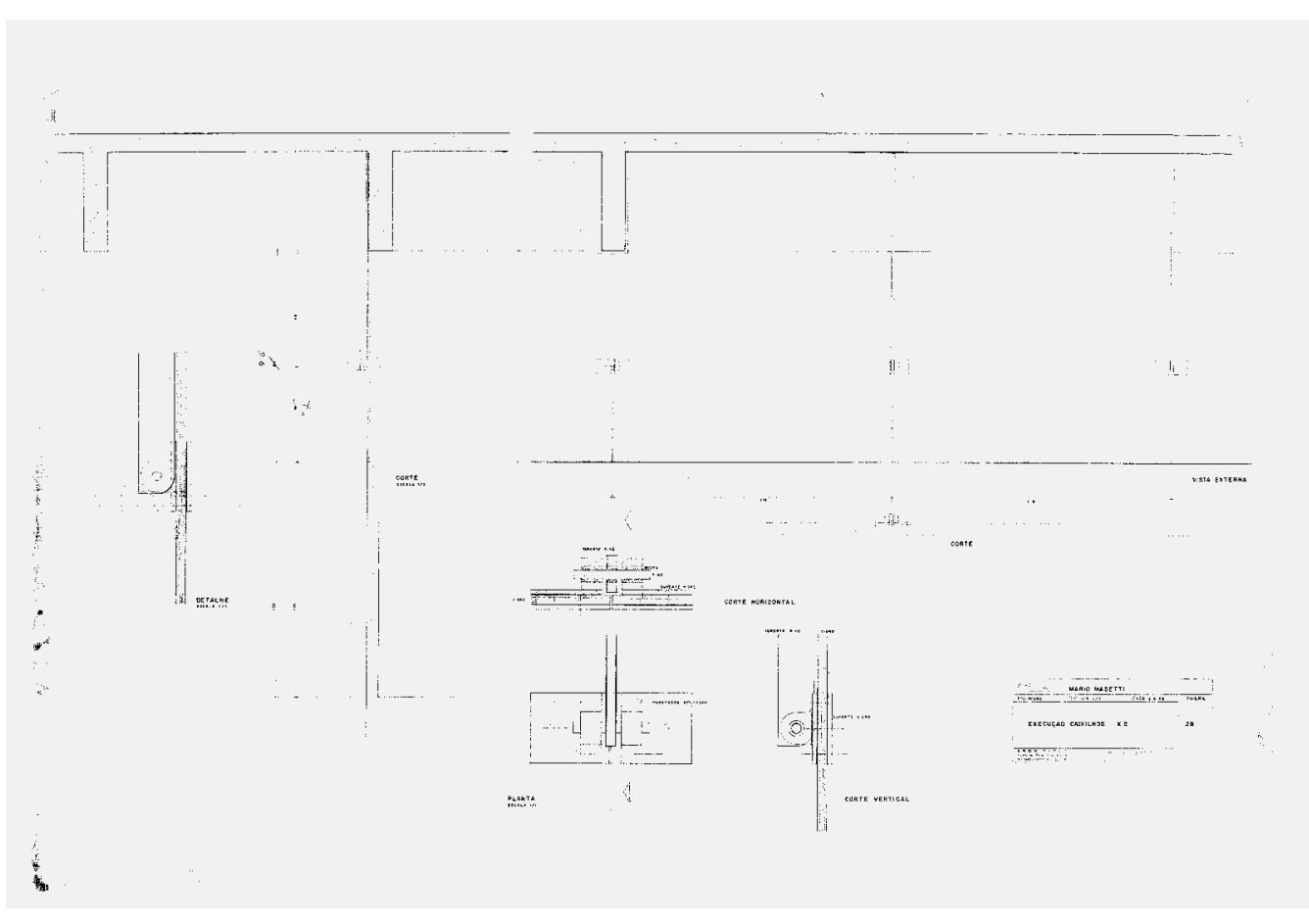

Detalhe de caixilhos (escala indicada) 


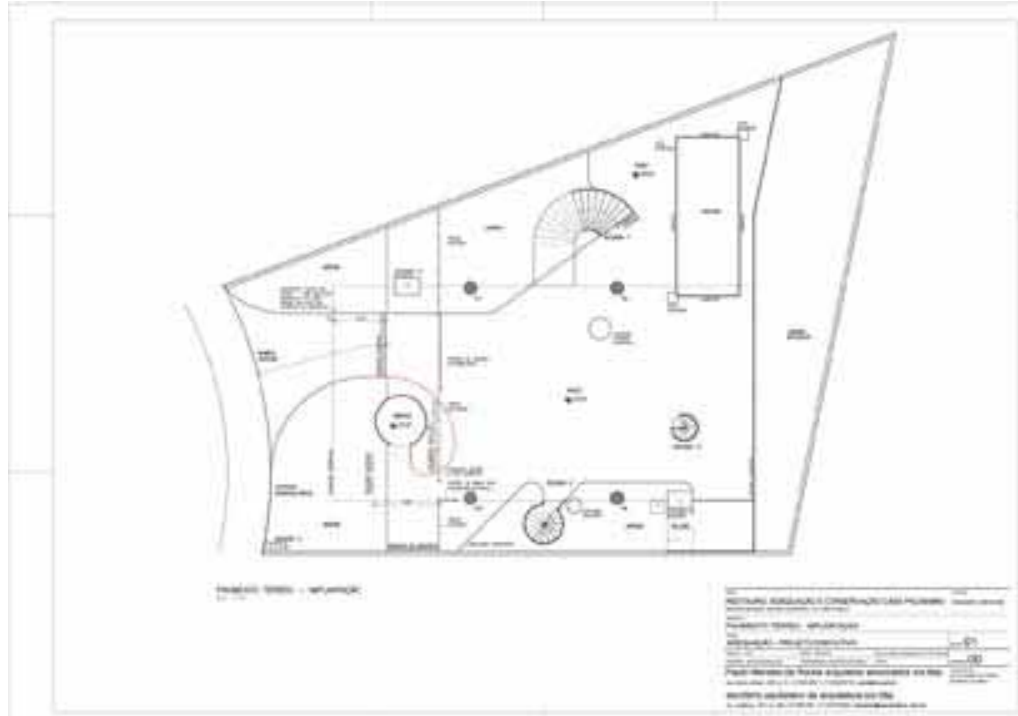

Planta do térreo (escala 1:100)

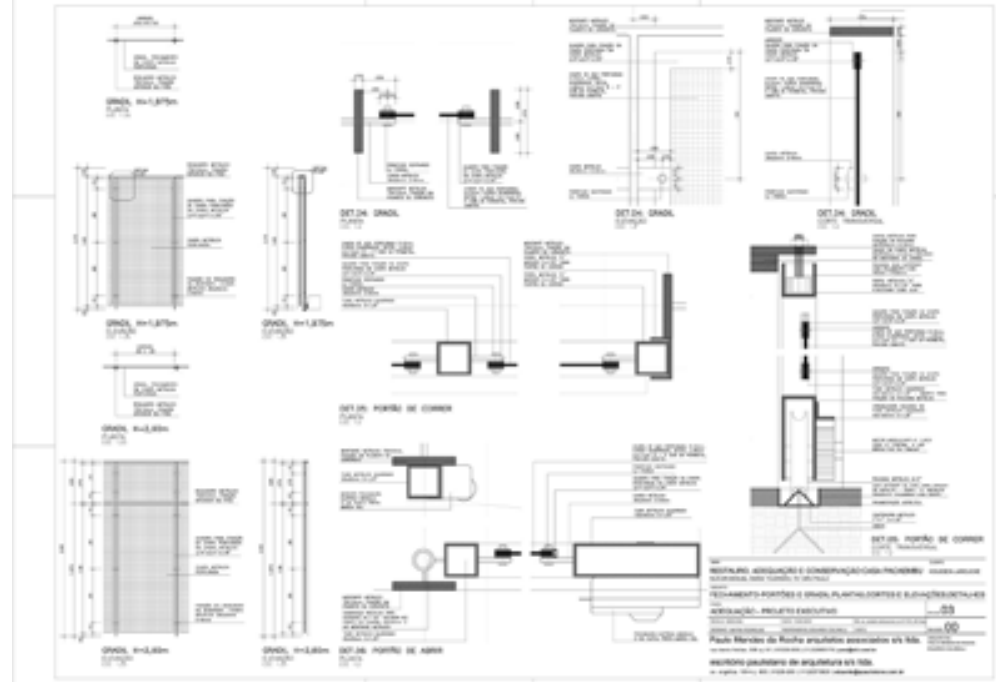

Fechamentos, portões, gradis e detalhes (escala indicada)

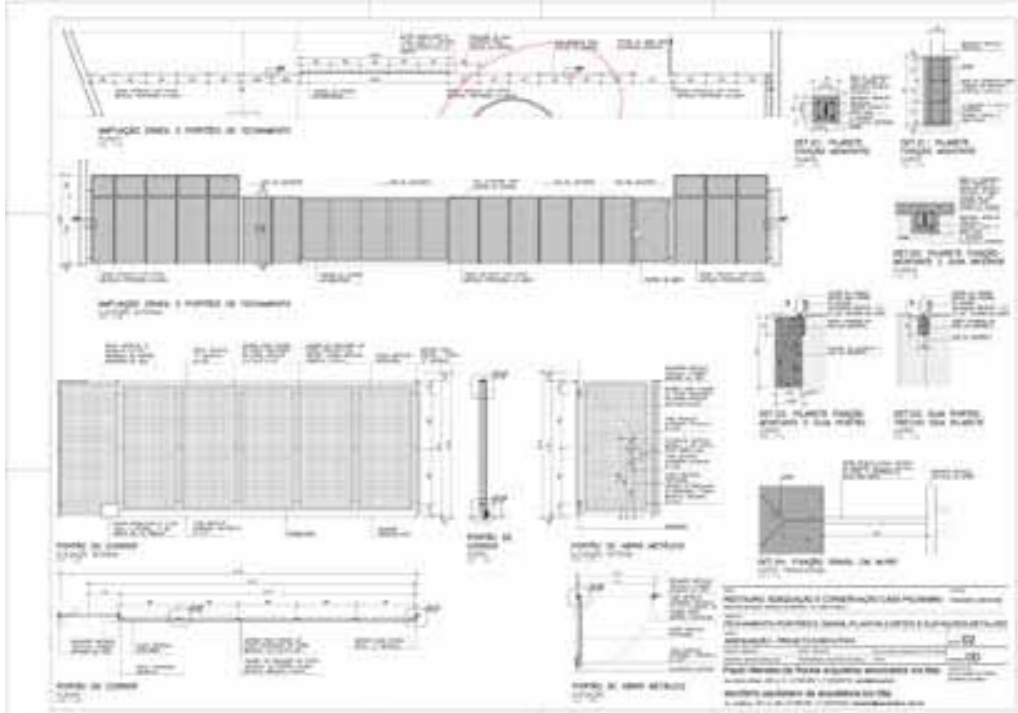

Fechamentos, portões, gradis e detalhes (escala indicada)

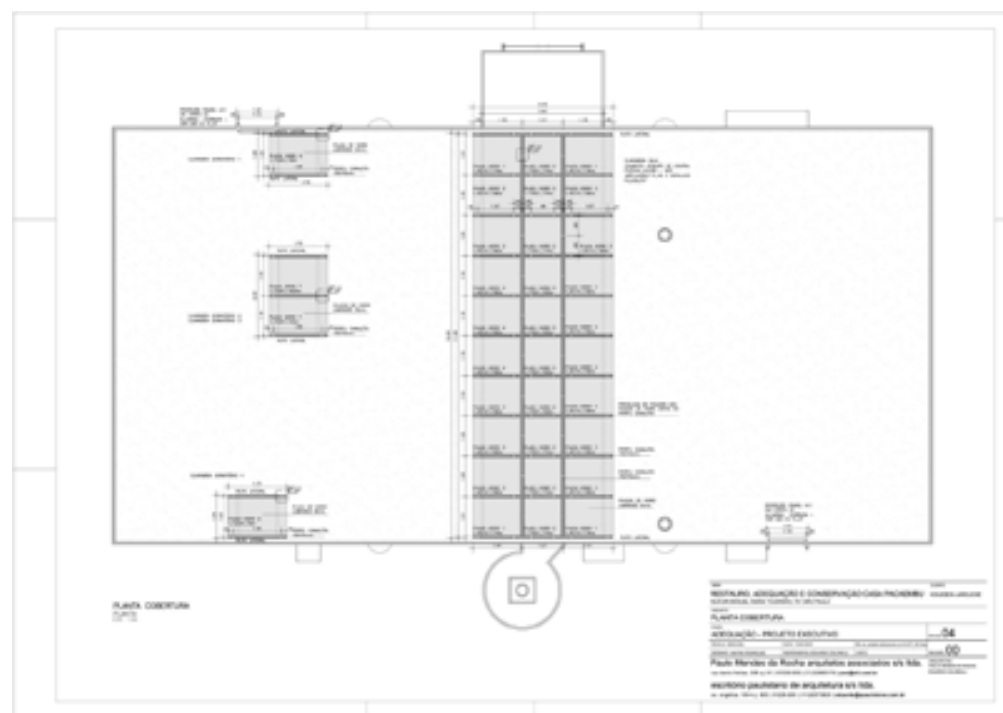

Planta de cobertura (escala 1:50) 


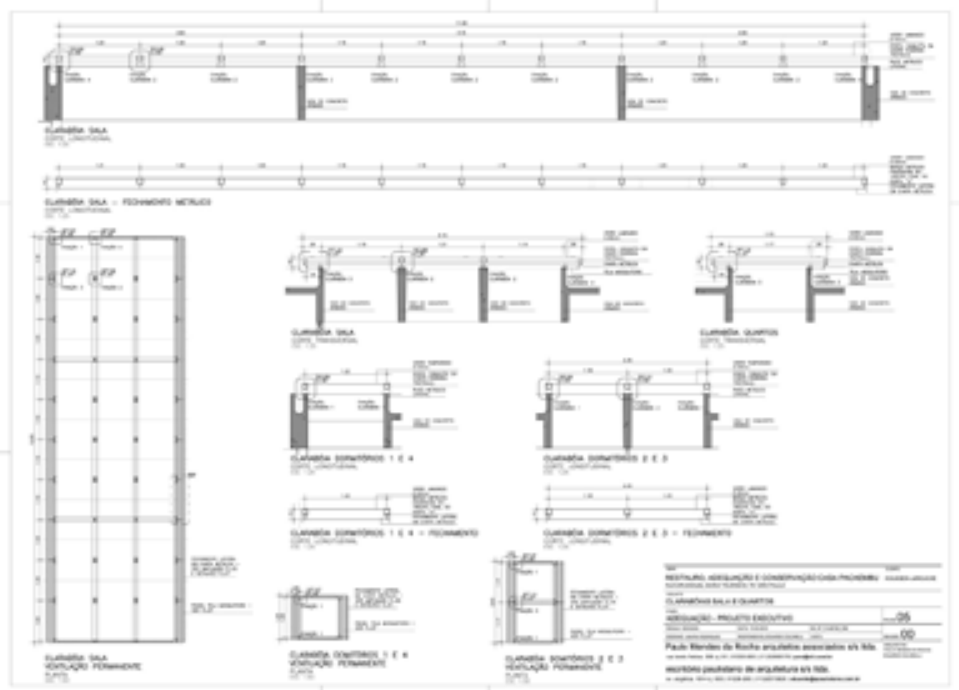

Ampliação e detalhes - claraboias da sala e dos quartos (escala indicada)

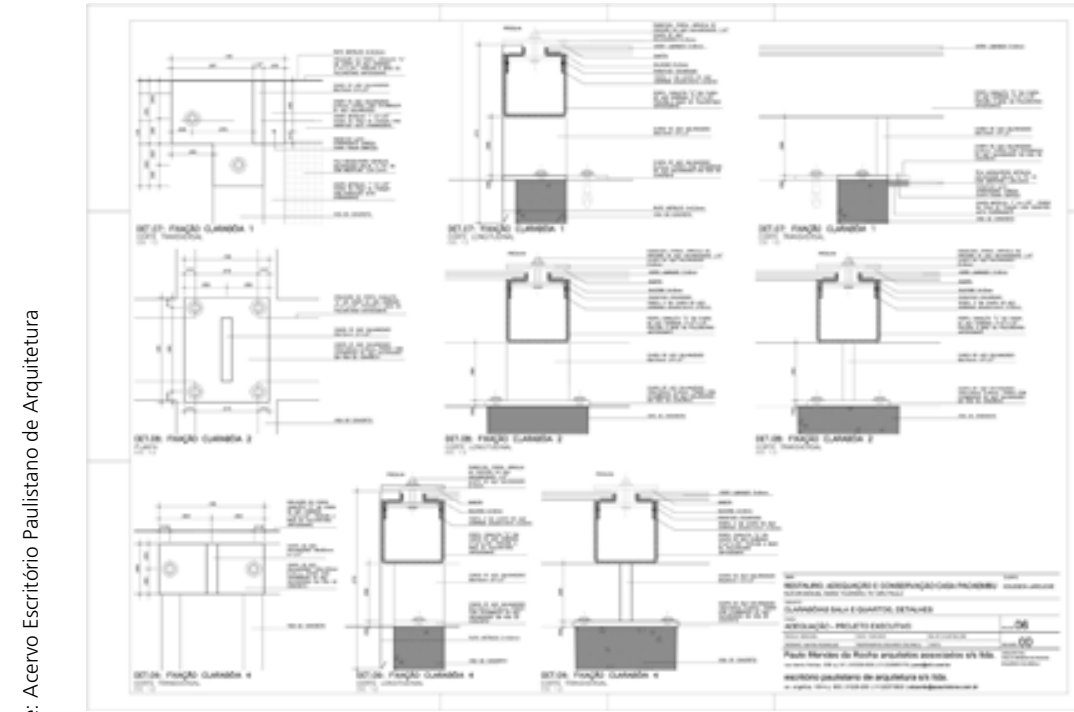

Ampliação e detalhes - claraboias da sala e dos quartos (escala indicada)

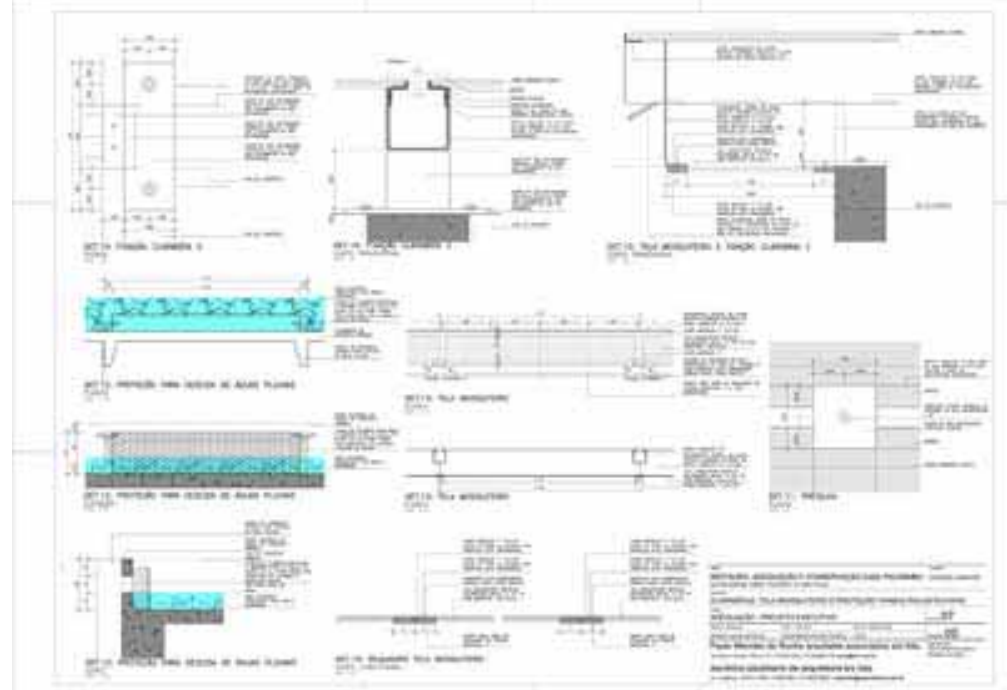

Detalhes - claraboias, tela mosquiteiro e painéis de descida de águas pluviais (escala indicada)

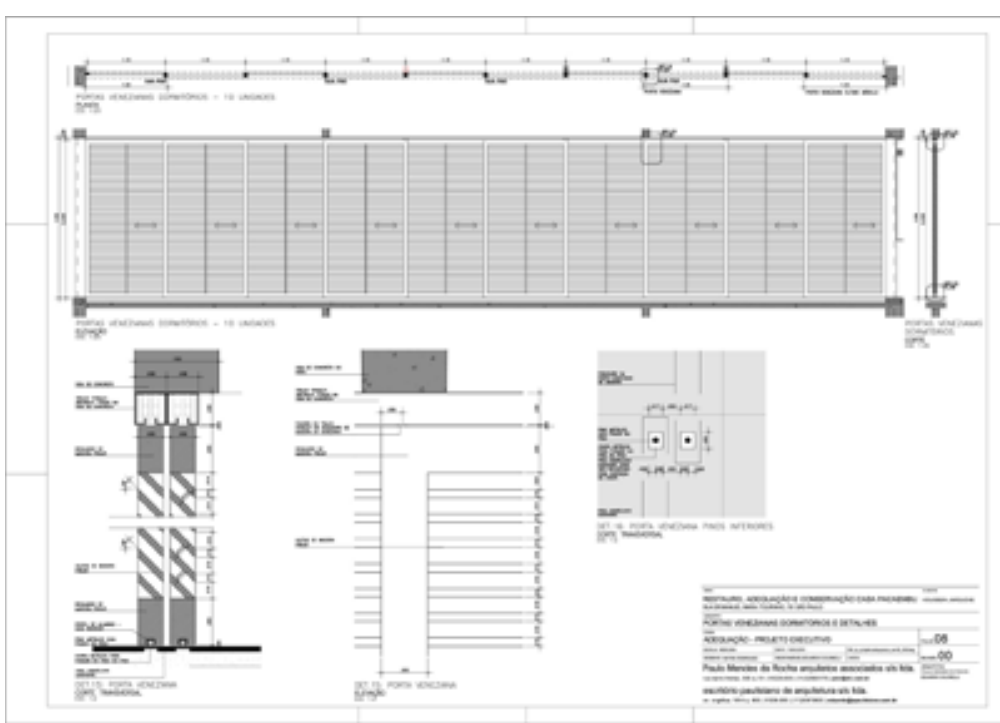

Planta, elevação e detalhes - portas venezianas dos quartos (escala indicada) 


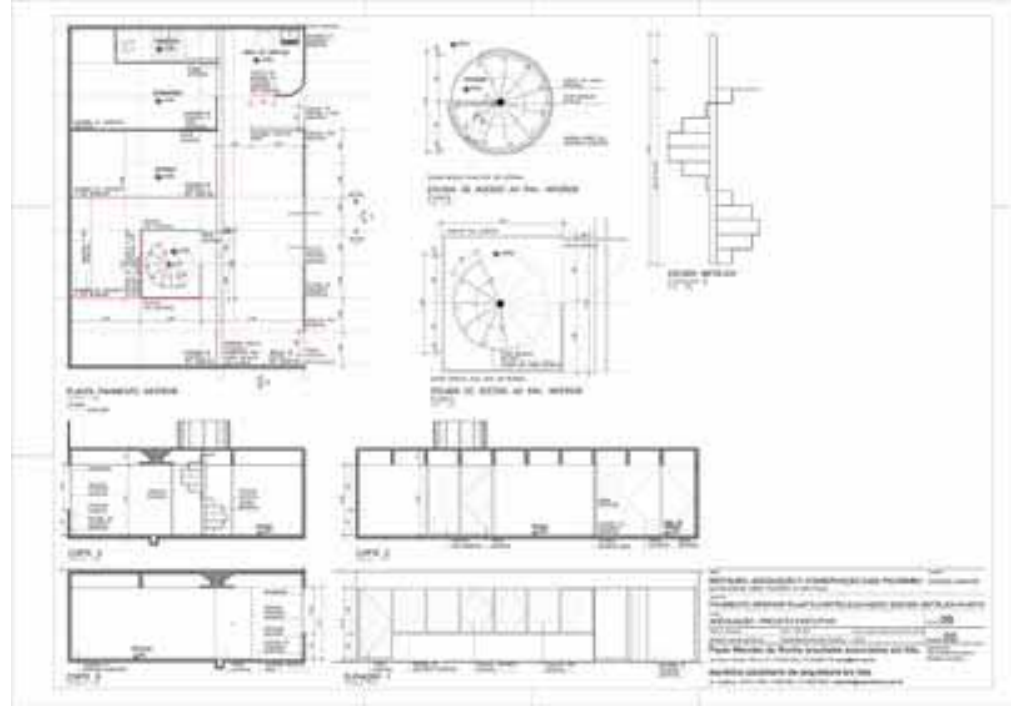

Plantas, cortes e ampliação de escada - pavimento inferior (escala indicada)

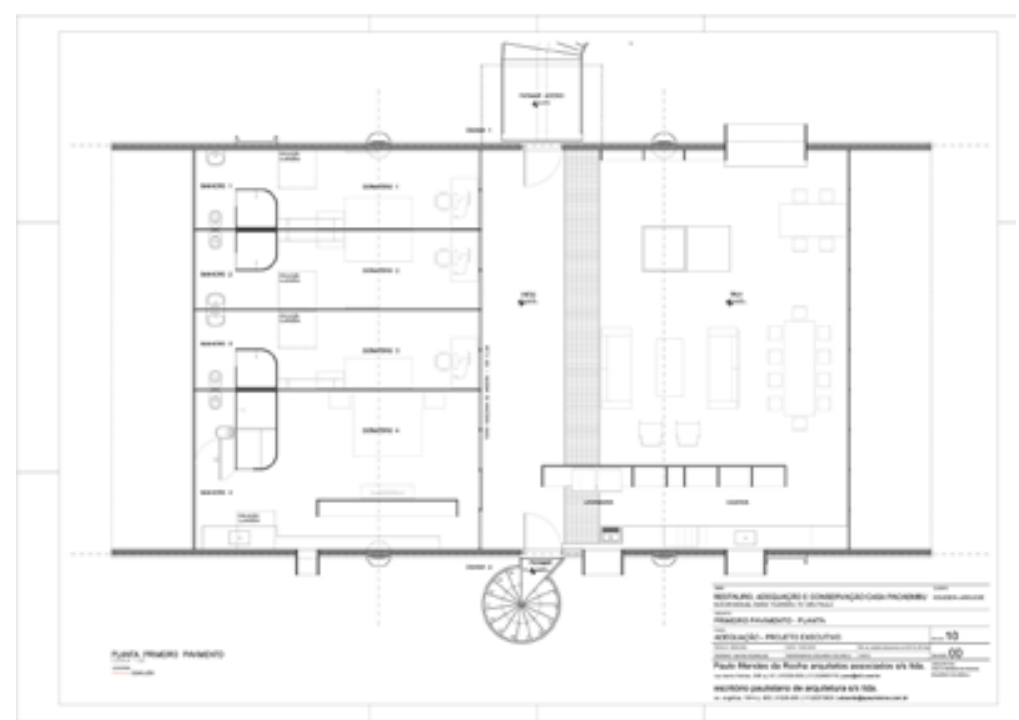

Planta - primeiro pavimento (escala 1:50)

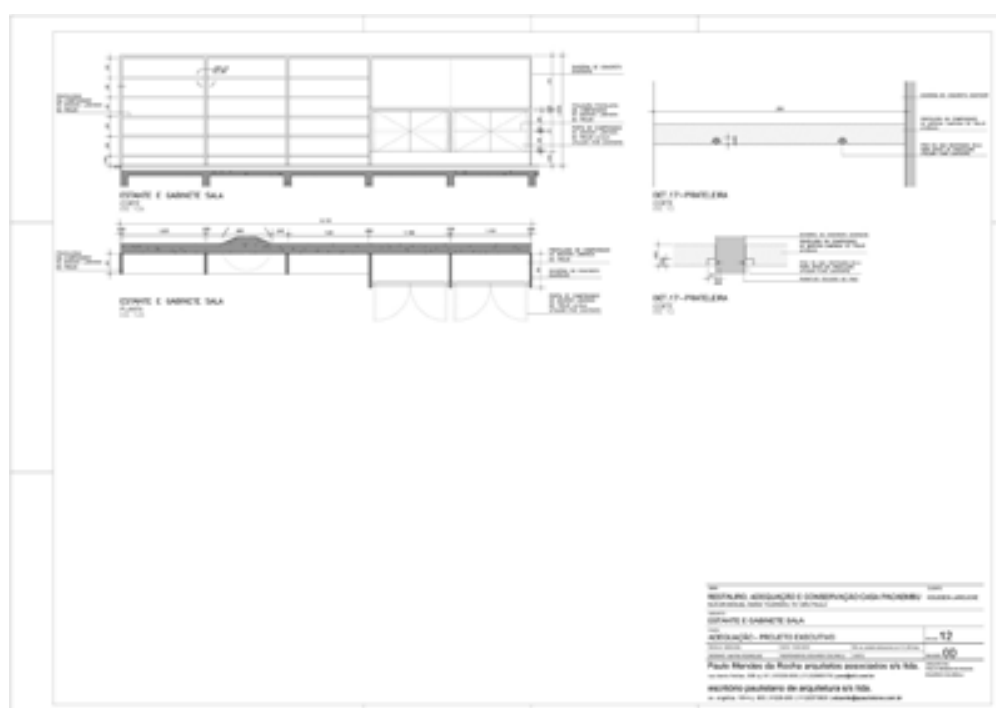

Ampliação e detalhes - estante e gabinete da sala (escala indicada)

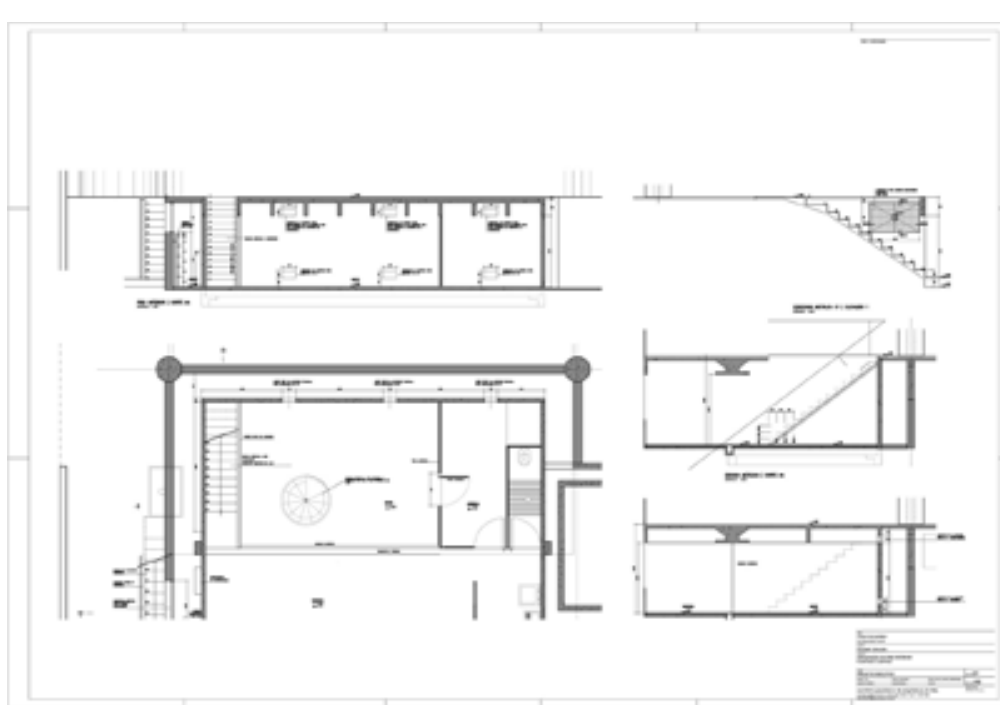

Plantas, corte e detalhes de escada - alternativa 2 - pavimento inferior (escala indicada) 


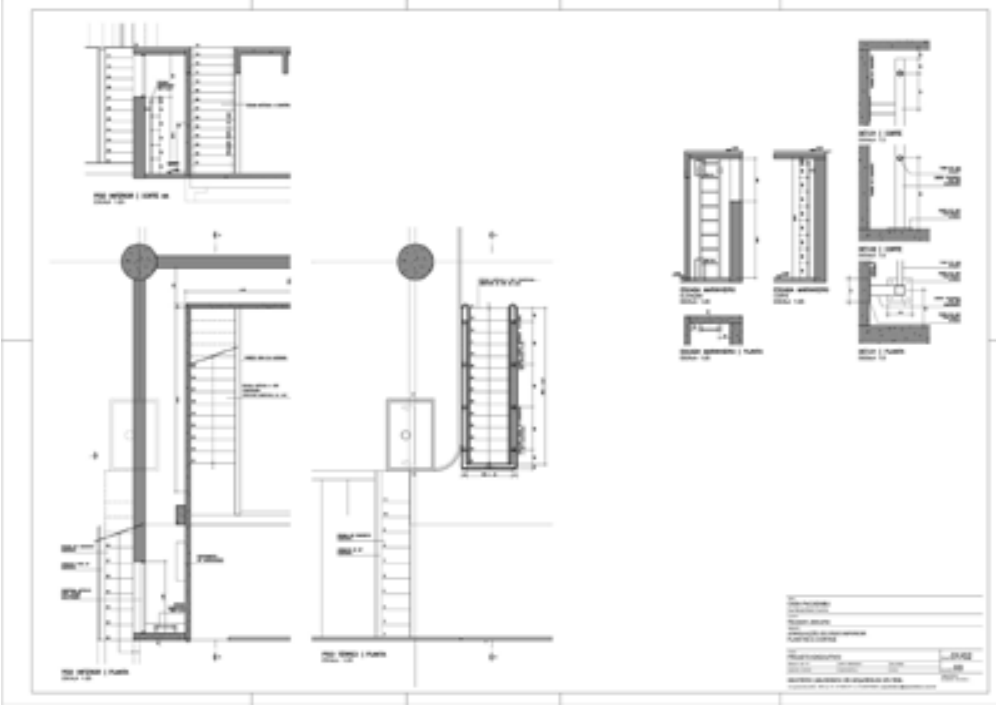

Plantas, corte e detalhes de escada - alternativa 2 - pavimento inferior (escala indicada)

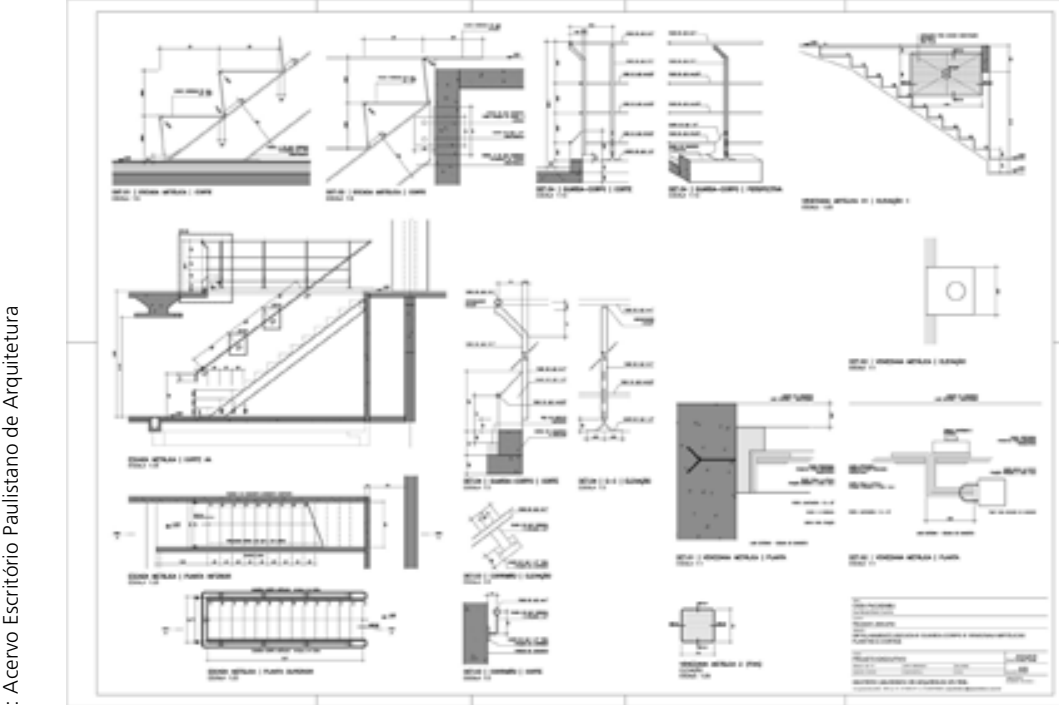

Plantas, corte e detalhes de escada - alternativa 2 - pavimento inferior (escala indicada) 


\begin{tabular}{|c|c|}
\hline \multirow{4}{*}{ 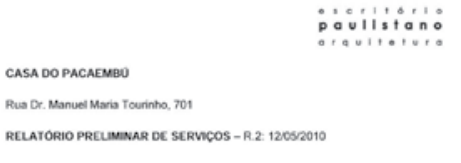 } & poviingon: \\
\hline & 3. FECHaMENTO FrowTAL \\
\hline & 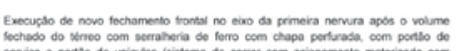 \\
\hline & 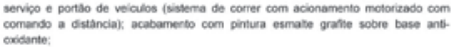 \\
\hline \multicolumn{2}{|r|}{ 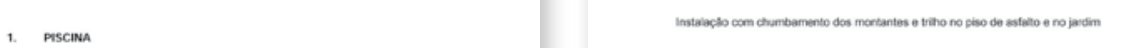 } \\
\hline \multirow{2}{*}{\multicolumn{2}{|c|}{ 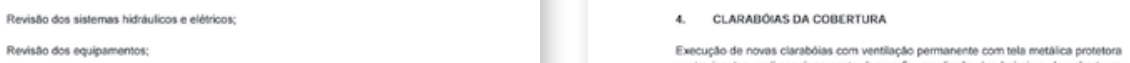 }} \\
\hline & 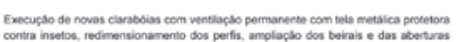 \\
\hline \multicolumn{2}{|r|}{ 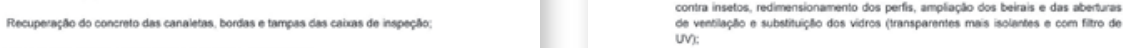 } \\
\hline \multirow{2}{*}{2 PSO ASFALTICO DO TERREO } & 5. RECUPERAGA E E TRAT TMEENTO DO CONCRETO APARENTE \\
\hline & 5.1 INTERNO \\
\hline 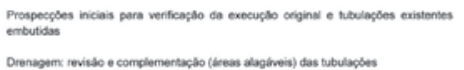 & 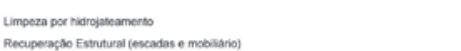 \\
\hline \multirow{2}{*}{ 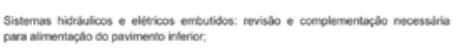 } & 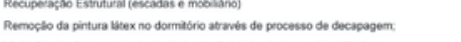 \\
\hline & 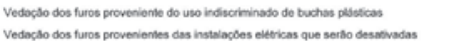 \\
\hline \multicolumn{2}{|r|}{ 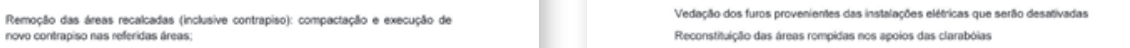 } \\
\hline \multicolumn{2}{|l|}{ 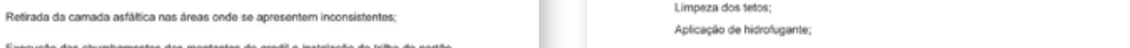 } \\
\hline 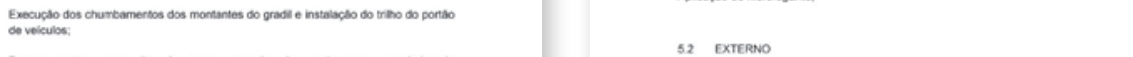 & 52 ExтевмN \\
\hline \multirow{2}{*}{\multicolumn{2}{|c|}{ 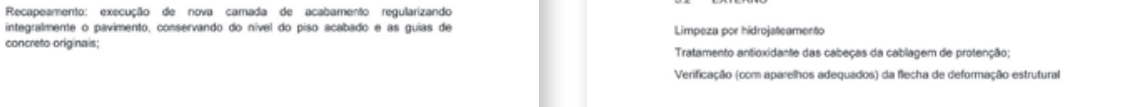 }} \\
\hline & \\
\hline \multicolumn{2}{|l|}{ - } \\
\hline \multicolumn{2}{|l|}{ posiinitan: } \\
\hline \multicolumn{2}{|l|}{ 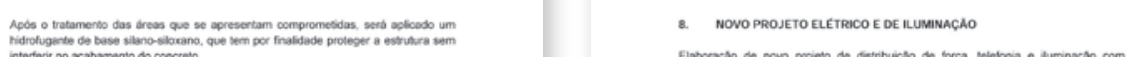 } \\
\hline \multirow{2}{*}{\multicolumn{2}{|c|}{ 6. LMPEZA DOS PSSOS DE LADRLLHOS HIDRAUUCOS }} \\
\hline & \\
\hline \multicolumn{2}{|l|}{ 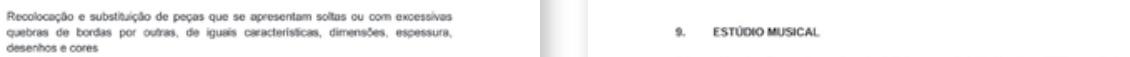 } \\
\hline \multicolumn{2}{|l|}{ 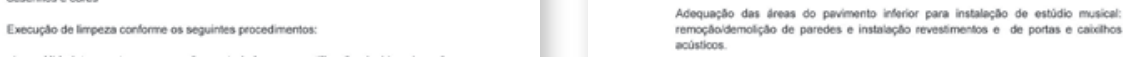 } \\
\hline \multicolumn{2}{|l|}{ 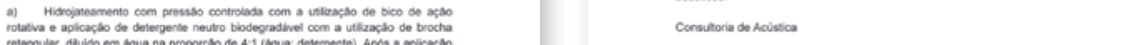 } \\
\hline \multirow{2}{*}{\multicolumn{2}{|c|}{ 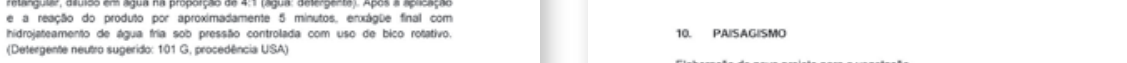 }} \\
\hline & 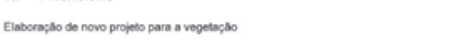 \\
\hline \multicolumn{2}{|l|}{ 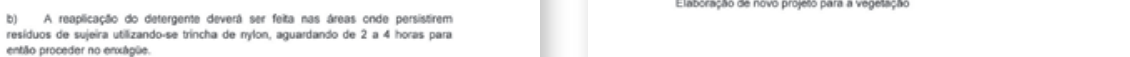 } \\
\hline \multicolumn{2}{|l|}{ 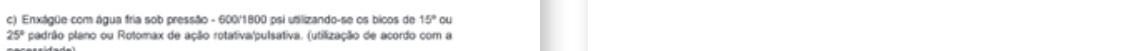 } \\
\hline \multicolumn{2}{|l|}{ 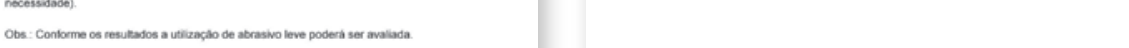 } \\
\hline \multicolumn{2}{|l|}{ 7. REVSAO DE VDROS E CAXXIHOS DE FERRO } \\
\hline \multicolumn{2}{|l|}{ 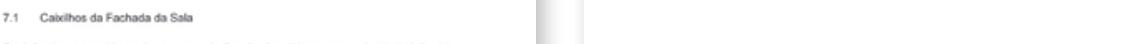 } \\
\hline \multicolumn{2}{|l|}{ 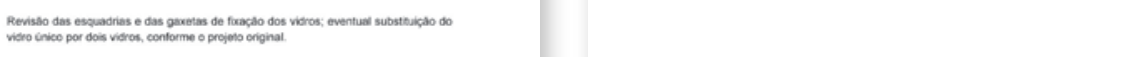 } \\
\hline \multicolumn{2}{|l|}{ 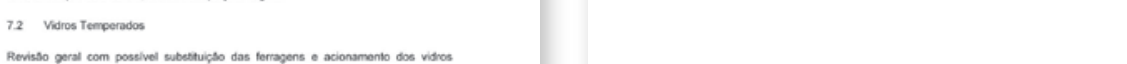 } \\
\hline \multicolumn{2}{|l|}{ 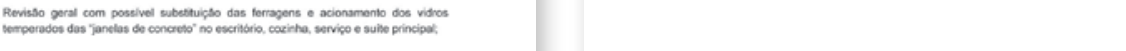 } \\
\hline 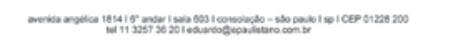 & 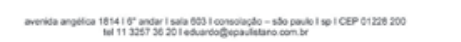 \\
\hline
\end{tabular}

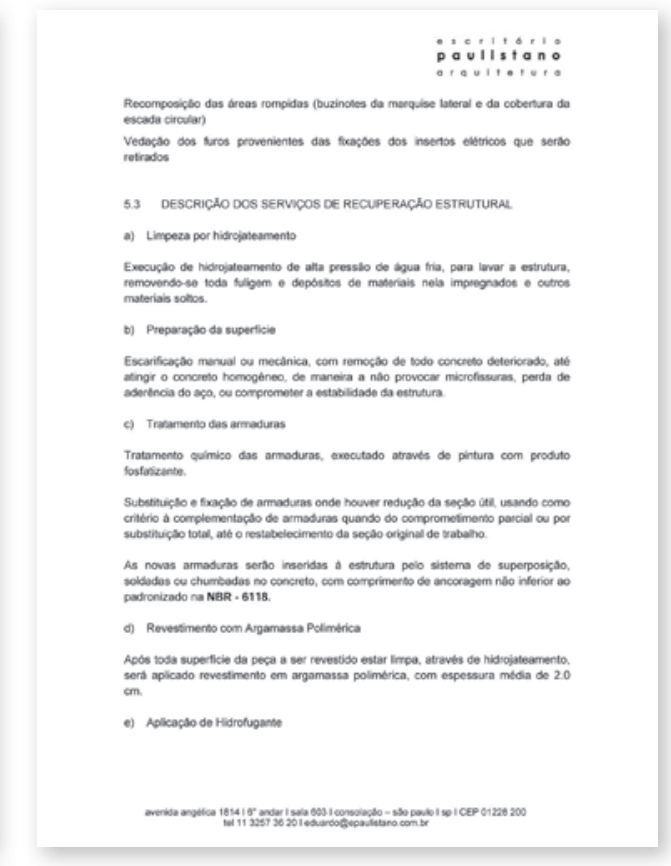

Relatório preliminar de serviços 
[APOENA AMARAL] Quando eu comecei, fiz o projeto, eu queria estudar intervenções em Patrimônios Modernos. E peguei uma lista enorme. Queria discutir os projetos. Não só obras executadas. Mas, ficou aquela coisa gigantesca! Eu tinha pensado em fazer um inventário de tudo o que já tinha sido pensado em intervenção. Não só a orientadora [Helena Aparecida Ayoub Silva], como depois, pessoas com quem fiz as disciplinas acharam que era um trabalho hercúleo e sem foco. Também calhou de conversar muito com o Sílvio [Oksman]. E o Sílvio...

[EDUARDO COLONELLI] O Sílvio fez algo parecido, não?

[AA] Na verdade ele acabou focando na FAU [FAU-USP, Faculdade de Arquitetura e Urbanismo da Universidade de São Paulo], mas no decorrer ele acabou analisando uma série de projetos, como a FIESP [Federação das Indústrias do Estado de São Paulo], a OCA [Pavilhão Lucas Nogueira Garcez, no Parque do Ibirapuera em São Paulo], uma série de projetos que, na verdade, são de interesse significativo, pensando em intervenção no Patrimônio. Mas, o que eu estava interessado em discutir era a questão da metodologia. E acabei achando que um programa da arquitetura moderna, no caso de São Paulo... É que, se você falar "institucionais" cabe tudo... Pensando em obras públicas, não tem exemplos... Veja: 0 FDE [Fundação para o Desenvolvimento da Educação], fez projetos para intervenções em escolas, mas nunca levou a cabo totalmente. Pega por exemplo o MMBB fez o projeto da escola de Guarulhos, o FDE vai lá, tem um dinheirinho...

[EC] Eu não sei... Num certo momento, o FDE fez muita coisa! Naquela escola de Guarulhos do [Vilanova] Artigas, fez um trabalho muito bonito. Depois, parece que ela precisou de uma segunda intervenção. Mas, a primeira intervenção foi muito legal! Teve uma leva de projetos que a gente participou que na sua maioria, eram escolas da Primeira República, que nós fizemos anexos... Vários escritórios participaram. Saiu um livro. Tem projetos interessantes ali. Quer dizer, foi levado a cabo completamente.

[AA] Não... Eu estava pensando nos edifícios de arquitetura moderna que tínhamos poucos exemplos.

[EC] Poucos exemplos, está certo. Eu não sei... Até essa segunda intervenção na escola do Artigas...

[AA] É. O Milton [Braga] fez o projeto. Mas, depois, eles acabaram fazendo tudo um pouco..

[EC] Depois teve o da Roosevelt [Escola Estadual Presidente Roosevelt], do Paulo [Mendes da Rocha]. Eu sei que chegou até a ser examinado. Não sei se tinha alguém fazendo esse projeto, mas eu sei que a FDE estava empenhada na execução lá.

[AA] A gente fez, em cima do projeto básico do Alvaro [Puntoni] o executivo pra Itanhaém [antigo Ginásio Estadual de Itanhaém] aí chegou na obra, os caras tinham 1/5 do valor... Parecia um pouco difícil...

[EC] Eu mesmo, eu fiz um projeto, mas também foi feito só uma parte. Pra escola do [EC] Corona, da Penha [Escola Estadual Nossa Senhora da Penha]. A escola do Corona a gente fez. Tem o memo- rial de restauro. Tem alguns estudos. Foi feita uma intervenção no teatro. No teatro está feito, já. Ficou legal!

Mas, é que a escola do Corona tem o teatro - Lembra como ela é? Tem aquele bloco do teatro, bloco administrativo; depois tem o bloco das salas de aula. Então, a gente só conseguiu fazer isto aqui.

[AA] Que tinha um ex-aluno que era do [banco] HSBC... Eu lembro dessa história.

[EC] Então, não sei o que vai dar o resto, porque não se conseguiu fazer nada do resto. Estão lá batalhando. Mas, esse aqui foi feito tudo direitinho, conforme o projeto.

[AA] Daí eu desencanei das escolas e precisava um recorte...

[EC] Aí tem o Esther que não foi pra frente... Ficou lá o projeto que aprovou no CONDEPHAAT [Conselho de Defesa do Patrimônio Histórico, Arqueológico, Artístico e Turístico], no CONPRESP [Conselho Municipal de Preservação do Patrimônio Histórico, Cultural e Ambiental da Cidade de São Paulo], mas ficou no preliminar. Porque você aprova um anteprojeto. Não é um projeto. Você não aprova um executivo.

Aí tem essa casa aí do Paulo que não foi aprovada em lugar nenhum. Mas, a gente fez de acordo com alguns protocolos, assim. Procuramos seguir uma certa metodologia, sim.

\section{[AA] É justamente isso!}

[EC] Trabalhamos, de alguma maneira, assim, nessa casa. 0 que é uma coisa rara, pegar um proprietário que estava interessado 
em conservar todas as características; mas, também - claro -, adequar às suas necessidades, sem fazer nenhuma alteração essencial. Então, essa aqui é a casa do Masetti. É isso que você quer falar?

[AA] É! Essa discussão da metodologia... É que, de certa maneira, você tem essa particularidade: você tem muito poucos exemplares de qualquer tipo de programa tombado. Mas, sabendo, reconhecendo 0 arquiteto, achar as bases originais, etc., etc., você pode ter um cuidado...

[EC] Aqui eu pude conversar com o arquiteto. 0 arquiteto foi comigo lá!

[AA] Aí é fonte primária! Fonte primária é melhor ainda!

[EC] Bom... O que a gente pode falar? Essa casa tem algumas particularidades que geram algumas dificuldades. Uma das questões eu acho que é o concreto aparente. 0 concreto aparente tem uma certa dificuldade porque ninguém mexe bem. Não tem grandes pesquisas sobre isso. Conversei, quando a gente começou a enfrentar esse problema, conversei com várias empresas que trabalham com restauro de concreto, com restauro de Patrimônio. 0 pessoal conhece muito a questão das argamassas; tudo lá do século XIX o pessoal desenvolveu bastante. Agora, concreto aparente... Inclusive, muitos estavam interessados em fazer 0 trabalho para usar como um laboratório, mesmo. Mas, aí não deu muito certo com algumas empresas, até por questões comerciais, etc., porque a escala é pequena. Os caras vão encarar muito como um laboratório! Mas, porque, também, existem poucas... Agora, talvez, é que esteja começando: o caso da FAU tá lá. Tem essa questão presente na FAU. Agora é que é o momento, já que essas obras estão precisando de uma intervenção. Mas, houve conservação e mesmo adequações.

[AA] Essas necessidades começaram a [surgir]...

[EC] Porque você pega o Esther. 0 Esther é a argamassa. 0 edifício lá do Corona é pastilha. Então, essas coisas são muito conhecidas. Agora, o concreto não! A pastilha você troca. É revestimento, para todos os efeitos. Essa casa não é revestimento. E a dificuldade é que, uma vez concretado, como você faz um reparo? Inicialmente a gente procurou a melhor homogeneização possível, mas percebemos que isso seria impossível. 0 que foi possivivel foi trabalhar para minimizar. Porque o problema é que fica tudo parecendo um "cimentadinho", sabe? Muda a cor. Não fica concreto! Fica argamassa, argamassa de cimento. Não é concreto. Não é a mesma coisa. E isso foi difícil de sair. Agora, o problema da textura e também da cor.

Essa casa do Paulo tem uma questão que eu também acho interessante, que ela é de um concreto bastante bruto. Ele, por si só, já não é homogêneo. Tem hora que muda a cor. Mas, se você falar: "Já que é assim, tudo bem!"... Mas, de qualquer maneira, ele não é homogêneo, mas é coerente. 0 problema desses reparos é que eles ficam um concreto incoerente. Fica uma coisa que não é. É um reparo. Mas, eu acho que isso é muito difícil de sair, porque, como é que você vai fazer: lá no meio de uma parede tem uma ferragem pra tratar? A gente procurou, de alguma maneira, as marcas das travas procurou seguir um pouco essas coisas, porque tinha a ver. Tem lá um tabuado, de repente tem um reparo e pega aqui. Então, isto daqui interrompe, fica com uma textura diferente. Então, isto daqui foi difícil. E é um serviço que o pessoal que faz restauro de concreto, faz restauro de concreto tecnológico. Não tem nada a ver com a questão arquitetônica. Então, é difícil lidar.
Mas, eu acho que se conseguiu um resultado bastante razoável, mas, assumindo que o reparo você vai perceber e ponto final. Não tem como igualar.

Se fosse um concreto feito com laminado, com etc. e tal, que há uma perfeição, acho que... Você estuda, fica muito perto. Aqui você não tem como fazer. Você tem que recriar a imperfeição! Como é que você vai criar a imperfeição? Às vezes a gente até tentava criar uma textura, cotava, umas coisas pequenas, até um certo ponto, um certo preciosismo. Mas, até na própria origem, às vezes tem lá um remendo. Mas, aquele remendo, foi feito lá naquela obra. Mas, eu acho que isto aqui é problema ponto a ponto. Aqui acho que deu. 0 resultado ficou satisfatório, na minha opinião. Até você olha assim, no geral, ficou bem homogeneizada.

[AA] Enquanto limpeza, por que o concreto vai absorvendo a poluição...

\section{[EC] Isso foi feito.}

[AA] Mas, a hora que se faz essa limpeza, é bom e é ruim. Tudo bem, a obra renova..

[EC] Não. Ela é boa. Eu sou de opinião de que ela é boa. É só uma lavagem. Porque, neste caso, é o material. Você lava o material. É como você pegar a pastilha e lavar a pastilha: jato d'água, faz o rejunte novo; ela fica renovada, mas ela não é nova. E você não tira tudo.

Na sua própria origem, o concreto apresenta, às vezes, uma cor um pouco lamalheira (sic), um pouco mais amarronzado. Teve manchas no concreto que nós não conseguimos tirar. Não sei a origem daquelas manchas. Não é umidade. Não sei. Ficamos desconfiados que fosse alguma reação de origem, de algum produto 
pra desforma; algum produto aplicado na forma. Isso eu não tive muita certeza porque nas paredes não apareceu; apareceu só nas lajes de cobertura, sobretudo. A cobertura, na Masetti, tem um filme d'água, mas não era infiltração, entendeu? Não era calcificação, nada disso. Não sei dizer. Lavamos; minimizou um pouco; mas eu não quis aplicar lixas, essas coisas. Não quis lixar. A casa não foi lixada. Foi só hidrojateamento e depois se aplicou um hidrofugante.

Eu acredito que, na origem, o hidrofugante não entrou. Não sei se usavam hidrofugante naquela época, mas eu acho que não. Mas aqui nós usamos o hidrofugante porque o concreto é muito permeável; e essa umidade começa a, eventualmente, ofender ferragens, etc..

Essa casa, ela tem espessuras muito pequenas nas nervuras, nas vigas. Mesmo assim, não havia nenhuma grande exposição de ferros. Só uma coisa muito localizada nas escadas. Nas nervuras, nas paredes, tudo perfeito. Agora, a nervura tem $10 \mathrm{~cm}$ aqui em baixo. Mesmo assim... Precisa tomar um certo cuidado, porque 0 cobrimento não é muito grande.

Essa foi a questão principal. Então, a gente foi se deparando com algumas coisas; fomos lidando com cuidado. Por exemplo: a minha grande preocupação era nunca perder a textura daquele concreto que estava lá. E, às vezes, a própria cor. Porque, às vezes, ficava o concreto um pouco rosado. Dependia da tábua, mesmo. Você percebia que era problema da tábua. 0 concreto incorporou. E a lavagem não mudou nada disso. Teve uma parede grande, em um dos dormitórios, que foi, que sofreu uma pintura, látex, e foi difícil retirar. Quando se tirou, a gente percebeu que o concreto tinha aquelas nuances todas. Então, o concreto absorveu. Quase que se pigmentou. Não era uma coisa superficial. Ficou mais impregnado daquilo. E deu certo. Fizemos isso.

[AA] E internamente? Mudanças radicais?
[EC] Nenhuma mudança... Não. No pavimento da casa, propriamente, nenhuma mudança radical. Fizemos alterações de componentes. Então, todas as portas-venezianas dos quartos para a sala haviam sido substituídas por venezianas de alumínio e nós retornamos à solução original, que era veneziana de madeira. Então isso aqui foi digamos assim... Voltamos ao componente original. Como é que a gente chegou nesse componente original? Não é original, obviamente. Ele foi refeito. Mas, usou-se como modelo um projeto que o Paulo tinha feito, na mesma época, numa casa em Goiânia e usamos como modelo a própria casa do Butantã do Paulo, que tem essa solução. Mas, a solução era uma solução que havia sido usada nessas três casas, na época. Não posso garantir que o que era na Casa Masetti era igual ao que estava projetado na Odilon Moreira [residência Bento Odilon Moreira, 1963], nem posso garantir que era igual ao que foi executado no Paulo. Sempre pode ter uma diferença. Mas, o conce to, o tipo de veneziana, o tipo de madeira, sim. A própria espessura. 0 marceneiro queria fazer $3,5 \mathrm{~cm}$ e a gente fez com $2,5 \mathrm{~cm}$, que era a espessura que tinha lá no Paulo. Então, havia algumas fotos e tal, mas a gente usou alguns projetos de referência, porque, no projeto do Masetti, que a gente tem os desenhos originais, esse detalhamento não aparecia. Talvez nem tenha sido feito, porque essas coisas...: "Não... Faz igual à casa do Butantã". 0 marceneiro vai lá, mede tudo, vai à casa do Butantã e faz igual. Então, pode acontecer assim. Então, nós não encontramos - o Paulo não lembra também - .. Nós não encontramos um detalhamento específico do Masetti. Mas, achamos que era importante ter essa solução da época.

Outra coisa que a gente fez foi reconstruir a claraboia. Os perfis da claraboia estavam, já, um tanto comprometidos. Achou-se melhor fazer novamente essa claraboia, e fizemos. Os perfis foram um pouco modificados.

[AA] Originalmente eram de aço?
[EC] Eram um pouco pequenos. Continuou de aço, a mesma coisa. A mesma solução de canaleta $U$, a mesma modulação. Nada disso foi alterado. Mas a gente ampliou um pouco a altura dos perfis, para dar maior capacidade contra a chuva e, também, demos uma pequena elevada, porque essa claraboia conserva uma ventilação permanente. $\mathrm{E}$ a gente levantou um pouco mais para ampliar, também, a capacidade de ventilação. Então, houve uma mudança, entendeu?

\section{[AA] Originalmente o vidro era translúcido?}

[EC] 0 vidro, originalmente, era um vidro temperado e continuou a mesma coisa. Transparente. Então, aqui foi usado... Chegamos a cogitar algum tipo de vidro que melhorasse essa questão de transmissão de calor pra dentro, mas, enfim, essas coisas têm toda uma questão financeira envolvida e se optou pelo original, mesmo. Pelo vidro temperado, cristalino. Mas, eu cogitei de colocar um vidro que tivesse melhor eficiência na transmissão de calor. Eu acho justo. Não vejo nenhum problema.

[AA] Usar a tecnologia atual da melhor maneira, não vai ofender...

[EC] Eu acho. Essa mudança na confecção da claraboia, também acho legítima. Discutimos. Pensei muito.

[AA] Mas, o quê? Maior espessura? No butirol [película que vai dentro do vidro laminado]?

[EC] Não, não. Digo aqui: aumentar um pouco o tamanho dos perfis, para que eles tivessem maior capacidade contra as águas, aí. Contra as chuvas e tudo. Ou seja, maior eficiência com relação 
à chuva, melhor eficiência com relação à ventilação, sem alterar o conceito, vamos dizer. E fizemos. A fixação é o mesmo sistema. Foi refeito. A peça, em si, não é mais a original. Nem é, exatamente, um fac-símile. Não foi feito igual Foi feito semelhante. Não é similar. Ou é similar, não sei.

Eu sei que é uma discussão metodológica. Eu sei. Estou te contando a história. 0 que você acha disso, você vai lá dizer. A história é essa. Algumas coisas foram, assim, mudadas. Não se buscou uma restauração, Mas, eu acho assim: toda compartimentação, tudo isso foi absolutamente mantido. Teve-se um grande cuidado com o concreto aparente, que é uma característica importante da casa; os caixilhos não se mexeu neles: estão em perfeito estado. Perfeito assim: apresentam desgaste, mas funcionam perfeitamente. Não se mexeu.

Essa claraboia, por outro lado, já estava apresentando problemas. A gente via o concreto todo manchado por vazamentos e tudo. Ela já estava um pouco... Precisava tomar uma decisão. E a decisão foi essa. Os perfis foram todos galvanizados. Eu não tenho certeza se os originais eram galvanizados. Não consegui claramente essa constatação.

\section{[AA] E os pisos?}

[EC] Piso foi conservado o mesmo que estava lá. Ele foi tratado, lavado. Fez-se uma limpeza com um certo abrasivo, mas sem ofender o ladrilho, para ter uma limpeza. Mas, ladrilho trincado ficou tudo lá, como estava. Mas, a limpeza sim. Ele já estava... Aplicaram uma resina: ele ficou um pouco esquisito, meio escuro. Lavou-se bastante e depois se fez uma limpeza com um abrasivo, uma espécie de lixa muito fininha, só para tirar essa película de cima e voltar ao ladrilho natural.

[AA] E daí aplicou-se algum produto?
[EC] Só um hidrofugante. Uma resina, mas uma resina absolutamente inócua.

Agora, que mais? 0 que foi muito interessante fazer foi a instalação elétrica. A casa tinha recebido um monte assim de gambiarras, porque o concreto é aparente, não é? Então, a solução original, a casa está suspensa nos quatro pilares e você tem lá um volume, logo na frente, redondo, onde ficam todas as utilidades. Nem encostam no teto, para liberar a fachada. E a caixa de elétrica e entrada era aqui. Isso subia - a mesma coisa o esgoto... Tudo desce aqui - e corria tudo pelo contra piso. Bom... Claro que apodreceu todo o conduíte, porque eram aqueles conduítes metálicos, daquela época. Então, para restabelecer o mesmo tipo de instalação, teria que tirar aquele piso. Priorizou-se, então, manter o piso e estudar uma alternativa para a elétrica. Inclusive a elétrica, por fora da casa, você pode ver nas fotos que a gente fez, estava cheio de gambiarras, de tubulação aparente por fora da casa: instalação nova, antena de TV a cabo, uma parafernália de encaminhamentos esquisitos de conduítes. Muito ruim! Isso a gente tirou tudo, limpou toda a fachada, e estudou um novo sistema de instalação aparente. Então, toda a distribuição de tomadas se faz... Não chega a ser um rodapé, mas funciona quase como um rodapé. Você tem conduítes, tanto de elétrica como de informática, que correm paralelos a $15 \mathrm{~cm}$ do chão, $10 \mathrm{~cm}$ entre um e outro, com tubulação aparente de ferro galvanizado.

E, para efeito de iluminação a gente dividiu a casa... A claraboia divide o corpo dos quartos e o corpo da sala, mas, também, tanto num caso quanto no outro, nós fizemos três linha de eletro calhas, que também vêm aparentes por baixo da nervura, e que também são de chapa galvanizada. E fizemos uma interligação da eletro calha, já por conduítes, utilizando algumas furações que as nervuras já tinham. Ficou muito bom. Ficou absolutamente incorporado à casa.
[AA] Originalmente era um outro tipo de iluminação?

[EC] Originalmente era o seguinte: tinha aqueles aparelhos industriais de pratos esmaltados verdes, que ficavam pendurados, vinham... E tinham, também, uns conduítes que corriam, furando as nervuras, e algumas coisas assim. Sabe, aquelas coisas? Fios que ficam pendurados? Um problema dessa iluminação é que ela cria um teto escuro, sabe? Eu acho que já não era uma iluminação adequada. Fora isso, a ideia da eletro calha dá grande flexibilidade: a partir da eletro calha vai se instalar qualquer aparelho. Mas, aí compra na esquina. Tem bracinho... Como você quiser. Até pode ser isso. 0 problema é de onde saiu o ponto. Para não ficar enchendo: "agora põe um ponto aqui". "agora põe um ponto lá". Não! Toda a energia está na eletro calha. Você pode prender a luminária na própria eletro calha ou você pode tirar um chicote, tirar uma haste da eletro calha e colocar o que você quiser. Uma delas corria no eixo da cozinha a outra no eixo da sala e a outra naquele espaço entre a lareira e a mesa do escritório, onde fica uma espécie de biblioteca. E, depois, em cada quarto corria uma. E fizemos também uma eletro calha lá no piloti, que era uma maneira de tirar o ponto a partir daquela central e poder correr pela casa toda, para subir para onde você queria. Ficou muito bom! Sei lá! Tá lá! Ficou muito bom, por quê? 0 material se incorporou ao concreto, mas está lá, você vê. É aparente. Incorporou-se ao concreto por causa da cor, por causa do acabamento em si. Um material tão - como eu diria, assim? - tão cru quanto o concreto. Galvanizado. E a tendência é que ele vai escurecendo com o tempo, vai ficar até mais incorporado.

[AA] Quando novo ele é até um pouco brilhante. Mas, depois, envelhece bem. 
[EC] Já, já! Pronto! Não vai estragar nunca mais! Porque está lá inclusive galvanizado. Está protegido. Eu achei legal! Fora que dá flexibilidade. Tanto que, a qualquer momento, eu posso por uma tomada nova. Então, isso aí foi examinado com esse cuidado e tal. A gente chegou a examinar de fazer interruptores à distância, mas era muito caro. Os interruptores descem e são poucos. Não chamam mais a atenção. Então, resolveu bem essa parte da instalação. Eu acho que fez a casa recuperar o seu aspecto, a sua integridade. Porque o que tinha de gambiarra era incrível! Muito ruim!

[AA] Um dilema da arquitetura moderna..

[EC] A casa contava, com questões aparentes, só as luminárias, que tinha adotado aquela solução industrial, que se fazia. A gente adotou uma outra solução industrial. De galeria de arte, também. Essas calhas são para suporte dos aparelhos. Não é iluminação indireta, nada disso. Ela corre, inclusive, transversalmente às nervuras.

Na parte de baixo, sim. Na área de serviço, que tinha lá vários quartos de empregada, ali acabamos fazendo uma intervenção um pouco maior, mesmo na compartimentação.

0 problema de casa é que há a necessidade do usuário! As famílias se compõem diferentemente; é outra necessidade; é outra estrutura.

[AA] Na teoria a casa não mudou. Mas, na micro escala mudou.

[EC] Mudou! É outra coisa! As necessidades são um pouco diferentes. Então, você não pode mexer? 0 que está se mexendo é naquilo que é divisório. Quer dizer, nenhuma intervenção conceitual. A casa tinha lá três quartos de empregada porque era o que se fazia naquela época. Tinha duas empregadas, outro quarto era a lavanderia... Mas, se agora você só tem uma empregada e precisa de um salão pra fazer outro tipo de atividade... Então, me parece legítimo isso aí. De qualquer maneira, eram três quartos e ficou um aqui. Aquela varanda que tem no serviço lá em baixo, tudo isso está conservado. É uma questão da compartimentação daquilo que eram paredes divisórias. Inclusive tem algumas fixadas lá tem frestas, tem peças metálicas; ou seja, eram paredes divisórias. Então, não acho que seja nenhuma mudança conceitual. Claro que tudo isso foi conversado com o Paulo.

[AA] E essa experiência? Nos casos Corona e Vital Brasil não estavam presentes. Já essa casa, com o Paulo presente, muda?

[EC] Olha: eu acho que não muda. Porque eu considero que foi feita, assim, uma conservação. Essencialmente uma conservação. Não muda. Por exemplo, essa questão da substituição da claraboia, essas coisas... Isso também fizemos no Esther. Estávamos propondo no Esther. Toda aquela parte das janelas do Esther que já não funcionam mais, que eram de madeira, eu propus de PVC [policloreto de vinila]. Lógico! É um material mais adequado, mais novo. Não me parece que refazer aquela janela em madeira fosse essencial. Na nossa proposta, está lá: era a mesma persiana, mas de PVC.

Há uma discussão que vale, aí. Eu sei que tem várias correntes em relação a isso. Mas eu acho que, aqui, com essas persianas de madeira, pelo menos naquele momento, não víamos nenhum fornecedor. Então, achamos que era melhor usar um material mais contemporâneo, mas que tivesse o mesmo tipo de conceituação da janela original - uma persiana: abriria da mesma maneira recolheria da mesma maneira, mas que poderia ser melhor conservada, etc., etc.

Então, você tem as questões e, muitas vezes, você age adotando vários aspectos conceituais, para dar uma solução ali, numa questão prática. Não se trata de uma tese.
[AA] A impressão que dá é que é uma questão de cuidado. Vamos dizer: essa casa, ou esses três projetos, são de arquitetos conhecidos. Você poderia até não saber de quem é e, a partir de uma pesquisa, você descobrir. Por outro lado, você poderia reconhecer a qualidade de um projeto de arquitetura, independente do autor. E falar: Ele tem qualidades...

[EC] Claro! Lógico! Ele tem qualidades. Isso é bom. Isso tem que ficar. No fundo, o mais importante eu acho que é manter o uso, deixar ele vivo. Usá-lo. Deixá-lo como uma coisa viva. É usá-lo plenamente e que ele conserve a sua essência, na sua conceituação, na sua arquitetura. Eu acho que certos ajustes são, às vezes, absolutamente necessários. Não vejo nisso um problema. Agora, que ajustes são esses? Caso a caso! Ninguém troca uma peça que esteja funcionando ainda! Agora, se ela não está funcionado, temos que discutir o que vamos fazer. Eu acho que se você tem a disponibilidade de algo mais eficiente, é justo que se use. Eficiente em quê? Naquela necessidade que se apresenta ali. Pode ser, às vezes, até uma necessidade de... Sei lá!... De vedação do caixilho, melhor vedação. Sei lá! Mudou a necessidade interna, tem que haver um controle maior de tudo isso... Aquela janela não funciona mais direito. É justo. Você troca. Às vezes você troca de madeira para alumínio. Em certas circunstâncias, eu não veria nenhum problema.

0 que foi feito na Pinacoteca: tiraram-se aquelas janelas e não se puseram outras, por exemplo. Por quê? Porque seria só armar um cenário, colocar janela, porque por dentro ela não poderia existir, se não, não haveria pinacoteca. Ali era uma questão dessa natureza. Ficaria, assim, só compor a fachada e não teria nada a ver com o que está lá dentro. Optou-se por fazer transparecer fora toda aquela alteração que estava acontecendo dentro. Mas, não porque isso tem que ser assim ou não! Porque pareceu mais lógico, até! 
[AA] Cada projeto, assim em específico, tem panos para manga...

[EC] É. Tem. E também acho que ter um consenso, sobre todas essas coisas, é muito difícil. Que mais?

[AA] E desenho? Do processo específico da Masetti, como é que foi? Você foi chamado? O Paulo foi chamado?

[EC] Apareceu um cara muito legal que comprou a casa e queria que a casa ficasse... Ele chamou o Paulo. O Paulo me chamou. Então, ele chamou o Paulo, o Paulo foi lá, viu, conversou. Aí o Paulo me chamou, fomos juntos com o cara, conversamos, blá, blá, blá. Aí, depois, eu desenvolvi o projeto. O Paulo acompanhou. Mas, aí, fiquei eu mais fazendo esse desenvolvimento, esse trabalho, esse contato. Acompanhei a execução. Acompanhei essa obra, assim, passo a passo, porque, inclusive, muitas coisas tinham que ser vistas, se ficaram boas ou não. Foi uma coisa delicada. Foi esse o processo.

[AA] Mas, operativamente: fez a executiva e foi pra obra? Ou foi tudo feito meio junto?

[EC] Mais ou menos assim. Eu não cheguei a fazer um memorial de restauro. Nós pegamos os desenhos originais, digitalizamos todos (esses que eu te mandei). Aí desenhamos neles as coisas que seriam eventualmente alteradas e depois trabalhamos nos detalhes: desenhei a claraboia, desenhei os caixilhos. Tem um pequeno memorial inicial de procedimentos com relação ao que fazer, mas não chegou a caracterizar, a formalizar um memorial de restauro, nada disso. Mas, foram instrumentos suficientes para que essa obra fosse feita, controlada. Mesmo porque eu estava presente. Fosse para fazer um pacote para mandar, provavelmente eu teria que fazer isso de outra forma. Foi tudo muito documentado, apesar de que não está organizado. Documentamos perfeitamente antes, durante. Mas, eu não consegui organizar de maneira..

[AA] A gente pode ajudar!

[EC] Seria uma boa! Te dou todo esse material e você organiza! Então, tem aí tudo fotografadinho, tudo bonitinho, mas... Alguns testes, tudo, que foram feitos.

[AA] Bacana! Estamos aí na busca dessa arqueologia... É que são coisas muito... No fundo, a minha ideia das casas, é porque são trabalhos que, muitas vezes, não se divulgam! É de uma operação tão delicada e é muito raro você ver uma publicação! Você tem um exemplo: Casa Baeta, a única publicação que tem foto do processo da obra é uma revista "Arquitetura \& Construção". Só

[EC] A Casa Baeta é aquela que tem o tronco de árvore?

[AA] Não. É aquela que tem o tirante.

[EC] A do tirante, que está super bem conservada!

[AA] Que foi o Angelo que fez.

[EC] 0 quê? A conservação?

[AA] A reforma.

[EC] Daquela dos tirantes? Na Vila Mariana?
[AA] Não essa. A que tem a escora. Só a escora.

[EC] Ah! Porque aquela que tem os tirantes, da Vila Mariana, é uma maravilha! Está nova! IMas isso é o proprietário que conserva!

[AA] Parece que mora a velhinha e o cachorro.

[EC] Mas, aquela que tem aqui no Sumaré, aquela que tem as paredes rosa, está muito bem conservada também. E aquela é uma conservação interessante. Parece que nunca foi repintada. Eu tenho essa impressão. Eu passo muito na frente. A impressão é que ela está do jeito que saiu. É a impressão que eu tenho. Bacana! É uma boa conservação. Mas eu acho que ela nunca foi repintada. Eu acho bacana aquela casa. Está lá muito íntegra.

O Angelo... Essa da Baeta ele fez. Você conversou com ele?

[AA] Conversei. Quando ele estava fazendo a obra, a gente ia muito, tinha muito contato. Depois, nesse resgate... Foi até engraçado, porque eu lembrava dessa matéria [da revista "Arquitetura \& Construção"] e falei: "Deve ter saído em outro lugar". E não saiu em nenhum outro lugar! Saiu ela feita, em várias " $2 \mathrm{G}$ " [2G International Architecture Magazine]... Artigas... Na própria [revista] Monolito do Ángelo... Agora, o processo... Na verdade, quem comprou [a casa] foi o irmão [do Angelo Bucci, Eugênio Bucci], e um parente da esposa do Eugênio, que estava na Abril na época. Então, acho que fizeram contato lá com a "Arquitetura \& Construção" e os caras documentaram, fotografaram o processo inteiro da obra e fizeram uma matéria.

[EC] Da obra do Angelo?

[AA] Da obra do Angelo! 
[EC] Ah, tá! Eu cheguei a ver qualquer coisa... Acho que em um filminho, não tem? Eu conheço essa obra porque eu acho que eu vi... Até o Angelo fala qualquer coisa lá. Eu não sei se foi inserido em algum vídeo sobre o Artigas. Eu estou aqui lembrando... Eu acho que foi numa exposição do Artigas que teve no [Instituto] Tomie Ohtake e tinha um vídeo lá. E uma hora eu vi o Angelo falando. Eu tenho impressão que é isso aí.

[AA] Vou dar uma olhada nisso.

[EC] Eu tenho impressão que foi aí que eu vi. Porque eu sabia que o Angelo tinha feito.

Mas, então, eu acho essas coisas. Acho que o importante é que... Por exemplo: o teatro aqui da escola, a gente fez uma mexida que, volumetricamente e externamente não está... Mas, internamente foi mudado bastante. Por quê? Porque, se não, não ia funcionar bem como teatro. Primeiro porque, na época, não tinha lá ar condicionado. Tinha umas janelas para ventilar. Tinha problema acústico que não era considerado algo relevante. 0 acesso no teatro se dava de uma maneira muito... Que hoje você não conseguiria mais criar acessibilidade: tinha degrau, dava no meio da plateia. Mudamos. Revisamos a plateia. Ao mesmo tempo, conservamos as poltronas. Restauramos as poltronas, porque elas estavam absolutamente restauráveis. Então, mantivemos as mesmas poltronas originais. Mudamos o forro, mas mantivemos o mesmo conceito do Corona, que era uma espécie de... O forro do Corona era um forro regular, inclinado, criando sancas de iluminação indireta. Só que essa iluminação indireta era voltada para o palco. Quer dizer, o cara do palco ficava meio ofuscado com isso. Nós invertemos essa direção da luz e trabalhamos as placas com as curvas adequadas conforme a acústica.

Quer dizer, há uma conversa com o projeto do Corona. Ele interage com o projeto do Corona. Abrimos a boca do palco para melhorar as possibilidades cênicas dentro daquela volumetria. É um palco de escola, um auditório de escola, mas é um belo auditório de escola, com 350 lugares! Então, achamos que isso deveria funcionar muito adequadamente. Tem ar condicionado. Porque, se não, você põe 350 pessoas dentro de uma sala... Não dá! Acústica: fizemo a cobertura isolada acusticamente. Virou um equipamento que permite uma ótima, muito boa utilização para várias finalidades. Está lá. Se não, não estaria. Não ficaria. Achamos que isso é perfeitamente viável, possível, justo, adequado. É uma adequação. Se não, não iria funcionar como teatro bom. Então, eu acho que essas coisas... Importante é saber essa medida! Sensibilidade da medida e da questão aonde você pode ter mais arrumação que se justifique. Acho que, no fundo, é isso. E que faça com que aquilo ganhe vitalidade. Se, no teatro, não fosse feito isso lá, eu acho que ele não ia ganhar vitalidade. la ficar um auditoriozinho de escola, que serve para formatura, essas coisas e só

[AA] É. Sobre o que você está falando... A impressão que dá.. Não sei. Posso estar errado, mas, quando se utiliza o conceito de legibilidade, às vezes acho um tanto exacerbado, como se dissesse: "0 arquiteto que vai fazer a reforma tem que deixar sua marca". Parece que tem um pouco esse equívoco. E se tem vários exemplos desse tipo.

[EC] Isso eu acho um equívoco. Mas, nesses casos que nós citamos aqui, eu acho que isso não surge.

[AA] Não, não! Justamente!

[EC] Nem na Pinacoteca, onde às vezes isso aparece. Aparece até externamente e tal. Acho que ali apareceu de uma maneira natural do discurso, sabe? Não uma coisa que foi buscada. Uma coisa que aconteceu. Não foi um objetivo. Aqui, também. Nada era esse objetivo. 0 objetivo era estudar cada uma dessas obras e cada um desses programas que se tem que adequar. Nestes casos que estávamos falando - caso do Paulo, Esther e a escola nada mudou de uso. Mas, as necessidades mudaram um pouco. E algumas coisas relativas à construção, quando houve. Então, acho que essas coisas são pertinentes.

Por exemplo, no Esther, veja só: a gente tinha proposto recuperar aquele vitrolite [placa de revestimento] que tinha no apartamento.

\section{[AA] Eu estava pensando nisso}

[EC] Eu pensei muito: Faz, não faz? Faz, não faz? Mas, eu achei que aquilo, apesar do edifício estar há tanto tempo sem aquilo... Você está sabendo. Aquilo foi retirado do edifício acho que nos anos 60. Portanto, ele ficou de 36 a 60. E, depois, de 60 para hoje. Então, ele está mais tempo sem do que com. Então, essa é uma questão pra pensar.

\section{[AA] Mas, a iconografia conhecida é com.}

[EC] É. Aquilo era um ponto tão forte no projeto! Muito ressaltado em todas as histórias, em todas as coisas. A iconografia, infelizmente, é branco e preto. Eu até fiquei meio assim: será? Será?... A gente propõe. Hoje teríamos, sim, até meios! Por que se tirou? Porque começou a cair. Você sabe da história, não? É um problema de detalhe! E, hoje, nós teríamos como resolver isso de uma maneira adequada. Eu propus mudar as persianas, mas recuperar isso, veja só! Não me parece uma incoerência. Eu acho que esse era um elemento que me pareceu muito importante de recuperar. Mas, tive minhas dúvidas! E ainda tenho! Como será que vai ficar aquele negócio amarelo e preto? 
Amarelo e preto! Mas tinha! Você vê aquelas fotos, aquele reflexo do céu no vitrolite [placa de revestimento] aparece! Então, aquilo me pareceu um aspecto importante daquele projeto, apesar de ser um revestimento! Não era nada relativo à concepção formal do edifício, mas achei que era interessante recuperar isso. Propus a recuperar, mas não sei como faria, porque o produto em si não existe mais! Mas, o vidro existe... Parece que o vitrolite era uma espécie de vidro, não era bem vidro... 0 pessoal fala que era algo como... Enfim, um outro tipo de vidro. Uma coisa sílica, mas não era vidro. A gente conseguiu um pedaço. Não sei aonde foi parar! Achamos lá, um pedacinho. Porque alguém fez uma reforma e achou um pedaço lá, da fachada. Eu não sei onde está... Eu guardei! Onde foi? Preciso achar! Mas, era um caquinho. Aí você vê que não era bem um vidro, mas era um material que usava a mesma base material do vidro. Acho que o porcelanato é algo parecido.

Mas, isso não vem ao caso! 0 importante era tentar recuperar 0 não aquele aspecto. Eu achei que era importante.

[AA] Mas, tiraram, você viu? Todas as venezianas são de alumínio...

[EC] Eu vi... Eu não entendi... Você está lá, não? Pois é eu propus isso, isso foi aprovado, CONDEPHAAT e CONPRESP, que aceitaram esse negócio do PVC. Naquele momento, a madeira me pareceu muito difícil. Mas, eles tiraram por quê?

[AA] Parece que estavam caindo aquelas de manutenção zero do $1^{\circ}$ e $2^{\circ}$ andares...

[EC] Andaram pintando... Aquelas do $1^{\circ}$ e $2^{\circ}$ estavam caindo faz tempo! Porque o cara fez lá uma absurdo naquele andar!
[AA] Aí eles tiraram tudo...

[EC] $01^{\circ}$ andar funcionava como depósito de alguma das lojas do térreo. Na esquina da 7 de abril acho que era um Donuts. E tinha o depósito. Olha, aquele edifício é uma confusão! 0 problema é que, cada vez, parece que só piora, só piora, só piora.. 
[AA] São dois projetos: as reformas na Casa Masetti e na Casa Millan.

\section{[PAULO MENDES] Reformas?}

[AA] É. Na Millan o senhor fez, acho que em 2000, com o MMBB [Arquitetos], fez aquelas adequações. .

[PM] Mas que interesse você tem?

[AA] É que eu estou estudando as intervenções no patrimônio moderno.

[PM] Ah, sei. Muito bem. Faz as suas perguntas.

[AA] Eu queria saber, no caso dessas duas casas, o Sr. foi chamado para fazer adequação, modernização de instalações, etc.. Isso é positivo?

[PM] 0 que eu posso te dizer? Vamos falar caso por caso, porque não são idênticos. 0 caso da Casa Millan. 0 Fernando Millan era um grande amigo meu. E, como todo mundo sabe, irmão de um grande arquiteto, Carlos Millan. E na ocasião que ele me encomendou esse projeto (o Fernando), o Carlos tinha acabado de morrer tragicamente em um desastre. Eu quero dizer que tudo isso está ligado a questões muito pessoais. Se você está fazendo um trabalho, poderia considerar esse aspecto, porque não se trata pura e simplesmente de uma questão de exercício da profissão, pura e simplesmente. Está associado a um aspecto afetivo muito digamos, forte. Ele, com o irmão, uma dedicação ímpar, à profis- são, como era o caso do Carlos; na situação já premeditada, que o irmão faria a casa, já tinha o terreno, e justamente é surpreendido por tudo isso. Portanto, eu fiz aquela casa, além da profissão, em uma situação bastante ligada à emoção, porque a questão casa por sua vez, etc. etc. é a sede da vida doméstica. Ele tinha já quatro filhos, e ainda ficou com os dois filhos que ficaram do Carlos, que ficaram sem pai e sem mãe da noite para o dia. Tudo isso deu àquela casa um sentido extraordinário para mim.

Quando nós estudamos, de qualquer modo, a casa, é possível imaginar, digamos, naquela planta, que a cozinha na posição em que está dentro da casa e aquela maneira de fazer a casa como quem cobre o que antigamente ficava atrás entre a casa e as áreas de serviço, que se faziam naquele recuo de $8 \mathrm{~m}$ no fundo, nós cobrimos de cristal, transformamos aquilo em uma claraboia, os quartos dão pra dentro da própria casa, é uma casa muito sui generis. Você deve concordar, não?

Nessa condição, a posição daquela cozinha foi discutida. E, du rante a obra, mesmo - já na obra - eu me lembro que foi falado se não era possível aproveitar aquela parte de fora, que era toda só pra estacionamento, etc., passando a cozinha para ali, na área externa. E aproveitando aquela área onde está a cozinha pra mais espaço de estar e coisa do tipo. Fácil de adaptar. Já pro Fernando mesmo, e a Matilde, a mulher dele, foi conversado isso. Eu falei: "Bom... eu, por mim, prefiro como está. Mas, não tem problema, vamos fazer isso". E o Fernando disse: "Não. Não vamos faze nada. Vamos deixar assim".

Quando a casa foi vendida, mais tarde - coisa que eu não tenho nada que possa comentar quanto a isso -; mas, entretanto, quem comprou a casa, foi o Eduardo Leme, de uma postura muito simpática, digamos assim, muito positiva, conversou comigo se eu não queria dirigir uma limpeza na casa - que ele precisava fazer - e se era possivel tirar a cozinha dali. Como tinha havido já a discussão, eu, sincera e honestamente, pensei no íntimo: "Essa cozinha sempre foi discutida. Principalmente se alguém comprou a casa..." . E disse: "Olha, sempre houve essa ideia. Se você quiser, a gente fecha uma área aqui em baixo, nessa parte que já está coberta pelo andar de cima, e você diz que cozinha você imagina eu desenho aqui e você vê. E aquela área que era a cozinha passa a ser o que você quiser, biblioteca, você amplia". E foi feito isso, simplesmente. Naturalmente que, pra fazer isso e uma coisa ou outra - não de transformação, mas de recuperação - eu perguntei pro pessoal do MMBB que trabalha comigo - Milton, Marta, Fernando - se não queriam acompanhar e dirigir isso, desenhar 0 que tivesse que ser desenhado, detalhar a tal cozinha e fizemos. E está lá.

Já a casa do Mário Masetti, no Pacaembu, o caso é completamente diferente, porque há, ao mesmo tempo, um rigor e uma simplificação da questão muito clara. 0 cidadão, Houssein [Jarouche], que comprou, me chamou, também - eu não sabia nada do negócio! Que a família tinha vendido, que ele comprou e que ele queria... Porque sabia que uma coisa ou outra tinha sido recomposta na casa, substituída (pelo tempo até da construção: é uma construção dos anos 70, se não me engano, portanto já faz 40 anos e tal)... Se eu queria conferir com ele se estava tudo... Porque ele queria que a casa retomasse absolutamente a condição original. Então eu fui lá e, de fato, constatei que isso e aquilo, claraboia, persianas de madeira... E disse literalmente a ele porque poderia até... - as persianas tinham sido substituídas por persianas de fibra (pode ser até útil, porque conserva melhor)... Mas, eu disse isso, isso e aquilo e ele mandou consertar tudo. 
E pedi ao Eduardo Collonelli, com quem eu trabalho há muito tempo também, se ele não queria acompanhar aquilo tudo e ele acompanhou. Aproveitei pra fazer uma coisa que eu sempre sonhei, que é uma piscina escura, como as águas do mar nas pedras do Arpoador. A pedra é granito escuro, o fundo é de areia clara, e as águas parecem cristalinas. Eu tenho implicância com piscina que fica com cara de aparelho sanitário, tudo de azulejo branco. Mas, é a mesma piscina que está lá, só que tinha mesmo que ser refeita a impermeabilização e etc., aproveitei e pedi pra por uma cor escura. Ele fez isso e ficou muito bonito. Ele foi muito gentil. Ou seja, coisas que eu faria, também eu.

E assim foi feito. Portanto são duas situações muito peculiares de retomar os estudos e ajustamentos, digamos assim, com o passar do tempo, de duas casas, pelo próprio arquiteto autor do projeto inicial. Não deixa de ser interessante pra você examinar.

Mas, só pra concluir. A situação toda é comandada por razões de uma lógica muito mais ligada à compreensão do andamento da vida e das situações, ligada muito mais a um plano afetivo do que a qualquer questão teórica ou mesmo técnica da arquitetura. Se é que a questão afetiva não faz parte de tudo isso. Vai ver nós podíamos descobrir uma coisa que sempre foi assim. Principalmente em uma casa.

0 arquiteto nesse ponto... Uma coisa é o plano habitacional da cidade, habitação popular. Outra coisa é um amigo que pede pra você desenhar uma casa pra ele. É preciso - já que você é um estudioso, está estudando, um estudioso, no caso estudante notar, ou melhor, registrar que, em minha opinião particular, uma casa assim, em terreno isolado, habitação individual, há muito tempo - desde essa época em que essas foram feitas - já não se devia fazer em uma cidade como São Paulo. Não faz muito sentido dentro de um plano da cidade. Hoje a casa é um apartamento em um prédio. A ideia de casa.
[AA] Essas casas isoladas foram utilizadas como modelos ou como experimentações...

[PM] Sim. A planta da casa que eu fiz lá no Butantã, que você conhece, uma casa de planta única, rigorosamente de planta única. Está tudo lá num plano só. Se você quiser multiplicar por dez andares, aquilo pode ser um prédio. Ali atrás onde está aquela escada, pode-se colocar o elevador e fazer aquilo passar adiante e fazer um prédio de cinco, seis andares muito bem, desde que existam certas condições.

Portanto, tem aspectos muito circunstanciais do ponto de vista de teorias de arquitetura. Eu acho que não tem muito... É muito aleatório tudo isso.

Uma questão que talvez tenha um interesse mais geral, do ponto de vista da questão arquitetura, se dá, talvez, no caso Masetti. Porque aparece, no nosso meio - porque isso é vulgar, digamos assim, em outros países - a valorização da casa, da arquitetura com autoria. Então, você por no mercado, por à venda, uma casa assinada pelo arquiteto fulano de tal, já em São Paulo - não sei se no Brasil todo, mas aqui em São Paulo eu estou sabendo em um âmbito ainda muito restrito, mas, de qualquer modo, já estabelecido, se valoriza, se sobrevaloriza, a autoria. É interessante, do ponto de vista da importância da questão da arquitetura e tudo isso... Memória... E esse aficionado da arquitetura, que faz questão que a coisa seja... - a coisa no sentido da palavra aquela construção seja a expressão daquilo que foi pensado pelo autor, limpidamente - ou estritamente, é interessante considerar como uma questão a explorar: o valor disso. Como você disse muito bem: que isso já é anacrônico a casa individual, isolada no lote. Por outro lado, é a origem das plantas das casas, etc. Casa é casa. Do ponto de vista da verticalização, não há uma contradição. Ao contrário, há uma evolução muito interessante.
[AA] Estava vendo, outro dia, um material da Alemanha, e vi aquelas cozinhas de Frankfurt, que são aquelas cozinhas lineares... Parece que, de alguma maneira, isso...

[PM] Pra nós já estava inventado!

\section{[AA] É!}

[PM] Porque é uma razão de coerência com a ideia de planta circulação, planta, distribuição dos espaços. Uma certa área de serviço, porque a cozinha recebe mantimentos, isso e aquilo, mais do que quartos e salas... Toda essa situação, principalmente no prédio vertical, por causa dos elevadores e tudo isso, é muito interessante... Quase que uma planta fatal. Não tem muita coisa pra você... De qualquer maneira, não estamos cultivando isso com inteligência, porque tudo isso está nas mãos de uma desenfreada e brutal especulação que deturpa os valores - pelo menos os valores como nós costumamos cultivá-los. Fica puro mercado, isso e aquilo.

A exiguidade dos espaços eu acho que deveria ter limite. Ninguém vive como se tivesse em gavetas e coisa assim! Precisa de uma certa liberdade, pra você não ser obrigado a fazer só aquilo. Uma casa onde você possa se aborrecer e andar daqui pra lá e de lá pra cá. Nós precisamos de um espaço! Entretenimentos com crianças, principalmente. Não do ponto de vista de distrair propriamente, mas, expandir uma mesa... Você pode dizer que é só pra comer... Pode ser pra cortar papel, pra costurar, pra desenhar. Portanto, eu acho que há um aviltamento... Mesmo que se considere a cidade como a casa, não há de ser tudo dentro de casa, mas um certo espaço nessa área para os que vivem ali, eu acho que tinha que se pensar. Deveria ter uma área mínima pré-estabelecida pela lei. Mas nós não temos lei que sirva pra nada! Nossos colegas 
do serviço público andaram muito pra trás. Ou o serviço público remunera mal, desanima, porque não propõe pra quem trabalha lá, nada de interessante, como estudo, realmente. Ao contrário, fica favorecendo, justamente, essa especulação. Cada vez mais as leis são mais favoráveis a eles [aos especuladores]. Eles no sentido de destruir qualquer ideia de espaço habitável urbano consistente, associado ao transporte, isso e aquilo. Como nós sabemos. Pra mim, é uma conversa um pouco cansativa, já essa. Um pouco repetitiva.

Aí você acrescenta o que você já sabe. Porque eu não sei mais nada além daquilo que você já sabe. É isso mesmo.

Portanto, talvez, como ação exemplar assim, essas casas - algumas - possam ter algum valor.

[AA] 0 Sr. tinha comentado, na semana passada, sobre a inserção do banheiro no quarto, que era uma coisa que até um dado momento não se fazia...

[PM] Eu acho que não é pra fazer isso, propriamente. Eu não tenho condição de justificar ou explicar. Eu só acho que a nítida separação daquilo que é banheiro daquilo que é quarto - quando o banheiro está dentro do quarto... Você faz um pequeno apartamento pra uma pessoa: um cantinho pra estudar, dorme e banho. Esse banho não precisa ter a característica de um banheiro público, digamos. Ter que fechar pra mais ninguém digamos assim. Mas, é tudo bobagem. Mesmo do ponto de vista de uma certa "graça", brincadeira, modo lúdico de trata o espaço da casa. É como se dissesse que não há possibilidade de comentar isso com palavras. Se eu fiz uma coisa ou outra mais ou menos assim, tem que ir lá ver. Você pode se estrepar se quiser, simplesmente, botar o banheiro dentro do quarto. Não é bem por aí.
[PM] É. De qualquer maneira, não é muito inteligente, você tem que admitir. Tem sua graça, mas é forçada. Se tem que encrencar um, por razões de instalação, uns dias, você pode usar qualquer um ou outro, etc.. Não é útil. Ao contrário. Hoje eu sou mais favorável a que haja uma área de banhos e de instalações desse tipo para a casa, como se fosse público. Quantas pessoas quiserem. Se o quarto é individual, mesmo que não caiba, no sentido da palavra, você põe um beliche e tudo isso se transforma. Ou você aluga a casa, seja o que for, para um grupo de estudantes, triplica a população da casa... Então, os banheiros... Seria mais interessante que tivesse cozinha, banheiros, dormitórios e estar. Qualquer coisa por aí. Mas, ninguém pode fazer muita teoria com isso. Se for bonito, pode ser assim ou assado. É uma tragédia da nossa condição humana.

[AA] Tem que passar pelos olhos...

[PM] É... Você vê a Guernica [mural de Pablo Picasso, 1937]. Aquilo é uma pintura do horror. Uma coisa pra você se indignar contra a guerra. A infâmia do que já foi feito. Não é nem a previsão de um desastre. É um desastre que houve. É um grito... Entretanto, é belíssimo! Portanto, essa questão é muito discutível. É muito difícil comentar o conceito de beleza, de emoção, o que provoca emoção, etc.. É lindíssimo enquanto manifestação de uma pessoa diante desse horror. 0 horror de quem produziu o horror e a beleza de quem produziu o libelo, o discurso da indignação diante daquilo. Portanto pra mim, pelo menos, é muito difícil comentar a emoção.

[AA] 0 Sr. fez outros projetos de intervenção: na Pinacoteca [do Estado de São Paulo], no Museu da Língua [Portuguesa] - na
Estação da Luz, o Sr. acha que quando se vai estabelecer determinadas ações em uma arquitetura mais recente, como a arquitetura moderna, a partir dos anos 50, muda essa operação? Quero dizer, tem diferença? Porque são técnicas mais recentes...

[PM] 0 patrimônio que é propriamente histórico e uma coisa que é totalmente contemporânea. Sim. Claro que tem uma diferença muito grande. É um assunto que você pode comentar por horas! Mas, assim, em primeira instância, se você diz que aquilo pertence ao patrimônio, o patrimônio é algo enorme e aquilo é um "exemplo exemplar", você tem que... Você deveria... Nós deveríamos, naquele caso, ver no que aquela construção contribui para o patrimônio particularmente, e deixar com muito destaque, se possível, até mais... É uma contradição interessante considerar enquanto possibilidade: se vai se tornar mais ainda vigoroso enquanto manifestação do patrimônio depois da sua intervenção, que é o desejável. Não, como pode parecer à primeira vista, de um modo ingênuo, que você vai tentar, o mais possível, não destruir o patrimônio, contemplando um programa novo. Isso é o mínimo que "se pó fare", como diz o italiano. 0 bom é você tentar imaginar - o estimulante - que o patrimônio vai ficar ampliado com a sua intervenção. 0 valor patrimonial daquilo vai se acentuar. Formalmente, em cada caso, você vai ver como. Não é uma receita. Isso não é uma teoria. Mas, é uma proposição. A ideia sadia pode ser comentada quanto à viabilidade, para não parecer de cara um absurdo - você precisa defender que não seja um absurdo, de cara -, do seguinte modo: se você atualiza o uso, só pode ser valorizada, a princípio, a questão do valor patrimonial. Agora, se você, para adaptar ao uso atual, revigorar, incentivar, tiver que desfigurar, digamos, a imagem que aquilo tinha como patrimônio, não é vantagem nenhuma. Como, então, você poderia enfrentar esse desafio que 
é a proposta de fazer que fique valendo mais ainda, agora, uma vez que for atualizado?

Na Pinacoteca, independente de quem seja o autor do projeto - não estou falando... Acho que foi um grande sucesso a intervenção. Aquilo ficou melhor do que poderia ser se... etc.. Simplesmente conservado, digamos. De modo intocável. Tocado ficou melhor.

[AA] A meu ver, é como o caso da FIESP [Federação das Indústrias do Estado de São Paulo].

[PM] FIESP? FIESP também. Porque a FIESP, além de uma atualização, foi muito interessante a convocação pra mexer naquilo, porque o prédio tinha ficado muito prejudicado pelo alargamento. A avenida Paulista foi alargada em $10 \mathrm{~m}$. E aquilo foi recomposto, na medida do possível, pelos prédios pro lado de cá, pro lado de lá, pra manter aquele eixo, etc.. E aquele prédio perdeu uma área vestibular de entrada e, ao mesmo tempo, deu chance de inventar aquele modo de perceber que o melhor era enfrentar os dois níveis em que está instalado, lá dentro, em "demi etage", como diz o francês, dois andares fazendo com que a Paulista seja intermediária. Portanto, você fazer sair por baixo e entrar por cima, aquilo salvou a situação. Com alguma demolição. Ficou bom. Ficou meIhor do que era antes. Não só com a instalação da biblioteca e melhoria do acesso ao teatro e tal, como o próprio acesso à torre do edifício, intensamente frequentado por conselhos, reuniões, etc., ficou melhor assim. Os elevadores sempre vazios. Você sai em baixo, o vestíbulo está vazio. 0 elevador sobe vazio e recebe o pessoal em cima e coisas assim. Você embarca no saguão, com o elevador sempre vazio. E desce no saguão que seria a avenida Paulista. Não tem o confronto dos que estão esperando, o que é meio desagradável. Dá um sentido de funcionalidade, assim, apertada, coisas do tipo... É mais agradável assim! E a circunvolução em torno do teatro e da biblioteca ficou bem com aquele café no fundo.

Mas, o pessoal não sabe usar as coisas com dignidade! Fica fazendo transformações, mexendo na biblioteca não sei por quê! A biblioteca vivia sempre cheia de gente! É tão interessante uma FIESP possuir uma biblioteca pública, especializada... a história de tudo isso!

[AA] Quando da inauguração, estava funcionando tudo perfeito.

\section{[PM] É. Estava bem.}

[AA] E agora, essa situação nova, do anexo da Pinacoteca. Ouvi dizer que vão adaptar aqui no colégio..

[PM] 0 governo está estudando, mais do que arquiteto, por enquanto. 0 governo não tem muita certeza do que vai fazer. Me parece. Por enquanto. Vamos ver. De qualquer maneira, uma pinacoteca ampliada, expandida... Porque a parte do século XIX já é muito forte, podia ficar o prédio antigo só pro século XIX. E construir um anexo, qualquer coisa assim, é intrigante para a arquitetura, a ideia de um anexo, com jardim, etc.. Vamos ver o que eles vão fazer. Eu já não tenho mais aflições, nem ansiedades, nem grandes entusiasmos com nada disso, sabia? Isso não quer dizer indiferença! Eu só não tenho o entusiasmo, digamos ... Como é que diz no samba? "Hoje em dia eu não tenho mais as alegrias de tempos atrás". É melhor ver as coisas serenamente. As coisas andam meio pretas, não é? Eu acho!

[AA] Como o samba [Meu caro amigo] do Chico Buarque: "... a coisa aqui tá preta..."
[PM] É. O cancioneiro brasileiro é muito inteligente e sagaz, já cantou essas coisas dos tempos atrás. Mas, é um engano dizer que os tempos eram melhores. Isso acontece em cada um. Por preguiça você fica cansado de acompanhar a história. A razão da Vida é uma maravilha! Tomara que mudasse todo dia! Mas, acho que você cansa. Os velhos vão cansando e começam a resmungar que os tempos passados eram melhores. Não deve ser verdade!

[AA] Parece que hoje, como não se tem um confronto tão claro, como, por exemplo, na época da Ditadura, parece que as coisas vão corroendo subterraneamente... Como se você não tivesse 0 inimigo ali... claro.

[PM] É. Não é muito claro. Quando você abre os olhos, as coisas já foram pro vinagre. É isso, não é? É um pouco verdade, sim. Pode ser um pouco verdade...

[AA] A gente estava falando de habitação e desses prédios... A gente viu uma estagnação nos anos $80 \ldots$ E agora, quando abriu o olho, o pessoal achou que pode tudo!

[PM] Fala-se muito, com os recursos do que se chama, em geral, Informática, eletro-eletrônicos, etc., a perda do livro e coisas assim. Mas, alguns aspectos são verdadeiros, porque, é claro que são muito mais ágeis, muito mais amplos, os recursos atuais de comunicação, do que um livro escrito. Mas, você tem que admitir que do ponto de vista de um certo erotismo da vida, você pega num papel, num livro, é diferente de você ler nessa coisa fria de tela líquida, de imagem digital, e você, com a pontinha do dedo, ver. Porque você, folheando um livro, você volta na página anterior vê ao mesmo tempo. Essa história de, pra ver uma coisa ter que apagar a outra, nós que estávamos habituados a abrir uma mesa 
com vários desenhos e ir formatando topografia e isso e aquilo, os croquis... Aí, você ter que tirar da sua cara isso, pra depois por aquilo, pra depois aquilo, fica, na minha opinião, um imaginário esquizofrênico, uma coisa de cada vez. Isso não quer dizer que as coisas vão andar pra trás. Essa ideia de bom ou mau, melhor ou pior, é muito relativa. É uma invenção nossa. As coisas vão se transformar e o homem vai ser outro. Não pode ter saudade...

[AA] Pode ser que, com as novas tecnologias, surjam outras maneiras de ler; mas, não quer dizer que se vá abandonar as existentes.

[PM] Também tem essa: ninguém te obriga a abandonar o livro. A falência do desenho da cidade, essa perda irremediável e o conformismo, automóvel, desastre, congestionamento, um horror... Poluição... Como se fosse inexorável, é muito desagradável, principalmente para o arquiteto, que sonhava com o espaço o mais possivel feito de modo ideal. Apesar de saber que nunca estaria pronto, etc.. Mas, não se fazer nem a tentativa de um desenho, digamos, de excelência, é uma tristeza muito grande! É você assistir ao desastre tranquilamente. Principalmente o desastre acentuado por algumas das ações exemplares que... Não vai dizer que nunca experimentamos! Você pega o Copan, uma maravilha dentro de uma cidade, com cinema, bares, com chão, etc.! E, no entanto, a porcariada que está se fazendo aí

Agora, você vê: o Mundo está em crise, a Europa está em crise. Mas, a Europa pensava o quê? Que poderia viver do processo colonialista a vida inteira? Está pagando o pato! Ela só quer comer o que os outros plantam! Vai passar fome! E quer vender armamentos! Só vive de vender armas! A grande indústria hoje, o grande ingresso de capitais, que a Grécia não possui - coitada! ... Você viu o que disse o [cineasta Jean-Luc] Godard outro dia? O Mundo deveria pagar royalties para a Grécia: é o berço da civilização, da Filosofia!

[AA] Se fala da dívida da Grécia, da Itália... Mas, e a dívida que a civilização ocidental tem...?

[PM] Que nós temos com a Grécia! Podia sustentá-la pelo resto da vida, sem precisar trabalhar! Agora, a Grécia foi pro brejo e está devendo pra Alemanha... Outra questão é a Alemanha estar ótima. Pois então, teria feito muito bem o que se fez nos anos 40 , nos anos 30! Não é à toa que está ótima! É uma desgraça de valores! Depois, essa história de Brasil, França, Alemanha... Acho que chega dessa história de país, bandeira, pátria! Eu já estou cheio! Mas, vai demorar... Vai ter que passar gerações...

Casinha no chão, de planta agradável, é uma que eu fiz numa esquina, numa praia da Lagoinha, você já viu? Aquela tem uma plantinha pra quem vem do banho do mar, entra em baixo, tem os quartos, vai lá pra cozinha, aí tem uma mesinha pra comer là fora, na calçada - como a casa de praia gosta, tem um sobreelevadozinho pra ficar em paz, mas de um jeito que abre tudo. Vai até o limite do terreno, esse elevado. Avança do recuo, do que seria recuo, até a calçada. Portanto, se você abre as portilhas da casa, aquela cadeirinha que se põe do lado de fora, fica só pra parte do living, da sala de estar, onde se joga baralho, conversa.. E se come na área da cozinha e também lá fora. É muito interessante aquela planta, com aquela ilhazinha elevada! Dá uma olhada lá. Conta com a sombra das castanheiras, que você bem pode plantar, que é crescimento rápido e está na calçada da rua. É muito interessante...

A planta do Edifício Guaimbê também é interessante. A salinha feita em semicírculo que põe a cozinha aqui pra frente e lá pra trás, como serviço. Cozinha e serviço. Lavanderia, passar a roupa , arrumar os quartos. É engraçado. Tem um elevador que para no patamar da escada. Uma coisa que eu fiz nos anos 60. 0 elevador de serviço para no patamar. Você desce meio ou sobe meio. Mas, é interessante considerar que se não fosse assim você não faz aquela planta nem a pau! Não é capricho. É um modo de resolver espaço. Você confunde o hall do elevador com o patamar da escada. Resolve a escada em dois lances, com o patamar. E o elevador abre para o patamar. Fica ótimo!

E, ligando, tem um quartinho de serviço, que naquela ocasião, na época, era indispensável, principalmente para um apartamento daquele porte, porque é um por andar, de $200 \mathrm{~m}^{2}$. É um belo apartamento! O bairro. A área da rua Augusta, Haddock Lobo, alameda Franca, por ali. É um bairro onde fizeram prédios, tirando casas assim. Casas de 300, $250 \mathrm{~m}^{2}$. É interessante imaginar a verticalização desse porte. Portanto, um quarto de serviço. Ainda que você não tenha uma pessoa que durma, mas, para durante 0 dia trocar a roupa, tomar banho para ir embora... Não é necessário que você tenha empregada do passado, criada. Não é isso. Não é necessariamente anacrônico. É um apoio bom de serviço. Pra quem presta serviço, mesmo que seja diário, entra de manhã e sai à tarde, é bom. Pode tirar uma sesta, um cochilo. Ver uma televisãozinha, receber uma amiga... E mesmo tomar banho e trocar de roupa. Tenho a impressão que esse quartinho de serviço também ficava no patamar da escada. Esqueci, agora!

Lavanderia e cozinha em um ambiente só. Cozinha com essa mesa comprida, que você falou, no meio do recinto. Não é encostada na parede. Rende muito. Fica um de um lado, outro do outro. É agradável para a vida doméstica. Conversar de tarde, fazer bolo, tomar café. Pra festa, contratar um bufê, gente de fora que ajude a servir. Pra fazer uma festinha bacana, é bom uma cozinha assim. Isso são interesses da planta. Pra resolver na planta. Pra planta da casa amparar. Favorecer. 
Depois, não se mora igual. Tem gente de tudo quanto é tipo. Basta o cara tocar um piano ou um violoncelo que muda a casa toda! Se ele tem biblioteca maior, gosta... Coisas assim. Um tear. Houve um tempo aqui que pegou a moda: todo mundo tinha um tear em casa. Quase todo mundo! Tecia à mão coisas. É bonito isso! Talvez seja mais interessante do que Internet.

[AA] Pelo menos, gera-se alguma coisa. Dá pra imaginar como estão, hoje, os estúdios da FAU [FAU-USP, Faculdade de Arquitetura e Urbanismo da Universidade de São Paulo]... Todo mundo na frente do computador... Ninguém desenha! Não sei como é que é! Como vocês fazem?

[PM] Você não tem idade para estranhar isso! Trate de ficar na Internet!

[AA] Mas, pra produção, eu acho bem difícil!

[PM] Porque enquanto você desenha, você transforma o desenho que tinha na mente. Ao passo que, se você desenha muito depressa, rápido como faz o computador, tudo fica um amontoado de coisas de "e por que não?". É como o dromedário: "e por que não?". Vai pondo troços e fica lá. Uma coisa meio esquisita.

Mas, é muito complicada essa história! 0 conceito de desenho é muito complicado! Você olha pra natureza e vê uma abelha, uma orquídea, um elefante... De que desenho nós estamos falando? Agora, com tanto recurso, quem sabe a turma vai endoidar mesmo. Por que não? Quem olha a natureza: escorpião, ornitorrinco e amebas! Você pode dizer até que o Frank Gehry tem até uma imaginação pobre... Se você pode fazer, faz. Portanto, cada vez mais a questão é mesmo política, ética. Não se trata de poder fazer ou não poder fazer. Se trata de "fazer por quê?".
Porque falta tudo, ainda. Ninguém tem casa decente, transporte. A cidade é um lixo! Acho que deviam proibir, da noite pro dia, automóvel, você não acha? Da noite pro dia! Não tem que remediar! Agora vem automóvel elétrico. Eu vi um, inclusive, em Portugal. É tão ridículo porque tem um aparelho na rua que você liga pra reabastecer a bateria. Mas, se todos tiverem que fazer isso, a rua vai ficar um delírio de fios esticados! Vai ter gente morrendo de curto-circuito, de descarga elétrica. Ridículo!

[AA] Recentemente fizeram a reforma da rua Oscar Freire. É um exemplo bom... Curioso... Bom no sentido hilário. A rua onde a calça jeans custa cinco, dez mil reais, e a calçada estava toda esburacada. Então, as madames... Tanto faz a rua, tanto faz a cidade! É tudo muito largado!

[PM] É pena! Mas, é isso, a conclusão de nossa conversa: cada caso é um caso. Não dá muito para teorizar. Mesmo em relação a patrimônio. Cada caso é um caso.

\section{[AA] Tem que olhar com calma.}

[PM] Eu já sonhei com uma construção, assim, extraordinária. Grande. Um edifício. Tombado. Em vez de você adaptar, fazer isso, fazer aquilo, pegar o essencial daquele espaço todo, consolidar pra não cair, com injeção disso ou daquilo, hoje existem fibras... Por exemplo, um edifício todo de tijolo, frágil... Igual à Pinacoteca, mesmo. E você tirar portas e janelas, entrar de um lado, sair do outro, como se fosse uma coisa do jardim, assim. Inútil. Tira o telhado. Deixa chover dentro. Pode ser bonito. Ruína. Ruína frequentada. Existe no mundo tanto! É que o nosso passado é pobre. É tudo taipa e tijolo. Mas, quando é pedra e granito... Você entra em catedrais que já não têm telhado e não vão ser restauradas nunca mais. Tem coisas livres. Entra de um lado, sai do outro. É bonito. Você lembrar da monumentalidade daquilo, porque foi feito. Da época. Quantos anos... Não pensar que sempre tem que da uma utilidade! $E$, entre nós, grande parte demolir absolutamente! É tudo lixo! A cidade de Salvador: se Netuno quiser dar um bufo naquilo ali, de taipa... Depois, num lugar tropical, o cupim come madeira que...

Você sabe que, em uma noite de luar incrível, estava em uma varanda alta... A casa estava em uma parte alta da topografia, na llha Bela... Uma casa que tinha já duzentos anos, do princípio daquilo tudo, que alguém comprou e restaurou muito bem e estava me hospedando. Meu amigo. Numa noite de lua maravilhosa, na varanda, com tudo apagado... A casa tinha luz, mas nós apagamos tudo e estávamos conversando na varanda. E, quando conversávamos, havia intervalos enormes de silêncio total. E assim ao lado, encostado quase no telhado, havia um tronco enorme e uma mangueira. Lá pelas tantas, num desses silêncios, eu comecei a perceber um barulhinho sistemático. Eu falei pra ele assim: "Você está ouvindo esse barulhinho?". Ele, que sabia muito bem o que era, olhou pra mim e falou: "Estou". Eu falei: "O que será isso?". E ele: "Pois é... Você não sabe?". E eu: "Não! Não posso imaginar!". E ele falou sem conferir. Depois, pegamos uma lanterna e fomos conferir. Uma coisa horrivel! Saúvas cortando pelo talo as folhas da mangueira, para elas caírem no chão, as folhas. E, depois, elas descem, as próprias saúvas, picam aquelas folhas e levam pro formigueiro. Aquilo fermenta lá dentro e é comida pra elas! Mas, de você ouvir o barulho das tenazes cricando, mastigando as folhas! E, o mais engraçado, é que tem as que ficam no chão... Não sei como é que é! Depois carrega. Corta e carrega. Mas, pra derrubar as folhas, elas vão cortando o talo! Tric, tric, tric e cai a folha! Lá pelas tantas, o serviço está feito, elas acham. Cortou folhas suficientes! Elas têm que descer. Sabe como elas descem, né? Corta a última folha e não 
larga! Desce com a última folha como paraquedas! Não é incrivel? Elas se jogam de asa-delta, com uma folha de mangueira! Nem sei se não escolhem a folha. Tudo isso é sabido. De você ouvir o barulho. E ouve-se também... Só que eu nunca ouvi. Esse caso eu vi. Eu estava lá e falei: "Que barulhinho é esse?". Porque é sistemático. Mas, você ouve o cupim comendo a madeira! Então, você conservar essas coisas... aqui? Não é a madeira da Europa que dura a vida inteira! Uma isba russa, com $40^{\circ}$ abaixo de zero, não há bicho nenhum que... Todo ano é uma limpa geral! Mesmo as fibras das madeiras dizem que são mais regulares, porque as estações são mais nítidas: verão, outono... As nossas não, varia muito, então fica tudo torto. Portanto, não é uma questão de você gostar ou não gostar de construir com madeira. Não é isso. Aqui é uma coisa, lá é outra. E acolá é outra.

Essa cidade que nós sonhávamos, já não há possibilidade de fazê-la. Que as crianças possam ir sozinhas para a escola a pé, que haja escola, transporte, trabalho. Não! É uma confusão desgraçada! É puro mercado! 0 mercado não pode comandar. Não está certo! Só terreno... Você já imaginou você vender um pedaço do Planeta, sabendo hoje o que nós sabemos do Planeta, o que ele é, etc. E você vende um pedaço pra fulano, outro pedaço pra outro. E pedaços enormes pra empresas não sei do quê! Não faz sentido nenhum!

[AA] Só o exemplo da Holanda: Esse território não é de ninguém. A gente vai fazer uma gestão.

[PM] Mas isso parece tão evidente, que eu acredito que vai mudar! 

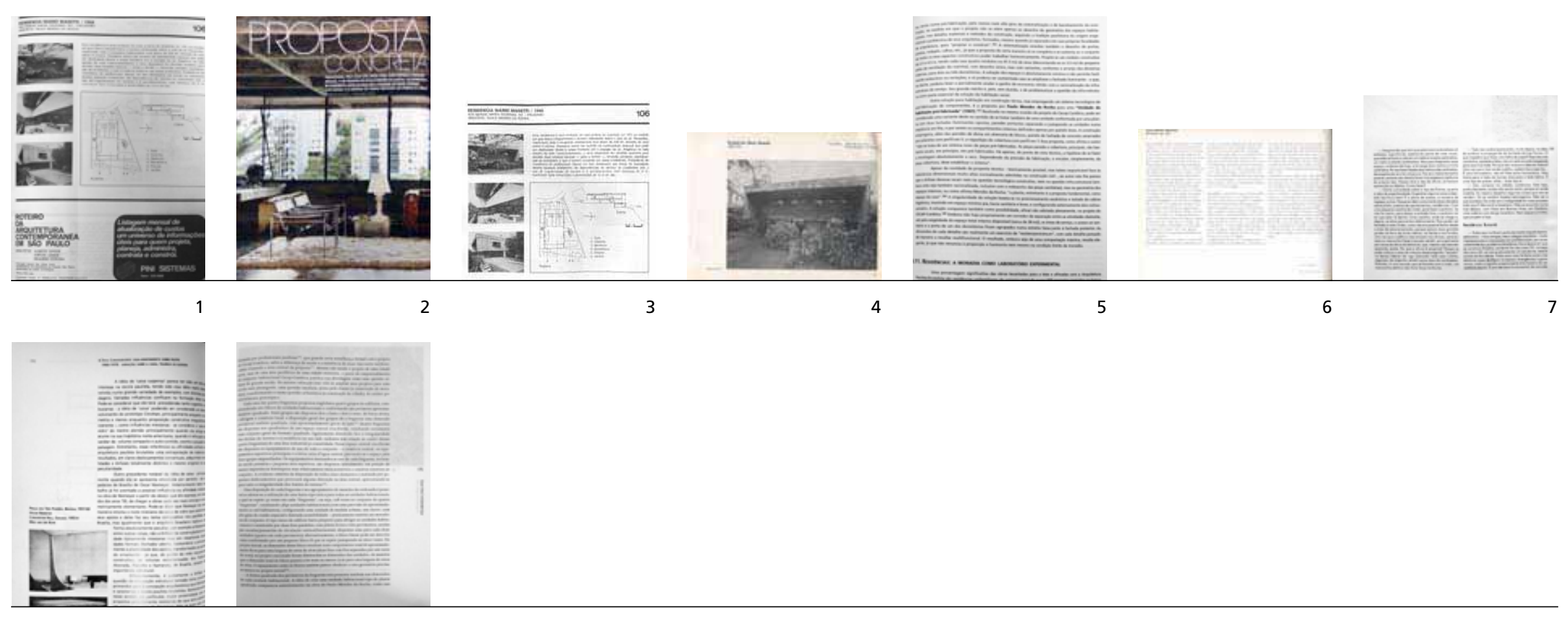

\begin{tabular}{l|l|l|l|l|l|l|l|l}
\hline & TIPO & NOME & EDITORA & CIDADE & DATA & No & AUTOR(ES) & TíTULO \\
\hline $\mathbf{1}$ & revista & A Construção São Paulo & Pini & São Paulo & mai/1982 & 1789 & ROCHA, Paulo Mendes da & Residência Mário Masetti (1968) \\
\hline $\mathbf{2}$ & revista & Casa Vogue & Edições Globo & São Paulo & jun/2011 & 310 & ROSSETTI, Beatrice & Proposta concreta \\
\hline $\mathbf{3}$ & livro & Arquitetura moderna paulista & Pini & São Paulo & 1983 & - & $\begin{array}{l}\text { XAVIER, Alberto; LEMOS, } \\
\text { Carlos; CORONA, Eduardo }\end{array}$ & Residência Mário Masetti/1968 \\
\hline $\mathbf{4}$ & livro & Residências em SP & Projeto & São Paulo & 1986 & - & ACAYABA, Marlene & Residência Mário Masetti 1968-1970 \\
\hline $\mathbf{5}$ & tese & $\begin{array}{l}\text { A arquitetura da escola paulista brutalista, } \\
1953-1973\end{array}$ & - & $\begin{array}{l}\text { Porto } \\
\text { Alegre }\end{array}$ & 2007 & - & ZEIN, Ruth Verde & $\begin{array}{l}7.4 .11 \text { Residência: a moradia como laboratório } \\
\text { experimental }\end{array}$ \\
\hline $\mathbf{6}$ & livro & Paulo Mendes da Rocha: bauten und projekte & Nigli & Sulgen & 2002 & - & SPIRO, Annette & Casa Mário Masetti São Paulo, SP, 1970 \\
\hline $\mathbf{7}$ & livro & Paulo Mendes da Rocha/Helio Piñón & Romano Guerra & São Paulo & 2002 & - & PINON, Helio & Residência Butatã \\
\hline $\mathbf{8}$ & tese & $\begin{array}{l}\text { Arquitetura brasileira, escola paulista e as } \\
\text { casas de Paulo Mendes da Rocha }\end{array}$ & PROPAR-UFRGS & Porto & 2000 & - & ZEIN, Ruth Verde & $\begin{array}{l}\text { PARTE II - 3.4 Tipos consolidados: casa-apartamentos sobre } \\
\text { pilotis 1968-1978: variações sobre a caixa, telúrica ou elevada }\end{array}$ \\
\hline $\mathbf{9}$ & livro & Brasil - Arquiteturas após 1950 & Plegre & 262-274 \\
\hline
\end{tabular}




\section{RESIDÊNCIA \\ FERNANDO MILLAN}

atual residência Leme

Endereço: avenida Circular do Bosque, 628, Morumbi, São Paulo, SP

Área do terreno: $628,56 \mathrm{~m}^{2}$

Área da construção: $582,00 \mathrm{~m}^{2}$

Data do projeto original/obra: 1970 / 1970-1974

Autor: Paulo Archias Mendes da Rocha e João de Gennaro

Cálculo das estruturas de concreto armado e das fundações: Conscal Consultas

e Cálculos Ltda (engenheiro responsável: Siguer Mitsutani)

Cálculo das instalações elétricas e hidráulicas: Caeg - Comércio e Indústria de Instalações

Elétricas Ltda (engenheiro responsável: Hélio Santiago)

Obra: Cenpla - Construções, Engenharia e Planejamento Ltda (engenheiro responsável:

Osmar Augusto Penteado de Souza e Silva)

Data do projeto de intervenção/obra: 2000-2001

Escritório responsável: Paulo Mendes da Rocha Arquitetos Associados e MMBB Arquitetos

Autores: Paulo Mendes da Rocha e Milton Braga

Colaboradores: Bela Vista Arquitetos (Apoena Amaral, Carlos Ferrata, Eduardo Ferroni,

Moracy Amaral e Pablo Hereñu)

Projeto de instalações elétricas e hidráulicas: Guimaro \& Associados Consultoria

e Projeto de Engenharia
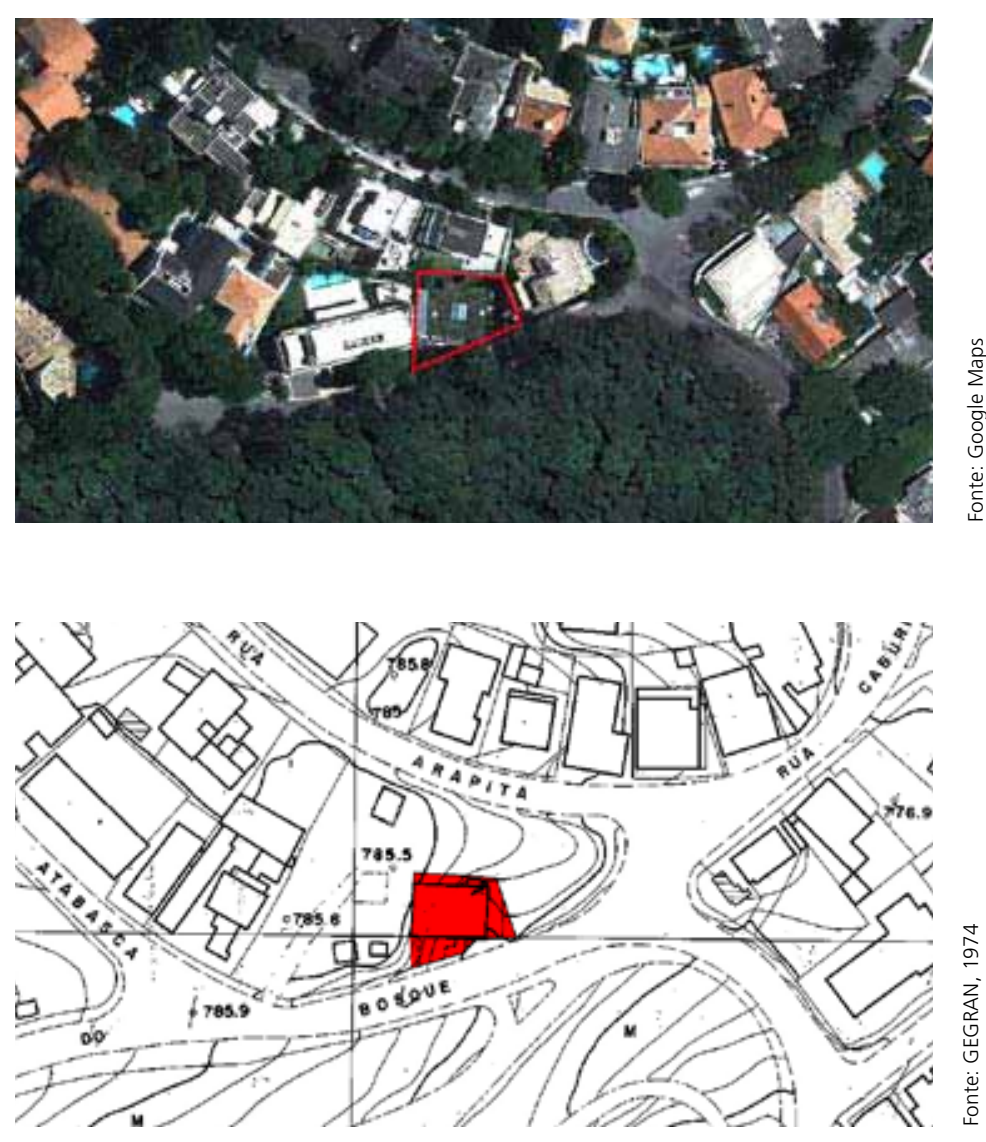


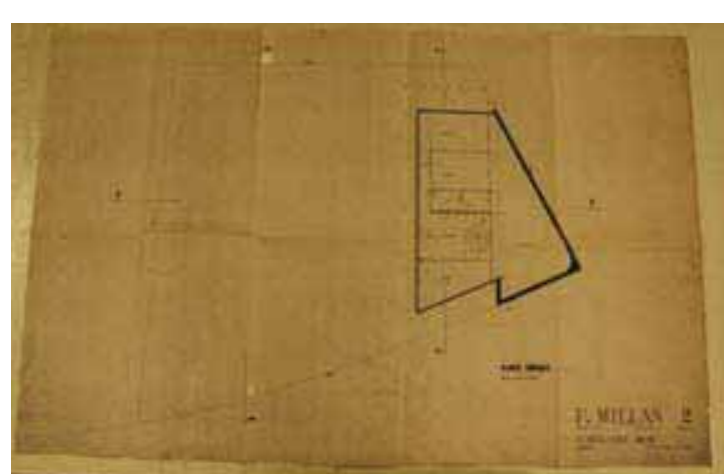

Planta do subsolo (escala 1:50)

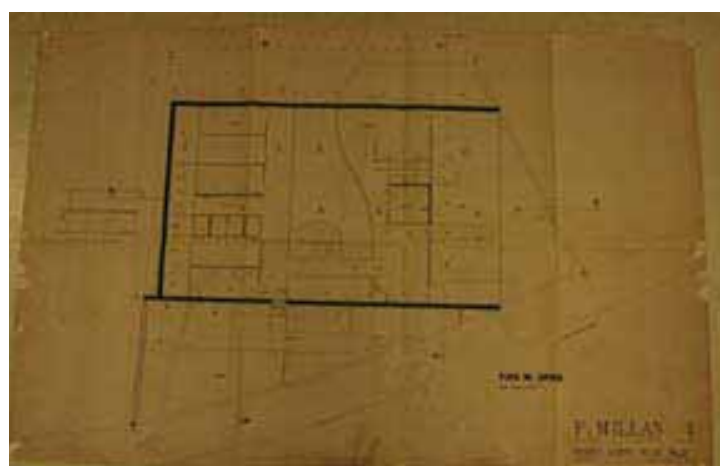

Planta do primeiro pavimento (escala 1:50)

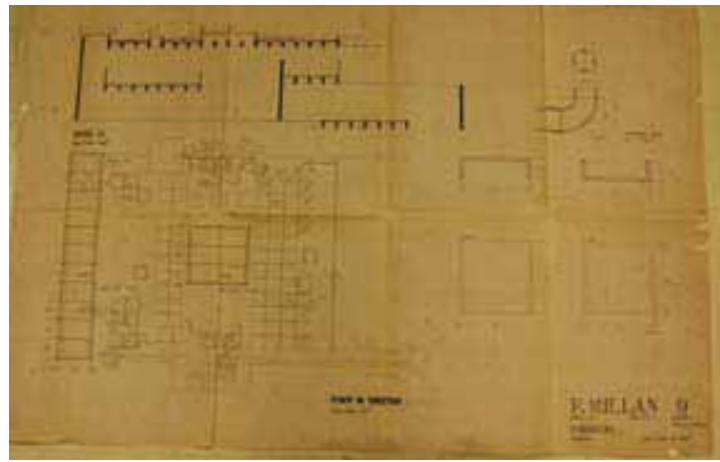

Corte, planta de cobertura e detalhes (escala 1:50)

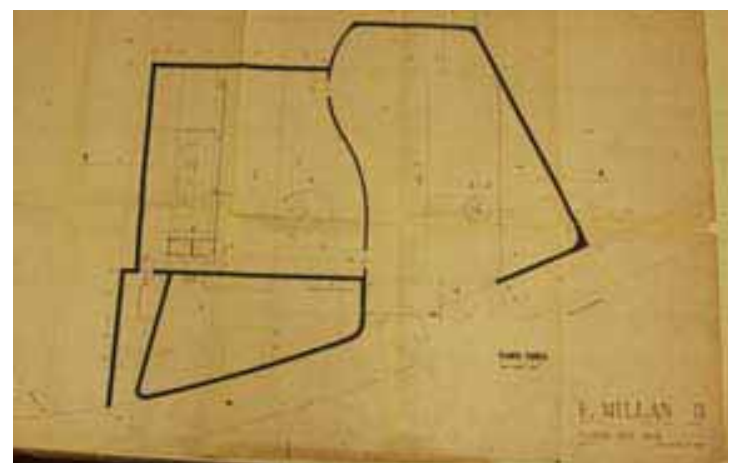

Planta do térreo - alternativa 1 (escala 1:50)

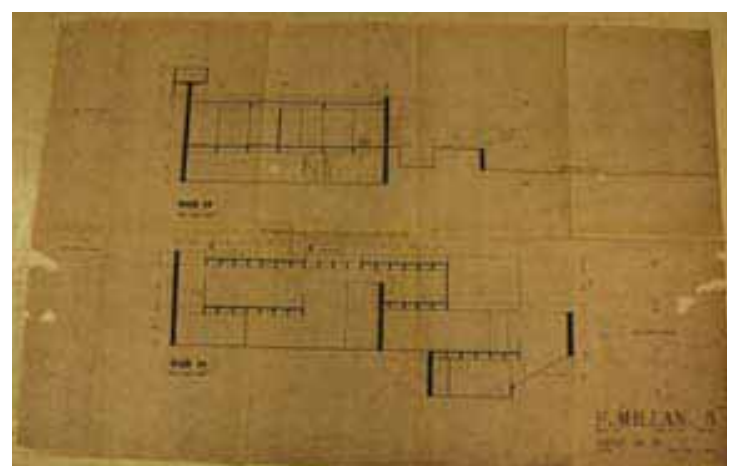

Cortes transversal e longitudinal (escala 1:50)

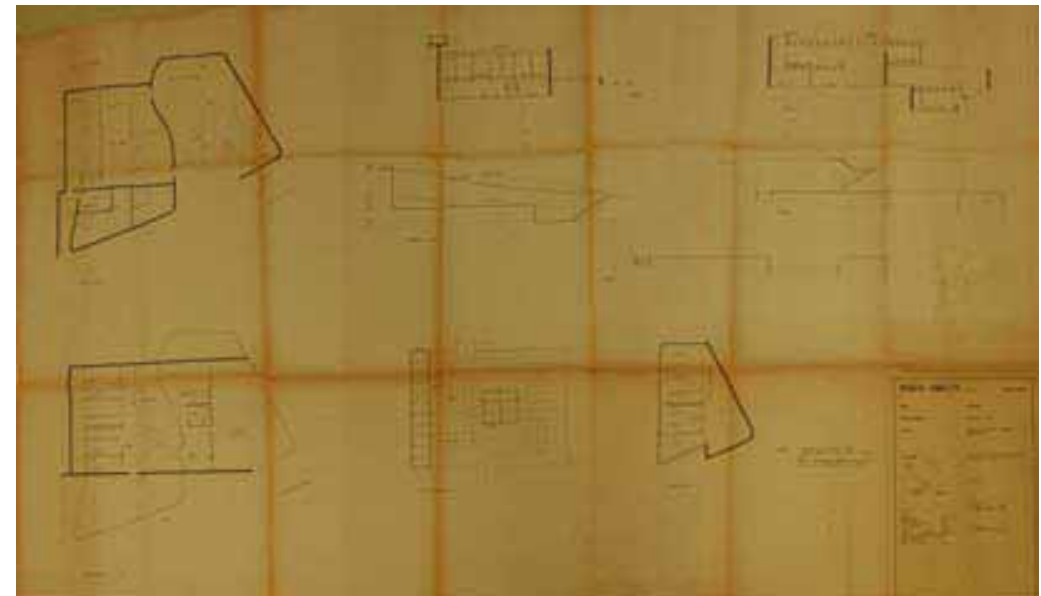

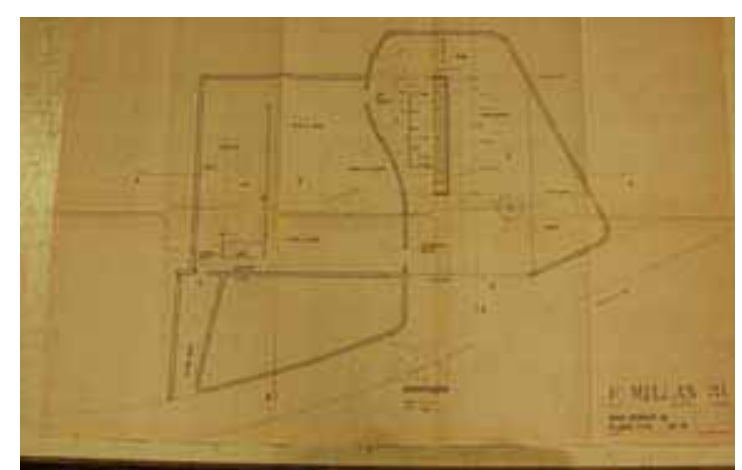

Planta do térreo - alternativa 2 (escala 1:50)

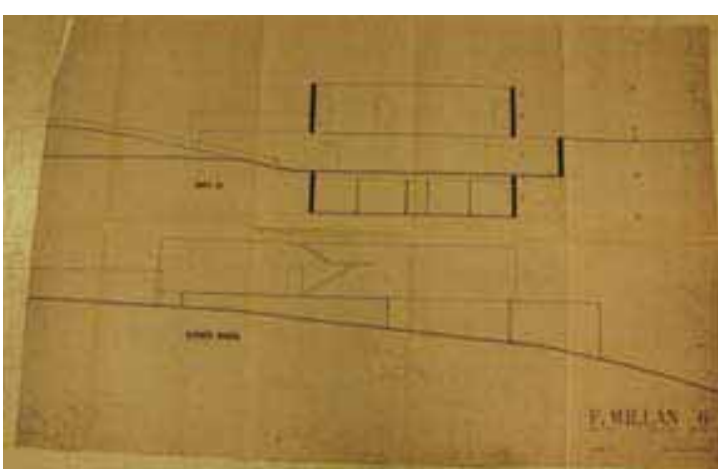

Corte transversal e elevação (escala 1:50)

Planta de aprovação na Prefeitura (escala 1:100) 


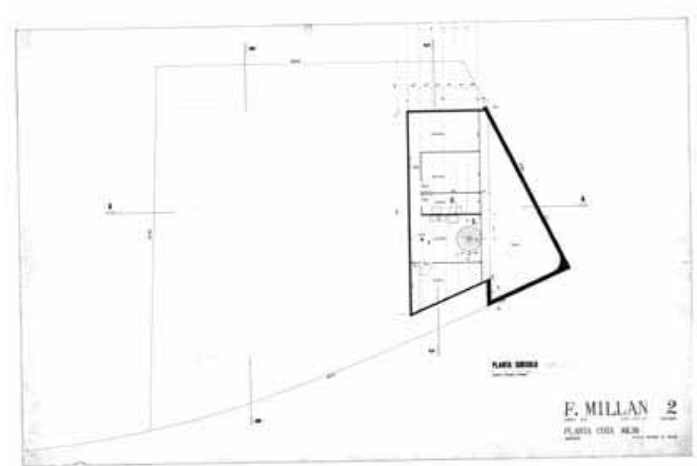

Planta do subsolo (escala 1:50) - tratada

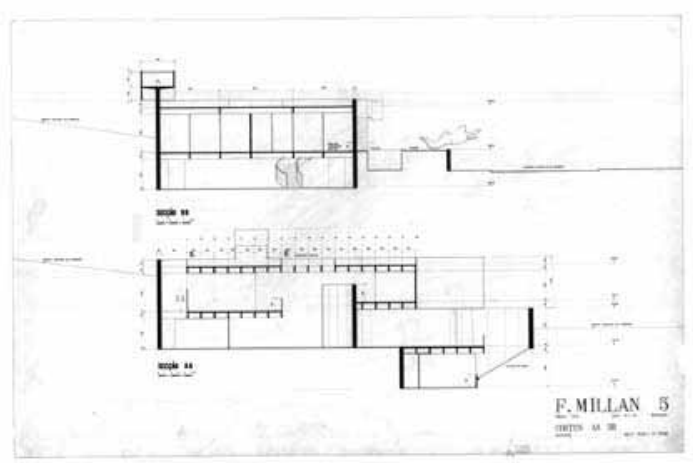

Cortes transversal e longitudinal (escala 1:50) - tratada

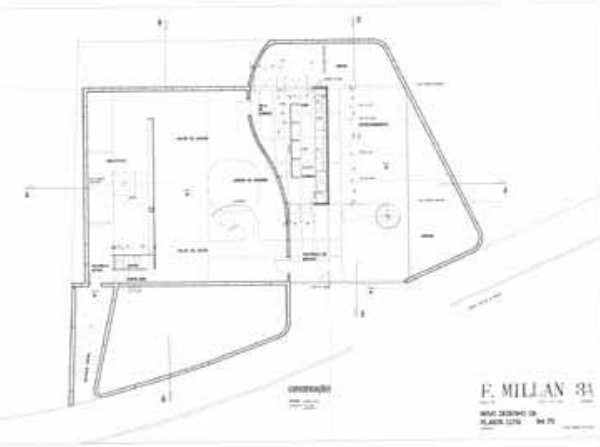

Planta do térreo - alternativa 2 (escala 1:50) - tratada

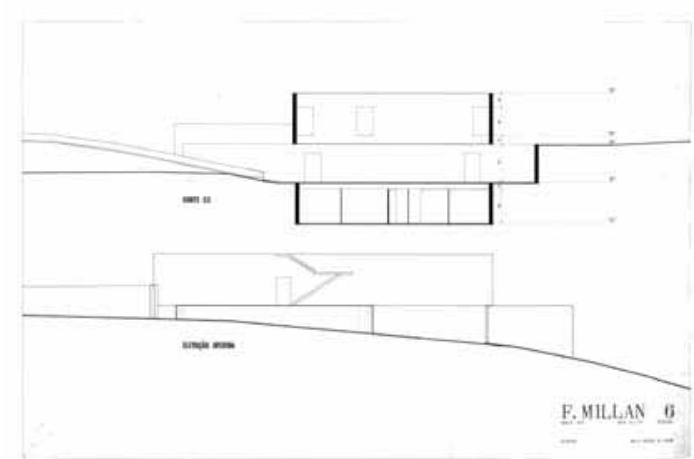

Corte transversal e elevação (escala 1:50) - tratada

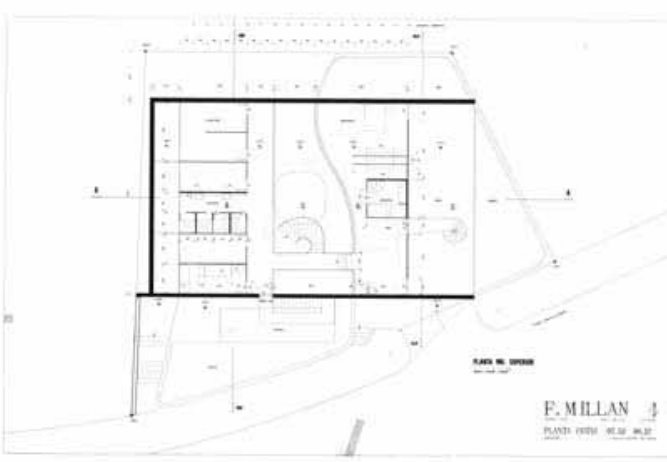

Planta do primeiro pavimento (escala 1:50) - tratada

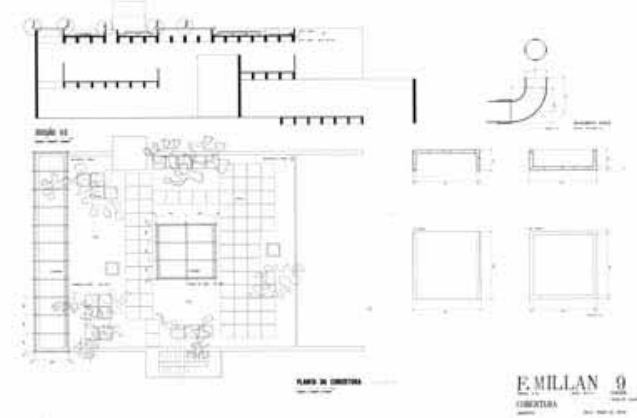

Corte, planta de cobertura e detalhes (escala 1:50) - tratada 


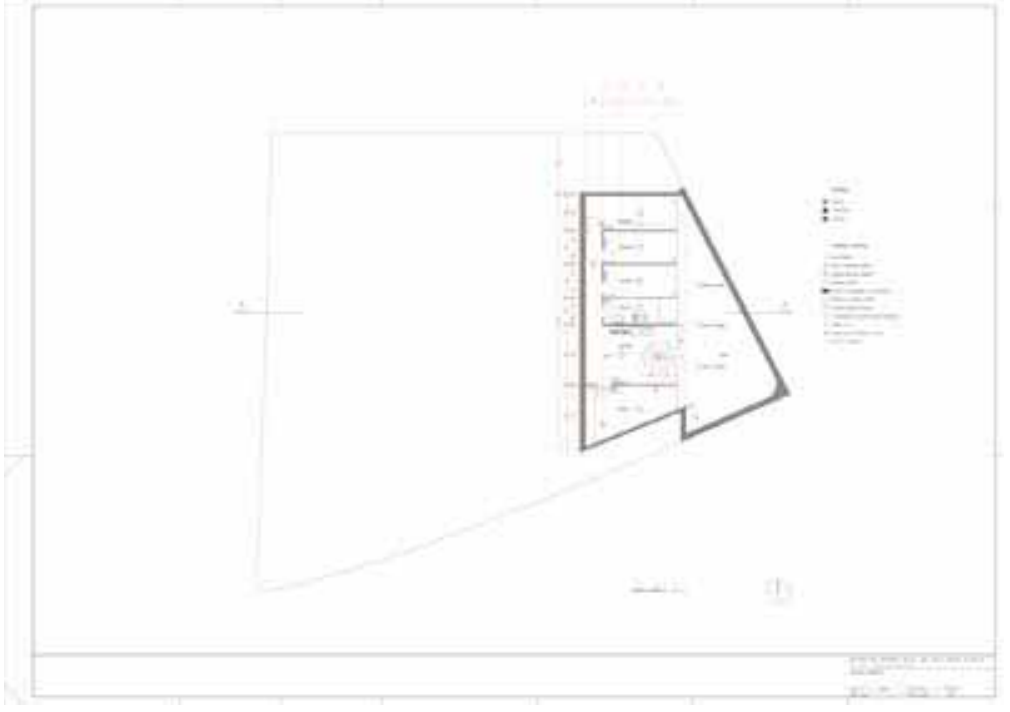

Planta do subsolo (escala 1:50)

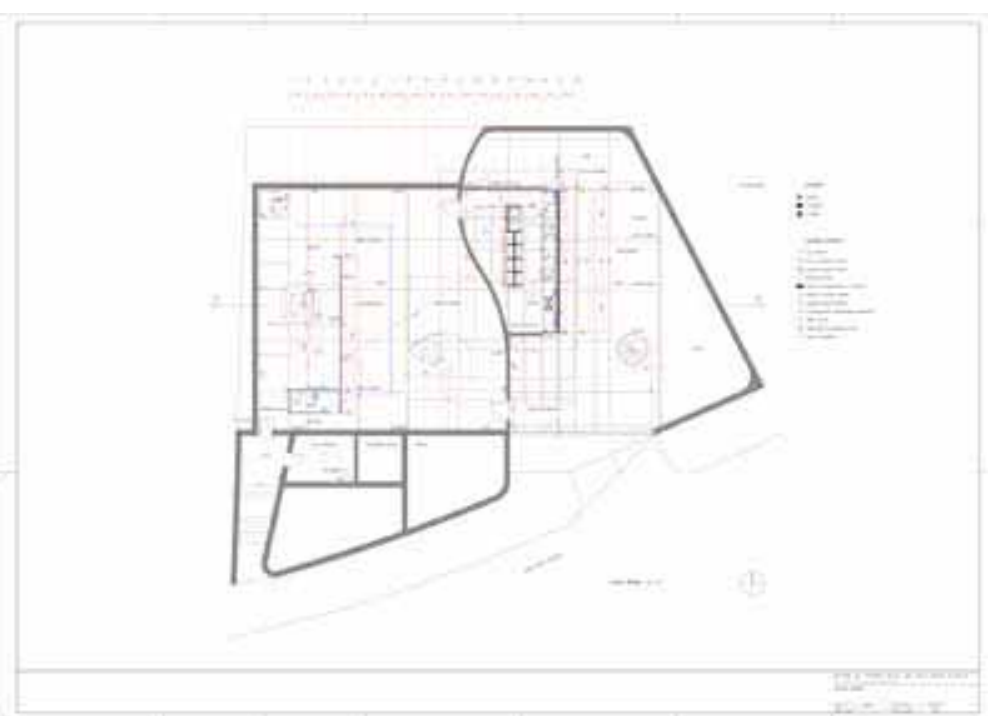

Planta do térreo (escala 1:50)

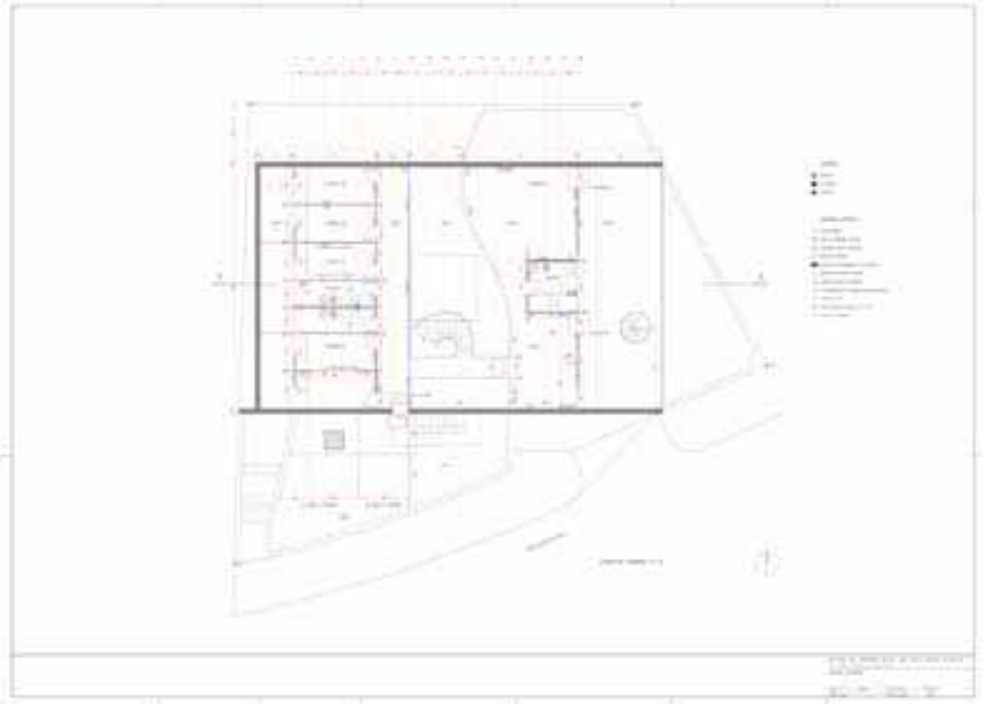

Planta do primeiro pavimento (escala 1:50)

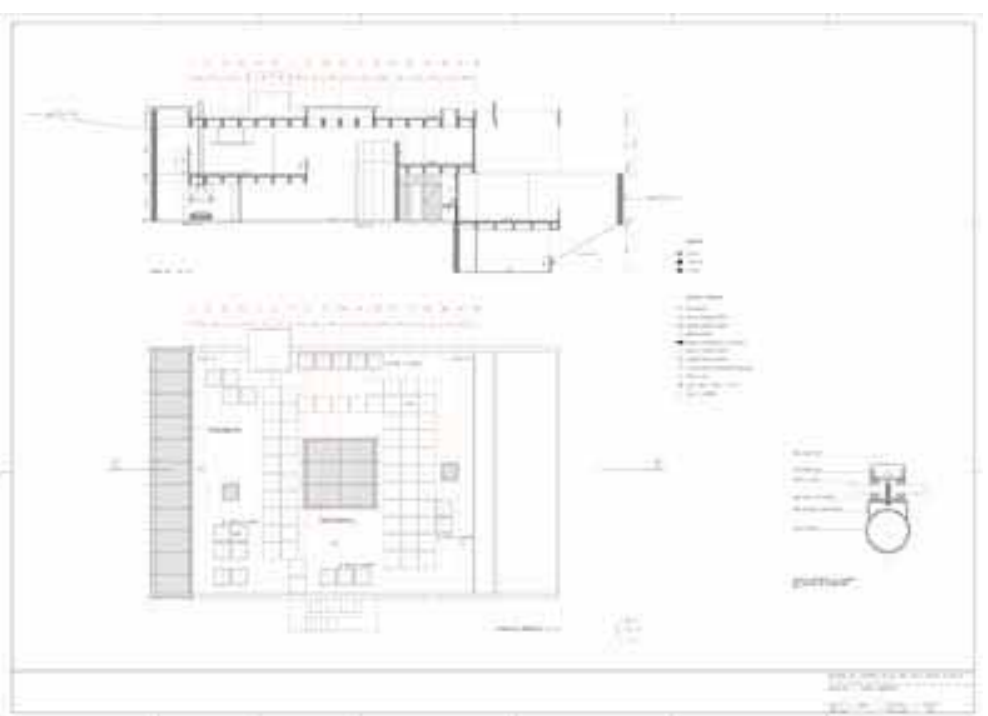

Corte longitudinal, planta de cobertura e detalhe (escala indicada) 


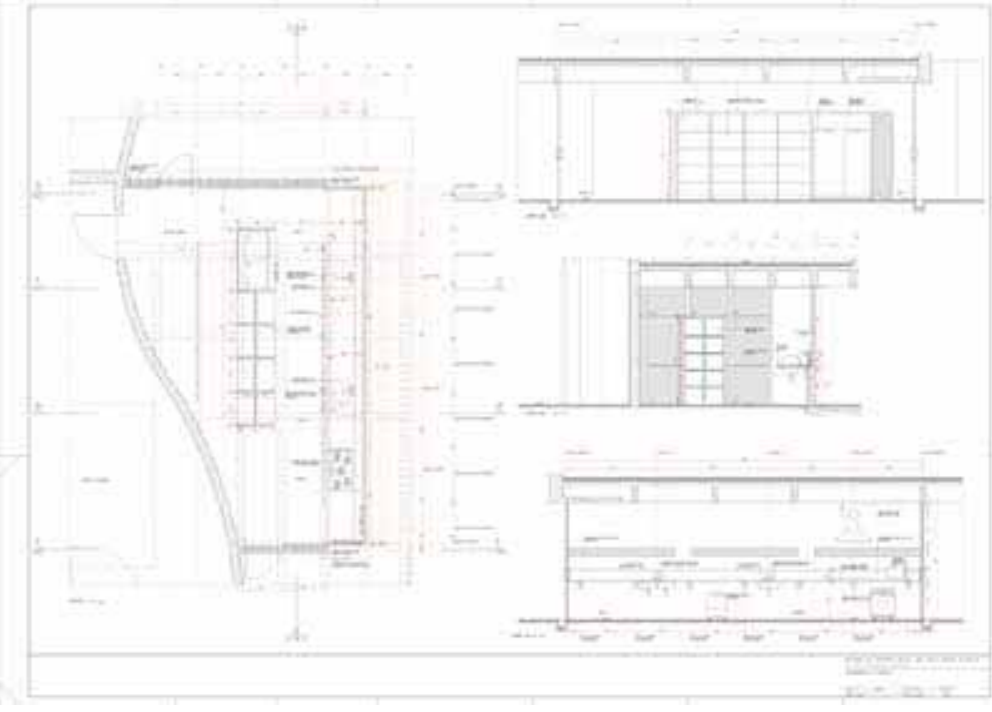

Ampliação cozinha - plantas, cortes e elevações (escala 1:25)

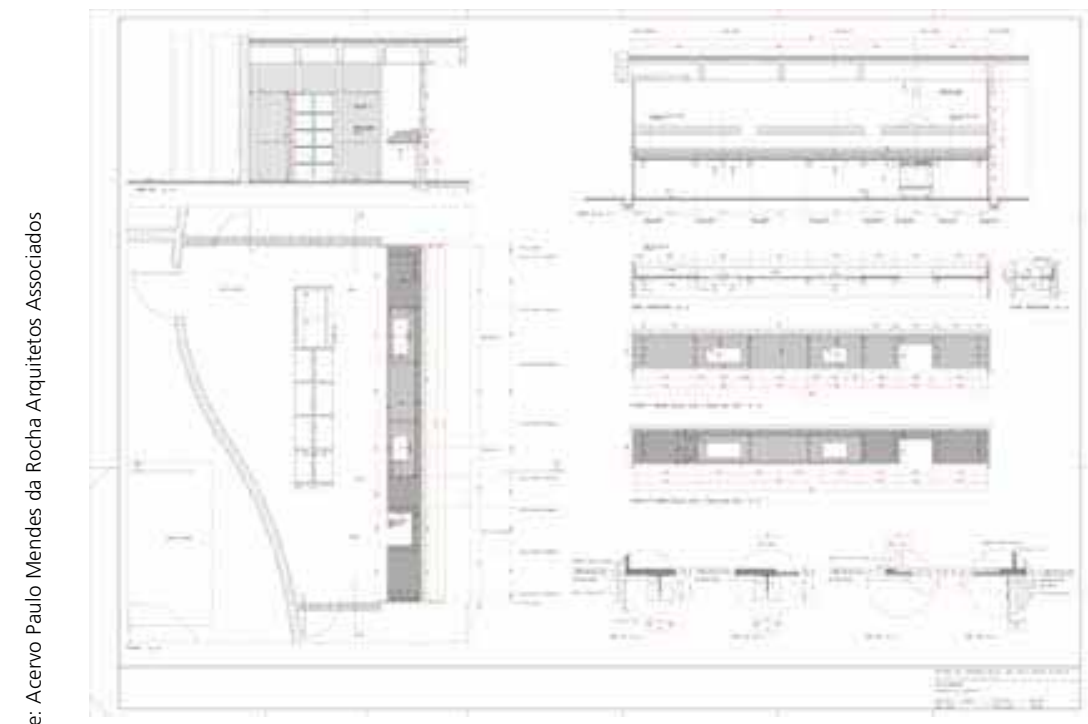

Ampliação cozinha - plantas, cortes, elevações e detalhes (escala indicada)

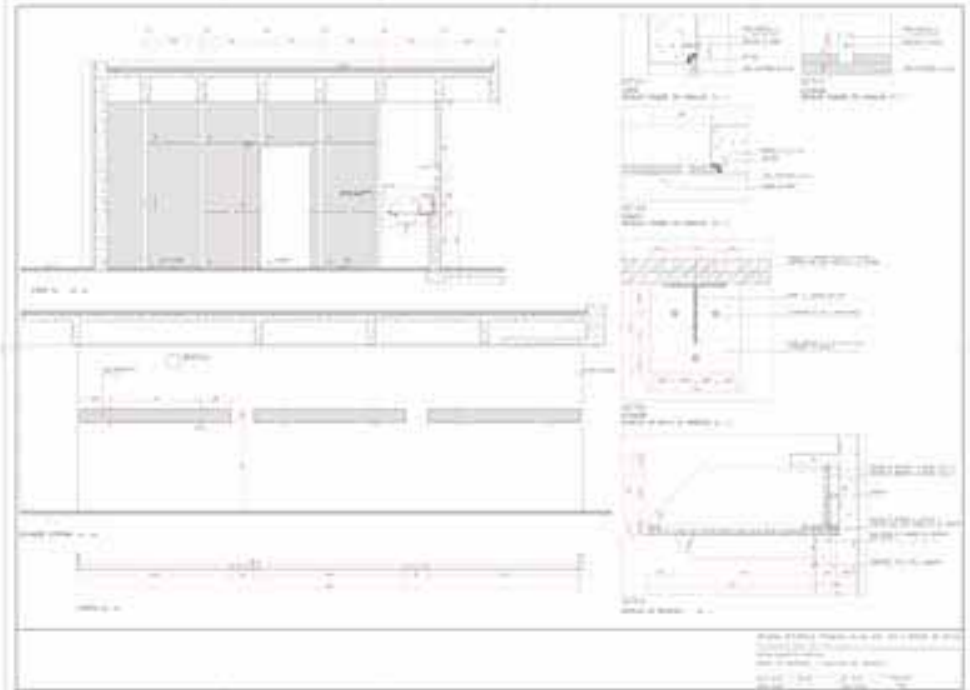

Ampliação cozinha - cortes, elevações e detalhes (escala indicada)

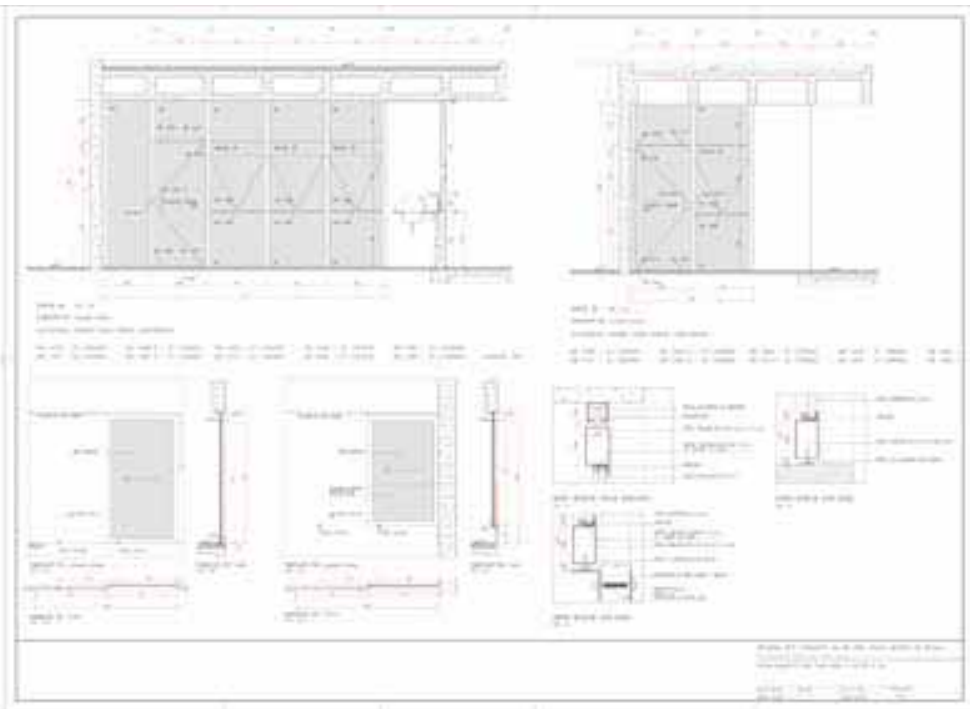

Ampliação e detalhes de caixilharia (escala indicada) 


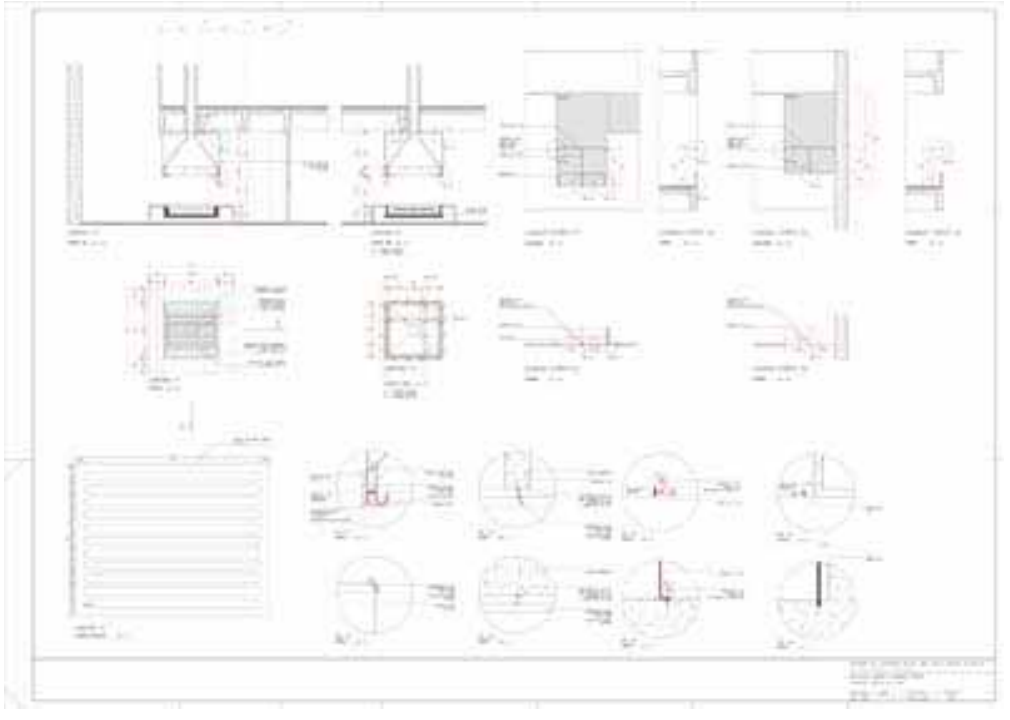

Detalhes gerais (escala indicada)

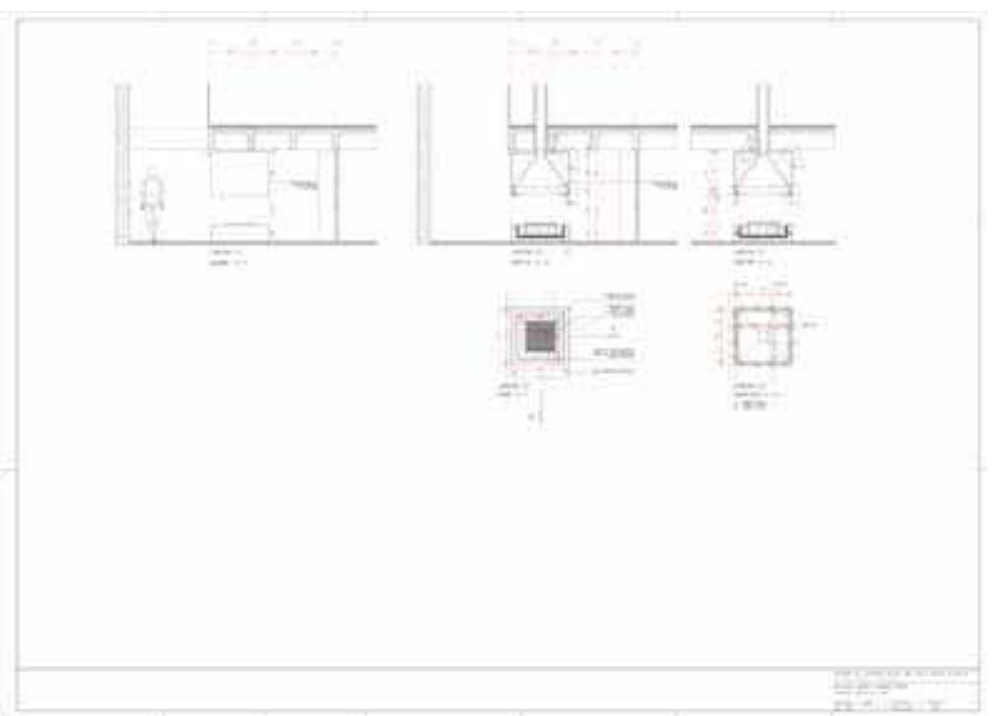

Ampliação da lareira (escala 1:20)

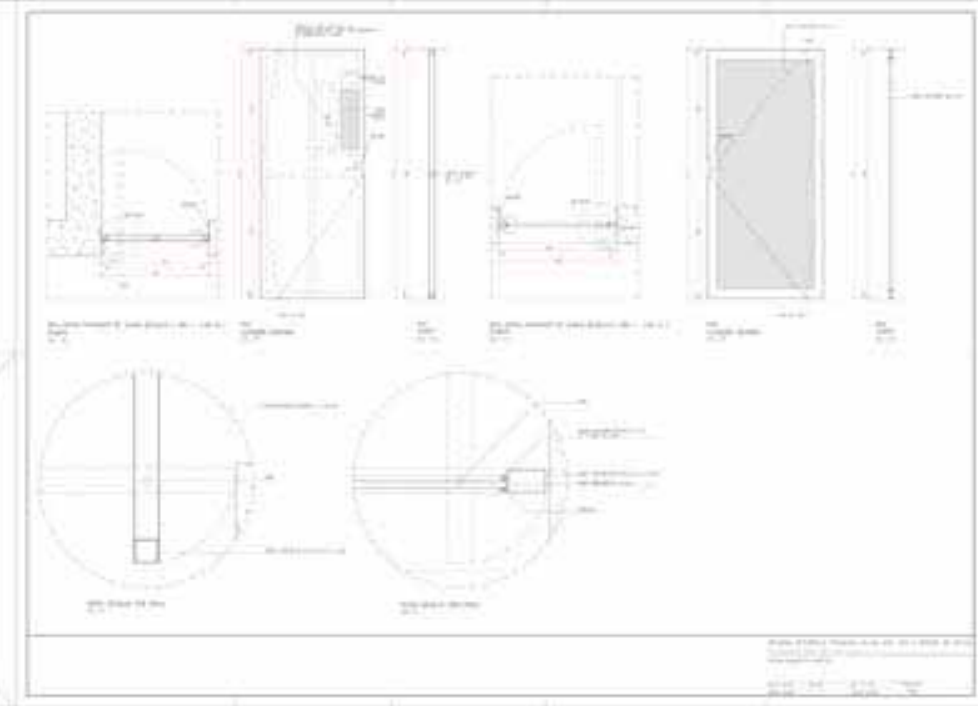

Ampliação e detalhes de portas (escala indicada)

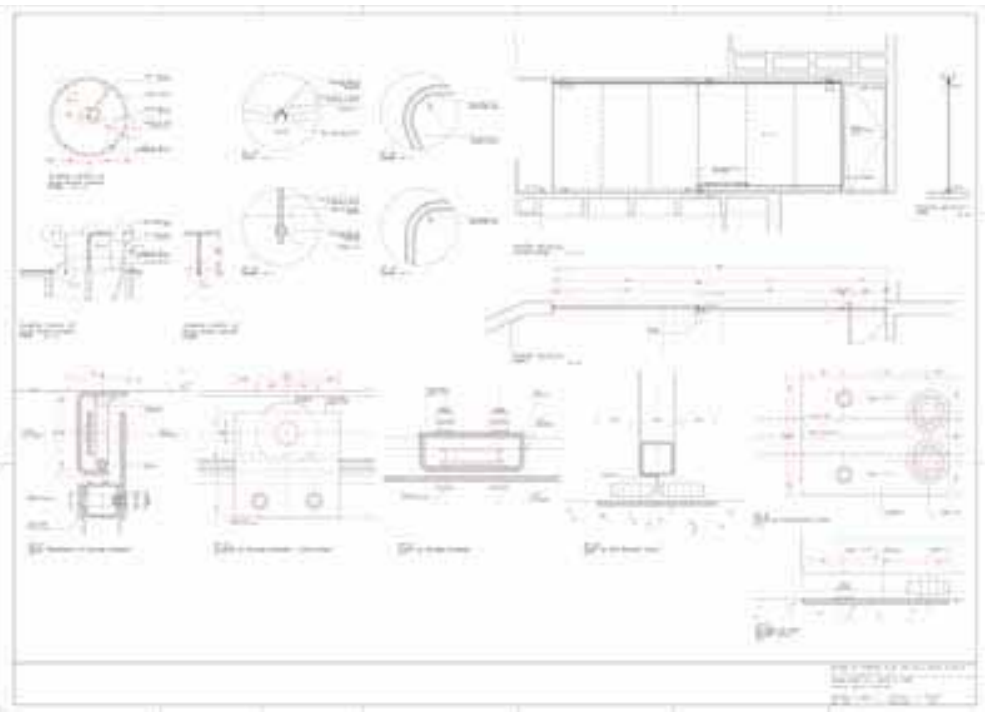

Ampliação e detalhes - portão e guarda-corpo (escala indicada) 


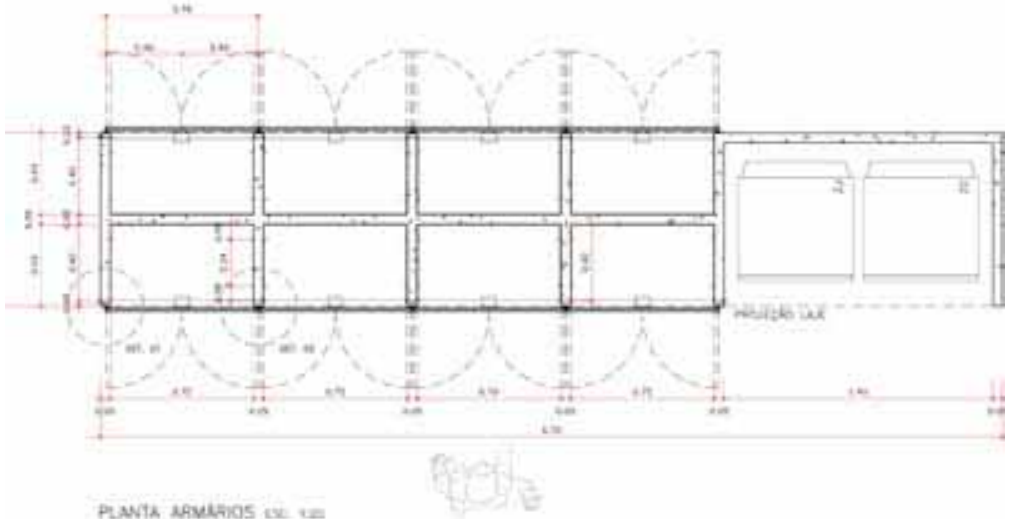

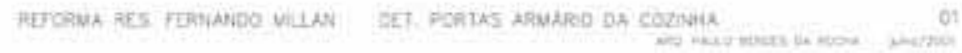

Ampliação de armários da cozinha - planta (escala 1:20)

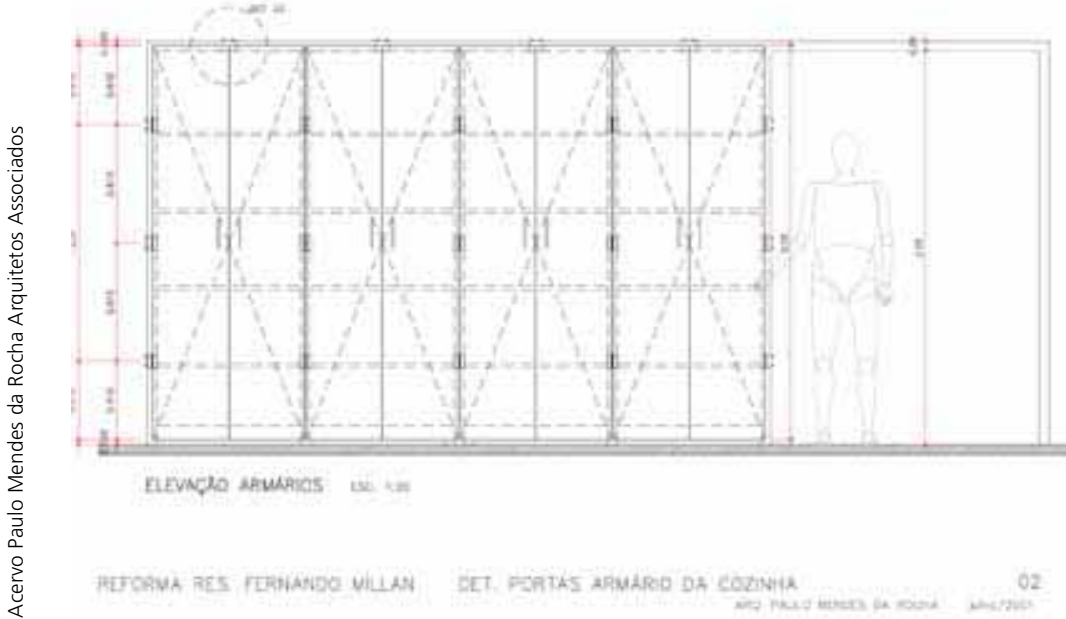

Ampliação de armários da cozinha - elevação (escala 1:20)

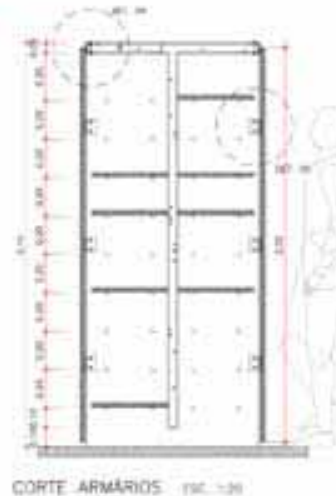

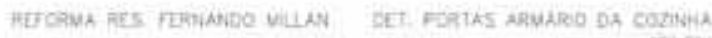
03

Ampliação de armários da cozinha - corte (escala 1:20)

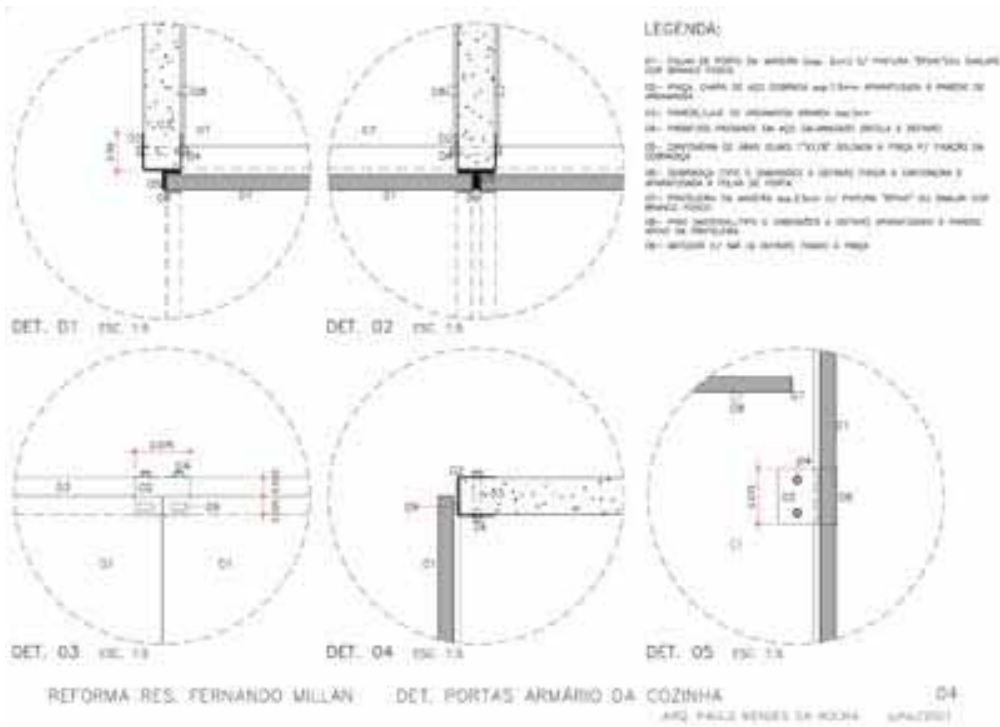

Ampliação de armários da cozinha - detalhes (escala 1:5) 

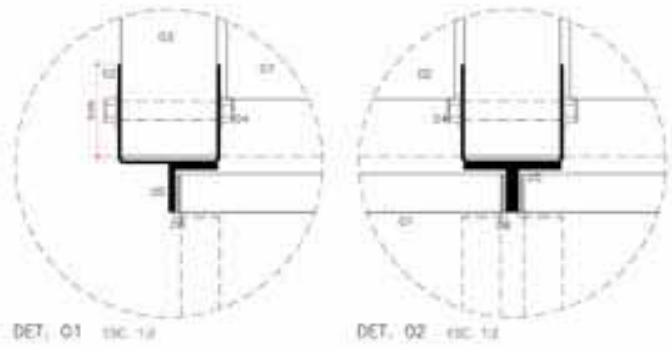

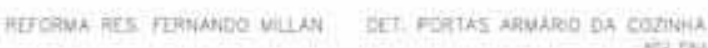
05

\section{Ampliação de armários da cozinha - detalhes (escala 1:5)}
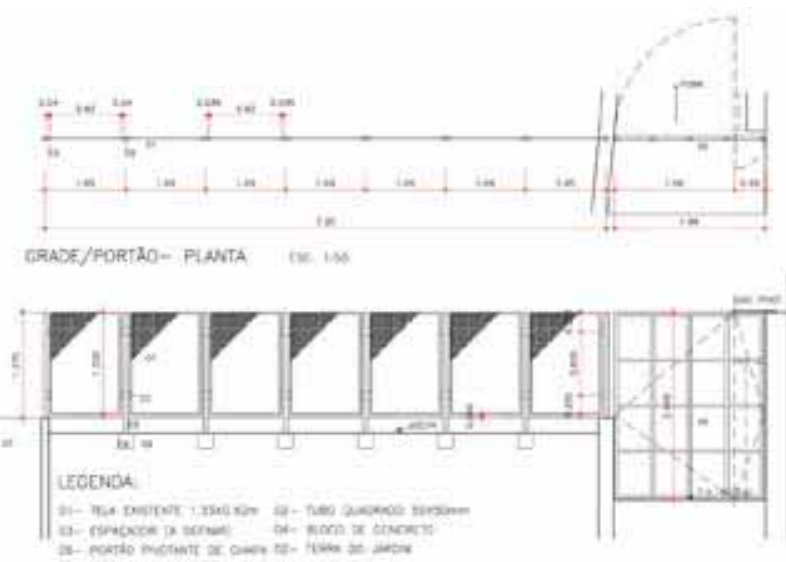

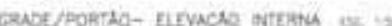

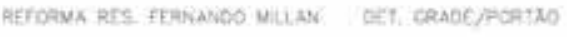

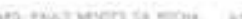

Ampliação do gradil e portão - planta e elevação (escala 1:50)

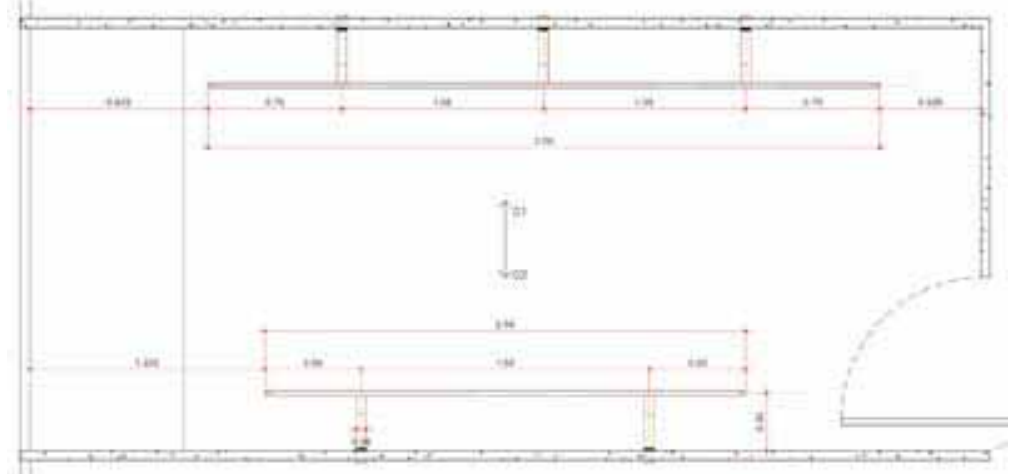

PANTA CICSET ne UE

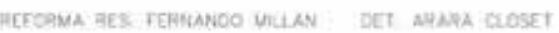

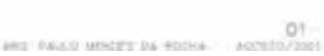

Ampliação do closet (detalhe da arara) - planta (escala 1:20)

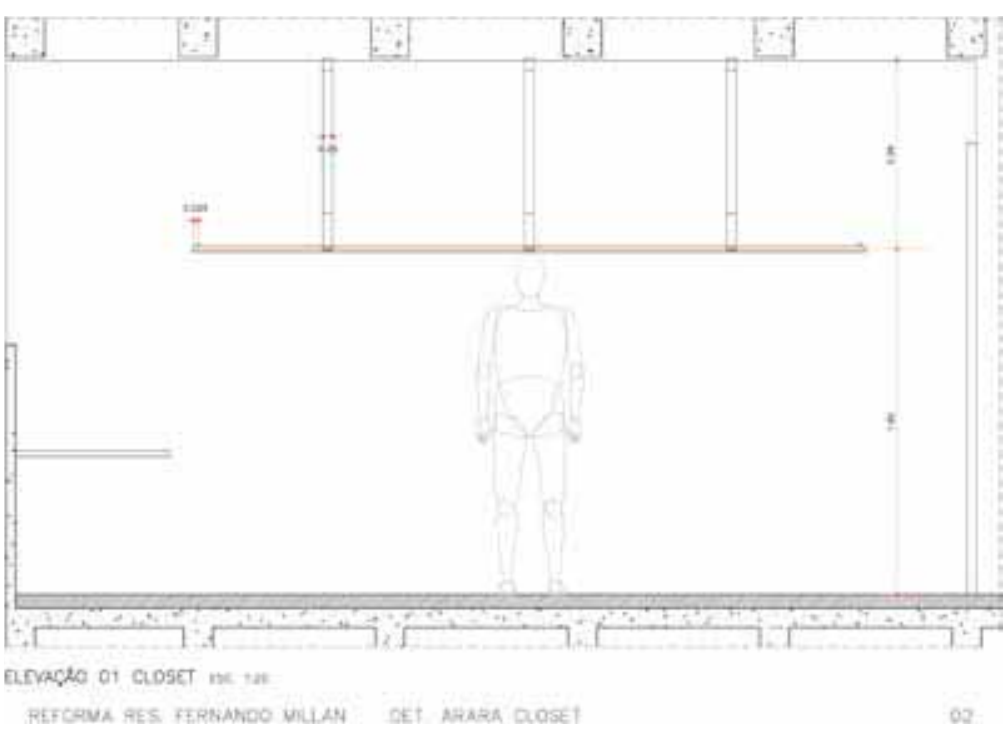

Ampliação do closet (detalhe da arara) - elevação (escala 1:20) 


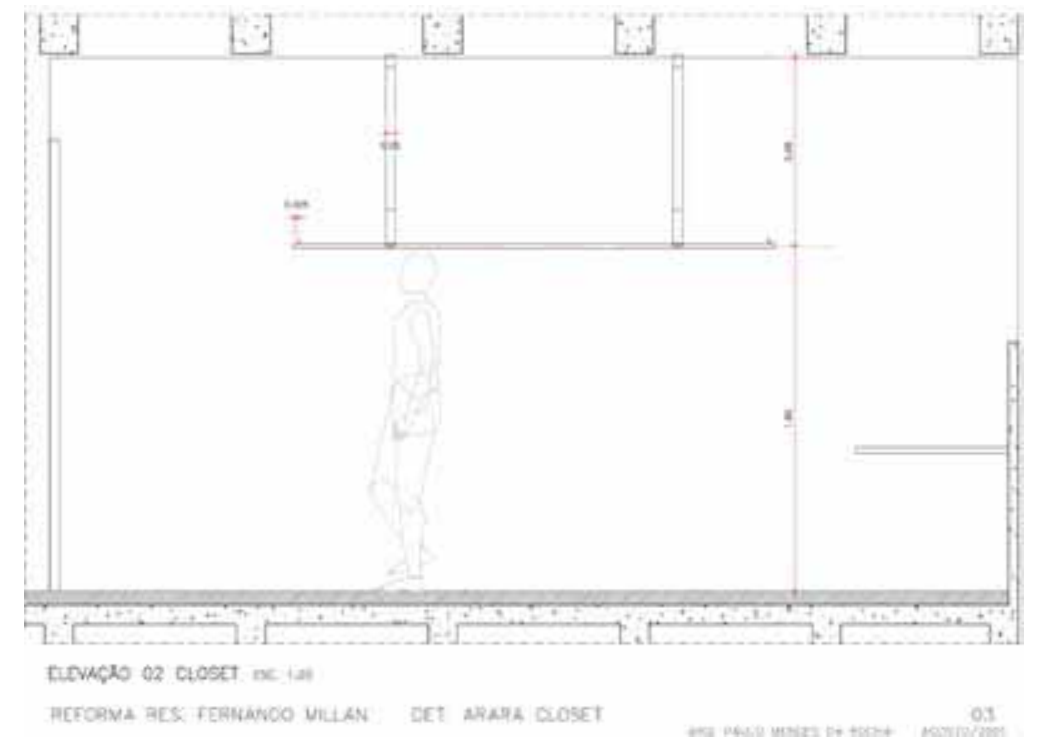

Ampliação do closet (detalhe da arara) - elevação (escala 1:20)

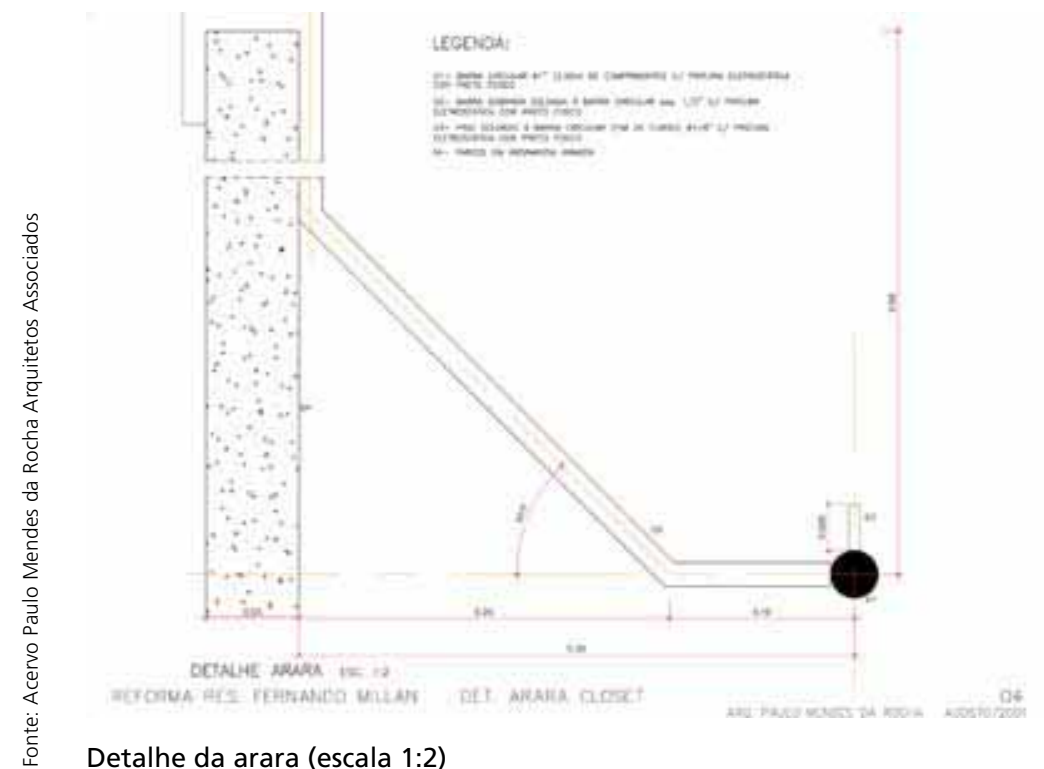

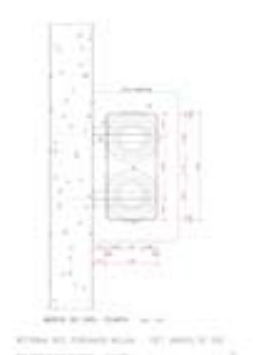
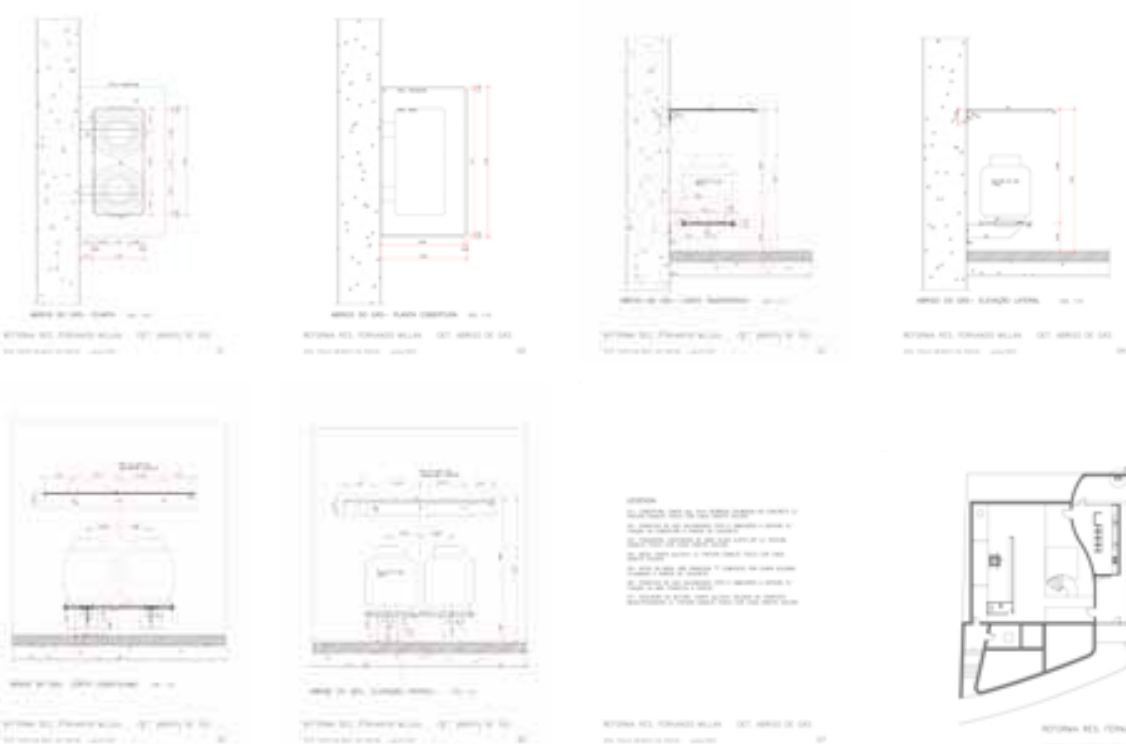

Ampliação do abrigo de gás - planta, cortes e elevação (escala 1:10)

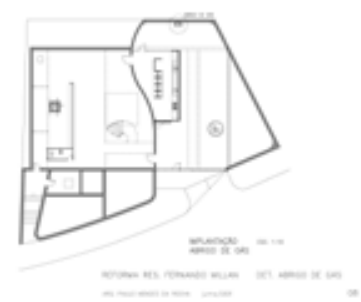

\section{ENTREVISTA PAULO MENDES DA ROCHA}

[CO-AUTOR DO PROJETO DE INTERVENÇÃO]

0 depoimento sobre a residência Millan, do arquiteto Paulo Mendes da Rocha, foi tomado em conjunto com a residência Masetti. Ver p. 225. 

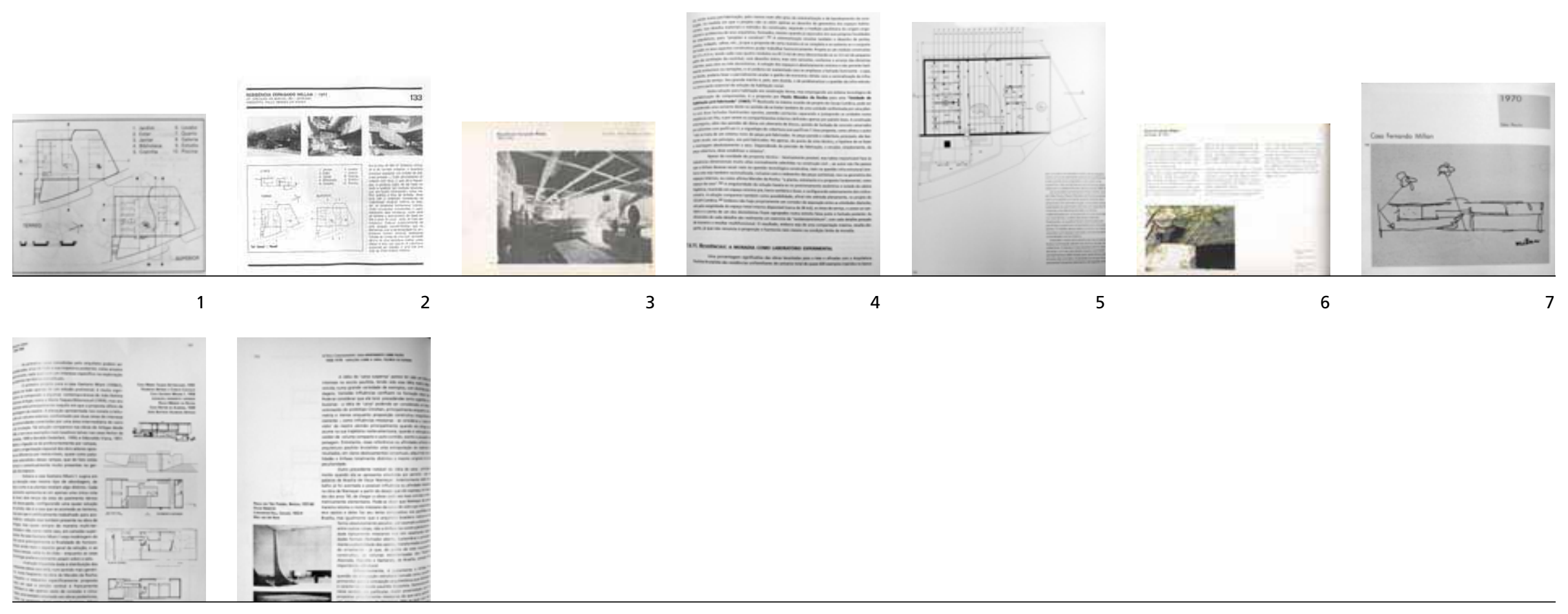

8

9

\begin{tabular}{|c|c|c|c|c|c|c|c|c|c|}
\hline & TIPO & NOME & EDITORA & CIDADE & DATA & $\mathrm{N}^{\circ}$ & AUTOR(ES) & TÍTULO & PÁG. \\
\hline 1 & revista & Construção São Paulo & Pini & São Paulo & set/1982 & 1805 & ROCHA, Paulo Archias Mendes da & Residência Fernando Millan (1971) & 22 \\
\hline 2 & livro & Arquitetura moderna paulista & Pini & São Paulo & 1983 & - & $\begin{array}{l}\text { XAVIER, Alberto; LEMOS, Carlos; } \\
\text { CORONA, Eduardo }\end{array}$ & Residência Fernando Millan/1971 & 133 \\
\hline 3 & livro & Residências em SP & Projeto & São Paulo & 1986 & - & ACAYABA, Marlene & Residência Fernando Millan 1971-1974 & $333-342$ \\
\hline 4 & tese & $\begin{array}{l}\text { A arquitetura da escola paulista brutalista, } \\
\text { 1953-1973 }\end{array}$ & PROPAR-UFRGS & Porto Alegre & 2007 & - & ZEIN, Ruth Verde & \begin{tabular}{|l|} 
7.4.11 Residência: a moradia como \\
laboratório experimental \\
\end{tabular} & $221-248$ \\
\hline 5 & livro & Arquitetura moderna brasileira & Phaidon & Londres & 2004 & - & ANDREOLI, Elisabetta; FORTY, Adrian & - & $168-169$ \\
\hline 6 & livro & Paulo Mendes da Rocha: bauten und projekte & Nigli & Sulgen & 2002 & - & SPIRO, Annette & Casa Fernando Millan São Paulo, SP, 1970 & 74-79 \\
\hline 7 & livro & Paulo Mendes da Rocha/Helio Piñón & Romano Guerra & São Paulo & 2002 & - & PIÑON, Helio & Casa Fernando Millan 1970 São Paulo & $146-153$ \\
\hline 8 & tese & $\begin{array}{l}\text { Arquitetura brasileira, escola paulista e as } \\
\text { casas de Paulo Mendes da Rocha }\end{array}$ & PROPAR-UFRGS & Porto Alegre & 2000 & - & ZEIN, Ruth Verde & - & $181-183$ \\
\hline 9 & tese & $\begin{array}{l}\text { Arquitetura brasileira, escola paulista e as } \\
\text { casas de Paulo Mendes da Rocha }\end{array}$ & PROPAR-UFRGS & Porto Alegre & 2000 & - & ZEIN, Ruth Verde & - & $\begin{array}{l}262-271 ; \\
275-279\end{array}$ \\
\hline
\end{tabular}




\section{TABELA COMPARATIVA}

BENS TOMBADOS NA CIDADE DE SÃO PAULO,

[os projetos sem indicação ENTRE 1930 E 1979, NOS ÓRGÃOS PATRIMONIAIS

de data não são tombados, (CONPRESP, CONDEPHAAT E IPHAN)

porém constam em listagem

nos referidos órgãos como

bens de interesse patrimonial]

\begin{tabular}{|c|c|c|c|c|c|c|c|}
\hline & ANO & NOME & LOCAL & AUTORIA & CONPRESP & CONDEPHAAT & IPHAN \\
\hline 1 & 1927 & Edifício Residencial & avenida Angélica, 170, 172 e 180 & Júlio Abreu Jr. & & & \\
\hline 2 & \begin{tabular}{|l|}
$1927 /$ \\
1928 \\
\end{tabular} & Casa Modernista & rua Santa Cruz, 325 & Gregori Warchavchik & 1991 & 1987 & 1987 \\
\hline 3 & $\begin{array}{l}\text { década } \\
\text { de } 30\end{array}$ & Residência do Arquiteto & rua Conselheiro Zacarias, 491 & Alfredo Becker & & & \\
\hline 4 & 1930 & Imóvel rua Itápolis & rua Itápolis, 961 & Gregori Warchavchik & 1991 & 1994 & 1986 \\
\hline 5 & 1930 & $\begin{array}{l}\text { Imóvel rua Bahia } \\
\text { (Residência Luiz da Silva Prado) }\end{array}$ & rua Bahia, 1126 & Gregori Warchavchik & 1991 & 1994 & 1986 \\
\hline 6 & 1930 & Residência Daphnis de Freitas Valle & rua São Carlos do Pinhal, 376 & G. Winter \& M. Whately & 2001 & & \\
\hline 7 & 1933 & Museu Lasar Segall & rua Afonso Celso, 362 e 368 & Gregori Warchavchik & 1989 & & \\
\hline 8 & 1933 & Vila Residencial & $\begin{array}{l}\text { alameda Ministro Rocha Azevedo,1052 a 1076/ } \\
\text { alameda Lorena, } 1257 \text { a } 1273\end{array}$ & Flávio de Carvalho & & & \\
\hline 9 & 1934 & Convento e Igreja do Carmo & rua Martiniano de Carvalho, 114 e 156 & Georg Przyrembel & & & \\
\hline 10 & 1935 & Edifício Esther & praça da República, 64 a 80 & Adhemar Marinho e Álvaro Vital Brasil & 1992 & 1990 & \\
\hline 11 & 1936 & Jockey Club & avenida Lineu de Paula Machado & Elisiário Bahiana & 2001 & & \\
\hline 12 & 1939 & Edifício Residencial & alameda Barão de Limeira,1003 & Gregori Warchavchik & 1990 & & \\
\hline 13 & 1939 & Parque Residencial Savóia & rua Vitorino Carmilo, 453 & Arnaldo Maia Lello & & & \\
\hline 14 & 1941 & Edifício Trussardi & avenida São João, 1032 e 1050 & Rino Levi & & & \\
\hline 15 & 1941 & Instituto Sedes Sapientiae & rua Marquês de Paranaguá, 111 & Rino Levi & 1986 & & \\
\hline 16 & 1941 & Edifício Anchieta & avenida Paulista, 2584 & Marcelo Roberto e Milton Roberto & & & \\
\hline 17 & 1941 & Residência João Arstein & rua Canadá, 714 & Bernard Rudowsky & & & \\
\hline 18 & 1942 & Edifício Mara & rua Brigadeiro Tobias, 225 a 275 & Eduardo Augusto Kneese de Mello & & & \\
\hline 19 & 1942 & Residência Rio Branco Paranhos & rua Heitor de Morais, 120 & João Batista Vilanova Artigas & 2001 & & \\
\hline 20 & 1946 & Edifício Louveira & rua Piauí, 1081 & João Batista Vilanova Artigas e Carlos Cascaldi & 2002 & 1993 & \\
\hline 21 & 1947 & $\begin{array}{l}\text { Edifício do Instituto dos Arquitetos } \\
\text { do Brasil }\end{array}$ & rua Bento Freitas, 306 & \begin{tabular}{|l|} 
Rino Levi e Roberto Cerqueira César; Jacob \\
Ruchti, Miguel Forte e Galiano Ciampaglia; \\
Abelardo de Souza, Hélio Duarte e Zenon Lotufo
\end{tabular} & & 2002 & \\
\hline
\end{tabular}




\begin{tabular}{|c|c|c|c|c|c|c|c|}
\hline & ANO & NOME & LOCAL & AUTORIA & CONPRESP & CONDEPHAAT & IPHAN \\
\hline 22 & 1947 & Hospital Central do Câncer & rua Prof. Antônio Prudente, 211 & Rino Levi e Roberto Cerqueira César & & & \\
\hline 23 & 1948 & Piscina Coberta Adhemar de Barros & rua D. Germaine Buchard, 451 & Ícaro de Castro Mello & & & \\
\hline 24 & 1949 & Residência do Arquiteto & rua Barão de Jaceguai, 1151 & João Batista Vilanova Artigas & & & \\
\hline 25 & 1949 & Casa de Vidro (Residência do Arquiteto) & rua General Almério de Moura, 200 & Lina Bo Bardi & 1991 & 1987 & \\
\hline 26 & 1950 & Grupo Escolar Pandiá Calógeras & avenida Paes de Barros, 1025 & Hélio Duarte & & & \\
\hline 27 & 1951 & Parque do Ibirapuera & avenida Pedro Álvares Cabral & $\begin{array}{l}\text { Oscar Niemeyer, Zenon Lotufo, Hélio Uchôa } \\
\text { e Eduardo Kneese de Mello }\end{array}$ & 1994 & 1992 & \\
\hline 28 & $\begin{array}{l}1951 / \\
1955\end{array}$ & Jardim Ana Rosa & rua Vergueiro/rua José de Queiroz Aranha & $\begin{array}{l}\text { Abelardo de Souza, Nelson Pedalini, Plínio Croce, } \\
\text { Roberto Aflalo, Salvador Cândia, Walter Kneese } \\
\text { e Walter Russo }\end{array}$ & & & \\
\hline 29 & 1952 & Edifício Três Marias & avenida Paulista, 2239 & Abelardo de Souza & & & \\
\hline 30 & 1953 & Estádio do São Paulo Futebol Clube & praça Roberto Gomes Pedrosa, s/n & João Batista Vilanova Artigas & 2000 & & \\
\hline 31 & 1953 & Edifício Nações Unidas & avenida Paulista/avenida Brig. Luiz Antônio & Abelardo de Souza & & & \\
\hline 32 & 1953 & Edifício Lausanne & avenida Higienópolis, 101 e 111 & Adolf Franz Heep & 1991 & & \\
\hline 33 & 1954 & Conjunto Residencial (Perdizes) & $\begin{array}{l}\text { rua Homem de Mello/rua João Ramalho/ } \\
\text { rua Franco da Rocha }\end{array}$ & Aberlado de Souza & & & \\
\hline 34 & 1955 & Residência Oscar Americano & avenida Morumbi, 3700 & Oswaldo Arthur Bratke & & & \\
\hline 35 & 1955 & Conjunto Nacional & $\begin{array}{l}\text { avenida Paulista/rua Augusta/alameda Santos/ } \\
\text { alameda Pe. João Manoel }\end{array}$ & David Libeskind & 2001 & 2005 & \\
\hline 36 & 1955 & Condomínio Viadutos & praça Gal. Craveiro Lopes, 19 & João Artacho Jurado & & & \\
\hline 37 & 1956 & Edifício Paulicéia & avenida Paulista, 960 e rua São Carlos do Pinhal & Jacques Pillon, Giancarlo Gasperini & & & \\
\hline 38 & 1956 & \begin{tabular}{|l} 
Edifício da OAB - Ordem dos \\
Advogados do Brasil
\end{tabular} & praça da Sé, 385 e 389 & $\begin{array}{l}\text { Rino Levi, Roberto Cerqueira Cesar } \\
\text { e Luiz Roberto Carvalho Franco } \\
\end{array}$ & & & \\
\hline 39 & 1957 & $\begin{array}{l}\text { Museu de Arte de São Paulo "Assis } \\
\text { Chateaubriand"(MASP) } \\
\end{array}$ & avenida Paulista, 1578 & Lina Bo Bardi & 1991 & 1982 & 1980 \\
\hline 40 & 1957 & $\begin{array}{l}\text { Ginásio de Esportes do Clube Atlético } \\
\text { Paulistano }\end{array}$ & rua Colômbia/rua Estados Unidos & Paulo Mendes da Rocha & & & \\
\hline 41 & 1958 & Residência Cunha Lima & rua Dr. Silvio Portugal, 193 & Joaquim Guedes & & & \\
\hline 42 & 1959 & Edifício & rua Arthur de Azevedo, 32 e 44 & Carlos Millan & & & \\
\hline 43 & 1959 & Edifício Palácio Quinta Avenida & avenida Paulista, 726 & $\begin{array}{l}\text { Pedro Paulo de Mello Saraiva } \\
\text { e Miguel Juliano e Silva }\end{array}$ & & & \\
\hline 44 & 1959 & Edifício Arlinda & largo do Arouche, 76 a 96 & Adolf Franz Heep & & & \\
\hline 45 & 1960 & Residência Roberto Millan & rua Alberto Faria, 646 & Carlos Millan & & & \\
\hline 46 & 1961 & Conjunto Esportivo - USP & Cidade Universitária & Ícaro de Castro Mello & & & \\
\hline 47 & 1961 & Faculdade de História e Geografia - USP & Cidade Universitária & Eduardo Corona & & & \\
\hline 48 & 1961 & $\begin{array}{l}\text { Departamento de Mecânica da Escola } \\
\text { Politécnica - USP }\end{array}$ & Cidade Universitária & $\begin{array}{l}\text { Ernesto Roberto de Carvalho Mange } \\
\text { e Ariaki Kato }\end{array}$ & & & \\
\hline 49 & 1961 & Residência Boris Fausto & rua Gaspar Moreira, 309 & Sérgio Ferro & & & \\
\hline
\end{tabular}




\begin{tabular}{|c|c|c|c|c|c|c|c|}
\hline & ANO & NOME & LOCAL & AUTORIA & CONPRESP & CONDEPHAAT & IPHAN \\
\hline 50 & 1961 & Assembléia Legislativa de São Paulo & $\begin{array}{l}\text { avenida Pedro Álvares Cabral/rua Abílio Soares/ } \\
\text { rua Curitiba/rua Pe. Manoel da Nóbrega }\end{array}$ & $\begin{array}{l}\text { Adolpho Rubio Morales, Ricardo Sievers } \\
\text { e Rubens Carneiro Vianna }\end{array}$ & & & \\
\hline 51 & 1961 & Garagem de Barcos & avenida Robert Kennedy, 4901 & João Batista Vilanova Artigas e Carlos Cascaldi & 2007 & & \\
\hline 52 & 1961 & Sede das Emissoras Associadas & rua Alfonso Bovero, 52 & Dorvalino Mainieri e Mario Ferronato & 2000 & & \\
\hline 53 & 1962 & Residência do Arquiteto & avenida São Valério, 505 & Roger Zmekhol & & & \\
\hline 54 & 1964 & Sociedade Harmonia de Tênis & rua Canadá, 658 & Fábio Penteado, Alfredo Paesani e Teru Tamaki & & 1993 & \\
\hline 55 & 1964 & Residência do Arquiteto & $\begin{array}{l}\text { rua Eng. João de Ulhôa Cintra, 26/ } \\
\text { praça Monteiro Lobato }\end{array}$ & Paulo Mendes da Rocha & & & \\
\hline 56 & \begin{tabular}{|l|l|}
$1966 /$ \\
1969 \\
\end{tabular} & \begin{tabular}{|l|} 
Faculdade de Arquitetura e \\
Urbanismo - USP \\
\end{tabular} & rua do Lago, 876 & João Batista Vilanova Artigas e Carlos Cascaldi & 1991 & 1982 & \\
\hline 57 & 1966 & Residência Waldo Perseu Pereira & rua Araxiá, 255/rua Carangola,420 & Joaquim Guedes & & & \\
\hline 58 & 1966 & Biblioteca Municipal do Ipiranga & $\begin{array}{l}\text { BP Min. Genésio de Almeida Moura } \\
\text { rua Cisplatina, } 505 \\
\end{array}$ & Aluizio da Rocha Leão & & & \\
\hline 59 & 1966 & $\begin{array}{l}\text { Biblioteca Municipal do Canindé - } \\
\text { BIJ Adelpha Figueiredo }\end{array}$ & praça Ilo Ottani, 146 & Antonio Carlos Pitombo & & & \\
\hline 60 & 1967 & Edifício Romi S.A. & rua Coriolano, 710 & Hélio de Queiroz Duarte e Lúcio Grinover & & & \\
\hline 61 & 1967 & Residência Elza Berquó & rua Paulo Roberto Paes de Almeida, 51 & João Batista Vilanova Artigas & 1999 & & \\
\hline 62 & 1967 & Residência Chiyo Hama & rua dos Emboabas, 628 & Ruy Ohtake & & & \\
\hline 63 & 1967 & $\begin{array}{l}\text { Escola de Metalurgia da Escola } \\
\text { Politécnica - USP }\end{array}$ & Cidade Universitária & Oswaldo Arthur Bratke & & & \\
\hline 64 & 1968 & Maternidade e Posto de Saúde & avenida Dep. Emílio Carlos, 3100 & Siegbert Zanettini & & & \\
\hline 65 & 1968 & Igreja de São Pedro e São Paulo & avenida Circular do Bosque, 31 & Carlos Bratke, Renato Lenci & & & \\
\hline 66 & 1968 & Estação Tietê & avenida Cruzeiro do Sul/rua Dr. Gabriel Pisa & Marcello Aciolly Fragelli & & & \\
\hline 67 & 1968 & Estação Santana & avenida Cruzeiro do Sul/rua Dr. Gabriel Pisa & Marcello Aciolly Fragelli & & & \\
\hline 68 & 1968 & Residência Mário Masetti & rua Manuel Maria Torinho, 701 & Paulo Mendes da Rocha & & & \\
\hline 69 & 1968 & Residência Tomie Ohtake & rua Antonio de Macedo Soares, 1800 & Rui Ohtake & & & \\
\hline 70 & 1969 & Residência João Marino & avenida Lopes de Azevedo, 265 & Sylvio Barros Sawaya e Edmilson Tinoco Jr. & & & \\
\hline 71 & 1969 & Fórum Criminal Mário Guimarães & rua José Gomes Falcão & $\begin{array}{l}\text { Fábio Penteado, Eduardo de Almeida, } \\
\text { Teru Tamaki e Alfredo Paesani }\end{array}$ & & & \\
\hline 72 & 1969 & Parque Anhembi & avenida Olavo Fontoura, 1209 & Jorge Wilheim e Miguel Juliano Silva & & & \\
\hline 73 & 1970 & Colégio Visconde de Porto Seguro & rua Clementine Brenne, 33 & Plínio Croce, Roberto Aflalo e Giancarlo Gasperini & & & \\
\hline 74 & 1970 & Residência Dino Zamataro & rua Hilário Magro Jr., 70 & Rodrigo Lefèvre & & & \\
\hline 75 & 1970 & Edifício da Ericson do Brasil & avenida Morvan Dias de Figueiredo/rua da Coroa & Charles Bosworth & & & \\
\hline 76 & 1970 & $\begin{array}{l}\text { Cento de Processamento de Dados } \\
\text { do Banco do Brasil }\end{array}$ & avenida das Nações Unidas/rua Verbo Divino & Maurício Roberto e Márcio Roberto & & & \\
\hline
\end{tabular}


